\title{
Time in Ancient Greek Literature
}




\title{
Mnemosyne
}

\author{
Bibliotheca Classica Batava
}

\author{
Editorial Board \\ G.J. Boter, A. Chaniotis, K. Coleman, \\ I.J.F. de Jong, P.H. Schrijvers
}

VOLUME 291 


\title{
Time in Ancient Greek Literature
}

Studies in Ancient Greek Narrative, volume two

\author{
Edited by \\ Irene J.F. de Jong \\ René Nünlist
}

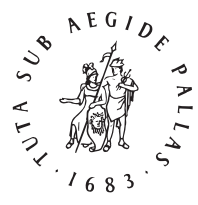

B R I L L

LEIDEN • BOSTON

2007 
This is an open access title distributed under the terms of the CG BY-NG-ND 4.0 license, which permits any non-commercial use, distribution, and reproduction in any medium, provided no alterations are made and the original author(s) and source are credited. Further information and the complete license text can be found at https://creativecommons.org/licenses/by-nc-nd/4.0/

The terms of the GC license apply only to the original material. The use of material from other sources (indicated by a reference) such as diagrams, illustrations, photos and text samples may require further permission from the respective copyright holder.

This book is printed on acid-free paper.

\section{Library of Congress Cataloging-in-Publication data}

A C.I.P. record for this book is available from the Library of Congress.

ISSN: 0169-8958

ISBN: 9789004165069

Copyright 2007 by Irene J.F. de Jong and René Nünlist. Published by Koninklijke Brill NV, Leiden, The Netherlands.

Koninklijke Brill NV incorporates the imprints BRILL, Hotei Publishing,

IDC Publishers, Martinus Nijhoff Publishers and VSP.

All rights reserved. No part of this publication may be reproduced, translated, stored in a retrieval system, or transmitted in any form or by any means, electronic, mechanical, photocopying, recording or otherwise, without prior written permission from the publisher.

Authorization to photocopy items for internal or personal use is granted by Koninklijke Brill NV provided that the appropriate fees are paid directly to The Copyright Clearance Center, 222 Rosewood Drive, Suite 910, Danvers, MA 01923, USA.

Fees are subject to change.

PRINTED IN THE NETHERLANDS 


\section{TABLE OF CONTENTS}

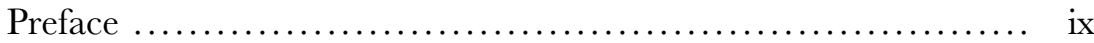

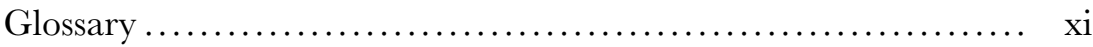

Introduction. Narratological theory on time ................... 1

I.J.F. DE JONG

PART ONE. EPIG AND ELEGIAG POETRY

Chapter One. Homer .................................. 17

I.J.F. DE JONG

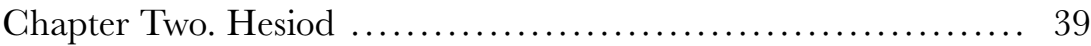

R. NüNLIST

Chapter Three. The Homeric Hymns ....................... 53

R. NüNLIST

Chapter Four. Apollonius of Rhodes ........................ 63 J.J.H KLOOSTER

Chapter Five. Callimachus ................................ 81 M.A. HARDER

Chapter Six. Theocritus ................................... 97 J.J.H. KLooster

\section{PART TWO. HISTORIOGRAPHY}

Chapter Seven. Herodotus

T. Rood

Chapter Eight. Thucydides

T. Rood

Chapter Nine. Xenophon

T. Rood 
Chapter Ten. Polybius

T. Rood

Chapter Eleven. Arrian 183

T. HIDBER

Chapter Twelve. Herodian

T. HidBer

Chapter Thirteen. Josephus ...

J.W. van Henten \& L. Huitink

PART THREE. GHORAL LYRIC

Chapter Fourteen. Pindar and Bacchylides

233

R. NÜNLIST

PART FOUR. DRAMA

Chapter Fifteen. Aeschylus

J. BARrett

Chapter Sixteen. Sophocles

I.J.F. DE JONG

Chapter Seventeen. Euripides M.A. LLOYd

Chapter Eighteen. Aristophanes

A.M. BowIE

PART FIVE. ORATORY

Chapter Nineteen. Antiphon

M.J. EDWARds

Chapter Twenty. Lysias

M.J. EDWARDs

Chapter Twenty-One. Demosthenes

M.J. EDWARDS 
PART SIX. PHILOSOPHY

Chapter Twenty-Two. Plato

K.A. Morgan

Chapter Twenty-Three. Xenophon

K.A. Morgan

\section{PART SEVEN. BIOGRAPHY}

Chapter Twenty-Four. Xenophon

M. BEGK

Chapter Twenty-Five. Plutarch

M. BECK

Chapter Twenty-Six. Philostratus

T.J.G. Whitmarsh

PART EIGHT. THE NOVEL

Chapter Twenty-Seven. Chariton

J.R. MORGAN

Chapter Twenty-Eight. Xenophon of Ephesus

J. Morgan

Chapter Twenty-Nine. Longus

J.R. Morgan

Chapter Thirty. Heliodorus

J.R. MORGAN

Epilogue. Time in Ancient Greek Literature

505

I.J.F. DE Jong \& R. NÜNLIST

Bibliography

Thematic index 
Irene J.F. de Jong and René Nünlist - 978-90-47-42293-8 Downloaded from Brill.come4/26/2023 09:46:52AM via free access 


\section{PREFACE}

This is the second volume of Studies in Ancient Greek Narrative (SAGN), a series which, as was set out in the General Introduction to Volume I, aims at investigating 'the forms and functions of the main devices which narratology has defined for us, such as the narrator and his narratees, time, focalization, characterization, description, speech, and plot'. Interestingly enough, this endeavour has gained an increased relevance and importance through the appeal, made in 2003 by the leading narratologist Monika Fludernik, for 'the diachronization of narratology', i.e. a scholarly interest in the history of narrative forms and functions, which, she notes, so far has been largely lacking. ${ }^{.}$She suggests questions like 'how much reader address occurs across the centuries and whether these formulas have specific functions that remain constant, or whether they alternate between a number of functions?'; 'when were certain techniques or constellations first used, or when did they become current and, even later, predominant?'; and whether 'certain features and techniques acquire a different function at crucial points of the restructuring process of the narrative paradigm?'

It is exactly this type of question which is discussed in Studies in Ancient Greek Narrative. Here for the first time in the relatively short history of the discipline an example of diachronic narratology is offered, spanning some twelve centuries, thirty authors, and eight genres. In the words of the General Introduction (again): 'The aim of this enterprise is to combine the synchronic and the diachronic, to offer not only analyses of the handling of a specific narrative device by individual authors, but also a larger historical perspective on the manner in which techniques change over time, are put to different uses and achieve different effects in the hands of different authors writing in different genres and handling different material'. In order to make this diachronic perspective visible, the reader is alerted to the existence (and discussion) of the same device in another author (chapter) through an arrow $(\rightarrow)$.

\footnotetext{
1 Fludernik 2003.
} 
As a glance at the table of contents shows, the second volume deals by and large with the same corpus as the first volume. Likewise the team of contributors is largely the same.

Like the first volume, the second one was prepared for in a workshop, held in Amsterdam on August 26-27, 2005. I wish to thank the Netherlands Organization for Scientific Research (NWO) and the Institute of Culture and History (ICG) of the University of Amsterdam for their financial support.

The preparation of the manuscript for publication was in thehighly efficient and careful - hands of the copy-editor of Mnemosyne, Wim Remmelink.

IdJ. 


\section{GLOSSARY}

actorial analepsis: an analepsis made by a character.

actorial prolepsis: a prolepsis made by a character.

analepsis (flashback, Rückwendung): the narration of an event which took place earlier than the point in the story where we are. A distinction can be made between narratorial and actorial analepses, internal and external analepses, in the case of internal analepses, between repeating and completing analepses.

argument function: the function or significance which an embedded narrative has for the characters. Compare key function.

completing analepsis: an analepsis which brings new information.

covert narratees: narratees whose presence in the text is not clearly or explicitly marked.

covert narrator: a narrator who does not explicitly or openly refer to his own activities as narrator and/or give expression to his emotions concerning what he narrates.

delay: see paralipsis.

ellipsis: a form of rhythm whereby no story-time corresponds to the fabulatime, i.e. an event is passed over.

embedded narrative: a narrative which is embedded in the main story; it is either told by the primary narrator or by a character acting as secondary narrator. It usually takes the form of an analepsis or prolepsis. See also argument and key function.

embedded or secondary focalization: when the narrator represents in the narrator-text a character's focalization, i.e., his perceptions, thoughts, emotions, or words (indirect speech). Embedded focalization can be explicit (when there is a shifter in the form of a verb of seeing, thinking, or a subordinator followed by subjunctive or optative) or implicit.

external analepsis: a flashback to an event which lies outside the time span of the main story.

external narratees: narratees who do not play a role in the story told.

external narrator: a narrator who does not play a role in his own story.

external prolepsis: a flash-forward to an event which lies outside the time span of the main story.

fabula: all events which are recounted in the story, abstracted from their disposition in the text and reconstructed in their chronological order.

focalizer: the person (the narrator or a character) through whose 'eyes' the events and persons of a narrative are 'seen'.

frame narrative: a narrative in which a frame hosts a series of embedded narratives, which together form the bulk of the text.

frequency: the number of times an event from the fabula is recounted in the story. Events may be told once (singulative narration), more than 
once (repeating narration), or repeated events may be told only once (iterative narration).

interlace technique: the technique of interweaving different storylines through regular switches between them.

internal analepsis: when an analepsis falls within the time span of the main story.

internal narratees: narratees who play a role in the story told.

internal narrator: a narrator who plays a role in his own story.

internal prolepsis: when a prolepsis falls within the time span of the main story.

iterative narration: when repeated events are told only once.

key function: the significance which an embedded narrative has for the narratees. Compare argument function.

main story: the events which are told by the primary narrator (minus external analepses and prolepses).

narratees: the addressees of the narrator. We may distinguish between external and internal, primary and secondary (tertiary, etc.), and overt and covert narratees. Compare narrator.

narrator: the person who recounts the events of the story and thus turns them into a text. We may distinguish between external narrators (who are not a character in the story they tell) and internal narrators (who are), primary narrators (who recount the main story) and secondary (tertiary, etc.) narrators (who recount embedded narratives), overt narrators (who refer to themselves and their narrating activity, tell us about themselves, and openly comment upon their story) and covert narrators. All narrators are also focalizers.

narrator-text: those parts of the text which are presented by the primary narrator, i.e., the parts between the speeches. We may further distinguish between simple narrator-text (narrator presents his own focalization) and embedded focalization (narrator presents focalization of a character).

narratorial analepsis: when an analepsis is made by the narrator.

narratorial prolepsis: when a prolepsis is made by the narrator.

order: the chronological order of the fabula may be changed in the story, for instance to create prolepses and analepses or any other anachrony.

overt narratees: narratees whose presence in the text is clearly and explicitly marked.

overt narrator: a narrator who explicitly refers to his activities as narrator and gives expression to his emotions concerning what he tells.

paralepsis: a speaker provides more information than, strictly speaking, he could, for example when the narrator intrudes with his superior knowledge into the embedded focalization of a character or when a character knows more than is logically possible. Contrast paralipsis.

paralipsis: a speaker provides less information than he could; details or events are left out, to be told at a later, more effective place. This is also known as delay. Contrast paralepsis.

pause: a form of rhythm whereby no fabula-time corresponds to the storytime, i.e. the action comes to a standstill. 
primary narrator: the first narrator we encounter in a story and who usually, unless we are dealing with a frame narrative, recounts the main story.

primary narratees: the addressees of the primary narrator.

prior narration: the narration of events which still have to take place at the moment of narration.

prolepsis (foreshadowing, Vorauswendung): the narration of an event which will take place later than the point of the story where we are. We may distinguish between internal prolepses (referring to events which fall within the time limits of the main story) and external prolepses (which refer to events which fall outside those time span), and between narratorial and actorial prolepses. See also seed.

repeating analepsis: an analepsis which repeats information.

repeating narration: when one event is told more than once.

reported narrators: when a primary narrator introduces characters as narrators, in indirect speech.

rhythm: the relation between story-time and fabula-time, which is usually measured in the amount of text. An event may be told as a scene (storytime $=$ fabula-time), summary (story-time $<$ fabula-time), slow-down (story-time $>$ fabula-time), or ellipsis, i.e., not told at all (no story-time matches fabula-time). Finally there may be a pause, when the action is suspended to make room for an extended description (no fabula-time matches story-time).

scene: a form of rhythm whereby the story-time matches the fabula-time.

secondary narratees: the addressees of a secondary narrator.

secondary narrator: a character in the story of the primary narrator, who recounts a narrative (in direct speech).

seed (hint, advance mention): the insertion of a piece of information, the relevance of which will become clear only later. The later event thus prepared for becomes more natural, logical, or plausible.

singulative narration: when an event is told once.

simultaneous narration: the narration of events which are taking place at the moment of narration.

slow-down: a form of rhythm whereby the story-time is longer than the fabula-time.

story: the events as dispositioned and ordered in the text (contrast fabula). The story consists of the main story + embedded narratives. In comparison to the fabula, the events in the story may differ in frequency (they may be told more than once), rhythm (they may be told at great length or quickly), and order (the chronological order may be changed).

subsequent narration: the narration of events which have already taken place at the time of narration.

summary: a form of rhythm whereby the story-time is much shorter than the fabula-time.

text: the verbal representation of the story (and hence fabula) by a narrator. 
Irene J.F. de Jong and René Nünlist - 978-90-47-42293-8 Downloaded from Brill.come4/26/2023 09:46:52AM via free access 
INTRODUCTION

NARRATOLOGICAL THEORY ON TIME

\author{
I.J.F. DE JONG
}

\title{
Introduction
}

The first volume of the Studies in Ancient Greek Narrative ( $S A G \mathcal{N}$ I) centred on the figure of the narrator, perhaps the most important criterion for calling a text a narrative. In the present volume we turn to the second most important main constituent of a narrative: time. In Forster's commonsensical formulation, a story is a 'narrative of events narrated in their time-sequence'. ${ }^{1}$ As a consequence of its importance, time in narrative has been extensively studied by narratologists. This volume will follow the narratological theories on time of Genette and Bal, ${ }^{2}$ where appropriate, eclectically supplemented with concepts from other theoreticians. $^{3}$

When discussing time in a narrative text, it may be instructive to start by considering just how much time awareness there is within that text: does the narrator provide us with a precise schedule, marking the years, months, days, and hours, or is the chronology fairly vague? An example of the first type of narrative is Woolf's The Years, where the chapter-titles are in the form of years ('1880', 'I89I', etc.) and each chapter opens with an elaborate description of a season ('It was an uncertain spring', 'The autumn wind blew over England'), while in Duras' L'après-midi de Monsieur Andesmas we are confronted with snippets from a man's life without any precise temporal anchoring. Where it is

\footnotetext{
${ }^{1}$ Forster [I927] 1979: 42. Cf. Mendilow 1952: I7-18; Lämmert I955: 2I ('Das Gerüst ... muss beim Erzählwerk die fortschreitende und zwar energisch, d.h. von einer Strebekraft, durchwirkte Handlung sein!').

${ }^{2}$ Genette [1972] I980: 33-I60 and Bal [1985] I997: 78-II4.

${ }^{3}$ Mainly G. Müller I947; Mendilow I952; and Lämmert 1955. Other narratological works on time, which are not included in the framework of this chapter, are Bakhtin I98I and Ricoeur [I983] I984-I985.
} 
impossible to determine the temporal relationships between the various events, we are dealing with an achronical narrative. ${ }^{4}$

Another preliminary observation concerns the temporal relation between the narrative and the events being recounted: the narration can be subsequent (the events have already taken place), simultaneous (the events are taking place at the moment of narration), or prior (the events have yet to take place). ${ }^{5}$ In all ages and all literatures, subsequent narration is the default form. Simultaneous narration is occasionally used in drama, to narrate offstage - usually backstageevents, and some modernists have adopted it for entire novels (e.g. Butor, La modification, and Robbe-Grillet, La jalousie). Prior narration is used primarily by characters, when they announce - often prophesywhat is going to happen. ${ }^{6}$

In order to describe in more detail the many forms of temporal relationships between narrative and the events recounted, we must turn to one of the cornerstones of narratology.

\section{The distinction fabula - story- text}

One of the oldest insights of modern narratology is the distinction between fabula and sjuzet: the aggregate of related events reported in a narrative in their chronological order (fabula), as opposed to those same events in the order and manner in which they are presented in the text (sjuzet). ${ }^{7}$ This crucial distinction has been reformulated in many ways, whereby unfortunately the terms have not always been used with the same meaning. ${ }^{8}$ In this volume we adopt the three-layer model devised by Bal: in his text a narrator relates a story; the story consists of the events of a fabula presented in a certain order and manner; and the fabula is a series of logically and chronologically related events that are

${ }^{4}$ Genette [1972] 1980: 84; Bal [1985] I997: 97-99.

${ }^{5}$ Genette [1972] 1980: 215-223.

${ }^{6}$ At first glance, it may seem that the categories of prior narration and prolepsis overlap, but the former concerns the form, the latter the function: prior narration usually functions as a prolepsis, but not every prolepsis necessarily takes the form of prior narration; it may just as easily take a past tense.

7 Tomashevsky [1925] I965: 66-67 ('In brief, the story is "the action itself", the plot "how the reader learns of the action")

${ }^{8}$ For a (selective) overview see Martin i986: Io8. Cf. also Forster [1927] 1979: 87; Lämmert I955: 24-26; and Culler 1975: I69-187. 
caused or experienced by characters. In effect, the fabula is nothing but a reconstruction by the narratees, on the basis of the story and text.

As argued in the Introduction to $S A G N \quad$ I, ${ }^{9}$ it may be helpful in certain cases to posit a fourth layer, that of the material from which a narrator forms his fabula: this can range from historical sources to the texts of predecessors or traditional stories.

It should also be noted here that in the case of an overt external narrator, who has a great deal to say about himself, his act of narration and his own time, the level of the text may undergo considerable expansion, occasionally turning into a narrative in its own right. In the present volume, this phenomenon will be discussed under the heading of 'reference to the narrator's own time' motif. ${ }^{10}$ An example is: 'The district is of historic, no less than of topographical interest. The vale was known in former times as the Forest of White Hart, from a curious legend ... In those days, and till comparatively recent times, the country was densely wooded. Even now traces of its earlier condition are to be found in the old oak copses and irregular belts of timber that yet survive upon its slopes, and the hollow-trunked trees that shade so many of its pastures' (Hardy, Tess of the D'Urbervilles; my italics).

The threefold distinction fabula - story - text makes possible a precise analysis of the various temporal procedures which narrators have at their disposal: they can change the order of events (order), they can spend more or less time on recounting events (rhythm), and they can recount events only once or more often (frequency).

\section{Order: analepses and prolepses}

One of the oldest and best known temporal procedures is the change of the chronological order of events or, as Genette has called it, anachrony. ${ }^{11}$ We can distinguish between prolepsis, the narration of an event which will take place after the point in the story where we find ourselves, or analepsis, the narration of an event which took place before the point in the story where we find ourselves. An example of a prolepsis

9 SAGN ı:9. Cf. Lämmert 1955: 25 ('Stoff').

${ }^{10}$ For this motif see also $S A G \mathcal{N}$ i: index.

${ }^{11}$ Genette [1972] I980: 33-85; Bal [1985] I997: 80-98. Cf. also Mendilow I952: I58I99, who refers to the phenomenon as 'time shift'. 
is: 'We shall see, in due course, that for quite another reason, the memory of this impression was to play an important part in my life' (Proust, Remembrance of Things Past). For an analepsis we may think of: 'We saw each other for the first time, drinking bad South African sherry because of the war in Spain. I noticed Sarah, I think, because she was happy ... I liked her at once because she said she had read my books and left the subject there-I found myself treated at once as a human being rather than as an author. I had no idea whatever of falling in love with her.' This passage occurs in the third chapter of Greene's The End of the Affair, when the narrator returns to the beginning of the affair which is already over at the start of the book; the analepsis is signalled through 'for the first time'.

The scale of prolepses and analepses may vary: some are brief, so as not to disrupt the flow of events in the main story, but they can also get the upper hand. Thus in Wilder's The Bridge of San Luis Rey, the analeptic narrations of the lives of the five people who die when the bridge collapses take up a large part of the novel. Prolepses are often used to create suspense or tension among the narratees about how things are going to develop, while analepses often fill them in on the background of characters or the 'prehistory' of the narrative they are reading. Just as prolepses heighten the narratees' expectations of what is to come, analepses may cause them to revise their previous interpretations. ${ }^{12}$

There seem to be no narratives which are totally devoid of anachronies, and their presence is one of the major points on which fabula and story differ: the fabula is the - reconstructed - chronological order of events, while the story usually displays deviations from that chronological order. An important consequence of this fact is that usually the time span or extent of story and fabula differ. To explain this, I use the well-known example of the Odyssey. Both fabula and story deal with the events which take place during Odysseus' ten-year journey home from Troy, but in the story a large number of these events are recounted by a secondary narrator, Odysseus, in a long embedded narrative, while the primary narrator concentrates on the last $\mathrm{L}^{\mathrm{I}}$ days of his return. This means that while the time span of the fabula is ten years, that of the main story is $4 \mathrm{I}$ days (and that of Odysseus' embedded narrative ten

\footnotetext{
12 For a discussion of the dynamics of the narratees' prospection and retrospection see Sternberg 1985: 264-320.
} 
years minus the last $4 \mathrm{I}$ days). ${ }^{13}$ Likewise, Virginia Woolf's Mrs. Dalloway deals with one day in the life of Clarissa Dalloway (main story), but on the basis of the many recollections of her and other characters, a fabula can be reconstructed which spans her life up to this point.

The concepts analepsis and prolepsis can be further refined. In the first place, we can distinguish between internal analepses/prolepses, which concern events which take place within the time span of the main story, and external analepses/prolepses, which fall outside this time span. Thus in the Iliad, where the time span of the main story is a period of $5^{\mathrm{I}}$ days, starting with the arrival of Chryses and ending with the burial of Hector, the account of the quarrel with Agamemnon (I.370392) which Achilles gives his mother Thetis is an internal analepsis; Odysseus' recollection of the gathering at Aulis (2.299-330) an external analepsis; the narrator's announcement that Hector was destined to be 'short-lived' (15.612-6I4) an internal prolepsis; and Priam's moving depiction of the fall of Troy (22.59-76) an external prolepsis.

But, as Bal notes, not all narratives are so clear-cut,,$^{14}$ and often a commonsensical approach is the best way to define the main story and determine which prolepses and analepses are external. Where does the main story of Flaubert's Madame Bovary begin? With the arrival of Charles Bovary at school (chapter I) or with the fateful night when he meets Emma Bovary for the first time (chapter 2)? If we choose the first option, then the sixth chapter, dealing with Emma's years in the convent, is an internal analepsis; if we choose the second option, it is an external analepsis. Similarly, what do we make of the typical fairy-tale ending 'and they lived happily ever after': is this the last element of the main story or an external prolepsis?

Sometimes we even come across events which are not merely external to the main story, but which do not seem to fit the fabula either, dealing as they do with a wholly different 'diegetic content'; these are called heterodiegetic analepses and prolepses..$^{15}$ An example is the analep-

${ }^{13}$ For the notion 'main story', cf. Genette [1972] I980: 48 ('We will henceforth call the temporal level of narrative with respect to which anachrony is defined as such, "first narrative"'); Bal [1985] 1997: 88 ('primary story-time'). For the notion 'time span', cf. Genette [1972] 1980: 48-49 ('The anachrony itself can ... cover a duration of story that is more or less long: we will call this its extent', 'the extent of the first narrative'); Bal [1985] I997: 92 ('span').

${ }_{14}$ Bal [1985] 1997: 88.

15 As opposed to the normal homodiegetic analepses and prolepses. Cf. Genette [1972] 1980: 50, 71. 
sis we find when the Prince de Faffenheim enters the story of Proust's À la recherche du temps perdu: a digression of several pages informs us about the vicissitudes of his career op to this point.

Within the group of internal analepses we can further distinguish between completing analepses, which fill in earlier gaps in the story, and repeating analepses, which cover the same ground as the story. In the case of a repeating analepsis, it may be relevant to compare the two versions, while the repetition may in itself underline the importance of an event. Some completing analepses have a surprise effect, when the information sheds new light on an existing situation. A completing analepsis may go hand in hand with what Genette calls a paralipsisand what classical scholars know as narrative delay: when a narrator withholds crucial information, in order to release it later, to greater effect. ${ }^{16} \mathrm{He}$ gives as an example the death of Swann and its effect on Marcel, which is recounted later, not at its proper place: 'The death of Swann had been a crushing blow to me at the time'.

Another important distinction is that between narratorial and actorial prolepses and analepses. An example of an actorial analepsis is:

"That is all", she said, looking at the fishmonger's. "That is all", she repeated, pausing for a moment at the window of a glove shop where, before The Jewish War, you could buy almost perfect gloves. And her old Uncle William used to say a lady is known by her shoes and her gloves. He had turned on his bed one morning in the middle of The Jewish War. He had said, "I have had enough". Gloves and shoes; she had a passion for gloves; but her own daughter, her Elizabeth, cared not a straw for either of them.

(Woolf, Mrs. Dalloway; my italics)

Of a narratorial analepsis:

I have dropped the curtain over this scene for a minute,-- to remind you of one thing,- - and to inform you of another. What I have to inform you, comes, I own, a little out of its due course; for it should have been told a hundred and fifty pages ago, ...

(Sterne, The Life and Opinions of Tristram Shandy, Gentleman)

In the case of prolepses, it is particularly relevant to distinguish between narrator and characters, since what a narrator announces is more likely to take place than what characters think, who may merely dream or

\footnotetext{
${ }^{16}$ Genette [1972] I980: 52. For narrative delay see Fraenkel [1950] I962: III 805 ('on the postponement of certain important details in archaic narrative').
} 
speculate about the future. ${ }^{17}$ The following is an example of such a 'dreamy' actorial prolepsis:

"He must propose to-morrow", thought Rebecca. "He called me his soul's darling, four times; he squeezed my hand in Amelia's presence. He must propose to-morrow." And so thought Amelia, too ... Oh ignorant young creatures! How little do you know the effect of rack punch! ... There is no headache in the world like that caused by Vauxhall punch. ... Through the lapse of twenty years, I can remember the consequence of two glasses! ... and Joseph Sedly, who had a liver complaint, had swallowed at least a quart of the abominable mixture.

(Thackeray, Vanity Fair; my italics)

Here the expectations of the female characters are immediately contradicted - for the benefit of the narratees - by the narrator.

But reliability or certainty is not the only respect in which narratorial and actorial prolepses may differ: there is also their emotional colouring or, more generally, their focalization. The effect they produce may also differ: a narrator may sovereignly, perhaps even moralisingly, anticipate the outcome of events, while a character optimistically or anxiously looks ahead to the future. Finally, it should be noted that not all narratorial prolepses are necessarily certain. There is the well-known type of the false prolepsis or misdirection (snare, trügerische Vorspiegelung). ${ }^{18}$ Conversely, certain characters, such as seers or wise advisers, may be-as good as - omniscient as regards the revelation of the future.

In the case of analepses, too, it is likewise relevant to distinguish between the narratorial and the actorial ones, again mainly because of their focalization and effect. In Galsworthy's The Man of Property, Soames' courtship of Irene, which took place before the start of the main story, is both recalled by the narrator and Soames: 'It [Soames' courtship of Irene] had been one of those real devoted wooings which books and people praise, when the lover is at length rewarded for hammering the iron till it is malleable, and all must be happy ever after as the wedding bells', versus 'And memories crowded on him with the fresh, sweet savour of the spring wind - memories of his courtship. In the spring of the year i88I he was visiting his old school-fellow and client ... [there follow two pages of analepsis] An enigma to him from the day that he first saw her, she was an enigma to him still ...'

17 Lämmert I955: I43-I92. Cf. esp. I75: 'Die Zukunft, wie sie sich im Laufe der Erzählung den handelnden Personen darbietet, ist von grundsätzlich anderer Realität als die, welche der Erzähler ... vorwegnimmt'.

18 Genette [1972] I980: 77; Lämmert I955: I86-I89. 
Comparing the two analepses, we may note the difference between the cynical narrator, who makes it clear that the courtship was forced and hence from the beginning contained the seeds of the later bitter estrangement between Soames and Irene, while Soames looks back at it as sweet but enigmatic.

In addition to prolepses, which are usually marked as such in one way or another (through the use of a future tense, through an explicit comment such as 'little could I know', 'as I will have reason to tell later', or by the use of verbs which concern the future, such as 'hope', 'fear', 'expect', etc.), narratives often feature other, more implicit, types of foreshadowing. We may think here of natural phenomena or embedded narratives which contain a message for the narratees. An example of the former is: 'Leaning her elbows on the parapet, she contemplated the River Arno, whose roar was suggesting some unexpected melody to her ears' (Forster, A Room with a View); this sentence concludes the chapter, in which the lovers-to-be, Lucy and George Emerson, have for the first time spent some time together.

A special type of foreshadowing is the seed (hint or advance mention): the insertion of a piece of information, the relevance of which will only later become clear. The later event thus prepared for becomes more natural, logical, or plausible. One example is the opening line of Forster's A Passage to India: 'Except for the Marabar Caves - and they are twenty miles off - the city of Chandrapore presents nothing extraordinary'. The narrator then continues to describe the city of Chandrapore, the setting of the narrative to follow. But mentioned in passing, the Marabar Caves already entered the story, and will soon become the scene of the central event of that story: the joint visit to these caves by the Indian Aziz and the English woman Adela Quested.

Finally, there is what might be called foreshadowing by convention. When a character in Herodotus is very happy or laughs, the narratees know this character will come to a bad end. Or when a character in a fairy-tale is allowed to make a wish, we know for sure that the outcome will not be what he or she expected.

\section{Order: beginnings and multiple storylines}

Analepses and prolepses are the most conspicuous, but not the only aspects of order. Order is also involved in the opening of narratives. By its very nature the opening of a narrative is an element to which nar- 
rators devote much attention, doing their utmost to captivate their narratees. ${ }^{19}$ Standard ingredients are time plus setting: 'While the present century was in its teens, and on one sunshiny morning in June, there drove up to the great iron gate of Miss Pinkerton's academy for young ladies, on Chiswick Mall, a large family coach...' (Thackeray, Vanity Fair).

But openings also have to do with relative time: does the beginning of the story coincide with the beginning of the fabula or do we start in medias res, that is, at some point further on in the fabula? Narrative texts where the beginning of story and fabula coincide exactly are rare, since few narrators would pass up the opportunity to add a 'prehistory' to their (main) story by means of external analepses. The in medias res opening is, of course, famously exemplified by the Odyssey, where we start in the tenth year of Odysseus' return and are informed about the preceding years through an embedded narrative by the hero himself. A modern example is Greene's The End of the Affair, which indeed starts near the end of the affair and where its earlier and middle phases are filled in by means of analepses, notably the diary of one of the main characters, Sarah, which at some point the narrator gets hold of. ${ }^{20}$

Not seldom do narrators elaborate on the effort involved in finding the right point to start their narrative: 'A story has no beginning or end: arbitrarily one chooses that moment of experience from which to look back or from which to look ahead. I say "one chooses" with the inaccurate pride of a professional writer who has been praised for his technical ability, but did I in fact of my own will choose that black wet January night on the Common, in 1946, the sight of Henry Miles slanting across the wide river of rain, or did these images choose me?' (Greene, The End of the Affair).

A topic not broached by either Genette or Bal is the case where a narrative contains two or more storylines. The crucial question here is how the temporal relation between the two parallel storylines is

${ }^{19}$ Cf. N. Miller 1965; Nuttall i992; and Morhange i995.

${ }^{20}$ It should be noted that in its original definition by Horace in his Ars Poetica I47-I48, the concept of in medias res also refers to an author selecting only the most interesting parts of the life of a character, as against starting $a b$ ovo, from the birth of that character. Here he is adopting ideas of Aristotle, as set out in chapter 8 of his Poetica. Both Horace and Aristotle are therefore talking about the choice of the fabula (e.g. the ten years of Odysseus' return) out of the material (the life of Odysseus from his birth). In later times in medias res has become exclusively associated with the choice of the beginning of the story as opposed to the fabula. 
handled: does the narrator who switches from storyline or character A to storyline or character $\mathrm{B}$ return in time to fill in what happened in $\mathrm{B}$ while the situation in A was evolving, or has time ticked on and does he proceed with $\mathrm{B}$ at the point where he left A? An example of a narrator who, generally, goes back in time is Thackeray in Vanity Fair; for example, 'We must now take our leave of Arcadia, and those amiable people practising the rural virtues there, and travel back to London, to inquire what has become of Miss Amelia'. In the Forsyte Saga, however, the narrator usually moves from one character to the next without retracing his steps.

\section{Rhythm}

Another important difference between fabula and story, apart from the order of events, is their speed. While in the-reconstructed-fabula events take up the same amount of time they would in real life, their duration in the story may be different; narrators may vary the pace of their narration, moving from quick to slow and back again. Narratologists use the term 'rhythm' (duration, speed) to refer to the amount of time which is devoted to an event in the story (story-time) as compared to that in the fabula (fabula-time). ${ }^{21}$ Since, as Genette remarks, in practice it is very difficult to measure variations in actual time between fabula and story, the rhythm of a narrative is usually defined in terms of the amount of text devoted to an event. ${ }^{22}$ The narrator of The Great Gatsby recounts one memorable summer in which he was Jay Gatsby's neighbour, got to know him well and was nearby when he was murdered. Certain days during this summer are singled out and recalled in great detail. Thus the first three chapters deal with his meeting with Gatsby's great love, Daisy, and her husband Tom; then with Tom and his mistress (the wife of the man who will kill Gatsby), and with the mysterious Gatsby himself. The narrator explicitly draws attention to

${ }^{21}$ Cf. Genette [1972] I980: 86-II2 ('duration'); Bal [1985] i997: 99-IIr. Roughly, rhythm covers the older distinction between erzählte Zeit (the time covered in a narrative) and Erzählzeit (the time needed to recount a narrative); cf. G. Müller I947: I5-17; Mendilow 1952: 65-73 ('conceptual' vs. 'fictional' time).

22 Genette [1972] I980: 'the speed of a narrative will be defined by the relationship between a duration (that of the story, measured in seconds, minutes, hours, days, months, and years) and a length (that of the text, measured in lines and pages)'. 
this rhythm at the end of the third chapter: 'Reading over what I have written so far, I see I have given the impression that the events of three nights several weeks apart were all that absorbed me. On the contrary, they were merely casual events in a crowded summer, and, until much later, they absorbed me infinitely less than my personal affairs.'

Theoretically, there are an infinite number of possibilities when it comes to rhythm. In practice, however, narratives typically modulate between scenes, in which events are told in great detail, often including the words spoken by a character, and we come close to-but of course never really match - their real-time duration, and summaries, where events are dealt with in broad strokes and without a great deal of detail. An example of the typical combination of summary and scene is found in Galsworthy's The Man of Property:

[summary:] The winter had been an open one. Things in the trade were slack; and as Soames had reflected before making up his mind, it had been a good time for building. The shell of the house at Robin Hill was thus completed by the end of April. [...]

On April 30 he had an appointment with Bosinney to go over the accounts, [scene:] and five minutes before the proper time he entered the tent which the architect had pitched for himself close to the old oak tree.

The accounts were already prepared on a folding table, and with a nod Soames sat down to study them. It was some time before he raised his head.

"I can't make them out", he said at last ... [There follows a scenic conversation between the two men]

The choice of one of these forms of rhythm can be highly effective. A telling example is found in the first chapter of Lawrence's Sons and Lovers: 'The next Christmas they were married, and for three months she was perfectly happy: for six months she was very happy'. The summary makes clear how brief the happiness of Paul Morel's parents was, soon to be followed by years of fighting and estrangement.

Sometimes the modulation or transition between scene and summary is gradual, and we notice how the narrator accelerates or slows down. Slowing down may be effected by the increase of details. ${ }^{23}$ An

${ }^{23}$ Genette [1972] I980: 95 suggests the category of slowing down, what he calls 'slow motion', but does not consider it sufficiently widespread to be included in his four-fold typology of duration. 
example is: 'On the morning appointed for her departure Tess was awake before dawn - at the marginal minute of the dark when the grove is still mute save for one prophetic bird, who sings with a clearvoiced conviction that he at least knows the correct time of day, the rest preserving silence, as if equally convinced that he is mistaken. She remained upstairs packing ...' (Hardy, Tess of the D'Urbervilles). Here, as so often, the slowing down marks a decisive moment in the narrative.

The narrator may even bring the flow of events of his story to a complete standstill (pause). An example of such a pause is the twopage description of Chandrapore which opens Forster's A Passage to India. Real pauses are, however, seldom; often, though the story seems to come to a standstill, it later turns out that time has ticked on. One example is the extended description of Yonville-l'Abbaye, at the opening of part 2 of Madame Bovary; it is preceded by the departure of the Bovarys from Tostes and followed by their arrival in Yonville.

A final form of rhythm consists in simply passing over events (ellipsis). Most instances are quite casual and the result of narrative efficiency ('Some two weeks later ...'), but occasionally the gap is emphatically flagged by the narrator, as in Thackeray's Vanity Fair: 'What were the adventures of Mr. Osborne and Miss Amelia? That is a secret. But be sure of this - they were perfectly happy, and correct in their behaviour.'

Whether implicit or explicit, ellipses can be highly significant. Thus the end of the first part of Flaubert's Madame Bovary ('Quand on partit de Tostes, au mois de mars, Mme Bovary était enceinte') is, as Bal notes,${ }^{24}$ telling: 'by skipping the conception and enhancing this skipping by the rapidity of the narrator's sentence ... the great disappointment of Emma's marriage, specifically its sexual poverty' is underlined. The exercise of the narratees' imagination when events are suppressed has been amply analysed by Iser under the heading Leerstelle. ${ }^{25}$

A special kind of ellipsis, which is highly relevant when discussing ancient Greek literature, is that occasioned by the fact that to a great degree this literature is traditional, that is, it deals with the same stock of mythological narratives over and over again. Counting on the narratees' knowledge of the totality of a narrative, a narrator may tell a story in an elliptical way, presenting only parts of it, or merely alluding to it.

${ }^{24}$ Bal [1985] 1997: 91-92.

25 Iser [1976] 1978. 


\section{Frequency}

A final temporal relationship between fabula and story is frequency: the number of times an event from the fabula is recounted in the story. The default form of frequency is the singulative mode: each event is recounted once. But a narrator may choose to present an event more than once (repetition). An extreme example is Faulkner's Absalom, Absalom!, where the central event, a murder, is presented no less than thirty-nine times. But small-scale repetitions occur in virtually all narratives. The repeated presentation of the same action or event may be distributed over narrator and characters or over different characters, which will bring with it differences in focalization and effect. We have already encountered the repeating analepsis (as opposed to the completing analepsis). And even analepses may be themselves repeated. For example, young Jolyon's affair, which led to a long brouille with his father, the old Jolyon, in Galsworthy's The Man of Property is recalled by many characters:

[James Forsyte speaking] "Jolyon, he will have his own way. He's got no children" and stopped, recollecting the continued existence of old Jolyon's son, young Jolyon, June's father, who had made such a mess of it, and done for himself by deserting his wife and children and running away with that foreign governess. ... She [Aunt Ann] thought of June's father, young Jolyon, who had run away with a foreign girl! Ah, what a sad blow to his father and to them all. Such a promising young fellow! A sad blow, though there had been no public scandal, most fortunately, Jo's wife seeking for no divorce! A long time ago! ... [Old Jolyon thinking] The two had not met for fourteen years. And not for the first time during those fourteen years old Jolyon wondered whether he had been a little to blame in the matter of his son.

As this example makes clear, repetition may also be effectively used for the gradual information of the narratees, who are filled in, step by step, on the exact details of the brouille between father and son.

The reverse of repetition is iterative presentation, whereby several identical events are presented only once. Not surprisingly, this form is often used to convey characteristic habits or to summarize. Galsworthy avails himself of this technique when characterizing the subject of his trilogy, the Forsyte family; for example, 'They had all done so well for themselves, these Forsytes, that they were all what is called "of a certain position". They had shares in all sorts of things. They collected pictures, too, and were supporters of such charitable institutions as might be beneficial to their sick domestics ... Like all Forsytes of a certain age 
they kept carriages of their own, and never took cabs if by any means they could avoid it.'

A special use of iterative narration, which is often encountered in classical texts, is omnitemporal narration, where a narrator describes natural phenomena (the waves which always roll towards the shore), or the habits of immortals gods.

\section{Conclusion}

Before concluding my tour d'horizon of narratological theory on time, I would like to stress that, as always in narratological analysis, the model and concepts set out are intended only as instruments which may help to identify new phenomena and to describe similar phenomena in the same terms, thus facilitating comparisons (highly important in an enterprise such as the Studies in Ancient Greek Narrative, which undertakes to write the history of a literature which spans some twelve centuries, and covers some eight genres). However, the model should never become a straightjacket, into which texts are forced. Narratology, often called the grammar of narrative, indeed is comparable to our grammars, in that it helps us to order and understand certain aspects of the texts we study.

The handling of time is one of the central tasks of a narrator and one of the most powerful instruments which he has at his disposal to influence the interpretation by the narratees, by placing accents and foregrounding or downplaying events. Because of its vital role in shaping narratives, it is to be expected that ancient Greek authors, though perhaps not as 'obsessed' with time as twentieth-century authors, ${ }^{26}$ did focus considerable artistic attention on this element. To establish the precise manner, degree, and effect of their handling of time is the object of this volume.

26 So Mendilow i952: $3^{-22 .}$ 
PART ONE

EPIC AND ELEGIAC POETRY 
Irene J.F. de Jong and René Nünlist - 978-90-47-42293-8 Downloaded from Brill.come4/26/2023 09:46:52AM via free access 
CHAPTER ONE

HOMER

I.J.F. DE JONG

\section{Introduction. Time awareness}

Is time important in Homer? Some fifty years ago Hermann Fränkel gave a negative answer in a celebrated article on the conception of time in archaic Greek literature:

In general, the concept of time is hardly developed in Homer. The narrative drifts by in calm, continuous journeys. It is surrounded by the fields of time, which are monotonous, indifferent, and without substance, as when a column marches through a broad, open steppe without any roads. Together with the events and through them, time moves on unnoticed, like the path which one creates in high grass. ${ }^{1}$

Fränkel's thesis rests on the fact that the Homeric epics do not contain abstract reflections on time, such as we find later in Pindar or in tragedy. But it would seem that the time awareness in Homer is greater than he suggests.

More than once the narrator makes clear that there is a significant difference between 'mortals such as they are now' and the 'semi-divine' heroes and heroines of the past he sings about (e.g. Il. 5.302-304), ${ }^{2}$ while his characters occasionally look forward to their role as 'subjects of song for men of future generations' (Il. 6.357-358). ${ }^{3}$ In this respect Bakhtin speaks of 'the epic world of the absolute past', 'walled off from all subsequent times by an impenetrable boundary'. ${ }^{4}$ I would modify this view by pointing at the abundant similes, which in their omnitemporality offer a bridge between past and present: thus 'the west wind stirs a deep cornfield with its coming, and the standing crop bows

${ }^{1}$ Fränkel I960: 6 (my translation).

${ }^{2}$ Cf. $\mathrm{Il}$. I2.38 $1-385,447-449 ; 20.285^{-287}$. This type of passage does not occur in the Odyssey. The qualification 'semi-divine' occurs at Iliad I2.23.

3 Other examples: Od. 3.203-204; 8.579-580; 24.196-202.

${ }^{4}$ Bakhtin I981: I6. 
its ears in the fury of the blast' (Il. 2.I47-I48) in the time of the heroes, of the narrator and his narratees, and, for that matter, of us, modern readers.

Indeed, characters show a constant awareness of time, of the near past, as when Helen regretfully recalls having come along with Paris (Il. 3.173-175); the more remote past, as when Phoenix tells the tale of Meleager, 'a story of long ago, no recent thing' (Il. 9.527); the near future, when Penelope fears for the life of Telemachus, who has left on a ship (Od. 4.817-823); or the remote future, when Tiresias reveals to Odysseus the manner of his death $(O d$. II.134-137).

But even the present does not escape the notice of either narrator or characters. Thus the narrator explicitly marks the advent of nearly every day and, in the case of drawn-out days, of parts of the day; for example, 'For as long as it was morning and the holy day was waxing, the weapons thrown by each side reached their mark, and men kept falling. But when the sun had straddled the centre of the sky, then Zeus opened out his golden scales' (Il. 8.66-69). ${ }^{5}$ At times the characters also show an explicit, indeed emotional, awareness of the passing of time, for example when Odysseus eagerly anticipates the moment the Phaeacians will convey him home: 'he turned his head again and again to look at the shining sun eager for it to go down. And as when a man longs for his meal, for whom his wine-coloured oxen drag the compact plow across the field, and welcome the light of the sun for him, so as to allow him to go to dinner, ... in like wise the sunset was welcome to Odysseus' (Od. $13.28-35) \cdot{ }^{6}$

These few passages already suggest that time is important for the Homeric narrator and the characters alike. Let us now turn to time as a narratological category, starting with an important aspect, that of the order in which the events of the fabula are presented in the story.

\section{Order}

The first step in any discussion of the various aspects of order in a narrative text is to determine what constitutes the main story. In the Iliad the main story consists of $5^{\mathrm{I}}$ days, which lie between Chryses' arrival in the Greek camp and the burial of Hector; while in the Odyssey

\footnotetext{
5 Other examples: Il. I1.84-9i; Od. 7.288; г3.93-95.
}

6 Another example is Iliad 8.487-488. 
we move in 4 I days from the council of the gods in which the 'ban' on Odysseus' return is lifted to the reconciliation between Odysseus and the families of the suitors. ${ }^{7}$ If we consider the fabula of the Iliad to be the ten years of the Trojan war (cf. 2.329-330), and that of the Odyssey the twenty years of Odysseus' absence from Ithaca (cf. 2.I75), we clearly see how the Homeric narrator has employed the in medias res technique. Rather than starting at the beginning, Paris' judgment and abduction of Helen (explicitly marked as 'the beginning' of all misery in Iliad 3.IOo and 22.116) and Odysseus' departure for Troy (evoked in a mixture of invention and truth in Odyssey I9.22 I-257), he has chosen a point in the middle, or rather, near the end, just before the fall of Troy and Odysseus' return home. The important choice of the beginning of the story is thematized in the proems: 'Sing ... from the moment when first' and 'Sing ... from some point onwards'. ${ }^{8}$ Through the in medias res the narrator not only starts at a dramatic moment, but also, concentrating on a short period of time, gives his narrative thematic unity: in the Iliad the wrath of Achilles, in the Odyssey the reunion of Odysseus with his country, family, and people.

The endings of the Iliad and the Odyssey have always seemed less spectacular, but upon closer inspection we see that there is closure. This is effected by ring composition (in the Iliad a divine assembly and a father coming to the enemy camp to release his child, in the Odyssey divine councils and Ithacan assemblies); by a curtain call of the major characters in Iliad 23-24 (notably the Games) and Odyssey 23-24; and by the presence of natural closural motifs such as burial (of Hector, the suitors, and, in embedded narrative, Achilles) and reconciliation (between Priam and Achilles and-temporarily-the Greeks and the Trojans; and between Odysseus and the families of the dead suitors). ${ }^{9}$

Despite this concentration on one specific phase of the Trojan War or Odysseus' return, the narrator manages to include the whole picture. He does so in two ways. The first device is the so-called 'symbolic parallel', the inclusion of scenes which resemble and thus evoke events from the beginning or end of the fabula. ${ }^{10}$ This technique is found

\footnotetext{
${ }^{7}$ Hellwig 1964: 40-45 and (for the Iliad) Latacz 1996: I08-II9; Clark 20or; (for the Odyssey) de Jong 2001a: 587-588.

${ }^{8}$ For the rhetoric of the seemingly arbitrary beginning in Odyssey I.Io see de Jong 200Ia: 7 .

${ }_{9}^{9}$ Whitman 1958: 249-284; Taplin 1992: $25^{\mathrm{I}-284}$; de Jong 200ra: Introduction to book 24 .

${ }^{10}$ Heubeck 1958.
} 
mainly in the Iliad: we may think of the catalogue of ships, the duel between Menelaus and Paris, the view from the wall, and Helen at the insistence of Aphrodite going to bed with Paris, all of which evoke the beginning of the war; and Patroclus' funeral, which suggests the death and funeral of Achilles. At times the narrator helps his narratees to see the symbolic parallel, for example in the above mentioned lovemaking scene, where he makes Paris say to Helen: 'Never before has desire so enveloped my heart, not even on that first time when I stole you away from lovely Sparta and sailed off with you in my seafaring ships' (Il. 3.442-444). The second way in which the whole Trojan War and Odysseus' return are evoked is through external analepses and prolepses, which will be discussed in the following sections.

\section{Analepses $^{11}$}

Having established the main story, we may next investigate the anachronies, or changes in the order of presentation, vis-à-vis the fabula. I start with narratorial analepses. The internal analepses are infrequent and brief, and nearly always repeat events told earlier, for example Achilles' wrath (Il. 2.688-689; cf. I.488-492), a hero's wound (Il. iा.8og; cf. II.58I-592), or Calypso giving Odysseus clothes (Od. 5.321, 372; cf. 5.264)..$^{12}$ They seem to serve as reminders for the benefit of the narratees. Occasionally a special effect is intended, as when the narrator remarks that the Trojans, chased by Achilles, are running out over the plain towards the city, 'where the Greeks had been driven back terrorstruck on the day before, when glorious Hector was raging' (Il. 21.45). Another memorable example occurs exactly halfway through the Odyssey, when Odysseus' sufferings thus far are recapitulated, just as he is about to return home to face his final challenge ( $O d$. $13.89-92)$.

The technique of the completing internal analepsis is only rarely employed, for example in Odyssey 5.276-277, where Odysseus is watching the stars as he sails, 'for so Calypso, bright among goddesses, had told him to make his way over the sea, keeping the Great Bear on his left

11 Cf. Hellwig I964: 46-53; Kullmann I968; de Jong [1987] 2004: 81-90; S. Richardson I990: I00-I08; Reichel I994 (though his category of cross-references includes more than analepses).

12 Other examples: Il. 2.77І-773; 5.795; 13.347-350, 679; I6.5II-512; 23.29I-292; Od. I3.125-127. 
hand'. Rather than recounting Calypso's nautical advice at the 'proper' moment, when she sends Odysseus off $(5.263-268)$, the narrator inserts it here, in the form of an analepsis, at the moment when Odysseus actually uses it. ${ }^{13}$ We might also analyse this as an instance of delay or paralipsis.

More often the narrator inserts external analepses, mainly to fill in the background on characters; for example, '[Euryclea], daughter of Ops, the son of Peisenor, whom once (tèn pote) Laertes bought with his own possessions when she was still in her first youth, and he gave twenty oxen for her, and he favored her in her house as much as his own devoted wife, but never slept with her, for fear of his wife's anger' $\left(O d\right.$. I.429-433). ${ }^{14}$ I note in passing the combination of a relative pronoun + pote which introduces the analepsis, a combination which will become the characteristic marker of embedded narratives in Pindar $(\rightarrow)$. Biographical analepses are never exhaustive but always focus on the information necessary for the scene at hand; thus, when we hear that Mentor had once been the companion of Odysseus and that when boarding his ship Odysseus had entrusted his household to him (Od. 2.226-227), we are prepared for the speech in which he reminds the Ithacans of their king, and criticizes them for letting the suitors destroy Odysseus' household.

A specific Iliadic use of this type of external analepsis is the 'obituary' of a warrior, inserted at the moment he is killed; for example, 'So there he [Iphidamas] fell and slept a bronze sleep, a pitiable man, far from his wedded wife, helping his people, far from his bride, of whom he had known no joy, and much he had given to get her: he had given a hundred cattle first, and promised a further thousand, goats and sheep mixed, from his immense flocks at pasture' (Il. II.24I-245). Striving for a pathetic effect the narrator selects those elements of a hero's life which make his death most sad. ${ }^{15}$

External analepses are also used when the narrator introduces objects which are about to play an important role in the story: for example, the history of Agamemnon's scepter, which is significantly - and perhaps ironically - presented at the moment he is about to make a far

${ }_{13}$ Other examples: $\mathrm{Il}$. 8.8I-86; I2.6-9; Od. 8.448; I6.4II-4I2; 22.327-328.

${ }^{14}$ Other examples: Il. 2.547-55I, 69o-693; I1.104-Io6, I23-125; Od. I5.225-255; I7.292-295; I8.322-325.

${ }_{15}$ Other examples: Il. 4.474-478; 5.6o-64, 543-553; 6.2 I-26; II.222-230; I3.364369, 428-433, 663-670; I5.43I-432; I6.572-576; 2I.I4I-I 43. Cf. Griffin i980: I03-I 43 . 
from royal speech (Il. 2.IOI-IO8), or the long analepsis on Odysseus' bow, which informs the narratees that it once belonged to the mythical archer Eurytus and had been given to Odysseus as a guest-gift, and thereby assures them that it will be an effective weapon of Odysseus against the suitors, who abuse the laws of hospitality (Od. 2I.I3-4I). ${ }^{16}$

It should be observed that such external analepses introducing characters and objects may be inserted at their first appearance in the narrative, as in the case of Euryclea mentioned above, but may also be reserved for the moment when such a character is about to play an important role. In the case of Polydamas, for example, it is only when he makes his major warning speech, which Hector is - fatally - going to reject, that he is given an introduction (Il. I8.250-252). At this point, it may be instructive to contrast the narrative strategy of the secondary narrator Odysseus in his long travel-story $\left(O d .9^{-12}\right)$. He does provide background information on the characters and objects of his story at the start of a new episode, even before actually confronting those characters or using those objects. Thus, in the case of the Cyclops adventure, he paints a negative portrait of the Cyclopes at the moment of his arrival in their country (9.IO7-II5) and describes the special wine which he will eventually use to inebriate and thereby incapacitate Polyphemus, at the moment he sets off to meet his as yet unknown opponent (9.197-21 I). In this way he creates suspense and elicits admiration.

I now turn to actorial analepses. Internal analepses are usually short and repeating, for example when an angry Ares complains to Zeus about Athena, who is setting up Diomedes against Aphrodite and himself (Il. 5.883-885), events which had been just narrated (793-86r). ${ }^{17}$ But occasionally we find longer instances, such as when Achilles tells his mother Thetis about the quarrel with Agamemnon which has led to his wrath (Il. I.370-392), or when Odysseus tells the Phaeacian royal couple how he arrived at their island and palace $\left(O d .7 .24 \mathrm{I}^{-}\right.$ 257). ${ }^{18}$ In the Odyssey we find a number of small-scale completing internal analepses, when a character recalls an event which had previously been presented by the narrator and adds new information. An example is to be found in Odyssey 4.653-657, when Noemon, informing the suitors

${ }^{16}$ Other examples: $\mathrm{Il}$. 6.290-292; 22.470-472; Od. I4.7-22. Cf. Griffin I980: I-49.

17 Other examples: Il. 5.206-208; 8.371-372; 15.75-77; 17.35-37; 21.396-398; Od. 5.13-20; 16.227-234; $23.74-77$.

${ }_{18}$ Other examples: $\mathrm{Il}$. I I.6I-65; 18.432-456 (combined with an external analepsis); Od. 7.24I-257 (combined with an external analepsis); I9.273-283; 20.128-I44; 23.40-5I; 24.125-185. 
of Telemachus' secret departure, says that at that time he also saw Mentor (whom the narratees know to be Athena) go on board, but that he later saw him again on Ithaca. Neither Noemon's perception of 'Mentor'/Athena nor of the real Mentor had been recorded by the narrator. ${ }^{19}$

More often characters refer in external analepses to a past which lies outside the boundaries of the main story: (in the Iliad) to events from earlier in the Trojan war (e.g. Odysseus recalling the favourable omen explained by Calchas in Aulis, 2.299-330), to episodes from their life before the Trojan expedition (notably Nestor recalling deeds of valour from his youth; e.g. I.260-273), or to exploits by heroes from the past (e.g. Meleager, 9.527-599);20 (in the Odyssey) to events from the Trojan war or the return of the various other Troy-veterans (Helen recalling an incognito visit to Troy by Odysseus, 4.242-264; Agamemnon telling Achilles about his own burial, 24.37-92), to life on Ithaca before Odysseus' departure (Penelope recalling how Odysseus once helped Antinous' father, I6.424-430), or to heroes from the past (Penelope comparing her fate to that of Pandareus' daughters, who just before their marriage end up in the Underworld, I9.518-523). ${ }^{21}$ In comparison with the Iliad, the Odyssey here shows a development in narrative technique, in that the ten years of Odysseus' return is recounted for its greater part at one go: the four-book long external analepsis told by Odysseus in Odyssey 9-12. ${ }^{22}$

External actorial analepses are unfalsifiable for the narratees, since they do not have the narrator's version for purposes of comparison. The many lying tales which Odysseus recounts in the Odyssey are not a problem, since they are explicitly marked as 'false things that resemble true ones' (Od. I9.203). However, a notoriously less clear-cut case is Penelope's recollection of Odysseus' instructions to her on his departure for Troy (I8.257-27I): did he really tell her that, if he did not return, she should remarry when Telemachus started to grow a beard, or is this story another of her tricks to avoid such a remarriage? In my view, this time Penelope is sincere in her intention to remarry, but invents

\footnotetext{
19 Another example: Od. 22.154-156.

${ }^{20}$ Other examples: (Trojan war) Il. 3.205-224; 6.435-437; i I.I04-Io6; 20.90-96, I87I94; 21.57-59, 76-82; (Nestor) 7.I32-I56; Ir.67I-76r; 23.629-643; (Phoenix) 9.447-984. Cf. Alden 2000.

${ }^{21}$ Other examples: (Ithaca) Od. I.255-264; 4.34I-344; I9.22I-257；23.I90-20I; 24.II4-II9; (mythical past) 5.I2I-I28; 2I.295-304.

22 There are three minor other 'instalments': Od. $3 \cdot 153-364 ; 4.555^{-560} ; 7.244^{-260}$.
} 
this anecdote in order to convince the suitors of her sincerity, and hence to elicit gifts from them. ${ }^{23}$ Some scholars have also wanted to see Odysseus' long travel story in Odyssey $9^{-12}$ as an invention, but here the narrator reinforces its reliability at various points: notably in his proem, where he refers to the slaughtering of Helius' cattle on Thrinacia (I.79). ${ }^{24}$

An interesting phenomenon is that actorial analepses, whether internal or external, are occasionally presented in the form of embedded focalization rather than speech. Most instances are brief, such as '[Achilles scrutinizes Hector's body to find the most vulnerable place] All the rest of the body was covered by his bronze armour, which he had stripped from mighty Patroclus when he killed him' (Il. 22.322-323);:25 it does not seem unreasonable to suppose that this is what flashes through Achilles' mind when he looks at Hector. Once the Odyssean narrator inserts a very long example, the external analepsis on Odysseus' scar, which was inflicted on him in his youth by a boar (Od. 19.393-466). I take this passage to be focalized by his old nurse Euryclea: ${ }^{26}$ at the moment she recognizes the scar the story behind it flashes through her mind.

\section{Prolepses}

Both narrator and characters are wont to make prolepses, ${ }^{27}$ which range from explicit ones (e.g. Zeus telling Hera that 'glorious Hector will kill Patroclus', Il. I5.68) to implicit ones (e.g. where Hector is compared to a boar or lion, whose 'courage kills him', Il. I2.41-50), to mere seeds (e.g. when Patroclus does not take along Achilles' Pelian spear at Iliad I6.I40-I44; this hints at the fact that he is no real second Achilles, but also allows Achilles later to use this very spear to kill the murderer of Patroclus, Hector, Il. 22.133-135, 326-327).

Let me start with the narratorial prolepses. The internal prolepses

\footnotetext{
${ }^{23}$ For a detailed discussion and secondary literature see de Jong 200ra: ad I8.250283 .

${ }^{24}$ Cf. S. Richardson 1996.

25 Other examples: Il. 5.319-320; II.III-II2; 24.479; Od. I3.125-I27; 23.310-34I (indirect speech); $24 \cdot 424$.

${ }^{26}$ For discussion and scholarship (including Auerbach [1946] I953) see de Jong I999, to which should now be added Köhnken 2003 (who attributes the analepsis to the narrator).

27 Cf. Duckworth I933; Hellwig I964: 54-58; de Jong [I987] 2004: 8I-9I; S. Richardson 1990: 132-I39; and Reichel I994.
} 
inform the narratees about developments within the story; for example, when Dolon sets out to spy on the Greeks, the narrator reveals 'but in fact he was never to return from the ships and to bring his report back to Hector' (Il. I0.336-337); the fulfillment follows immediately afterwards, when Dolon encounters Odysseus and Diomedes and is killed (339-468). This prolepsis is typically made with the help of the verb mello, which adds a note of fatality to the future. ${ }^{28}$ As this example makes clear, the prolepsis not only informs but also creates a certain effect. Here it stresses that Dolon's endeavour was doomed from the beginning and hence that the optimism with which he undertook it (I0.319-327) was ill-founded, a blindness which is occasionally noted explicitly by the narrator in the form of a narratorial comment (neppios 'fool'). This special effect is all the more clear in the case of the repetition of prolepses. The Homeric narrator repeatedly anticipates the major events of his story - the deaths of Patroclus, Hector, or the suitors - thus underscoring the importance of the event, creating suspense, pathos (in the case of Hector and Patroclus), or glee (in the case of the suitors).

The effect of narratorial prolepses depends to a large degree on the fact that their information reaches the narratees, but not the characters. Thus in Odyssey 20.390-394, just prior to Odysseus' bloody revenge, the unsuspecting merriness of the suitors is effectively contrasted with the grim determination of the avengers Odysseus and Athena: '[the suitors] were laughing aloud as they prepared a dinner that was sweet and staying, for they had made a very big sacrifice. But there could not be a meal that was more unpleasant than this one, such was to be the attack that the powerful man and the goddess would make on them.'

When we turn to external narratorial prolepses, it appears that the Iliad contains only a handful, most of them concerning the death of Achilles and the fall of Troy. ${ }^{29}$ A lengthy and remarkable one is Iliad I2.3-35, where the narrator relates how the wall around the Greek camp (erected in 7.433-44I), after the fall of Troy and the departure of the Greeks, was destroyed by Poseidon and Apollo with the assistance of natural forces. ${ }^{30}$ This glimpse into the future (which for the narrator

28 Other examples: Il. I2.113-117; 13.602-603; I6.460-46r; 17.497-498; 20.466; 21.47-48; (death of Patroclus:) ir.6o4; i6.46-47, 249-252, 685-691, 693, 787; Od. (death of suitors:) I7.364; 18.155-156; 20.392-394; 21.98-99, 418; (varia:) Od. 24.470-47г.

${ }^{29}$ Death of Achilles: 17.I97; 24.85-86; return of Philoctetes: 2.274-275; fall of Troy: Il. 22.4IO-4II.

${ }^{30}$ Discussion in Reinhardt I96r: 267-269 and Scodel I982. 
is already the past) has a pathetic effect: we find ourselves in the middle of fierce fighting around this very wall, but are reminded that one day there will be no trace of the gruesome battles fought and the many lives lost. The narrator of the Odyssey never refers to events outside his main story: with the return of Odysseus and the happy reunion with his family the story has come to an end.

Turning now to the characters, we note that they are much more inclined than the narrator to make external prolepses, for example when Priam foresees the fall of Troy and his own death (Il. 22.66-76); Achilles' mother, many other people, and even his horses foresee his death, and Tiresias reveals to Odysseus how he must pacify Poseidon, and how he will die (Od. II.I2I-I37) ${ }^{31}$ Recalling that most of the external analepses concerning Troy and Odysseus' nostos were also made by characters, we may conclude that the way in which Homer, though concentrating in his main stories on some fifty or forty days, succeeds in evoking the entire Trojan war and Odysseus' nostos consists in making his characters look backward and forward. ${ }^{32}$

Most of the internal actorial prolepses take the form of plans and fearful or optimistic expectations; for example, (Achilles to Hector in Iliad 22.270-272) 'But I tell you there is no escape for you any longer, but soon Pallas Athena will beat you down under my spear', or (Odysseus to Calypso in Odyssey 5.22I-222) 'And if some god batters me far out on the wine-blue water, I will endure it, keeping a stubborn spirit inside me'. These abound throughout the Iliad and the Odyssey. A special group, consisting of the so-called 'table of contents' speeches, in which (divine) characters explain their plans to other characters, inform the narratees about what they can expect in upcoming books. A clear example is Athena's speech in Odyssey r.8I-95, which delineates the events of books I-5: the encouragement of Telemachus in book I; the Ithacan assembly in book 2; Telemachus' visit to Nestor in Pylos and to Menelaus in Sparta in books 3-4; and Hermes' mission in book $5 .{ }^{33}$

31 Other examples: $I l$. 4.I6o-I68; 6.447-465; 7.40I-402; 22.487-507; 24.244-246, 727-738; (death of Achilles:) I8.59-6o, 89-93, 95-96, 98-120, 329-332, 440-44I, 464465 ; I9.328-330, 409-4I7, 42I-422; 20.I27-I28, 337; 2I.IIO-II3, 277-280; 22.359-36o; $23.80-8 \mathrm{I}, \mathrm{I} 25^{-1} 26$; I44-I5I; $24.85^{-86}, \mathrm{I} 3{ }^{-}{ }^{-1} 32$.

32 Cf. Kullmann ig68.

33 Other examples: Od. 5.30-42; I3.393-415. 
Prolepses, like analepses, may take the form of embedded focalization; for example, Athena broke the waves 'until Odysseus would meet with the oar-loving Phaeacians, having escaped death' (Od. 5.385386); Athena's focalization, in the form of a final clause, announces Odysseus' arrival at the island of the Phaeacians. ${ }^{34}$

Because the Homeric narrator is omniscient, his prolepses in general are reliable, unlike the actorial ones, which, being based on feelings rather than knowledge, need not come true. Thus when the narrator anticipates Sarpedon's death (Il. I6.460-46I), we know it will happen (which it does in 16.479-503), but when Achilles threatens to sail home (Il. I.I69-I7I; 9.356-363), this does not happen. However, this distinction is not absolute, and characters - notably gods, seers, or dying heroes - also make reliable prolepses, for example Athena, who announces to Telemachus the death of the suitors $\left(O d\right.$. I5.3 $\left.3^{\mathrm{I}-} 3^{2}\right) .{ }^{35}$ Conversely, the narrator may employ the technique of misdirection, for example by inserting the duel between Paris and Menelaus in book 3 and for a time suggesting that the war - and hence his story - may come to a peaceful end. ${ }^{36}$

A special form of anticipation, which is strictly speaking not a prolepsis, since the story has not started yet, is the proem, which gives an indication, though not a full synopsis, of the story which follows: the wrath of Achilles, which will lead to the deaths of many (no specific mention is made of the deaths of Patroclus and Hector, nor of the remarkable encounter between Priam and Achilles), and the return of Odysseus (no mention of the killing of the suitors). ${ }^{37}$ While deceivingly similar, the proems of Iliad and Odyssey nevertheless differ as regards their temporal make-up: both herald the theme of the narratives to follow, but the Iliadic proem announces events which, when the story starts, have yet to take place (the wrath of Achilles, which will lead to the death of many Trojans and Greeks), while the Odyssean proem announces events which have already taken place (Odysseus' long wanderings which ended with the loss of all his companions and ships). In the Iliad the transition from proem to the starting point of the story is effected by means of an epic regression (the narrator first going back in

${ }^{34}$ For Athena's proleptic embedded focalization in the Odyssey see de Jong 20ora: ad 3.77-78. Other examples: Il. 15.596-602; i6.644-655.

${ }_{35}$ Examples: Il. I2.215-229; I5.56-77; I6.707-709, 852-854; 18.59-60; 20.339; 22.359-36o; Od. 4.56I-569; II.IOo-I37; I5.I72-178; 20.35'-357, 367-370.

${ }^{36}$ Cf. Morrison 1992.

37 Bassett I923; van Groningen I946; Redfield I979. 
time and then forward again), while in the Odyssey the narrator starts his story at the point where the proem ended, marking the relation between the two sections by entha 'then'/ 'there'.

The abundance of prolepses, together with the fact that the Homeric epics deal with traditional tales, has led many scholars to contend that the notion of suspense is absent from these narratives: at no time are the narratees in the dark as to how the story is going to end. ${ }^{38}$ In my view, this thesis should be modified: ${ }^{39}$ it is true that the narratees can count on Hector to die in the Iliad and Odysseus to come home in the Odyssey, but there are nevertheless moments of suspense, because (I) the exact how and when of the denouement are not disclosed beforehand (how is Patroclus going to die, how is Odysseus going to kill the suitors?); (2) characters are often ignorant of their future, and when sharing their hopes and fears, the narratees may for the moment be less conscious of their foreknowledge (e.g. when Achilles in Iliad 21 or Odysseus in Odyssey 5 expects to drown); (3) the expected or announced outcome may be postponed (e.g. when Achilles' revenge on Hector is thwarted by his nearly fatal encounter with the river Scamander, 2I.228-289);4 (4) the narrator may spring a genuine surprise on his narratees (when Odysseus uses the bow of the contest to kill the suitors); finally, (5) he may insert an open end as in Odyssey I3.125-I87, where we are never told whether Poseidon, after petrifying the ship of the Phaeacians, also executes the second part of his plan, to cover the city of the Phaeacians with a mountain.

\section{Combinations}

Thus far, for the sake of clarity, I have dealt with the Homeric analepses and prolepses separately. Often, however, they are combined in various effective ways. In the first place, we have the juxtaposition of narratorial and actorial analepses, for example in Iliad 2I, where first the narrator informs us that the young Trojan Lycaon had been taken captive by Achilles, sold on Lemnos, and then bought free by a guest-friend (35-

38 E.g. Auerbach [1946] I953: 4; S. Richardson I990: 133.

39 Cf. Schmitz I994 and Rengakos I999.

40 This form of suspense is discussed by Morrison 1992 under the headings of 'false anticipation' ('when the narrator introduces true, persuasive predictions, yet the fulfillment of such predictions is unexpectedly postponed') and epic suspense (when untraditional episodes are inserted which conflict with the narratees' expectations). 
46), then Achilles in surprise asks himself how Lycaon managed to escape from Lemnos (57-59), and finally Lycaon himself refers to the fact that Achilles sold him on Lemnos, in the hope that he would again take him alive (76-82). All of this prepares for the tragic outcome of this encounter: enraged by the death of his friend, this time Achilles shows no mercy and kills Lycaon. Another effect is created in Odyssey 2, where a narratorial analepsis informs us that one of the sons of the Ithacan Aegyptius has been killed by the Cyclops (I9-20), while the father himself, unaware of this fact, expresses his hope that there is news of the return of Odysseus and his son $\left(3 \mathrm{O}^{-}-3 \mathrm{I}\right){ }^{41}$

In the second place, narratorial and actorial prolepses may be effectively combined, as when Achilles prays for Patroclus' safe return ( $\mathrm{Il}$. I6.233-248), but the narrator, in the form of Zeus' negative response to this prayer, reveals that this will not be the case (16.249-252).

In the third place, some of the major events of the Iliad and the Odyssey are anticipated by narrator and characters alike, who also look back on them later, resulting in a dense network of narratorial and actorial prolepses and analepses. A prime example is the death of Hector, which is anticipated by the narrator (I5.6I2-6I4; I6.799-780; 22.5) and characters alike (6.409-4IO, 50I-502 (embedded focalization); I5.68; I6.852-854; I7.20I-208; I8.I32-I33，334-335; 21.294-297), and then looked back on by characters (24.214-216, 384-385, 499-50 $)$.

In the fourth place, there is the device of the 'recalled prophecy', for example when Alcinous recalls the prophecy by his father Nausithous, which foretold that Poseidon one day would smite a ship of the Phaeacians while on their way home from escorting a stranger (8.564-57I). Here we find the combination of an analepsis containing a prolepsis. ${ }^{42}$ Typically, such proleptic analepses are inserted at the moment the prophecy comes true.

Long embedded narratives, which are themselves analepses, may also contain prolepses and analepses. Thus a secondary narrator like Odysseus within the course of his Apologue (itself an external actorial analepsis) both anticipates events ('Listen to what I say, companions, though you are suffering evils, while I tell you the prophecies of Tiresias and Circe. Both have told me many times over to avoid the island of Helius, who brings joy to mortals, for there they spoke of the most dreadful disaster that waited for us', I2.27I-275) and looks back on

\footnotetext{
41 Another example: Il. II.I23-I25+ I39-I4I.

42 De Jong 2001a: ad 2.I7I-I76, where more examples.
} 
them ('Dear friends, this [Charybdis] is no greater evil than it was when the Cyclops had us cooped in his hollow cave by force and violence, but even there by my counsel and my intelligence we escaped', I2.208-2I2).

\section{Simultaneity and parallel storylines}

A specific Homeric device for handling time in connection with parallel storylines is what has become known as 'the law of Zielinski'. ${ }^{43}$ It consists of two parts. (I) The Homeric narrator does not retrace his steps: when he moves from one storyline to another, time ticks on and storyline B continues where storyline A left off; while one storyline is in the foreground, the other remain stationary, that is, time ticks on, but nothing important happens. (2) When two storylines are announced; for example, when a character issues two orders, their fulfillment is told successively, but they should in fact be thought of as occurring simultaneously; thus Zielinski reconstructs a real action, as opposed to the apparent action which we find in the text. The first part of this law is by and large correct and is also known as the 'continuity of time' principle. As always, this rule is proved by its exceptions, in that occasionally the narrator does retrace his steps (e.g. in Il. I5.390-394; cf. I I.842-I2.2) ${ }^{44}$ or important developments do occur in the background (e.g. in Od. I5.30 I495: while Odysseus and Eumaeus converse, Telemachus manages to sail home safely). The second part of this law is less convincing: in the case of the execution of two orders, successive really means successive, as can be proven by the fact that characters belonging to storyline $\mathrm{B}$ react to events from storyline A. For example, in Iliad I5.I43-262 Zeus summons both Iris and Apollo, then first sends Iris to stop Poseidon from fighting, and then, when the Iris-storyline has been completed, instructs Apollo to revive Hector, referring to the fact that Poseidon has stopped fighting. ${ }^{45}$ An even more famous example is the second divine council in Odyssey 5, which does not mean a return in time to the first council of book I, since Athena, reiterating her plea to help Odysseus,

43 Zielinski I899-I9oi.

44 Other examples: Il. I6.508 (cf. 492-50I); Od. I6. I-3 (cf. I5.495); and I7.492493 (cf. 462-465). Cf. Rengakos I995 and Nünlist I998b. It should be noted that in most cases the return in time is accomplished in that characters focalize an event earlier recounted by the narrator, which 'camouflages' the fact that the narrator is retracing his steps.

45 Cf. Patzer i99o and Rengakos I995. 
now adds the latest developments on Ithaca (5.18-20), which took place in books 2-4.

Of course, should he so wish, the narrator is perfectly capable of presenting simultaneous actions, for example in Odyssey 8.438-448, where he explicitly notes that the little scene of Arete handing over a chest to Odysseus takes place while the water for his bath is getting warm. ${ }^{46}$ Then there is the technique, already mentioned by Zielinski, of rapid changes of scene, which create an impression of simultaneity. An example is found in Odyssey I7.492-6o6, where the narrator switches rapidly between Penelope's upper room and the megaron, where 'the beggar' / Odysseus, the suitors, and Telemachus find themselves. ${ }^{47}$ Finally, there is the most frequent and the most inconspicuous form of simultaneity, namely that conveyed by changes of scene via men ... de or similar expressions: since the men-clause usually contains a verb in the imperfect, the suggestion is clearly that while we turn to another place or storyline, the action in the first place continues. The Homeric narrator often exploits this simultaneity by contrasting the two actions; for example, 'So the Trojans (men), panicked like deer, spread through the city, dried their sweat and slaked their thirst, but the Greeks (de) came up closer to the wall ... and his fate shackled Hector to stay outside' (Il. 22. I-6).

\section{Rhythm}

The Homeric epics, with their large proportion of speech (45 percent in the Iliad and 66 percent in the Odyssey), contain many scenes. And even when heroes are acting rather than speaking their actions are usually described at a leisured pace and hence scenically. For example, Telemachus' departure for Pylos is narrated in full detail: the bringing of provisions on board, taking their seats, raising the mast, and pouring libations for the gods (Od. 2.414-433). As in most narratives, scenes alternate with summaries; thus the scene of Telemachus' departure is capped by a summary: 'all night long and into the dawn the ship ran on her journey' $(O d .2 .434) \cdot{ }^{48}$

\footnotetext{
${ }^{46}$ For other instances of simultaneity see de Jong 20ora: ad 8.438-448.

47 For a detailed analysis see de Jong 2001a: ad loc.; another example is Odyssey $4.625^{-8} 847$.

${ }^{48}$ For discussion and more examples see S. Richardson I990: 9-30.
} 
The many Iliadic battle-scenes in particular display an effective combination of scene and summary, whereby the narrator starts off and caps such episodes with an impression of the general array, and in between zooms in on the actions of individual warriors. An example is Iliad 16.394-637: [summary:] 'Now when Patroclus had cut through the leading Trojan battalions, he penned them back again towards the ships, and would not allow them their desire to reach their city, but in the space between ships and river and high city-wall he kept charging and killing' (394-398) ...; there follows a series of individual scenes culminating in Patroclus killing Sarpedon (399-63I) ...; [summary:] 'Then like the crashing that arises in the glens of a mountain when woodcutters are at work ... so from the wide-wayed earth rose up the thud and clash of the men's bronze and well-made ox-hide spears, as they thrust at each other with swords and double-pointed spears' (63I-637).

In the course of a scene the narrator may further slow down his pace and insert a close-up, for example the wounding of Menelaus by Pandarus, which is presented at great length and in great detail (the arrow going through the elaborate belt, the worked corselet, and the skirt-piece, until it scratches the surface of Menelaus' flesh, Il. 4.I30-I47). A quite horrifying example of slowing down is found when Patroclus is given the first, mortal blow by Apollo (I6.79I-804) and we hear in harrowing detail how the god strikes his back and shoulder, knocks the helmet from his head, how his 'long-shadowed spear, huge, heavy, massive, and tipped with bronze' was shattered in his hand, how his shield dropped and his corselet was broken off. It is as if we are witnessing an arming scene in reverse and slow-motion.

In Homeric scholarship the term 'retardation' was introduced by Goethe ${ }^{49}$ not only to refer to the slowing down of the narrative pace, but also the postponement of an expected event, either by inserting a reversal of the action (e.g. the Trojans, who have the upper hand according to Zeus' plan, are in books I4.I-I5.235 themselves temporarily repulsed), or by interrupting the action (Achilles' revenge on Hector, which he announces in I8.II4-II5, is postponed until book 22, through the insertion of numerous incidents, notably the fight with the river Scamander, 21.136-382, and the Theomachy, 21.385-520).

When there is no fabula-time which corresponds to the story-time, we are dealing with a pause: the story comes to a standstill. Such pauses

${ }^{49}$ For a discussion of the term and of examples see Reichel 1990. 
are rare in Homer. The only examples are the narratorial external analepses on characters and objects, which were discussed above. As Lessing famously remarked in his Laokoon, the Homeric narrator prefers to describe objects dynamically, as in the case of the Shield of Achilles, which is not presented as a finished object, but is described as it is being made by Hephaestus. Another way of avoiding pauses consists in having something focalized by one of the characters. Thus most descriptions of scenery are focalized by characters (e.g. Hermes, taking in the scenery of Calypso's island in Odyssey 5.63-75), which means that the story does not come to a complete standstill. Even the description of the Phorcys bay (Od. I3.96-II2), though focalized by the narrator rather than by one of the characters, is not static, in that at the moment the description starts the ship is said to be approaching the bay (95), while at the moment it ends, the ship has entered it (II3).

The reverse of a pause is ellipsis: when no story-time corresponds to fabula-time, an event is not recounted at all. This device is employed in the Homeric epics in order to skip relatively unimportant or selfevident events: for example, in Iliad r6.432 Zeus speaks with Hera on Mount Ida; earlier (in I5.79) we had been told that Hera went from Mount Ida to the Olympus, so her return from the Olympus to Mount Ida (somewhere between I5.79 and I6.432) has been left out. ${ }^{50}$ But ellipses are also typical of the allusive style of many external analepses: because the stories are well-known, their narrators can leave out details, motives, prehistory, etc., relying on the narratees to fill them in. An example is the story of the battle between the Centaurs and Lapiths, as recounted by Antinous in Odyssey 21.295-304: all we are told is that the Centaur Eurytion became drunk in the palace of Peirithous and that a fight ensued; the larger context (the Centaur's attempt to rape Peirithous' bride Hippodamea) is omitted. This allusive style will become typical of choral narration $(\rightarrow$ Pindar, $\rightarrow$ Aeschylus, $\rightarrow$ Sophocles) and Hellenistic poetry ( $\rightarrow$ Theocritus).

Taking into account the rhythm of the Homeric epics as a whole, we may note that the Iliad starts and ends with summaries (book r: nine days of plague, nine first days of Achilles' wrath; book 24: nine days of mutilation of Hector's corpse, nine days of gathering wood for Patroclus' burial), while in the middle slows down, when describing the four climactic battle days featuring the death of Patroclus and

\footnotetext{
50 The scholia already noted this phenomenon, which they subsumed under the
} category kata to siōpōmenon (lit. 'according to the unexpressed'). 
Hector. In the Odyssey most summaries are found in book 5 (four days of building the raft, seventeen days of safe journey, two days of storm), while before that we have the series of scenically presented visits by Athena/Mentes (to Ithaca) and Telemachus (to Pylos and Sparta), and afterwards the protracted days of Odysseus' return to his own palace and of the contest of the bow, the killing of the suitors, and the reunion with Penelope.

\section{Frequency}

The default form of frequency in the Homeric epics is singulative: each event of the main story is recounted once. Indeed, these narratives are singulative to an almost unique degree, in that even the recurrent acts of daily life, retiring to bed, eating, preparing a ship - which most narratives tend to skip except when thematically significant - are presented more or less each time they occur, in the form of type-scenes.

Occasionally the Homeric narrator turns to iterative narration, for example when recounting the first days of Achilles' wrath: '[Achilles] sat idle by his speedy ships and kept up his wrath. He never went to the assembly where men win glory, nor into the fighting, but stayed where he was, wasting his heart out day after day, and yearning for the clamour of battle' (Il. I.488-492). Most instances of iterative narration function as summaries, ${ }^{51}$ but there is also the special case of simultaneous iterative narration, which is used in connection with the habitual actions of gods; for example, Athena 'took her powerful spear, edged with sharp bronze, heavy, huge, thick, with which she is wont to beat down the battalions of fighting men against whom the daughter of the mighty father is angered' (Od. I.99-IOI). This narrative mode is found again, in similar divine contexts, in the Homeric hymns $(\rightarrow)$ and Hesiod $(\rightarrow)$. Finally there is the iterativity of the similes, which recount recurrent events of all times; for example, 'the Argives roared loud, like the waves on a sheer headland, when the south wind whips them with its coming, and they roar against a jutting cliff' (Il. 2.394-397); hence it is customary to speak of the similes as omnitemporal.

When we turn to repeating narration, we see that the narrator never employs large scale repetition where the main story is concerned: just

51 Cf. S. Richardson 1990: 2I-30 on iterative summary. 
as he (almost) never retraces his steps, he does not go over the same ground twice. We do, however, find small-scale instances, which mainly have to do with the organization of his narrative: he may insert a 'header' at the beginning of an episode (e.g. 'Menelaus took Adrastus alive', Il. 6.37), which is then followed by an elaboration (the narrator explains how Adrastus' horses had become tangled in the shoots of a tamarisk and Adrastus therefore had to beg Menelaus for his life); ${ }^{52}$ or he may add a concluding recapitulation at the end of an episode ('Thus commanding he [Agamemnon] went round the ranks of men', Il. 4.250$) ;{ }^{53}$ or he may mark off a passage through ring composition at its beginning and end (e.g. 'But illustrious Odysseus remained in the hall, pondering how, with the help of Athena, he would murder the suitors', which we find in I9.I-2 and $19.55^{-}-52$, while in between we hear about what Odysseus is pondering). ${ }^{54}$ The devices of the 'header' followed by elaboration, the concluding recapitulation, and ring composition will recur in Hesiod $(\rightarrow)$, Pindar $(\rightarrow)$ and Bacchylides $(\rightarrow)$, and drama, but also in prose texts, such as Herodotus' Histories or in the narrative parts of oratory.

A special - complex - form of ring composition is the device of the 'epic regression', which means that a narrator mentions an event, then (in a number of steps or in one go) moves back in time to a certain point, and then (in a number of steps) again moves forward until the first event is reached again. An example is Iliad I.8-305: (D) Apollo caused Agamemnon and Achilles to quarrel (8-9a) - (C) for he sent a plague $(9 \mathrm{~b}-\mathrm{IO})$ - (B) because Agamemnon did not treat Chryses with respect (II-I2a)-(A) when he came to ransom his daughter (I2b2I) - (B') Agamemnon did not treat Chryses with respect (22-33)-(C') Apollo sent a plague $\left(34^{-} 5^{2}\right)$ - (D') Achilles and Agamemnon quarreled $\left(53^{-}{ }^{-305}\right) \cdot{ }^{55}$ This technique is also found in Pindar $(\rightarrow)$ and the choral lyrics of Aeschylus $(\rightarrow)$, Sophocles $(\rightarrow)$, and Euripides $(\rightarrow)$. Both ring composition and epic regression are also employed by secondary narrators, for example Achilles in Iliad 24.602-6I3 (ring composition) or Nestor in Iliad I I.67I-76 I (epic regression).

\footnotetext{
${ }^{52}$ Other examples: $\mathrm{Il} .3 .328-329 ; 6.156-159 ;$ I6.257-258.

${ }^{53}$ For more examples see S. Richardson I990: $3{ }^{\mathrm{I}}-35$ on appositive summary.

${ }^{54}$ For more examples see van Otterlo i944.

${ }^{55}$ Schadewaldt [1938] 1966: 84. This device was already noted by the scholiast, who called it 'narration in reverse order'. The device is also known as 'lyric narrative'. It is a form of anachronical narration.
} 
In another form of repetition, narrator and characters deal with the same events, the so-called mirror-story (or internal actorial analepsis). One example is Achilles' report to his mother Thetis on the mission of Chryses, the plague, the quarrel with Agamemnon which led to his wrath, and the carrying away of Briseis (Il. I.370-392), an account which repeats - with interesting changes in focalization - what the narrator had recounted just before $\left(\right.$ I.I2-347). ${ }^{56}$

Finally, there is the repetition of actorial analepses. Different characters may tell the same story, as in the case of the story of Tydeus' embassy to Thebes, which is told by Agamemnon in 4.372-398, Athena in 5.802-808, and Diomedes in 10.285-290.57 Although recounting the same story, these passages may vary in greater or lesser detail due to the personalities of speaker and addressee, and the context and purpose of speaking. Occasionally we find the device of 'piecemeal distribution', which means that the narratees only gradually get to hear the whole story. A complex example is the set of stories of the nostoi of Agamemnon, Odysseus, and Menelaus in the Odyssey, which are distributed over Nestor, Menelaus, and Odysseus, who complement each other. Thus, in the case of Agamemnon, Nestor is able to tell Telemachus that when half of the Greeks departed from Troy, Agamemnon stayed behind (3.I30-I56) and that having come home he was killed by Aegisthus (3.193-194). The intervening period, Agamemnon's voyage from Troy to Greece is then later filled in by Menelaus $\left(4 \cdot 5^{12-523}\right)^{58}$

\section{Conclusion}

This chapter has shown that just about the whole arsenal of timerelated narrative devices which modern narratology has identified is to be found in Homer. The narrator recounts the main story by and large in chronological order and without retracing his steps, singula-

\footnotetext{
${ }^{56}$ Cf. de Jong [1985] 2002 and [1987] 2004: 216-218, where also more secondary literature is given. For other examples see n. I8.

${ }^{57}$ Cf. Alden 2000: II2-I52. Other examples: Il. I4.249-26I and I5.I8-30 (Hera and Heracles); 5.638-642, 648-65I; 7.452-453; 21.44I-457 (Laomedon); I8.84-85, 432-434; 24.59-6I (marriage of Thetis and Peleus); Od. 2.93-IIO; I9.I38-I56; 24.I28-I50 (Penelope's web); 4.27I-289; 8.499-520; II.523-532 (the Wooden Horse); I9.5I8-529; $20.66-$ 82 (Pandareus' daughters). For discussion and secondary literature on the Odyssean examples see de Jong 200ra: ad locc.

58 Cf. U. Hölscher I989: 94-IO2; de Jong 2001a: 59I-593. Another example is the gradual revelation of Zeus' will, for which see Duckworth I933: 39 .
} 
tively, and via an alternation of scenes (the greater part of the story) and summaries. His analepses and prolepses are for the most part internal, inserted for the benefit of the narratees and as a means of tightening the structure of his story. His external analepses concern the background of characters and objects, and hence are heterodiegetic. For homodiegetic external analepses and prolepses, which sketch the prehistory and aftermath of the Iliad, we must turn to the characters. Thus there is a neat division of labour between narrator and characters.

While the rhythm of epic narration is typically slow (epische Breite), external analepses concerning well-known 'mythological' events are told in an elliptic, allusive style, which will become the hallmark of later lyric narrative. 
Irene J.F. de Jong and René Nünlist - 978-90-47-42293-8 Downloaded from Brill.come4/26/2023 09:46:52AM via free access 


\title{
CHAPTER TWO
}

\section{HESIOD}

\author{
R. NÜNLIST
}

\section{Theogony}

The subject matter and general structure of the Theogony proper (II6ff.; on the introductory 'Hymn to the Muses' see below) are dominated by the genealogies of the Greek pantheon, which are presented in what essentially is a chronological order. After asking the Muses to tell him 'from the beginning' (ex arkhess) and to 'say what thing among them came first' (II5), the Hesiodic narrator opens the Theogony as follows: 'First (prōtista) came the Chasm (Chaos); and then broad-breasted Earth (Gaia) ...' (I 6; tr. West). He goes on to narrate the birth of the gods and divinities who belong to the first generation (children of Chaos and Gaia), the second (children of Gaia's children Uranus [the Titans] and Pontus, and of Chaos' child Night), the third (grandchildren of Pontus and Uranus; esp. Zeus and his Olympian siblings) and the fourth (the children of the Olympians) respectively. ${ }^{1}$ While the general sequence of these genealogies is chronological, it is clear that the narrator's goal is not to maintain a rigid chronology. He regularly pushes ahead and narrates the birth and experiences of divine characters who belong to the same family branch, especially if 'the end of a branch is in sight'. ${ }^{2}$ Genealogical method and transparency prevail over strict chronology. An illustrative example comes from the passage on Pontus' children Phorcys and Ceto and their children: Ceto gives birth, among oth-

\footnotetext{
${ }^{1}$ Scholars have long noted that the first three generations of gods occur, in reverse order, in the 'Hymn to the Muses': II-2I. For an attempt to explain the reverse order see Muellner 1996: 54-55 with n. 7 (but cf. n. 3I below). Note that the counting of divine generations (first, second, etc.) is a modern abstraction. The Hesiodic narrator himself always speaks in terms of genealogy. Contrast the myth of the races in Works and Days, where the counting is his own. Occasionally, the narrator indicates the sequence of children that are born from the same mother (cf. n. 9).

2 M.L. West I966: 38.
} 
ers, to the Gorgon Medusa (276), who, together with Poseidon (278), begets Chrysaor and Pegasus (28I), with Perseus acting as an unusual 'midwife' (he cuts off Medusa's head, 280). Chrysaor, together with the nymph Callirhoe, begets Geryoneus (287), who is killed by Heracles (289) on account of his cattle (the tenth of Heracles' labors). The narrator gives up strict chronology in order to make clear the details of a family tree. Not only does he push down the family line by several generations (when the section on Phorcys and Ceto and their offspring comes to an end in 337, the narrative will return to the Titans Oceanus and Tethys, who belong to the same generation as Phorcys and Ceto), he also accepts the mild paradox that his narrative presupposes the presence of characters who strictly speaking are not born yet: in the present case Poseidon (birth narrated in 456), Callirhoe (35), and Heracles (943). While it is true that the Hesiodic narrator has no difficulties with the presence of such characters, it must also be said that the relevant passages mostly are comparatively short (i.e. summary; see below). ${ }^{3}$ Some scholars treat passages with 'unborn' characters as a form of prolepsis, which is a less than fortunate extension of the concept. ${ }^{4}$ The narrator does not really 'look ahead' to the future birth of a character, but simply allows his narrative to jump ahead to a time when the character was born already.

Such chronological 'inconsistencies' (if the term is appropriate) occur regularly and at both a larger and a smaller scale. An example of the former is the passage that has just been interpreted. An example of the latter can be found in the passage about the birth of Aphrodite. Cronus cuts off Oceanus' genitals and throws them behind himself into the sea, while Gaia receives the drops of blood: 'and as the year went round she bore the powerful Erinyes and the great Giants in gleaming armor with long spears in their hands and the nymphs whom they call Meliai on the boundless earth' (I84-187). After briefly indicating what happens to the blood drops, the narrator sets back the clock, so to speak, by one year and returns to Oceanus' genitals, from which Aphrodite is born

\footnotetext{
${ }^{3}$ Cf. Meyer I887: 2I-22, who argues that, in the sequence of the Theogony's story, Zeus' birth precedes Prometheus', because Hesiod did not want to confront Prometheus with an 'unborn' Zeus in this extended scene. The objections by J.S. Clay 2003: I05 n. I2 do not address Meyers' point about the length of the relevant passage.

${ }^{4}$ Cf. esp. Stoddard 2004: I45-153, similarly her mentor J.S. Clay 2003: I5. Stoddard's use of 'prolepsis' appears to be indebted to Robert [1905] I966: I63, who, of course, did not know Genette's model.
} 
(188-192). Whether on a large scale or small one, the narrator adheres to a form of narrative economy in that he can deal with the relevant character or topic once and for all (they usually do not return in the course of the Theogony). By sacrificing a strictly chronological narrative and allowing himself to cover the same temporal ground twice, he frees himself of the necessity to cover the same thematic ground twice. ${ }^{5}$

Perhaps one can even argue that a transparent chronology matters little to him. Not only does he not count the generations (n. I), there are virtually no temporal markers such as 'in the meantime', 'to return to $\mathrm{X}$ ', etc., which would help the narratees orient themselves. ${ }^{6}$ As a result, it is not always easy to determine the exact temporal relationship between events. And if it can be determined (Hecate's birth, for example, apparently precedes the Titanomachy, Th. 424), this determination is usually due to 'circumstantial evidence' and not to the narrator's efforts to clarify the temporal picture. He seems to have little interest in providing this kind of information. ${ }^{7}$

Yet another 'violation' of a purely chronological narrative can be found in the well-known story of Prometheus. It is presented as follows (52 I-534): Zeus bound Prometheus and sent an eagle that would torment him. Later, Zeus allowed Heracles to kill the eagle, thereby giving up his previous grudge against rebellious Prometheus. At this point, the narrator steps back in time and explains (introduced by kai gar, 535) in some detail how Prometheus twice attempted to outwit Zeus. At the end of the long section, which includes the creation of Woman (called 'Pandora' in Works and Days) and its consequences for humankind, the narrative returns to Prometheus' in chains (6I6), that is, the approximate point where the narrator had left the chronological sequence of events. ${ }^{8}$ It could perhaps be argued that the bulk of the Prometheus

5 This explanation, which in essence is M.L. West's (I966: 37-39), has been criticised as 'rather mechanical' and 'not very helpful' (J.S. Clay 2003: i3 n. 3). To my mind, J.S. Clay's (2003: 12-30) own analysis (indebted to Muellner I996: 52-93), which cannot be rehearsed here, does not force us to dismiss M.L. West's insights.

${ }^{6}$ An exception is the completing analepsis in Theogony 617-623. It recounts the Hundred-Handers' binding by their father Uranus, which contains the explicit temporal marker 'when first' (hōs prōta).

7 This, of course, is not to say he could not do it. Some scholars seem to lean in that direction (e.g. M.L. West I966: ad 450), but it might be more prudent to say that the Hesiodic narrator shows little interest in maintaining strict chronology.

8 'Approximate point', because the present tense in 616 (erukei) describes a permanent status and not a specific moment (note that in Hesiod's version Heracles does not release Prometheus, M.L. West I966: 313). Whether the eagle is still thought to be alive 
scene $\left(535^{-616)}\right.$ is in fact an explanatory analepsis, which itself is narrated in chronological order. In any case, the events of $535^{-6}$ I 6 precede those narrated in $5^{2{ }^{-}-534}$.

If the Theogony at large is determined by the sequence of divine generations, a similar pattern can be seen at work on a smaller scale too. The order in which the members of one family are born usually determines the sequence in which these members and their respective offspring are taken up by the narrator. ${ }^{9}$ While this usual sequencing of events applies to the bulk of the Theogony, the clearest counter-example can be found with the Titans. 'The order in which they are listed in ${ }^{13} 3^{-1} 3^{8}$ bears no relation to that in which their families are catalogued in $337^{-}{ }^{1 \mathrm{II}^{\prime}} \cdot{ }^{10}$

As we have seen, the Theogony exhibits a good number of passages that do not preserve a strictly chronological order of events. Conversely, neither of the two devices that are normally treated as instances of 'anachrony', analepsis and prolepsis, is particularly frequent. ${ }^{11}$ Probably the most striking example of a completing analepsis is when the narrator relates that Uranus had put the Hundred-Handers in chains (6r7-623, marked off by 'when first'; cf. n. 6). Similar, though shorter and therefore less noticeable, is 502 on the binding of the Cyclopes. ${ }^{12}$ Elsewhere the analepsis seems to emphasize the difference between two different stages (in which case the analepsis is repeating): while the tide of the battle has turned now in favor of Zeus' side, the Titans and Olympians had before (to prin) been fighting on equal terms for a long time (7II-7I2). Still other instances have the typical function of providing the logical or factual basis of the current situation, for example when Cronus swallows all his children, 'for he learned from Earth (Gaia) and starry Heaven (Uranus) that it was fated for him to be defeated by his own child, powerful though he was, through the designs

in 616 remains unclear. While the eagle is not specifically mentioned in $613-616$, the same passage speaks of Zeus' anger (kholos), which, according to 535, he gives up when he allows Heracles to kill the bird.

${ }^{9}$ In this connection, the narrator occasionally specifies that a child is the 'youngest' (hoplotatos): Cronus at I37, the apple-garding serpent at 333, Zeus at 478 , etc.

${ }^{10}$ M.L. West 1966: 38-39.

11 The analysis of anachrony in the Theogony by Stoddard 2004: I26-I6I must be used with caution (cf. above with n. 4).

12 The anachronies as such are noted by M.L. West ig66: ad 502, 617, who, however, makes compositional problems ( $\mathrm{ad} 502)$ or a violation of Zielinski's law (ad 617, similarly ad $7 \mathrm{II}-7 \mathrm{I} 2)$ responsible for what he appears to consider a flaw of the narrative. But why should the Hesiodic narrator not be allowed to insert completing analepses? 
of great Zeus' $\left(463-465\right.$, introduced by gar). ${ }^{13}$ All these analepses are internal. External analepsis is a priori excluded, because the Theogony begins at the very beginning (I 6 )..$^{14}$

Narratorial prolepsis is rare in the Theogony (e.g. 'and he [Zeus] boded evil in his heart for mortal men, which was to come to pass', 552). There is, however, a particularly memorable example that resembles the explicitness of Homer's neppios-passages. Instead of the infant Zeus, Rhea has Cronus swallow a stone wrapped in a cloth. The Hesiodic narrator comments: 'the brute (skhetlios), not realizing that thereafter not a stone but his son remained, secure and invincible, who before long was to defeat him by physical strength and drive him from his high station, himself to be king among the immortals' (488-49I). The explicit narratorial comment in the form of a prolepsis draws particular attention to the imminence of what the narrator arguably considers the most important event of the Theogony: Zeus' accession to the throne. In this particular case, it is clear that the prolepsis is internal. In other cases (if there were any), the determination might turn out to be difficult because there is no way of telling where exactly the Theogony ends. ${ }^{15}$

Examples of actorial prolepsis are not very frequent either. Uranus utters the threat that the wanton behavior of his children, the Titans, will be punished (2I0). This threat of punishment can be seen as a prolepsis of their defeat in the Titanomachy with subsequent confinement to Tartarus. ${ }^{16}$ Likewise, Gaia predicts that the Olympians will defeat the Titans if they enlist the Hundred-Handers as allies (627-628). Elsewhere, it is the vagueness (or even absence) of an actorial prolepsis that is noticeable. Thus when Rhea's parents tell her 'all that was fated to come to pass concerning Cronus the king and his stern-hearted son' $(475-476)$, the prolepsis remains tellingly vague. However, the narratees will have known or guessed that Cronus' time is over.

One of the more prominent temporal features of the Theogony is the frequent changes in narrative speed: short and therefore summary

\footnotetext{
${ }^{13}$ Cf. 505 (previously, Gaia had hidden thunderbolt and lightning), 894-898 (destiny regarding Metis' children; this narratorial analepsis encloses an actorial prolepsis).

${ }^{14}$ Frazer 198I ignores this when he argues that passages such as Theogony 7II-7I2 precede the time of the main narrative and are therefore in accordance with what he considers Zielinski's law.

15 Cf. e.g. J.S. Clay 2003: 30.

16 M.L. West ig66: ad loc.
} 
passages (usually genealogical and often catalogue-style) alternate with fairly extensive stretches of narrative (usually with a non-genealogical subject matter). ${ }^{17}$ The latter are perhaps best described as expansion of the former: ${ }^{18}$ the narrator decides to add narrative flesh to the bare bones of the genealogical skeleton. Needless to say, some of the most memorable episodes of the Theogony fall into this category: Gaia's plan with subsequent castration of Uranus by Cronus and the birth of Aphrodite (154-206*), Zeus' birth and the subsequent overthrow of Cronus (453-506), Prometheus' tricks and punishment (52I-6I $6^{*}$ ), the Titanomachy $\left(6 \mathrm{I} 7-720^{*}\right)$, Zeus' fight against Typhoeus (820-868). In several cases (indicated by *), the narrative speed is further slowed down by the insertion of speeches. Contrary to these passages of 'slow' narrative, the instances where the narrative is allowed to jump ahead in time tend to remain summary and not linger on the subject matter. Exceptions are the somewhat longer passages on Styx and Hecate (389-403, 4I $\left.{ }^{\mathrm{I}}-449\right)$. The latter is in 'omnitemporal' narration.

Changes of narrative speed can, of course, occur within a single episode. Thus in the passage that finally leads to the overthrow of Cronus, the swallowing of the other children is narrated summarily $(459-467)$. Once the narrative is about to reach the climactic moment (signaled by the temporal marker 'but when ... then', all' hote de $\ldots$ tot' epeita, 468-469), the narrative is slowed down by the insertion of more details. If the tension is increased here by reducing the narrative speed, elsewhere a similar effect of suspense is achieved by inserting a nonnarrative element: when Zeus exposes the inequality of Prometheus' meat portions, his angry reaction is postponed by an aetiological explanation of human sacrifice (556-557), a quite un-Homeric way to handle the climax of a story. ${ }^{19}$ Another good example of retardation comes from the Titanomachy. An alliance with the Hundred-Handers will lead to a victory by the Olympians (627-628), and the relevant conversation is treated in some detail $\left(643^{-664)}\right.$. If the narratees, however, expect that the new allies will cause an immediate victory, their

17 Some scholars treat only the latter as narrative. For a defence of the genealogies as narratives see Muellner I996: 56 . The difference is simply one of narrative detail, that is, speed.

${ }^{18}$ E.g. Muellner 1996: 6o on Th. I54ff. Cf. also the pattern 'initial summary with subsequent elaboration' ( $\rightarrow$ Homer, $\rightarrow$ Pindar, $\rightarrow$ Herodotus) and in general van Groningen 1958: 66 .

${ }^{19}$ Cf. $S A G \mathcal{N}$ i:3o. 
expectations are thwarted. A fairly long account of the battle (esp. the various cosmic reactions to it) precedes the actual victory, which is dealt with rather summarily (71 I-720).

As to the time span that these 'slower' passages cover, there is a certain variety. A comparatively short time span can be assumed (the narrator does not say) for the castration of Uranus (I59-I82). Conversely, the story about Zeus' birth covers a time span that is somewhat longer, as can be gathered from the temporal markers. Rhea gets to Crete 'during the black night' (48I). More importantly, a marker of temporal ellipsis shows that 'within a year' (493) Cronus is defeated by an apparently grown-up Zeus. ${ }^{20}$ One year, of course, is a very quick coming of age (typical of gods), but nevertheless makes this account one of the 'longer' stories in the Theogony. The longest in absolute terms is the Titanomachy, the beginning of which is an analepsis (see above). After they are put in chains by their father Uranus, the Hundred-Handers suffer 'for a long time' (623) until Zeus enlists them as allies against the Titans. This fight has been going on 'for a long time' (629), which is then specified as 'ten full years' (636). It is, however, true that this long period is only mentioned en passant in the form of an explicit temporal ellipsis, whereas the actual fighting in alliance with the HundredHanders is a comparatively short matter (cf. the treatment of the Trojan war in $\rightarrow$ Homer). The Hesiodic narrator does not specify its length, but ominously mentions 'that day' (émati keinōi, 667) when the decisive battle took place.

Another prominent feature of the Theogony is directly related to its subject matter. Given that the overwhelming majority of the characters are immortal, the narrator inevitably resorts to simultaneous iterative narration when he describes their functions and spheres of activity. ${ }^{21}$ It goes without saying that the same holds true for any narrative that happens to deal with the eternal characteristics of immortal beings $(\rightarrow$ Homer, $\rightarrow$ Homeric hymns, $\rightarrow$ Callimachus). The sole difference is that the frequency of passages in simultaneous iterative narration is directly related to the prominence of the divine characters in a particular text. ${ }^{22}$ Therefore, they are comparatively frequent in the Theogony. Examples include the workings of the following divinities: Eros (I2O-I22), the

20 Cf. the similar marker in 184 (pregnancy of Gaia).

21 For the argument that such passages should nevertheless be treated as narrative see $S A G \mathcal{N}$ i:26.

22 For a differentiation of this view see Homeric hymns $(\rightarrow)$. 
Fates (218-222), the Harpies (268-269), Eos (372-373), Hecate (416420, 426-449), Night and Day (748-757), Death and Sleep (759-766), Cerberus (769-773), Styx (780-787, 793-804), etc.

Apart from these passages, which are not only simultaneous but also contain a certain element of repetition, the bulk of the Theogony is characterized by a narrative mode that is subsequent and singulative. ${ }^{23}$ Occasionally, however, the narrator resorts to iterative narration. A good example is Uranus repeatedly hiding away his several children (I57). ${ }^{24}$ Even more memorable (due to its horrible implications) is the eagle that 'fed on his (Prometheus') liver, which grew the same amount each way at night as the great bird ate in the course of the day' $\left(5^{24-}\right.$ 525). Subsequent narration means that the action is located in the past, which, given the subject matter of the Theogony, most likely is a very distant past, but the issue remains vague. ${ }^{25}$ Conversely, passages in 'omnitemporal' narrative mode automatically affect the narrator's own time too (witness the present tenses). This effect on the narrator's own time is made particularly clear on one occasion when the section on Hecate's workings is introduced by the telling remark 'even now' (kai gar nun, $4 \mathrm{I} 6) .{ }^{26}$

The introductory 'Hymn to the Muses' (I-II5) is best treated separately for the purposes of a narratological analysis. ${ }^{27} \mathrm{~A}$ temporal feature that sticks out is the high proportion of simultaneous iterative narration as opposed to subsequent singulative narration. The latter mode, which is overall much more common in narrative literature, pertains to the Hymn's best-known scene, the Dichterweihe (22-35), to most of the passage on the birth of the Muses (53-6o), including lines 68-71, which

23 This poses a problem to the view of Neitzel i980: 397-398, endorsed by J.S. Clay 2003: 65-66, that ta t'essomena pro t'eonta ('things of the future and things that were aforetime') in Theogony 32 does not refer to 'Menschliches und Zeitliches', but designates 'das ewig Göttliche' and 'besagt nichts anderes als ta aien eonta' ('things that are for ever'), in which case one would expect considerably more simultaneous iterative narration in the Theogony. It is true, however, that there is virtually no 'prophecy' (i.e. prior narration) either. The correlation between Theogony 32 and the Theogony itself remains difficult.

${ }^{24}$ Marked by iterative hopos + opt. in the subordinate clause and the frequentatives apokruptaske and ouk anhieske in the main clause. Cf. the frequentative kaleeske in 207 (of Uranus calling his children 'Titans'; the past tense is at first surprising, but can perhaps be explained in such a way that a god bound in chains is as good as dead).

25 Occasionally (29I, 390, 667, 836), the narrator singles out a particular day ('on that day when'). However, the temporal precision is apparent only because these single days are up in the air and not part of a continuum.

${ }^{26}$ Cf. the aetiological explanation of sacrifice in $55^{6-557}$, also nun in $94^{2}$.

27 Cf. $S A G N$ I:25. 
narrate that the Muses ascended to Mt Olympus, probably in order to join the other Olympian gods (a typical story element). Conversely, the three previous accounts of the Muses' dancing and singing (2-2I, $\left.3^{6-45}, 65-67\right)$ are presented in simultaneous iterative narration: they are envisaged as happening repeatedly or, perhaps, permanently (hence 'omnitemporal narration').28 The same sense of permanent repetition underlies the passage on the workings of the Muses, especially their good influence on the talent and rhetorical ability of kings and poets (79-93, similarly 94-103).

It has been noted long ago that the subject matter of the Muses' songs bears resemblances to that of the Theogony itself in ways that can hardly be coincidental. In the present context of temporal analysis, it is the order of events that deserves particular attention. No one will fail to notice that the Muses, too, 'celebrate first (prōton) in their song the august family of gods, from the beginning (ex arkhes), those whom Earth (Gaia) and broad Heaven (Uranus) begot, and the gods that were born from them' $\left(44^{-46)}\right.$. The sequel of the program is equally straightforward ('second [deuteron] they sing of Zeus ..., and again [autis] they sing of the family of men and of powerful Giants ...') and it is not impossible to equate it with that of the Theogony and the subsequent Catalogues. ${ }^{29}$

The same cannot be said about the sequence of the Muses' 'first' song (II-2I). While it reproduces the three divine generations that form the backbone of the Theogony, they are in fact in reverse order: Olympians - Titans - Gaia/Oceanus. ${ }^{30}$ This not only 'contradicts' the order of the Theogony, but also that of the Muses' 'second' song. The difference would perhaps not bother us too much, were it not for the fact that both passages are 'omnitemporal'. How can the Muses be imagined as permanently singing a song that is both chronological and in reverse order? ${ }^{31}$ However, the question may be more hairsplitting

${ }^{28}$ In the case of the first passage (Th. 2-2I), this view is not shared by all scholars; for a discussion of the various views see $S A G \mathcal{N}$ i:26 with n. 9 (among recent contributions, J.S. Clay 2003: 54 and Stoddard 2004: I30 appear to be unaware of the arguments put forward by M.L. West I989).

${ }^{29}$ M.L. West ig66: ad 44 .

30 J.S. Clay 2003: $54^{-5} 5$ points out that Theogony I I-2I do not exactly match the three generations of the Theogony, but she agrees that they are in reverse order.

31 The explanation given by Muellner 1996: 54-55 ('either forward, in performance sequence [45-5I, etc.], or backward, in thought sequence [II-2I]') fails to address the songs' omnitemporality. Essentially the same objection applies to other explanations of the difference between the sequence of the two songs (e.g. J.S. Clay 2003: 54-56). 
than is perhaps justified, and the Muses may simply be imagined as repeatedly singing two songs that display a different order.

Of the passages in subsequent singulative narration the Dichterweihe is located in an unspecified past ('once', pote; $\rightarrow$ Homeric hymns, $\rightarrow$ Pindar) and narrated chronologically. ${ }^{32}$ The passage on the birth of the Muses comprises an explanatory completing analepsis in iterative narration: 'Nine nights Zeus the resourceful lay with her [sc. Mnemosyne], going up to her holy bed far away from the immortals' $\left(5^{6-57)} \cdot{ }^{33}\right.$ One temporal marker that sticks out is the explicit temporal ellipsis of the period between conception and birth of the Muses that covers two full lines and nicely steps down from year to season to months to days (cf. schol. ad loc.): 'And when the year came and the seasons turned about and the months passed away and the long tale of days was completed,

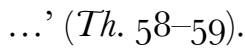

\section{Works and Days}

It has been argued in $S A G \mathcal{N}$ I that the distinction of narrative levels is not immediately evident, because line io ('I should like to tell Perses words of truth') can arguably be interpreted in such a way that Works and Days is an example of a 'pseudo-diegetic' text (hence 'primary' etc. narrative in inverted commas). ${ }^{34}$ To this line of interpretation should be added that large portions of the 'primary' narrative are in fact not narrative in the sense that they tell a story, but are perhaps better described as a form of instruction and argumentation. ${ }^{35}$ In recognition of this difficulty for the present analysis, the following paragraphs will mainly focus on the narrative sections proper within Works and Days (esp. the myths of Pandora and the five races).

The myth of Pandora (47-99) is meant to explain why humankind must work for a living. ${ }^{36}$ Structurally, the passage is perhaps best ex-

\footnotetext{
32 Curiously, Stoddard 2004: I26 n. 2, I29-136 considers the Dichterweihe an analepsis.

${ }_{33}$ Parallels for the notion that the number of children corresponds with the number of intercourses are listed by M.L. West I966: ad loc.

34 SAGN I:32.

35 These passages are dominated by 'omnitemporal' tenses (present tense, timeless aorist).

36 This is not the place to rehearse the difficult question in which way the Pandora myth does or does not illustrate the assertion in $42-46$; cf. e.g. M.L. West 1978: I55; J.S. Clay 2003: II7-II9.
} 
plained as 'initial summary with subsequent elaboration' ( $\rightarrow$ Pindar) or 'header' (found from $\rightarrow$ Homer onwards). To put it in the form of a very loose paraphrase: 'Zeus made life difficult for men because he was angry with Prometheus; let me explain ...', at which point (49) the elaboration begins. The prevalent narrative mode is subsequentsingulative and the order is essentially chronological (including one analepsis; see below). The whole passage presupposes and hence invites comparison with the Prometheus myth as narrated in the Theogony. ${ }^{37}$ Focusing on the treatment of time, the observation can be made that Hesiod presents very summarily the passage that had been dealt with 'slowly' in the Theogony: the trick regarding the division of meat (Th. 535-564), which is presupposed rather than narrated in line $48 .^{38}$ Conversely, the theft of the fire is slightly expanded (Th. $5^{62-569}$ vs. WED 47-58) and, equally important, has a different focus: the speech of Zeus (54-58) in which he announces (internal actorial prolepsis) great trouble for Prometheus, on the one hand, and humankind, on the other. While the former of these threats is then passed over in silence (contrast Th. 521-525, 613-6I6), the making of Pandora (as she is called in Works and Days) is substantially expanded (Th. 570-589 vs. WED 5999), ${ }^{39}$ that is, presented in a 'slower' narrative mode. Part of this expansion is achieved by a feature that is typical of early Greek poetry: after reporting (in indirect speech, 6o-68) Zeus' instruction to create Pandora, a modern author might simply add or presuppose 'and they did as told'. Not so the Hesiodic narrator, who recounts the execution in some detail (69-82), which results in a form of repetition..$^{40}$ At the end he adds Pandora's 'box', which, notoriously, has no equivalent in the Theogony. One can conclude that the version in Works and Days treats the part of the story that affects humankind more slowly than it does the effect on the purely divine realm, for the divine realm takes center stage in the Theogony. This phenomenon may well be indicative of the difference in outlook between the two poems. ${ }^{41}$ However, one should

\footnotetext{
37 Philips 1972-1973.

38 This is the communis opinio (e.g. M.L. West 1978: ad loc.); for the opposite view that 48 alludes to Prometheus stealing the fire see J.S. Clay 2003: I04, II8 n. 42, with doxography.

${ }^{39}$ Cf. J.S. Clay 2003: I04.

${ }^{40}$ Instruction and execution do not exactly match (cf. M.L. West I978: ad loc.). Note that, in the Theogony, the narrator does not expressly report Zeus' instruction. He only mentions that Hephaestus created the woman 'by Cronus' son's design' (Th. 572).

41 J.S. Glay 2003: ch. 3.
} 
perhaps not rule out the possibility that the narrator also avoids covering a second time a topic that had been dealt with in some detail in the Theogony.

The section on Pandora includes an explanatory analepsis in subsequent iterative narration (WED 90-92, the anachrony being marked by prin 'formerly') that describes how, previously, men used to live free of cares, until, that is, Pandora opened the lid of her box. It was, so to speak, a golden age, but the narrator does not specify whether or how it should be equated with the golden race in the myth of the five races (Io9-20I). To these questions I now turn. ${ }^{42}$

In this passage, the sequence of the races is chronological and describes a gradual decline, exemplified by four metals: gold, silver, bronze, and iron. ${ }^{43}$ Whereas the sequence of metals is not complete (the fourth race of Demi-Gods is not characterized by one), the counting of races is: first (I09), second (I27), third (I43), fourth (I57), and fifth (I74). While the first four races represent a former stage and are therefore presented in subsequent narration, the fifth race clearly is the narrator's own (I74-176, including the telling phrase nun gar dè genos esti sidêreion 'for now it is a race of iron'). However, the prevalent narrative mode here is not, as one might expect, simultaneous, but prior (future tenses abound). This phenomenon should not be explained as a permanent or eternal prolepsis (for which $\rightarrow$ Homeric hymns), for it is expressly stated that this fifth race, too, will eventually be destroyed (I80). Likewise, the context makes it clear that the passage is meant to recount how the fifth race $i$ s, and is not, for example, a warning, a gloomy anticipation or the like. Generic influence of literary models from the East ${ }^{44}$ cannot be ruled out, but the prior narration in $176-201$ remains a puzzling feature in the specific context of Works and Days.

If the Iron race is identified with the narrator's own time, the former races are 'dated' too. The Golden race is contemporaneous with Cronus' reign (II I). The Silver race, probably created by the Titans, ${ }^{45}$

\footnotetext{
${ }^{42}$ J.S. Clay 2003: I04 seems to equate the two golden ages.

43 While the sequence of metals primarily stands for a general decline (this is the communis opinio, challenged by Most I997) and is therefore indicative of an essentially pessimistic outlook, it is remarkable that the Bronze race is characterized by the absence of iron ( $W \& D$ I5I). This not only points to a 'historical' distinction between 'Bronze Age' and 'Iron Age', but may well represent a sense of progress that in a way contradicts the pessimism.

${ }^{44}$ Thus M.L. West 1978: 198.

45 The phrase Olumpia dômat' ekhontes (I28) need not point to the Olympian gods (i.e. Zeus' generation) but can designate the Titans in Hesiod (M.L. West I978: ad IIo).
} 
is destroyed by Zeus (I38), who creates the Bronze race (I43-I44). He also creates ( $5^{3}$ ) the Demi-Gods (hèmitheoi) or Heroes, who are identified with Oedipus and his children and with Helen and the armies at Troy. Needless to say, these 'dates' remain rather vague, and so does the time span covered by the story. ${ }^{46}$

The prevalent subsequent narrative mode in these four races is interspersed three times with simultaneous iterative narration, which at first sight is surprising, because the characters in question are not immortal. The narrator, nevertheless, identifies the race in two cases 'with objects of current popular respect: the Golden race with daimones who walk the earth and concern themselves with men's fortune, the Silver with the occupants of certain venerated graves'. ${ }^{47}$ Similarly, some of the Demi-Gods are said to live now on the islands of the Blessed (I70-I73).

While the creation and destruction of the individual race is a singulative event and therefore narrated in the corresponding narrative mode, all five sections abound in generalizing statements about the race ('they $\operatorname{did} \mathrm{X}$, they did not do $\mathrm{Y}^{\prime}$ ), that is, are presented in iterative narration (II2-II9, I30-I37, I45-I5I, I6I-I65, I76-I96; the last is in prior narration).

The '(auto)biographical' passages (esp. 633-640, 650-659, 662) provide interesting (if not always unambiguous) background information. ${ }^{48}$ However, their temporal features are straightforward and unspectacular. The prevalent narrative mode is subsequent (located in an unspecified past: pote, 635, 651; contrast kai nun 'even now', 396), singulative (except for 634 on the father's seafaring, which is iterative) and essentially chronological (two analepses, at 659 and 662, call back to memory the crucial incident of the Dichterweihe, narrated in Theogony 22-34).

Although it falls outside the narratological scope of the present volume, it may not be superfluous to mention that 'a considerable part [sc. of Works and Days] is taken up by advice relating to the agricultural tasks that arise in the course of the year' (often referred to as Bauernkalender in German scholarship) and ends 'with an almanac of days in the month that are favourable or unfavourable for different operations' ${ }^{49}$

46 An exception is Works and Days i3o: the Silver race spent a hundred years with their mothers until they had grown up.

47 M.L. West I978: I8I, with a view to WED I2 I-I26 and I40-I42.

48 The present analysis leaves out the particularly thorny passage about the 'lawsuit(s)' with Perses (WED 35-39), on which no two scholars can agree.

49 M.L. West i978: I. 
To conclude: while the narratives of both Hesiodic poems display an order that is predominantly chronological, the Theogony, in particular, shows that chronological rigor is not the narrator's main goal. This pertains especially, but not exclusively, to stories involving characters who appear only once in the poem. The result is a fair number of passages that are 'out of sequence'. Conversely, the other typical forms of anachrony, narratorial analepsis and prolepsis, are comparatively rare. The narrator's limited concern for exact chronology can also be inferred from the relative scarcity and vagueness of explicit temporal markers. The picture looks quite different in the case of varying the narrative speed. Both poems contain several remarkable instances of acceleration and deceleration, the story of Prometheus being particularly instructive, because the two versions can be compared with each other. In a related matter, the pattern 'initial summary with subsequent elaboration' is a feature that the Hesiodic poems share with many other Greek narrative texts. The unusually high proportion of 'omnitemporal' narration is most likely due to the predominance of immortal characters and the description of their characteristics. Conversely, the unexpected use of prior narration in the passage on the fifth race (WED I76-20I) has not yet received a fully satisfactory explanation. 


\section{GHAPTER THREE}

\section{HOMERIC HYMNS}

\section{R. NÜNLIST}

For the most part ancient Greek narrative texts are narrated in a mode that is called subsequent singulative narration: the narrator recounts once what happened once in the past. ${ }^{1}$ Conversely, the corpus of Homeric hymns contains a disproportionately high percentage of simultaneous iterative narration: the narrator recounts what is happening repeatedly (or permanently). ${ }^{2}$ The comparatively high proportion of this rather unusual narrative mode is most likely the result of the hymns' purpose and subject matter. Generally speaking, the hymns praise gods, who are immortal by definition, and they often do so by describing the gods' appearance, possessions, privileges, spheres of activity, etc. If the narrator chooses to recount how, for example, the god in question was born or received his or her special privileges, he will do so by means of subsequent singulative narration, because he is dealing with a unique event that happened in the past. ${ }^{3}$ If, however, he decides to narrate what the particular spheres of activity etc. are, he will resort to simultaneous iterative narration because gods are immortal and therefore possess and make use of their privileges for ever. ${ }^{4}$ Needless to say, a narrator can always choose to combine the two narrative modes, in that he recounts, for example, both that a god received his or her privileges and what those privileges are. Such a combination of the

\footnotetext{
${ }^{1}$ On subsequent singulative narration see Introduction $(\rightarrow)$.

${ }^{2}$ On simultaneous iterative narration see Genette [1972] I980: II3-II6 and $S A G \mathcal{N}$ I:26.

${ }^{3}$ Cf., for example, the shorter Hymn to Aphrodite (hh. 6), similarly hh. 26 (to Dionysus), the narrative section (D) of which consists of subsequent singulative narration only. For the principal five-part structure of the Homeric hymns see $S A G \mathcal{N}$ г:35. Unless indicated otherwise, the arguments of this chapter all apply to the narrative section (D) of the hymns. All translations are taken from M.L. West's (2003) Loeb edition, occasionally with minimal adaptations.

${ }^{4}$ Cf., for example, the shorter Hymns 9, IO, II, I4, 2I, 23, 24, 25. Such passages are of course not an exclusive prerogative of the Homeric hymns $(\rightarrow$ Homer, $\rightarrow$ Hesiod, $\rightarrow$ Callimachus).
} 
two modes can even be found in a very short hymn such as $h h .22$ (to Poseidon), which has a narrative section of three lines only.

Unlike the shorter hymns listed in n. 4, most mid-sized and all longer hymns in fact contain either a mixture of the two modes or consist of subsequent singulative narration alone. ${ }^{5}$ The latter description applies to the Hymns to Demeter and Hermes, to hh. 6 (Aphrodite), 7 (Dionysus), I8 (Hermes), and 26 (Dionysus). The mixture of the two modes characterizes the Hymn to Aphrodite, hh. I9 (Pan) and in particular the Hymn to Apollo. The Hymn to Aphrodite and hh. ig display a similar structure in that a first part in iterative narration is followed by the singulative narration of an 'episode'. Strictly speaking, the structure of the Hymn to Aphrodite is slightly more complicated because the predominantly iterative narration at the beginning $(2-44)$ is interspersed with short snippets of singulative narration (I2-I3, 22-30, 42-44) ${ }^{6}$ A case of particular interest is line 36: 'She [Aphrodite] even led astray the mind of Zeus', which could be part of either narrative mode. ${ }^{7}$ Only the sequel makes it clear that the passage is actually iterative: Aphrodite led Zeus astray 'when(ever) she liked' (eut' etheloi, $3^{8}$ ). ${ }^{8}$ Up to this point one might well have expected that the narrator was going to give an example of how Aphrodite made Zeus fall for one of his human lovers ${ }^{9}$ - an account that would of course be in singulative narration. Conversely, the Hymn to Apollo is virtually unique in that its narrative repeatedly jumps back and forth between the two narrative modes. This switching between modes creates a rather unusual impression, which is further enhanced by the narrator's similar tendency to switch back and forth between 'third person narration' and 'second person narration'. ${ }^{10}$ The Hymn to Apollo really is a narrative text sui generis.

\footnotetext{
${ }^{5}$ Exceptions are hh. 27 and 30. Their narrative sections consist of simultaneous iterative narration alone.

6 The analysis of $2-44$ as predominantly iterative lends support to the view that the central narrative section begins in line 45 (de Jong I989: I3 n. 2, with doxography).

${ }^{7}$ Ruijgh 1971: 913.

${ }^{8}$ Whether the iterative passage $\left(3^{6-39}\right)$ is in fact simultaneous or subsequent is the subject of a scholarly debate that cannot be rehearsed here; cf. J.S. Clay I989: I62-I66, with literature, who argues in favor of the latter and discusses the disputed purpose of Aphrodite's punishment by Zeus.

${ }^{9}$ Janko I982: I9.

10 Cf. $S A G \mathcal{N}$ i:36, 40. To be exact, this is only true for the first 'half' of the Hymn to Apollo (down to line 282), whereas the second half does not use either simultaneous iterative narration or second-person narration. The boundary does not, however, coincide with that between the 'Delian' and the 'Pythian' part of the Hymn (SAGN i:40).
} 
Although both narrative modes allow for an identification of the temporal relationship between the recounted event and the act of narrating (cf. subsequent vs. simultaneous narration), simultaneous iterative narration lends the event a temporal vagueness or open-endedness that cannot be pinned down. Consequently, the temporal extent or time span of the relevant passages cannot be determined. They are, in a way, omnitemporal.

But after all, every mid-sized or longer Homeric hymn is at least partially narrated in the subsequent singulative mode, which does allow, at least in principle, for an approximate determination of the story's time span. ${ }^{11}$ In all these hymns, the span tends to be short, which is not really surprising given the limited size of the hymns (the longest being the Hymn to Hermes with 580 lines). The hymn with the longest time span is the Hymn to Demeter, although temporal markers are rare and mostly vague. An exceptionally specific marker is found in line 47: 'for nine days' Demeter is searching for her daughter without either eating or washing herself, 'but on the tenth' she is approached by Hecate (the formula is of course Homeric: e.g. Il. I.53-54). More typical is the vagueness of line 94: 'for a long time' (days?, weeks?, months?) Demeter traveled among men without being recognized until she met the daughters of Celeus. It is nevertheless possible to give a rough estimate of the time span because some parts of the story (narrated summarily) require time to develop their effect: the growing up of Celeus' son Demophon ${ }^{12}$ and in particular the barrenness of the fields that forces the other gods into action. ${ }^{13}$ In the other hymns the story is a matter, probably, of days (Hymn to Apollo) or even hours (Hymn to Aphrodite, hh. 7). The Hymn to Apollo contains only one specific temporal marker (Leto is in labor for nine days and nights, 9I), whereas the story of how Apollo founded the Delphic Oracle (214-544), in particular, is conspicuously vague in temporal terms. The Hymn to Aphrodite introduces its final part by means of the marker 'at the hour when herdsmen turn their cattle and fat sheep back to the steading' (I68-I69; cf. n. 2I below).

${ }^{11}$ Conversely, various factors make it very difficult or even impossible to determine the time span of the fabula: the openendedness of iterative narration and 'eternal' prolepsis (see below), the scarcity and vagueness of temporal markers.

12 Cf. especially the frequentative verb forms khriesk(e) (237: [Demeter] would anoint [him]), krupteske (239: she would hide [him]), teletheske (24I: [Demophon] grew and grew).

${ }^{13}$ A rather vague indication of the duration is given in 305-306: 'the most dreadful and abominable year she [Demeter] made it for mankind across the nurturing earth'. 
If the story's time span is noticeably vague in these cases, the temporal structure of the Hymn to Hermes is mapped out with much detail. The time-markers are in fact so frequent and specific that one is reminded of a minutely documented report. The summary that precedes the main narrative sets the tone:

Born in the morning, by midday he [sc. Hermes] was playing the lyre, and in the evening he stole the cattle of far-shooting Apollo- on the fourth of the month, the day the lady Maia bore him. (h.Herm. I7-19)

Not only does the narrator present a program of his narrative by anticipating two of its main elements, ${ }^{14}$ but he also sketches a specific time frame (morning, midday, evening) and gives a comparatively precise date for the events..$^{15}$ The point is, of course, how much a newborn child of divine origin such as Hermes can achieve in a single day. (This traditional point will humorously be taken up when Hermes, still in his diapers, pleads not guilty to the charge of stealing Apollo's cattle because he was born 'only yesterday' and therefore incapable of such a deed. $)^{16}$ But that is not all. The program also betrays a considerable interest in the exact chronology of the story. The implementation is accordingly specific. Right after formulating the program, the narrator starts out by saying 'Once he [sc. Hermes] had sprung from his mother's immortal legs, he did not stay long lying in his cradle, but ...' (h.Herm. 2I-22) and continues by providing specific temporal markers at important way stations of his story:

The sun was dipping below the earth towards Ocean with his horses and chariot, when Hermes [sc. in search of the cattle] came running to Pieria's shadowed mountains.

[Hermes is driving the cattle back to Cyllene:] His ally, the dark divine night, was coming to an end, the greater part, and soon it would be lightening and arousing people to work; the lady Moon had just reached

${ }^{14}$ Inventing and playing the lyre (taken up in lines 24-64a), stealing Apollo's cattle $(64 \mathrm{~b}-\mathrm{I} 53)$. The third principal element, the consequences of the theft (I54ff.), is not expressly mentioned in the program.

${ }^{15}$ Conversely, all the other hymns that narrate the birth of a god place it in an undetermined past. Held against this background, the concreteness of the Hymn to Hermes is all the more striking. To put it naively: how does the narrator know that Hermes was born on the fourth of the month?

${ }^{16}$ Cf. h.Herm. 273, 376; yet another reference occurs when Apollo, discovering the hides of the slaughtered cows, wonders how a newborn infant could have the power to kill animals of such size $(405-407)$. Finally, Apollo is amazed that Hermes, though small (oligos), can play the (newly invented) lyre so well $\left(455^{-456) .}\right.$ 
her height, daughter of Megamedes' son, lord Pallas. Then it was that Zeus' brave son drove Phoibos Apollo's broad-browed cattle to the river Alpheios.

(97-IO2)

and [Hermes] levelled the dark dust over them [sc. the embers] for the rest of the night, while the moon's fair light shone down upon him. In the early twilight he swiftly returned to Cyllene's noble peaks.

$\left(\mathrm{I} 4 \mathrm{O}^{-} \mathrm{-I} 43\right)$

When Dawn the early-born emerged from Ocean's deep waters to bring light to mortals, then Apollo came to Onchestus. ${ }^{17}$

$(184-185)$

This account has the taste of a modern police report and shows that the narrator of the Hymn to Hermes has a strong interest in questions of chronology. (The focus on the night hours is, of course, characteristic of the god Hermes.) A similar penchant for temporal specifics can be found in the actorial analepses that deal with the same events. Apollo, as he asks the old man about the whereabouts of his cattle, appears to know that they 'went off soon after sunset' (193). Similarly, he reports in his pleading to Zeus that Hermes came to steal the cattle 'in the evening' (34I). Conversely, Hermes tells Zeus that Apollo came to charge him 'today, as the sun was just rising' (37I). The temporal markers as such can mostly be paralleled with similar Homeric examples..$^{18}$ What is different, though, is the dense distribution of temporal markers throughout the text. The Hymn to Hermes is narrated not merely in strictly chronological order, but rather with the exactness of a protocol, a phenomenon for which there seems to be no exact parallel in early Greek literature.

In fact, one might even say, without pressing the details too much, that the Hymn to Hermes displays almost a one-to-one correlation between narration and 'reality': the duration of the narration is not so very different from that of the events that are recounted (i.e. a 'scene'). In any case, this and the other Homeric hymns are characterized by a 'slow' narrative: a comparatively short time span is narrated in quite some detail. In this, as in many other respects, the hymns are heirs to the tradition of the Homeric epics ( $\rightarrow$ Homer). They share with them, among other things, a high proportion of direct speech, the 'scenic' quality of which almost automatically results in a 'slow' narrative.

17 Cf. also 'and the deathless immortals were assembling after gold-throned Dawn' (h.Herm. 326).

18 The only exception is orthr(i)os 'in the early twilight' (h.Herm. 98, I43), which does not occur in Homer, but cf. the semantically similar word eerios (e.g. Il. I.497). 
It would, however, be mistaken to assume that the narratives of the Homeric hymns are equally 'slow' throughout. In reality, the narrator has several possibilities to vary the speed of his narrative, and a good example is a feature of the hymns that marks a clear departure from Homeric practice: the hymns make both more frequent and more prominent use of indirect speech. An example from the Hymn to Demeter will illustrate the point. ${ }^{19}$

[The conversation between Demeter, disguised as an old woman, and the daughters of Celeus has come to an end:] They [sc. the daughters] soon reached their father's mansion, and quickly told their mother what they had seen and heard. She told them to go quickly and invite the woman to come, at an unstinting wage.

(h.Dem. I7I-I73)

This conversation between mother and daughters constitutes an important step for the development of the plot, and it is quite likely that the Homeric narrator would have quoted at least one of the relevant speeches. Be that as it may, the hymn's narrator does not, thereby accelerating his narrative noticeably. Only three verses suffice to relate a crucial element of the story, and this phenomenon is not unique. ${ }^{20}$ In the quoted example, the variation of speed is particularly striking because the concise summary is followed by a fairly detailed (i.e. 'slow') description of the daughters (including a simile of three lines) on their way back to Demeter (h.Dem. 174-178). A similar descriptive slowing down can be found in the Hymn to Aphrodite 85-90, where Anchises takes in the various features, one by one, of the gorgeous young girl/Aphrodite (for such focalized descriptions $\rightarrow$ Homer).

To return to acceleration: in addition to the frequency of indirect speech, it is also worth emphasizing that - unlike the Homeric epicsthe Homeric hymns may treat real cornerstones of the plot in indirect speech. Prominent examples include: Demeter swears that she will neither return to Olympus nor let the crops grow again before she gets to see her daughter again (h.Dem. 33 ${ }^{\mathrm{I}-333)}$; with Leto in ongoing labor, the other goddesses instruct Iris to fetch Eileithyia behind Hera's back, lest Hera interfere (h.Ap. I02-Io6); Hermes and Apollo, finally recon-

\footnotetext{
${ }^{19}$ Cf. in general Létoublon I987: I32-135.

20 Other instances of indirect speech are h.Dem. 202-204, 207-209, 294-298, 314315, 327-333, 443-447; h.Ap. I02-Io6, III-II2, 510; h.Herm. 57-6I, 39I-394, 427-433, $522-523,525-526$, (probably) $569-573 ;$ h.Aphr. $26-28$. It is hardly a coincidence that the hymn whose story is the longest, the Hymn to Demeter, has a high proportion of 'timesaving' indirect speech. However, the Hymn to Hermes shows that this is not the only reason for a high proportion of indirect speech.
} 
ciled after the theft, take oaths to honor and not harm one another (h.Herm. 522-526). The Homeric narrator is likely to have resorted to direct speech in such cases. Overall, then, the hymns' narratives are comparatively 'slow', but at least some of them show more frequent and prominent variation of speed than the Homeric epics.

Given the comparatively short time span of the individual story, it is hardly surprising that there is virtually no instance of patent temporal ellipsis. The only example worth mentioning is the scene where Aphrodite and Anchises make love.

And then [sc. after undressing Aphrodite] Anchises by divine will and destiny lay with the immortal goddess, the mortal, not knowing the truth of it.- At the hour when herdsmen turn their cattle and fat sheep back to the steading from flowery pastures, then she poured a sweet, peaceful sleep upon Anchises ...

(h.Aphr. $\mathrm{I} 66-\mathrm{I} 7 \mathrm{I})^{21}$

Unlike the apparent parallel from Madame Bovary mentioned in the Introduction, the present ellipsis is probably due to a concern about decorum (cf. the similar ellipsis between Iliad I4.35I and 352). Needless to say, there are other cases of temporal ellipsis - no text is literally complete - but they are hardly remarkable.

It has been stated above that the Hymn to Hermes is exceptionally concrete by dating Hermes' birth to 'the fourth of the month'. In most other cases the narrated event is located in an undetermined, probably distant past (the Hymn to Aphrodite can be 'dated' by means of one of its main characters: Anchises). This impression that the events happened in the distant past is achieved first and above all by means of the ubiquitous verbal forms in the past tense. ${ }^{22}$ Secondly, the event is regularly said to have taken place 'at that time' (tote). ${ }^{23}$ Thirdly, the narrator can indicate a difference between 'then' and 'now', for example:

${ }^{21}$ The temporal marker 'at the hour when ...' nicely instrumentalizes a generic indication of time (Smith I98r: 6r-62) in a concrete situation: Aphrodite of course needs to leave before Anchises' peers return from the fields.

${ }^{22}$ Like the Homeric epics, the Homeric hymns do not make use of the historic present.

${ }^{23}$ Cf. h.Dem. I0, 97, 434, 45I; h.Ap. 375, 388; h.Herm. I3, 73, 82, 233, 294, 513, 52 I; h.Aphr. 54; hh. 7.43, 26.8. Of these, Hymn to Demeter 45I is particularly noteworthy because the narrator makes an effort to explain that the standing epithet 'life-giving' (pheresbion, of ploughland) did not apply 'then' (due to Demeter's ban), but 'in the past' (to prin). 
[You, Apollo,] arrived at the site of Thebes, which was cloaked in vegetation, for no mortal yet dwelt in holy Thebes and there were not yet any paths or roads crossing the wheat-bearing Theban plain.

(h.Ap. 225-228)

Or he can refer to things of his own time in the present tense (e.g. the description of the horse ritual in Onchestus in honor of Poseidon,

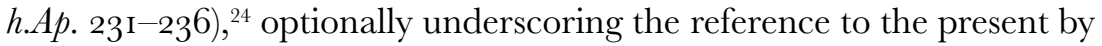
means of the adverb 'now' (nun).

Hence the place is now called Pytho, and the people give the god the title Pythios, because it was just there that the keen sun's force rotted [gr. puthein] the monster [sc. Chimaera] away.

(h.Ap. $372-374)^{25}$

In accordance with the hymns' principal subject matter, such references to the present mostly occur in connection with ritual practice and/or aetiological explanations.

As for the devices of analepsis and prolepsis, they do occur in the Homeric hymns, but not very often - at least not in the narrator-text. ${ }^{26}$ In the speeches (in other words, as actorial analepses and prolepses) they are more frequent, whereas in the narrator-text they are rare and usually short. The most significant, but unparalleled, exception comes from the Hymn to Apollo, where the narrator gives a detailed account of how Hera decided to give birth to the monster Typhaon (h.Ap. 305354). The uniqueness of this narratorial analepsis is further increased by the fact that it even contains speeches. The 'stepping back in time' of the analepsis is indicated here by the temporal adverb 'once (upon a time)' (pote, h.Ap. 305), which often marks the beginning of the narrative section in the odes of Pindar $(\rightarrow)$.

Most actorial analepses intend to bring the secondary narratee upto-date, for example by informing him or her of an event at which he or she was not present. In the case of such internal analepsis, there often is an element of repetition (i.e. repeating analepsis), which allows the primary narratee to compare the two versions. In at least two cases the discrepancy is worth mentioning. When Persephone tells her mother how she came to eat a pomegranate seed before leaving the Underworld (which will force her to return there on a regular

${ }^{24}$ Cf. h.Ap. 385-386, 393-396.

${ }^{25}$ Cf. h.Herm. ${ }^{125-126,507-508, ~ a n d ~ i n d e x ~ s . v . ~ ' r e f e r e n c e s ~ t o ~ n a r r a t o r ' s ~ o w n ~ t i m e ' ~}$ (also index to $S A G \mathcal{N}$ I).

${ }^{26}$ Given that the hymns are comparatively short, the scarcity is perhaps less surprising than frequency would be. 
basis), she claims that Hades 'made me taste it with force against my will' (akousan de bièi me prosenagkasse pasasthai, h.Dem. 4I3). Conversely, the narrator's version is dominated by the idea of Hades stealthily tricking Persephone into eating the seed (h.Dem. 37I-374), apparently a source of embarrassment for her, which makes her resort to self-defence. ${ }^{27}$ Secondly, Hermes' plea of 'not guilty' to the charge of stealing Apollo's cattle (h.Herm. passim) blatantly clashes with the narrator's account of it. But, in fact, not even the secondary narratees are persuaded by his protestations.

Many Homeric hymns narrate, among other things, how the god in question received his or her particular privileges. Given the gods' immortality, this account can lead to what perhaps may be called 'eternal prolepsis': the narrator or (more often) a character enumerates and describes the sphere(s) in which the god will be the master or mistress forever. For example:

[Hades to Persephone:] By being here [sc. in the Underworld], you will be mistress of everything that lives and moves, and have the greatest privileges among the immortals, while there will ever be punishment for those who act unrighteously and fail to propitiate your fury with sacrifices, in holy performance, making the due offerings. ${ }^{28}$

(h.Dem. 364-369)

A similar device comes into play when the god explicitly instructs his or her worshippers (as in fact Hades indirectly does in the previous example).

[Apollo to his would-be priests from Crete:] I brought you here over the mighty main not with any ill intent, but you are to occupy my rich temple here, which is greatly honored by all men, and you shall be held in honor for all time. (h.Ap. 48I-485; cf. 535-539, also 56-6o)

Although the immediate (secondary) narratees of these instructions are of course mortal, the implication is that generation after generation will follow their example. As a result such prolepses are, at least in principle, 'eternal' too. A striking example is the passage in which Demeter predicts eternal strife among the Eleusinians (h.Dem. 263-266), which, however, is usually explained as reference to a ritual mock battle, the ballètus. ${ }^{29}$

\footnotetext{
27 N.J. Richardson i974: ad loc.

${ }^{28}$ Cf. h.Dem. 398-403, 46I-465; h.Herm. 283-288, 29I-292, 458-462, 527-532, 54I-

${ }^{29}$ Attested by Hesychius (s.v.); the connection was first made in the early nineteenth century by Creuzer (cf. N.J. Richardson 1974: ad loc.).
} 549 . 
The 'eternity' of these prolepses results in connecting the distant past of the event with the present time of the narration and the future. The content of the various prophecies often has an immediate relevance for the primary narratees of the hymns, for example when current cult practice is given an aetiological foundation. The same applies mutatis mutandis to the passage in which Aphrodite prophesies that Anchises' and her son Aeneas will rule over the Trojans, as will his children and his children's children (h.Aphr. I96-197), which is likely to be intended as an 'eternal' prolepsis.

Finally, the factor 'time' plays an altogether different role in $h h .28$, which recounts Athena's birth from the head of Zeus. Her entrance into the world in full armor causes extraordinary and portentous natural phenomena: Mt Olympus trembles, the earth shakes, followed by a tsunami (hh. 28.9-12).

But suddenly the main was held in check, and Hyperion's splendid son [i.e. Helius, the Sun] halted his swift-footed steeds for a long time, until the maiden, Pallas Athena, took off the goldlike armor from her immortal shoulders.

(hh. 28.12-I6)

In other words, time comes to a temporary and ominous halt until Athena takes off her armor. ${ }^{30}$

To conclude: as a text corpus, the Homeric hymns are characterized by the juxtaposition of subsequent singulative narration with the much less common mode of simultaneous iterative narration (best illustrated by the first half of the Hymn to Apollo), probably due to the hymns' subject matter. The passages in singulative narration show a similar preference, though on a much smaller scale than the Homeric epics, for a single (or perhaps a few) momentous event(s), leading to a story whose time span is comparatively short. This preference results in a generally 'slow' narration, which still manages to show more noticeable changes of speed than the Homeric epics. Overall, the hymns' temporal structure is straightforward: narrated in roughly chronological order, there are few anachronies in the form of narratorial analepses or prolepses. With only one storyline in each case, the problem of dealing with simultaneous events does not arise. The chronological details of the narrative are mostly vague, except for the unparalleled specificity of the Hymn to Hermes.

\footnotetext{
${ }^{30}$ For the notion that time comes to a halt cf. Od. $23 \cdot 24 \mathrm{I}^{\mathrm{I}}-246$ and schol. D Il. I $4 \cdot 323$ $=$ Pherecydes $3 \mathrm{~F}$ i3 $\mathrm{C}$ Jacoby (on Zeus and Alcmene). The notion of the sun standing still during battle is found in Joshua ro.13.
} 
GHAPTER FOUR

\title{
APOLLONIUS OF RHODES
}

\author{
J.J.H. Klooster
}

\section{Introduction. Time awareness in the Argonautica}

It has been amply recognized that time is of the essence to Apollonius' epic narration of the Argonautic journey. ${ }^{1}$ The proem of the Argonautica begins with a reference to the deeds of 'men born long ago' (I.I), thus placing its subject in a distant legendary past, as indeed we would expect in an epic. Near the end of the proem the narrator asserts that the construction of the Argo is the subject of 'earlier singers', of an unspecified antiquity, whose works still celebrate it (hoi prosthen eti kleiousin aoidoi, I.18-19). ${ }^{2} \mathrm{He}$ adds that therefore he will now recount the names and genealogies of the heroes instead. The reference to earlier singers creates a distinct layer of time between the present of the narration and the past of the Argonauts. We are dealing with a remote past that is yet accessible through literary sources. This points to the continuing impact of the Argonautic journey while distancing at the same time the actual event. The intervening lines $\mathrm{I} \cdot 5^{-1}$ 7 allusively recount the pre-history of the Argonautic quest: the oracle that king Pelias received, and the reason of Hera's anger at Pelias.

In sum, in the compass of circa twenty lines, we bridge a distance from early times (before the Argo), through a legendary past (the voyage of the Argo itself), to a closer, historical past (the earlier singers who recount the Argo's construction). Finally the present of the overt narrator is brought emphatically to our attention. ${ }^{3}$ Over these events

\footnotetext{
${ }^{1}$ Cf. Mehmel I940; Fränkel ig68: 32; Fusillo i985, whose book, entitled Il tempo delle Argonautiche, provides an extensive narratological treatment of time in the Argonautica. For a discussion of time as a literary motif, cf. also Hunter ı993: г62-I69; Clauss 2000.

2 The phrasing points to oral sources, but this is probably not a reflection of reality, cf. $S A G \mathcal{N}$ i:51.

${ }^{3}$ Although some would argue that the narrator is on another, extradiegetical, level
} 
towers the quasi-eternal figure of the god Apollo, from whom the narrator 'begins' (arkhomenos, I.I). This god, through his oracles, was the cause of the Argo's voyage and is now invoked to inspire the epic about that voyage. ${ }^{4} \mathrm{He}$ is a pivotal point connecting past exploits and their present narration, also pointing to the continuity of the past rather than to its being 'absolutely walled off' from the present. ${ }^{5}$ Apollo was revered by the Argonauts as well as by the Hellenistic narratees and narrator of the Argonautica. ${ }^{6}$

In the recounting of the journey, the narrator shows considerable accuracy regarding the passing of time. It is related to seasonal phenomena like the Etesian winds, ${ }^{7}$ or kept track of by the conscientious recording of daybreak and nightfall $(\rightarrow$ Homer). We may thus calculate that the journey takes one sailing season, that is, from spring to autumn. An exception to the general accuracy is found in the Lemnian episode, i.6og-9io. It is kept deliberately unclear how long exactly the Argonauts linger with the Lemnian women. Instead we find a summary: '.. and the sailing was ever delayed from one day to another ...' (86I-862). The vagueness may well indicate that the time awareness of the Argonauts themselves is somewhat lacking at this point, because they are amusing themselves so well. Alternatively, it may reflect the mounting irritation of Heracles, who eventually points out the danger of their dalliance, after which the Argo departs and the narrator's counting promptly resumes.

Day-endings and beginnings, and sometimes other significant moments of a drawn-out day, are often elaborately described, frequently in terms of agricultural labour, that is, of an omnitemporal world distinct from the heroic exploits of the Argonauts $(\rightarrow$ Homer $):{ }^{8}$ Now at the

of the narrative, the fact that he intrudes so emphatically in his own poem seems to justify taking his own 'present' as a time-category to be reckoned with here.

${ }^{4}$ Cf. González 2000: 272-290; Wheeler 2002.

${ }^{5}$ Cf. Bakhtin I981: I6, for the idea of the 'epic world of the absolute past'.

${ }^{6}$ Cf. 2.707-709; in a hymn to Apollo sung by Orpheus the narrator appears to break in to correct the phrase 'with locks still unshorn': 'be gracious, ever, o Lord, are your locks unshorn, ever unravaged'. According to Margolies DeForest I994: 82, the ever-growing locks of Apollo serve as 'a visual image' of the continuity from the time of the heroes to the present of the narrator. Cf. also the apostrophes of Eros $\left(4.445^{-}\right.$ 449 ) and Zeus (4.I673-I677), who both function within the narrative and are gods to be reckoned with in the present of the narrator $(\rightarrow$ Homeric hymns).

${ }^{7} 2.49^{8}-526$, discussed in an exceptionally long digression, probably to evoke the long delay (forty days) they cause the Argonauts.

${ }^{8}$ E.g. I.450-453; 2.I64-I65 (agriculture); 4. Io9-II4 (hunting). Argonautica 3.1340I344, when Jason is ploughing the field of Ares, is different: here the agricultural vehicle 
hour when from the field some delver or ploughman goes gladly home to his hut, longing for his evening meal, and there on the threshold, all squalid with dust, bows his wearied knees, and, beholding his hands worn with toil, with many a curse reviles his belly; at that hour the heroes reached the homes of the Cianian land ...' (I.II72-1I77). ${ }^{9}$

The first and second books both end at daybreak; the third book with nightfall. ${ }^{10}$ The last book ends with the disembarkation of the Argonauts back at Iolcus, giving a distinct sense of closure. ${ }^{11}$

\section{Time span of the fabula and the story}

It is not so easy to decide what the fabula, as opposed to the story, of the Argonautica is. Hermann Fränkel claims that Apollonius has quite rigorously delimited the main story of his epic. 'He has cut out the material for his narrative out of the gigantic colourful tapestry of Greek Myth, as if with a sharp cutting knife, severing sharply at the edges, there where the theme begins and where it ends, without caring about the resulting fragmentation of intricately knit cohesions stretching out beyond, both in the past and in the future. ${ }^{12}$

This is partly true. The main story of the Argonautica is exactly what is outlined in 1.20-22: 'the long sea-journey and all they did while wandering', that is, the Argo's roundtrip Iolcus - Colchis and back. We might say that the fabula comprises this period, plus the prehistory leading up to it, that is, Pelias' reception of the oracle (I.5-I7). Yet, due to the narrator's emphatic attempts to link the Argo's quest to countless other events in the (legendary) history of the Greek world, even up to his own time, we might doubt whether the limits of the fabula should be determined so rigidly. Where does the tale of the Argonauts really begin? For example, what led up to Pelias' reception of the oracle in

gains contextual relevance. Some similes (e.g. 4.1280-I287) and gnomic utterances (e.g. $\left.2.54 \mathrm{I}-542 ; 4 . \mathrm{II} 65^{-\mathrm{II}} 67\right)$ also contain such references to an omnitemporal world.

9 All translations are adapted from Seaton I912, unless otherwise noted.

10 This may symbolize the fact that in the first two books the Argonauts are on the outward journey towards the East, the land of the Sunrise, while in the third book their journey home towards the west (the Abendland) already begins.

${ }^{11}$ Cf. SAGN I:45. eisapebete, the Argonautica's final word, may have connotations of 'ending' in general. Thus, it echoes the opening word arkhomenos 'to begin': the path of the Argo is coterminous with the path of Apollonius' song. Cf. also Clare 2002.

12 Fränkel I968: 21, my translation. 
the first place? And at what point does the Argo's tale really end, if its effects are, as the narrator continuously claims, still visible?

In this perspective, the large chronological scope of the Argonautica's proem could be considered programmatic. ${ }^{13}$ The narrative includes a great number of heterodiegetic external analepses and prolepses (mainly aetiological digressions) that actually span the period from the beginnings of the cosmos up to the times of the narrator, and link the story of the Argonauts to past and present. Reflecting the chronological structure of the proem, the narrator broadly speaking refers to four different periods: (I) the times before the Argo sailed, that is, from the beginning of the cosmos up to the construction of the Argo; (2) the time when the Argo sailed, the actual story of the epic; (3) times in the past, after the Argo sailed, but before the time of the narrator's present; (4) the present of the narrator.

We might even say that the gradual evolution of primeval cosmos into the present world as third century BC Greeks knew it constitutes the most sweeping aetiology of the narrative as a whole. ${ }^{14}$ This 'great aetiology of the world' begins with the actorial analepsis in the form of the cosmogonical song of Orpheus (presented in indirect speech), preceding the departure from Iolcus (I.496-5II). ${ }^{15} \mathrm{He}$ sings of the creation of the world from chaos. Orpheus' song ends when Zeus is still a baby, that is, just before the reign of the Olympian gods in which the exploits of the Argonauts fall. ${ }^{16}$ Throughout the epic, we receive frequent indications as to the relative chronology of the birth of Zeus and the journey of the Argo. For instance, we hear how Chiron, the old centaur who has been the tutor of Jason (1.33), and who figures in the epic as the babysitter of Achilles (I.554), was begotten by Cronus and Philyra at the time when Zeus was still an infant (4.812). The fact that this same Chiron (Zeus' near coeval) is still alive, although he is now old, shows that the Olympian order under the reign of Zeus must be relatively young. ${ }^{17}$ At the same time, the fact that Chiron's ward Achilles is still

\footnotetext{
13 Clauss 2000: II.

14 Clauss 2000: 25.

15 Clauss 2000: I2-I3. Cf. the more geographically and historically oriented excursus by Argus, son of Phrixus in 4.26I-293, who speaks of a time 'when the stars ... were not yet, nor ... the sacred race of the Danai'.

16 Part of the ekphrasis of Jason's mantle (I.730-734) picks up the final image of Orpheus' song, viz. the Cyclopes ( $\mathrm{I}^{\mathrm{IO}} \mathrm{IO}^{-} 5^{\mathrm{II}}$ ) forging Zeus' thunderbolts.

${ }^{17} \mathrm{Cf}$. e.g. the reference to Zeus' childhood toy (a ball resembling the cosmos) promised by Aphrodite to Eros (3.132-I42). Clauss 2000: 28 suggests that the fact
} 
a baby also positions the Argonautica in relation to another focal point in Greek mythical chronology: its events are situated one generation before the Iliad. ${ }^{18}$ In this way, the narrator continuously scatters clues to connect the story of his epic to the much larger 'fabula' of world history. Returning to Fränkel's quote, we see that, although Apollonius indeed focuses on a small patch of the great tapestry of Greek myth, he makes sure that the threads connecting it to the rest of the textile are clearly visible.

\section{Order}

Like a cyclic epic or a work of historiography, the main story of the Argonautica proceeds chronologically from a given starting point (embarkation) to an established ending (disembarkation); the stops underway become episodes that are related chronologically rather than causally. In this sense, the epic apparently goes against Aristotle's injunctions (Po. I451ai6-30) concerning poetical unity. ${ }^{19}$ The episodic, linear narrative, however, is often sidetracked by digressions latched onto every object, landmark or person the Argo encounters or leaves behind. Thus a pattern is created in which, on the one hand, items are discussed in brief (heterodiegetic) aetiological digressions explaining their provenance (external analepsis). ${ }^{20}$ On the other hand, the Argo itself leaves in its wake cults, topographical names, and sanctuaries (external prolepsis), which are often 'still there to be seen', 'even now' ('reference to the narrator's own time' motif). ${ }^{21}$ The Argo traces a path through time, linking past and present.

Many examples of this pattern of digressions are found in the 'catalogue of heroes' (I.23-233) preceding the actual departure of the Argo.

that Eros is still a child, as Zeus has so emphatically been, may imply that another Olympian monarch is in the making.

18 And the Odyssey, of course, as is implied by the many 'Odyssean' adventures in book 4 , for example the visit to Circe, the Sirens, and the (as yet childless) Phaeacian royal couple Alcinous and Arete.

19 Cf. SAGN I:45 and the discussion in Hunter 1993: 190-195.

${ }^{20}$ For example, the explanation of the foul-smelling waters of the Eridanus, where Phaethon, crashed to earth, burnt (4.597-602).

${ }^{21}$ For example, the tombs of Idmon and Tiphys, in Heraclea Pontica, 2.852 (eti semmata phainetai). Although the question remains whether the majority of these landmarks that are supposedly 'still there to be seen' would in actuality have been seen by the readers of the Argonautica. Cf. $S A G \mathcal{N}$ i:50-5I. 
It functions as a kind of list of dramatis personae, furnishing each hero with a genealogy and a ' $\mathrm{CV}$ ', as in the introduction of Orpheus:

First, then, let us name Orpheus, whom once Calliope bore, it is said, wedded to Thracian Oeagrus, near the Pimpleian height. Men say that he by the music of his songs charmed the stubborn rocks upon the mountains and the course of rivers. And the wild oak trees to this day, tokens of that magic strain, that grow at Zone on the Thracian shore, stand in ordered ranks close together, the same which under the charm of his lyre he led down from Pieria. Such then was Orpheus, whom Aeson's son welcomed to share his toils, in obedience to the behest of Chiron, Orpheus, ruler of Bistonian Pieria.

(I.23-34)

Orpheus' introduction begins with his genealogical background (external analepsis), introduced by means of a relative phrase (ton ... pote; $\rightarrow$ Homer, $\rightarrow$ Pindar). It is unclear who furnishes the information regarding Orpheus' birth, and when, but it is likely that the information ('it is said') dates from a moment later than Orpheus' birth; the 'earlier singers' of I.I8-I9 come to mind. ${ }^{22}$ This also applies to the next fact related about Orpheus (enepousi), viz. that he charmed nature. This particular ability is then backed up by a reference to the wild oak trees at Cape Zone that to this day grow in orderly ranks ('reference to the narrator's own time' motif). The material nature of the evidence apparently serves to substantiate the claims about Orpheus' powers, while the passage also provides an explanation (aition) for the remarkable growth of the oaks at Zone - in reality, this is of course a hermeneutical circle. Finally, it becomes clear why this analepsis regarding Orpheus' nature was inserted: his musical abilities are adduced as the reason why Chiron advised Jason to take Orpheus along. With that, we return to the time just before the present of the story.

Paradoxically, these aetiological digressions, which make for a fragmentary narrative, imply a kind of unity on a cosmic scale at the same time, suggesting as they do that an intricate web of causal relations keeps the history of the world together. ${ }^{23}$ Characters themselves are often also explicitly aware of events from the (far) past (e.g. Orpheus,

22 The vague source reference ('it is said') is particularly strange as the Muses, of whom Orpheus is said to be the progeny, have been invoked only two lines earlier. Compare the frequent occurrence of expressions like kaleousi, kiklèskousi, (meta)kleiousi, kleizetai, phasi kaleesthai, pephatai, phatizetai, pephatistai, hudeontai, etc. In all likelihood, these serve to acknowledge the literary and historical sources Apollonius used, $S A G \mathcal{N}$ r:50.

${ }^{23}$ Compare the remarks of Hardie I986: 66 concerning the unity we find in Theogonic accounts of the world, as quoted by Clauss 2000: I3. 
I.496-5II; Argus, 4.26I-293) ${ }^{24}$ and the future (note the numerous seers and prophesying deities in the Argonautica, for example Phineus, Mopsus, Idmon, Glaucus, Triton, the Libyan Herossae). ${ }^{25}$ This implies that history is, theoretically at least, ultimately a knowable continuum, stretching from the beginnings of the cosmos to the present of the quasi-omniscient narrator. ${ }^{26}$

\section{Simultaneity and parallel storylines}

The larger part of the narrative consists of a single storyline (the journey of the Argo). Yet occasionally the narrative divides up into two simultaneous storylines, when individual members (e.g. Heracles and Hylas, I.I I98-1272) wander off or the Argonauts meet important antagonists (e.g. the Lemnian women, I.6o9-9io).

The use of parallel storylines is particularly conspicuous when the Argonauts start to interact with the inhabitants of Colchis (book 3). Their actions then coincide with that of the goddesses Hera, Athena and Aphrodite scheming on Olympus, Aeetes anxiously ruminating about the plans of the Argonauts, and Medea falling in love with Jason. The switching of storylines is signalled by means of the temporal adverbs tophra and teiōs, or with correlative men ... de. ${ }^{27}$ The simultaneity adds to the atmosphere of duplicitous action, where one party is unaware of the actions or schemes of the other. As in Homer $(\rightarrow)$, one storyline is usually stationary, or at least no important action takes place, at the moment the other is foregrounded; for example, the Argonauts leave the palace of Aeetes (3.448)-Medea despairs of her love for Jason $\left(3.45^{\mathrm{I}}-47 \mathrm{I}\right)$ - 'But when [the Argonauts] had gone forth ...' (3.472). If important action does occur, the narrator retraces his steps: the Boreads pursue the Harpies, until Iris stops them and they

${ }^{24}$ Characters, too, frequently describe the provenance of objects, names or customs (aitia): for example, Argonautica 2.703-710 (Orpheus' hymn to Apollo) explains the name of Delphi from Delphyne, the monster that Apollo slew, and the refrain hiēpaiēon from the cry the nymphs uttered at that occasion.

${ }^{25}$ Duckworth [1933] I966: I8 moreover notes the unusually high number of omens and portents in the Argonautica. Although it is less than half the length of the Iliad or Odyssey, it contains thirteen instances, as against fifteen in the Iliad and eleven in the Odyssey.

${ }^{26}$ However, in the recounting of events of the past, just as in prophecy, uncertainty remains in many cases; this is actually acknowledged by the narrator, cf. González 2000; $S A G \mathcal{N}$ г:50-51.

27 E.g. 3.275, 609, 807, I246, I314. 
return (2.273-30o) - 'Meanwhile' (tophra), the heroes cleansed the old man Phineus - Phineus lengthily prophesies (2.30I-426); with 'meanwhile' the narrator turns back in time.

\section{Analepsis}

The relation of the immediate causes of the Argo's journey arguably constitutes the first narratorial external analepsis in the epic. After first outlining his subject, the Argo's journey (I.I-4), the narrator goes backwards to the point where King Pelias received the oracle that he will be slain by Jason (I.5), the reason why he decides to send him on his dangerous mission. To choose an oracle that took place before the main story and prophesies an event that falls after it might be called remarkable: it is an external prolepsis wrapt in an external analepsis. ${ }^{28}$ The choice once more brings home that the journey of the Argo is a necessary causal link between past and future events.

Some characters actually choose an earlier starting point as the cause (one might be tempted to say, aition) of the expedition of the Argo, viz. the flight of Phrixus and Helle on the back of the golden ram. For example, an anonymous woman, witnessing the departure of the heroes, says: 'Would that the dark wave had overwhelmed Phrixus too with the ram when the maiden Helle perished; but no, the dire portent even sent forth a human voice, so that it might cause Alcimede [Jason's mother] sorrow and countless pains thereafter' (I.256-259). ${ }^{29}$ The analepses concerning Helle and Phrixus are distributed piecemeal throughout the epic, they are sometimes found in the text of the narrator, sometimes in that of the characters. They help the narratees reconstruct both the history of the Golden Fleece and the complicated family ties connecting Jason to the sons of Phrixus, who will figure quite prominently in the epic later on (books $2-4) \cdot{ }^{30}$

\footnotetext{
${ }^{28}$ Cf. the completing actorial analepses in $\mathrm{I}_{3} 300-302$ and $\mathrm{I} .360-362$, where Jason refers back to the propitious oracles of Apollo regarding their journey; these too contain (internal) prolepses.

${ }^{29}$ Cf. I.29I, Alcimede referring to Phrixus' flight as the beginning of her woe.

30 On the completing character of these analepses see Fränkel I968: 27. Cf. I.730764: the description of the speaking ram in the ekphrasis of Jason's cloak; 2.II4III5I: the sons of Phrixus introduce themselves, mentioning the history of their father; 2.I 193-I 195: Jason refers to Phrixus' intended sacrifice at the hands of Pelias; 3.190-I9I: Jason tells how Aeetes received Phrixus kindly; 3.330-339: the sons of Phrixus explain to Aeetes why Jason wants the Fleece, referring to the tale of Phrixus; 3.356-366:
} 
Internal narratorial analepses are infrequent. An exceptional example may however be found in 2.I090-Iog2 (referring back to the prophecy of the seer Phineus at 2.388-389, which instructed the Argonauts to stop at the isle of Ares): 'What then was the purpose of Phineus in bidding the divine band of heroes land there? Or what kind of help was about to meet their desire?' This analepsis is actually a kind of (actorial) prolepsis in disguise, pointing forward to the meeting between the Argonauts and the sons of Phrixus; its function is to heighten the narratees' anticipation. The narrator duly proceeds to recount this meeting, after first explaining in a long completing analepsis how the Phrixids came to be stranded on the isle (2.1093-II22).

Internal actorial analepses are mainly repeating, for example the brief summary of the Argonauts' exploits as told by Jason to his host king Lycus (2.762-77I, reported speech), which looks like an allusion to Odysseus' apologoi (Od. 9-12). ${ }^{31}$ At 4.1319-1321, the Libyan Herossae, indigenous goddesses of the desert, even more briefly show they know all about the Argonauts' exploits.

At first sight, some of the external narratorial analepses may seem hardly relevant to the context in which they appear, but on closer consideration there usually is some implicit connection. An illustrative example is the analepsis recounting the provenance of the mantle with which Medea and Jason lure Medea's brother Apsyrtus, in order to kill him:

[They gave him] a sacred robe of Hypsipyle, of crimson hue. The Graces with their own hands had wrought it for Dionysus in sea-girt Dia, and he gave it to his son Thoas thereafter and Thoas left it to Hypsipyle. And she gave that fair-wrought guest-gift with many another marvel to Aeson's son [Jason] to wear ... And from it a divine fragrance wafted from the time when the king of Nysa [Dionysus] himself lay to rest thereon, flushed with wine and nectar as he clasped the beauteous breast of the maiden daughter of Minos [Ariadne], whom once Theseus forsook on the island of Dia, when she had followed him from Cnossus.

$(4 \cdot 423-434)$

The technique of sketching the history of an object in an external analepsis is already found in Homer $(\rightarrow)$, but in characteristic Hellenis-

the sons of Phrixus explain their tie of kinship with Jason through Athamas and Cretheus; 4.II5-I2I: the description of the altar at which Phrixus once sacrificed the ram.

31 Cf. $S A G \mathcal{N}$ i:57. 
tic fashion the Apollonian passage also abounds in allusive analogies. ${ }^{32}$ In book I, Jason himself arrives at Lemnos wearing another crimson robe woven by a goddess (Athena), which, at that point, symbolizes his erotic appeal, by which he seduces both Hypsipyle and Medea. Later, as he is slaughtering a sheep for Hecate in preparation for the trial with the bronze bulls, he wears a dark robe (kuaneon pharos), which was given to him by Hypsipyle, 'a memorial of many a loving embrace' (3.1206). The present mantle is also a gift from the Lemnian queen, whom Jason has loved and left, as he will love and eventually (beyond the scope of the Argonautica) leave Medea. The Lemnian women had treacherously killed their kinsmen, as Jason and Medea will treacherously kill her brother Apsyrtus. Jason has moreover wooed Medea by comparing their affair to that of Theseus and Ariadne (3.997-I006), leaving out, of course, the fact that Theseus eventually left Ariadne. Just as Theseus, the Greek hero, leaves Ariadne, the foreign princess, Greek Jason will eventually leave foreign Medea. The fact that Jason and Medea use this portentous robe to betray Medea's brother Apsyrtus and slay him, as Medea will one day slay their own children and kill Jason's bride with a poisonous robe (cf. Euripides' Medea), confers yet another significance to the passage. Formally, this is a heterodiegetic analepsis, then, but it resonates with ironical analogies to the narrative in which it is embedded, pointing both backwards and forwards.

In another example of a thematically significant external analepsis (I.I2II-I220), the narrator, about to tell the episode in which Heracles loses Hylas, launches into the story of Heracles' violent confrontation, once upon a time, with Theodamas, Hylas' father. Quite suddenly, the narrator cuts his tale short: 'But these tales would lead me far astray from my song' (I.I220). At this point, however, the narratees have already seen Heracles as a violent brute, which colours their appreciation of his love for his squire Hylas. Breaking-off formulas like this one are reminiscent of Pindar $(\rightarrow)$. In the Argonautica, they deliberately seem to invite the question why these particular digressions should be broken off, when so many other tales are told at length. ${ }^{33}$

32 Hutchinson I988: 28.

${ }^{33}$ Contrast I.64I-649, the digression about the herald Aethalides, of whom it is told that he enjoys undying memory, even now, in Hades ('reference to the narrator's own time' motif). The story is cut short by the remark 'But why need I tell at length tales of Aethalides?' (г.649). The possible significance of this analepsis remains unclear. 
Prolepsis ${ }^{34}$

Internal narratorial prolepsis occurs at several points in the story, usually to introduce a new episode and thus to steer the narratees' expectations ('header'-technique). ${ }^{35}$ At 4.1225-1226 the narrator announces, 'not yet was it ordained for the heroes to set foot on Achaea, until they had toiled even in the furthest bounds of Libya'. ${ }^{36}$ This 'header'-technique, combined with the fact that the Argo's tale was well known, suggest that some of the interest of the poem depended on the learned narratees' awareness of the many choices to be made between the different variants of the Argonautic myth. It will have interested them which variant would be chosen by the narrator, how it would be developed and to what effect. ${ }^{37}$ Added to this was in all likelihood the suspense created by the narratees' identification with the characters, who are largely unaware of their fates. This unawareness may be employed to create a pathetic effect, for example by means of the Homeric $(\rightarrow)$ device of referring to a character with the word neppios or skhetlios. ${ }^{38} \mathrm{On}$ the other hand, the opposite, that is, a character's explicit awareness of the future in combination with an internal narratorial prolepsis, also creates a particularly pathetic effect, as in the introduction of the seer Idmon (I.I39-I4I), who is said to be aware that he will die on the journey, being a prophet. ${ }^{39}$

${ }^{34}$ For a seminal discussion of prolepsis in Apollonius see Duckworth [1933] I966.

35 The proem (I.I-4) also looks forward to some of the later parts of the narrative $(\rightarrow$ Homer). It is not, however, strictly speaking a prolepsis, as the story proper has not begun yet.

${ }^{36}$ Cf. I.IO30-IO3I: "the king of the Doliones was not to escape his fate and return from battle'; 2.85I: 'who was the next that died?'; 4.450-45I: 'how did Medea slay Apsyrtus?'; 4.552-556: the narrator asks the Muses why the Argonauts had to pass around Italy; he also emphasises the heroes' ignorance of their fated detour (4.56I), thus heightening the anticipation of the readers, cf. Duckworth [1933] I966: 4 I.

37 These choices are often addressed in Muse invocations. In $4 \cdot \mathrm{I}^{-}-5$ the narrator wonders whether he must attribute Medea's flight to love or fear. Cf. 4.I38I-I390: the phrase 'this is the tale of the Muses, and I sing obedient to the Pierides' refers to the fact that Pindar Pythian 4 describes the carrying of the Argo by the heroes, which therefore could not be ignored. Cf. also the Muse invocations addressing the (in later times wrongly identified) grave of Idmon $\left(2.845^{-850}\right)$ and Cronus' castration, a 'tale of olden days' (4.982-990).

${ }^{38}$ Cf. 2.65-66, the Bebrycians; 3.II33-II34, Medea. Cf. Duckworth [1933] I966: I2I3.

${ }^{39}$ Cf. his own prophecy at I.440-447, which moreover predicts that the Argonauts will return safely. Mopsus, another seer, is also fated to die on the journey (I.79-85). Cf. Il. II.328-335: the seer Merops has foreseen the death of his two sons, and tries to keep 
A more indirect way of foreshadowing future events is found in some of the similes ( $\rightarrow$ Homer). Thus, for instance, in the fight between Polydeuces and Amycus, the brutal king of the Bebrycians, we find the following simile (2.70-74): 'Hereupon the Bebrycian king - as a fierce wave of the sea that rises in a crest against a swift ship, but she by the skill of the crafty pilot just escapes the shock when the billow is eager to break over the bulwark - so he followed up the son of Tyndareus ...'. This situation, where 'the swift ship just escapes the shock of the wave by the skill of the crafty pilot', will actually occur some hundred lines later (2.I69-I76), as the Argo is passing through the Bosporus, having just left behind the land of the Bebrycians, and once more in $2.577-587$, when it is about to pass through the Symplegades. ${ }^{40}$

Internal actorial prolepses are usually connected with prophecy, dreams and omens, important motifs in the Argonautica. The most striking example is the prophecy of the seer Phineus. Zeus has punished him, because he would not refrain from revealing the entire divine plan to mankind (2.178-I82). When the Argonauts encounter him, he is reduced to a skeletal state, plagued by Harpies that come and steal his food or defecate on it. In return for chasing away the Harpies, Phineus tells the Argonauts the route they must take, and how they may successfully pass the Symplegades and return with the Fleece. This lengthy prophecy $\left(2.3^{17}-407,420-425\right)$ is later repeated verbatim at several points by the narrator, as it is fulfilled. Through the exact fulfilment of Phineus' prophecy, the voices of the omniscient prophet and the omniscient narrator as it were mutually enhance each other's credibility. ${ }^{41}$ Heeding Zeus' wrath, Phineus also utters predictions that are more implicit, for instance, that 'Aphrodite will be the Argonauts' divine helper' once they arrive in Colchis $(2.423-424) .^{42}$ This points forward to the fact that Medea will fall in love with Jason and help him obtain the Fleece with her magic. Unlike the Argonauts, the primary

them from going to the war, in vain.

${ }^{40}$ Although no literal echoes occur, cf. Fränkel i968: I59 n. I4. Furthermore, Amycus is compared to a wounded lion and a monstrous son of Typhoeus or Earth (2.26-29, $38-40)$, and Polydeuces to a shining star $(2.20-42)$ : this provides a strong indication of the outcome of their boxing match. Jason, appearing before Medea, is compared to Sirius, the baneful Dog Star (3.956-959; cf. Achilles at Il. 22.25-3I), foreshadowing his eventual detrimental influence on her life. Cf. Duckworth [1933] I966: I5.

41 SAGN г:6r. Cf. the advice of Circe and Tiresias to Odysseus in Odyssey i and 12.

${ }^{42}$ Cf. 2.388-39I, where he prophesies the encounter with the sons of Phrixus: 'Now here an unspeakable help will come to you from the bitter sea ... but what need is there that I should sin yet again declaring everything to the end by my prophetic art?' 
narratees will have understood this, although they may not have been prepared for the great elaboration of Medea's love, a theme new to epic.

An intriguing part of the prophecy is found when Phineus declines to reveal whether the Argonauts will be able to gain passage through the Symplegades $\left(2.34^{-}-346\right)$. Despite this, he continues his prediction, telling at length what will be ahead if they do successfully gain passage. This creates the impression that Phineus is construing a deliberate proviso ('you may yet fail'): perhaps he does not dare to make a full prediction for fear of angering Zeus again. In reality, we know that the Argonauts will pass; otherwise, the rest of the prophecy (2.346-425) would have been unnecessary. Moreover, their successful passing has already been hinted at by the narrator in the proem (I.2-3).

External actorial prolepsis also occurs mostly in prophecy, for example when Hera tells Thetis that Medea will be wedded to Achilles (who is as yet a baby) in the Elysian Fields, in future times (4.8II-8I5), or when Glaucus reveals to the Argonauts Heracles' future fate (I.I3I7I320). These divine prolepses are reliable, but when Jason vows eternal marital love to Medea (3.II28-II30), the narratees know that this will be tragically refuted by their later fates.

In numerous external narratorial prolepses, we learn the future fate of individual heroes, though not of the main characters. Thus, the narrator tells that the sons of Boreas will in future times be killed by Heracles, because he believes they are the cause of his being left behind (I.I302-I309); or that the progeny of Euphemus will colonize Thera, born from the clod of earth he throws into the sea (4.I756-1765). As indicated, we also frequently learn the future fate of objects, locations or of cults left behind or instituted by the Argonauts. These may in later times (metopisthen, opissō, vel sim.) have been called so and so, are still (eti nun) there to be seen, called thus, practised in like fashion, etc. ${ }^{43}$

In these external prolepses, which frequently turn into 'references to the narrator's own time', it may seem unclear what the immediate relevance to the main story of the Argonautic quest is. It would appear that often there is none, that is, none other than providing a 'proof' for

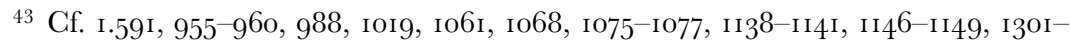
I309, I354-1357; 2.296, 526, 717, 746, 842, 853, 909-910, 929, 977; 3.203-209; 4.115,

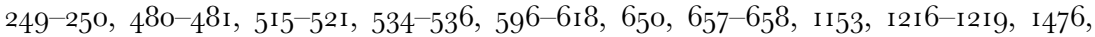
I6I9-1622, I727-1730, I770-I772. The link to the present is often expressed in such cases by phrases such as (eis) eti nun, exeti (keinou), ex hou, ek tou, es aiei/aien, kai opsigonoisi idesthai, etc. 
the fact that the Argonauts actually passed this or that way, that their actions had lasting results, and that the past may therefore be used to explain the present. In reality, we may guess, the process is rather the other way round; the fact that a given cult on a given location is attributed to the passage of the Argo in some literary or historical sources is used by Apollonius to plot the journey of the Argonauts in his epic. ${ }^{44}$ Omnitemporal digressions on geographical features are related to these external prolepses, since they imply a similar kind of continuity: in mythical times, the Syrtes (4.1235-I244) posed the same danger to ships as they still do. ${ }^{45}$

One aspect of external prolepsis remains to be discussed. It has often been observed that the Argonautica, especially books 3 and 4, functions as a prequel to Euripides' Medea. ${ }^{46}$ This is of course operative on the level of the actions, speeches and characterisation of the protagonists, for example the many threats Medea utters that she will visit Jason as an avenging fury if he will not keep his word to her. It also works on a more subtle level, as, for example, in the digression on the mantle of Hypsipyle discussed above, or in the time-marker at 3.747-748, where the narrator says that everyone sleeps, 'even some mother whose children are dead', but not Medea. This instantly triggers our association with Medea's future as the tragic murderess of her own children. Interestingly though, we never find any explicit mention of Medea's future fate as Jason's unhappy wife.

\section{Rhythm}

The abundance of temporal markers makes the rhythm of the Argonautica easy to determine. During the voyage, several episodes are worked out in detailed scenes, whereas the actual travelling and the uneventful periods of delay are usually dealt with in summaries. Thus, from the

\footnotetext{
44 This may be seen most clearly in passages like $4.55^{2-} 55^{6}$ : 'Now, Goddesses, say how it is that beyond this sea ... the mighty tracks of the ship Argo are clearly sung of? What great constraint and need brought the heroes so far? What breezes wafted them?' Cf. also 2.84 I-857, on which see $S A G \mathcal{N}$ I:55. For the idea of the Muses as a trope for the narrator's interaction with his literary sources see e.g. $S A G \mathcal{N}$ г:48-50.

45 Cf. I.935-94I: the Isle of the Doliones; 2.729-745: Acherusian headland; 2.1002I029: discussions of the customs of the Chalybes and Mossynoeci.

${ }_{46}$ E.g. Duckworth [1933] 1966: 33; Schmakeit-Bean 2003. For the prequel technique see Theocritus $(\rightarrow)$.
} 
embarking at Iolcus to the arrival at Lemnos, seven days pass, of which only the first two days, comprising embarkation and sailing, are related in any detail. ${ }^{47}$ Pauses are created by the manifold digressions, which together constitute more than half of the actual poem. They consist of aetiological explanations pointing backwards and forwards, (omnitemporal) descriptions of geographical or ethnographical phenomena, or of ekphraseis of objects, such as Jason's mantle.48

The outward journey (books I-2) is told in somewhat more detail than the journey back (4.2I I-end). ${ }^{49}$ Book 3, the episode in Colchis, is the most scenic of all and the least sidetracked by digressions. It comprises three days, related in I,407 lines. The scenic nature is of course mainly due to the great amount of direct speech. ${ }^{50}$ An exceptional position in book 3 , however, is taken occupied by the episode of Jason's ploughing the field of Ares with the fire-breathing bronze bulls, which fully concentrates on physical action rather than dialogue. The chronology of this passage (3.1278-1407) is clearly marked by elaborate time-markers (dawn, noon, dusk). The narrative is moreover continually interrupted by elaborate similes and comparisons (fifteen, in the compass of 129 lines), which have the effect of lengthening the narrative, as well as emphasising its miraculous nature.

A remarkable feature of the Argonautica is the use of explicit ellipsis. Several times, the narrator deliberately and explicitly passes over episodes in silence. In two cases, this is related to a claim of piety $(\rightarrow$ Callimachus): he refuses to relate the initiation of the Argonauts into the secret mystery cults at the island of Electra (I.9I6-92I) and the preparations of Medea for the cult of Hecate $\left(4 \cdot 247^{-250}\right) .^{51}$ The narra-

${ }^{47}$ Cf. four days journey from Lemnos to the land of the Doliones (I.910-935); three days spent in lamentation over Cyzicus (I.I057); twelve days keep Argonauts from sailing from the land of the Doliones (I.IO78); twelve days and nights spent carrying the Argo through the Libyan desert (4.I386).

${ }^{48}$ We find the ekphrasis of Jason's mantle in $\mathrm{I} .72 \mathrm{I}-768$, preceding his meeting with Hypsipyle, and thus creating retardation and suspense.

49 On the organisation of the books see Fränkel I968: 2I-22.

50 For example, the goddesses on Olympus scheming about Medea's love for Jason; the Argonauts pleading with Aeetes, and failing; the Argonauts planning to persuade Medea; Medea's frequent outbursts of despair; Medea's scheming with Chalciope; Jason's wooing of Medea. An exception is the remarkable lengthy indirect speech of Aeetes (3.579-608). A great amount of attention is moreover devoted to the psychological processes in Medea's mind (recounting of dreams, thoughts and feelings rather than actions). In general, the Argonautica contains less direct speech (29 percent) than the Iliad (45 percent) and the Odyssey (66 percent).

${ }^{51}$ It seems attractive to relate these pious silences of the narrator to Phineus' choice 
tor's suggestion that he will pass over in silence the construction of the Argo (I.I8-22), however, is in reality gainsaid by his frequent allusions to this building process, distributed over character-text and narratortext, throughout the epic..$^{52}$ His apparent refusal to relate this process may point to the fact that there were opposing traditions as to how it actually took place. Alternatively, we may want to relate it to the narrator's hesitancy throughout the poem to describe the interaction of humans with Olympian gods, since the Argo was traditionally said to have been built by Jason and Athena together. ${ }^{53}$

The epic begins and ends on an elliptic note. In the proem, the causes leading up to the eventual departure are related quite allusively $(\rightarrow$ Pindar), which seems to presuppose a great deal of prior knowledge on the part of the narratees. Some of this, however, is gradually filled in by the analepses relating to the story of Phrixus. At the end, the narrator takes his leave of the Argonauts saying that he has nothing more to tell about the Argo's journey 'since no adventure befell you as you came home from Aegina, and no tempest of winds opposed you ... and gladly did you step forth upon the beach of Pagasae' (4.I776-I78I). We might of course also interpret this as an extreme summary. At any rate, it serves to make clear quite explicitly that the narrative goal of the Argonautica, that is, the relating of 'the famous deeds of men of old, their long journey and all they did while wandering' has been reached. The end of the adventures is also the end of the story of the Argonautica.

\section{Frequency}

The default mode of narrating is singulative, although sometimes, especially in the speeches of the characters, repetition does occur. Unlike the Homeric $(\rightarrow)$ epics however, the Argonautica makes no use of 'typical scenes', that is, of the repeated singulative recording of events that recur practically daily, such as eating and drinking or sleeping.

Simultaneous iterative narration is found in the many 'omnitemporal'

\footnotetext{
to remain elliptic in his prophecy for fear of angering the gods (cf. 2.31 ${ }^{-}-316,390-$ 39 I), $S A G \mathcal{N}$ г:6o-6r. We may also compare 4.984-987, where the narrator sees himself forced against his will, and, he fears, against the will of the Muses, to refer to the castration of Cronus by Zeus.

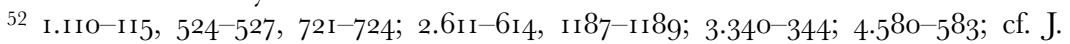
Murray 2005.

${ }^{53}$ Cf. Klooster forthcoming.
} 
descriptions of geographical features, natural phenomena, customs or rituals ( $\rightarrow$ Homer, $\rightarrow$ Herodotus), for example 'Circe's plain' in Colchis:

And there in line grow many willows, on whose topmost branches hang corpses bound with cords. For even now it is an abomination with the Colchians to burn dead men with fire, nor is it lawful to place them in the earth and raise a mound above, but to wrap them in untanned ox hides and suspend them from trees far from the city ..., for that is the custom of the land.

$(3.200-203)$

Such omnitemporal passages, which point to the continuity between the mythic past and the present, also occur in similes and time-markers $(\rightarrow$ Homer).

Repetition is occasionally exploited to corroborate or contradict statements of characters. In one case, an internal actorial prolepsis (the prediction of Phineus concerning the route east of the Argonauts) is echoed faithfully by the omniscient narrator at the time of its fulfilment, as we saw. The opposite is found in the Lemnian episode. When the Argonauts arrive at Lemnos, the narrator starts recounting what the Lemnian women have done to their husbands (external analepsis): 'Here the whole of the male population had been slain ruthlessly through the transgressions of the women, in the year gone by' (I.6og6ro). It is explained that this is the result of the Lemnian women's neglect of Aphrodite. In her anger this goddess then caused their husbands to fall in love with slave girls, so that the jealous Lemnian women killed them all. However, on their arrival the Argonauts do not know what has happened, and are dependent on the information the Lemnian women provide. In I.793-833 Hypsipyle presents a version of the story that leaves the Lemnian women free of blame. She claims that the men have left the island of their own free will. At the end of her lengthy speech, the narrator remarks: 'she spoke, glossing over the murder that had been wrought upon the men' (1.834). Later on, when the Argonauts arrive at the palace of king Lycus, Jason recounts everything the Argonauts have experienced so far, including the episode with the Lemnian women $(2.76 \mathrm{I}-77 \mathrm{I})$. The narrator merely summarizes Jason's account ('how they were welcomed by the Lemnian women'). Strictly speaking, then, we do not know what Jason's version of the Lemnian women's past is. But we may guess it is more like Hypsipyle's account than like that of the narrator. 


\section{Conclusion}

Although the Argonautica is an epic, like the Iliad and the Odyssey, its treatment of time is quite different. Some of the devices we observe in the Iliad and the Odyssey (such as foreshadowing through similes, internal prolepsis by characters, parallel storylines, external analepses describing objects) return in the Argonautica, but overall the differences are greater than the similarities. The narrator of the Argonautica does not choose to begin in medias res but chronologically recounts the story of the journey from beginning to end, while at the same time referring to events external to the story and heterodiegetic facts on a much larger scale than the Homeric epics do. Instead of indulging in many scenes, and allowing his characters to speak, the narrator includes many digressions and descriptions, which makes for a somewhat fragmentary narrative and draws attention to the process of narrating, rather than making the narrator 'disappear'.

A cosmic unity on a grander scale might however be sought precisely in the fact that the narrative of a single heroic journey is constantly connected chronologically and causally to events from the (mythical) history of the Greek world. Apollonius has a definite idea about the chronology of mythical times. As stated, he goes out of his way to connect these legendary times to his own time by means of aetiologies and omnitemporal ethnographical and geophysical asides. In this way he brings home his view that a strong continuity with the past pervades the Greek world. This continuity manifests itself in names, cults, objects and, most importantly, the stories that have been told and written down to explain these things, the ultimate sources for this learned epic. Collecting and combining the manifold historical, ethnographical and literary sources that refer to events somehow related to the Argo's journey, Apollonius turns this event into a pivotal point in Greek history. $^{54}$ In many respects, then, he seems indeed, as was argued in $S A G \mathcal{N}$ I, a historiographer turned epic poet, or vice versa.

54 Clauss 2000: 28. 
GHAPTER FIVE

\title{
CALLIMACHUS
}

\author{
M.A. HARDER
}

\section{Introduction}

In this chapter it will be shown how Callimachus' treatment of time is closely related to specific aspects of his literary technique, and often helps to convey a programmatic or metapoetic 'message'. The corpus studied for this chapter consists of Callimachus' Aetia and Hymns; examples from Hecale and Iambi will be adduced only when relevant.

\section{Order}

\section{Time and the order of events}

The narration in Callimachus' Aetia and Hymns is always subsequent, and the narrator repeatedly draws attention to this fact by marking the distance in time between the narrator and his narrative.

On the one hand this distance is marked by references to the narrator's own time. These are found particularly in aetiological passages, where the present appears as a result of events in the past, as in the Aetia, where aetiology is the overall framework, but also in, for example, Hymn I.II-I4, where Callimachus tells us that the Arcadians still regard the place where Rhea bore Zeus as a sacred spot, and 37-41, about the river Neda, which came into being as a bath for Zeus and is 'now' the oldest river of the Arcadians. ${ }^{1}$

On the other hand there are sometimes indications that something took place in the distant past when something familiar to the narratees

\footnotetext{
1 There are many examples of such passages in the Hymns; cf. e.g. also Hymn I.4445, 5I; 2.97-IO4; 3.197-203; 4.275-276.
} 
was 'not yet' so, as in, for example, Hymn I.I8-27 about the rivers of Arcadia, which were 'not yet' there when Zeus was born, or Hymn 6.24, where the story of Erysichthon is situated in a time when the Pelasgians had 'not yet' moved to Cnidus. ${ }^{2}$

Other passages too draw attention to the distance in time, though in a more implicit manner. Thus one in a series of brief comparisons in Aetia fr. 23.4, 'as the lustful ears of young men listen to a poor lover', evokes in a story about Heracles the kind of erotic setting also familiar from contemporary Hellenistic epigrams. Elsewhere, the narrator shows his own learning and reminds the narratee of the position of the Hellenistic poets in Alexandria, who have access to the sources of learning in the Library and to scholarly and scientific discussion. For instance, in Aetia fr. 43.I8-53 'the young Callimachus' gives a long list of Sicilian cities and their founders, before he allows the Muses to answer his question about the anonymous founder-ritual in Zancle; in Aetia fr. 75. I2-I4 the narrator takes position in the discussion about epilepsy as a 'sacred disease', and in $53^{-77}$ of the same fragment he summarizes his source for the story of Acontius and Cydippe which he has just told: this lengthy summary of the work of Xenomedes of Ceos particularly recalls the contemporary poet at work in the Library.

There are no large-scale instances of simultaneous or prior narration, that is, the narrative never runs parallel to or precedes the events as in prophecies. The picture Callimachus creates is always that of a learned narrator who looks back on a shared past from his own point of view late in the Greek tradition.

There is a certain amount of - seemingly-precise time-markers in Callimachus, but close analysis suggests that time is generally not indicated just for its own sake. Callimachus' primary purpose in these timemarkers does not seem to be chronological precision, but rather to convey some programmatic or metapoetic message to his narratees. For instance, the story of the Charites at Paros, which is the first story of the Aetia, is located in time by fr. 4, which tells us that it took place when Minos had extended his rule over the Cyclades. Thus the narratee is reminded of the fact that the Aetia begins at the point where

${ }^{2}$ For more examples cf. Hymn 2.88-89; $3.244^{-245} ; 4.40$, and for related phrases e.g. Hymn 3.47-48 about Lipara, which was 'then', that is, at the time of the events, called Meligounis; cf. also Hopkinson I984: ad Hymn 6.24. Also in the Homeric hymns $(\rightarrow)$ such passages may be found, as in e.g. h.Ap. 225-228. 
Hesiod's Theogony more or less ends, ${ }^{3}$ and may therefore be read as a sequel to that work. ${ }^{4}$ In fr. $7.23-26$ Calliope asks Callimachus to bring to mind the island Anaphe and the moment when the Argonauts left Colchis and sailed home to Greece. Thus she begins the story of the Argonauts in the Aetia at the end, as was well-known to readers of the Argonautica of Apollonius of Rhodes, where the events at Anaphe were one of the last adventures before the Argonauts set foot on Greek soil again. ${ }^{5}$ The time-marker therefore reminds the narratee of the contrast between Callimachus' and Apollonius' treatment of the Anapheepisode, and makes him wonder about the relationship between the two poets. At the same time it may have reminded him of the Iliad and the Odyssey, where the narrative also begins at the end of the Trojan war and at the end of Odysseus' vagaries, respectively. Another example is SH 259.5-8, where we find an epic time-marker, 'when the evening star was about to loosen the yoke of the oxen ...', at the moment when the old farmer Molorcus is disturbed by mice, which are invading his cottage and damaging his possessions. In the Iliad, however, such timemarkers indicate moments when the heroes prepare for battle. ${ }^{6}$ Using exactly such a time-marker at this point the Callimachean narrator playfully turns the following battle of Molorcus against the mice into a mock-epic fight. ${ }^{7}$

Apart from these occasional exact time-markers, aspects of time are usually vague. Thus stories may begin with an unspecified 'once upon a time', as in Hymn 5.57 en 70 and Hecale fr. 230 (= I Hollis) (and often in other poets, like Pindar). Besides, the duration of certain events is far from clear. Thus we may wonder how long Erysichthon's bulimic illness in Hymn 6.66-II5 really lasted. The imperfect tenses in which the story is told suggest that it took a certain amount of time before Triopas' stock was finally exhausted and Erysichthon had to leave his father's house to sit as a beggar at the crossroads. The series of excuses invented by his mother in $74^{-86}$ suggests a number of invitations to festivals, weddings and meals, and therefore also hints at a certain

${ }^{3}$ Although it is not quite certain where the Theogony actually ended and some passages in the later part of the work have been regarded as not authentic by various scholars, from Theogony 937 onwards we reach the time of the early Greek heroes, like Minos, Heracles, etc.

${ }^{4}$ Cf. Harder 2003: 296 n. 25; Fantuzzi \& Hunter 2004: 55 .

${ }^{5}$ C. A.R. 4.1694-I730.

${ }^{6}$ As in e.g. Il. Ir.86-93 and I6.779-780. Cf. further Fränkel I968: I4I and 6ı2.

7 Cf. Harder 2002: 194-195, with further references. 
amount of time. On the other hand Erysichthon's enormous hunger, which keeps him eating all day long (68-69 and 87-93), and his father's desperate prayer (98-IIO) suggest that Triopas' possessions must have shrunk rather quickly. Callimachus may have kept the time involved deliberately vague, in order to give the narratee the impression of an illness that on the one hand lasted long enough to cause a great deal of suffering and embarrassment and on the other hand showed the force of Demeter's anger because it destroyed Erysichthon quickly and effectively.

In Aetia fr. 75.12-21, where three diseases hit Cydippe when her father tries to marry her off to the wrong men, there are several time-markers, but they do not create a clear picture. The first disease, epilepsy, hits her on an afternoon and almost kills her; the second, a quartan fever, makes her suffer for seven months; the third, a cold, is merely said to have hit the girl; after that Cydippe's father does not wait for the fourth disease, but consults the oracle of Apollo. Callimachus here seems to be modifying and elaborating an epic pattern ('three times $\mathrm{X} \operatorname{did} \mathrm{Y}$, and the fourth time he ...'), ${ }^{8}$ and he may want to draw the narratee's attention to the fact that he fills in the unspecified 'three times' of the old epic.

In the Hymns the order of events is generally chronological, but Hymn 4 is fairly complex. The hymn begins in the present of the narrator, who announces his intention to sing about Delos and wonders which subject he will choose $(\mathrm{I}-29)$. He then decides to tell about the distant past, when Delos, still called Asteria, was left unfixed and floated across the seas until the time when it offered hospitality to Leto so that Apollo could be born (30-54). Having briefly announced his subject, the narrator then embarks on his story, Leto's vagaries (55I96) and Delos' receiving Leto (197-274). When Apollo is finally born, the narrator returns to the present: 'therefore you are called the most sacred of the islands since that time, the nurse of Apollo' (275-276), and the last part of the hymn $\left(275^{-326)}\right.$ mirrors the beginning by its setting in the narrator's present. ${ }^{9}$ Meanwhile, in the story of Leto's search for a place to bear her child, the narrator's present is also evoked in an external prolepsis: Apollo's prophecy from the womb when Leto approaches Cos (162-I95). This island is the birthplace of

\footnotetext{
${ }^{8}$ Cf. Hopkinson i984: ad Hymn 6.13-15.

${ }^{9}$ Schematically one may render the sequence as follows: A $(\mathrm{I}-29)-\mathrm{B}(3 \mathrm{O}-54)-\mathrm{C}$

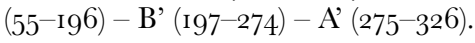


Ptolemaeus II Philadelphus, the narrator's contemporary, and Apollo adds a brief eulogy of the future/present king and his exploits against the Celts. Thus the hymn encompasses a wide range of time, in nonchronological order.

The same is true of the Aetia. The Aetia as a whole has a roughly chronological framework: it begins with the early myths of Minos, the Argonauts and Heracles and ends with the lock of Berenice in the narrator's present. ${ }^{10}$ Between these two points in time the chronology seems, however, to be rather unorganized. There are stories from various periods: after the early mythological period the time of the Trojan War is represented by only a few, rather marginal stories and by some stories about the return of the heroes and the aftermath of the war (e.g. the story of Peleus at Icus in fr. I78). Then we find stories which evoke the Greek colonisation of the East and the West, the local strives and battles on the islands in the Aegean Sea, the early classical period, and the early wars of Rome. Thus a long period of human history is represented, but to a large extent the narratee has to find out the exact chronology for himself. Only at the beginning and the end of the work is he made aware of the basic chronological order, but just before the story of the lock of Berenice (fr. IIo), at the end of the Aetia, he is back again with the Argonauts (fr. 108).

On a smaller scale we see the same 'chronological disorder' within some of the stories. In fr. 7.19-2I, the story of the Argonauts at Anaphe, Callimachus starts at the end of the Argonauts' journey. In the course of the story he evokes various events from the Argonaut-myth as it is found in Apollonius' Argonautica, such as the murder of Medea's brother Apsyrtus (fr. 8), the stay at the island of the Phaeacians (fr. I2-15), the colonisations of the Colchians, who are afraid to return to Colchis without Medea and therefore settle on the Adriatic coast (fr. Io-I2), and the departure from Pagasae according to Apollo's oracle (fr. I8.9-13).

The way in which Callimachus reminds his narratees of the whole Argonautic expedition within the brief compass of the story of Anaphe draws attention to his 'elegiac' treatment, which forms a contrast with the well-organized chronological treatment in Apollonius of Rhodes' $(\rightarrow)$ epic Argonautica. He is also clearly indebted to Pindar's Fourth Pythian Ode, where the temporal structure is also complex, and one of the first events we are confronted with is Medea's prophecy on the Argonauts'

10 Cf. Harder 2003. 
homeward journey ( $\rightarrow$ Pindar). Again we see that the treatment of time is to a large extent programmatic and helps to represent Callimachus' literary views.

In a similar way the order in the catalogue of Sicilian cities and their founders in fr. 43.18-53 may be explained. When compared to the chronological list of colonisations in Thucydides 6.3-5, it becomes clear that the Callimachean narrator has opted for a non-chronological order. This is in tune with the claim of discontinuity which he voiced in the prologue of the Aetia (fr. I.3) and at another level mirrors the overall scheme of the equally discontinuous Aetia. It also evokes the picture of a scholar who has the vast resources of the Library at his disposal and can at any given moment elaborate any point of his text with little narratives from the past. Thus the catalogue's arrangement may be to a large extent programmatic.

\section{Prolepsis}

Callimachus makes use of narratorial prolepsis in several passages. We find internal prolepsis on a small scale, adapted to the format of short stories which leave no room for long lines of suspense, in, for example, Aetia fr. 43.6I-65, where the secondary narrator Clio tells us that the founders of Zancle did not pay attention to the inauspicious birdomen of the harpasos when they were building their town. Immediately afterwards the expectations raised by this passage are fulfilled: the two founders quarrel over their status and cannot agree who must be regarded as the main founder of the new town (68-74). In Hymn 4.57-58 the words '[Hera was particularly angry with Leto,] because only she was going to bear Zeus a son who would be dearer to him than Ares' refer to the birth of Apollo, which will take place later in the hymn.

Sometimes the prolepsis is less explicit and relies on the narratees' understanding of an allusion, as in Aetia fr. 67.3, where Callimachus recounts how Eros taught Acontius his tricks, because the boy was not very clever. The adjective chosen here, polukrotos, recalls the beginning of the Odyssey, where in I.I Odysseus is called polutropon (for which a variant reading polukroton of unknown date is also recorded), and a fragment of Hesiod, where Odysseus' plans are called polukrotos, when he is wooing Helen (fr. I98.3). It may also convey the notion of 'producing a lot of noise'. Consequently we are not only informed that Acontius is 'no Odysseus', because of his lack of cleverness and eloquence, but we are also prepared for the sequel, when his courtship of Cydippe 
takes place in silence because he throws an apple at her inscribed with the oath that she will marry Acontius, in this way securing her as his bride. ${ }^{11}$

External prolepsis ${ }^{12}$ is found more often in Callimachus' works, and this may be related to the fact that in this respect short stories have no a priori limitations. As external prolepsis points forward to the future beyond the time of the story, it is also often found in aetiological passages, where the narrator informs the narratee about later events. Some examples are Hymn I.20-21, where we are informed that the now dry Arcadia 'later would be called very well-watered'; $3.24^{8}-250$, where Callimachus tells that 'later' the famous temple of Artemis was built in Ephesus; and 4.253-254, where the narrator talks about the seven strings of the lyre. A particularly interesting instance is Hymn 3.IO7-Io9, where we read that, when the young goddess Artemis has gone hunting for the first time and has shot four deer, Hera helps the fifth to escape so that 'later' it will become one of Heracles' labours. Later in the hymn,

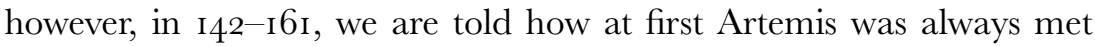
by Hermes and Apollo when she returned to the Olympus after the hunt, but 'now' Heracles waits for her when she returns, and takes her spoils and urges her to shoot more animals. All the gods laugh heartily at him and his mother-in-law Hera most of all. This implies that a considerable amount of time has passed since Artemis' first hunt, and that in the meantime Heracles after having lived his life to its end and having performed his labours has gone up to the Olympus, where he married Hera's daughter Hebe. The use of proleptic 'later' in I07-Io9 seems to draw the narratee's attention to the contrast between thelimited - life-span of Heracles on earth and that of the goddess, who is eternally young and vigorous, as well as to the narrator's own time, when both divinities are living on the Olympus.

The way in which the Callimachean narrator combines here the technique of the external prolepsis with the 'reference to the narrator's own time' device is an interesting development. In this way continuity is suggested between the mythological past and the historical present. This is even more clear in a passage like Aetia fr. $75.5^{0}-54$, 'and from that marriage a great name would arise, for still your tribe, the Acontiads, rules widely and is much honoured in Iulis, Cean, and we

${ }^{11}$ Cf. Harder 2002: 192-I93.

${ }^{12}$ In fact the narratee often is able to establish whether a prolepsis is internal or external only when he has read the whole narrative. 
heard about this love of yours from ancient Xenomedes ...'. What is initially presented as an external prolepsis turns out, after the narrator's speculations about the delights of Acontius' wedding-night, to be a fact in the narrator's present. The narrator draws special attention to this present by explaining how he found the preceding story in an old source. Another, somewhat similar, but more complex case is found in fr. 12.4-6 about the later migrations of the Colchians: 'moving again from there they founded Orician Amantine. And these things would thus be fulfilled in later times'. Here we are first offered a description of events which took place well after the time of the story of the Argonauts, and then the narrator checks himself and explicitly presents these events as an external prolepsis. In this way the narrator draws attention to his own position in the present, from which he looks back at the earlier events and is free to select what he will tell or withhold (see also section 2.I above).

Sometimes external prolepsis is open-ended, in the sense that the outcome of the events is only suggested but not presented as certain. It takes the form of a prayer or request by a narrator who has just told his own story, so that narratorial and actorial prolepsis in fact overlap. This happens in fr. 64.II-I9, where the dead Simonides prays to the Dioscuri and presumably asks them to help him against the tyrant of Acragas, who had destroyed his tombstone, just as in the past when they helped him against Scopas, who refused to pay him for a poem. The concluding passage of Aetia fr. i Io, the Coma Berenices, preserved only in Catullus $66.79^{-} 92,{ }^{13}$ suggests that this poem also included an external prolepsis in the form of a request by the lock for sacrifices in the future.

External actorial prolepsis also is a means to extend the story beyond the time span covered by the actual narrative. In these cases the character speaking may have a certain status or express his intentions in a prayer, so that the prolepsis gains authority and makes the narratee inclined to believe in it. Thus we find Jason promising to send many sacrifices to Apollo in his prayer when the Argonauts are covered by darkness near the small island of Anaphe in Aetia fr. 18.5-8. Elsewhere

13 Catullus 66.79-88 does not correspond to anything in Callimachus' Coma Berenices, where in the papyrus line 89 follows immediately on line 78; Catullus 66.89-92 may correspond to the Greek text, but the papyrus-fragment is too scanty to be certain. For the view that Catullus 66.79-88 may still go back on another version of Callimachus' poem see recently Jackson 200i (with further references). 
gods are predicting the future and particularly in Hymn 4 this technique is used with great encomiastic effect, highlighting important issues in the hymn. First Apollo speaks from his mother's womb in Hymn 4.88$9^{8}$ about his future oracle in Delphi, which is 'not yet' there, and about Niobe, who in the future will offend Leto so that even now Thebes is unfit as a place of birth for Apollo. A little later in the same hymn this motif is repeated in a second prophecy by Apollo, in which he also rejects Cos as a place of birth, not because it is unworthy, but because there Ptolemaeus II Philadelphus will be born, the future king of Egypt, who will defeat the Celts (I62-I95). In this second prophecy the encomiastic element is clear and the king is neatly connected with the god, who shows him his respect and predicts that he will be his faithful ally. In a third actorial prolepsis the island Delos predicts her own future as Apollo's sacred island (266-273). Here the prolepsis helps to enhance the status of the island and it is confirmed by the ensuing narratorial description of her importance in $275-326$.

In Hymn 5 the fate of Tiresias, who is made blind by Athena because he saw her bathing, is contrasted with the sadder fate of Actaeon, who 'in the future' will be torn to pieces by his own dogs for a similar offence (107-I 18). Subsequently, in I I9-130, Athena predicts Tiresias' future: he will be a great prophet and have a long life and even after his death he will be the only mortal who keeps his conscience when he is in the underworld. As in Hymn 4 the prolepsis seems to acquire additional weight by being pronounced by a god and again the narrator confirms it by adding in $13^{\mathrm{I}-\mathrm{I} 33}$ that Athena nodded her assent to her own words and that she was the only goddess whom Zeus had given the means of thus fulfilling her promises.

\section{Analepsis}

There are no examples of internal analepsis in Callimachus' work. This may be explained by the fact that his narratives are generally short and do not seem to have room for this device (see also above on internal prolepsis, which is also rare).

External analepsis as a means to include the past and extend the time span of the stories is well-attested. On a small scale examples of external analepsis are found in, for example, Aetia fr. I8.4-I3, in the story about the Argonauts at the little island Anaphe, where it works on several levels. In this passage, dealing with one of the last stages in the Argonauts' homeward journey, Jason returns to Apollo as the cause of 
the expedition in 9 and to the departure from Pagasae in I0-I3. Thus the whole journey is briefly evoked. However, there are also several allusions to Apollonius of Rhodes' Argonautica in this passage, which add to its complexity and help to evoke other episodes from the Argonautic expedition before the events at Anaphe. For instance, in 4 there is an allusion to the Argo's 'good keel', which recalls Argonautica I.4O I and 526-527 (where Athena adds a speaking piece of wood to the ship's keel) and 4.580-595 (where the Argo urges Castor and Pollux to pray for a safe journey after Apsyrtus has been killed and the Argonauts have become frightened). In 6-I3 Jason's prayer recalls similar prayers by him in Argonautica I.4II-424 (at the Argonauts' departure) and 4.I70II705 (also at Anaphe). By means of these allusions Callimachus also evokes the building of the Argo, the killing of Apsyrtus (which in the Aetia took place in Colchis, not during the homeward journey as in the Argonautica; cf. fr. 8) and the scene of the Argonauts' departure, and particularly Apollonius' treatment of these events. ${ }^{14}$ The effect of this analepsis is therefore twofold: it is external in the sense that it evokes events that took place before the time span of the main story, but it also refers the narratee to other texts which treat these events differently and more elaborately. We also see how actorial and narratorial analepsis are subtly interwoven in Jason's prayer: as a fictional character he refers back to what he 'remembers', but the narrator stays in charge, because he uses indirect speech, and by his choice of words and phrases refers the narratee to the Argonautica.

An intriguing case of narratorial analepsis is also found in Aetia fr. 75.53-77. Here the love-story of Acontius and Cydippe is followed by a summary of the narrator's source, the Cean history of Xenomedes of Ceos (ca. 45o BC). This summary offers the pre-history of the story just told and ends with the foundation of the four towns of Ceos, among which is Acontius' home-town Iulis. Within this summary other poetic texts are also alluded to, which offer additional information about the story of the destruction of the Telchines at Ceos, briefly told in 64-69. As in the Anaphe-episode the narratee himself is urged to complete the analepsis.

Elsewhere in the Aetia Callimachus experiments with narratorial and actorial analepsis by turning the narrator into a fictional character, who from a more or less unsatisfactory situation in the present looks back

\footnotetext{
14 For further discussion see Harder 2002: 217-223.
} 
and comments on his own history before it tries to mend the present so that the future will become better. This happens for instance in fr. 64, where the dead poet Simonides from a rather undefined position in the present recalls the fate of his tombstone, which was destroyed and built into the wall of Acragas, and then prays to the Dioscuri for help, and in fr. IIo, where the lock of Berenice describes how it came to be a star and recalls events from Berenice's earlier life before it focuses on the present and on its future cult. In both aitia the speaker's present seems to be sandwiched between the past and the future on which his interests are focused.

A special case of external analepsis is the narrative framework of Aetia $\mathrm{I}-2$, where the narrator looks back on his past: as a young man he was carried by the Muses to Mt Helicon in a dream and there heard aetiological stories from them. By this means he seems to 'paste' the earlier edition of Aetia $\mathrm{I}_{-}-2$ into a new edition of four books of aitia.

\section{Beginnings and endings}

Many Callimachean stories start at the beginning of the fabula. In the Hymns the beginning of the story is always well-marked and the narratee is first of all provided with some background information which helps him to evaluate the issues about to be narrated in the story. Thus in Hymn 4.1 -27 the story of Delos is introduced by an extensive description of the island. Then a question follows, in which the narrator asks Delos what it would like to hear and proposes to tell the story of how it became a fixed island after floating on the sea for a long time (28-54), beginning at the very beginning (cf. 'first of all', 3o), when the other islands got their positions in the sea, but Asteria (later Delos) did not. In 55, finally, the story of Leto's search for a place to give birth to Apollo begins and by that time the narratee is well-prepared to appreciate the story of how the floating island and the roaming Leto came together and found peace. In a similar way in Hymn 5.57-69 the story is preceded by a description of Athena's friendship with the nymph Chariclo, the mother of the very man whom she will subsequently rob of his eyesight, viz. Tiresias, and in $6.24-30$ we are told how the Pelasgians - still- live in Dotium, and the beautiful sacred wood they had created there for Demeter is described at some length. In these passages the narratee is prepared for the tragic dimensions of Athena's punishment of Tiresias and the enormity of Erysichthon's crime of cutting down Demeter's trees. 
In the Aetia we have the beginnings of only a few stories, but here a similar technique of providing background information may be observed. Thus Calliope begins the story of Anaphe, which belongs to the end of the Argonauts' homeward journey, at the moment when they leave Colchis (fr. 7.25-26). She includes amongst other things the Argonauts' stay at the island of the Phaeacians, where Medea acquired the servants who take part in the scurrilous ritual at Anaphe (fr. I2-I5 and 2I.5-7). In a similar way, Clio's story of the anonymous founder ritual in the Sicilian town Zancle in Aetia fr. $43 \cdot 5^{8-83}$, is preceded by a catalogue of other Sicilian cities and their founders in $18(?)-55$ by the primary narrator, 'the young Callimachus'. None of these towns has an anonymous ritual, so that the narratee is made well aware of the exceptional character of the ritual at Zancle.

At first sight, the story of Acontius and Cydippe seems an exception to the custom observed so far, to make a story start at the beginning (of the fabula). It seems to start in medias res in fr. $67 . \mathrm{I}^{-} 4$, where the primary narrator recounts how Eros taught Acontius his tricks when he was in love with Cydippe. However, in fr. 67.5-21 and fr. 68-69 the narrator retraces his steps and first offers a great deal of background information about the young people's countries, their descent and particularly their exceptional beauty.

Turning now from beginnings to endings, we may observe that endings in Callimachus may be quite abrupt but at the same time generally suggest that life went on after the end of the narrative and may contain a more or less explicit reference to the narrator's own time. Sometimes the suggestion of a continuation of the events is implicit in the narration of the events towards the end of the story. Thus in Hymn 6.1 6-II7 the story of Erysichthon has ended with a description of the boy sitting as a beggar at the crossroads, and the narrator hopes that no one who is an enemy of Demeter will ever be his neighbour or friend. The narratee may expect that soon afterwards Erysichthon died, but nothing to this effect is said. In Hymn 5.I37 the narrator turns to the women waiting for the procession after stating that Athena's promise to Tiresias will surely be fulfilled. Again the story ends abruptly and the narratee has to assume that Tiresias will indeed become a famous prophet. On the other hand the story of the birth of Apollo also ends abruptly with the baby being received by Delos in Hymn 4.274, but here the remaining part of the hymn contains an elaborate and explicit description of Delos' present fame, which was the reward for her hospitality to the pregnant Leto. 
In the Aetia the story about the founder's ritual at Zancle in fr. $43.80-$ 83 ends with an invitation to come to the ritual banquet, presented as if it is still thus formulated in the narrator's own time; the story of Acontius and Cydippe in fr. $75 \cdot 5^{0}-5^{2}$ ends, after a brief indication of the delights of the wedding-night, with the statement that the descendants of Acontius still rule at Iulis in the narrator's own time.

The story of Acontius and Cydippe must have contained two narrative strands, each with its own beginning and ending. When after their first meeting at Delos the boy and girl had gone home to Ceos and Naxos respectively, it was told how Acontius pined in the countryside (fr. 72-74) and Cydippe fell ill whenever her father tried to marry her off to another man, until he finally went to consult Apollo's oracle (fr. 75.I39). We do not know how Callimachus managed the separation of the two narrative strands and their respective beginnings, but only how in fr. $75 \cdot 4^{\mathrm{O}}-4^{\mathrm{I}}$ the two strands came together in a simple and straightforward way, when Cydippe went to Naxos: 'she was better; and then, Acontius, it was up to you to go to Naxos [?]'.

\section{Rhythm}

In the Aetia the amount of text devoted in the story to an event from the fabula is often very small, and on the whole we find few scenes and many summaries. One example is the story of the Argonauts at Anaphe in Aetia fr. 7.19-2I, where a large number of events are covered in ca. I50 lines: the departure from Colchis with Aeetes' angry speech, the journey to the island of the Phaeacians with the Colchians in pursuit, the Colchian colonisations on the Adriatic coasts and islands, the Argonauts' stay with the Phaeacians and eventually the adventures at Anaphe, where in response to a prayer by Jason Apollo saved the Argonauts from darkness and they celebrated on the island and established the new ritual for Apollo Aegletes. ${ }^{15}$

In Aetia fr. 75, part of the love-story of Acontius and Cydippe, we get a picture of a fairly uneven and complex rhythm. ${ }^{16}$ In 77 lines the fragment covers the episode at Naxos, when Cydippe's father tries to marry his daughter off to other men and she falls ill each time until

15 The same period is covered in roughly I,500 lines in Apollonius of Rhodes' Argonautica 4.183-1730.

${ }^{16}$ For an earlier discussion see Cairns I979: II7-I20. 
the situation is finally solved when her father consults Apollo's oracle. Of these 77 lines some twenty are used to tell the actual story, and the fabula-time covered by these lines is considerable, as one of the illnesses is said to have lasted seven months. ${ }^{17}$ Lines $38-40$ may give a good impression of the laconic treatment of the narrative: 'The god spoke, and he [sc. Cydippe's father] went back to Naxos and asked the girl herself; she told him the whole story and was better'. The rest of the 77 lines is taken up by two pauses, a digression about a weddingritual at Naxos (2-9) and one about epilepsy (I2-I4), a long quotation of Apollo's oracle, with some digressions not directly relevant to the plot (22-37), speculations about Acontius' delight in the wedding-night (44-49), and a summary of the narrator's source (53-77). Thus passages of great speed alternate with pauses and narratorial comments.

In the summary of Xenomedes the speed is even higher, as lines $5^{6-}$ 74 cover the history of Ceos from its beginnings through various generations and populations until the foundation of its four main towns. Even so, the summary refers the narratee to other works beside the Cean history of Xenomedes himself. He is referred to the poems by Pindar and Bacchylides about the destruction of the Telchines at Ceos and allusions to the Odyssey help him to acquire a better picture of the crimes committed by the king of the Telchines. ${ }^{18}$ Thus the narratee is enabled to expand the story himself if he wants to and the apparent summary style in fact hides other layers of information relevant for the understanding of the narrative.

A similar kind of unevenness can be observed in the Victoria Berenices, where the battle of Molorcus with the mice who invade his cottage is treated at length in $S H$ 259, but the narratee is invited to find out about the battle of Heracles with the Nemean lion for himself in $\mathrm{SH}_{2} 64$. The ellipsis is quite explicit, and the metapoetic message seems to be that a well-known story such as the death of the Nemean lion is not worth telling and can be found elsewhere. At the same time the way in which the ellipsis is brought to the narratee's attention enables those who wish to do so to add the information left out and to fill in the gaps in the poem. ${ }^{19}$

Implicit ellipsis is found in the catalogue of Sicilian cities in Aetia fr. $43.18-55$ : the narrator presents the towns only briefly (e.g. 'I know

\footnotetext{
${ }^{17}$ Cf. fr. $75 \cdot 17$ about the quartan fever.

18 Cf. Harder 2002: 198--199.

19 Cf. Harder 2002: I99-20I.
} 
of ... Cretan Minoa, where the daughters of Cocalus poured boiling water on the son of Europa', 46-49) and leaves it to the narratee to look up the details of their foundation. Again the ellipsis seems to be presented in a way that invites the narratee to fill in what is left out and thus extends the actual narrative so that it includes more than is actually said. In this respect ellipsis in Callimachus has a function which is different from that in the early epic and drama: there it is a means to focus the narratee's attention on the things that are really important, whereas in Callimachus' poems it is a means to activate and challenge the narratee..$^{20}$

In the Hymns, in view of the scarcity and often unspecific nature of the time-markers, it is often difficult to determine what the exact time span of the story is, but in general, as in the Homeric hymns $(\rightarrow)$, it is rather short: some days or months. The narration mainly proceeds through a combination of summary and scenes, including a great deal of direct speech..$^{21}$ In Hymn 5 the narrative of Tiresias' blinding is limited to the scene of the conversation between Athena and his mother Chariclo. In Hymn 4 the time covered is that of Leto's search for a place to give birth and her protracted labour. All this is presented in a narrative of some 220 lines (Hymn 4.55-275), with long speeches of various characters creating a series of scenes. In Hymn 6 we again have a simple plot and a considerable amount of direct speech in three short scenes, which illustrate Erysichthon's crime and the embarrassment and despair of his parents. It is not entirely clear, however, how long Erysichthon's illness lasted. Even so, on the whole the speed is slower in the Hymns than in the Aetia, with a comparatively large amount of direct speech.

Variety in rhythm is often employed by Callimachus to great effect. A good example is Aetia fr. 75.38-40, where after the lengthy quotation of Apollo's oracle (scene) the subsequent events are presented in a summary of only a few lines. In a similar way Hymn I.IO-54 gives a lengthy description of Zeus' birth and babyhood and then deals with his growing into a young man summarily in only two lines $\left(55^{-56}\right)$; in Hymn 3.46-85 Artemis' visit to the Cyclopes is described at length, and then in 86 the completion of her armour, which was the purpose of the visit, is described in less than a line.

${ }^{20}$ Cf. Schmitz I999: I56-I57 and I65-178.

21 Cf. Harder 2002-2003: 52-55. 
The narrator not only may accelerate his speed but even interrupt his story altogether. A good example is Aetia fr. 75.2-9, where the narrator starts to explain a wedding-ritual at Naxos and then checks himself and speaks about the dangers of too much knowledge in a garrulous character like himself. One is reminded here of Pindar $(\rightarrow)$, and his Abbruchsformel. Another example is the brief 'dialogue' with the Muses about tree-nymphs, which interrupts the story in Hymn 4.82-85.

On the whole Callimachus' style of narration is very compact, and we do not find any significant repetition. In fact, passages like fr. $75.3^{8-}$ 40 show that Callimachus sometimes indicates quite clearly that he does not want to repeat what has been told already. Iterative presentation is found occasionally, for example in Hymn 6.68-69 and 87-93, Erysichthon's continuous eating and drinking.

\section{Conclusion}

A striking aspect of Callimachus' treatment of time is that it is closely related to the special character of his self-conscious and learned poetry. It draws attention to the scholarly narrator, who looks back on a shared past and is able to make use of the whole literary tradition before him, and it helps to highlight aspects of Callimachus' literary technique in relation to his contemporary Apollonius of Rhodes. It also draws attention to the role of the narratee in this kind of poetry. Callimachus' use of prolepsis, analepsis and ellipsis activates the narratee, in that it incorporates preceding, future or even central events by means of allusions to other literary treatments. The same applies to his treatment of rhythm, which becomes more elliptic and allusive as soon as the narratee can be relied on to think of other texts for his information. Thus 'time' is one of the tools used by Callimachus in order to create his own sophisticated kind of poetry. 


\title{
GHAPTER SIX
}

\section{THEOCRITUS}

\author{
JJJ.H. Klooster
}

\section{Introduction. Time awareness in Theocritus' poetry}

Thinking of the world of Theocritean Idyll, our first impression may be that it is one in which the concept of time must be of little or no account. ${ }^{1}$ Especially the so-called bucolic poems, which established Theocritus' name as a canonical author, convey the idea of remote and endless summer afternoons, the typical time of day for bucolic singing (Idylls I, 6 and 7) when 'Pan is resting' (I.I5-I6) and even 'the lizard sleeps in the stone walls' (7.2I-22).

When an indication is given as to the relative time in which the narrative should be placed, it is often vague: 'once upon a time' (e $\bar{e}$ khronos hanika, 7.I; pote, 6.2; I8.I). ${ }^{2}$ These indications may refer both to a remote mythical past (as in Idyll I8, describing the wedding of Helen) and to a more recent past, for example within the lifetime of the internal narrator (Id. 7, where Simichidas is reminiscing). Although this vagueness in itself may not be surprising, it gains relief through the peculiar recurrence of identical names in a number of the Idylls. So we may ask: does Idyll 6 feature the mythical cowherd Daphnis (about whom Thyrsis sings in Idyll I) or a contemporary cowherd, who just happens to be called Daphnis? ${ }^{3}$ It seems that the ambiguity serves to underline the a-temporality of the bucolic world as represented in

\footnotetext{
${ }^{1}$ Cf. Segal i981: i: 'pastoral's tendency to exclude the temporal dimension'; Stanzel I995: 38-43; Goldhill r991: 245-246.

2 There are no references to relative time in the pastoral mimes without a narrative frame, that is, I, 3, 4, 5, Io. In the absence of references to contemporary political events in these poems, they are impossible to date.

${ }^{3}$ Cf. on this Wilamowitz ı9o6: i36; Ott I969: г2г; Lawall ı967: 69; Dover ı97г: I40; Bernsdorff I994; Stanzel 1995: 39-40. This in turn entails the question of whether Daphnis in 6 is supposed to be singing about the Cyclops Polyphemus as a contemporary or as a figure from the mythical past; cf. Hunter 1999: 245. The same applies to Comatas in Idyll 5 and 7; cf. E.A. Schmidt I987: 88.
} 
Theocritus' Idylls: the countryside and the pursuits of the herdsmen are always the same. ${ }^{4}$ In Homer, by contrast, the difference between men living in the heroic past and 'men who live now' is signposted explicitly $(\rightarrow$ Homer).

The fact, furthermore, that the herdsmen in the poems never seem particularly pressed for time, nor engage much in what may reasonably be termed 'action', but leisurely saunter along with their cattle or seek shelter from the heat in the shade of the nearest tamarisk, adds to this mood of dreamy timelessness. ${ }^{5}$ The general impression that is consciously created in the bucolic Idylls, then, is one of a world in which time matters little. Only when love is involved do Theocritean characters all of a sudden display an acute awareness of time, for example when Simaetha mentions that her lover has not visited her 'for eleven days' (2.4) ${ }^{6}$

But if time may not be of prime importance to the characters, the narrator Theocritus is certainly interested in experimenting with narrative time. It would be impossible to describe the single Theocritean way of dealing with time, since the corpus consists of a wide-ranging collection of poems which display a considerable variety in narrative form (purely narrative, mimetic, or mimetic with a narrative frame). ${ }^{7}$ In this chapter, some of the more characteristic and striking instances of Theocritean handling of time will be discussed. ${ }^{8}$

\footnotetext{
4 The point that human nature does not change is explicitly made in the opening of Idyll I3 (I-3): 'Love was not born for us alone, Nicias ... we are not the first to consider beautiful things beautiful'. This is illustrated by the tale (placed in heroic times) of Heracles' love for Hylas. Cf. also Id. i I.

${ }^{5}$ Cf. Rosenmeyer I969: 65-98 on the otium characteristic of pastoral poetry. Strootman 2007: 206 tentatively suggests that the leisure of Theocritus' fictive herdsmen may be a reflection of the otium of the elite who read about them.

${ }^{6}$ A characteristic aspect of the time awareness of many of Theocritus' characters is their reckoning of time by the days since they first/last saw their beloved. (Id. 2.4; I0.I2; II.25-26; I2.I-2; I4.44-47; 30.2).

${ }_{7}$ Cf. $S A G \mathcal{N}$ r:83, 94 on the many narrative forms represented in the Theocritean corpus.

8 The 'Theocritean corpus' refers to all the Idylls handed down to us under the name of Theocritus. Some of the Idylls (8, 9, 19, 20, 21, 23, 25, 27) are generally considered spurious. The epigrams are not discussed, as they do not contain much narrative material.
} 
The time span of the narratives

The time span of the mimetic idylls (Idylls I, 2, 3, 4, 5, IO, I4 and I5) is usually short. The same is true for mimes embedded in a narrative frame, in which an external narrator sketches the setting (Idylls 6, [8], [9], II and I8). No events to speak of happen in these short narrative frames.

Many of the poems, however, contain embedded narratives that reach beyond the time span of the main story (e.g. in Idylls I, 2, I I and I4). Thus in I4 the time span of the poem itself is only a brief conversation; but in it one of the speakers outlines the history of the estrangement from his ex-sweetheart, starting at a point 'two months minus two days' before the actual conversation, as he conscientiously calculates (14.44-47). We find something similar in the narrative Idyll [25]. The time span of the poem encompasses the meeting of Heracles with an old man who accompanies him to the stables of Augeas, his inspection of the cattle and a walk to the palace with the son of Augeas, all in all comprising a couple of hours. However, the larger part of the poem consists of a speech, in which Heracles recalls in detail how he once, at some point in the past, slew the Nemean lion (I92-282).

The narrative idylls may comprise variable time spans. Idyll 22 (Dioscuri) contains two separate narratives of exploits of the Dioscuri in one poem $\left(27^{-1} 34, \mathrm{I} 35^{-2 \mathrm{II}}\right)$; it is not indicated what the relative chronology of the events told in the two narratives is. They both comprise events of one day. A longer time span is covered in $\mathrm{I} 3$ (Hylas) and 24 (Heracliscus). The latter poem (Heracliscus) can be divided into three parts: I63 recount the events of a single night; 64-I02 relate a conversation between Alcmena and Tiresias on the morrow of that same night, in which the seer predicts Heracles' future; and I03-140 (where the manuscript breaks off) tell of Heracles' childhood.

In 13 , the first event, strictly speaking, is found in the relative clause 'Heracles, who withstood the fierce lion' (I3.6), alluding to the first of Heracles' twelve labours. This might however also be called a heterodiegetic analepsis, if we prefer to consider the main story we are dealing with here to be that of the Argonautic expedition, rather than that of Heracles' exploits. ${ }^{9}$ Chronologically the last events in the narrative $(72-75)$ are the establishment of Hylas' immortality (which consti-

${ }^{9}$ We may compare the reference to the birth of Dionysus in $26.33-34$ (Maenads or Bacchantes). 
tutes a kind of never-ending future; $\rightarrow$ Homeric hymns) and Heracles' arrival in Colchis on foot. In between (25-7I), the narrator relates how Heracles lost his beloved Hylas and went searching for him while the Argo departed, events that span only a couple of hours.

\section{Modes of narration: subsequent, simultaneous and prior}

As in most Greek literary genres, by far the most frequent form of narration in the Idylls is subsequent narration. Theocritus does display a certain fondness for simultaneous iterative narration. A first example is found in 17.18-33 (Encomium of Ptolemy), the description of a banquet on Olympus, and later in $77^{-116 .{ }^{10}}$ The latter passage glorifies the enduring accomplishments of the ruler: the political and economic situation of Egypt under Ptolemy Philadelphus. This is achieved by bringing the marvels of Egypt and the martial prowess of its king before our eyes in detail, for example in:

Countless countries, and countless tribes of men therein, with the aid of rain from heaven, bring their crops to ripeness ..., but none is so prolific as the plains of Egypt when the overflowing Nile soaks and breaks up the soil, nor has any so many towns of folk skilled to labour. ... And of all Lord Ptolemy is king. Yes, and of Phoenicia he takes himself a part [apotemnetai $]^{11}$ [etc.] ... the best ships that sail are his ... about him gather horsemen and shielded warriors in host, harnessed in flashing bronze. ${ }^{12}$

$\left(77^{-94)}\right.$

The praise of the king is reminiscent of the way victorious athletes and rulers are honoured in Pindar's $(\rightarrow)$ victory odes, or of the way in which

${ }^{10}$ Cf. also 22.8-22 (Dioscuri); I6.8-I2, description of the poet's Graces, always returning home moodily, when they have been sent out to no avail. The joke here is that these Graces are goddesses and personifications of Theocritus' poems at the same time. It is therefore fitting and ironic at the same time that this is a case of simultaneous iterative narrative: the ways of goddesses are usually unchangeable, and Theocritus' poetry will, he presupposes, never find a patron ...

${ }^{11}$ It is hard to make out the precise nuance of the present tense here. Theoretically, it could be singulative narrative in the historic present (Ptolemy has in the past encroached on the borders, that is, was engaged in warfare). Gow I952: II 339 is in doubt whether an ongoing war is being described (i.e. 'he cuts off') or whether this is a description of pacified regions (i.e. 'he has cut off'). Hunter 2003: ad loc. resists the idea of drawing chronological conclusions regarding Ptolemaic warfare from the passage and remarks: 'that Philadelphus is cutting slices off ... merely shows that he is acting as a proper warrior-king should'. This points to an iterative reading of the form.

12 All translations are adaptations from Gow 1952. 
deities are sung of in the Homeric hymns $(\rightarrow),{ }^{13}$ not accidentally the two genres with which this poem is often compared. The marvels of the land of Egypt, on the other hand, might be related to the geographical digressions (usually in the present tense) found in historiography. The simultaneous iterative narration, with its use of the present tense, gives the impression - without spelling it out - that what is presented is an unchangeable, everlasting situation.

In the same poem, the simultaneous iterative narration of I8-33 indeed describes such an everlasting situation unambiguously. Theocritus here relates how Ptolemy Soter is sitting on Olympus with on the one hand his ancestor Heracles and on the other Alexander the Great, and how the two minor godheads help Heracles whenever he returns drunk from his banquet to the chamber of his wife Hebe (note the iterative optative ioi in 28 and the gnomic aorist edōken in 30).

Idylls 14 and 55 also contain stretches of simultaneous narration. In I4.46-49 Aeschinas describes the present behaviour of his ex-sweetheart Cynisca; for example, 'Now Lycus is everything to her, and she keeps her door open for him at night' (47).

In Idyll i6 (Graces or Hiero), we find a more complicated case of simultaneous narrative. The narrator presents himself as trying to find a patron for his poetry. He hopes Hiero II, tyrant of Syracuse, will fulfill this position, and therefore addresses him as follows:

Not yet are the heavens wearied of bringing around the months and years; often still shall the steeds set the wheel of Day in motion. That man shall be who shall have need of me for his poet when he has done such deeds as great Achilles wrought or dread Aias ... Already the Syracusans grip their spears by the middle and charge their arms with shields of wicker, while Hiero in their midst girds himself like the heroes of old with crest of horsehair shadowing his helmet.

$(72-8 \mathrm{I})$

(A long prayer for the defeat of the Phoenicians and the establishment of peace on Sicily follows, 82-ıoo.) The reason why Idyll i6 predominantly expresses wishes for the future instead of praising laudable accomplishments has been sought in the fact that Hiero had not yet done anything praiseworthy at the moment Theocritus chose to write him an encomium - if we are to take the poem literally, this encomium

13 Of course, the Homeric hymns describe an everlasting state (gods are immortal); this is not what Theocritus explicitly claims for Philadelphus, although he obviously tries to create the impression of everlastingness, cf. the opening lines, juxtaposing Ptolemy to heroes and gods (I-8); and the deification of Philadelphus' parents (I3-52; I2 I-I25). 
was in fact unsolicited. ${ }^{14}$ Yet, after a short introduction, which consists of prior narration (72-75), lines 76-81 employ simultaneous narration, as if Hiero's warfare were already in full swing. The following prayer for peace on Sicily, which is neither exactly a prediction nor, obviously, a narrative, manages to capture exactly the same suggestive tone.

The third form of narration, prior narration, is sparingly used. There is, however, one intriguing case: the song of Lycidas in 7.52-89 (Thalysia). In this embedded narrative the goatherd-singer Lycidas pictures to himself the day when the boy he loves, Ageanax, will depart: ${ }^{15}$

Fair voyage to Mitylene shall Ageanax have [essetai $\ldots$ if he saves Lycidas from the burning of Aphrodite [rusêtai, prospective subjunctive]. $\quad{ }_{(52-56)}$

He then describes in detail what he himself will do:

And I on that day will wreathe my brows with anise ... and draw from the bowl of Pteleatic wine as I lie by the fire ... and will drink at my ease remembering Ageanax ...

$(63-66)$

The paradoxical effect of reminiscing about Ageanax in the future tense is one of distancing, almost of acquiescing in advance in the absence of Ageanax.

\section{Prolepsis and analepsis}

Straightforward prolepsis is only sparingly used throughout the Idylls. An instance is the external actorial prolepsis made by Tiresias concerning Heracles, his life, death, and apotheosis (24.72-I0o). We do find instances of subtle foreshadowing, for example in $13.49^{-53}$, where it is couched in a comparison. Hylas falls into the spring of the Nymphs:

And headlong into the dark pool he fell as when some flaming star falls from the heavens headlong in the sea, and some sailor cries to his comrades, 'Loosen your tackle, my boys, it is a sailing breeze'. ${ }^{16}$

(I3.49-53)

This passage appears to be foreshadowing the actual departure of the Argo (68-70), leaving Heracles behind, still searching for Hylas

${ }^{14}$ So Gow 1952: II 305-307; F.T. Griffiths i979: I2-I6; but contrast Hunter 1996: 77-78.

${ }^{15}$ Hunter 1999: I67 following Puelma I960 and Williams I97I (Lycidas is really the god Apollo in disguise) suggest that Lycidas is prophesying here.

${ }^{16}$ Cf. van Erp Taalman Kip I99ı: Ir6; Hunter I999: 28I. 
$(\rightarrow$ Homer, $\rightarrow$ Apollonius). Another variant is the playful foreshadowing of future events known to the audience in Idyll II (Cyclops), in which we see young Polyphemus before the events of Odyssey 9. ${ }^{17}$ These allusions to the future are not inserted into the text of the external omniscient narrator (II.I-I8 and $8 \mathrm{O}-8 \mathrm{I}$ ), but are, ironically enough, evoked by certain utterances of the character Polyphemus, who is of course pathetically unaware of his future. In this way, they get the character of so-called 'dramatic irony' ( $\rightarrow$ Apollonius). Polyphemus, in love with Galatea, refers to his single eye in a way deliberately calculated to remind the reader through intertextual hints of his blinding by Odysseus in Odyssey 9. So in II.50-53:

But if it is myself that seem too shaggy to you, I have oak-logs and undying fire beneath the ash, and you may burn my soul, and my one eye too, than which nothing is dearer to me. ${ }^{18}$

(II.50-53)

Sometimes we find no prolepsis where it might be expected, as in 18 (Epithalamium of Helen), which recounts the songs sung at the wedding of Menelaus and Helena. An external narrator introduces the song of the Spartan maidens in lines $\mathrm{I}-8 .{ }^{19}$ The wishes then expressed by the maidens for the future happiness and eternal mutual love of the couple in lines $5^{-}-53$ would seem to clash poignantly with the fated outcome of this notoriously unhappy marriage, as told in, for example, the Iliad and Euripides' Hecuba and Troades. Alternatively, we might think of the other version as told in the Helen of Euripides, or the Palinode of Stesichorus, in which Helen was not unfaithful to Menelaus, but was abducted to Egypt, while a phantom-Helen stayed at Troy. Which of these two outcomes is here to be presupposed? ${ }^{20}$ It might just

${ }^{17}$ His youth is explicitly referred to in lines 8-9: 'When, with the down new on his lips and temples, he was in love with Galatea'. This reference probably has a double intention: to explain the youthful gaucheness of the Cyclops in the affairs of the heart, and to make clear that this episode is taking place before the famous meeting of Odyssey 9 .

${ }^{18}$ Further allusions to this episode in his later life: $6 \mathrm{I}-62$, his wish that some stranger might arrive by ship in order to teach him how to swim; 79 ('It's plain that on land I too am somebody'-tis phainomai èmen), perhaps an allusion to Odysseus' false name Outis (Nobody) in Odyssey 9.408; cf. Hunter 1999: 242.

19 There is one reference in the frame to events before the wedding. This is found in lines I6-I8 (the chorus speaking): 'Menelaus alone of all princes who came to Sparta was awarded the daughter of Zeus as bride'.

20 The poem may have been written to celebrate the wedding of Arsinoe and Philadelphus (F.T. Griffiths 1979: 86-9I). If so, reference to a negative outcome of the marriage would have had to be carefully avoided. In view of Helen's Egyptian 
be that Theocritus was interested in the fact that at this point in the story, every ending was theoretically still possible. There are no hints in the text foreshadowing the great upheaval this marriage was eventually going to cause. Thus, the suppression of the external prolepsis arguably dramatizes the impossibility for ordinary human beings to foresee the future, but also points to the possible variants of the myth. Clearly, Theocritus relishes exploiting the ironic or comic potential inherent in 'before the famous story'-episodes of myth, or prequels. He makes use of this potential by the insertion of what might be called intertextual prolepsis or prolepsis based on the narratees' prior knowledge and, conversely, by leaving out an expected prolepsis. The same techniques are found in Apollonius $(\rightarrow)$; they seem typically Hellenistic.

Yet another variant of external prolepsis is found when the narratees are actually left in the dark as to whether or not what a character says will come true, while the odds against are high. An example is Simaetha's prediction that she will win back her lover:

Now with my love magic will I bind him, but if he will vex me still, so help me the Fates, he shall beat upon the gates of Hades, such evil drugs, I vow, I keep for him in my box, lore that I learned, o mistress, from an Assyrian stranger. Farewell, now Lady Moon, and turn your steeds towards the Ocean. And I will bear my longing as until now I have endured it.

(I59-I64)

To this prospect can be added her assertion in lines 8-9: 'Tomorrow I will go to Timagetus' wrestling-school to see him and will reproach him that he treats me so'. Evidently, this leaves room for four alternative endings of the affair: either (I) Simaetha will go and scold Delphis at the gymnasium; or (2) he will succumb to the magic of her drugs, and love her again; or (3) he will not, and she will try to poison him; or (4) she will just 'endure her longing as she has done until now', that is, do nothing but indulge in melodramatic expressions of self-pity. Judging by what we have witnessed so far, the choice will probably be between the first and the last alternative. Although the narratees in this case have no objective information about events and only hear Simaetha's subjective

connection, the popularity of the cult of chaste Helen (cf. Hdt. 2.I12) there and the assimilation of Arsinoe with Helen in Idyll I5.I I I, such a positive conception of Helen is not at all unlikely (cf. Call. Pannychis fr. 227 Pf.). Contrast Konstan I979: the disparity between the divine Helen and the human, slow-witted Menelaus foreshadows the unhappy outcome of the marriage. In some respects, Idyll I8 is reminiscent of Sappho 44 Voigt (the wedding of Hector and Andromache), which also excludes references to future tragedy, focusing on the happy present. 
account, the net result is still that they can form a clear picture of the eventual outcome, which is something that is beyond Simaetha's grasp. ${ }^{21}$

Analepsis is much more frequently used, mostly to sketch (usually briefly) what went before, in order to explain the current situation (completing external analepsis) to the narratees. Thus, Simaetha's narrative $\left(2.64-5^{8}\right)$ is one long analepsis, explaining her statement in lines 2-6:

... I will bind a spell upon my lover, so hard to me. For eleven days, he has not even visited me, the wretch, and knows not so much whether I am dead or alive.

After some hocus-pocus and prayers to Hecate to win back Delphis' love (Io-63), she proceeds to unravel the story of how she has ended up in the present situation. She starts with the aporia-topos:

Now that I am alone, from what point shall I lament my love? From where shall I begin? Who brought this curse upon me?22

$(64-65)$

She then actually goes back in time a bit too far, describing in great detail irrelevant facts about the neighbour who invited her and a friend who lent her a wrap when she went out to see the parade of Artemis (66-76). At the same time, of course, this apparently irrelevant excursus provides us with valuable information both about Simaetha's social environment (not too elevated) and her intellectual capacities (not too great).

A comparable characterizing use of actorial analepsis is found in Aeschinas' narrative in Idyll I4.I2-55. In his account of the last occasion on which he saw Cynisca, his ex-sweetheart, he relates how somebody mentioned a certain 'Lycus', Cynisca's present lover:

There is this Lycus, it's Lycus, the son of Labes, the neighbour, a tall softskinned fellow that many think handsome. It was for him, that precious passion that had Cynisca on the grill. The thing had come to my ears one day, just on the quiet, but I never looked into it ...

$(24-28)$

Judging by this little story about Lycus, Aeschinas could have spotted trouble coming long ago. His inability to do so illustrates his disinterest for Cynisca's feelings, which probably contributed to the break-up, and is comically at odds with his sentimental moping for her loss.

21 Cf. I .77-79, Polyphemus asserting that he can get any girl he wants.

22 For this topos see also I7.8-12 and $S A G \mathcal{N}$ I: index s.v. 'narratorial devices'. 
A final topic related to order concerns the handling of simultaneous events. In Idyll I3, when Hylas has fallen into the spring and is being comforted by the nymphs (I3.53-54), Heracles is already worried and searching for him (I $3.55^{-57}$; men ... de...); while he is doing so, the Argo departs (I3.68-7I; gemen). The synchronization underlines the unheroic nature of Heracles' behaviour: while looking for his lover, he 'misses the boat'. In Idyll 24, Amphitryo is alerted by Alcmena to the weird phosphorescence caused by the snakes sent by Hera, and prepares to intervene $\left(34^{-52}\right.$ ), while baby Heracles has already strangled the monsters (23-32). Here, the synchronization serves to emphasize Heracles' precocious powers, and independence.

\section{Ellipsis and allusive narrative}

Ellipsis is employed to some effect by Theocritus. An intriguing use is found in Idyll 7 (Thalysia). The internal primary narrator Simichidas recounts his meeting with the goatherd Lycidas and their exchange of bucolic song. Throughout this narrative, temporal ellipses seem to occur that create the enigmatic atmosphere clinging to Lycidas. Thus, when the two meet (line 2I), they call each other by their respective names $(20,27)$. Yet, we have not yet heard how they became acquainted. Have they ever met before, or have they just introduced themselves to each other? The narrator does not tell us anything on these points. ${ }^{23}$ The air of mystery caused by the ellipsis may well be deliberate (on the part of Theocritus), and has led to much speculation about the true identity of Lycidas. ${ }^{24}$

Related in effect is the remarkable use of temporal ellipsis or allusive narration in I.65-I42, Thyrsis' song about Daphnis. ${ }^{25}$ The embedded narrative tells us about Daphnis' wasting away and death while animals and men mourn him, and gods come to enquire into the cause of his

\footnotetext{
${ }^{23}$ Cf. Hunter 1999: 155: 'Whether the narrator's information about [Lycidas] is to be understood as something Simichidas had at the time, or something he subsequently acquired, is left mysterious'.

${ }^{24}$ Cf. Stanzel I995: 35-36. For the idea that Lycidas is Apollo see e.g. Puelma I96o; Williams I971; Hunter i999: i67.

25 On the elusiveness of the story of Daphnis, and the ancient testimonia concerning it, see Hunter 1999: 63-68, with bibliography. The myth of Daphnis is found in e.g. Ael. VH Io.I8 and D.S. 4.84. This local Sicilian myth presumably would not have been widely known to Theocritus' contemporaries and, at any rate, the version we find here does not fit the traditional story.
} 
suffering and offer commiseration or comment upon it. The narrator, Thyrsis, omniscient and external to the narrative he recounts, does not explain why Daphnis is suffering. There is no analepsis to relate what has caused the situation that is narrated in the song; it is passed over in silence. The narratees must base their guesses on the fragmentary, and perhaps unreliable, information that can be gathered from the remarks of Daphnis' visitors. Yet, this is not enough to form a consistent fabula. It has been a scholarly challenge to reconstruct the 'true' story of Daphnis' suffering and death from ancient testimonia. This approach starts from the assumption that there was a well-known myth, which is alluded to here, leaving it to the narratees to fill in the gaps, a practice we find in the victory odes of Pindar and Bacchylides. However, as recent critics have argued, it is possible that what we find here is a pastiche of this kind of allusive narrative. In reality, the primary narratees would not be able to piece together a complete fabula -even if the secondary narratee in the Idyll itself, the goatherd, does appear to be familiar with it. In other words, the primary narratees are meant to be tantalized by the elusive details of Daphnis' story. ${ }^{26}$ It looks as if the story starts in medias res, but in reality Thyrsis completely leaves out the 'what went before'-part, and leaves the primary narratees with an incomplete story.

\section{Other forms of rhythm}

In the mimetic Idylls the fabula-time and story-time naturally coincide, and we are dealing with scenes. In narratives that are embedded in such Idylls, we may find effective variations in rhythm. Thus, the change of tack in the narrative is psychologically revealing in Simaetha's account of her love affair with Delphis (Idyll 2). The day she meets Delphis is described with elaborate detail in 66-80 (scenic). A dramatic acceleration follows as Simaetha breathlessly emphasizes the disastrous speed with which she fell in love with Delphis $\left(8_{2}-8_{3}\right)$ : 'The instant I saw him, madness seized me, my poor heart was set aflame, and my looks wasted away'. This is followed by an account of the effects of her lovesickness (85-92; summary, comprising ten days). She finally decides to tell her maid what is ailing her (94-I02; scene, emphasized because

\footnotetext{
${ }^{26}$ Hunter I999: 62-63; Goldhill I99I: I42.
} 
it forms a turning point in her story). The maid goes to fetch Delphis, and he immediately arrives (IO2-IO4; the acceleration underlines Delphis' eagerness). Simaetha's instant emotional and physical reaction to this is once more described in a detailed way (IO5-IIO; slowing down). Delphis embarks upon a lengthy speech, repeated verbatim (III-I37; scene; Simaetha, recalling the scene, has apparently absorbed every single word Delphis said). The lovers then yield to their desires (I40I43): 'And quickly body warmed to body and faces burned hotter than before, and sweetly we whispered. And to tell you no long story, dear moon, all was accomplished, and we both came to our desire.' This (slightly elliptic) summary underlines Simaetha's coyness, ${ }^{27}$ which is strangely at odds with the fact that it is she who invited Delphis (whom she has only glimpsed in the street) to her house in the first place and the eagerness with which she yields to his proposals. In this way she glosses over her own part in the proceedings, while earlier spending a lot of time on Delphis' first speech to her. She plainly tries to exonerate herself. The rest of the relationship is briefly summarized in a single line (I44): 'and he had no fault to find with me until yesterday, nor I with him', accentuating the unexpectedness for Simaetha of the troubles that followed. In the remaining lines, Simaetha relates what happened today (she has heard Delphis is unfaithful; I45-I58; scene), announces her plans for the future (159-166; summary), and takes leave of the Moon, to whom she has been addressing her tale. This variation of narrative rhythm is a psychologically realistic tool, used to characterize Simaetha in her plight.

In the narrative Idyll 22 (Dioscuri), which all commentators agree has a distinct hymnic flavour, we also find a varied use of rhythm, reminiscent of Pindar $(\rightarrow)$. The $I d y l l$ starts out with a passage employing simultaneous iterative narrative (hymning the Dioscuri, the narrator wonders which of the two heroes he will hymn first, $\mathrm{I}-26)$; next, in a summary, the voyage of the Argo is recounted until the moment the Dioscuri land in the country of the Bebrycians (27-29). Between 30$3^{6}$ the rhythm of the narrative gradually slows down: the Argonauts debark and prepare their camp; Castor and Polydeuces wander off into the woods to investigate the surroundings. In 37 they find a spring, which is described extensively in no less then seven lines (37-43; pause). By this beautiful spring a hideous man is seated, Amycus, who is

27 Not Theocritus' own sense of decorum, cf. 4.58-59; 5.41-43. 
again described in seven lines $\left(44^{-} 52\right.$; pause). The narratees are invited mentally to picture the spot and the man. ${ }^{28}$ At the same time the slowing down, the pause and the contrast between the surroundings and the man create suspense: what will happen next?

The poet then brings the 'mental picture' evoked by the elaborate description of the spring and Amycus to life: Amycus and Polydeuces engage in a stichomythic dialogue, extremely unusual in hymn, taking up over thirty lines (scene). Amycus refuses to let the Argonauts draw water from his spring, unless Polydeuces will engage with him in a boxing match. After this conversation, five lines are taken up to tell how both parties summon their cronies (75-79; acceleration). Next a detailed - and rather gory - account is given of the boxing match $(80-$ I36; scene), which is interrupted at II $5^{-\mathrm{I}} 7$ by an address to the Muse by the narrator asking how Polydeuces laid low Amycus. The final phase of the fight at 1 i $8-136$ is once more scenic. ${ }^{29}$

\section{Frequency}

As in most narrative, the default form of frequency is the singulative one. Of the other forms of frequency, repetition is used sparingly in Theocritus, which is not surprising as we are dealing with relatively short poems. An effective example can however be found in Idyll 2, where Simaetha relates the same event three times, each time with a slightly different emphasis. First she reveals that it has been some time since she last saw Delphis, and what the presumable reason for this is:

For eleven days now he has not even visited me, the wretch, and knows not so much as whether I am dead or alive. No, he has not once knocked on my door, so cruel is he. Surely Eros and Aphrodite have turned his fickle heart elsewhere.

Later, in line I44, she states: 'He found no fault with me, nor I with him, until yesterday'. This seems a strange thing to say, when the narratees know that she has not seen Delphis for eleven days nor, presumably, heard from him. This would surely be a reason to find fault with him? I assume that this was self-delusion to make herself

28 For comparable descriptions of loci amoeni, cf. 13.39-42, the spring of the Nymphs (similar in function, that is, pause, meaning suspense and pictorial effect), and 7.135I46, no pause, but only a (overly) picturesque sketch of a bucolic pleasance.

29 The second half of the poem displays a similar rhythmic pattern; cf. also Id. I3. 
believe that 'until yesterday', when she was told that Delphis was in love with another (I49-I54), everything was fine. Now that she has heard this, she can no longer deny the true nature of her situation, and interprets the eleven days of absence rather differently (I57-I58): 'But now eleven days are gone since I have so much as seen him. Must he not have some other delight, and have forgotten me?' Simaetha's pathetic mulling over the question why Delphis has not come to see her for eleven days and trying to tell herself that this was really only normal is once more psychologically convincing.

Iterative narration is used, apart from the hymn-like cases already discussed, mainly in passages that characterize protagonists, describing typical actions. Thus, it is found in II.IO-I8, recounting the behaviour of Polyphemus in love: ${ }^{30}$

And he did not love with apples or roses or lovelocks, but with downright frenzy, counting all else but trifles. Often [pollaki] would his sheep come of their own accord back from the green pastures to the fold while he, alone upon the wrack-strewn shore, would waste away with love as he sang of Galatea from the dawn, having deep beneath his breast an angry wound which the shaft of the mighty Cyprian goddess had planted in his heart. Yet, he found the remedy, and seated on some high rock he gazed seaward and sang thus...

(II.IO-I8)

When we compare the ending 'Thus Polyphemus shepherded (epoimainen, note the imperfect) his love' ( $8 \mathrm{I}$ ), we may conclude that the song we have just read is only a sample of the many love songs Polyphemus may be supposed to have sung.

\section{Conclusions}

Though, by and large, Theocritean characters appear not to be interested in time, except when they are suffering from love, the narrator Theocritus is clearly experimenting with forms of temporality, a characteristic aligning him with his Hellenistic contemporaries Lycophron, Apollonius $(\rightarrow)$ and Callimachus $(\rightarrow)$, and looking back to the practice of predecessors like Pindar $(\rightarrow)$ and Bacchylides $(\rightarrow)$. He uses the devices available to him to achieve very different effects, depending

${ }^{30}$ Cf. I3.8-I5: the way Heracles' love for Hylas expressed itself; 24.I35-I40: eating and dressing habits of young Heracles; simultaneous iterative narrative in $14.46-49$ : present behaviour of Cynisca. 
entirely on the context. Thus, prior narration expresses the melancholy detachment of a lover in 7 , and predictions by a seer in 24; combined with simultaneous narration, it is employed for encomiastic purposes in I6. Simultaneous iterative narration is found in hymn-like contexts, whereas in other cases it describes situations taking place in the present of the narrator ( $14 ; \mathrm{I} 5)$.

In Theocritus' employment of analepsis and prolepsis, we may note the omission of explicit prolepsis to the conclusions of well-known myths (II; I8), and omission of analepsis in an unknown, and possibly incomplete myth, to create a tantalizing and allusive narrative (I, song of Thyrsis). Conversely, Theocritus makes primary narrators construct their stories in such a way as to enable the narratees to imagine the objective facts beyond the presentation by the narrators (2; I4).

The potential of rhythm is fully exploited to characterize the narrator Simaetha in 2, while in 22 the change of tack is reminiscent of Pindaric practice. We find a decided penchant for descriptive pause in what we might call ekphrastic narrative (13;22).

Repetition and iterative narrative are both, in different ways, used to characterize characters. In Simaetha's mouth repetition becomes a recognizable psychological trait, whereas in in the iterative narrative of the Cyclops' behaviour gives relief to the hopeless incurability of his impossible longing for Galatea. 
Irene J.F. de Jong and René Nünlist - 978-90-47-42293-8 Downloaded from Brill.come4/26/2023 09:46:52AM via free access 
PART TWO

\section{HISTORIOGRAPHY}


Irene J.F. de Jong and René Nünlist - 978-90-47-42293-8 Downloaded from Brill.come4/26/2023 09:46:52AM via free access 


\section{GHAPTER SEVEN}

\section{HERODOTUS}

\section{T. Rood}

At the start of his work, Herodotus writes that 'among the matters covered is, in particular, the cause of the hostilities between Greeks and non-Greeks'. ${ }^{1}$ He goes on to relate the causes of the conflict according to 'learned Persians' - a story of the seizure of women (Io, Europa, Medea, Helen) with the final kidnapping leading to the Trojan Warand a variant Phoenician story of the circumstances under which Io came to abandon her native Argos (I.I-5). This Persian story, revolving around events before and up to the time of the Trojan War, is then contrasted with the events that Herodotus marks as the start of his story proper:

I will talk about the man who, to my certain knowledge, first undertook criminal acts of aggression against the Greeks. I will show who it was who did this, and then proceed with the rest of the account ... Croesus was Lydian by birth ... He was the first non-Greek we know of to have subjected Greeks to the payment of tribute, though he made alliances with some of them ... Before Croesus' reign, all Greeks were free.

$$
(\mathrm{I} \cdot 5 \cdot 3-6.3)
$$

No sooner has Herodotus made this claim, however, than he qualifies it by explaining why he has not started with an earlier incursion against the Greeks: 'the Cimmerian expedition which reached Ionia before Croesus' time was a raiding party, intent on pillage, and not a conquest of the communities there' (ı.6.3). Another external analepsis follows as Herodotus proceeds to tell the story of how rule over the Lydians had passed from the Heraclidae to Croesus' family, the Mermnads, and to narrate the noteworthy incidents in the reigns of Croesus' predecessors - incidents that include earlier cases of conflict with the Greeks (the war between Lydia and Miletus, for instance, which Croesus' father Alyattes inherited from his father Sadyattes) as

1 Translations are mostly from Waterfield (Oxford World's Classics). All dates are $\mathrm{BC}$ and all references to Herodotus unless otherwise stated. 
well as more peaceful interaction ('as far as we know, Gyges [the first Mermnad ruler] was the first non-Greek to dedicate offerings at Delphi since the Phrygian king Midas', I.I4.2).

Dionysius of Halicarnassus praised Herodotus' choice of the beginning and end of his history: 'he begins with the reasons why the barbarians injured the Greeks in the first place, and proceeds until he has described the punishment and the retribution which befell them: at which point he ends' (Pomp. 3). But Herodotus' disposition of material at the start of his work complicates his definition of Croesus' reign (56o) as the start of his story. It is not just that he contrasts his story of Croesus' subjection of the Ionians with the Persian variant about the seizure of Asiatic and Greek women. It is also that he gives the background to Croesus' subjection of the Greeks by explaining how Croesus' family came to power and by showing how Croesus' predecessors had interacted with the Greeks. The chain of causation means that it is impossible to isolate one event as the start of the story. And the allusion to Gyges' dedications at Delphi offers a different beginning to another story, the story of the offerings made by eastern kings at Delphi (and here Herodotus is prepared to allow the sort of 'mythical' precedentMidas' dedications - that he was reluctant to tolerate when explaining the development of conflict between East and West).

Herodotus also complicates Dionysius' patriotic reading of his choice of an ending for his story. He continues the story of Greek-Persian hostility beyond the battles of Plataea and Mycale, both fought in 479, by narrating the events of the rest of that year, as the Athenians - under the generalship of Xanthippus, father of Pericles - start to assume the leading role in pressing the war against Persia in the eastern Aegean. Herodotus concludes with the statement 'Nothing further happened for the remainder of the year' (9.I2I) - and with an analeptic account of a proposal put to Gyrus that the Persians should move to a less rough land. The proposal was made by Artembares - an ancestor of the Artayctes whom the Athenians have just crucified at the richly symbolic setting of the Hellespont - on 'the shore on which Xerxes' bridge across the straits had ended' (9.I20.4). Herodotus' story ends with strong hints that a new story of the Athenian rise to power is starting: nothing further may have happened in that year, but the story of the Athenian rise to naval hegemony would continue. ${ }^{2}$

2 The end of Herodotus' work has been much discussed in recent years: cf. Boedeker ı988; Herington ı99ı; Moles I996; Dewald I997; Pelling ı997; and Flower \& 
At the same time, Herodotus' ending further undermines the opening of his story. The fact that Artayctes is punished for despoiling the shrine of Protesilaus (9.116, I20.4) provides a sense of an ending by looking back to the Trojan War - the beginning of Greco-barbarian hostilities highlighted by the 'learned Persians' at the start of the work. Herodotus seems to be suggesting that the Trojan War might after all have been an appropriate beginning for his story. Indeed, he had earlier compared the size of Xerxes' army with Agamemnon's and described how Xerxes visited Troy on his way to Greece (7.20.2, 43.I).

The difficulty of marking the end of Herodotus' story is further underlined by numerous external prolepses. These prolepses look ahead both to events involving Greeks and non-Greeks (e.g. 7.Io6-I07, I5I) and to the increased tensions among the Greeks in the years after their successful resistance to Persia (e.g. 7.137; 8.3.2; 9.35.2, 37.4, 64.2, 73.3 , I05). The accumulation towards the end of the work of prolepses narrating fighting between Greeks in the years between the Persian and Peloponnesian Wars and even events in the Peloponnesian War is an eloquent way of suggesting how the internal tensions that marked the Greeks' resistance to Persia later escalated into war between the states that had played the leading role in the Persian Wars.

Defining Herodotus' story is also made problematic by his practice of reporting variant versions. ${ }^{3}$ As well as creating a parallel metanarrative about the way in which tales about the past are transmitted, this practice destabilizes the notion of a single story. And even when Herodotus does not tell variants he does not necessarily guarantee the truth of what he reports: he sometimes claims to report what is told without necessarily believing it (2.123.I; 7.I52.3) - though elsewhere he does select the most plausible stories (e.g. I.214.5). Grasping the inescapably mediated and fragmented nature of his story is an essential part of understanding Herodotus' view of history.

The problems that Herodotus poses to the narratologist are even more acute because he is the first historian whose work we possess in full. The extraordinary variations in his temporal ordering seem the more striking for their contrast with Thucydides' season-by-season narrative of the Peloponnesian War. We do have fragments of earlier or contemporary writers such as Charon of Lampsacus and Xanthus of

\footnotetext{
Marincola 2002: ad loc.

${ }^{3}$ Cf. Groten 1963 and Lateiner r989: 84-9o for basic discussion and listing of variants, and Luraghi 200I for analysis of the metanarrative.
} 
Lydia, but concerted narratological analysis of their handling of time is impossible. If we did possess more of these writers, our own story of time in Greek historiography might be rather different.

\section{Frequency}

Herodotus departs from a singulative frequency most often in iterative summaries such as his account of Croesus' conquests: 'the Ephesians were the first Greeks Croesus attacked, but afterwards he attacked all the Ionian and Aeolian cities one by one. He always gave different reasons for doing so ...' (I.26). This sort of iterative summary is more common in the earlier books, when Herodotus is describing the more distant past. Compare, for instance, his account of Cyrus' conquests in inland Asia: 'While Harpagus was laying waste to coastal Asia, Cyrus himself was doing the same in inland Asia. He systematically defeated every tribe, passing over none (ouden parhieis). I will pass over (parhēsomen) most of these ...' (I.I77). Here the use of the same verb draws attention to the contrast between Cyrus' systematic conquest of inland Asia and the selective treatment in the narrative. The selectivity of the narrative stands in opposition to Cyrus' ruthless quest for totalizing power. At the same time, the narrative remains in thrall to Cyrus' heroism: Herodotus will narrate those events that gave Cyrus 'the most difficult time (ponon pleiston) and were the most noteworthy (axiapēétotata)'.

The handling of iterative narration causes Herodotus some problems when it conflicts with the ordering of his narrative by kings - that is to say, when a repeated action is carried over by one king from his predecessor. All that Herodotus reports under the reign of the Lydian king Sadyattes is that he succeeded his father, reigned for twelve years, and was succeeded by his son Alyattes (I.I6). It is in recounting Alyattes' reign that Herodotus reveals more about the father:

Alyattes inherited from his father a war between Lydia and Miletus. This is how he used to conduct the invasion of Milesian territory ... they would destroy the fruit-trees and the crops and then return home ... This is the way he conducted the war for eleven years ... For six of the eleven years Sadyattes the son of Ardys was still the Lydian ruler and it was he who invaded Milesian territory each year; ... but for the next five years, it was Alyattes the son of Sadyattes who carried on the war.

(I.I7-I8) 
Here the iterative narration of the first eleven years of the war (varied only by a mention of two major Milesian defeats during this time) contrasts with the singulative narration of the decisive twelfth year-when Alyattes made peace with Miletus after being deceived into thinking that the Milesians were faring much better under the invasions than they in fact were. But Herodotus creates some confusion by appearing to attribute the campaign of all eleven years to a single king (epolemee etea hendeka): Waterfield's translation smoothes over the difficulty by making the ambiguous 'Lydian king' rather than 'he' (i.e. Alyattes) the subject of the verb. Herodotus then uses the technique of progressive correction ${ }^{4}$ to modify the impression he has created. Or is that impression itself a suggestive blurring of the two kings, pointing to the continuity between father and son?

Repeating narration tends to be found when Herodotus uses 'headers' or when he makes his characters repeat stories found in the earlier narrative. 'Headers' (from $\rightarrow$ Homer onwards, and $\mathrm{cf}$. the 'initial summary with subsequent elaboration' in $\rightarrow$ Pindar) involve repetition because they introduce a section of narrative by giving its substance in summary form (e.g. 'After this King Darius captured Samos', 3.I39.I, followed by a detailed narrative of how he captured the island). Here the departure from singulative frequency is simply a matter of the arrangement of the narrative. Repeating actorial analepses are more potent: they highlight the way characters are swayed by the urge to imitate, or avoid, precedents. Herodotus does, however, show some concern for avoiding repetition: when he makes Xerxes argue that 'there would be no point in recounting all the victories Cyrus, Cambyses, and my father Darius won, and all the peoples they annexed, because you

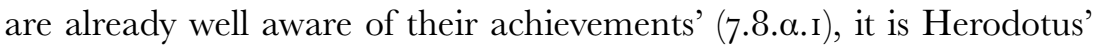
own audience as well as Xerxes' that is aware of the achievements of these kings. ${ }^{5}$ The mere mention is enough to show how Xerxes feels the weight of precedent.

The use of repeating actorial analepsis also hints at how Herodotus' work can be read as repetitive at a deeper level. As the Histories progress, a powerful sense is created that the same story of imperial ambition and overreach is being told a number of different times, and the explicit allusions to earlier examples are part of the way this sense of repetition is created. (There are also links in terms of the repetition

${ }^{4}$ Cf. R. Lattimore 1958 for this technique.

${ }^{5}$ Cf. de Jong 20orb: Io6. 
of narrative patterns, above all connecting Darius' invasion of Scythia and Xerxes' invasion of Greece. $)^{6}$ That is not to say that the singulative aspect does not remain important. Indeed, the singulative supports the repeating: the very fact that Croesus and the various Persian kings differ among themselves highlights more strongly the feature they share - the fact that they all eventually succumb to the expansionist urge and confirm Herodotus' judgement that human prosperity never stays in the same place $(\mathrm{I} \cdot 5 \cdot 4) .^{7}$

\section{Speed}

The transience of human prosperity itself affects the speed of Herodotus' narrative - at least according to a methodological statement placed near the start of the narrative: 'I will cover minor and major human settlements equally, because most of those which were important have diminished in significance now, and those which were great in my own time were small in times past' (I.5.3). It is not clear in practice how this principle affects the speed of the narrative: Herodotus does not in fact cover - or even promise to cover - major and minor settlements with the same amount of detail; his comment is mainly a way of focussing on the theme of human fragility. Herodotus does offer other comments on the space he has devoted to a section of narrative. Twice he claims that the presence of extraordinary monuments is a reason for expanding his coverage of a place (2.35. I on Egypt; 3.60.I on Samos). ${ }^{8}$ More commonly he draws attention to ellipses. We have already seen the contrast between the singulative and iterative treatment of Cyrus' conquests - where Herodotus says that he will narrate those achievements 'which gave him the most difficult time and were the most noteworthy (axiapēgētotata)'. The same criterion of the noteworthy is found when he writes that Gyges attacked two Greek cities and seized another, 'but he achieved nothing else of significance (mega ... ergon) during the thirty-eight years of his kingship, so I will say no more about him' (I.I4.4). In none of these comments, however, does

${ }^{6}$ Cf. Hartog [1980] I988: 30-35.

${ }^{7}$ Cf. Pelling I99ob: 259; Dewald 2003.

8 There is a difference between the two passages in that the first is placed before, and the second after, the lengthy description: the second in a sense justifies the historian in going on to describe three Samian building achievements. 
Herodotus comment explicitly on the relation between his selectivity and the duration of the actions he has selected. So too Plutarch in his De malignitate Herodoti criticises Herodotus for his judgement of what is eventworthy, not for the relation between textual space and duration (e.g. $858 \mathrm{a}-\mathrm{b} ; 866 \mathrm{c}-\mathrm{d} ; 87 \mathrm{Ib})$. But that is not to say that we should not analyse speed ourselves.

Analysis of speed is hampered by Herodotus' lack of precision. ${ }^{9}$ It is possible to measure the textual space devoted to the reign of different kings against the length of their reigns (which Herodotus often reveals at the end of their reigns). Croesus' fourteen years are covered in 52 OCT pages; Cyrus' reign takes up 64 pages, but its length is unclear; Cambyses' reign of seven years and five months takes up I74 pages; Darius' 36 years are covered in 275 pages, Xerxes' seven years in $25^{1 .}{ }^{10}$ These figures, however, give a distorted sense of the speed of the work, above all owing to the ethnographic and geographic components and to the extensive anachronies found in Herodotus' work. The narrative of Cambyses' reign, for instance, includes I25 pages on Egypt, a section introduced only ten lines into his reign and that itself includes spectacular variations of speed (330 kings are summarized in a page at 2.IOO-IOI).

Some significant trends may still be noted. Like Livy's account of the rise of Rome, Herodotus' narrative slows down as it advancesits expansions matching in some sense the expansion of Persian power (though Herodotus' greater tendency to digress and his ethnographic concerns make the effect less clear-cut than in Livy). The slower narrative of the Persian expeditions against Greece contrasts with the much faster narratives of conquest found in the opening book. As we have seen, it is in the opening sections of the work that Herodotus tends to use iterative, summary forms (see, for instance, the summary of the peoples Croesus had conquered at I.28). The effect of this arrangement is to establish the will to conquer as in some sense the natural path for rulers. The same restless urge for, and fear of, conquest is taken over by

9 On Herodotus' chronology see Strasburger ig65; Cobet 2002.

10 Figures for Croesus, Cambyses, and Darius are given at I.86. I; 3.66.2; and 7.4. Xerxes' seven years are from his accession to the end of the story. Cyrus is more problematic: Herodotus never gives the length of his reign (modern historians reckon it at approximately 29 years); his conquest of Croesus is reckoned here under Croesus' reign; and the pages allotted to his reign here include the accounts of Median kings and of his birth and childhood. His reign after his conquest of Croesus (sixteen years) takes up forty pages. 
later characters but subjected to a more detailed analysis. In particular, the steps through which conquests are achieved are now examined in much greater detail.

Variations in speed on a smaller scale become easier to isolate in the course of the work. Starting with the narrative of the Ionian Revolt, Herodotus does sometimes mark divisions of seasons and years (see, for instance, the indications by year at 6.I8, 3I.I, 40.I, 42.I, 46.I; 9.I2I, and the indication of the start of spring at 6.43.I; 7.37.I; 8.I30.I) ${ }^{11}$ and a break-down by days is found in some parts of the Persian Wars narrative. But at the micro-level of, say, the battle narrative analysis of speed is often difficult because Herodotus tends to offer a series of incidents rather than a continuous narrative - though Plutarch $D e$ malignitate Herodoti 873e did attempt such an analysis of the Salamis narrative: 'he has written more on queen Artemisia than on the rest of the fighting put together' (in fact 32 lines out of I3I). ${ }^{12} \mathrm{He}$ also tends to be vague about how long episodes lasted: $:^{13}$ the fighting at Marathon, for instance, went on for 'a long time' (khronos ... pollos, 6.II3.I), and chronological detail on the preceding and following days is also scarce 6.ro6.I, the runner Philippides reached Sparta from Athens on the second day; I06.3, it was the ninth day of the month at Sparta - a detail required to explain why the Spartans delay until the full moon before sending help; I07.I, the night before the Persians landed Hippias had a dream; iı, the battle was fought on the day Miltiades held the prytany (but we do not learn how many days had passed since the decision to fight was taken); 120, the Spartan army arrives on the third day after setting out).

\section{Order}

Herodotus' disposition of his material has often been admired (e.g. D.H. Pomp. 3). ${ }^{14}$ As we have seen, he starts with a brief account of the Lydian king Croesus, then goes back to his predecessors before giving

\footnotetext{
${ }^{11}$ Cf. Pohlenz I937: I98-I99; also Bouvier 2000, who rightly warns against attributing to Herodotus the same sort of seasonal perspective found in Thucydides.

12 The calculation of Bowen I992: I47.

${ }_{13}$ Powell 1938 s.v. khronos helpfully lists many of the common temporal expressions used by Herodotus.

14 Modern treatments include Immerwahr i966: 79-147; de Jong 2002; de Jong also focusses on narrative transitions, on which see also Lang I984: I-I7.
} 
a fuller account of Croesus' conquests, leading up to his conquest by the Persian king Cyrus. He then turns back to give one of the stories about Cyrus' birth and to describe his rise to power in Persia and his successes as king. He then describes in succession the reigns of the next three Persian kings, Cambyses, Darius, and Xerxes.

While Herodotus' work has a broadly linear pattern set by the succession of Lydian and Persian kings, it has numerous anachronies, many of them of considerable length. Some shorter instances of analepsis are a mark of deft storytelling - for instance, the type of 'archaic' delay analysed by Fraenkel in a classic note. ${ }^{15}$ An excellent example of Herodotus' use of delay comes in his description of Cambyses' death. When Cambyses heard that one of the magi who rebelled against him was called Smerdis, he 'saw the true meaning of the dream, in which someone had brought him a message that Smerdis was sitting on the royal throne with his head touching the sky' (3.64.I). Stricken with grief for having had his brother Smerdis killed, he leapt on his horse to make for Susa - and as he did so he was wounded with his own sword in his thigh, 'in exactly the same spot that he had previously wounded the Egyptian god Apis' (3.64.3). Realising that the wound was fatal, he asked the name of the place and was told that it was Ecbatana: 'Now, the oracle in Buto had earlier told him that he would die in Ecbatana. He had supposed that he would die of old age in Ecbatana in Media, ... but the oracle, as it turned out, had meant Ecbatana in Syria' (3.64.3-4). Realising that he had misinterpreted the oracle, he announced that this was the place where he was to die. Here Herodotus' handling of time creates an extraordinary sense of destiny. There are two analepses involving repetition of earlier information the dream, the wounding of Apis) in addition to the delayed narration of the Ecbatana oracle. The analepsis about Cambyses' wounding of Apis suggests a possible causal link between that outrageous action and his death. But whereas the dream about Smerdis had to be narrated earlier (3.36.2) to make Cambyses' decision to kill his brother Smerdis intelligible (since that decision was based on a misinterpretation of the dream), the Ecbatana oracle could be left until the moment it was fulfilled $\left(\rightarrow\right.$ Homer). ${ }^{16}$ Or rather, it could be postponed because Herodotus

15 Fraenkel i950: III 805, with Rood I998: 28 n. I2.

16 I.85 is another example of this technique. Oracles (e.g. I.53.3), dreams (e.g. I.Io8.I), portents (e.g. 7.37.2), and neglected warnings (e.g. 4.83.I, 7.Io) are also often narrated when they first occur, with proleptic force (though there is still room for sus- 
was not concerned to endow Cambyses' misinterpretation of the oracle with deep psychological significance. The misinterpretations highlight, rather, the general fragility of human reasoning.

Longer analeptic passages are often used to explain characters' actions. When characters are motivated by gratitude or by the desire for revenge, Herodotus tends to pause to explain how the reciprocal bond had been created: when, for instance, he explains that Croesus seeks revenge on Cyrus on behalf of his brother-in-law, he pauses to reveal how the marriage bond had arisen (1.73-74); and when he mentions Syloson's appeal to Darius for help in Samos, he tells the story of how Syloson had once lent Darius a cloak in Egypt before Darius became king and then outlines the situation in Samos that had led to Syloson's appeal (3.I39-I43, all following on from the 'header' 'Darius captured Samos' at 3.I39.I). ${ }^{17}$

A complex example of this technique occurs when Herodotus describes the Spartan expedition against Polycrates, tyrant of Samos. Here the expedition is loosely attached to the narrative of Persian expansion by means of a synchronism: 'At the same time as Cambyses' campaign against Egypt, the Spartans attacked Samos' (3.39.I). There follows a number of connected stories: Polycrates' seizure of power at Samos; Polycrates' ring; exiles from Samos appealing for help from Sparta; variant Samian and Spartan explanations of why the Spartans were ready to help; an account of why the Corinthians were willing to help-through anger at the Samians for helping 300 Corcyraean youths sent to Sardis for castration; and finally an explanation of the origin of hostility between Corinth and Corcyra, which stemmed from the hostility between the tyrant Periander and his son Lycophron. It is only at 3.54 (nine pages after the shift to Samos) that Herodotus recounts the Spartan expedition (which only takes up a page, followed by a page and a half on the Samian exiles). Through the synchronism and the consequent chain of explanation, Herodotus interweaves the stories of two Greek tyrants into his narrative of Persian rulers. The Polycrates narrative highlights the general theme of the instability of good fortune, while the story of Periander and Lycophron interacts with the story of Cambyses by focussing on the difficulty of transmitting rule from father to son (different stories concerned with Periander are deployed elsewhere: the Arion story at I.23-24 and the evils of

pense about how they will turn out); on warners see R. Lattimore I939; Pelling I99I.

17 Cf. in general Gould I989: 42-62. 
his tyranny in Socles' speech at 5.92). At the same time, Herodotus prepares for his later narratives of Polycrates' slaughter by Oroites (3.120-I25) and of Samos' conquest by Persia (3.139-I49). His careful interweaving of Greek and Persian narratives in this section of the work is especially pointed because many of the themes are brought together in the Persian constitutional debate $(3.8 \mathrm{o}-82) .{ }^{18}$

Another common pattern is for Herodotus to describe foreign lands as the Persians try to conquer them or when embassies are sent to them. While such descriptions tend to be geographical and ethnographical, they do also often have a narrative component, especially in the long account of Egyptian kings in book 2. There is also a narrative component when Herodotus explains the origins of customs (e.g. I.94 on the Lydian invention of games during a draught). These analeptic passages are more common in the earlier books. In the account of Xerxes' expedition, background information about places tends to be given as Xerxes arrives at them. But the analeptic technique is used, for instance, when Herodotus describes the origins of Gelon's tyranny at Syracuse in the context of the Greeks' appeal for help to Gelon (7.I53I56).

One effect of the long descriptive passages of foreign lands found in the earlier books is to create a sense of a pause: as we have seen, the account of Egypt is far longer than the account of Cambyses' own achievements. The sense of a pause created by ethnographic sections can be read as a sign of resistance on the level of the narrative to the forward momentum of Persian expansion. ${ }^{19}$ Yet Herodotus' long account of Egypt also highlights what is at stake for the Persians, explaining why they want to conquer Egypt and placing their ambitions within the traditions of Egyptian history. So in another sense Herodotus' long analeptic account of Egypt panders to the spirit of Persian expansion. Indeed, his account of Egyptian kings itself pays attention to their urge to construct lasting monuments for themselves, and there are even two internal prolepses that reveal how Darius sought to establish himself as heir to the Egyptian royal tradition: he wanted to place a statue of himself in front of a statue of Sesostris but was prevented by a priest who claimed that his own conquests were dwarfed by those of Sesostris (2.110); and he finished the canal to the Red Sea that had been started by an earlier Egyptian king (2.158).

\footnotetext{
18 Cf. Pelling 2002b.
}

19 Cf. Payen i995. 
Especially adroit is the way Herodotus fills in the stories of Athens and Sparta in the course of the work. He includes analeptic narratives of Athenian and Spartan history first when Croesus seeks to make an alliance with the most powerful Greek state (I.56-70); later when Aristagoras seeks support for the Ionian Revolt in Sparta and Athens (5.39-48, 56-96); and finally when Persian envoys are sent to seek the submission of the Greek cities in Europe (6.5 $\left.\mathrm{I}^{-93}\right)$. Herodotus highlights in this way the two leading Greek states in the Persian Warsand the two states who were at war at the time when he was finishing his work. He could easily have arranged the material differently: since Croesus also made alliances with the Egyptian king Amasis and with the Babylonians, Herodotus could have exploited those alliances to introduce accounts of the situation in Egypt and Assyria. As it is, he only mentions those alliances analeptically (I.77.2), and he gives his descriptions of Egypt and Babylon when they are conquered by Persia.

Particularly distinctive of Herodotus is the use of anachrony in what some critics have thought equivalent to modern footnotes or endnotes. ${ }^{20}$ Herodotus often pauses to give interesting anecdotes connected with people mentioned in the narrative or with members of their family. He narrates, for instance, the punishment and revenge of Euenius, the 'negligent nightwatchman', introduced as the father of a character mentioned in the narrative $(9.93-95) .{ }^{21}$ Often the placing of these apparently incidental analepses or prolepses seems telling. We have already seen that Herodotus closes his work with an anecdote concerning an ancestor of the Persian Artayctes, who has just been crucified by the Athenians (9.I22). Many critics have noted how this anecdote provides a closure (though not a resolution) to major themes in the Histories: the contrast of 'hard' and 'soft' nations and the effects of environment and luxury. An example of a suggestive prolepsis introduced through a family relationship occurs when Herodotus relates that Aristagoras in his desire to become tyrant of Naxos persuades the Persians to send an expedition against Naxos, and that the command of this expedition is given to Megabates: 'Years later - if there is any truth to the story-Pausanias of Lacedaemon, the son of Cleombrotus, wanted to become the tyrant of all Greece, and he got himself betrothed to Megabates' daughter' (5.32). This external prolep-

20 Myres 1953: Io9 (with the italicised parts of his useful 'Tabular Analysis' of the Histories on pp. I $18-\mathrm{I} 34)$.

21 Cf. A. Griffiths i999. 
sis is an explicit hint of a topic only hinted at obliquely in the later narrative - the medism of Pausanias, the victor of Plataea. In its context, the prolepsis hints at parallels between Aristagoras and Pausanias: 'The lush Ionian and the archetypally unspartan Spartan are juxtaposed just as the gaze returns to the West, destabilising any univocal picture of Ionian/eastern luxury and Spartan hardiness'. ${ }^{22}$

Herodotus' prolepses often have an overtly moral point. He frequently looks ahead to the punishment of characters for the action they have just performed (e.g. Oroites' comeuppance, described at 3.126I28); he also digresses specifically to describe a punishment inflicted by a character mentioned for other reasons $\left(8.105^{-106}\right.$, the eunuch Hermotimus forcing the man who had castrated him to castrate his own sons and be castrated by them in turn). ${ }^{23}$ Such instances of 'proleptic closure' ( $\rightarrow$ Thucydides, $\rightarrow$ Xenophon, $\rightarrow$ Herodian) show the importance of reciprocity as an organising principle in Herodotus' narrative, but they may still interact suggestively with their contexts. The story of the revival of the anger of the herald Talthybius during the Peloponnesian War - when the Athenians execute the sons of the Spartan heralds sent to make amends for the execution of Persian heralds (7.I37) - is placed just before Herodotus' praise of the Athenians for not abandoning their fellow Greeks or surrendering to Xerxes (7.I39). This external prolepsis is, as we have seen, one of a number of anticipations of the later conflict between the two great victors of the Persian Wars. Here the prolepsis moulds the narratee's response to Herodotus' praise of Athens - especially as Herodotus claims that he expresses that opinion 'despite the fact that it will offend a great many people', another hint at Athens' later unpopularity.

Prolepsis is also used to undercut apparent moral approval of Athens when Herodotus describes how the Athenians yield command of the sea to the Spartans. Herodotus uses a generalization to present this action in a positive light: 'what was important to them was the survival of Greece and they knew that if they made leadership a point of dispute, Greece would be lost. And they were right, because internal dissension is worse than a united war effort to the same degree that war is worse than peace' (8.3.I). But he then subverts this praise with an allusion to Athens' later imperial ambitions: 'it was appreciation of this fact that made the Athenians give way without making a fuss-

\footnotetext{
22 Pelling I997: n.p.

23 Cf. S. Hornblower 2003. Another instance is 7.213.2 (death of the traitor Epialtes).
} 
but, as they later demonstrated, only for as long as they badly needed the rest of the Greeks. Once Xerxes' invasion had been repulsed and they were fighting for his territory rather than their own, they deprived the Spartans of the leadership, using Pausanias' arrogant behaviour as a pretext. But all this happened later' (8.3.2). Anachrony is here used to deepen the narratee's understanding by setting actions in a broader historical context.

Analepsis and prolepsis are subversively combined in Herodotus' defence of the Alcmeonids against the charge of signalling to the Persians at Marathon (6.I2I-I3I). Herodotus relates the history of the family, starting with Alcmeon gaining his wealth from Croesus, and looking ahead as far as the birth of Pericles. The details he gives about the past and future of the family pointedly undermine the narratorial defence of the Alcmeonids. Herodotus hints at a progression from the liberty won at Marathon to the quasi-tyrannical position of Pericles at Athens. ${ }^{24}$

Some anachronies are introduced with no apparent narrative justification. Alan Griffiths has aptly commented on the strange story of how the Persian king once blocked the outflow of some rivers on a high plateau that 'it is difficult to find any obvious reason for its standing where it does' (3.II7; an analepsis followed by iterative narration of how the tribes affected pay each year for the sluice-gates to be opened). Griffiths has, however, noted structural parallels with the narrative that immediately follows: the anachrony is 'a kind of allegorical overture to the main theme, a hydrological metaphor for ... Persian Machtpolitik' ${ }^{25}$

Anachronies are most obviously justified when they are required to deal with simultaneous events. We have already seen that the Polycrates saga was introduced through a synchronism (3.39.I). Here the new story-line was not demanded by the context and the synchronism is a very loose one (a genitive absolute with a present participle). ${ }^{26}$ That looseness is typical of Herodotus' technique even when events are interconnected: the Thermopylae/Artemisium narratives are connected only by men ... de clauses (7.239.4-8.I.I); it is only later that Herodotus reveals that the decisive battles happened on the same days (8.I5.I). The battle of Mycale, by contrast, is synchronized with Plataea

24 Thomas I989: 264-272.

25 A. Griffiths I999: $176-\mathrm{I} 77$.

${ }^{26}$ Cf. 3.I50.I for a similar technique; also 3.I20.I for a new narrative strand synchronized with an earlier stage of the narrative (Cambyses' illness - when the main narrative has moved on well beyond his death). Immerwahr ig66 has much detailed analysis of these structuring techniques (cf. esp. 59-6I for simultaneous events). 
from the start ('It happened that on the same day as the Persian defeat at Plataea ...', 9.90.I); the narrative then goes back in time to give the antecedents to the battle, and the exact synchronism is resumed only at 9.100 - where the reason for the precision becomes clear: it is a miracle that reports of the victory at Plataea were heard on the same day at Mycale. In general, connection between narrative strands is brought out as is needed for events to be understood - and that is often as characters discover information about the enemy (e.g. 7.I45.2, I72.I, I77; 8.5O.I).

There is no room here to consider any other of the anachronies that give the Histories their distinctive texture - and that undermine by their frequency and extent the very attempt to separate out a main narrative from anachronic digressions. In almost all of the anachronies it is possible to read rich thematic resonances. ${ }^{27}$ One general feature that should be noted, however, is that Herodotus is often vague about the scope of his anachronies. Cylon's attempt at tyranny in Athensintroduced to explain the Cylonian curse (5.7I) - is merely said to be 'before the time of Peisistratus' - that is, before the time of the first actual tyranny at Athens. When the inclusion of anachronies is justified by the pattern of reciprocity, even that degree of temporal precision tends to be superfluous (cf. e.g. 5.82-88, the account of the origin of hostility between Athens and Aegina: here a general sense of the past is produced only by the allusion to a change in clothing customs among Athenian women, but that sense of distance is in relation to the narrator's present). ${ }^{28}$

It remains to consider actorial anachrony. I have already noted that many arguments in speeches involve allusions to the past, with some repetition of the earlier narrative - though often the presentation of earlier events is distorted by the speaker's rhetorical needs. These actorial analepses bind together Herodotus' diffuse narrative. There are also occasions when characters tell stories not found elsewhere, as when Solon tells Croesus the stories of the most fortunate men (Tellus the Athenian and Cleobis and Biton). The scope of these anachronies is not given (in the Tellus narrative there is only a reference to a war between the Athenians and their neighbours in Eleusis; the fact that

27 There are many suggestive remarks in Dewald 1998.

${ }^{28}$ Scholars have generally been interested in Herodotus' shifting levels of detail for what they reveal about the nature of the oral tradition with which he was working: cf. e.g. Thomas 2001 . 
Tellus is buried on the site where he fell may also convey a general sense of the past, since it contrasts with the procedure for burying the war dead in Athens described at Thucydides 2.34). The reason is not that the scope of the analepsis is not relevant to its explanatory power, as in the narratorial analepses mentioned above. Rather, the stories are timeless paradigms. Another paradigmatic narrative told by a character is the story of the punishment of Glaucus for asking the Delphic oracle whether he should keep some money left in his keeping (6.86). This story is told by the Spartan Leotychidas when the Athenians refuse to return men left in their safe keeping. Here the scope of the analepsis is given: 'three generations back'. The precision helps bring out the moral of the story: 'today there is not a single descendant of Glaucus alive, nor is there a single household that is considered to stem from Glaucus'. The moral would evidently be weaker if the story were undated or placed further in the past.

A slightly different use of paradigmatic narrative is Socles' story of the origins of the Cypselid tyranny at Corinth and of the crimes of Periander $(5.92$, completing the stories of Periander told by the narrator earlier in the Histories). That a Corinthian tells this story as a warning to the Spartans not to reinstate tyranny at Athens is given an ironic twist by the implicit parallel between the situation in Herodotus and the events leading up to the Peloponnesian War - when there is again fear of increasing Athenian power, but now it is the Corinthians who take the lead in pushing the Spartans to overthrow the tyrant city, Athens.

Socles' story forms a fitting end for this chapter because, as we have seen, it is from the dynamic interplay between the perspectives of participants and narratees in past and present that Herodotus' handling of time derives much of its force. And it is for that reason that order has received much more attention in this chapter than frequency or speed. It is pointless to judge Herodotus' chronology by the standards of later historians. Rather, his vast work - probably far larger than any other prose work to date - is extraordinary for the way it maintains coherence even as it constantly brings in the past and future as a way of forming links, many of them unexpected, and deepening our sense of the uncertainties as well as the regularities of human achievement. 


\section{GHAPTER EIGHT}

\section{THUCYDIDES}

\section{T. Roop}

In his narrative of the winter of the sixteenth year of the war (4I6/4I5), Thucydides describes how the Athenians want 'to sail to Sicily again with a larger force than the one under Laches and Eurymedon and subjugate it if possible' - though most of them were 'unaware of the size of the island and the number of its inhabitants' (6.I.I). ${ }^{1}$ He then gives an account of the colonization of Sicily that looks back to its earliest alleged inhabitants (the Cyclopes and Laestrygonians) and traces the successive non-Greek and Greek settlers of the island (6.2-5). It is after this analepsis that he explains how the Athenians had come to form their plan of conquering Sicily:

Against a place of this size the Athenians were bent on campaigning ... In particular, the presence of Egestan envoys and the increased urgency of their invitations spurred them on. The Egestans, neighbours of the Selinuntians, had gone to war with them over marriage rights and disputed territory, and the Selinuntians, by bringing in the Syracusans as allies, were pressing them hard in the war on both land and sea. So the Egestans reminded the Athenians of the alliance formed with the Leontines in the time of Laches and the earlier war and begged them to send ships in their defence ... The Athenians listened to them in assemblies and, after the Egestans and their supporters had repeated their arguments many times, voted to send envoys first ...

In this brief stretch of narrative, we see the force of the narratological categories of time. The importance of order is shown by the allusion to the earlier force that the Athenians had sent to Sicily 'under Laches and Eurymedon'. That phrase looks back to the first Athenian expedition to Sicily $(427-424)$ and indeed compresses together two separate fleets, the twenty ships sent with Laches in 427 and the forty sent with Eurymedon in 425 (3.86.I; 4.2.2). At the same time, the phrase shows how aspects of

${ }^{1}$ All references in this chapter are to Thucydides unless otherwise stated and all dates are BC. I have used, with slight adaptations, the translation of S. Lattimore 1998 (Hackett). 
temporal order may be linked with focalization. Is it the Athenians who want to send a larger fleet than the earlier one? Or is it the narrator who is comparing the two fleets?

The most striking departure from a linear order comes with the account of Sicilian colonization - and here too we see how temporal order is related to focalization. The analepsis (which has a scope of several hundred years) fills a gap in the knowledge of the characters (here, the Athenians). The narrator's greater knowledge is set against his characters' limited perspective.

Particularly controversial is the actorial analepsis in Thucydides' account of the Egestan envoys. Why do the Egestan envoys remind the Athenians of the alliance between Athens and Leontini (itself not previously mentioned by Thucydides) and not of their own alliance with Athens, attested epigraphically (Meiggs \& Lewis [I969] I988: 37) and datable to $45^{8 / 457}, 454 / 453$, or $4 \mathrm{I} 8 / 4 \mathrm{I} 7$ ? One solution to this problem is to extend the scope of the narratorial analepsis at 6.6. Thucydides does not specify when it was that the Egestans first appealed to Athens. It has been suggested that Thucydides is compressing events that took place over a number of years (note the iterative presentation of the Athenians' decision-making: 'after the Egestans and their supporters had repeated their arguments many times'). That is, the original Egestan appeal is in fact to be dated before $4 \mathrm{I} 8 / 4 \mathrm{I} 7$ and their failure to mention their alliance with Athens explained by the fact that that alliance had not yet been formed. ${ }^{2}$ If that is a plausible interpretation of Thucydides' chronological strategy, the effect of his imprecision is to make the Athenian decision to invade Sicily seem more spontaneous and ill-considered. Thucydides would be manipulating narrative time to increase the sense of foreboding surrounding the Athenian expedition at its outset. On the other hand, it may be that the Egestan alliance is to be dated to the $45^{\mathrm{os}}$, and the Egestans' failure to mention it explained by their perception that the Athenians would respond better to an appeal to a more recent alliance with their fellow Ionians. ${ }^{3}$

Thucydides' treatment of the Egestan embassy to Athens shows the interpretative problems raised by his handling of time. This section is by no means untypical of Thucydides' work as a whole: it is not

\footnotetext{
2 Smart 1972, esp. I33-136.

3 The phrasing Leontinōn hoi Egestaioi, as Dover notes in Gomme, Andrewes \& Dover I945-I981: ad loc., perhaps supports this interpretation in that the slightly forced juxtaposition stresses the unexpectedness of the Egestan appeal.
} 
least by his manipulation of the narratological categories of time that Thucydides tries to persuade the narratee to accept his interpretation of the Peloponnesian War. Variations of order are perhaps the most marked and interpretatively potent form of deviation in Thucydides' work, but, as we shall see, variations of frequency and speed are also used to great effect. ${ }^{4}$

\section{Frequency}

Departures from a singulative frequency are relatively infrequent in Thucydides' narrative. Repetition is most commonly introduced by actorial analepses: references to the past in Thucydides' speeches mostly repeat information contained in the earlier war narrative or in the narrative of the Pentecontaetia. When speakers allude to events earlier than the Pentecontaetia, the analepses are not strictly repeating. But it is striking that such allusions tend to repeat information found in Herodotus: ${ }^{5}$ if Thucydides can be seen as making his own story in a sense continuous with Herodotus', then references to events covered by Herodotus are similar in effect to repeating analepses. Sometimes, however, speakers in Thucydides add details not contained in the earlier narrative, as when the Plataean speakers say that the Theban attack on Plataea happened at a sacred time of the month (3.56.2). ${ }^{6}$

A good example of iterative narration is the account of the burial of the Athenian war dead (2.34). Thucydides narrates (using the present tense, in a quasi-ethnographic manner) the first instance of a procedure he says was used throughout the war. One part of this procedure was a funeral oration, and here too Thucydides gives only the speech delivered by Pericles in the first year of the war. Pericles' speech stands in a sense for all the funeral orations delivered in the course of the war, even though it is important for the narrative that it is placed where it is (just before the outbreak of the plague) and even though some of its content is perhaps to be explained by the specific context of $43 \mathrm{I}^{7}$

\footnotetext{
${ }^{4}$ For a more detailed discussion of Thucydides' handling of narrative time see Rood I998: ch. 5, and also index, s.vv. 'analepsis', 'frequency', 'order', 'prolepsis', 'speed', 'time', with the further bibliography cited there. Many of the passages discussed in this chapter are treated more fully in that book.

5 S. Hornblower I99I-I996: II I33.

${ }^{6}$ On actorial analepses in Thucydides see further $S A G \mathcal{N}$ I:124-I27.

7 Bosworth 2000.
} 
Iterative presentation is used more often in the narrative of the first year of the war than elsewhere in the work. Thucydides lets the narratee know that there will be ellipses in the later narrative by recording at their first occurrence proceedings that took place regularly - the dispatch of cavalry to protect the Attic countryside (2.22.2), for instance, and the Athenian invasion of the Megarid (2.3I). The iterative narration of Athenian invasions of the Megarid contrasts with the singulative narration of the annual Peloponnesian invasions of Attica, but that is not to say that Thucydides is downplaying Athenian aggression against Megara. The Athenian strategy is in fact stressed by prolepsis: 'later in the war there were other Athenian invasions of the Megarid every year, both with cavalry and in full force, until Nisaea was captured by the Athenians' (2.31.3). At the same time, Thucydides' presentation implies that the Peloponnesians' invasions of Attica were more important to their strategy than invasions of the Megarid were to the Athenians' strategy.

Thucydides also uses iterative narration in his more developed battle narratives to offer a generalized account of the course of a battle. Indeed, some of his most famous and emotive descriptions owe much of their effect to iteration. The final battle in the harbour at Syracuse is a particularly good example: 'any who saw their own men prevailing would take heart and turn to appeals to the gods that they not be deprived of their salvation; but those witnessing defeat would let out cries of lamentation ... one could hear everything at the same time, lamentation, shouting, "we're winning", "we're losing", every other possible outcry that would be wrung from a great army in great danger' (7.71.3-4). Iteration is here linked with a slowing down of narrative speed - an unusual technique, as iterative narration normally brings about an increase of narrative speed. The climactic battle of the Sicilian campaign is further accentuated by the iterative treatment of Nicias' battle exhortations. Thucydides reports in direct speech Nicias' appeal to the whole army, then in indirect speech the further appeals he makes to individuals, 'supposing, as leaders usually feel about great battles, that ... everything expressed in words was not yet sufficient' (7.69.2). Encouragement that Nicias uttered more than once is reported once. Nicias' exhortations are iterative in a broader sense too: he says 'other things as well which men in so great a time of crisis would not mention if they were guarding against appearing to speak in platitudes, especially references to women and children and ancestral gods'. That is, Nicias' words at this crisis stand for what men say at all such crises. 
Iterative narration is used for speeches elsewhere too. There is an iterative element in speeches attributed to more than one speaker: two Plataeans are named at $3.5^{2} .5$ as speakers of the Plataean appeal to the Spartan judges, while a pre-battle speech is attributed to 'Gylippus and the Syracusan generals' at 7.65.3. At times, this iterative element is explicit: at $8.76 .3-7$, a passage of indirect speech gives the substance of many different speeches. In the case of the Egestan envoys at Athens (6.6.2), as we have seen, appeals made at a number of different assemblies are narrated once. So too with other envoys: Thucydides gives the first Spartan appeal for peace in 425 in full (4.17-22), but treats their later envoys iteratively (4.4I.4) - a hint at the futility of those further appeals once the Athenians were set on further gain. Iterative presentation of advice-giving (Themistocles at I.93.7, Pericles at 2.13.2, 9), by contrast, seems to point to the constancy of these two politicians, both admired by Thucydides. Thucydides uses a similar technique for Brasidas' appeals to Athens' allies in the north: Brasidas is said to have made speeches at Torone and Scione (4.II4.3, I20.3) similar to his speech at Acanthus (4.85-87). Some of the special arguments used by Brasidas on the later occasions are included, but the first speech is given in most detail because it is paradigmatic. ${ }^{8}$

Paradigmatic sections of narrative such as Brasidas' speech at Acanthus may themselves be regarded as the converse of Genette's category of pseudo-iteration. ${ }^{9}$ Genette was struck by some scenes in Proust that are supposed to be iterative but that are narrated in such detail that they cannot in practice be interpreted as iterative. It is typical of Thucydides, by contrast, to narrate once an episode that the narratee comes to understand as paradigmatic. Thucydides records, for instance, the debate at Athens over the treatment of the first ally in the war to revolt, Mytilene (3.36-49), but not the similar debates that took place over later allies such as Scione (4.122.6). One debate is enough for the relevant arguments to be aired. It is telling, indeed, that much of the debate over Mytilene revolves precisely around the town's status as a paradigm: it is as if Thucydides is self-consciously pointing to the paradigmatic role of the debate. The Mytilene debate is also paradigmatic of the nature of debate in the Athenian assembly, and here too

${ }^{8}$ Cf. S. Hornblower I99I-I996: II 86-89 on 'Brasidas' periodically adjusted manifesto'.

${ }^{9}$ Genette [1972] I980: 12I-I23. 
Thucydides perhaps alerts the narratee to its function by making Cleon start his speech with an iterative narration of his own views of democracy: 'Many times before now, I have felt that a democracy is incapable of ruling others, and more than ever during your current change of heart ...' (3.37.I; the iteration is also a mark of Cleon's desire to endow himself with a Periclean constancy).

The narrative of the civil war at Corcyra (the first in the war) may also be regarded as a narrative of all later civil wars in the Peloponnesian War (only the oligarchic coup at Athens will receive detailed treatment). Indeed, the detailed narrative culminates in an explicitly iterative account of the collapse of moral values caused by civil war: Thucydides writes, for instance, that 'the man of violent temper was always credible, anyone opposing him was suspect ... kinship became alien compared with party affiliation' $\left(3 \cdot 82.5^{-6}\right)$. Like Nicias' emotive speech at Syracuse, the account of what happened during the course of the civil wars is also iterative in a deeper sense: 'during the civil wars the cities suffered many cruelties that occur and will always occur as long as men have the same nature, sometimes more terribly and sometimes less, varying in their forms as each change of fortune dictates' (3.82.2). That is, Thucydides claims to describe not just what happened in the civil wars that occurred in the Peloponnesian War, but what happens in all civil wars. His account is almost omnitemporal.

Thucydides' claim about his account of civil war recalls the bold ambition he proclaims for his work as a whole: 'any who wish to look at the plain truth about both past events and those that at some future time, in accordance with human nature, will recur in similar or comparable ways' (I.22.4). Thucydides collapses together the events of the Peloponnesian War with those of all later wars. His whole narrative is an account of events that occurred once and of events that occur many times. In Herodotus, by contrast, a singulative narration of the campaigns of different oriental monarchs comes to seem repetitive because of the similarities between those campaigns. What Herodotus is able to achieve owing to the broader chronological extent of his fabula, Thucydides manages by claiming that his whole narrative is, in essence, iterative.

One sentence in Thucydides' analysis of civil war even seems to call for an expansion of Genette's temporal scheme:

In peacetime when they had neither the pretext nor the willingness to call them in - but during war, with alliances available to both factions for damaging their opponents and at the same time strengthening them- 
selves, occasions for bringing in outsiders were readily found by those wishing to make any change in government.

$(3.82 . \mathrm{I})$

What is striking here is the anacoluthon in the first part of the sentence: the men-clause (kai en men eirēenèi ouk an ekhontōn prophasin oud' hetoimōn parakalein autous) breaks off after a genitive absolute. Textual corruption has sometimes been suspected. But 'the missing main verb in the first limb of the sentence ... is to be supplied by the reader ... and what happened in peace - anyway, in effect nothing - is not the historian's concern'. ${ }^{10}$ That is, Thucydides twists the sentence so that a blank at the textual level is felt to correspond to a blank in the story - a temporal organization that is hard to fit to Genette's scheme. Does the blank of peace happen once or repeatedly? How long does this blank last? Thucydides' narrative of the nothingness of peace seems to deconstruct the division between singulative and iterative narrationand the division between narrative pause and narrative acceleration for that matter.

\section{Speed}

It is not only when an unchanging state of peace is (not) narrated that narrative speed is hard to measure. As with Herodotus $(\rightarrow)$ and other ancient historians, Thucydides' narrative rarely gives precise information on how long an action has taken. Sometimes lengths in days are given (e.g. 4.6.2, the Peloponnesians spent fifteen days in Attica- the shortest invasion; 7.87.3, the Athenian prisoners were in the quarries at Syracuse for some seventy days). More precise chronology within seasons is given by reference to the beginning or end of the season, the morning rising of Arcturus (2.78.2), the winter solstice (7.I6.2; 8.39.I), and, most commonly, crops (e.g. 2.I9.I; 3.I.I, I5.2; 4.6.I); but these indications are often isolated and (in the case of crops) vague and often explanatory (the state of the corn or wine harvest can affect behaviour). The variations in speed that are easiest to discern are variations between different seasons and years. ${ }^{11}$ Analysis shows that winters tend to be narrated more quickly than summers and that the years of

${ }^{10}$ C. Macleod I983: 136 n. 5 .

${ }^{11}$ Cf. the chart of war-years at Luschnat i971: III7-III8 (measured by Teubner pages): the shortest year is 2.5 pages, the longest 59.5 ; the average page-length for years I-IO is 24.9 , for years II-I6 8.7, for years I7-I9 46.0, and for years 20-2I 35 . 
the uneasy peace are narrated more quickly than most other years (five years in 39 OCT pages - fewer than devoted to four separate single years). There is also a slowing down in Thucydides' treatment in books 6-8 ( $\rightarrow$ Herodotus). While the space devoted to the Sicilian expedition may be explained by its importance in Thucydides' conception of the war as a whole, the slow speed of book 8 is more unexpected: to some scholars the accumulation of facts that creates the slow-down is a mark of the book's incompleteness, but it may also reflect a slight change of style for the more complex narrative of the Ionian War.

Variations within the narrative of individual seasons are also easy to spot, but harder to analyse with the same accuracy. Slow-downs, for instance, happen whenever direct speech is included ('scenes'). A challenging instance of a variation of pace between speech and narrative is when Thucydides devotes seven pages to a conference between the Athenians and the Melians and then describes the Athenian treatment of the Melians after their surrender in a summary of just three lines: 'They killed all the grown men they captured, enslaved the children and women, and settled the place themselves by sending out five hundred colonists later' (5.I 6.4). How are we to interpret the brevity with which Thucydides narrates the Melian massacre? Is it the cool detachment of the historian scornful of the Melians' folly in earlier resisting the Athenians' arguments as to why they should surrender? Or is it a way of bringing out the Athenians' brutality? On other occasions, Thucydides uses brevity to indicate speedy, effective action by characters - especially by the Athenians, who are overtly characterized as swift. The swift (iterative) treatment of the later Spartan embassies in 425 (discussed above: the Athenians 'sent them away unsuccessful as often as they came', 4.4I.4) seemed, by contrast, to highlight the futility of those embassies and the intransigence of the Athenians. This brevity is especially effective at the close of the detailed Pylos narrative.

In many of his more detailed sections Thucydides does offer (at least in part) a day-by-day narrative that enables narrative speed to be charted with some accuracy (indications of mealtimes also occur). In his narrative of the civil war at Corcyra, he uses temporal markers sufficiently detailed for the narratee to see how the arrivals of Athenian and Peloponnesian ships provoke a change in the speed of the narrative, corresponding to their influence on events. The decisive Athenian arrival, for instance, is followed by a brief, iterative narrative of slaughter: 'during the seven days that Eurymedon stayed with his sixty ships, the Corcyraeans were engaged in butchering those of their fel- 
low citizens whom they regarded as their enemies ... Death thus raged in every shape; and, as usually happens at such times, there was no length to which violence did not go; sons were killed by their fathers ..' (3.8I.4-5).

\section{Order}

The Corcyra stasis-narrative's day-by-day progression to a murderous climax gains from its linear order, which well brings out the escalation in violence. But within the generally linear structure there are variations of order, notably an analepsis to highlight the arrival of Eurymedon's fleet: 'towards night the Peloponnesians learned through torch signals from Leucas that sixty Athenian ships were approaching, which the Athenians had sent ... when they found out about the civil war and that the ships with Alcidas were going to sail to Corcyra' (3.80.2). By mentioning the Athenian ships when the Peloponnesians learn of their approach, Thucydides emphasizes the reversal to their ambitions. As often, the placement of information is related to the perceptions of participants.

The Corcyra narrative itself starts with mention of the revolutionary action initiated after their return to Corcyra by prisoners taken in the battle of Sybota (3.70.I, looking back to I.55.I). As their release is not dated, it is not certain whether this analepsis is external or internal-unless, that is, one includes the Corcyra dispute in book I within Thucydides' story. His story can most easily be taken as 'the war between the Peloponnesians and Athenians' (I.I.I) - that is, the war that starts at the beginning of book $2 .{ }^{12}$ Like Polybius $(\rightarrow)$, however, Thucydides precedes his account of his main topic with a narrative of its antecedents: 'as to why they broke the peace, I have first written an account of the complaints and disputes' (I.23.5) - that is, the disputes over Corcyra and Potidaea and the diplomacy preceding the Peloponnesian declaration of war. The account of these events (covering 435432) fills book I, and can be seen either as analeptic to the main story

12 The absolute chronological markers at 2.I - in the fifteenth year of the truce, 'when Chrysis had been priestess at Argos for 48 years, Aenesias was ephor at Sparta, and Pythodorus had two more months as archon at Athens ... at the beginning of spring' - are fitting for the start of the story; they also prepare for Thucydides' criticism of dating by local magistracies at 5.20. 
or (less satisfactorily) as the start of the story. As for the end of the story, Thucydides defines the end of his work in the narrative of $42 \mathrm{I}$, when he insists that the peace made in $42 \mathrm{I}$ was not a proper peace and looks ahead to the renewed outbreak of full-blown war again: 'The same Thucydides ... has recorded these events as well ... up to the point when the Spartans and their allies overthrew the empire of the Athenians and captured the long walls and the Piraeus' (5.26.I). In fact the narrative is incomplete, breaking off in the twenty-first year of the war (4II). There are, as we shall see, some prolepses to the final years of the war which are external if the story is defined as ending in 4II, internal if it is defined as ending in 404: the distinction is a purely formal one.

The introduction of analeptic material is linked with focalization not just in the internal analepses in the Corcyra stasis-narrative but also in a number of much longer external analepses. We have already seen that the account of Sicilian colonization $(6.2-5)$ fills a gap in Athenian knowledge. Similarly the excursus on the tyrannicides (6.54-59) corrects mistaken Athenian beliefs. The Archaeology (I.2-I9), by contrast, is a survey of Greek history that justifies Thucydides' perception at the start of the war that the war would prove to be great; while the Pentecontaetia (I.89-II8) is a narrative of the growth of Athenian power placed at the moment when the Spartans are swayed by their fear of that power to declare war on Athens. The only other extensive external analepses are explained by the manipulation of the past in the diplomacy before the start of the war: the invocation of curses connected with Cylon and Pausanias prompts the narrator to explain the origin of those curses (I.I26, I28-I34); at the same time, the level of detail of these analepses (especially the Pausanias excursus, I.I35-138, which itself is extended to cover the later career of Themistocles) exceeds the needs of the narrative and encourages thematic readings (the contrasting Spartan and Athenian treatments of Pausanias and Themistocles pointing ahead to the careers of Lysander and Alcibiades).

There are also many shorter external analepses. A number of later analepses, for instance, fill in gaps in the Pentecontaetia: 2.68.8 (the Athenian alliance with Acarnania); 3.2.I (a Lesbian appeal to Sparta before the war); 4.IO2 (the foundation of Amphipolis). The mention of the alliance with Acarnania is itself part of a longer analepsis starting with the foundation of Amphilochian Argos ('Amphilochus the son of Amphiaraus founded Amphilochian Argos and the rest of Amphilochia on the Ambracian gulf after the Trojan War ..., 2.68.3). As such, it 
resembles a number of other analepses recounting the foundation and some of the later history of places when they first become prominent (e.g. I.24.2-4 on Epidamnus).

Common to many such foundation narratives is an interest in the origin of place names and the inclusion of what we would regard as mythical material. Thucydides explicitly says that Amphilochus named Amphilochian Argos 'after his own country' (2.68.3; he does not need to comment on the derivation of 'Amphilochia' from 'Amphilochus'). Elsewhere he reports that Alcmeon named Acarnania after his son Acarnan (2.102.6), and that the inhabitants of Scione, 'a city in Pallene', 'say that they are Pellenians from the Peloponnese, and that when their founders were sailing from Troy, they were forced into this place by the storm which the Achaeans encountered, and settled it' (4.I20.I). The Scionaeans' claim that they came from Pellene is evidently offered in explanation of the name Pallene - or perhaps Thucydides is suggesting that it is the name Pallene that explains their claim. Such notes on foundations are particularly common in geographical works such as the periplus: the form and the aetiology of Thucydides' notice on Scione is close, for instance, to that found at Ps.-Scylax 22 ('The neighbours of the Bulini are the Hylli. These people say that Hyllus the son of Heracles settled them'). Another type of analepsis common in the periplus and occasionally found in Thucydides is the mythological notice based on a geographical link. Of the strait of Messina, for instance, Thucydides comments that 'this place is the water between Rhegion and Sicily where Sicily is the shortest distance from the mainland, also the place called Charybdis where Odysseus is said to have sailed through' (cf. 3.96. I on Hesiod and 4.42.2; cf. also e.g. Ps.-Scylax 98: 'next ... the harbour of the Achaeans; in this the Achaeans are said to have deliberated whether to make an expedition against Telephus or to go away'; I04). Like the detailed foundational narratives, these passages tend to be found in the earlier parts of the history and in descriptions of marginal areas. Perhaps indeed they are in part a way of marking marginality - and so the geographical spread of the Peloponnesian War, itself justification of Thucydides' belief in the war's greatness.

There is strong stylistic differentiation both among the various external analepses and between external analepses and the rest of the narrative. Some are argumentative and marked by an overt narratorial presence, by arguments from probability, and by the citation of evidence such as inscriptions (e.g. the Archaeology; 2.15, an account of the settle- 
ment history of Attica and Theseus' synoecism; 2.29, where Thucydides is sceptical about a link between Teres and the Thracian ruler Tereus; 6.55, on Hippias as the eldest son of Peisistratus). Other sections have a more Herodotean style. Herodotean features are particularly marked in the excursuses on Cylon, Pausanias, and Themistocles. The start of the Cylon narrative - 'Cylon was an Olympic victor, an Athenian of former times, both well-born and influential' (I.126.3) - adopts a classic story-telling manner. Here the indeterminacy about the scope of the analepsis ('an Athenian of former times') is itself telling: the sense of Cylon's conspiracy as something remote and detached from the present stands juxtaposed - and in tension - with the report of the Spartans' attempt to exploit the Cylonian pollution. By pointing to the antiquity of the Cylon affair, Thucydides is sardonically anticipating his analysis of the Spartans' motivation: the Spartans were reviving an old story to undermine Pericles, who was connected on his mother's side with the family that had incurred the pollution (I.127).

At the start of his war narrative, Thucydides writes that the account 'has been written in the order that events occurred, divided into summers and winters' (2.I). This claim is justified in the sense that one season follows another, but within each season there are considerable variations of order, including analepses and prolepses that go beyond the seasonal divisions. Many departures from a linear order are caused by the complexity of the historian's subject matter, which necessitates the narration of simultaneous events. ${ }^{13}$ As in Herodotus $(\rightarrow)$, explanatory analepses following on from introductory 'headers' are common: material is delayed until it is most relevant, and it is most relevant when it is explanatory. Common, too, is the technique of prolepsis to round off a passage, also found in Herodotus $(\rightarrow)$ and seen already in the allusion to the later colonization of Melos at the end of the Melos narrative (5.I 6.4, cited above). The scope of such explanatory analepses and proleptic closure is often left imprecise, presumably an indication

13 The extremely helpful chronological tables at Gomme, Andrewes \& Dover 1945I98I: III 7I6-72I and V 445-453 list the introductory chronological marker and bring out the main structuring techniques; see now also the detailed analysis by Dewald 2005, which particularly focusses on the formulaic opening sentences to new sections. The weakest marker is 'in the same summer/winter' (tou autou therous/kheimōnos); 'at the same time' (hupo or kata ton/tous auton/-ous khronon/-ous) is used at e.g. 2.26.I, 95.I; 3.I8.I, 52.I; en de toutōi or en toutōi de is commonly used for a sudden event that interrupts an existing state of affairs (esp. often in book 8: Rood I998: 257 n. 28). 
that this detail is not essential to their function in the narrative (it does not matter much how long afterwards the Athenians sent colonists to Melos). ${ }^{14}$

In interweaving simultaneous actions, Thucydides tends to give just enough detail to understand the relation between events. It is telling that when there is a dispute over whether Scione had revolted before or after the armistice of 423 , the narrator has to add that 'the truth about the revolt was more in accordance with Athenian claims, since the Scionians had revolted two days later' (4.122.6). The narratee could not have inferred this fact from the earlier narrative. The greater complexity of the events in book 8 called for a slight development of technique: here there are longer overlapping narratives with the temporal relationship between the parallel accounts indicated where necessary. ${ }^{15}$

Analepses acquire a greater interpretative weight when they are used to compare or contrast past and present. After the Athenians' defeat in the final battle at Syracuse, Thucydides writes that 'what they had suffered was almost exactly what they had dealt out at Pylos; for when the ships of the Spartans were destroyed, their men who had crossed over to the island were also as good as lost, and this time there was no hope for the Athenians to reach safety by land unless something unaccountable happened' (7.71.7). This explicit parallel is bolstered by a number of implicit parallels between the Athenian victory at Pylos and their defeat at Sicily - parallels that bring out the causal connection between their overconfidence in the aftermath of Pylos and their ambition to conquer Sicily. External analepses may also be fruitfully used to the same effect. When Thucydides compares the position in which the Spartans were placed at Thermopylae and on Sphacteria (4.36.3), the analepsis explains the contemporary perception of the Spartan surrender at Sphacteria as the most unexpected event in the war (4.40.I).

This interpretative use of analepsis is especially potent in a number of passages focussing on the strengths and weaknesses of Athenian resources and strategy. Many of these instances of temporal deviation concern the Sicilian expedition - in Thucydides' view, the Athenians' greatest blunder. When Thucydides reports the departure of the fleet for Sicily, he notes that in number of ships and hoplites, the one against Epidaurus under Pericles and then against Potidaea under Hagnon was not inferior ... But it set out for a short voyage

14 Cf. 3.50.2-3, 68.3; 4.74.4; cf. further Rood I998: II3-II5, 222-223, 273 n. 67.

15 Cf. Rood i998: 263-265, 272-274. 
with limited equipment, and this expedition sailed with expectations of a long campaign and furnished with both ships and men' (6.31.2-3). The contrast with the earlier expedition shows how much is at stake in the Sicilian expedition - and how the expedition goes against Pericles' defensive strategy. That is to say, the analepsis has itself the function of foreshadowing: ${ }^{16}$ it furthers the sense of doom that hangs over the Athenian expedition. But the Athenian rashness is combined with an extraordinary resilience, and this resilience is brought out forcibly in a passage of striking temporal shifts where Thucydides describes the effect on Athens of the Spartan occupation of Decelea. Thucydides looks ahead to the later effects of Decelea on Athens' war effort-but he also delays until this point a comment on how the Athenian decision to invade Sicily in $4 \mathrm{I} 5$ had astonished the Greeks: 'in their strength and daring they did something so astounding for the Greeks - inasmuch as some of these thought they would survive a year, some two, and no one more than three if the Peloponnesians invaded their land - as coming to Sicily in the seventeenth year after the first invasion' (7.28.3). From the perspective of 4I3, Thucydides invites the narratee to look back not just to the Athenian decision to attack Sicily two years earlier, but also to perceptions of Athenian weakness at the start of the war.

Thucydides' treatment of Decelea is typical in that he looks at the later effects of the Spartan fort at the moment when the site is first occupied. So too he treats Athens' 'enslavement' of the allies in the Pentecontaetia in the context of the subjection of Naxos (I.99); he describes the full effect of the plague at Athens when it first appears (2.47-54); and he gives a general analysis of civil war in the context of the first instance during the war $(3.82-83)$. As we have seen, emphasis may be given to such first occurrences because they are taken by participants as paradigmatic. Thucydides lays great stress, for instance, on the arrival of Brasidas, the first Spartan general to appear in the north, at one point making explicit his paradigmatic force with a specific prolepsis: 'In the later part of the war after the Sicilian expedition, the courage and intelligence of Brasidas in earlier times, known to some by experience and assumed by others from hearsay, especially inspired enthusiasm for the Lacedaemonians among the Athenian allies. For by being the first to go out, and by showing himself a good man in all respects, he left behind the lasting conviction that the others were of the same

\footnotetext{
${ }^{16}$ On foreshadowing see Introduction $(\rightarrow)$. The technique is common (cf. e.g. Lateiner 1977 on laughter in Herodotus as a hint of a reversal of fortune).
} 
sort as well' (4.81.2-3). The prolepsis creates a striking shift in temporal perspective that takes the narratee from a period of great Athenian momentum after Pylos to an anticipation of their decline. ${ }^{17}$ This prospective vision is itself balanced by a slightly later prolepsis where Thucydides describes the response of Athens' allies to the revolt of Amphipolis: 'they were strongly motivated toward revolutionary action ... It was obvious to them that they could do so with impunity, a mistake about Athenian power as great as the obviousness of that power later on' (4.108.3-4). Here Thucydides seems to be looking ahead to the surprising Athenian resilience after the Sicilian disaster. There is a tension between the two prolepses that raises questions about the nature and durability of Athenian power. At the same time, the prolepses strengthen the teleological momentum of a narrative geared to explaining the Athenians' defeat in Sicily and their paradoxical recovery. ${ }^{18}$

The two most important prolepses in Thucydides' work look ahead explicitly to the final defeat of Athens. Following Pericles' speech encouraging the Athenians not to give in to the Spartans (2.6o-64), Thucydides anticipates Pericles' death and then extends this prolepsis by drawing an extensive contrast between Pericles' style of leadership and the inferior ability of his successors - a decline which he sees as the cause of Athens' final defeat (2.65). At the same time, the fact that Athens was able to last for so many years after the defeat in Sicily is seen as justification of Pericles' analysis of Athens' strength.

The straight contrast drawn at 2.65 between Pericles and his successors is complicated by the second most important prolepsis-Thucydides' analysis of Alcibiades. In the context of Alcibiades' speech in the debate on invading Sicily - the decision that contributed above all to Athens' ruin - Thucydides returns to the causes of Athens' final defeat:

\footnotetext{
17 Compare the prolepsis on Athenian recovery at 8.97.2, placed immediately after a strong stress on how the Spartans miss the opportunity to exploit to the full the revolt of Euboea.

${ }_{18}$ A similar teleological momentum is gained through the prolepses in the Pentecontaetia that look ahead in various ways to the war that the account helps to explain (Rood I998: 226-228); the brief allusion at 4.8.9 to 'the ones finally trapped there'-which is oblique without knowledge of later events on Sphacteria; and the paired prolepses at 7.4.6 and 7.24.3, both instances of 'firsts' that propel the Athenians to disaster in Sicily (Rood I998: 175-176).
} 
He was held in such esteem among the citizens that he indulged himself in expenditures beyond his actual resources, both for horse-breeding and for other luxuries; and to a great extent it was this that destroyed the Athenian city. The masses, frightened by the magnitude of his license in conducting his personal life and of his aims in absolutely everything he did, whatever it was, developed hostility toward him as an aspiring tyrant, and while he as a public person managed the war with the utmost skill, they as private individuals detested him for his behaviour, and by entrusting the city to others they ruined it in short order.

$(6.15 \cdot 3-4)$

While Alcibiades is guilty of the same sort of personal ambition Thucydides deplored in other post-Periclean leaders, it emerges here that the Athenians' greatest problem was their failure to cope with a leader of Alcibiades' style of individualism.

Thucydides includes no external prolepses - that is, he nowhere looks beyond the final defeat of Athens - unless, that is, the prolepsis at 2.I00.2 on the achievements of Archelaus of Macedon (who died in 399 ) is taken as a post-mortem assessment, and unless the third eruption of Etna mentioned at 3.II6.2 is the eruption of $396 .{ }^{19}$ Where the narratee is invited to look beyond the end of the war is in an emotive actorial prolepsis placed immediately before Thucydides' analysis of the causes of Athens' defeat. Pericles closes his final speech by imagining how Athens will be seen in the future: 'Athens ... has acquired certainly the greatest power known up to this time, of which it will be forever remembered by posterity, even if in the present we give way at some time (for it is in the nature of all things to be diminished too), that we as Hellenes ruled over most Hellenes ...' (2.64.3). ${ }^{20}$ It is Thucydides' work - 'a possession for all time' (I.22.4) — that will guarantee Athens' fame - even while its temporally complex narrative invites a more questioning view of the nature of Athenian power.

${ }^{19}$ Cf. the discussions of Gomme, Andrewes \& Dover i945-I98I and S. Hornblower I99I-I996: ad loc.; the allusion to Etna is more commonly taken to imply a date before 396. The extent to which a historian of contemporary events can use external prolepsis is always of course limited.

20 There are, of course, many other actorial prolepses (speakers typically express expectations about the future when they formulate plans), but there is no space to discuss these here. 


\title{
GHAPTER NINE
}

\section{XENOPHON}

\author{
T. Rood
}

Themistogenes of Syracuse has recorded the story of that campaign - of how Cyrus collected an army and marched inland against his brother, of the battle in which Cyrus was killed, and how afterwards the Greeks came safely to the sea. ${ }^{1}$

(Hell. 3.I.2)

When the guide arrived, he said that in five days he would lead them to a place from which they could see the sea; and he said he was ready to be put to death if he failed to do so. So he led the way, and, when they had crossed the border into his enemies' country, he urged them to burn and lay waste the land, thus making it clear that it was for this purpose that he had come to them, and not because of any goodwill to the Greeks. And on the fifth day they arrived at the mountain (the name of the mountain was Theches). When the men in front reached the summit, there was much shouting. Xenophon and the rearguard heard it and thought that there were some more enemy attacking in the front, since there were natives of the country they had ravaged following them up behind, and the rearguard had killed some of them and made prisoners of others in an ambush, and captured about twenty raw ox-hides, with the hair on. But as the shouting kept on becoming louder and closer, and the successive groups going forward kept on running towards the men in front who kept on shouting, and the more there were of them the more shouting there was, it seemed then to Xenophon as though this was something of great importance, and he mounted his horse and taking Lycius and the cavalry with him rode forward to give support; and soon they hear the soldiers shouting 'The sea! The sea!' and passing the word down the column.

(An. 4.7.20-24)

As Xenophon reminds us, there is always more than one way of telling a story - and analysis of time is a vital step in interpreting the differences between variants. At one extreme, Xenophon offers in the Hellenica a bare summary of Cyrus' expedition and the Greeks' subsequent

1 All dates are $\mathrm{BC}$ and all references are to Xenophon unless otherwise stated. Translations are taken mainly from Warner (Penguin) for Hellenica and Waterfield (Oxford World's Classics) for Anabasis. 
retreat - here reported as the version of the nebulous 'Themistogenes'. A year's exciting events are told in three lines - and there is even an ellipsis of the events of the last three books of the Anabasis, which cover the Greeks' tumultuous journey along the Black Sea coast and their service in Thrace under a Thracian despot. At the other extreme, there is the section of narrative in which Xenophon reports a key moment towards the end of the Greeks' march towards the sea-a section which in itself shows some of the powerful effects gained by shifts of narrative speed: the scenic treatment of the stirring happenings on Mount Theches gains force by contrast with the meagre sketch of the four days before the Greeks arrived on the mountain.

Xenophon's famous account also reminds us of the importance of integrating analysis of time with analysis of point of view. The attacks on the rearguard are mentioned because they explain why the rearguard misinterpret the shouts ahead as a sign of another attack. And the motivation for sending the guide is mentioned when the Greeks come to understand it: as often in the Anabasis, Xenophon restricts the narrative to what was known by the Greeks at the time. Indeed, Xenophon's account of the sight of the sea is another instance of the same technique: the sight is left to be inferred from the shout of 'The sea! The sea!', and that shout is mentioned as it is heard by the rearguard (where Xenophon himself was stationed). ${ }^{2}$

The handling of time in these two passages seems simply to be a matter of storytelling skill. Xenophon did not want to repeat in the Hellenica the story he (or 'Themistogenes') had told so well in the Anabasis. And in the Anabasis itself it is natural enough that Xenophon should have drawn on a large repertoire of narrative techniques for the climactic 'Thalatta' moment. Yet already here we can see that the two analepses highlight one important theme - the uneasy relations between the Greeks and those whose lands they had to pass through; while the slowing down of the action is needed to create a sense of joyful unity among the Greeks that stands in contrast with the increasing tensions among them after their arrival at the coast (tensions omitted in the triumphalist summary of the Anabasis attributed to Themistogenes). We shall see in the rest of this chapter further evidence that variations of frequency, speed, and order are an important part of Xenophon's

\footnotetext{
2 Note, however, that some manuscripts add the phrase 'and saw the sea' after 'when the men in front reached the summit'.
} 
interpretative strategies and that interesting differences can be seen in his techniques in the historiographical Hellenica and the Anabasis, an innovative war-memoir.

\section{Frequency}

Xenophon's handling of frequency in the Hellenica raises few problems. The dominant mode is singulative. There are occasional pieces of iterative narration (e.g. Hell. I.6.20: 'They stayed aboard during the day and were put ashore in the evening, when it became dark ... On the fifth day ...'- -here the routine of the first four days tricks the enemy). Repetition is generally caused by actorial analepses repeating information earlier told by the narrator: some examples of this technique will be considered later (see 'Order' below).

In the opening section of the Anabasis, Xenophon also adheres to singulative narration. But this adherence comes to seem rather an addiction:

From there Cyrus progresses two stages, ten parasangs, to the river Psarus, which was three plethra in breadth. From there he progresses one stage, five parasangs, to the river Pyramus, which was a stade in breadth. From there he progresses two stages, fifteen parasangs, to Issi, the last city of Cilicia, settled on the sea, large and prosperous. There they remained three days.

(An. I.4.I)

This type of narration, with its regular use of the stage or parasang formula, resembles what Genette classifies as 'narrating $n$ times what happened $n$ times' - for example, 'Monday I went to bed early, Tuesday I went to bed early, Wednesday I went to bed early', etc. As Genette observes, 'this anaphoric type is still in fact singulative ... since the repetitions of the narrative simply correspond ... to the repetitions of the story' ${ }^{3}$ Nonetheless, Genette is right to highlight this type of singulative narration. Singulative narration is the norm, but the apparent monotony of Xenophon's account of Cyrus' progress seems to break expected norms of narration.

Unexpected though it may be, the regularity of Xenophon's parasang narrative does have a striking effect. It brings out how the Greeks are trapped by geography as they are lured by Cyrus' false promises

\footnotetext{
3 Genette [I972] I980: II4-II5.
} 
deeper and deeper into Asia. In the retreat, the same iconic regularity is often used to bring out how the Greeks in their turn conquer geography and force their way back to the sea (e.g. An. 4.7.I5, I8). In the retreat, however, Xenophon does not stick to singulative narration with such regularity. Instead, departures from this frequency highlight disruptions in the Greeks' march: the difficult crossing of the Carduchian mountains, for instance, is emphasized by an iterative conclusion focalized through the Greek soldiers: 'they often talked over the hardships they had been through; for they had been fighting continually through all the seven days during which they had been going through the country of the Carduchi' (An. 4.3.2). Occasionally, too, stages and parasangs are used in summarizing 'headers' (from $\rightarrow$ Homer onwards) that are followed by more detailed narratives: at An. 4.8.I, 'the Greeks marched three stages, ten parasangs, through the Macrones', and then a more precise account is given, revealing how the Macrones first opposed the Greeks at a river crossing until they came to an agreement.

\section{Speed}

The Hellenica is marked by the same general lack of temporal precision found already in Herodotus $(\rightarrow)$ and (to a slightly lesser extent) Thucydides $(\rightarrow)$. The lack of precision is established right at the start: meta de tauta... ('and after this ...'). Xenophon's opening words mark the work as a continuation of Thucydides' History - but he does not state how long after the end of Thucydides' work his own narrative starts. A later meta de tauta in the account of the Arginusae trial (I.7.I5) raises questions of legal procedure: this phrase may indicate a new day, since otherwise Socrates as epistatēes could have stopped the illegal motion to have all the generals put on trial together. If Xenophon was content with such vagueness at a heightened moment of his narrative such as the Arginusae trial, it is scarcely to be expected that measuring narrative speed will be any easier elsewhere in his work. ${ }^{4}$ At one point in his account of the Thirty Tyrants, Xenophon does provide the precision of 'on the fifth day' (Hell. 2.4.I3) - but it is revealing that this detail comes in a speech that is in fact more specific than the earlier narrative.

\footnotetext{
${ }^{4}$ Other common phrases are the singular meta de touto (e.g. 3.3.I; 4.6.I; with further precision, ou pollōi husteron at 7.4.I2) and ek de toutou (e.g. 4.4.I4, 5.I, 5.I8, 7.2).
} 
Some generalizations may be helpful. The opening section of the work (the 'continuation' to the end of the Peloponnesian War) does contain a number of annalistic-style year-closures or notices of ephors and archons (e.g. Hell. I.I.37, 3.I, 5.2 I; 2.I.Io, 2.24), but these are generally thought to be interpolated..$^{5}$ There are, however, some authentic seasonal markers in the 'continuation' (though there is a notorious problem of a missing year) and occasionally in the later narrative (e.g. Hell. 3.2.6, 4.I6; 7.2.10). Often where Xenophon does mark year-ends it is to explain why Spartan officers are replaced (e.g. Hell. 3.4.20).

It is possible to trace broad shifts in the speed of the Hellenica as it progresses. Books I-2 cover eight years $(4 \mathrm{I}-403$, the last years of the Peloponnesian War and the civil war at Athens) in 62 pages (roughly eight pages a year). By contrast, the remaining 4I years are covered in 20I pages (roughly five pages a year). The contrast is more, however, due to the increased number of omissions in the later sections of the work than to any decline in scenic treatment. ${ }^{6}$ Xenophon moves from a Thucydidean concentration on the narrow topic of Athens' defeat to a more selective treatment of the less clear-cut and bipolar interstate relations of the fourth century.

Xenophon offers four comments on his inclusion of material in the Hellenica. In narratological terms, these comments relate to the alternation between scenic and summary treatment. Thus at one point, Xenophon divides his narrative by land and sea, but explains that he has been more selective about events at sea: 'The war at land was fought in this way. I shall now describe what happened at sea and in the cities on the sea while all this was being done; I shall write those events that are worth remembering (axiomnemoneutous), and pass over those that are not noteworthy (axias logou)' (Hell. 4.8.I). The comment on his criterion for inclusion recalls Herodotean $(\rightarrow)$ practice as well as Thucydides' $(\rightarrow)$ overtly selective narrative of the first Sicilian expedition (Th. 3.90.I). Narratorial explanations of the inclusion of unexpected material, by contrast, hint at a shift away from Thucydidean practice. When Theramenes is led to death through the agora, Xenophon mentions two anecdotes reported of him: 'When Satyrus told him that if he did not keep quiet he would suffer for it, he replied: "Shall I

${ }^{5}$ Cf. e.g. Henry ig66: 40-43.

${ }^{6}$ I use the term 'omissions' for gaps which can be inferred only from other sources, whereas 'ellipses' are inferred from the text (cf. Rood I998: I0, I34). 
not still suffer, if I do?" And when he was forced to die and drank the hemlock, they say that he threw the dregs out of the cup, as one does when playing kottabos, and said: "And here's to that delightful fellow, Critias." ' Xenophon then justifies mentioning these stories: 'these remarks are not really worth mentioning; but I do think it admirable in the man that, with death hanging over him, his spirit never lost either the ability to think or the taste for making a joke' (Hell. 2.3.56). As Vivienne Gray notes, 'the alleged apology is simply a rhetorical flourish designed to bring attention to the underlying virtue. Xenophon is boldly and unashamedly championing the idea that history should concern itself with great and astonishing moral achievements. ${ }^{77}$ So too when Xenophon justifies his account of an incident revealing Teleutias' leadership skills ('I know that in describing this scene I am not telling of any noteworthy (axiologon) expense or danger or contrivance, but by Zeus I think it is very well worthwhile to consider this, how ...', Hell. 5.I.4) or of the loyalty shown to Sparta by the small town of Phlius ('if one of the great powers does some fine and noble action, all the historians write about it; but it seems to me that if a state which is only a small one has done numbers of great and glorious things, then there is all the more reason for letting people know about them', Hell. 7.2.I). These three passages 'seem to represent a progression suggestive of a stronger Thucydidean color at the start'. ${ }^{8}$ But in each case Xenophon is justifying either the inclusion of unusual material or the length of his account, and not the relationship between textual space and narrated time. That is, we see again that ancient historiographers (like their ancient critics) tend to measure textual space against the category of the eventworthy rather than against duration.

The type of methodological statement found about the inclusion of material in the Hellenica is entirely lacking in the Anabasis. The Anabasis, indeed, starts almost in the timeless world of the fairy-story as Xenophon narrates the origins of the dispute between Artaxerxes and Cyrus: 'Darius and Parysastis had two sons. Artaxerxes was the elder of the two and Cyrus was the younger. When Darius was growing feeble and began to suspect that he had not long to live, he wanted both his sons to be at hand ...' Cyrus' first journey up country from his satrapy is narrated in a single sentence - indeed, almost in the single word

\footnotetext{
7 V.J. Gray i989a: 28.

${ }^{8}$ Moles I992: 283.
} 
anabainei. It is only when Cyrus has gathered together his rebel army and started the march from Sardis that the narrative becomes more precise. But from that point it is precise enough to allow the narratee (or at least the scholar) to construct a day-by-day itinerary for the Greek march. ${ }^{9}$

In the early stages of the march, there is a variation between the swift parasang formula and the more extensive treatment of pauses in the march. After Cyrus had arrived at Peltae, for instance, 'he stayed there for three days, in the course of which Xenias the Arcadian celebrated the Lycaean festival and organized athletic sports. The prizes were gold crowns, and Cyrus himself watched the sports' (An. I.2.Io). It is almost as if these details are a way of bringing out a sense of a pause. As the narrative progresses, however, these pauses assume more thematic weight as they become more threatening to Cyrus' own ambitions (there is a mutiny at Tarsus, for instance). The pace after the battle of Cunaxa slows down as Xenophon traces in detail the tortuous negotiations between the Greeks and Persians that lead to the massacre of five of the Greek generals. And it is at this point that an even more spectacular slow-down occurs: the extraordinary night after the murder of the generals, when the soldiers are despondent and unable to sleep - the night when Xenophon comes to the fore, calling and addressing first the commanders in Proxenus' contingent, then the other commanders, and finally a general meeting of the whole army. Some fifteen pages are devoted to this memorable night (An. 3.I-2)-a slow-down matched only in the scene where Xenophon addresses the disorderly army at Cotyora $(A n \cdot 5 \cdot 7-8)$.

\section{Order}

The same imprecision that makes it hard to plot narrative speed in the Hellenica is also seen in the handling of order. We have seen that anachrony is commonly found in Herodotus $(\rightarrow)$ and Thucydides $(\rightarrow)$ as a way of dealing with simultaneous events. The same techniques are found in the Hellenica - but with rather more freedom in the definition of simultaneity. This freedom is well illustrated by a transition

\footnotetext{
${ }^{9}$ Cf. e.g. the reconstruction in Lendle 1995; there is, of course, scope for disagreement at various points.
} 
between the narrative of Sparta's campaign in Asia and events back in Greece: 'At the same time (kata ton auton khronon) as these campaigns of Dercylidas in Asia, Sparta was having trouble with Elis. The Spartans had been angry for a long time (palai) with the Eleans for the following reasons ...' (Hell. 3.2.2I). Here the scope of the explanatory analepsis can be discovered from Thucydides' History, where the two sources of Sparta's anger - Elis' alliance with Athens and the Olympic ban imposed on Sparta - are mentioned (Th. 5.47, 49). But the synchronism itself is 'wildly inexact'10 — even if allowance may be made for the vagueness of 'at the same time as these campaigns': Dercylidas' campaigns were in the years 399-397 while the Spartan Agis (who died no later than 400) was active in the Elis affair. Xenophon seems to be arranging material thematically: the narrative moves from Spartan ambitions in Asia to the sort of disruptions first within Greece (over Elis) and then within Sparta (the Cinadon conspiracy, Hell. 3.3) that will ultimately threaten Sparta's Asian strategy. The narrative then returns to the grander ambitions of the new Spartan king Agesilaus in Asia (Hell. 3.4), themselves soon to be destroyed by wider disturbances in mainland Greece. ${ }^{11}$

Many of the other ordering techniques found in Herodotus $(\rightarrow)$ and Thucydides $(\rightarrow)$ can be paralleled in the Hellenica. Just as Thucydides ends his treatment of the stasis at Megara by looking ahead to the lasting settlement achieved (Th. 4.74.4), so too Xenophon's narrative of the Athenian civil war ends with a prolepsis which culminates in a 'reference to the narrator's own time': 'Oaths were sworn that there should be an amnesty for all that had happened in the past, and to this day both parties live together as fellow citizens and the people abide by the oaths which they have sworn' (Hell. 2.4.43). Here the Athenians are held up for approval, with perhaps more of an overtly moral emphasis than is found in Thucydides. The same moralism is perhaps evident when Xenophon uses the proleptic closure device to anticipate the sorry fates of those who turned the vote against the Arginusae generals (Hell. I.7.35; cf. the prolepsis at Anabasis 5.I.I5 on the death of the treacherous Dexippus).

${ }^{10}$ Cawkwell I979: I54 n.

11 Other phrases for introducing (near-)simultaneous actions are skhedon de peri touton ton khronon (6.I.2; 7.3.I, 4.I2); en de toutōi tōi khronōi (6.2.5). The loose men ... de (often with imperfect tenses) coupling found in Herodotus and Thucydides is also used (e.g. 4.8.I; 6.I.I, 2.39). 
Another Thucydidean technique used to telling effect in the Hellenica is the analeptic narration of information as it is discovered by a character (compare already the discussion of the 'Thalatta' passage above for the use of this technique in the Anabasis). The battle of Cnidus, for instance, is narrated as its result is reported to Agesilaus (Hell. 4.3.Io). As we know that Xenophon was serving with Agesilaus, it could be suspected that Xenophon reports the battle when he became aware of it himself - just as he reports the shout of 'The sea! The sea!' when he hears it. This technique does, however, help to focus on the response made to the new information: in this case, Agesilaus lets out a false report that the Spartans had been victorious in the sea battle (Hell. 4.3.13-I4), and then leads them to victory at Coroneia. This technique is used with particularly pointed effect when Xenophon narrates Spartan responses to developments in the north. Twice envoys at Sparta, Cleigenes of Acanthus (Hell. 5.2) and Polydamas of Pharsalus (Hell. 6.I), warn of the growth of dangerous new powers in the north of Greece (Olynthus and Jason of Pherae) by narrating recent moves that, they argue, make it particularly important to confront these powers (compare the Corinthian speech warning the Spartans of the danger from Athens at Thucydides I.68-7I). It may be significant that Xenophon was composing the Hellenica at a time when the danger from Philip of Macedon was beginning to make itself felt.

While Xenophon uses many techniques derived from Thucydides, he does not use anachrony in the same concentrated way seen in the connected series of analepses and prolepses through which Thucydides explored the Athenians' sources of strength and weakness. Perhaps Xenophon was precluded from following this technique by the more diffuse action of the Hellenica. That is not to say, however, that he does not suggestively link different instances of anachrony. Two striking heterodiegetic analepses are used to mark the reversal in Agesilaus' ambitions in Asia. When Agesilaus sets out for Asia, he tries to offer a sacrifice at Aulis - 'where Agamemnon had sacrificed before sailing to Troy' (Hell. 3.4.3). When he returns to face the problems that have arisen in Greece he goes 'by the same route as that followed by the King of Persia when he invaded Greece' (Hell. 4.2.8). That is to say, the would-be panhellenic hero, self-consciously modelling his behaviour on the conqueror of Troy, is assimilated to the Persian king who invaded Greece in 480 . The implied message was brought out by George Grote: 'Though Agesilaus, in leaving Greece, had prided himself on hoisting the flag of Agamemnon, he was now destined against his will to tread 
in the footsteps of the Persian Xerxes'. ${ }^{12}$ We can contrast the way that a similar analepsis is used in the panegyric Agesilaus to point merely to the fact that Agesilaus covered the same route much more quickly than Xerxes had done: 'he passed through the very same tribes as the Persian with his mighty host; and the distance that had been traversed by the barbarian in a year was covered by Agesilaos in less than a month' (Ages. 2.I).

One major strand in the Hellenica that is highlighted by anachrony is the decline of Sparta:

Many examples could be given both from Greek and foreign history to show that the gods are not indifferent to irreligion or to evil doing. Here I shall mention only the case which occurs at this point in my narrative. The Spartans had sworn to leave the cities independent, and then they had seized the Acropolis of Thebes. Now they were punished by the actions of these men, and these men alone, whom they had wronged ... I shall now tell the story of how this happened.

(Hell. 5.4.I)

This passage strikingly contains an ellipsis of passages which, if included, would be instances of anachrony: that is, Xenophon adverts to the fact that he could have told other stories from earlier or later in history, but is restricting himself to the case that lies to hand. The passage is like a new preface: the coupling of Greeks and barbarians recalls the start of Herodotus' Histories, and the mention of divine punishment also adds a Herodotean feel. It is as if Spartan decline calls for a rather different sort of narrative from the more Thucydidean narrative of Athens' defeat in the Peloponnesian War.

More commonly Xenophon articulates the narrative of the Hellenica by means of foreshadowing. The allusion to Sparta's punishment itself follows directly on from the ironic claim that 'things had certainly gone well for Sparta ... it appeared (edokei) that now at last Spartan supremacy had been well and truly established' (Hell. 5.3.27). Earlier, the apparent closure marked by the end of the Peloponnesian War is undermined by the irony evident in the Greek perception that 'that day was the beginning of freedom for the Greeks' (Hell. 2.2.23) - an instance of foreshadowing that itself evokes an actorial prolepsis in Thucydides'

12 Grote 1852: 432; cf. Higgins 1977: Io6; Coventry r989: I3 n. 51; Tuplin I993: Io6. Grote also picked up an earlier prolepsis (Hell. 3.4.24, where Xenophon says that Agesilaus later brought back to Greece some camels taken in the battle of Sardis) when he wrote that the march 'now bore an Oriental impress'. 
account of the outbreak of the Peloponnesian War, the prediction of the Spartan envoy Melesippus: 'This day will be the beginning of great misfortunes to the Greeks' (Th. 2.I2.3).

Xenophon also evokes Thucydides' narrative in his actorial analepses. When the Athenians hear the news of the defeat at Aegospotami, they are despondent 'thinking that they would suffer what they had done to the Melians, the colonists of the Spartans, after they had conquered them in a siege, and to the Histiaeans and Scionaeans and Toronaeans and Aiginetans and many others of the Greeks' (Hell. 2.2.3). The allusion to Melos triggers thoughts of the Melian dialogue - where the Athenians had predicted that they would have less to fear from the Spartans than from their allies in the event of defeat (Th. 5.9I.I). As it turns out, their earlier prediction is borne out: 'many Greek states, and in particular the Corinthians and Thebans, were against making any peace with Athens, and said that Athens should be destroyed. The Spartans said that they would not endanger a city that had done great good for Greece at the time of its greatest dangers' (Hell. 2.2.19-20). The Thucydidean intertext is particularly suggestive if the Spartans' analepsis is taken as an allusion to Athens' performance in the Persian Wars - and if one recalls that the Athenians at Melos had said that they would not press any moral claims based on the Persian Wars in their dealings with the Melians (Th. 5.89).

The Peloponnesian debate over the fate of Athens in 404 is itself the subject of an actorial analepsis later in the Hellenica. Nine years later, the Thebans find themselves seeking Athenian support against Sparta - and having to excuse their earlier behaviour: 'It was not the city of Thebes that voted then; it was just one man who happened at that time to have a seat at the council of the allies' (Hell. 3.5.8). The Theban speakers attempt to 'correct' the earlier narrative-but scepticism about their claim is encouraged by an echo of their rhetoric in Thucydides' Plataean debate, where they try to excuse their medism by claiming that the city was at that time enduring 'domination by a few men' - so that 'the city as a whole was not independent when it took these actions' (Th. 3.62.3-4).

My final example of the way actorial analepses in the Hellenica are enriched by association with Thucydides concerns Alcibiades. When Alcibiades returns to Athens in 407, Xenophon reports how everyone flocked to see him (the scenic treatment echoes Thucydides' account of the departure of the Athenian fleet for Sicily, Th. 6.30-3I). He then gives in indirect speech two different narratives about Alcibiades: 
They said that he was the best citizen they had got and he alone had been banished not because he deserved it but because of the intrigues of people who were inferior to him in power, who lacked his abilities to speak, and whose policies were directed to their own personal profit; Alcibiades, on the other hand, was always doing good to the state as a whole, using both his own private resources and the resources of the public ... It was not in the character of people like Alcibiades to work for revolution or violent change; his position under the democracy had been that of a man who had been more distinguished than any of his contemporaries and no less distinguished than any of his elders. Others said that Alcibiades alone was responsible for the troubles of the past, and that the chances were that he, too, would turn out to be the chief cause of all the perils of the future.

(Hell. I.4.I3-17)

The difference in length between the two analeptic narratives (the defensive account occupies twenty lines, the hostile one a mere two) shows how Alcibiades 'encouraged debate in terms of polarized viewpoints'. ${ }^{13}$ And the content of the analepses recalls Thucydides' proleptic analysis of how suspicions of Alcibiades led to his second exile - and ultimately to defeat for Athens (Th. 6.I5). By means of these anonymous spokesmen, Xenophon suggests that the same suspicions that led to Alcibiades' first exile already haunted him at his return from exile: his understated use of actorial analepsis relies on the narratee's recollection of the more dominant use of narratorial anachrony in his predecessor.

How do the ordering techniques used in the Anabasis compare with those we have seen in the Hellenica? Similar techniques may be used to rather different ends. We have seen how Xenophon undermined Spartan ambitions in Asia by the use of heterodiegetic analepses based on geographical association (Agesilaus first as Agamemnon, then as Xerxes). Such apparently incidental, or implicitly aetiological, mythical details are typical of the periplus ( $\rightarrow$ Thucydides). In the Anabasis, Xenophon does briefly adopt the form of the periplus as the Greeks sail along the Black Sea coast - including allusions to myth: 'As they sailed along they saw the Jasonian headland, where the Argo is said to have been moored ... And they moored by the Acherousian Chersonese, where Heracles is said to have descended for the dog Cerberus at the place where they now show signs of his descent for more than

\footnotetext{
13 Gribble i999: г18.
} 
two stades down into the earth' $\left(A n\right.$. 6.2.I-2). ${ }^{14}$ The achievement of the Greeks is elevated by the citation of heroic antecedents (cf. also the actorial analepses evoking the Odyssey at Anabasis 3.2.25; 5.I.2) - and, unlike in the Hellenica, no deflating counterpoint follows. We can read the Anabasis as a commemoration of the glorious return of a Greek army that inscribes that army's movements in the Greeks' geographical imagination.

The allusion to two heroic journeys contrasts with the sort of analeptic geographical allusion found earlier in the Greeks' march: during the march up country with Cyrus, seemingly exotic allusions to the places where Apollo flayed Marsyas (An. I.2.7), where Xerxes built a palace on his return from his defeat in Greece (An. I.2.9; like the Marsyas allusion, perhaps a note for foreboding for Cyrus), and where Midas captured the Satyr (An. I.2.I3); and during the retreat through Mesopotamia, the stories of how the Persians had taken the cities of Larisa and Mespila (Nimrud and Nineveh) from the Medes (An. 3.4.8, I2) — stories that suggestively set the Greeks' heroic retreat in the context of the transition of oriental empires. The allusions to Jason and Heracles also redefine retrospectively the absence of such geographical notices during the narrative of the Greeks' tough retreat through Kurdistan and Armeniaareas that not even those two heroes visited. At the same time, the Greeks' survival seems all the more impressive for the fact that their prisoners reveal before they enter Kurdistan that 'a royal army of a hundred and twenty thousand had once invaded the country of the Carduchi, and not a man of them had returned home, because of the difficulty of the terrain' (An. 3.5.I6; cf. 7.2.22, a similar analepsis in the Thracian narrative).

Celebration of the Greeks' achievement may, however, be complicated by the contrast between two external actorial analepses. When the Greeks are cut off in Mesopotamia, the character Xenophon invokes a glorious precedent - the Persian Wars: 'Remember how the Persians and their friends came with an enormous army, thinking that they would wipe Athens off the face of the earth; but the Athenians had the courage to stand up to them by themselves, and they defeated them' (An. 3.2.II; he goes on to allude to victories over Xerxes by land and sea). Later, Xenophon warns of the danger of facing a hostile Sparta by appealing to a more sinister paradigm-Athens' recent experience in

14 The allusion to the Argo may, however, be an interpolation (there is a problem with the geography: cf. Lendle ig95: ad loc.). 
the Peloponnesian War (An. 7.I.27). The change in Xenophon's rhetoric is eloquent of the experience of the Greek mercenaries, enmeshed first in a battle against the barbarian reminiscent of the Persian Wars, and later in problems of reintegration in Greece, where Sparta is now the dominant imperial power.

The ordering strategies of the Anabasis are still more remote from those of the Hellenica when Xenophon describes his own actions. Elsewhere in the Anabasis, external analepses help to emphasize (and to some extent problematize) the scope of the Greeks' achievement. When Xenophon turns to his own role, anachrony seems to be linked with self-defence.

Xenophon rises to prominence after the murder of the Greek generals, and it is at this point in the narrative (and not at his two earlier appearances) that Xenophon explains how he had come to serve with Cyrus. Invited by Proxenus, a Boeotian guest-friend, to join Cyrus, he had consulted Socrates, who 'thought that friendship with Cyrus might well be actionable in the eyes of the Athenian authorities, because Cyrus was widely believed to have wholeheartedly supported the Spartans in their military operations against the Athenians'. Socrates advised him to consult the Delphic oracle to see whether or not he should go, but Xenophon asked instead for the names of gods to whom he should sacrifice in order to achieve a successful return. ${ }^{15}$ So he set out for Asia and joined Cyrus - deceived, he says, about the aim of Cyrus' expedition (An. 3.I.4-IO).

Xenophon's analeptic account of how he came to serve with Cyrus is also an instance of foreshadowing. Socrates' warning that Xenophon would get into trouble is later confirmed by a proleptic account of his life in exile, settled by the Spartans at Scillus: he bought a piece of land for Artemis with his own portion of the tithe set aside after the sale of prisoners captured during the retreat, and built a temple and founded a festival in the goddess' honour (An. 5.3.7-r3). And Xenophon again alludes to his exile in a prolepsis near the end of the work: 'Xenophon ... made no secret of the fact that he was getting ready to go homefor there was no sign yet in Athens of any proposal that he should be officially banished' (An. 7.7.57).

15 The god's answer is given analeptically at Anabasis 6.I.22, when Xenophon consults 'Zeus the King' over whether to seek leadership of the army (Xenophon also mentions at this cardinal moment his earlier dream from 'Zeus the King' (An. 3.I.I I-I2) and - for the first time - an omen he received earlier in the march). 
Interpreting Xenophon's proleptic references to his exile is difficult. It is not certain when or why he was exiled: it may have been not so much serving with Cyrus (as Socrates had feared) as marching against Artaxerxes or else later serving with the Spartan king Agesilaus that got Xenophon into trouble with the Athenians. Depending on the circumstances, dates between 399 and 394 are possible for the exile. ${ }^{16}$ And without secure knowledge of the scope of the prolepses, it is hard to know against what charges - if any-Xenophon was trying to defend himself.

There is a further temporal problem with the proleptic account of the festival Xenophon established at Scillus. Xenophon uses imperfect tenses to describe how neighbours would come to the festival and feast on the sacrificial victims and on other goods and how the young men would go out hunting. Those imperfect tenses may be a mark of iterative narration - or else a sign that Xenophon was writing after he was forced to leave his estate at Scillus at some point after the Spartan defeat at Leuctra in 37r. A hint of nostalgia has often been felt in Xenophon's description of his country estate. And the proleptic inscription Xenophon says he put up at Scillus may also hint that Xenophon was no longer at Scillus when he was writing: the inscription proclaimed that the possessor of the sacred land should offer a tithe each year to the goddess and keep the temple in good repair, and 'neglect of these duties will not go unnoticed by the goddess' (An. $5 \cdot 3 \cdot 13)$.

Xenophon's anachronic allusions to his own career gives us some hint of the controversies over his role in the Greeks' retreat - while at the same time his obliqueness makes the text as a whole hard to interpret. That self-defence was an issue is, however, made explicit in the narrative of the retreat, when Xenophon shows himself answering charges firstly of misleading and mistreating the soldiers in his charge, and then of acting against Spartan interests by helping the Thracian ruler Seuthes. In both cases, Xenophon uses actorial analepsis to describe his self-defence.

When accused by his fellow soldiers, Xenophon responded to charges by narrating at some length events which had taken place during the army's stop further up the coast, but had been omitted in the

\footnotetext{
${ }^{16}$ The most important recent discussions are Rahn I981; Tuplin I987; and Green
} I994. 
earlier narrative: an unprovoked attack on a village, the murder of some envoys, an attack on some officials. He narrates these to illustrate 'a problem I see beginning in the army' (An. 5.7.I2): disorder. As in the two speeches in the Hellenica warning the Spartans of the growth of new powers in northern Greece, ${ }^{17}$ Xenophon's disposition of material highlights the way the audiences respond to the advice contained in the speeches. Xenophon himself is successful in the short term, as the army decides to institute judicial procedures. But then he finds himself accused of hitting a soldier in the winter march through Armeniaanother incident not mentioned in the earlier narrative. He justifies his action by mentioning that the man he had hit had been trying to bury a wounded soldier alive - and the other soldiers shout that he had not hit the man enough (An. 5.8.I-I2).

By withholding information until these two speeches, Xenophon highlights his ability to quell the disruptive army at the same time as defending his own leadership earlier in the march. When Xenophon has to defend his leadership later, by contrast, he uses actorial analepsis that involve the repetition of information given in the earlier narrative (see especially his lengthy speeches to the Spartans at Anabasis 7.6.I I- 38 and to Seuthes at Anabasis 7.7.20-47). Here what Xenophon is defending is not his behaviour in an isolated incident, but the whole (very complicated) course of action pursued by the Ten Thousand after they had crossed over to Byzantium. He also, however, moves from defending past actions in front of the Spartans to rebuking Seuthes for his ingratitude to the Greeks and to Xenophon in particular. By the end of the work, rehearsing the past is important not just for Xenophon's selfdefence, but also for the key moral themes of pistis and philia. That is to say, Xenophon uses anachrony to show how he progresses from the impetuous young Athenian who ignores Socrates' advice to the hardened general who is able to act as adviser himself.

We have seen, then, that comparison between Xenophon's handling of time in the Anabasis and the Hellenica proves revealing. In the Hellenica, Xenophon uses some Herodotean and Thucydidean elements, but produces a temporal scheme that is nonetheless distinctively his own - and in many ways eloquent of his perception of the new

17 The opening of Cleigenes' speech is particularly close to Xenophon's speech: 'Spartans and allies, we think you have not noticed a great problem arising in Greece' (Hell. 5.2.12). 
texture of Greek history in the aftermath of the Peloponnesian War. In the Anabasis, by contrast, the demands of the journey narrative make themselves felt - but closer narratological inspection highlights variations revealing of the personal and ideological concerns that lie behind Xenophon's apparently artless memoir. 
Irene J.F. de Jong and René Nünlist - 978-90-47-42293-8 Downloaded from Brill.come4/26/2023 09:46:52AM via free access 
CHAPTER TEN

\section{POLYBIUS}

\section{T. Roop}

Had previous chronicles neglected to speak in praise of History in general, it might perhaps have been necessary for me to recommend everyone to choose for study and welcome such treatises as the present, since there is no more ready corrective of conduct than knowledge of the past.

Polybius shows at the outset that he is writing with a far stronger sense of his place in a historiographical tradition than the three historians treated in the previous chapters. And he maintains that difference by continually returning to historiographical issues. At the start of book 9, for instance, he defines three types of history - genealogical history, accounts of foundations and kinship, and political or pragmatic history - each appealing to a different sort of audience, and explains why he decided to write a history of contemporary events: accounts of genealogies and foundations have been written by many others, but 'there is always some novelty in actual events which demands novel treatment, since it was not in the power of the ancients to narrate events subsequent to their own time' (9.2.4-a rare flash of Polybian wit?).

Polybius' constant dwelling on the nature of historical writing proves fruitful for the narratological analysis of time. Polybius explicitly addresses his own and other historians' handling of Genette's temporal categories. He almost seems to be writing with the narratologist in mind. His constant analysis of his method even makes up to some extent for the fragmentary state of his text (after book 5 at least). We must, however, beware of succumbing too readily to the terms set by Polybius himself. He may start by claiming that it is not necessary for him to outline the advantages of studying history-but that does not stop him from elaborating those advantages at length in the later parts of his work. That technique of false praeteritio is harmless enough. What is far more important is to uncover the ways in which Polybius' comments on his own and other historians' handling of time frequently mask the profound political bias manifest in his History. 
As with the other historians analysed above, it will be helpful to break down Polybius' treatment of time into the three aspects of frequency, speed, and order. ${ }^{1}$

\section{Frequency}

Iterative narration was sometimes used by earlier historians $(\rightarrow$ Herodotus, $\rightarrow$ Thucydides) for regular practices and for generalized descriptions of fighting. Both types of iterative narration, subsequent and omnitemporal, are also found in Polybius, ${ }^{2}$ and in his account of the First Punic War, Polybius even explains the reason for using iteration in battle narratives, or at least for certain types of fighting such as ambushes, where to write a detailed account (ta kata meros) would be impossible and in any case unprofitable (I.56.II-57.4; 7.I5.I). Polybius uses iteration to point up both a shortcoming and an advantage of narrative. The shortcoming is that an iconic narrative of a complex succession of ambushes is more or less impossible (Polybius compares the difficulty of describing all the blows in an evenly fought boxing match). The advantage is that narrative can compress the complexity of actual fighting so as to bring out the general trends that are useful for understanding the development of a war. It should be noted, however, that Polybius defends his technique in both passages using the same terminology he applies to narrative speed (kata meros; see below). That is, he treats iterative narrative as a form of summary.

The most common departures from singulative frequency are repetitions caused by Polybius' strong narratorial control. ${ }^{3}$ At the start of book 3 (after the two introductory books), he offers a summary of the whole work, at least as it was originally planned, in two pages (3.2-3), explaining that 'a previous general view is of great assistance to the mind in acquiring a knowledge of details, and at the same time a previous notion of the details helps us to knowledge of the whole' (3.r.67). He then explains why he decided to continue beyond the end he

${ }^{1}$ All dates are BC and all references are to Polybius unless otherwise stated. Translations are taken from Paton (Loeb), with some changes (some drawn from Walbank $1957^{-1979,}$ a work to which I am heavily indebted).

${ }^{2}$ Cf. e.g. 4.32 on Messenian policy (combined with overt advice to the Messenians); 4.45 on the constant warfare between Byzantium and the neighbouring barbarians; and 6.53 on Roman funerary practice.

${ }^{3}$ Cf. Ibendorff I930: 27-30; SAGN I:I5I-152. 
had originally set for his work ( 167 ) down to 146 , and summarizes this additional period in slightly under a page (3.5). The work ends with a briefer recapitulation (39.8) and with a whole book (which does not survive) giving the periods covered by the history, the number of books, and the arithmos of the whole work. The repetition caused by summaries of the History's contents at the beginning and the end is matched by frequent recapitulations within the work itself - notably passages where Polybius marks out synchronisms, gives summaries at the start and end of the contents of separate books, ${ }^{4}$ and resumes topics from earlier in the work. When resuming his Greek narrative at the start of book 4, for instance, Polybius 'briefly recalls to the minds of my readers the sketch I gave in my second book of Greek affairs and especially of the growth of the Achaean League' (4.I.4): a one-page sketch follows that even repeats the 'fact' that the first Achaean king was Tisamenus son of Orestes. Later Polybius marks out Philip V's change for the worse with a similar repetition (7.I3.2, recalling 'a statement I made in my fifth book'). These repetitions seem to be connected with Polybius' awareness that the length of his work made it difficult to follow (3.32.I). At the same time, in the passages on the Achaean League and on Philip V Polybius' own Achaean bias is manifest: the claim that he first makes in book 5 and then repeats in book 7 is that Philip's failings were due to Demetrius, not to the Achaean statesman Aratus.

\section{Speed}

The most striking variations of speed in Polybius' History are related to temporal order. Polybius opens with two introductory books to provide the reader - especially the Greek reader, who is not expected to be familiar with the period $\left(\mathrm{I} \cdot 3 \cdot 7^{-8}\right)$ - with the knowledge required to follow the main story (Rome's rise to power). First he offers an eightpage summary of the period 386-264 (I.6-I2.4), leading up to what has already been defined as the start of the introduction proper, 'the occasion on which the Romans crossed the sea from Italy' (I.5.I). Then

4 The term for the initial summary is proekthesis: cf. Walbank I957-I979: I 297-298. For the first six books Polybius included prographai, lists of contents appearing either outside the scroll or inside, before the text; the only proekthesis was the general summary of the whole work at 3.2-6 (cf. ir.ra, with Walbank ad loc.). At I4.ai.i Polybius claims that the proekthesis 'arrests the attention of the reader' by showing the interconnections between events. 
he gives a brief (epi brakhu and kephalaiōōos, I.I3.I) listing of the events to be covered in the introduction (the First Punic War, Carthaginian wars in Libya and Spain, the Roman crossing to Illyria and war against the Italian Celts, and the Cleomenic War in Greece, I.I3.2-5) and a justification of the brevity of his treatment: 'to recount all these events in detail (exarithmeisthai ta kata meros) is neither incumbent on me nor would it be useful to my readers; for it is not my purpose to write their history but to mention them summarily (kephalaiōdoss) as introductory to the events which are my real theme' (I.I3.6-7). ${ }^{5}$ It is only later, when the narrative turns from Roman and Carthaginian affairs to Greece, that Polybius offers a 'not wholly convincing' ${ }^{6}$ explanation for his failure to give in the introduction a sketch of prior events in Asia and Egypt: they are said to have been covered by many historians already, and 'in our own times Fortune has wrought no such surprising change in these countries as to render any notice of their past necessary' (2.37.6). Again Polybius' Achaean interests are evident.

The summary form of books $\mathrm{I}^{-2}$ is shown when nine years of the Carthaginian war in Spain are described in sixteen lines (2.I.5-9) or when the successes of the Spartan king Cleomenes are listed (2.5I.I2). But that extreme brevity is not typical of the narrative of books I-2 (it is perhaps no accident that Polybius uses the list form for the successes of an enemy of the Achaean League). The narrative of the First Punic War covers 23 years in 67 Loeb pages (I.I6-63), with a partly annalistic arrangement (new consuls are generally noted) and some annalistic formulae (e.g. 'the Roman troops in Sicily did nothing worthy of note during the following year', I.24.8). It is followed by an even more detailed account of the Carthaginian war against the mercenaries (three years and four months in 32 pages, I.65-88); by a quicker treatment of Carthaginian fighting in Spain and Roman involvement in Illyria and against the Gauls in the years leading up to the outbreak of the Second Punic War $\left(2 . \mathrm{I}-36 ; 4^{6}\right.$ pages for $\left.23^{8-220}\right)$; and by 42 pages on Achaean affairs (2.37-71; mainly the war against the Spartan king Cleomenes, but also including a survey of Achaea that goes back to the first king).

\footnotetext{
${ }^{5}$ Polybius uses kephalaiōōos or a cognate several times elsewhere of the summary form of books I-2: cf. I.65.5; 2.I.4, I4.I (all three times with reference to the original plan: note esp. 2.I4.I, 'in order not to depart from what is proper for the introduction as defined in the preface'); 2.35.IO.

${ }_{6}$ Walbank 1957-1979: I 215 .
} 
Polybius does offer an explanation for the detail of one section of the introductory books. He promises at the outset to narrate the First Punic War 'somewhat more carefully (brakhu epimelesteron) ... since it is not easy to name any war which lasted longer, nor one which exhibited on both sides more extensive preparations, more unintermittent activities, more battles, and greater changes of fortune' (I.I3.II). Later he adds another reason for narrating the war at length (epi pleion) - that the readers should know the origins of Rome's naval power (I.20.8). Focussing as it does on continuity and length, Polybius' explanation of why he has chosen to narrate the First Punic War at greater length recalls Thucydides' $(\rightarrow)$ criteria for judging the greatness of the Peloponnesian War. The progress of the war is marked in two pauses ('this was in the fourteenth year of the war', I.4I.4; 'eighteenth year', 56.2) thought to be a sign that one of Polybius' sources, Philinus of Acragas, used an annalistic form; but also an effective reminder of the length of the war and of the combatants' extraordinary ability to maintain the war for so long. The claim about the greatness of the war is repeated at I.63.4, and there Polybius even contrasts the sort of ships used in the war with those used in the Persian and Peloponnesian Wars. The narratives of the Mercenary and Gallic Wars also close with narratorial claims about their greatness: the Mercenary War 'far excelled all wars we know of in cruelty and defiance of principle' (г.88.7), while the Gallic War was 'second to no war in history' in 'the desperation and daring of the combatants and the numbers who took part and perished in the battles' (2.35.2). By making claims generally used to magnify a historian's overall subject in relation to wars that are only part of his introductory books, Polybius underlines the even greater importance of the subject of the work proper. In the case of the Mercenary and Gallic Wars, however, the superlative claims do not justify the length of the accounts. On the contrary: the account of the Gallic invasion'summary indeed, but going back to the beginnings' (2.35.II) - is motivated by the fact that it was 'quite contemptible as regards the plan of the campaigns' (2.35.2). Polybius is writing to reassure an audience of Greeks, who 'not only in old times but more than once in my own days ... have been alarmed by the prospect of a Gaulish invasion' (2.35.9).

Polybius differentiates the opening two books from the remaining narrative in his reluctance to use digressions. When he describes the Po, he alludes to Greek tales about Phaethon as 'matter for tragedy', but 'detailed treatment (akribologian) of such things not suiting very well the character of the introduction', he promises proper mention of them 
when he finds 'a suitable occasion (kairon harmattonta)' (2.I6.I4-I5). On other occasions, too, in the introductory books Polybius indicates an omission of topics to be covered later on occasions 'more suitable' (1.36.4; 2.13.2). And at one point in the main story he notes that he is now treating in detail (kata meros) a topic mentioned in the introductory books (3.26.5). And yet the introductory books do contain digressive material - above all a detailed critique of the historian Phylarchus where Polybius' political bias is to the fore $\left(2 \cdot 5^{6}-63\right)$.

Polybius contrasts the summary narrative of the introduction with the detailed account of the main story (apodeiktike historia, 2.37.3; met' apodeixeōs exaggellein, 3.I.3). ${ }^{7}$ The fragmentary state in which Polybius' main story survives makes it hard to assess the speed of his narrative. The remains of book 8 , for instance, include a highly detailed and technical account of the Roman siege of Syracuse, two long ruse narratives, and a methodological section on the bias shown by historians when dealing with kings. These sections survive, however, as isolated set-pieces. It is hard to integrate them into a coherent analysis of narrative rhythm.

The remains of Polybius' History are at least sufficient for the ratio between books and years to be analysed. ${ }^{8}$ Polybius makes the task easier by commenting on his own practice in the preface to book 9: 'These are the principal events included in the above-mentioned Olympiad, that is in the space of four years which we see must be regarded as an Olympiad, and I shall attempt to narrate them in two books. I am not unaware that my work owing to the uniformity (to monoeides tês suntaxeoss) of its composition has a certain severity' (9.I.I). It is not totally clear, however, whether this comment refers to the principle of chronological order or to the practice of devoting two years to a book: as he goes on to talk of the different audiences to whom the three types of history are addressed (see above), it may be pragmatic history's relentless concentration on recent events that is at issue. But a norm of two years to a book is clearly stated in the preface to book I4, where Polybius has reached the I44th Olympiad (covering the years 204-20I, the end of the Second Punic War): 'as I wish to give such an account of the facts as their importance deserves, I have not comprised the events of two years in one book, as was my practice in previous cases' (I4.Ia.5). The importance of the contents demands that that book

\footnotetext{
7 Cf. Sacks i98ı: I7I-I78 on these terms.
}

8 Cf. Walbank i972: i29 for a chart. 
and the next should be devoted to a single year each - a degree of slowdown found later for the climaxes of other significant wars (the war against Antiochus III in book 20, covering I92/I9I, and that against Perseus in book 29, covering $\mathrm{I} 69 / \mathrm{I} 68$ ). The narrative is also sometimes faster than the two-years-to-one-book principle: a whole Olympiad is covered in each of books I9, 22, 25, and 26. The narrative of the continuation (books 29-39) starts at an equally fast pace, with the first four books $\left(3^{-}-33\right)$ being devoted to a single Olympiad each, but it slows down for the climactic narrative of the Third Punic War and the disaster in Greece, with three successive books (37-39) covering a single year each.

As well as commenting on his own handling of speed, Polybius engages in polemic against the space devoted by other historians to certain events. In particular he is critical of the 'sensational' and 'tragic' treatment of the downfall of individuals and cities $\left(2.56 ; 7.7 ; 15.34^{-}\right.$ 36). ${ }^{9}$ He complains that Phylarchus treated the fate of Mantineia 'with exaggeration and rhetorical elaboration' (met' auxēseōs kai diathesēos) but made no mention at all of the noble actions performed at the same time by the citizens of Megalopolis - Polybius' native city (2.6I.I-2); and he disparages historians of Hieronymus for writing at 'great length' (polun tina ... logon, 7.7.I) and historians of Agathocles for 'largely transgressing the bounds of what is essential to give coherence to the narrative'whereas he himself 'refrained from giving an exaggerated account (ton met' auxēsē̄s logon) of the story of this man' (I5.34.I, 36.I). As in Plutarch's criticisms of Herodotus, however, it is not the ratio between textual space and temporal duration that Polybius is criticising, but the relation between textual space and his notions of the eventworthy. ${ }^{10}$

The definition of different genres of history is also at stake in Polybius' criticism of the speed of other historians. The problem for historians of Hieronymus was that 'those who write narratives of particular events (hoi tas epi merous graphontes praxeis), when they have to deal

${ }^{9}$ Similar language is found in the three passages: terateuomenon, kathaper hoi tragōidiographoi at 2.56.IO; terateian, tragöidountes at 7.7.I-2; terateias, ekplēktikas peripeteias at I5.34.I, 36.2 .

${ }^{10}$ Note that criticisms of auxessis mainly concern rhetorical style - but they do bear indirectly on textual space. For other criticisms of historians' handling of speed, cf. 8.IO.I, I2.26b. 
with a subject which is circumscribed and narrow, are compelled for lack of facts to make small matters great and to devote much space to matters really not worthy of record' (7.7.6). And just as the writers of monographs may devote too much space to their topics, some writers who claim to have composed universal histories devote too little space to theirs: 'certain writers of history in my own times after giving an account of the war between Rome and Carthage in three or four columns, maintain that they write universal history ... giving a slighter sketch of it even than those who on public authority set up memoranda of occasional happenings in chronological sequence' (5.33.I-5).

\section{Order}

We have already noted Polybius' complex arrangement of his material at the start of the History: having defined the first two books as a summary treatment necessary for understanding his main topic, he also gives (in the case of the Roman crossing to Sicily) an even briefer introduction to that introduction. The handling of these different periods, each marked out by different speeds, raises the question of whether the introductory books are to be defined as analeptic to the main story or as the start of the story.

Polybius explicitly marks out the sketch of what had led to the Roman crossing to Sicily as an analepsis: 'my readers need not be surprised if, in the further course of this work, I occasionally go back in time (prosanatrekhomen tois khronois) to add some of the earlier history of the most famous states ... in order to take such a starting point as will make it clear in the sequel starting from what origins and how and when they severally reached their present position' (I.I2.8-9). At the same time, the very inclusion of the sketch makes problematic Polybius' attempt to establish a clear starting point for his story. Polybius was consciously grappling with the problem of causation that Herodotus confronted at the start of his work: after marking the Roman crossing to Sicily as 'the starting point of this book [viz. book I]' (I.5.I), he wrote that 'the actual cause of their crossing must be stated without comment (psilōs); for if I were to seek the cause of the cause and so on, my whole work would have no clear starting point' (I.5.3). But the length of the sketch (eight pages, most of it devoted to the last decade of the period 386-264) stands in some tension with Polybius' earlier statement that he would simply give the cause of the crossing to Sicily without comment 
(the sketch ends with Polybius writing that he has now given the cause of the crossing, I.I2.5).

The problem of a starting point also arises with the summary introduction that fills the first two books. At first it seems that these two books are marked out as analeptic: Polybius starts by saying that 'the date from which I propose to begin (arxei de tês pragmateias hêmin) is the I4oth Olympiad', justifying this with the claim that 'previously the doings of the world ... were held together by no unity of initiative, results, or locality; but ever since this date history has been an organic whole (sōmatoeidê)' (I.3.I-4). That is, Polybius is implying that the story proper only begins in book 3. But later he calls the first Roman crossing to Sicily not just the 'starting point' of book I (I.5.I) but also 'the most suitable starting point of this whole work' (oikeiotatēn krinantes arkhēn einai tēs holēs protheseōs): 'I have therefore made it my serious base, but went also somewhat further back in order to leave no possible obscurity in my statements of general causes' (I.I2.5-6, ringing with I.5.I). The two beginnings are further justified by the fact that they coincide with the endings of the works of two earlier historians - Timaeus for the first crossing to Sicily (I.5.I; 39.8.4) and Aratus of Sicyon for the I40th Olympiad (I.3.2; 4.2.I). But later Polybius does return to defining the I40th Olympiad as his opening (tên arkhēn tēs heautōn suntaxeōs, 2.37.2; it is time for me to call to mind my original plan (protheseōs) and return to the starting point of my history (tēn arkhēn têes hautōn hupothesēos)', 3.5.9). Indeed, he even implies that there is no dispute over the temporal range of his story: 'The subject I have undertaken to treat, the how, when, and wherefore of the subjection of the known parts of the world to the dominion of Rome, should be viewed as a single whole, with a recognised beginning, a fixed duration, and an end which is not a matter of dispute' (3.I.4-5). In his epilogue, however, he adopts a slightly different perspective when he refers to this start as a 'fresh beginning' (palin ... arxamenoi, 39.8.6). Like Herodotus $(\rightarrow)$ and Thucydides $(\rightarrow)$, then, Polybius confronts the narratee with the problem of defining the start of the story. But Polybius handles the problem in a far more explicit and abstract way than his predecessors.

The same difference is seen in the way Polybius deals with the treatment of simultaneous events. Polybius sets out his principles in his narrative of the I40th Olympiad at the point where he moves from the Social War in Greece to events in Asia and Egypt. He explains that whereas in later Olympiads he adopts an annalistic method, with the narrative arranged by different geographical regions (and with those 
regions treated in a fixed order, with events in Italy first), for the I4oth Olympiad he treats in single units the events in the different areas (5.30.8-33).

Polybius brings out the reason for his change of ordering technique earlier in his work, when he synchronizes affairs in Greece with Hannibal's attack on Saguntum (4.28.I) and makes clear the lack of connexion between the two events: 'now had there been any connexion at the outset between Hannibal's enterprise and the affairs of Greece it is evident that I should have included the latter in the previous book, and, following the chronology, placed my narrative of them side by side in alternate sections with that of the affairs of Spain' (4.28.2). He explains that the sumploke- the interconnexion of events - did not occur until the third year of the I4oth Olympiad (4.28.5; cf. 5.I05.4-8 for the moment itself), but that he introduced synchronisms to make clear the chronological link between events ('merely recapitulating the contemporary occurrences set forth in the previous book', 4.28.6). His explicit comment at this point makes clear a point made by a number of other synchronisms found in his introductory books and in the main story before the sumploke itself occurs - namely that 'previously the doings of the world ... were held together by no unity of initiative, results or locality' (I.3.3-4). ${ }^{11}$

Towards the end of the History, Polybius anticipates the charge that his narrative is 'imperfect and disconnected' (atele kai dierrimmenēn, 38.5.I). He defends himself by appealing to the need for diversity felt by the sensory organs. Most thoughtful historians, he claims, have followed the lessons of nature and rested their readers with digressions. But while their digressions have been irregular and have left topics in the air, Polybius can claim that he has provided both diversity and regularity, thereby still enabling students to satisfy their desire for a continuous narrative $\left(38.5^{-6)}\right)^{12}$

One consequence of Polybius' chronological principle was that later events in one area were narrated before earlier events in another area

11 Other synchronisms: I.6.I-2; 2.44.2; 4.37.3-8, 66.8-10 (where Polybius notes that he had dealt with the synchronized matters 'in detail in my previous book, and now merely recall them to my readers in pursuance of my original plan that they may know what events were contemporaneous'); 5.I.3-5, I08.9-Io. Elsewhere there is a connection between geographically remote places, but the connection is not yet a global one (e.g. $2.29 \cdot 9-\mathrm{IO})$.

12 Cf. Meister i97 I on this passage. 
even when they followed causally from those earlier events. Polybius expressly confronts this feature of his work at $15.24 \mathrm{a}$, and later notes that it is a particularly common feature of his presentation of embassies (28.16.5-II, where he states that such reminders of the consequences of his method were frequent).

Polybius adverts to his maintenance of his chronological system by combining prolepsis with narratorial cross-references to the treatment of the events at the appropriate time, e.g. 'having, with the approval of Philip, made a foolhardy and ill-managed attempt to seize Messene, he perished in the action, as I shall narrate in detail (ta kata meros) when we reach that date' (3.I9.II; cf. 4.8I.I4; 5.12 .8 labontes ton oikeion kairon). He also uses the criterion of suitability when he promises a later treatment of Greek myths localized at the River Po (2.I6.I4-I5; detailed treatment about such stories is not suitable for the introduction). Similar signals that the narrative is sticking to a linear order are common in Diodorus (e.g. 2.31.2, 34.6; 5.3.6, 21.2; I4.63.2, I I7.6).

Polybius does not stick to his chronological principle consistently. The principle is broken when he groups together related events that took place in more than one year in the narrative of a single year. This is a common procedure in annalistic historians: it is the cause, for instance, of many of the chronological problems posed by Diodorus (cf. e.g. II.545-549 on the career of Themistocles). In itself this procedure is comparable to the common practice in non-annalistic historians of the explanatory analepsis and completing prolepsis; it only causes confusion when the departure from the annalistic structure is not marked out as such. Polybius is careful to note when he adopts this procedure and to justify his decision by explaining that the events would seem insignificant if narrated separately. One such occasion is his account of how Ptolemy IV Philopator took to a life of dissipation and late in his reign fought 'a war which, apart from the mutual savagery and lawlessness of the combatants, contained nothing worthy of note, no pitched battle, no sea-fight, no siege': 'It, therefore, struck me that my narrative would be easier both for me to write and for my readers to follow if I performed this part of my task not by merely alluding every year to small events not worth serious attention, but by giving once for all a unified picture so to speak of this king's character' (I4.I2.4-5; a note by the excerptor shows that this section went on for 48 pages). It is perhaps surprising that Polybius uses the adjective sōmatoeidēe ('unified': Paton's 'life-like' is wrong) of a section that breaches his normal rulesgiven that he applies the same adjective to the contents of his work as a 
whole (I.3.4) and compares reading the work itself to looking at a living animal rather than the dismembered limbs of a dead one (I.4.6-8; note the use of dierrimmena, the word put in the mouth of the detractors of his chronological system at 38.5.I..${ }^{13}$ Later Polybius notes that he has continued his narrative after the departure of Ariarathes from Italy until his restoration to power in Cappadocia, and then reverted to events in Greece, 'partly recurring to the past and partly anticipating the future, so that, the separate details of it being by no means striking, I may not by relating them under different dates, produce a narrative both obscure and insignificant' (32.II.I-6). Here Polybius has departed both from the normal ordering of events within the year (affairs in Greece were normally described between those in Italy and those in Asia) and from the annalistic framework.

Polybius also breaks the annalistic framework by the use of proleptic closure. Like Herodotus $(\rightarrow)$ and Xenophon $(\rightarrow)$, he looks ahead to the punishment of characters - but with a relish not easy to parallel in his more demure predecessors. When Philip V and Antiochus III agree to divide up Egypt, he looks ahead to their subjection to Rome, asking 'who among those who reasonably find fault with Fortune for her conduct of affairs, will not be reconciled to her when he learns how she afterwards made them pay the due penalty, and how she exhibited to their successors as a warning for their edification the exemplary chastisement she inflicted on these princes?' (I5.20.5). For Philip V he later expressly marks out 'the first outbreak of terrible misfortunes (deine tis arkhe kakōn)': '14 'it was now that Fortune, as if she meant to punish him at one and the same time for all the wicked and criminal acts he had committed in his life, sent to haunt him a host of the furies, tormentors and avenging spirits of his victims' (23.IO.I). In both cases anachrony is used to emphasize the workings of Tukhe. And in the second passage the departure from linear chronology is accompanied by another departure: Polybius abandons his historiographical principles and uses the sort of sensational and tragic language that he decries in other historians.

Prolepsis is used to particularly striking effect in Polybius' account of the early stages of the Second Punic War. Polybius alludes to Carthage's

13 Though note that the manuscripts are defective-but, as Walbank notes, the reading seems secure.

14 For the (Homeric, Herodotean, and Thucydidean) phrase arkhe kakōn, cf. also I8.39.I and 22.I8. I (again of Macedon). 
defeat when he explains the causes of the war: he tells how Hannibal's father made him swear as a boy never to be friend of the Romans - and justifies the anecdote by revealing that Hannibal told it to Antiochus when he had taken refuge at Antiochus' court (3.II). Again, in calculating the distance covered in Hannibal's march he mentions that a certain part of the road has 'now been carefully measured by the Romans and marked with milestones at every eighth stage' (3.39.8-looking ahead a century to the construction of the Via Domitia in ri8). But the most significant prolepsis occurs right at the end of the third book. The chronological structure adopted for the I40th Olympiad allowed Polybius to offer a unified treatment of the Second Punic War up to the Battle of Cannae in a single book. He also heightened the sense of Rome's desperate position by looking beyond Cannae and mentioning the surrender of Tarentum (3.I 8.3), even though that only occurred in 2I3, three years after Cannae (but not expressly marked out as proleptic). Polybius increases the sense of the Romans' hopeless position to make their response to disaster the more impressive:

the Senate neglected no means in its power, but exhorted and encouraged the populace, strengthened the defences of the city, and deliberated on the situation with manly coolness. And subsequent events made this manifest. For though the Romans were now incontestably beaten and their military reputation shattered, yet by the peculiar virtues of their constitution and by wise counsel they not only recovered their supremacy in Italy and afterwards defeated the Carthaginians, but in a few years made themselves masters of the whole world.

(3. $118.7-9)$

With astonishing speed Polybius has moved from one of the Romans' worst defeats to their position of global domination - the central theme of his narrative.

Polybius' use of internal prolepsis in the account of the Second Punic War is revealing of the forward momentum of his work. None of his three predecessors ( $\rightarrow$ Herodotus, $\rightarrow$ Thucydides, $\rightarrow$ Xenophon) stated at the outset the end result of his work. When Polybius defines his work at the start, by contrast, he looks ahead to Rome's unparalleled subjection of almost the whole world (I.I.5). The same teleology informs his decision to give a summary of the contents of the work at the start of book 3 .

Polybius' internal analepses vary greatly in scope and extent and in the contexts in which they are introduced. As in Herodotus, they may be used to underline breaches of reciprocity, with a strong moral tone (e.g. the repeating analepsis at I.8o.I2). When the Achaean Alexon 
helps Carthage by some timely news, Polybius introduces him as a man 'who had on a former occasion saved the Agrigentines' (I.43.2), and then repeats this information ('Alexon, who had previously saved by his loyalty not only the city and district but the laws and liberties of Agrigentum, now was the cause of the Carthaginians being saved from total ruin', I.43.8). As we have seen, this is not the only time that events with an Achaean connection are privileged.

Longer analepses are often marked out as such by an overt signal (most commonly (pros)anadramontes) and used to give background about a city or person. As we have seen, Polybius introduces at the start of his work a brief account of Roman history before the crossing to Sicily, stating that he will occasionally 'go back in time to add some of the earlier history of the most famous states' (I.I2.8; prosanatrekhōmen tois khronois) later in the work as well. That brief account of Roman history has the same explanatory function as the sketches of the immediately preceding events in Egypt and Syria introduced before the account of the war over Coele-Syria fought between Antiochus III and Ptolemy (note the analeptic markers at 5.31.8 (brakhu prosanadramontes) and 5.40.4 (anadramontes): these analepses go back to the period covered in the two introductory books, where Polybius explicitly noted that he was omitting Asian and Egyptian history). Later, when Polybius introduces Philopoemen, he defends the principle of giving the earlier history of characters as well as details of the foundations of cities (I0.2I.23 , presumably referring both to foundations included in works and to whole works devoted to foundations).

Polybius tends to employ a summary form in these explanatory or scene-setting analepses. The summary (kephalaiōd $\bar{e}, 5.40 .4)$ account of Antiochus' reign aligns it with the introductory books, while the summary form is used for Philopoemen's background because Polybius had already written a separate biography of Philopoemen (I0.2 I.7).

Analepses are especially common in Polybius' frequent didactic and argumentative sections. In his treatise on the art of generalship (9.I220), for instance, he condemns Nicias' refusal to leave Syracuse owing to an eclipse of moon (9.I9.I-4), while in a discussion of treachery (I8.13-I5) he at first claims that he will not 'draw examples from far-off times' but 'from the very circumstances we are dealing with' (I8.13.7), but soon moves on to a critique of Demosthenes' views of treachery in the De Corona (I8.I4). Sometimes his technique is to give parallel instances (e.g. 8.35, followed by an explicit moral in $8.36 ; 9.8,23$ ) or to draw contrasts (e.g. Philip V's savage sack of Thermos stressed by 
contrast with examples of previous Macedonian moderation such as Alexander's sparing the temples in his sack of Thebes, 5.9-Io).

Typical of Polybius is the use of analepsis in the course of his polemics against earlier historians. Book $\mathrm{I} 2$ is devoted entirely to such polemic and includes discussions of the treatment of battles by Callisthenes and Ephorus. Similarly at 8.10-1 I a discussion of Philip and Alexander follows criticism of Theopompus' treatment of them. At times Polybius assesses suitable topics for historians with moral and patriotic criteria that recall the strictures of Dionysius of Halicarnassus in his criticism of Thucydides: at 7.7.7-8 Polybius complains about sensational accounts of Hieronymus and says that historians should write about the thirdcentury rulers Hiero and Gelon instead (a brief account of their lives follows), while at $15 \cdot 34-35$ the same point is made with reference to the Egyptian regent Agathocles (historians should write about the Sicilian Agathocles). Most intriguing, perhaps, is the passage where Polybius points out inaccuracies in the works of Zeno and Antisthenes of Rhodes (16.I4-20) - and reveals that he wrote a letter to Zeno pointing out his mistakes (i6.20.6-9).

Scholars have examined Polybius' many and varied references to the past in order to discover his historical perspective. ${ }^{15}$ What emerges from detailed analysis is that there are relatively few references to the fifth century or earlier. Polybius pays most attention to the fortunes of the Greek cities from the fourth century onwards and to the Macedonian royal house. The Persian Wars of the early fifth century are, however, important for understanding Polybius' placement of his own fabula in relation to the past. As he approaches his climax, he magnifies the disasters suffered by the Greeks in 146 by reviewing their earlier misfortunes from the Persian Wars on and concluding that the disasters he is about to describe were the greatest ever (38.2).

By contrast with the wealth of external analepses that Polybius employs to bring out his political and moral messages, there are few external prolepses in Polybius - even though Polybius himself seems to have lived at least until is8. It was not, of course, in Polybius' power to narrate events subsequent to his own time-but he did shape his narratee's historical understanding with several hints of the future.

Polybius displays his powers of foresight when he describes the silting caused by the influx of rivers into the Pontus (Black Sea): 'when a

${ }^{15}$ Cf. Millar i987; Lehmann I989-I990; Walbank 2002: I78-I92. 
period has elapsed which stands to the time it takes to fill up the Palus Maeotis in the same proportion as the cubic capacity of the larger basin to that of the smaller, the Pontus will become, like the Palus Maeotis, a shallow fresh-water lake' (4.42.4). Here the flow of water from the Palus Maeotis out towards the Ocean mirrors Polybius' view of historical causation, with one war leading on to another $(3 \cdot 32.7) .^{16}$ At the same time, Polybius is evoking two earlier historians: Herodotus and Thucydides had shown a similar power to look into the distant future when discussing the silting caused by the Nile and the Achelous (Hdt. 2.I .4; Th. 2.102.3).

Polybius also looks to the future when he outlines his cyclical view of constitutional change in book 6 . He argues that it was the Romans' mixed constitution and their military practices that enabled them to recover from Cannae. But he also speaks of the 'change for the worse which is sure to follow some day'-for Rome 'will undergo a natural decline' (6.9.I2-I4). The relation of Polybius' circular view of constitutional change in book 6 (the anakuklosis) to the rest of his account is a notorious problem: according to Momigliano, "when he came to historical narrative, he forgot cycles'. ${ }^{17}$ But the organic view of decline that is expressed in book 6 is one with great resonance in the rest of the History.

Hints of Roman decline are strongest in two actorial prolepses, ${ }^{18}$ one placed near the end of the work as originally planned, the other near the final end of the work. In the first passage, Polybius quotes a passage from Demetrius of Phalerum's prose work on Fortune. Demetrius had written that fifty years previously neither the Persians nor the Macedonians would have believed that Macedon would have crushed Persia: 'But nevertheless Fortune ... who always defeats our reckoning by some novel stroke ... now also, as it seems to me, makes it clear to all men, by endowing the Macedonians with the whole wealth of Persia, that she has but lent them these blessings until she decides to deal differently with them' (29.2I.5-6). Polybius, pondering the downfall of Perseus, reflects that 'this utterance of his seems to me to have been more divine than that of a mere man' (29.21.9). Once more it is the extraordinary workings of Fortune that disrupt Polybius' annalistic scheme. And the

16 Cf. Clarke i999: I26.

17 Momigliano I977: I89.

18 There are also many actorial analepses in Polybius: cf. my remarks at $S A G \mathcal{N}$ I:I6o-I62, with bibliography cited there. 
temporal dislocation - an analeptic account of a pessimistic proleptic vision - may lead the narratee to reflect that Fortune could well treat Rome just as she had just treated Macedon. ${ }^{19}$

The second prolepsis of Rome's downfall comes at the fall of another enemy, Carthage:

After being wrapped in thought for long, and realizing that all cities, nations, and authorities must, like men, meet their doom; that this happened to Troy, once a prosperous city, to the empires of Assyria, Media, and Persia, the greatest of their time, and to Macedonia itself, the brilliance of which was so recent, ... Scipio said, 'A day will come when sacred Troy shall perish, and Priam and his people shall be slain'.

Scipio's tears evoke Antiochus' tears towards the end of Hieronymus' history, ${ }^{20}$ while the general stress on mutability also looks back to Herodotus' reflection that cities once great were now small and that cities now great were once small (I.5.4) and to Thucydides' anticipation of Athens and Sparta as ruins (I.IO.2). At the same time, while the historians agree that all things decline, there is no way of knowing when decline will set in. For Polybius, as for Herodotus and Thucydides, the possibility of calculating the development of a natural process such as silting contrasts with the difficulty of foreseeing the human future.

The passages where Polybius shares a long-term perspective with his predecessors are, however, isolated. For the most part, he shows vastly more awareness of chronological issues, repeatedly drawing on an abstract theoretical vocabulary drawn from rhetorical writers. In his handling of time, as in so many other ways, Polybius adopts the stance of the professional-not least to conceal the political.

19 Paton makes Perseus subject of the opening sentence of the section: 'so then often and bitterly did Perseus call to mind the words of Demetrius of Phalerum' (29.2I.I). If that is right, then Perseus' bitter recollection is parallel to Croesus' belatedly recalling Solon's wise words (Hdt. I.86). But Walbank I957-I979: ad loc. objects that 'neither the text nor probability offers any justification' for this.

${ }^{20}$ J. Hornblower i98I: I04-106. 
Irene J.F. de Jong and René Nünlist - 978-90-47-42293-8 Downloaded from Brill.come4/26/2023 09:46:52AM via free access 
GHAPTER ELEVEN

ARRIAN

T. HidBer

The future of the past: Alexander and I

Anyone who is surprised that with so many historians already in the field it should have occurred to me too to compose this history should express his surprise only after pursuing all their works and then reading mine. ${ }^{1}$

(I.praef.3)

How can you not only outdo all your numerous predecessors with their often contradictory accounts but also write the perfect and most reliable history of the most renowned and celebrated achievements and events that took place almost 500 years ago? Well, first, the greatest deeds call for the greatest narrator and the most able and sharp-witted historian. So, nobody should be left in any doubt that you are the one to do it - as Achilles had his Homer, Alexander would have his Arrian. ${ }^{2}$ Second, as for the distance between the time of narration and the time of the fabula, you have to single out the few really trustworthy sources contemporary to the events and brush off the bulk of the erroneous tradition. This is the key that gives you direct access to that remote past and brings you at eye-level with your hero. In Arrian's preface 'Ptolemy, son of Lagus, and Aristobulus, son of Aristobulus'-both not very well known as historians at the time - are identified as the only two reliable authorities, since both were not only contemporaries but also unbiased eyewitnesses of the events (I.praef.). By sticking to these two supreme sources and given his own outstanding intellectual abilities, the narrator is certain to produce the first and only account to equal

1 Translations in this contribution are all taken (with slight modifications) from Brunt 1976-1983. All dates are BC and all references to Arrian's Anabasis unless otherwise stated.

2 Cf. I.I2.I-5. 
Alexander's great deeds in literary terms. ${ }^{3}$ Therefore, the Anabasis of Alexander appears not only as a worthy monument of that unparalleled enterprise and its great leader but also provides a new and direct access to and thus revives those glorious days of the great Greek past for the benefit of both the present and future generations.

\section{On the march}

As the title - authentic or not - suggests, the subject of the Anabasis is not so much Alexander's 'life' or 'reign' but rather his great expedition. Accordingly, a preliminary narrative sets in with Alexander's accession in 336 . The dubious and much disputed circumstances of his acceding to power after his father's murder are not even mentioned (though later Alexander accuses Darius of the crime),${ }^{4}$ and the first months of preliminary diplomatic activities in Greece are only summarily dealt with in a few sentences (I.I.I-3). The marching activity starts in I.I.4: 'At the advent of spring he marched towards Thrace against the Triballi and Illyrians'. Europe, however, is swiftly left behind, and already in I.I2 the king, having crossed the Hellespont, is found paying tribute to Achilles in Troy. This is the moment for the narrator to insert his 'second preface' marking the beginning of the main story, that is, of the account of the achievements and deeds that earned Alexander fame and that the Anabasis is all about - the Persian campaign and the conquest of the East. The main story, then - virtually coinciding with the fabula, since there are hardly any external analepses or prolepses - encompasses the time span of the eleven years from Alexander's departure from Troy (334) to his death in Babylon in 323. ${ }^{5}$

As a consequence of the chosen point of departure and period of time - not immediately relevant to the narratologist, but often deplored by modern historians - , the complex and troublesome histories of the

\footnotetext{
${ }^{3}$ Cf. I.I2.5: 'That is why I think myself not unworthy of the masters of Greek speech, since my subject Alexander was among the masters of warfare'; and 7.30.3: ' $\ldots$ it was for that purpose that I embarked on this history, and like Alexander not without God's help'. As for the construction of the narrator's persona in the two prefaces cf. $S A G \mathcal{N}$ i:165-i66.

${ }^{4}$ In his letter to the great king (2.14.5).

${ }^{5}$ A similar instance - though on a much larger scale - of the main story being preceded by a preliminary narrative can be found in Polybius $(\rightarrow)$, whose first two books function as an introduction to the main story (books $3 \mathrm{ff}$.).
} 
Macedonian dynasty and its relationship with Greece and Persia hardly get into view. Obviously, Arrian did not intend to offer an analysis either of the origins and causes of the Macedonian expedition or of its historical impact. 'The present record', the narrator points out, 'must be restricted to what appears sufficient to explain Alexander's achievements' (5.5.I). Hence, 'history' in the Anabasis is very much reduced to the reconstruction of the character and deeds of the one central figure; it proceeds, as it were, keeping its step in time to Alexander's own advances.

Not surprisingly, then, Arrian's history of Alexander's expedition may appear as what Stadter called 'a march narrative consisting of alternating marches and halts'. ${ }^{6}$ In fact, the narrative closely follows the movements of the king as he makes his way through Asia and the East. It is thus structured by the stages and halts (reception of embassies, administrative measures, and, above all, battles and sieges) of Alexander's expedition and is brought to a natural close by the death of the hero. The stages of the king's advances are often dated quite precisely. The narrative begins with the date of Alexander's accession ('in the archonship of Pythodelus at Athens', I.I.I) and his age at the time ('about twenty'). In the following, the single years of the campaign are in some cases marked by the 'advent of spring'7 — a scheme reminiscent of Thucydides $(\rightarrow)$. Exact dates indicate not only the year but also the month of the capture of Tyre ('in the archonship of Nicetus at Athens in the month Hecatombaeon', 2.24.6) and of the great victories over Darius in the battles of Issus ('So ended this battle, fought in the archonship of Athens of Nicocrates and in the month Maimacterion', 2.II.Io) and Gaugamela ('So ended this battle in the month Pyanepsion of the archonship at Athens of Aristophanes', 3.15.7 $)^{8}$ as well as of the death of Darius himself ('This was the end of Darius, when Aristophon was

${ }^{6}$ Stadter 1980: 76 .

7 I.I.4 (beginning of 335: 'at the advent of spring he marched towards Thrace'); I.I I.3 (334: 'In early spring he marched to the Hellespont'); I.24.5 (beginning of 333: 'by the time he had completed all this it was the depth of winter'); 3.6.I (beginning of 331: 'When spring began to show itself, Alexander started from Memphis for Phoenicia'); 4.7.I (beginning of 328: 'he arrived at Zariaspa, and remained there till the depth of winter was past'); 4.I8.4 (beginning of 327 : 'With the first appearance of the spring Alexander marched forward towards the Rock of Sogdiana'); 7.15.3 (beginning of 323: 'neither the wintry season nor the difficulties of the country stood in his way').

${ }^{8}$ Alexander's arrival at Thapsacus 'in the month Hecatombaeon of the year in which Aristophanes was archon at Athens' (3.7.I) is also noted, since it marks the beginning of the opening phase of the battle of Gaugamela. 
archon at Athens in the month Hecatombaeon', 3.22.2). Alexander's own end is dated by referring to the eponymous archon at Athens and to the Olympiad, which is unique in the Anabasis (contrast $\rightarrow$ Polybius) and no doubt due to the narrator closely following his source Aristobulus, thus stressing the historical importance of the date. Additionally, the king's exact age and the duration of his reign are noted according to Aristobulus:

Alexander died in the hundred and fourteenth Olympiad and the archonship of Hegesias at Athens. According to Aristobulus, he lived thirtytwo years and eight months; his reign lasted twelve years and the same eight months.

While these dates mark the main stages and achievements of Alexander's great expedition, the numerous indications of relative chronology are, perhaps, more striking because they seem to encourage the narratee to keep them in mind. Often the narrative seems to follow the advances of the king on a day-to-day basis:

From Ilium Alexander came to Arisbe, where his whole force had encamped after crossing the Hellespont; next day to Percote, the next he passed Lampsacus and camped by the river Practicus, which flows from Mount Ida and runs into the sea that lies between the Hellespont and the Black Sea. Then he reached Hermotus, passing by Colonae. ${ }^{9}$

Thus, the narratees are invited, as it were, to join the hero on his expedition, to admire his quick progress and, at the same time, the number and wealth of the cities and regions that he swiftly conquers. The presentation of an immense amount of geographical detail, such as the names of foreign rivers, mountains and towns passed and taken by Alexander, serves the same goal. At the same time, the richness in detail is intended to underscore the narrator's authority and trustworthiness.

The speed of Alexander's advances is often emphasized by mentioning the specific number of days it took him to march with his army from one place to another:

[Alexander] ... reached Sestus twenty days in all after starting from home.

(I.II.5)

9 'Next day' (tềi husteraiai) is a particularly frequent way to start off a sentence in the Anabasis; the subject almost always being Alexander himself; cf. e.g. I.7.9, I8.3, 21.5; 2.4.I; 3.18.3; 4.2.4, 26.5; 5.28.2; 6.9.1, I9.4; 7.25.3. 
After thus capturing the five cities in two days ... Alexander marched against the largest of them, Cyropolis ... ${ }^{10}$

In the record of a particular military operation chronology is often noted on an even smaller level, when the time of the day or even the watches of the night are stated. This precision is a means to create vividness in the account and to demonstrate how Alexander proceeds step by step in a way that is both daring and prudent:

About the second watch of the night they burned the wooden tower.

$(\mathrm{I} \cdot 23 \cdot 3)$

... at nightfall he himself marched with his whole force to seize the Gates again ... about midnight he was in possession of the passes once more ... just upon dawn he descended from the Gates along the road. (2.8.I-2)

A special case of the presentation of circumstantial relative chronology can be found in the chapter on Alexander's last eight days (7.25), claimed to be taken from the 'royal journals'. Although this claim seems rather dubious, the narrative, in fact, takes the form of an 'official journal' or bulletin only recording the state of health and the activities of the sick king by the day. Perhaps the very sober tone implied in such a narrative seemed to be particularly appropriate for an account of the hero's last hours. It also creates a certain distance and, as it were, gradually removes the hero both from his former life of active self-determination and from the narratee, in that Arrian's account is coming to a close.

\section{Order}

As a 'march narrative' concentrating on and closely following the proceedings and advances of the protagonist, the Anabasis clearly maintains the chronological order much more strictly than many other historiographical works. The linear pattern is preserved for the most part, and different story-lines are normally avoided; thus, the narrator explicitly excludes a report of Nearchus' voyage by sea from the Anabasis and promises to treat it on another occasion (6.28.6). This, of course, was only possible because Arrian chose to write on a topic of such a narrow scope as regards both the subject matter and the time covered. Conversely, 'universal history' encompassing thousand years and taking

${ }^{10}$ Cf. e.g. also I.7.7, I7.I0; 3.I.I, I6.7, 20.2; 6.24.I. 
into account the fate of numerous individuals or peoples such as Cassius Dio's or Appian's Roman Histories simply could not be arranged in such a linear way. Still, even the Anabasis features various anachronies of a smaller degree.

Let us first look at analepsis. It should be said right away that narratorial analepsis does not play an important role in the Anabasis. I should like to distinguish two categories: historical digressions and closing narratorial comments.

Short digressions on the geography and topography of a particular place or town usually introduce the account of Alexander's conquest of that place. In a few instances, these initial digressions contain some information on the history of the place, for example on the origins of the strange dialect of Side (I.26.4) ${ }^{.11}$ Explanatory narratorial analepses can also be found in instances when Alexander is confronted with remains from the past, as with Gordius' famous waggon and the knot of the waggon's yoke (2.3.2).

While antecedent events are thus presented at the beginning of a particular stretch of narrative, the end of an episode is sometimes marked by the narrator's reasoning about the historical dimension of the event. By far the most elaborate sunkrisis of this sort can be found at the end of the capture of Thebes (I.9.I-8). There the narrator marks the disastrous nature of the fall (in terms of 'the size of the captured city, the sharpness of the action, and not least the general unexpectedness of the event', I.9.I) by comparing it to other defeats of the Greeks, which he briefly calls to mind (the Sicilian expedition, Aegospotami, etc.). This analepsis, as it precedes the main story of Alexander's conquests in the east, directs the narratees' attention not only back to the Greek past, but also - and perhaps even more so - raises expectations as to what is still to come in Asia.

Obituaries can be seen as a special form of closing narratorial comments. There are three instances of some length: on Darius (3.22.2-5), on Alexander's horse Bucephalas (5.19.5-6), and, of course, on Alexander himself (7.28-30). Darius' obituary, characterizing his life as 'one series of disasters, with no respite, after his accession' (3.22.3), is in fact the only, rather short, passage that allows for a closer examination of the Persian King, who otherwise remains very much a shady figure in the Anabasis. The same is even more true for Bucephalas, who

${ }^{11}$ For historical elements in geographical digressions also cf. 2.I6.I-6; 4.28; 5.I.I-2. 
acquires some prominence only with his death. Much more important is, of course, Alexander's long obituary which closes the Anabasis. This peroration does not highlight the king's achievements again, but rather offers a general view of Alexander's qualities, thereby almost adopting the form of a panegyric. ${ }^{12}$ Thus, having recounted the Anabasis, the narrator presents the sum of his hero's outstanding personality - the keystone, as it were, to the monument he so proudly erected.

As for actorial analepsis, short passages of retrospection most frequently occur in the form of messages brought to Alexander about plans or actions taken by his enemies or the people in the region which cause the king to react:

There messengers reached him with the news that Clitus, son of Bardylis, was in revolt.

Hegelochus ... reported to Alexander that the people of Tenedos had revolted from the Persians and come over to them.

$(3 \cdot 2 \cdot 3)$

Such actorial internal analepses (often anonymous) report the actions by others and constantly keep Alexander at the centre of attention. The only thing that matters is his reaction. The same holds true when envoys beg Alexander to spare their city by referring to its great history. Thus, Acuphis speaks on behalf of his city Nysa by explaining that it had been founded by Dionysus (5.I.5-6). The speech has the desired effect. Alexander in fact 'wanted to believe the tale about the wandering of Dionysus; he also wanted Nysa to be founded by Dionysus' (5.2.I).

In other instances of actorial analepsis Alexander himself can be seen looking back to events of the past. This is often the case in letters and speeches. Thus, a letter written by the Macedonian king reproaches Darius of hostile actions taken by the Persians against Greece and Macedonia as well as against Philip, Alexander's father (2.I4.4-9). This is a reply to a letter of Darius (reported only indirectly) in which the Persian king had accused Philip and Alexander of having begun the hostilities. This short passage about the contrary views of the kings is in fact the only external analepsis in the Anabasis that refers to the prehistory of Alexander's campaign, which thus remains rather obscure. Later, however, it is reported that Alexander justified the burning of the Persian palace by saying 'that he wished to punish the Persians for

\footnotetext{
12 Cf. Bosworth ig88: $135^{-1} 5^{6 .}$
} 
sacking Athens and burning the temples when they invaded Greece, and to exact retribution for all the other injuries they had done to the Greeks' (3.18.12) - a reference to the past which the narrator explicitly disapproves of in a moralizing way. ${ }^{13}$

Conversely, the past provides Alexander with examples of excellence that inspire him with emulation. Thus, he chooses the way from Ora to Pura through the desert knowing that only Semiramis and Cyrus son of Cambyses had ever managed to get through safely with an army: 'The relation of these stories to Alexander is said to have inspired him with emulation of Cyrus and Semiramis' (6.23.3). Another parallel with a great, or rather, the greatest hero of the remote past is drawn in the famous scene that introduces the 'second preface': ${ }^{14}$

Some say that Alexander crowned the tomb of Achilles, while Hephaestion, others say, placed a wreath on Patroclus' tomb; and Alexander, so the story goes, blessed Achilles for having Homer to proclaim his fame to posterity. Alexander might well have counted Achilles happy on this score, since, fortunate as Alexander was in other ways, there was a great gap left here, and Alexander's exploits were never celebrated as they deserved ... That, I declare, is why I myself have embarked on this history, not judging myself unworthy to make Alexander's deeds known to men.

(I.I2.I-2, 4)

Past, present and future are remarkably intertwined in this passage, with analepsis and (implied) prolepsis going hand in hand. Alexander is not only presented as an admirer of Achilles but also as being concerned about his future fame, even before his own great undertaking has really begun. At the same time his looking back to Homer is intended to direct the narratees' attention forward to Arrian, who seems to be prefigured in the singer of the Trojan war. And just as Achilles has always been known as a hero to men thanks to Homer, Alexander's deeds will always be known to posterity thanks to Arrian, the narrator of the Anabasis.

Whereas external actorial analepsis attached to Alexander thus most often refers to the king's own models with whom he rivals, ${ }^{15}$ internal

13 3.I8.I2: 'I too do not think that Alexander showed good sense in this action nor that he could punish Persians of a long past age'.

${ }^{14}$ For a discussion of the 'second preface' cf. Moles I985; V.J. Gray 1990; Swain 1996: 244-246; $S A G \mathcal{N}$ г:165-I66.

${ }^{15}$ Cf. also 2.7.7-8 (Alexander recalls Xenophon and his Ten Thousand as he addresses his troops at Issus); 2.I8.I (Heracles appears in a dream). 
analepsis is rather aimed at his soldiers. When on the banks of the river Hyphasis Alexander recalls the great victories and successes of the expedition so far, he unsuccessfully tries to convince his commanding officers to advance with him further east. ${ }^{16}$ Similarly, the king's address to his mutinous troops at Opis lists the achievements of the campaign in an impressive catalogue, claims that his soldiers are the real beneficiaries of these conquests, and reminds them that he had always shared their hardships. ${ }^{17}$

Actorial analepses, then, on the one hand provide some additional information, but perhaps even more importantly demonstrate Alexander's thinking in historical dimensions and his rivaling with the heroes of the remote past. They thus underscore the unique greatness of Alexander's undertaking.

I now turn to instances of prolepsis. It is characteristic of Arrian's march narrative that the next stage or destination of the campaign is repeatedly announced in a summary statement that introduces the ensuing and more detailed account (for this technique $\rightarrow$ Homer, $\rightarrow$ Pindar, $\rightarrow$ Herodotus):

Alexander now determined to make his expedition to Egypt ... (2.25.4)

After this a longing seized Alexander to pay a visit to Ammon in Libya.

Such summary way stations in the narrative call attention to the individual stages of the campaign and, thus, have an important structuring function.

More decidedly proleptic are omina or portents. Their number is, however, comparatively small in the Anabasis and the reliability of their predictive value is limited because they are interpreted by the characters, whereas the narrator, unlike, for example, Cassius Dio's, refrains from doing so. Thus, Parmenio and Alexander argue over the meaning of the sight of an eagle 'perching on the shore astern of Alexander's

\footnotetext{
${ }^{16} 5 \cdot 25 \cdot 4-6$.

17 7.9-10; catalogue of achievements: 7.10.5-7. This internal analepsis, however, is preceded by a short external one referring back to the benefits and favours of Alexander's father Philip: 'Philip took you over when you were helpless vagabonds, mostly clothed in skins, feeding a few animals on the mountains ... He gave you cloaks to wear instead of skins, he brought you down from the mountains to the plains ... He made you city dwellers and established the order that comes from good laws and customs' (7.9.2). This picture of Philip as the creator of Macedonian society is certainly 'wildly inaccurate'; cf. Bosworth I988: I08-Iog.
} 
ships' (I.I8.6). Parmenio thinks that it promises a successful naval campaign against the much greater Persian fleet. Alexander, however, does not follow Parmenio's interpretation of the omen but rather acts following his own 'rational' arguments (I.I8.9) and waits for a better occasion to attack the Persians on land and, of course, proves to be right (I.20.I). In another instance, Alexander, laying siege to Tyre, 'in some degree' is 'influenced' by an omen, for in a dream 'he found himself approaching the wall of Tyre, and there was Heracles, stretching out his right hand, and conducting him into the city' (2.I8.I). In fact, Aristander's interpretation of this dream-'Tyre would be taken, but with an effort, for Heracles' achievements involved effort' (2.18.2.) - turns out to be correct, in that the ensuing narrative of the siege and the final capture of the city fills no fewer than seven chapters (2.18-24).

A particularly intriguing form of prolepsis in the Anabasis (and still a matter of lively debate among historians) is the record of Alexander's plans and projects that were never realized. In his speech at the Hyphasis the Macedonian king unveils a grand scheme of conquest not only of the territories on the other side of the river, but ultimately involving the entire world (5.26.I-3). A similar plan is noted by the narrator at the beginning of book 7 (7.1.2-3). The point about the recording of these projects is obviously to demonstrate that for Alexander there were no limits at all. Thus the narrator assures us:

There is one thing I think I can assert myself, that none of Alexander's plans were small and petty and that, no matter what he had already conquered, he would not have stopped there quietly, not even if he had added Europe to Asia and the Britannic Islands to Europe, but that he would always have searched far beyond for something unknown, in competition with himself in default of any other rival.

(7.I.4)

What, if Alexander had not died as young as he did? What would the future have had in store for him? And what would the world look like now?

Finally, there are also a few instances of the narrator 'referring to his own time', for instance, when, wondering about how Alexander might have managed to cross the Indus, he turns to his own experience because his sources do not give a clue: 'the quickest way of bridging I know is the Roman use of boats, and I shall here describe it, for it merits description' (5.7.3). The following digression on that Roman military technique, then, is simply triggered by the narrator's aim to demonstrate and share his privileged knowledge with his narratees.

Overall, the sequence of the narrative is mainly chronological. In 
two cases, however, events that took place at different times are taken together in order to throw into relief a particular characteristic of the hero: chapters 4.8-I4 record examples of Alexander's arrogance and 6.26. $\mathrm{I}-3$ report instances of his endurance. Thus, Alexander's one flaw and one of his many outstanding qualities are brought into special prominence.

\section{Rhythm: keeping pace with the king}

As we have already seen, the narrative first sets in after the preface recounting Alexander's succession to his father's throne in 336 , but the main story does not begin until after the 'second preface', which marks the king's setting off for his grand campaign in the East in 334 . Thus, the first two years of Alexander's reign are hurried through in a rough summary of only a few chapters (I.I-II), whereas the remaining eleven years are dealt with in no fewer than 205 chapters. Although the narrative generally slows down as soon as Alexander reaches Asia, the speed still varies substantially.

Clearly, the most elaborate scenes, related in detail and at a slow pace, deal with Alexander's greatest challenges and achievements. These are, first of all, numerous battles and sieges, such as the battle at the river Granicus (I.I3-I6), the battle of Issus (2.6-II), the siege and capture of Tyre (2.I6-24), or the battle of Gaugamela (3.7-I5). These 'scenes' can further be subdivided into passages of different speed. Thus, the narrative of the battle at the Granicus is structured as follows: Alexander arrives at the river Granicus, when scouts report that Persians are drawn up for battle on the farther bank of the river; all this is reported summarily (I.I3.I-2). A debate recorded in direct speech between Parmenio and Alexander follows (I.I3.3-7) - a stretch of narrative where story-time nearly corresponds to fabula-time. Then the battle array is presented in a survey that almost takes the form of an ekphrasis; but inherent to such a pause is also a 'resultative' mode of presentation, since it implies the idea that the battle array is the result of corresponding orders and measures (2.I4.I-4). The circumstantial account of the course of the battle itself follows in chapters 2.I4.5-I5.8. Finally, the narrative speed is accelerated again as a summary is drawn with a listing of the number of the dead on both sides, the names of the fallen Persian commanders and a record of Alexander's care for the dead and the wounded (2.I6). 
Other challenges faced by Alexander and also dealt with in scenes include his injury (6.9-1I), the debate held on the banks of the Hyphasis whether to advance further east (5.25-29), and the mutiny of his troops at Opis (7.8.I-I2.4). The scene at the Hyphasis is particularly elaborated and comprises the longest debate in direct speech in the Anabasis. It thus marks the turning-point of Alexander's campaign with its reasoning about the limits of such an undertaking and the absence of any limits for the king himself.

On the whole, the halts and stages of the expedition are recorded in shorter or longer scenes, whereas the march of the army from one halt to the next is usually dealt with summarily or simply passed over in an ellipsis ('On the third day after the battle Alexander reached the Ister', I.3.I). In a few instances, however, the march itself appears as such a challenge that it is narrated in a scene of its own right. Thus, the march through the desert from Ora to the Gadrosian capital Pura (6.24-26) is recounted in detail, highlighting the hardships and sufferings of the Macedonian army. Not much attention is paid to administrative or building measures, usually treated only by way of summary.

Pauses often mark the beginning of a new stage of the campaign when the town or region that Alexander approaches next is introduced by a geographical and topographical digression that highlights the particular military challenges of the place. ${ }^{18}$ There are also a few other ekphraseis of temples or monuments such as the temple of Heracles at Tyre (2.16.I-6) or the tomb of Cyrus (6.29.4-8).

On the whole, then, the narrative's rhythm (minimizing the time between the stages of his conquests) evokes a picture of restless activity of the king, who is constantly being confronted with new challenges, always advancing and fighting his way through Asia and the eastern world.

\section{Conclusion}

The narrative's narrow scope regarding both subject matter and time covered has the effect that Alexander and his great achievements are constantly kept at the centre of interest. Due to the handling of time in the Anabasis, the hero seems to be heading from one challenge to

${ }^{18}$ Cf. e.g. I.2.I; 2.26.I; 3.23.I; 5.4.I-2. 
the next, not finding any limits to his ambitions. The narratees are, as it were, invited to join Alexander on his campaign, enter new lands, conquer city after city, advance to regions that not even Heracles or Dionysus had reached. On the whole, the portrait of a man is created who restlessly and impatiently keeps pushing further and lives a vehement life. However, the Anabasis is not a biography. Rather, it is a vivid march narrative that focuses on the hero's greatest achievements. 
Irene J.F. de Jong and René Nünlist - 978-90-47-42293-8 Downloaded from Brill.come4/26/2023 09:46:52AM via free access 


\title{
CHAPTER TWELVE
}

\section{HERODIAN}

\author{
T. HidBer
}

\section{Choosing contemporary history}

The History of the Empire after Marcus comprises the period of roughly $5^{8}$ years from the death of the Roman emperor M. Aurelius in AD I8o to the accession to the throne of the young Gordian III in AD 238. The narrator lays stress on the fact that he is a contemporary witness of the whole period and of the events he recounts:

My aim is to write a systematic account of the events within a period of seventy years, covering the reign of several emperors, of which I have personal knowledge. ${ }^{1}$

In the proem the temporal closeness to the chosen period of time is presented as a methodological advantage. This choice, the narrator explains, rules out the danger of inserting 'fabulous elements' and brings along the possibility of using first-hand information only (I.I.I3). He also draws attention to the fact that the narratees, too, are contemporary witnesses of the events, which is additionally to guarantee, as it were, the authenticity of the narrative on behalf of 'future generations of readers' (I.I.3). ${ }^{2}$ The narrator, then, presents himself as a trustworthy observer and unbiased transmitter who hands down the history of his own life-time as a representative of his generation. This distinguishes the History of the Empire after Marcus from the popular 'universal' Roman Histories of the second and third centuries - such as those by Appian,

\footnotetext{
1 Translations in this contribution are all taken (with slight modifications) from Whittaker I969-1970. All references are to Herodian's History of the Empire after Marcus unless otherwise stated. The 'seventy years' here contrast with the accurate figure 'sixty' in the proem (I.I.5). Herodian probably changed his mind on where to end his account and failed to correct the passage quoted in the main text; cf. Hidber 2006: IO-I5.

2 Cf. $S A G \mathcal{N}$ I:20I-2IO.
} 
Cassius Dio or Asinius Quadratus - as well as from the similarly popular genre of histories of the 'classical' Greek past such as Arrian's $(\rightarrow)$ Anabasis of Alexander. Conversely, the narrator aligns his History in particular with Thucydides $(\rightarrow)$, the acknowledged model of contemporary history, whose section on method ( $\mathrm{I} .2 \mathrm{I}-22)$ is constantly recalled in the proem. At the same time the History is separated from another ubiquitous genre of imperial history, the encomium on a single (still living and ruling) emperor (I.I.I-2; 2.I5.6-7). As a matter of fact, Herodian's choice is quite unusual, indeed, and no Greek predecessor can be found treating a similar time span of contemporary Roman imperial history in a work of comparable scope.

\section{Where to begin}

The time span of the main story covers the last days of the old M. Aurelius to the very first day of the reign of Gordian III. The beginning of the main story is clearly marked in I.3.I by means of mentioning time and place ('When Marcus was an old man [...] he was seriously taken ill on a campaign in Pannonia'). This beginning is preceded by an introduction consisting of three parts: the initial preface positioning the text in the tradition of contemporary history and outlining the main characteristics of the period in question (I.I.I-6), a short sketch of M. Aurelius' qualities and reign (I.2.I-4) and, finally, the resumed preface giving the reasons for the choice of the starting point of the History (1.2.5). This structure of the introduction recalls the beginnings of Herodotus' $(\rightarrow$ ) and Thucydides' $(\rightarrow)$ work, an arrangement that J. Moles has labelled as 'sandwich structure'. ${ }^{3}$ As in those classics of historiography the 'sandwiched material' in Herodian contains the prehistory, as it were, of the main story, which sets in right after the resumed preface. The 'prehistory', however, in this case is not so much a narrative but rather a shady and quite non-historic portrait of the ideal ruler and of his perfect kingship. It thus establishes a standard against which the narratees are to measure M. Aurelius' successors. ${ }^{4}$ This short preliminary sketch, then, discloses the outlines of the system of values

${ }^{3}$ Cf. Moles i993: 98.

${ }^{4}$ Cf. Widmer I967: 20-22; Marasco I998: 2840-2857; Sidebottom I998: 2804-2805; M. Zimmermann I999: 24-28; Kuhn-Chen 200I: 266-272. 
inscribed into the History immediately before the main story begins and, thus, functions as a point of orientation for the narratees. At the same time it is made clear at the outset that none of M. Aurelius' successors of the period taken into account can be expected to equal the perfect rule of the ideal emperor.

\section{The order of the History}

A linear order is announced by the narrator in the proem:

How all this happened I intend to relate in chronological order [kata khronous], taking each reign in turn.

This narratorial comment, however, makes it also clear that the presentation of the history will not follow an annalistic pattern but rather a freer scheme, with the reigns rather than temporal units such as years structuring the narrative. Without detriment to the generally linear structure, there are, however, many anachronies.

Let us first look at analepses. Not surprisingly - given the historiographical character of the text-, examples of this form of anachrony are much more numerous than prolepses. ${ }^{5}$ A recurrent form and function of narratorial analepsis (both internal and external) is the summary introduction of characters and their family background when they first enter the narrative. These analepses, usually short, are always very selective and highlight only a few particulars that explain a given behaviour or a certain reaction by other actors. Thus, the narrator looks back to Commodus' noble ancestors when he recounts how the young emperor was enthusiastically greeted by the people of Rome at the occasion of his first adventus:

His father's family background included prominent senators, while Faustina, his mother, who became empress, was the daughter of Antoninus Pius, the grand-daughter of Hadrian on her mother's side, and actually traced her line back to Trajan as her great-grandfather. ${ }^{6}$

(I.7.4)

Unlike the extensive analeptic character-sketches in Cassius Dio, these introductory analepses in Herodian usually fit very smoothly into the

${ }^{5}$ Cf. also $S A G \mathcal{N}$ i:8-9.

${ }^{6}$ Cf. e.g. also r.8.3 (on Commodus' sister Lucilla), ıо.I (the robber Maternus), 12.3-4 (Cleander); 2.I.4 (Pertinax), 7.4-5 (Pescennius Niger), 9.2 (Septimius Severus), I5.I (Clodius Albinus); 3.Io.3-4 (Caracalla and Geta), Io.6-7 (Plautianus); 4.I2.I-2 (Macrinus); 7.4.2 (Gordian I). 
narrative and hardly interrupt the main story-line, as they are not only short but also often presented in embedded focalization. Thus, Commodus is first considered by M. Aurelius, Didius Iulianus by the emissaries of the praetorians, Caracalla and Geta by Septimius Severus and so forth. Only the introductions of Maesa and Elagabal $(5 \cdot 3 \cdot \mathrm{I}-7)$ and of Maximinus Thrax (6.8.I-3) exceed the usual length of one or two sentences.

Another type of very short (internal) narratorial analepsis, which does interrupt the progression of the narration, takes the form of summarizing narratorial comments at the end of episodes and particularly after the death of a character (i.e. normally of an emperor or a rival). These comments, which refer to certain qualities of the figure just deceased, never, however, have the extent of a full obituary, and only one of them is longer than one sentence:

Such was the end of Niger, who paid the penalty for sloth and procrastination. Otherwise, the reports say, he was not a bad man, either as emperor or as an ordinary person.

Such was the end of Commodus after thirteen years' rule since his father's death. More nobly born than any emperor before him, he also had more handsome looks and a better physique than any other man in his day; as for more virile accomplishments, he was a better marksman and had a surer hand than anyone else; but all this talent he debased by corrupt living, as we have seen above. ${ }^{7}$

Similar short summaries, looking back to what has just been narrated, can be found at the beginning of each book and also at the end of books 3 and 7; they are all repeating analepses, that is, do not provide additional information. They also resemble each other in style:

In the previous book a description was given of the death of Pertinax, the overthrow of Julianus, Severus' arrival in Rome and the departure of his expedition against Rome.

In this book I have described how Severus ended his life and how his sons succeeded him to the rule. ${ }^{8}$

7 Cf. also the short obituaries of Cleander (I.I3.6), Didius Iulianus (3.4.7), Pescennius Niger (3.7.I), Clodius Albinus (3.7.8), Plautianus (3.12.12), Septimius Severus (3.I5.2-3), Macrinus (5.4.12), Maesa (6.1.4), Severus Alexander (6.8.9), Gordian I (7.9.10), Maximinus Thrax (8.5.9), Maximus and Balbinus (8.8.8). Other closing remarks can be found e.g. in 2.I3.12; 3.3.2, 4.7, 9.12; 4.9.9, II.8; 7.12.9.

8 Cf. also 2.I.I; 4.I.I; 5.I.I; 6.I.I; 7.I.I; 8.I.I. 
Completing narratorial analepses, giving additional information concerning earlier events or times, occur only rarely, when that piece of information seems indispensable for the narratees' understanding, for example:

It had been a practice of Commodus to hold as hostages the children of the governors of provinces as guarantees of their loyal support. Aware of this practice ... Severus ...

Finally, external heterodiegetic narratorial analepses can be found in digressions which explain Roman or foreign customs (such as religious ceremonies) or sketch the prehistory of a particular place, building or region:

This is the site, we are told, where Darius too, having fought his last and greatest battle with Alexander, was defeated and captured, and where the people of the northern regions on that occasion, too, defeated the Easterners.

Tradition says that Dido the Phoenician set up the statue at the time, presumably when she founded the ancient city of Carthage, after cutting up the hide. ${ }^{9}$

Actorial analepsis is frequent, both in its external and internal form. External actorial analepsis concern exempla taken from the more distant past. Thus, the old M. Aurelius, 'guessing that there was little hope for his recovery and realizing that his son was at the age of early adolescence' (I.3.I) recalls 'rulers in the past who had succeeded to power as young men' such as some of Alexander's successors (I.3.3) or 'in the not so distant past', most prominently Nero (I.3.4). The short evocation of these examples causes the old emperor to take action, and, as a result, he asks his friends to take care of his young son. A reference to the Persian history of pre-Roman times supports the Persian king's claim to the Roman territories in Asia (6.2). An example of internal actorial analepsis can be found when Commodus wins over the hearts and minds of his soldiers by giving a sketch of his youth:

My father used to have an equal affection for all of us. At least he used to like to call me 'fellow soldier' rather than 'son', because he thought that the title of son was simply conferred by nature, whereas the former name showed we all shared in his merit. When I was a small boy he used to bring me with him and entrust me to your care. So I am optimistic that I shall win your complete loyalty without difficulty.

$(\mathrm{I} \cdot 5 \cdot 3-4)$

${ }^{9}$ Cf. also 3.2.8 (on the feuds among Greek cities). 
Caracalla argues with exempla taken from Roman history that the killing of his own brother must be seen as a legitimate act of self-defence:

'Self-defence against plots is not only justified but natural. After all, even Romulus ... did not stand for his brother simply making fun of his labours; not to mention Germanicus, the brother of Tiberius, Britannicus, the brother of Nero, or Titus, the brother of Domitian. Marcus himself, while professing his philosophy and humaneness, did not tolerate the arrogance of Lucius, his son-in-law, and got rid of him by a plot. And so I too have defended myself against my enemy who was preparing to kill me and raised his sword against me.'

This passage combines external and internal analepsis. As for the latter, the narratees know from the narrator's version (4.4) that Caracalla's version of the death of his brother is not true, and that, therefore, the exempla adduced in defence are of no value. Interestingly, however, M. Aurelius' otherwise perfect image in the History gets a slight scratch here, as Caracalla mentions - a special case of completing analepsis - a possible flaw in the record of the model ruler.

Caracalla, however, is not the only character who is lying about the past in his speeches. Even the 'good' conspirators who killed the tyrant are heard lying to the people about the fate of Commodus:

Commodus, our emperor has died of apoplexy; but only he himself is to blame for this death. He continually rejected our advice, which was in the interest of his well-being. You know about his way of life; he choked to death from over-eating.

Septimius Severus is shown to be lying to his soldiers about Clodius Albinus' intentions (3.6. $\mathrm{I}-7$ ) and Macrinus is lying about his feelings for Caracalla (4.I4.4-5). Macrinus' letter to the senate (5.1.2-8) offers a remarkable retrospective view on a problem presented as crucial also in the narrator-text (e.g. I.6; 3.10.3-4): the succession to the throne of young 'princes' such as Commodus and Caracalla. Referring to the bad examples of these predecessors Macrinus recommends himself as being of equestrian origin and, therefore, not being corrupted by patrician birth. Unfortunately, however, this does not guarantee a good reign either, as the sequel of the story, which shows Macrinus hesitating to do the right things and indulging in a life of luxury, soon makes clear. Another case of internal repeating analepsis is Fadilla warning her brother Commodus against Cleander; the narratees, instructed by the narrator's own account, know this warning to be correct:

'My lord', she cried, 'here you are blissfully unaware of what is going on, while you are in deadly peril ... The Roman people and most of the 
soldiers have deserted you ... Cleander has organized the soldiers and the people against you ...'

The repetition of the information serves to increase the tension as to how Commodus is going to react.

I now turn to prolepsis. As often in Greek historiography, a proem (strictly speaking no prolepsis, since the story has not started yet) outlines the most significant features and characteristics of the period in question:

A comparative survey of the period of about two hundred years from Augustus ... to the age of Marcus would reveal no such similar succession of reigns, variety of fortunes in both civil and foreign wars, disturbances among the provincial populations, and destruction of cities in both Roman territory and many barbarian countries. There have never been such earthquakes and plagues, or tyrants and emperors with such unexpected careers, which were rarely if ever recorded before. Some of these men ruled for quite a long time, others held only transient power; some hardly reached the title and fleeting honour before they were deposed. In a period of sixty years the Roman empire was shared by more rulers than the years warranted, so producing many strange phenomena. The more mature emperors took greater care to control themselves and their subjects because of their political experience. The very young ones led rather less disciplined lives and brought in many innovations.

This proem does not only advertise the singularity and greatness of the subject matter in order to justify its choice by the narrator and to convince the narratees to keep reading, ${ }^{10}$ it also intends to direct and guide the narratees' focus of interest. It is the quick succession of reigns, bound up with the phenomenon of many adolescents succeeding to the throne, that is announced as the most noticeable feature of the period, deserving the narratees' special attention. Indeed, this not only anticipates the most important results of Herodian's presentation of the period, but also makes it clear from the beginning that the History of the Empire after Marcus is not so much a history of the empire but rather a history of the emperors and, above all, of their winning and losing supreme power. ${ }^{11}$

Narratorial prolepses ('headers') generally herald a new episode, for example:

${ }^{10}$ For this topos of prefaces (not only in historiography) cf. Marincola 1997: 34-43; for Herodian's introduction cf. Hidber 2006: 72-I23.

${ }^{11}$ Cf. the summary in Hidber 2006: 273-278. 
As it turned out Commodus was destined to escape the plot, while Perennius and his sons met a sorry end.

After only one year of a life of ease as emperor it was obviously inevitable that Macrinus would lose the empire, and his life too, whenever chance provided a small, trivial excuse for the soldiers to have their way. ${ }^{12}$

Similar references to future developments can also be found in narratorial comments at the end of a particular episode. In some of these instances of 'proleptic closure' ( $\rightarrow$ Herodotus, $\rightarrow$ Thucydides, $\rightarrow$ Xenophon, $\rightarrow$ Polybius), the tone is more neutral, in others it is quite moralizing:

Indeed, this was a major reason for the later development of these barbarians' skill in close-quarter fighting against the Romans.

Some people forecast from the occasion that the destruction of the temple of Peace was a portent of war. And, as it turned out, subsequent events confirmed this prophesy, as I shall relate.

The fact that there was nobody to take revenge on the perpetrators of this savage murder of an emperor, and nobody to prevent the shameful auction and sale of the empire, was a prime cause in the development of a shameful state of indiscipline that had permanent consequences for the future. $^{13}$

Whereas these internal narratorial prolepses announce developments to which the narrative will return later, other prolepses wrap up a sidestory:

He also detached some troops to go to the siege of Byzantium, which was still holding out under blockade after Niger's generals had taken refuge there. Later the city was starved out and completely destroyed; deprived of its theatres, baths and all its splendour and honour, it was handed over

12 Cf. e.g. also I.I6.I: 'At last it became imperative to check the madness of Commodus and to free the Roman empire from tyranny'; 4.I2.3: 'But it was obviously inevitable that Antoninus' life would come to an end and this was how the event occurred'.

${ }^{13}$ Also cf. e.g. I.8.7: 'This was the first and foremost reason why young Commodus hated the senate ... He never forgot the sound of his assailant's words, and regarded the whole senate as his enemies'; 2.I4.4: 'By this speech he [sc. Septimius Severus] enticed most senators into adopting a favourable attitude because they believed in his promises; but there were some more senior men who knew Severus' character and privately circulated their opinion that he was really a crafty man and a master of the art of contrivances, who was absolutely accomplished at acting out any kind of deception but in the end obtained his own benefit and advantage. This was later, in fact, proved to be true.' 
with the status of a village to be the subject of Perinthus. The same had happened to Antioch, which became subordinate to Laodicea. (3.6.9)

Certainly what happened afterwards confirms this charge, since at a later date after the general restoration of order and a return to security, Severus richly rewarded the rest of his generals. Laetus was the only one he executed, apparently remembering the treachery at Lugdunum. All this, however, was in the future.

A remarkable and frequent form of narratorial prolepsis occurs in statements that something happened 'for the first time'. Such comments underline the paradigmatic quality of the fact or the event in question and create an expectation as to when a similar event would happen again. Thus, Commodus was 'the first' emperor born in the purple (I.5.5). Commodus was the first emperor to be seen fighting in the arena (I.15.4). Septimius Severus was 'the first' to give the soldiers a substantial increase in pay (3.8.5) and he was also 'certainly the first to undermine the tough austerity of their [sc. the soldiers'] diet, their obedience in face of hardship and their disciplined respect for commanders, by teaching the men to be greedy for riches and seducing them into a life of luxury' (3.8.5). Maximinus Thrax is 'the first' to rise from so humble origins to the throne (7.I.I), and so on. ${ }^{14}$

Like Thucydides $(\rightarrow)$, Herodian does not make use of external prolepses, but there are some examples of the narrator referring to his own time: thus, on a few occasions Herodian refers to his researching or writing activity (as in I.II.I: 'Through my research I have discovered why the Romans have an especial veneration for this goddess ...'); $;^{15}$ more often, however, the narrator's (and the primary narratees') own time is referred to in a more general way in digressions:

Even when one sees the ruins of the wall as they are today, one has to admire the skill of the first builders and the power of those who later destroyed it. ${ }^{16}$

However, such references are much less frequent than in Appian or Cassius Dio.

An intriguing instance of foreshadowing can be found in the very last sentence of the History:

${ }^{14}$ Cf. also I.I4.4, I5.4; 2.I4.I; 3.8.5, 7; 4.6.4, 8.8; 6.5.Io; and Sidebottom I998: 2797.

${ }^{15}$ Cf. $S A G \mathcal{N}$ i:205.

${ }_{16}$ Cf. e.g. also 3.4.3. 
Gordian, aged about thirteen, was saluted as emperor and took over the Roman empire.

This is hardly an auspicious ending, given that the narratees by now are well aware of the fatal problems that are in store for adolescent rulers. In fact, a narrative that ends with the accession to the throne by the youngest emperor ever, brought to power by the praetorians, is the sombre counter-piece to the evocation of the glorious days of M. Aurelius' reign at its beginning. As such it marks the culmination of the most problematic features of the whole period. In the end the future does not look bright. But it is left to the narratees to draw such conclusions. ${ }^{17}$

Actorial prolepsis in the History is most frequently bound up with the motifs of sorrow and fear. ${ }^{18}$ The beginning of the main story features the first and most significant instance of such actorial prolepsis, as the sorrows of the old and ill emperor M. Aurelius, thinking of his young son Commodus, are presented in embedded focalization:

Guessing there was little hope for his recovery and realizing that his son was at the age of adolescence, he was afraid that the young man would grow up in control of absolute, unchecked power without parental authority ... He also felt considerable anxiety about the Germans on the frontier whom he had not yet completely subdued ... there were some who had fallen back for the time being and retreated in fear of the presence of an emperor like Marcus, but who he suspected would despise Commodus for his youth and attack him. ${ }^{19}$

Whereas the first part of M. Aurelius' fear later comes true and thus proves to be justified, the anxiety about the Germans turns out to have been unwarranted. Such an actorial prolepsis is clearly meant to taint the future events and to direct the narratees' attention to critical points in the narrative. M. Aurelius' sorrows and fears about his young successor form a model for similar proleptic worries by other parents: Septimius Severus is concerned about the corrupted habits and the violent quarrel between his sons (3.10.3-4; 3.I3, I4.2), which later prove

${ }^{17}$ In many respects this end is reminiscent of the closing paragraphs of Sallustius' Bellum Iugurthinum; cf. Hidber 2006: I96-20I.

${ }^{18}$ Cf. Opelt 1998 for the motifs of terror and fear in Herodian.

19 This prolepsis is later resumed in a speech that the dying emperor delivers to his friends (I.4.3-4): 'Here is my son ... who has just reached the age of adolescence ... There is a danger that he will be carried away and dashed against the rocks of evil habits because he has an imperfect experience of what to do ... Take care of him and give him sound advice.' 
to be fatal not only for Geta, but also for Septimius Severus himself. Maesa is worried about the reactions that the oriental habit of her grandson Elagabal might provoke in Rome (5.5.5) and later realizes that his dissolute life and behaviour would no longer be tolerated by the soldiers (5.7.I).

Actorial prolepses do not only take the form of sorrows of emperors and their relatives, but also of feelings of fear uttered by others such as the people or the soldiers. Thus, the people of Rome are afraid that the praetorian cohorts would not be happy with the emperor Pertinax. This throws distrust on the reign of the moderate emperor even before he accedes to the throne:

Most of the population rushed to the praetorian camp because they were very much afraid that the soldiers would be rather reluctant to acknowledge Pertinax' rule. They were expected to be totally against accepting a rule of moderation since they had grown used to a tyrant as their master and were experts in pillage and violence.

$\left(2.2 \cdot 4^{-5}\right)$

An exception to the rule of pessimism is the energetic Septimius Severus, who is encouraged by dreams and oracles to aspire to the highest power $(2 \cdot 9 \cdot 3-9)$.

Herodian's History focusses on the emperor. Only those regions of the empire come into view where the emperor himself or his rivals happen to be. That is why the main story can proceed in a linear way, always closely following the deeds and fate of the ruler. However, the narrative becomes more complex in periods with more than one emperor or with rivals challenging the ruler. Extended passages with such a constellation occur in books 2 and 3 (giving an account of the events of the turbulent year i93, featuring four emperors) and in book 8 (recording the hectic first months of the year 238, featuring even six rulers). In these passages the narrator switches to and fro between the different story-lines, often by following the track of individuals, letters or news, which move from one place to the other. Thus, in 2.7.I the narrator finds himself in Rome, where the people, not content with Didius Iulianus, call for Pescennius Niger. Following the spread of this 'news', he switches to Antioch, where Niger happens to be as governor of Syria (2.7.6). The narrator follows first the events in Syria, before he switches again, with this news, to Pannonia, where Septimius Severus decides to remove Didius Iulianus as well as Pescennius Niger and to seize power himself (2.9.I-3). The narrative now follows the events in Pannonia and Septimius Severus' march on Rome. It is only with the news of Septimius Severus' arrival in Italy that Didius Iulianus gets into the picture again; 
and now his fate is followed until his death (2.II.7-I2.7). The news of Iulianus' death is brought to Septimius Severus, whose actions are recounted in the following stretch of narrative (2.I3-I5). The narrator does not return to Syria until the beginning of book 3, where Pescennius Niger receives 'the totally unexpected news that Severus had taken Rome'. The following war between the two rivals, then, is recounted along the same story-line. This narrative technique highlights the succession of action and reaction and, thus, confronts different personalities and characters and qualities such as energy and hesitancy. ${ }^{20}$

\section{Frequency}

The singulative mode is absolutely predominant in the History. However, there are some instances of repetition and iteration. Digressions such as the long excursus on the deification of Septimius Severus (4.2) or the depiction of a procession by Elagabal in Rome (5.6.6-Io) might be seen as instances of iterative narration: an event that took place in similar form at several times in the period is recounted (or even mentioned) only once in detail. The iterative mode can also be found in the main narrative; thus, the two campaigns that Septimius Severus launched against the desert fort of Hatra appear as one and the same attack (3.9.I-8) - obviously an instance of economic narration. ${ }^{21}$

We have already seen that there are also some examples of the reverse case: one particular event is recounted more than once. Such repeating narration can be found in speeches which give an (often different) account of what had already been presented in the narratortext.

\section{The rhythm of history and the dynamics of power}

Historiography is inevitably based on a selection of facts, events and sources. Herodian's History, however, features a degree of selection that has disturbed many modern critics and has led some to label the text as a novel. Not only is the narrative focused almost exclusively on the emperor - as the proem makes clear - but even the different

\footnotetext{
20 The switches of focus in book 8 are analyzed by Sidebottom I998: 28I5.

21 Cf. Whittaker i969-I970: I xlii with more examples.
} 
phases of the individual reigns are considered with varying intensity. The narrator himself points out the strongly selective character of his account in an important comment at the end of book 2, where a sharp line is drawn between the History and circumstantial panegyrical presentations of Septimius Severus' life:

In what follows, I shall narrate only the most important and conclusive of Severus' actions separately. I shall not exaggerate to flatter Severus, as writers at his time did; nor shall I omit anything which merits attention and record.

$(2.15 .7)$

As a consequence, the narrative rhythm differs substantially between various parts of the History. Thus, book I is dedicated to thirteen years, book 2 to six months, book 3 to seventeen years, book 4 to seven years, book 5 to five years, book 6 to thirteen years, book 7 to three years, and book 8 to approximately three months. Even taking into consideration the different lengths of the single books, this brief survey makes clear that the rhythm undergoes dramatic changes. The slowest pace is always found in the passages that recount changes - the death of an emperor and the accession to the throne of his successor. These passages, then, are presented in the form of 'scenes'. The episode of the conspiracy against Commodus which leads to the accession of Pertinax comprises only 24 hours of fabula-time, but fills no fewer than five long chapters (I.I6-2.3). In fact, this is the most elaborate und the slowest stretch of narrative in the History.

Given the focus on changes in rulership, it is not surprising that the periods featuring more than one ruler are narrated in a particularly slow pace, which explains the extraordinary figures in books 2 and 8. Thus, Septimius Severus gaining supreme power by eliminating three rivals in turn covers two thirds of the narrative dedicated to this emperor, although this particular phase did not even last a fourth of his reign's duration. Other 'scenes' show emperors being challenged by conspiracies, campaigning, ${ }^{22}$ or performing (e.g. Commodus as marksman and gladiator in the arena; Caracalla's masqueradings in Alexandria and other parts of the world; or Elagabal as priest in the streets of Rome). ${ }^{23}$ Speeches, dialogues or letters embedded in such scenes offer stretches of particularly slow narration. ${ }^{24}$ They are regularly accom-

${ }^{22}$ Cf. e.g. 3.9, I4 $; 4$.IO.I-I4.I5; 6.2.I-6.6; 7.2.

${ }^{23}$ I.I3.7-I5.9; $4.7-9 ; 5.6$.

${ }^{24}$ I.4.2-6, 5.2-8, 6.4-6, 9.4, I3.2-3; 2.2.6-8, 3.5-I0, 5.6-8, го.2-9, I3.5-9; 3.6.I-7, II.5-7; $4.5 .2-7$, I4.4-8; 5.I.2-8; $6.3 \cdot 3^{-7} ; 7 \cdot 7 \cdot 5 \cdot 5^{-6}, 8.4^{-8} ; 8.3 .5^{-6}, 7 \cdot 4^{-6 .}$. 
panied by pauses, that is, descriptions, digressions or short narratorial comments. ${ }^{25}$ Such pauses often provide the local and temporal setting of the action narrated in the scene.

Scenes are normally linked by short summaries which often cover several years of fabula-time. Administrative and juridical actions, everything related to 'normal' home affairs, and, in short, all the quiet years of each reign are dealt with in such 'summaries'. Thus, hardly anything is said about the administrative actions taken by Macrinus during the year of his reign, but both his accession and his sad ending are depicted in scenes. And the home affairs dealt with by Septimius Severus between the Parthian and the Britannic wars are mentioned in a single colon (3.10.2). The most striking example of a summary can be found in the account of Severus Alexander's reign: whereas the last three years with the wars against the Persians and the Germans almost fill an entire book, the first ten years of peaceful rule are hurried through in a few sentences (6.I.6-7). In some instances, the temporal space between scenes is not even summarily dealt with but either passed over with a narratorial remark such as 'a short time later' or omitted altogether (ellipsis). The devices of summarizing or even elliptical transitions create stark contrasts or highlight particular developments. Thus, Commodus' reign looks like a single chain of conspiracies finally leading to the embittered emperor's retirement into the arena. ${ }^{26}$ Or, the shameful scene of Severus Alexander trying to buy peace from the Germans is directly followed by the scene where the energetic Maximinus Thrax is acclaimed emperor by his young soldiers.

\section{Conclusion}

The handling of time in Herodian's History is quite remarkable in many respects. This holds true already for the peculiar choice of the scope of time and for resuming the interrupted tradition of contemporary history. As for the chronological order, the annalistic scheme is given up completely (contrast, for example, Cassius Dio). Not a single date is given in absolute terms. History is structured by the succession of reigns, whose durations are always noted, which provides a frame of

${ }^{25}$ For the narratorial comments cf. $S A G \mathcal{N}$ I:20I-2IO; digressions in e.g. I.Io.5, II.I-5, I6.I-3; 2.II.4-5, 7-9; 3.I.5-7; 4.2.I-II; 6.2.6-7, 5.3-4, 7.6-7; 8.2.I-6.

26 Cf. M. Zimmermann i999: 62-I24. 
relative chronology. References to eponymous magistrates seem to have become obsolete since everything is determined by the emperors. On the whole, the picture is created of a period of troubled times, dominated by the changing dynamics of imperial power. The restlessness of the period is depicted, as it were, in a narrative that hurries through peace and dwells on conspiracies, wars and emperors winning and (often quickly) losing the precarious position at the head of the empire. 
Irene J.F. de Jong and René Nünlist - 978-90-47-42293-8 Downloaded from Brill.come4/26/2023 09:46:52AM via free access 


\title{
GHAPTER THIRTEEN
}

\section{JOSEPHUS}

\author{
J.W. van Henten \& L. Huitink
}

\section{Awareness of time}

Two of the four works of Flavius Josephus (37/38-ca. Ioo CE), Joseph Ben-Matityahu for his fellow Judeans, are elaborate histories. The seven books of The Jewish War (De bello Fudaico) describe the war between Jews and Romans in 66-70 CE, with its devastating consequences for the Jerusalem Temple. The preamble to that war is also part of the story, which starts at 17//170 BCE. The Fewish Antiquities (Antiquitates Fudaicae) offer a comprehensive history of the Jews from the creation of the world until $66 \mathrm{CE}$ in twenty books. ${ }^{1}$

The introduction to The Fewish War strongly emphasises the importance of an accurate account of the events in line with a Thucydidean preference for akribeia (Bf I.3, 6, 9, 25-26; cf. also 7.454-455 and $A \mathcal{F}$ $3.230 ; 8.56$; 9.208), which was taken up by other authors from the imperial period as well ( $\rightarrow$ Philostratus). One of the ways in which Josephus obtains this akribeia is by choosing a recent subject instead of from the more remote past, just like, as he himself emphasises, the 'ancient historians' do (Bf I.I3). This remark can be taken as a veiled reference to Thucydides, who had rebuked Herodotus for choosing a remote subject. $^{2}$

The Ferwish War abounds in time-markers, which is another way of effecting the akribeia promised by the historian. Josephus is very precise with his time-markers in comparison to several Greek historiographers $(\rightarrow$ Herodotus, $\rightarrow$ Xenophon). Throughout The Jewish War we find

${ }^{1}$ Bilde 1988 offers a concise introduction to Josephus and his works.

${ }^{2}$ Cf. Th. I.20-22 with S. Hornblower I99I-I996: ad 20.3, 21.I, 22.4, and Thucydides $(\rightarrow)$ on the origins of contemporary history. 
references to the reigns of Roman emperors. ${ }^{3}$ Events from the prelude to the war against Rome ( $B \mathcal{F}$ I. $3^{\mathrm{I}^{-2.28}}$ ) are mainly dated by references to the Hasmonaean rulers, around whom the episodes are structured. ${ }^{4}$ After Pompey's conquest (completed in I.I52) references to Roman persons, especially the procurators of Judaea, take over the rulers' role. ${ }^{5}$ After the war has started (2.284) and the narrative gets more detailed and slows down, Josephus frequently dates events also by the months of the Macedonian calendar, usually providing the exact day of the month. ${ }^{6}$ References to such dates are particularly dense in book 6 , before the climax of the narrative - the dramatic fall of the Temple. It is hard to determine whether this is because Josephus' sources were more precise about these events, or because the precise dates serve rhetorical ends, highlighting the importance of events: does providing an exact date lend credibility to otherwise unlikely stories? Interestingly, Josephus often provides more than one indication of time: in such cases rhetorical effect was probably an important narrative goal, because such dates are usually inserted at dramatic moments in the story. A case in point is the beginning of the war against the Romans (66 CE), where the years of Nero's reign and of the Jewish king Agrippa II are mentioned together: 'War broke out in the twelfth year of Nero's reign and the seventeenth of Agrippa's, in the month of Artemisios' (BF 2.284). ${ }^{7}$

In The fewish Antiquities Josephus constructs a chronological framework that comprises the history of the world in 5,000 years, with the creation of humankind as its beginning. ${ }^{8}$ Important events of Jewish history, like the Babylonian Captivity, are linked to this chronological system through calculations mostly based on biblical data. ${ }^{9}$ As a con-

${ }^{3}$ Deaths of Roman emperors in The Jewish War: 2.168, I80, 204, 248; 4.49I, 499, 548,652 .

${ }^{4}$ BJ г.38, 48, 50, 54, 70, 85, го7, г20.

${ }^{5}$ Cf. e.g. BJ I.I83 (Julius Caesar master of Rome), 218 (murder of Caesar); Roman procurators: $B J$ 2.117, I69, 220, 223, 247, 271, 272, 277.

${ }^{6}$ E.g. $B f$ 2.285, 315; 5.99, 302; 7.40I.

7 Another example concerns the end of the siege of Jerusalem, which takes place 'in the second year of Vespasian's reign, on the eighth of Gorpiaios' (Bf 6.435). Cf. also Bf 2.555; 3.339; and 4.577. Translations of passages from The Fewish War are taken from G.A. Williamson [1959] I98I, with slight adaptations; those from The Jewish Antiquities are our own.

${ }^{8}$ Af г.13; Ap. I.I.

${ }^{9}$ Rather the Septuagint than the Hebrew Bible. Cf. Af I.80-88, I48-I50; 2.318; 7.68; 8.6I-62; 9.277-282; I0.I $47^{-1} 4^{8}$. 
sequence, the work is very rich in references to rulers and dynasties, indigenous as well as foreign (kings of Israel and Judah, Hasmonaean and Herodian rulers, emperors, procurators, etc.). ${ }^{10}$ We also find more double and triple dates in The Fewish Antiquities than in The Fewish War, which often combine references to different dating systems. References to Olympiads are, for example, combined with regnal years of a Jewish ruler, or with other non-Jewish ways of dating, such as references to Seleucid rulers or Roman consuls. One such combination of several systems is found in the dating of the Seleucid king Antiochus IV's drastic desecration of the Jerusalem Temple on Kislev 25, i67 BCE: 'Two years later, in the hundred and forty-fifth year, on the twenty-fifth day of the month which is called by us Chasleu [Kislev], and by the Macedonians Apellaios, in the hundred and fifty-third Olympiad, it happened that the king went up to Jerusalem with a large force ...' (Af 12.248). This date combines the Seleucid era (the I45th year is October I68-October I67) with the dating by Olympiads (the I53rd Olympiad is July I68-July 164). ${ }^{11}$ The passage also shows another trend in The Jewish Antiquities: the months' Jewish names are given together with non-Jewish names, be they Egyptian, Athenian or Macedonian. ${ }^{12}$ Incidentally, such complex dating devices provide a time frame for Jewish and non-Jewish narratees alike.

\section{Order}

In general, Josephus presents the events of his story chronologically. The narrative flow is chronological even where we know from his sources that the chronological framework is problematic. Josephus' presentation of Jewish history after the Babylonian Exile is a case in point. The historical settings of the stories about the post-exilic lead-

${ }^{10}$ Foreign eras: Babylonian regnal years: $A \mathcal{f}$ 10.87, I46, I81, 219, 231, 248; Persian regnal years: $A f$ гі.г, 33, 99, го7, І35, г68, г79, г86, 202; Ptolemaic era: $A f$ г2.ı; I3.79; Seleucid era: $A f \mathfrak{f}$ 12.246, 248, 264, 285, 297, 361, 363; i3.35, 86. Regnal years of Hasmonaean rulers: Af i3.213; 20.242, 244, 245; Herodian rulers: Af I5.121, 299; ı6.ı36; I8.ı66; cf. I7.347. Roman dates: $A 7$ I3.260; I8.I, 26 (census of Quirinius); 20.I , IO4, I38, I48, I58, 257, 267.

${ }_{11}$ Other multiple datings: $A f$ I2.321; I4.4, 66, 389, 487; I6.I36 (cf. Bf I.415, with only one date for the same event).

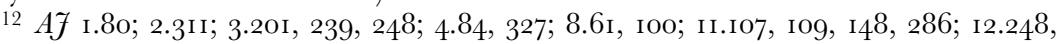
319, 32I, 4I2. See for these synchronisations between the Macedonian and 'Eastern' calendars Hannah 2005: I35-136. 
ers Ezra, Nehemiah and Queen Esther is a notoriously difficult problem, since the biblical references to foreign rulers are unclear or even contradictory. Nonetheless, Josephus' narrative presents these stories in a simple and coherent chronological order (Af II.I20-296). He sets the stories about Ezra and Nehemiah in the reign of the Persian king Xerxes I (486-465 BCE; Af II.I20-I2I, I59, I83). After concluding the Nehemiah story, we find a brief reference to Xerxes' death, and then Josephus simply continues with the Esther story as set in the reign of Xerxes' son Artaxerxes (Af ir.184-296). Thus he maintains a chronological order in this section by letting the deaths of Nehemiah and Xerxes coincide, more or less. Meanwhile he bypasses lacunae in the evidence and ignores discrepancies among his sources, as well as other historiographical problems.

A close reading of Josephus' narrative, however, reveals changes in the sequence of events. It appears that Josephus often uses analepses, prolepses and parallel stories. In the following sections we will deal with each of these devices in turn. We will also discuss several possible reasons that may have prompted Josephus to insert anachronies in his narratives.

\section{Prolepsis}

Narratorial and actorial prolepses are a common narrative device of Josephus. In this section, we will first treat narratorial prolepses and then focus on actorial ones.

Josephus maintains an episodic structure in large parts of his narrative, carefully rounding off one episode before embarking on another. Sometimes such episodes create anachronies, because he tends to supply information relevant to a certain episode all at once, sacrificing proper chronology to thematic unity $(\rightarrow$ Hesiod). For instance, there is the story about Herod the Tetrarch, whose tetrarchy is taken away from him by the emperor Caligula. Lest the narratees should think this is an unwise decision taken by a notoriously insane emperor, the episode closes with the remark that at that time Caligula was still a good ruler, and only became mad 'as he went on (to rule)' (proiōn; Af I8.256). This premature reference to Caligula's future insanity is picked up later in more detail, at the proper place (Af I9.4). Similarly, the narrator highlights the fact that Caligula's letter to Petronius, the governor of Syria, with the order to execute the latter's own death-sentence, had not reached Petronius before Caligula died (Af 18.305-308). This refer- 
ence to Caligula's death is supplied with the narrator's cross-reference that he will disclose the assassination details when proper ( $A \mathcal{f}$ I8.307). A detailed account of the plot against Caligula is indeed offered later on (Af I9.105-II4).

Other narratorial prolepses draw attention to particularly important motifs of the narrative. Internal rebellion is a Leitmotiv in Josephus' narratives of both The Jewish War and The Jewish Antiquities. The first major rebellion, that of Korah against Moses, is first mentioned in a prolepsis (Af 4.II-I3), in which the dreadful consequences together with Moses' tough, saving leadership are recounted in general but strongly rhetorical terms. This passage provides a universal blueprint, as it were, of the internal rebellion theme. The particularities of Korah's rebellion and Moses' counteractions are related only further on $(A \mathcal{f}$ 4.I4-66). Another indication that the narrator puts emphasis on the rebellion against Moses is that this paraphrase of the biblical version $(\mathcal{N u}$. I6) is very long, compared to Josephus' recreation of other biblical stories.

A special case in the narratorial announcements of future events, as linked with strong thematic overtones, concerns the fall of Jerusalem and especially the Temple in book 6 of The Jewish War, which forms the work's climax. Most events in The Jewish War lead up to this fall, and book 7 essentially functions as an epilogue. In The Jewish War's Preface Josephus includes the destruction of the Temple in his summary of the entire work (I.28) by means of an explicit announcement. When he starts his actual narrative with the desecration of the Temple by Antiochus IV Epiphanes (BF I.31-33), he puts the Temple right in the centre of attention. By placing this brief episode at the beginning of the narrative, Josephus is demonstrating that the Temple is not invulnerable to attack, thereby signalling its destruction as a theme. This theme is resumed several times in the prelude. ${ }^{13}$ As soon as the narrative focuses on Jerusalem in book 4, the narrator announces the fall of Jerusalem and the Temple more than once by means of explicit prolepses, which often mention internal strife as the cause that 'ultimately wrecked the city' (BJ 4.I37). ${ }^{14}$ One particularly effective way of indicating that the city will fall is the excursus on Jerusalem in The Jewish War $5.136-247 .{ }^{15}$

\footnotetext{
13 Bf I.148, I79.

${ }^{14}$ Cf. $B \tilde{f} 4 \cdot 3$ I 8 .

15 Similar descriptive excursuses: Bf 2.188-I9I; 3.35-58, 70-109, I58-16o, 506-521; $4 \cdot 3^{-8}, 45^{\mathrm{I}-475}, 47^{6-485}, 607-6 \mathrm{I} 5$.
} 
Such excursuses are normally presented in simultaneous narration; the present tense indicates that the places still exist in the narrator's own day. It is therefore significant that this particular excursus is the only one in The Jewish War that is recounted in subsequent narration, thus clearly indicating that Jerusalem no longer existed at the time of writing. ${ }^{16}$ The narrator's anticipation of the Temple's destruction also contrasts with Titus' continuous efforts to save it. ${ }^{17}$ After Titus' decision to do no more than surround the Temple in order to press the Jews to surrender themselves, Josephus comments in a final, elaborate prolepsis just before the fall: 'That building had, however, been condemned to the flames by God long ago: by the turning of time's wheel the fated day had now come, the tenth of Lous, the day which centuries before it had seen it burnt by the king of Babylon. But it was the Jews themselves who started and caused this conflagration' (Bf 6.250-25I).

Josephus also uses prolepses to pass judgment on characters. For example, the narrative about Samson $\left(A \mathcal{f} 5.285^{-3} \mathrm{I} 7\right)$ notes at a certain point that this biblical hero became unfaithful to his mission as a prophet: 'He was transgressing the practices of his ancestors and debasing the way of life of his fellow Israelites with his imitation of foreign customs. This proved to be the beginning of his ruin' (arkhe autöi kakou, Af 5.306; an obvious reference to Iliad ir.604 and Herodotus 5.97.3). The proleptic statement at the end of this passage makes the reader curious about the nature of Samson's transgression. Josephus reveals Samson's unfaithfulness to the ancestral customs immediately afterwards: the problem was his lust for the Philistine hetaera Delilah. Samson's relationship with Delilah was obviously a flagrant violation of the Jewish customs concerning sexual contacts with foreign women, and the continuation of the narrative describes in detail how Delilah accomplishes Samson's downfall (Af 5.306-313).

A positive assessment of a character, combined with explicit prolepsis, concerns the Hasmonaean ruler John Hyrcanus (I35/I34-IO4 BCE). Josephus concludes the report about Hyrcanus' rule in The fewish War (Bf I.54-69) with an appraisal of John that highlights, among other things, his prophetic gift. The prolepsis at the beginning of this passage, 'For the rest of his life John enjoyed prosperity ...', matches the narra-

${ }^{16}$ Contrast $B \mathcal{7} 4 \cdot 45^{2-} 475$ on Jericho and $4 \cdot 53^{-}-533$ on Hebron.

${ }^{17}$ Cf. Bf 6.236-243, 249, 25I, 254-266; in 6.228 Titus deliberates destroying the Temple for the first and only time. 
tor's overall highly positive assessment of this leader (Bf г.68-69). The time-marker 'for the rest of his life' flags the prolepsis.

Finally, narratorial prolepsis frequently highlights God's intervention. One example concerns Herod the Great's disastrous relationship with his sons, which ends in the execution of three of them. A prolepsis indicates the involvement of the Deity called Tyche (Fortune) here, at the moment the relationship deteriorates even further: 'The affairs in his family were greatly troubled and the situation with his sons was much worse in this period. For, on the whole, in the earlier period, it had been quite easy to perceive how the greatest and most troublesome events that happen to humans were threatening the kingdom through Fortune, but they steadily increased and then got even a greater impact for the following reason' (Af i6.300).

Two typically Josephan forms of actorial prolepsis, to which we now turn, also bear witness to Josephus as a firm believer in the God of Israel as the orchestrator of world history, namely prophecies and dreams. In general, according to Josephus, characters associated with prophecy, especially the prophets, foresee future events accurately. A nice example of a prophecy is found in the episode where the young Herod is put to trial before the Synhedrion because he has executed a group of brigands. Samaias, one of the court members, prophecies that Herod will kill the king and all members of the Synhedrion except himself ( $A \mathcal{F}$ I4.I74; quoted in direct speech). In this case, the actorial prolepsis is confirmed by an explicit narratorial prolepsis: 'and he was not mistaken in anything he had said' (Af I4.I75). ${ }^{18}$

Apart from the prophets, one of the most reliable characters of all is Josephus himself. Although he does not explicitly call himself a prophet, sometimes when he appears as a character in his own works, he does refer to his own prophetic qualities. At certain points he emphasises his prophetic skills, by means of which he establishes authority for his character in the narrative. Thus, before he correctly predicts that Vespasian will become emperor (BJ 3.399-402), as foretold to him in a dream, he insists that 'in the matter of interpreting dreams he was capable of divining the meaning of equivocal utterances of the Deity' (3.352). Once Vespasian has become emperor, Josephus emphasises once more

18 The outcome of Samaias' prophecy is less clear than Josephus suggests, cf. Af I5.2-4 and I5.I $64^{-1}$ - 79. For other prophecies see $A f$ 7.92-93; 8.319, 322, 36I; 9.20-26,

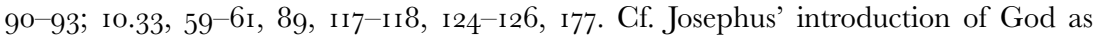
determining actor in the Esther story, which is highlighted by actorial and narratorial prolepses (Af i $1.247^{-259)}$. 
that he 'was now believed capable of foretelling what was still to come' (4.629). Josephus even claims that he made correct predictions about future events as a general in the war. Thus, when he is in charge of the Galilee defence, he immediately fortifies its cities, because he already knows that the Romans will launch their first assault there (Bf 2.572573). The narratees can only guess how he came to know this, but, of course, he is correct. At a later point, he foresees the future defeat of the Jews and recognises 'that their one safety lay in a change of heart' (BJ 3.136). Each time Josephus the character makes a prediction, Josephus the narrator corroborates it. Vespasian, who is portrayed as the paragon prudent ruler, is given the same credit. ${ }^{19}$

Dream reports, transmitted (partly) in indirect or direct speech by either the person to whom the dream had come or the person who retells and explains it through divine inspiration, are less common than prophecies but still typical for Josephus..$^{20}$ Joseph's dreams, also reported in the Jewish Bible, are a case in point. The Jewish Antiquities 2.III9 concerns Joseph's first and second dreams, anticipating his future position in Egypt and the migration of his brothers and father to Egypt during a severe famine. The first dream, about Joseph's own wheat-sheaf standing motionless while his brothers' sheaves are running up and bowing to it, is briefly paraphrased in indirect speech (cf. Ge. 37.5-6; direct speech). The brothers fully understand the dream's message, but do not reveal that to Joseph. Instead, they pray that the dream will not come true and treat Joseph with even more hatred ( $A \mathcal{F}$ 2.II-I2). The continuation of the narrative shows that God did not answer their prayer, and sent Joseph another dream (2.13). Josephus describes how Joseph reported his second dream to his father in his brothers' presence. The sun, moon and stars, symbolizing Joseph's parents and brothers, appeared to come down to the earth and kneel in front of him. Jacob is delighted with this dream because he grasps the dream's prediction (2.I4-I5). Joseph's brothers also understand the dream's message; they get very angry and are eager to kill him (2.17I9), which rouses the narratees' curiosity. The story then unfolds to show, step by step, that the dream comes true $(2.20-193){ }^{21}$

In short, prolepsis in its various forms is a most common narratorial device in Josephus. It is used to strengthen the cohesion of episodi-

\footnotetext{
${ }^{19}$ Cf. for Josephus Bf 2.569, 570, 573; 3.I36; for Vespasian: 4.89, 44I.

${ }^{20}$ R. Gray I993; Gnuse I996.

${ }^{21}$ Cf. also $A 7 \mathcal{7}$ 8.125-129.
} 
cally told narrative parts, and frequently helps to articulate important recurrent themes; and actorial prolepses highlight God's intervention through prophetic predictions and dreams.

\section{Analepsis}

Analepsis, both narratorial and actorial, is just as common in Josephus' works as prolepsis. Because The Jewish Antiquities cover a period from the creation of the world until $66 \mathrm{CE}$, there can hardly be external analepsis in this work $(\rightarrow$ Hesiod). The time span of The Jewish War is much shorter, starting with Antiochus IV Epiphanes' interference in Jerusalem in $169-167 \mathrm{BCE}$, as the necessary background information for understanding the events of the actual war that started in $66 \mathrm{CE}$. In this work, then, there is room for external analepses, but their use is rather limited. External analepses are mostly heterodiegetic in nature and occur in two contexts. First, they are found in excursuses in which the history of a city, country or building is briefly explained. Thus, the extensive description of Jerusalem (BJ 5.136-247) contains external analepses that concern David or Solomon (5.137, I43, I85). Incidentally, there are also internal ones to be found in this passage, mostly about the Hasmonaean dynasty (5.I39, I48-I55, I6I-I62, I83, 238; cf. also 205, 227, 246). Together, the external and internal analepses focus on the periods when the Temple flourished. They serve as a poignant counterpoint to the deplorable state of Jerusalem and the Temple at that point in the main story. The Babylonian destruction of the Temple is so far conspicuously absent from the narrative; it is narrated in The Jewish War 6.435-442 after the conflagration of the Temple, when its entire history is reviewed by Josephus, again in a mixture of external and internal analepses. ${ }^{22}$ Second, external analepses occur in speeches. In The Jewish War 2.358-36r, for instance, Titus reinforces his argument that the Jews would do better to surrender immediately by referring to the exempla of Athens, Sparta and Macedon: three states that withstood the Persians but were now the servants of Rome. ${ }^{23}$

All other narratorial and actorial analepses are internal. We will first focus on the narratorial ones, most of which are very short. The most common are completing analepses that provide the narratees with essential background information on certain characters or events, as

${ }^{22}$ Cf. Bf 2.487-489; 4.459-464, 530-533; 6.250; 7.422-432.

${ }^{23}$ Cf. BJ 5.379-394. 
and when the information is needed. Thus, when after a previous reference in The Jewish War 2.575 Josephus' personal enemy John of Gischala enters the stage as actor, his previous career is outlined in an analepsis (BJ 2.585-594). This analepsis also serves as a character-sketch, in which the narrator puts John in a bad light. Most analepses that inform the narratees about certain characters' previous actions are not that elaborate but merely consist of a single sentence or clause, frequently a relative or gar-clause. ${ }^{24}$ Such analepses are often completing, but may also be repeating, in which case they serve to refresh the narratees' memory about a certain character when he or she is about to play an important role in the narrative once more. The frequent addition of a formula like 'as I said (before)' marks such analepses explicitly as repeating. ${ }^{25}$

Short analepses also appear in a different context, namely when important characters 'leave the stage', that is, when they die $(\rightarrow$ Arrian, $\rightarrow$ Herodian). In these cases their previous actions are recalled in repeating analepses ('obituaries'), usually with some qualifying comments by the narrator. In connection with the death of Niger the Peraean (Bf 4.359) the narrator states that this man had been 'the bravest' in the war with the Romans. He reminds the narratees of the valour he had shown in conflicts narrated as far back as The Jewish War 2.520 and 3.I I-28.26 The death of rulers is often an occasion to look back at their government. ${ }^{27} \mathrm{~A}$ good example of such an analepsis concerns Nebuchadnezzar in The Jewish Antiquities 10.219-228. It stands out because it is compiled from references to works of other historians. One of these, Berossus, is even quoted literally, because Josephus' own narrative only retells the Biblical account, as he himself has just emphasised (I0.218).

Occasionally, brief completing narratorial analepses contain information that is highly relevant for the narratee, despite their apparent inconspicuousness. In The Fewish War 6.28 the Romans finally succeed in demolishing the wall of the fortress Antonia. The initial sense of triumph they experience is immediately annulled by the fact that behind Antonia's wall there appears a second wall 'which John and his party had built just within' (BF 6.3I). As this is the first time the narratees

${ }^{24}$ Short narratorial analepses: e.g. Bf 2.183, 224, 249; Af 2.70; 7.34, 67; 17.34.

${ }^{25}$ Explicit analepses: e.g. Bf 4.208; 5.6r; $A \mathcal{F}$ I3.320; 20. IOI, IO2.

${ }^{26}$ Cf. Bf 4.319-325.

27 Sometimes a more extensive retrospect is offered: $A 7$ 4.327-33I (Moses); 7.389-39I (David); 8.21 (Salomon); I7.I9I-I92 (Herod the Great; cf. Bf I.665). 
are informed about John's secret building activities, the appearance of the wall in the narrative is just as much a surprise for the narratees as it must have been for the Romans. It becomes clear that the wall will considerably prolong the battle for Jerusalem (cf. Bf 2.436).

Finally, we find narratorial analepses that seem to be motivated by the narrator's aim to present a smoothly running narrative in which thematically linked stories are told in close proximity. This also explains the insertion of certain prolepses, as discussed above. The introduction of book 2 of The Jewish Antiquities, for example, is followed by a paraphrase of the famous story about Esau selling his birthright to Jacob for some lentil soup (Af 2.2-3; Ge. 25.29-34). From a chronological perspective, the episode should have been part of the Isaac and Rebecca section in book I. The narrator introduces this analepsis with a reference to Esau's surname: 'For he obtained his surname, which was Adom [which means 'red' in Hebrew], for the following reason' ( $A \mathcal{F}$ I.I). The transposition of the brief passage about the red lentil soup to the beginning of book 2 of The Jewish Antiquities clearly has the narrative function of highlighting the Jacob and Esau characters, on whom the ensuing narrative will focus.

Josephus also applies actorial analepsis in various ways. Sometimes the interpretation of certain events by a character differs significantly from the way they have been narrated. This occurs, for example, in the scene where Adam and Eve are called to account by God because they have eaten from the tree of wisdom. Adam makes excuses and claims that he was deceived into sinning by Eve ( $A \mathcal{f}$ I.48). However, the narrator has already reported that Eve merely persuaded Adam (I.43), apparently without any trouble. The Deity seems to be aware of this and ignores Adam's speech, but warns him never to listen to a woman's advice (I.49). It is worth noting that in the Hebrew Bible Adam merely repeats to God the words that were present in the narrative: 'she gave me fruit from the tree, and I ate' $(G e$. 3.12), which corresponds to 'and she also gave some to her husband, who was with her, and he ate' $(G e .3 .6)$. On the other end of the spectrum, we find the narrator corroborating a character's view on past events. He may do so explicitly or implicitly. An example is Jacob's discussion with Laban, in which both men accuse each other of ill treatment (AJ I.3I4-32I; actorial analepses, partially in direct and partially in indirect speech). After both men have given their views, the narrator takes sides and professes in a narratorial analepsis: 'And indeed, Laban had treated Jacob very badly' (Af г.320). 
A more ingenious example is found in The Jewish War in the long speech Titus addresses to John and Simon, the leaders of the rebels in Jerusalem, after the fall of the capital. In The Jewish War 6.333-346, Titus gives an overview of the dealings of the Romans with the Jews. He stresses the Romans' humanity throughout, as well as his own and Vespasian's clemency in the present war. They allowed the Jews their own worship and customs, treated prisoners compassionately and time after time tried to spare the Temple, for example by offering the Jews the choice of a different battlefield. However, Titus concludes: 'Every proposal you treated with scorn, and your Sanctuary you set on fire with your own hands' (BF 6.347). Angry about the arrogant attitude of the Jewish leaders, who for all his clemency and benefaction even now make demands, Titus decides to raze Jerusalem to the ground. The better part of the preceding book in The Jewish War can be seen as leading up to this final evaluation of the events. The narrator portrays Titus as lenient towards prisoners (Bf 6.II5). He undertakes the crucifixion of prisoners only with great reluctance $\left(5 \cdot 44^{6-45 I}\right.$ ) and is concerned about Jewish customs, especially the preservation of the Temple (6.236-243, 249, 25I $254^{-266)}$. In his speech Titus also reminds John and Simon that they were offered a change of battlefield (6.346), as is indeed described in The Jewish War 6.128. Moreover, in his judgement about who is to blame for the destruction of the Temple, Titus appears to be repeating the narrator's words almost exactly: the Jews had set the north-west portico on fire, 'thus beginning the burning down of their holy places with their own hands' (BJ 6.I65). The close correspondence between the narrative and the speech invites the narratees to accept Titus as a highly reliable secondary narrator, and suggests that his evaluation of the war must be accepted as final and authoritative. Furthermore, it urges the narratees to show understanding for the fact that now, after this speech, Titus loses patience and changes his attitude. In fact, Titus' change of attitude is rather baffling. It strongly suggests that he was never the lenient general concerned with the Jewish temple, as Josephus purports him to be. ${ }^{28}$ However, the presentation of the narrative as just described makes the transition more acceptable and the sudden cracks in Titus' character more convincing.

28 Cf. S. Mason 2005. 


\section{Parallel storylines}

Sometimes Josephus links two larger storylines that are set in different places to each other by means of a brief time formula. These formulas often indicate synchronisms. ${ }^{29}$ Josephus' frequent presentation of parallel stories has earned him a bad reputation as a historian. Scholars have argued that he uses this device rather loosely by synchronising stories that do not refer to events occurring at the same time. It has even been suggested that Josephus' frequent use of parallel stories shows his incapacity to present large quantities of source-based information in the proper chronological order. ${ }^{30}$ Indeed, some passages in Josephus strongly suggest that the material he synchronises stems from two different sources. ${ }^{31}$ And yet, sometimes his tendency to synchronise different storylines can be satisfactorily explained as attempts to make the narrative run more smoothly, or to present stories that are linked together thematically. ${ }^{32}$

The famous Testimonium Flavianum about Jesus (Af 18.63-64) is a good example of a parallel story that fits well into its narrative context, displaying a common theme. ${ }^{33}$ The passage is preceded by reports about two actions by the procurator Pilate: the introduction of the emperor's images on military standards, and the confiscation of Temple money for the construction of an aqueduct $\left(A \mathcal{F}\right.$ i $\left.8.55^{-62}\right)$. Both measures trigger fierce protests by the Jews, and their revolt (stasis) has to be stopped by military force. Next, the brief passage about Jesus is being introduced with a synchronising formula: 'about this time there was a man Jesus ...' (Af 18.63), which connects Jesus with the stasis just reported. ${ }^{34}$

${ }^{29}$ Josephus uses a wide range of formulas to introduce parallel stories, suggesting differences in precision: e.g. en toutö 'at that moment' or a variant (e.g. BJ 2.IOI, I78); hama de 'at the same time' (e.g. Bf 2.409; 4.526); formulas with kairos 'critical moment' (e.g. Af 6.325; Bf 7.4I), khronos 'time' (e.g. Af io.3o; cf. Bf 7.259), hèmera 'day' (e.g. Bf 5.I09; $A 7$ 5.360) or etos 'year' (e.g. $A f$ 8.62). Some of these formulas can also function as introduction of an analepsis if they are followed by an aorist or pluperfect ('in the meantime').

${ }^{30}$ Otto I9I3: I79. Cf. G. Hölscher I9I6: I983-I987; H.G.M. Williamson I977.

31 Schwartz ig82. Also Bf I.3I.

32 Cohen I979: 44 characterises Josephus' narrative strategy of clustering related materials as 'Josephus' fondness for thematic organization'.

33 Also Bf 7.259.

34 The synchronisation of Seleucus IV's succession by Antiochus IV (I75 BCE) and Ptolemy V's death (I8I BCE) may be explained by the common surname 'Epiphanes' of both kings, as stated in The Jewish Antiquities 12.235 . See also reports of various rebellions 
An example of the narrator's effort to provide a readable, smooth narrative is his treatment of the history of the Israelite and Judaean kings. The narrator presents the simultaneous reigns of two kings by first focusing on the rule of an Israelite king, then switching to the rule of the contemporaneous Judean king, and vice versa. ${ }^{35}$ Josephus is quite explicit about his motivation for presenting the story in this way. Concerning the reports about the Israelite King Jeroboam and the Judean King Rehoboam, he defends his method claiming that in this way 'the orderly arrangement' (to eutakton) of his history can be maintained in this section just as in the rest of his history (Af 8.224). He then proceeds to relate the history of Jerobeam (from 8.225) and after that the history of Rehoboam (from 8.246). It is interesting to note that he deviates from the presentation of the same stories in the Bible. It may be emphasised that here, as often, the order of events is indicated by narratorial comments pointing to synchronic events, or cross-references to other sections of the narrative.

Large sections of The Fewish War also seem to be structured on the basis of a similar synchronising narrative strategy. The Jewish War narrative combines multiple storylines from the end of book 4 up to the beginning of book 7 , which concern various events in Israel and Rome that occur more or less at the same time. The narrator interweaves widely divergent storylines by using parallel stories and analepses. The shift from one storyline to another is often thematically motivated. The various storylines - surprisingly - form coherent narratives of their own, although they are frequently interrupted. The result is a wellstructured and evocative narrative that guides the narratees through the events and anticipates their responses. After the destruction of the Temple, for example, the multiple storylines that have been left at the end of book 4 are concluded in book 7 . To give a few examples from this section, in The Fewish War 7.20 the narrator mentions that the winter season prevents Titus, who is still in Judea, to sail for Italy. The reference to Italy leads up to an analepsis concerning Vespasian (7.2I). The story line is picked up exactly where it was left in 4.663. In an analepsis which is explicitly dated ('at the time when Titus Caesar was busy directing the siege of Jerusalem'), we hear of Vespasian's journey

as in the follow-up of the Jewish rebellion against Archelaus, the king of Judea ${ }_{4} \mathrm{BCE}-$ $6 \mathrm{CE} ; A 7$ 17.206-218, 250-298).

${ }_{35}$ Af 9.16-278. Josephus also synchronises other rulers; cf. e.g. Af 12.234-236. 
to Italy from Alexandria, which ends with his overland trip to Rome. In 7.23 the narrative returns briefly to Titus, who receives news of the capture of Simon bar Giora, one of the rebellion leaders, 'which had happened as follows: ...' (touton genomenon ton tropon). The next section describes the rebel Simon's capture (7.26-36), which fulfils Josephus' earlier promise to relate this (6.433).

While Josephus' synchronisations may not always be correct from a historical point of view, they enable the narratees to follow the developments of the main story and greatly enhance the readability of his lengthy works. In this way, a narratological perspective warrants a more positive assessment of Josephus' achievements.

\section{Rhythm}

Josephus frequently applies variation in rhythm. On a grand scale, it can be observed that the story about the history of the Herodian dynasty up to the beginning of the Jewish War takes up seven books of The fewish Antiquities (14-20). This section comprises a period of roughly I35 years, a very short duration when compared to the story's total time span of about 3,826 years. Similarly, in The Jewish War the prelude spanning $17 \mathrm{I} / \mathrm{I} 7 \mathrm{OBCE}$ to $66 \mathrm{CE}$ takes up less than two books, whereas the four years of the actual war are allotted more than five books.

On a smaller scale scenes, summaries and ellipses are all common features in Josephus' histories. The detailed report about Herod's military conflicts with 'the Arabs' (i.e. the Nabataeans) in The Jewish Antiquities $15 \cdot 108-160$ is an example of such a scene. The scenic character of this passage appears from the presence of an elaborate commander speech, with many rhetorical topoi of commander speeches from the classical period ( $A \mathcal{F}$ 15.127-146; cf. the much shorter speech in $B \mathcal{F}$ I.373-379) ${ }^{36}$ Herod delivers this speech before a third and decisive battle with 'the Arabs', when the Jews' prospects look particularly bad because of a defeat and devastating earthquake. Clearly, at this dramatic moment the narrator is slowing down the pace of the narrative. He quotes Herod's entire speech, and describes the battle's beginning and the outcome in detail (Af I5. I47-I59; cf. Bf г.380-385). Вy

\footnotetext{
${ }^{36}$ Van Henten 2005. Cf. Titus' commander speeches in The Jewish War 3.472-484; $6.33^{-53}$.
} 
contrast, the main combat is summarised very briefly in general terms: 'A fierce battle started and a great number fell on both sides. But finally the Arabs were routed and started to flee' (Af I5.I5I). ${ }^{37}$

Various kinds of summaries function as time management device for the narrator, who sometimes chooses to greatly accelerate the narration of events lasting several years. The report about Herod's son Archelaus' rule as ethnarch of Judea is extremely brief, while the beginning and end of his reign are narrated at a much slower pace (cf. Bf 2.III with 2.I-IOo and 2.II2-II6; also $A 7$ I7.339-34I with I7.200-338 and $\left.\mathrm{I} 7 \cdot 34^{2-}-353\right) \cdot{ }^{38}$ Other summaries function as introduction, conclusion or intermezzo in a context of more elaborate descriptions (e.g. $A \mathcal{F}$ 6.I29-I30; I6.I30, I46) or in brief generic phrases, and may characterise events or actions (e.g. $\left.B \mathcal{f} 4.3^{6} 3^{-} 365\right)$. A combination of scene and summary can be found when within a longer stretch of narrative one or two events are singled out by considerably slowing down the narrative speed. Interesting examples may be Pilate's two conflicts with the Jews (BJ 2.I69-I77). Just half a sentence about Pilate's appointment to governor is immediately followed by an anecdote about the transfer of the military standards to Jerusalem, which is narrated in two brief scenes (2.I69-I74). The beginning of this passage suggests that this anecdote concerns the beginning of Pilate's reign $(26 \mathrm{CE})$. A second anecdote about Pilate's confiscation of money from the Temple, for the construction of an aqueduct, follows in The Jewish War 2.175I77, which can be dated in $36 \mathrm{CE}$, the year of Pilate's death. ${ }^{39}$ When placed together these anecdotes, and the lack of further information, clearly characterise Pilate as a brute governor who showed very little consideration for Jerusalemite Jews and their practices. The two anecdotes about Pilate's reign are linked with the formula meta de tauta (BF 2.I75). This formula indicates that some story time has elapsed between the two, but this is too vague to infer that ten years separate them; the text passes over this matter completely.

${ }^{37}$ Several other scenes concern Herod the Great's dramatic dealings with his sons (Af г6.90-126, 356-394; 17.89-145; Bf г.617-640). Scenes with other contexts: Af I7.228-249 (cf. Bf 2.26-38); Bf 2.I92-20I and $A f^{\text {I } 8.263-284 ; ~ B f ~ 3.344-392, ~ 399-408 . ~}$

${ }^{38}$ Cf. $A 7$ 9.232-235, 277-278 about the end of the Israelite kingdom. Also Bf 2.I67I68, $27 \mathrm{I}$ and $A f$ I0.81 -83 .

39 Cf. Bf 2.178, which reports an event from the same time that is dated in the parallel passage in The Jewish Antiquities 18.126 a year before Tiberius' death (37 CE). Detailed discussion in Schwartz I992: 182-217. 
In fact, the narrator regularly passes over events by means of ellipsis. He may do so explicitly, as in the previous example or when he informs the narratees that Adam had many children but the narrative will only focus on Seth's descendents, because it would take too much space to deal with all of Adam's children (Af r.68). Less explicit, but still clear, are several indications of the passing of time within episodes. So, during the siege of Jerusalem in The Jewish War, one of Josephus' most elaborately narrated episodes, some days are told in detail while others are passed over completely by means of ellipsis. The omission of days from the narrative is usually indicated by a brief temporal formula, like 'two days later' or 'the following day', which is found in between two more elaborately told events. Such formulas are ultimately relative to other time-markers that contain more exact references to, for example, a specific date. ${ }^{40}$ Similar formulas such as trisi men ... hèmerais ..., tè $i$ tetartēi de ('for three days they maintained a stubborn defence and held their ground; but on the fourth ...', Bf 5.346) indicate a short summary of events of three days with many things omitted, after which the events of the fourth day are more elaborately told. It is hard to tell whether the precision suggested by such formulas is real or merely apparent. It is striking that there is not much variation; the ellipses in the siege of Jerusalem almost always comprise one or two days. This suggests that they are just a conventional way of dating the events in the story.

Finally, there are ellipses to be found that are not indicated at all. We have seen that the narrator is careful to provide his narratees with necessary background information about certain characters that he had not yet related. Sometimes, however, the omission of such short completing analepses make the reader wonder whether he has missed something important in the preceding narrative. Thus, the narratees may be surprised to find out that Cain settles in Nais 'with his wife' (Af r.6o), since nothing has been said about Cain's marriage in the preceding narrative. In The Jewish Antiquities I0.I95 an event from the reign of Nebuchadnezzar is dated 'two years after the sacking of Egypt', but nothing about this sacking has been narrated in the preceding context.

40 'Two days later': $B 75.473$ (relative to the reference to the day of the month in 5.466). Also 6.67-68, I66, I92 (idem 6.I77), 236 (idem 6.220), 354 (relative to 6.32I 'on the fifth day'), 363 (relative to 236 ). 


\section{Conclusion}

In line with the Thucydidean ideal of akribeia Josephus is very precise with his time-markers. He frequently offers multiple dates, following Jewish as well as non-Jewish conventions, for the events of his narrative. His presentation of events is principally chronological, but he often uses the devices of analepsis, prolepsis and parallel stories to enhance the readability of his story or to make his narrative more evocative. Prolepses may highlight important themes (e.g. the theme of internal rebellion, the destruction of the Jerusalem temple, etc.), emphasise God's intervention, or pass judgment on characters. Prophecies and dreams are forms of actorial prolepsis typical of Josephus. Completing analepsis frequently provides the narratees with essential background information on certain characters or events. The confrontation of a character's explanation of past events in an actorial analepsis with that of the narrator often reveal the narrator's sympathies and antipathies. Finally, he frequently synchronises reports and clusters stories that share a common theme. Scenes, summaries and ellipsis are commonly used by Josephus to adapt the pace of his narrative. 
PART THREE

CHORAL LYRIC 
Irene J.F. de Jong and René Nünlist - 978-90-47-42293-8 Downloaded from Brill.come4/26/2023 09:46:52AM via free access 
CHAPTER FOURTEEN

\title{
PINDAR AND BACGHYLIDES
}

\author{
R. NÜNLIST
}

\section{Pindar}

As has been argued in $S A G \mathcal{N}$ I, the victory ode is not a narrative genre per se. ${ }^{1}$ Narrative sections can, but need not be integrated into an epinician ode. What is more, Pindar's narratives display a considerable variety. It is therefore difficult to make generalising statements about his treatment of time that apply to all of them. An exception is the fact that virtually all the narratives are located in a distant past, with the result that the bulk of Pindar's primary narratives are subsequent. ${ }^{2}$ This characteristic also affects the way in which Pindar regularly marks off the narrative section from the surrounding text of the victory ode. The narrative is regularly introduced by the indefinite temporal adverb 'once upon a time' (pote, often subsequent to a relative pronoun or adverb that functions as a pivot; $S A G \mathcal{N}$ г:35): O. 3.13; 6.13; 7.30 (not at the very beginning of the narrative but still part of the first sentence); I3.63; P. І.I6; $3.5 ; 4.4 ; 8.39 ; 9.5,79 ;$ I0.31; I2.6; N. $4.25 ; 9$. I I (tote 'at that time' instead of pote, but cf. 1. I3); I. 4.52 (cf. also proteron 'in the past' in $P$. 6.28). ${ }^{3}$ As an alternative, Pindar can achieve a similar effect by

$1 S A G \mathcal{N}$ 1:213. The present chapter only takes into account the epinician odes (translations are taken from Race 1997), nine of which do not comprise a narrative (SAGN I:2 I3): O. 5, II, I2 and I4; P. 7; N. 2 and II; I. 2; 3. In accordance with the goal of this volume ( $\rightarrow$ Introduction), 'time' is treated here as a narratological category. Pindar's general concept of khronos and its philosophical ramifications would require a study of its own; cf. e.g. Hurst 1985, with literature in n. I, and, more recently, Theunissen 2000.

2 Virtually the only exceptions are cases that are of an 'omnitemporal' nature (e.g. Heracles, made immortal, lives among the gods, I. 4.58-6o; on 'omnitemporal' narration $\rightarrow$ Hesiod, $\rightarrow$ Homeric hymns). Prior narration seems to be confined to secondary narratives.

${ }^{3}$ On the introduction of narratives by means of a relative pronoun/adverb and/or pote see e.g. Braswell ig88: 64-65 (including examples from authors other than Pindar). 
means of adjectives with a distinctly temporal meaning such as 'ancient' (palaios: P. 9.105; N. 3.32 ; arkhaios: $\mathcal{N}$. I.34). In fact, even the use of verbs in the past tense (excluding gnomic aorists) has a comparable effect in that they are relatively rare outside the narrative sections of Pindar's odes. Similar to the demarcation of the beginning, though less frequent, the use of the adverb 'now' (nun, often kai nun 'and now') brings about a transition from the narrative of the mythical past back to the here and now of the victory celebration: 0 . I.90; $3.34 ;$ го.78; P. г.ı7; 6.44; 9.7I; also I. 8.6r. By inserting a narrative section into the essentially non-narrative genre of the victory ode, the narrator, as it were, steps back into a mythical past, the precise date of which remains vague. While Herodotus (2.I45) attempts to date Heracles and the Trojan War, Pindar, whose narratives are inhabited by the same heroes, leaves them in an unspecified, probably remote past. This placement of heroes in the distant past even applies to the cases where the mythical hero is a direct ancestor of the victor and his family (especially Aeacus and his sons as forefathers of the frequently celebrated Aeginetans). ${ }^{4}$

Another feature typical of several Pindaric narratives is their extraordinary compression. The underlying myths are not narrated for their own sake. Rather, a brief mention of the story's gist, sometimes even a potentially riddling allusion, is considered enough to evoke the whole picture. This characteristic applies to several of the mythological exempla that are strewn throughout Pindar's odes. They are particularly dense in the priamel that opens Isthmian 7 (for a Theban victor):

In which of your land's former glories, o blessed Thebes, did your heart take most delight? Was it when you raised up flowing-haired Dionysus as companion to Demeter of the ringing bronze? or when, in a midnight snowstorm of gold, you received the greatest of the gods [sc. Zeus], when he stood in Amphitryon's doorway and sought his wife to beget Heracles? or because of Tiresias' profound counsels? or because of the skillful horseman, Iolaus? or ...

${ }^{4}$ An exception is Pythian 4, where the victor Arcesilaus is said to represent the eighth generation (65) after the founder of Cyrene Battus, who himself is in the seventeenth generation (Io) after Medea and the Argonauts. For an analysis of the chronology see Malten I9II: I9I-I93 (including a comparative table on p. I92). 
Needless to say, such exempla can occur alone too (e.g. O. Io.i8-ig on Patroclus, IO4-IO5 on Ganymede, etc.) and need not form a cluster as in Isthmian $7 .{ }^{5}$ If it remains questionable whether these passages should actually be treated as narratives at all, it is clear in any case that they are of comparatively little value to an analysis of how Pindar treats time in his narratives. All one can say with confidence is that the 'narrative' is extremely summary. ${ }^{6}$ The same description essentially applies to very short narratives such as the one about Philoctetes:

They tell that the godlike heroes came to fetch him [sc. Philoctetes] from Lemnos, wasting from his wound,

Poias' archer son, who destroyed Priam's city and ended the Danaans' toils; he walked with flesh infirm, but it was the work of destiny. ${ }^{7}$

(Pythian I.52-55)

While the status as narrative is undisputed here, the treatment of the myth is equally summary. Little more than the bare facts are stated. It is, however, the case that such summaries play a role in more extended narratives as well. This trait pertains, for example, to the passages where Pindar opens the narrative section by first giving its gist, which is then elaborated in greater detail. The narrator, as it were, decides not to let the summary speak for itself (as, for instance, in the Philoctetes example), but to give a more extensive narrative. The example from Pythian 6 is sufficiently short to be quoted here in full:

[initial summary:] In the past [proteron] as well, mighty Antilochus bore such thoughts in mind, who died to save his father [sc. Nestor] by standing up to the man-slaughtering general of the Ethiopians, Memnon. [elaboration:] For Nestor's chariot had become entangled when his horse was struck by Paris' arrows, and he [sc. Memnon] was brandishing his powerful spear.

${ }^{5}$ For a similar cluster of exempla cf. $\mathcal{N}$. I0.4-18 and fr. 29.

${ }^{6}$ Such a brief treatment of the myth presupposes that the narratee is familiar with it, which, however, is not the topic of the present volume (cf. $S A G \mathcal{N}$ I:220-22I).

7 Other short and therefore summary narratives include: $\mathcal{N}$. 6.49-53 (on Memnon killed by Achilles); also $0.2 \cdot 3^{-4} 4$ (on Oedipus and his sons), 79-83 (on Achilles

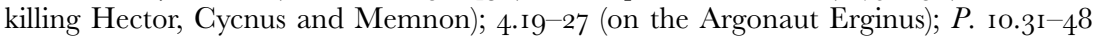
(on Bellerophon visiting the Hyperboreans, interrupted in 36-44 by an 'ethnographic' description of his hosts); $\mathcal{N}$. 4.54-68 (Peleus survives Hippolyta's attempted seduction and her husband's ambush and finally marries Thetis). Even the ostensibly long narrative in Nemean $3.3^{2-6}$ falls into this category, because its numerous topics receive a rather summary treatment. 
In panic the mind of the old man from Messene shouted to his son, nor indeed did he hurl forth a word that fell to the ground: that godlike man [sc. Antilochus] took a stand right there and bought his father's rescue with his own death, and, for doing that awesome deed, he was deemed by the young men of that ancient generation to be foremost in virtuous behavior toward parents.

(Pythian 6.28-42)

If the elaboration is not dramatically more detailed than the initial summary, this phenomenon is primarily due to the relative brevity of the illustrative example chosen here with a view to space. Other narratives display the same pattern of 'initial summary with subsequent elaboration' (cf. the 'header device', found from $\rightarrow$ Homer onwards); ${ }^{8}$ and the difference in detail and hence narrative speed can be more poignant than in Pythian 6. See, for example, Nemean I0.55-59 (initial summary) and 6o-9o (elaboration, on the Dioscuri) or Olympian I, where, however, initial summary $\left(25^{-27}\right)$ and elaboration $\left(3^{6-89}\right.$, on Tantalus and Pelops) are separated by no fewer than nine lines of generalizing on the workings of storytelling. See also Pythian 2.2 I-24 (initial summary, including the moral lesson) and $25^{-48}$ (elaboration). The only difference here is that the initial summary presupposes rather than states the gist of the myth: Ixion tried to make love to Hera and was punished for it. In all these cases, there is a patent difference in narrative speed between summary and elaboration.

8 The description 'initial summary with subsequent elaboration' is borrowed from ancient rhetoric, where the two elements can be called, for example, kephalaia ('main points'; cf. already P. 4.II6 and Illig I932: 57) and (ep)exergasia ('elaboration'). Race 1997: I 20-2I gives a similar general description, but, following in the footsteps of Illig I932: $55^{-67}$, then speaks of 'ring composition', a concept that needs to be applied with more caution than is sometimes done. (Race applies the term to the narratives in O. I, 3, 7 and I3; P. 3, 6, 9, Iо, II and I2; $\mathcal{N}$. Iо.) 'Initial summary with subsequent elaboration' is more apt to capture the difference in narrative detail between the two parts. More generally, it seems advisable to differentiate between thematic ring composition and temporal ring composition. In other words, does the narrator return to the same topic in general (as in most of Race's examples) or to exactly the same scene? Only the latter means that he covers the same ground twice, and such temporal ring composition is comparatively rare. The Pindaric narrative that comes closest is the 'little Oresteia' in Pythian Ir.I7-37 (gnomic interruption in 25-30), but even here the two installments rather complement than repeat each other (similarly P. I0.3 I-48; I2.624). In connection with ring composition, Race 1997: I 20 claims that the elaboration 'usually [is] in reverse chronological order', which is not supported by the evidence (see below). For the analysis of Pindar's narratives as 'ring composition' see also Hamilton I974: esp. 6I-65). 
Summaries are also of importance in a second recurrent type of Pindaric narrative. Here the Pindaric narrator chooses to focus on a short scene within the larger myth. The chosen scene is narrated in some detail (i.e. slowly), sometimes involving fairly extensive speeches, while the bulk of the entire story is either narrated in a summary fashion or omitted altogether (that is, presupposed as known to the narratees)..${ }^{9}$ In the former case, the result is a striking difference in narrative speed between scene and summary, as can be illustrated, for example, with the narrative in Olympian i3. Pindar narrates in quite some detail how Athena visits Bellerophon in his sleep and gives him the bridle and bit with which to yoke Pegasus. Bellerophon then repeats Athena's speech (in indirect speech) to the seer Polyidus, who validates the importance of Athena's visit. ${ }^{10}$ The whole account takes up twenty lines:

who [sc. Bellerophon] once [pote] suffered much indeed in his yearning to yoke Pegasus, the snaky Gorgon's son, beside the spring [sc. Peirene], until, that is, the maiden Pallas brought him the bridle with the golden bands, when his dream suddenly became reality and she spoke: 'Are you asleep, prince of Aiolus' [sc. his greatgrandfather] race?

Come, take this horse charm, and, sacrificing a white bull, show it to your father, the Horsetamer [sc. Poseidon].'

So much did the maiden of the dark aegis seem to say to him as he slept in the darkness, and he leapt to his feet. He took the marvel that lay beside him and gladly sought out the local seer, the son of Coeranus [sc. Polyidus], to whom he revealed the entire outcome of the affair, how he slept the night on the goddess' altar at the bidding of that seer's oracle, and how the very daughter of Zeus, whose spear is the thunderbolt, gave him

\footnotetext{
${ }^{9}$ Given that the works of the earlier lyric poets are badly fragmented, it is difficult to decide, whether this focus on a short scene is influenced by contemporary tragedy (as suggested by B. Zimmermann I992: I I4, though with a view to Bacchylides' dithyrambs only). After all, tragedy developed from dithyramb according to Aristotle (Po. I449aioI5). The concentration on a shorter episode may well precede tragedy. Besides, even the Homeric epics focus on a comparatively short time span.

${ }_{10}$ This repetition is one of the clearer examples of Pindar 'going over the same ground twice', which, however, is mitigated by the fact that the second installment is in reported speech, that is, shorter.
} 
the spirit-taming gold.

The seer commanded him to heed the dream

as quickly as possible, and, upon sacrificing

a strong-footed victim to the mighty Earthholder,

to erect at once an altar to Athena Hippia.

(Olympian $\mathrm{I} 3.63-82)$

Conversely, the ensuing narrative of how Bellorophon actually captures and mounts Pegasus and his subsequent great success in several battles is dealt with in only seven lines, that is, a palpable acceleration of the narrative speed.

And indeed powerful Bellerophon,

eagerly stretching

the soothing remedy around its jaws, captured

the winged horse. He mounted him, and clad in his armor

of bronze immediately began to make sport in warfare.

And with that horse thereafter, firing

from the cold recesses of the empty air, he slew

the army of female archers, the Amazons,

and the fire-breathing Chimaera and the Solymi. (Olympian I3.84-90)

Interestingly, the gnome that briefly interrupts the narrative states: 'The gods' power easily brings into being even what one would swear impossible and beyond hope' $\left(O\right.$. 13.83). ${ }^{11}$ It seems as if the gnome were saying that, due to the support by the goddess Athena, Bellerophon's exploit is comparatively easy and can therefore be narrated summarily.

Similar changes in narrative speed can be found elsewhere. Part of the narrative in Olympian I deals with Pelops' chariot race for the hand of Hippodamia but focuses on his prayer to Poseidon, while the actual race is narrated summarily (O. г.67-87 vs. 88-89). Olympian 8 generally recounts how Aeacus helped Apollo and Poseidon build the Trojan wall, but singles out the incident in which three snakes try to jump upon the rampart. Two fail and one succeeds, which is interpreted by Apollo to mean that Troy is doomed to be sacked by Aeacus' descendants (O. 8.3 I-52). Likewise, Heracles' exploits together with Telamon's are dealt with summarily, but when Heracles comes to enlist Telamon as an ally against Troy, the prayer that Telamon be given a valiant son receives much emphasis and narrative space $(I$. $6.27-35$ vs. $\left.35^{-5} 6\right)$.

11 Pindar regularly punctuates his narratives with gnomic statements $\left(O .7 \cdot 3^{\mathrm{I}-} 3^{2}\right.$, $44^{-47}$; I0.39-40; $P$. 2.34-36; 3.I I-I2; etc.). Similarly, a gnome can also mark the end of the narrative $(S A G \mathcal{N}$ г:2 I 6$)$. 
If these examples are characterised by the discrepancy between summary on the one hand and detailed narrating of a short but crucial incident on the other, other Pindaric narratives only look at a short episode and omit the wider context altogether. Thus the short narrative at the end of Olympian 4 deals with a comparatively minor incident during the Argonauts' stay on the island of Lemnos (O. 4.19-27). Likewise, the shorter of the two narratives in Olympian 6 quotes Adrastus' reaction when Amphiaraus, another of the Seven against Thebes, is swallowed by the earth $\left(0.6 .13^{-17}\right)$. However, even longer narratives display a similar limitation to a particular moment in the story. An excellent example comes from Nemean io, which describes the fatal encounter of the Dioscuri with Idas and Lynceus and demonstrates that Pindar is fully capable of writing a gripping battle narrative with speeches and all. The comparatively short incident covers no fewer than thirty-six long (dactylo-epitritic) lines. An excerpt must suffice in the present context.

[Castor is shot by Idas and Lynceus:]

and they [sc. Idas and Lynceus] suffered terribly

at the hands of Zeus, for immediately

the son of Leda [sc. Polydeuces] came in pursuit, while they took

a stand against him beside their father's tomb.

From it they seized the grave marker of polished stone

and threw it against Polydeuces' chest, but they did not crush him

or drive him back. He attacked them with his swift javelin

and drove the bronze into Lynceus' side.

Zeus hurled against Idas a smoldering thunderbolt of fire

and the two men burned all alone. [short gnome omitted]

The son of Tyndareus [sc. Polydeuces] returned swiftly

to his mighty brother

and found him not yet dead,

but gasping hard for breath.

Hot indeed were the tears he shed; he groaned

and cried aloud: 'Father, son of Cronus, what release

will there ever be from sorrows? Grant me death

along with him here, lord.'

(Nemean 10.65-77)

Zeus replies and presents Polydeuces with the well-known choice either to live on Olympus or to share in his brother's destiny. Polydeuces' acceptance of the latter option is narrated in no more than a dozen words ( $\mathcal{N}$. Io.89-90), a striking contrast to the leisurely account that precedes. ${ }^{12}$

${ }_{12}$ The ends of the narrative and the entire ode coincide, which is rare. Race 1997: 
As has been argued in the Introduction $(\rightarrow)$, the most natural order for a narrative is chronological. Pindar is no exception in that several of his narratives are recounted in what is essentially a chronological order. The comparatively long narrative in Olympian 6, for example, narrates the genealogy and appointment of the seer Iamus in chronological order $(O .6 .29-70){ }^{13}$ It is true, however, that some narratives are not in chronological order. A rather extreme example is Olympian 3, which recounts how Heracles founded the Olympic Games and introduced the olive tree in order to provide shade for the attendants. Reconstructed in chronological order (i.e. as fabula) the single steps of the story are: (I) Zeus orders Heracles through Eurystheus to fetch the golden-horned doe, one of the twelve labors. (2) Heracles obeys and meets with Artemis. (3) On his way he happens to see an olive tree with the Hyperboreans and admires it. (4a) Some time later he establishes the Olympic Games, (4b) but misses the shade. (5) He returns to the Hyperboreans and persuades them to give him some olive trees. (6) $\mathrm{He}$ brings them to Olympia and plants them. However, this fabula is actually narrated $(O .3 \cdot 13-34)$ in the sequence $6-5-4 \mathrm{a}-4 \mathrm{~b}-5-2-\mathrm{I}-3-4 \mathrm{~b} .{ }^{14}$ This sequence constitutes a complex temporal structure, and a reader who is not familiar with the exact details may need to read the story twice. To describe the structure of the narrative as 'ring composition' ${ }^{15}$ does not seem to do full justice to its complexity. It is true that Olympian 3 to some extent resembles the structure that some scholars see as the hallmark of narratives in ring composition: 'a movement is created backward toward the chronological point from which the narrative may then move forward to the point at which it began'. ${ }^{16}$ However, the nar-

I 21 mentions Nemean Io and Pythian 9; see also Olympian 4, where it is even a speech within the narrative that ends the ode. On Bacchylides' abrupt endings see below.

${ }^{13}$ Other essentially chronological narratives include: $0.9 \cdot 42^{-79}$ (extensive genealogy of the inhabitants of Opous in Elis, the victor's hometown, and its most important immigrants); I0.24-78 (Heracles takes revenge on Augeas, who broke his word, then establishes the sanctuary of his father Zeus in Olympia and introduces the Olympic Games); $\mathcal{N}$. I. 35-74 (the newborn infant Heracles kills the two snakes sent by Hera and is prophesied a great future); 7.35-47 (after sacking Troy, Neoptolemus misses Scyros on his way home and is eventually killed in a quarrel in Delphi); also O. 8.31-52; I3.63-90; P. 8.39-56; etc.

14 This analysis is in general agreement with that by Köhnken 1983 (with literature), including the disputed number of Heracles' journeys to the Hyperboreans.

${ }^{15}$ Race 1997: I 76.

16 Slater I983: I18, who, following in the footsteps of Illig I932: I, Schadewaldt [1938] I966: 84 and others, speaks of 'lyric narrative', expressly contrasted with 'epic (i.e. chronological) narrative' in an earlier publication (Slater 1979: 64). This is something of 
rative in Olympian 3 neither reaches the point at which it began, nor will it suffice to see the repetition of story element $4 \mathrm{~b}$ as a ring (let alone element 5). ${ }^{17}$ The schematic structure of Olympian 3 is indicative of a certain reluctance to go over the same ground twice. This tendency even applies to the two elements that are repeated, 5 and $4 \mathrm{~b}$, which, however are complementary and not exactly repeating.

The bulk of the narrative in Olympian 3 essentially displays a gradual movement back towards the beginning of the fabula. ${ }^{18} \mathrm{~A}$ similar structure can be found in Olympian 7, which comprises, so to speak, 'a short history of Rhodes'. The structure is simpler, though, in that it consists of three larger building-blocks: ${ }^{19}$ (I) the allotment of Rhodes to the sun god Helios; (2) Helios' instruction to his children on Rhodes to introduce fireless sacrifice in honor of Athena, born from Zeus' head with the assistance of Hephaestus; and (3) the foundation of Rhodes by Tlepolemus. The actual sequence of the three units in the narrative of Olympian $7(27-33,34-53,54-76)$ is retrograde: $3^{-2}-\mathrm{I} .{ }^{20}$ It is, however, not reverse order in a strict sense, because the sequence within the three blocks is essentially chronological (i.e. forward). In other words, Pindar uses the standard mode of chronological narrative, but twice makes a substantial step back in time. Interestingly, these steps back are signaled in the same way as the demarcation of the narrative section as such: once by means of the adverb pote ('once', 34), once by means of the adjective 'ancient' (palaios, 54).

The preceding emphasis on Pindar's use of chronological narrative is deliberate, because a glance at modern scholarship could easily lead to the impression that ring composition and non-chronological narrative prevail in Pindar. ${ }^{21}$ But this prevalence is at least an exaggeration.

a misnomer. For 'lyric narrative' can be found in epic poetry (cf. the examples discussed by Slater 1983 and $\rightarrow$ Homer under the rubric 'epic regression') and vice versa (cf. e.g. above on 0 . 6). It seems preferable to speak of chronological or non-chronological narratives.

17 Pindar does speak of the same thing at the beginning and at the end of the narrative, the olive tree, but that is thematic (or verbal) and not temporal ring composition (cf. n. 8).

${ }^{18}$ Cf. van Groningen 1958: 351.

19 Described as 'triptych' by Race 1997: I I 8.

${ }^{20}$ Rivier 1950: 77-80.

${ }^{21}$ Slater i979: 65, for example, counts thirteen instances of 'lyric narrative' $(O$. I, 3 and I0; $P .2,3,6 ; 8,9$, I0, II and I2; $\mathcal{N} .7$ and I0; his distinction between 'complex' and 'simple' is ignored for the present purposes). Race 1997: I 20-2I finds eleven narratives in ring composition $(O . \mathrm{I}, 3,7$ and I $3 ; P .3,6,9$, го, II and I2; $\mathcal{N}$. го). 
True, there is one ode, Pythian 3, which nicely lends itself to an analysis as ring composition due to its backward-forward movement. The fabula is: (I) Coronis sleeps with Apollo and becomes pregnant. (2) She ignores the divine wrath and sleeps with a human. (3) Apollo learns this and (4) in anger sends Artemis, (5) who kills Coronis before she can give birth to Asclepius. (6) There is a funeral, (7) where Apollo rescues the baby and (8) then brings it to Chiron, (9) who raises the child. (Io) Asclepius is a successful doctor, until (II) he tries to revive a dead man, (I2) for which he is killed by Zeus. The narrative presents these events in the sequence: $9-(\mathrm{IO})-5-2-\mathrm{I}-2-3-4-(5)-6-7-8-(9)-\mathrm{IO}-\mathrm{II}-\mathrm{I} 2 .{ }^{22}$ Note, however, that even in this 'perfect' example ${ }^{23}$ there is an imbalance with the symmetric axis clearly to the left of the middle. In other words, even in Pythian 3, chronological narrative prevails. This phenomenon is even clearer in an ode such as Pythian 9, which exhibits a strikingly unbalanced ring composition. Other alleged examples for ring composition are better explained as 'initial summary with subsequent elaboration' (see above on $O$. I; $P .2 ; \mathcal{N}$. Io): the narrator first gives the gist of the story and then narrates it in more detail and in essentially chronological order. ${ }^{24}$ Still others seem to be examples of thematic ring composition but not necessarily of temporal ring composition: Pythian IO, II, I2, which all cover a short time span. Needless to say, the presence of non-chronological narrative in Pindar must not be denied. But it is fair to say that, in the final analysis, patently non-chronological narratives such as Olympian 3 and 7 or the ring composition of Pythian 3 are rather the exception than the rule. The prevalent sequence of Pindar's narratives is chronological.

For Pindar's fondness of retrograde narrative see e.g. Köhnken ı983: 52 n. I6 (with literature). R.D. Griffith 1993 adds nothing of importance.

${ }^{22}$ Figures in brackets mean that the element is suggested rather than narrated. As seen in Olympian 3, Pindar is reluctant to go over the same ground twice. The only exception is story element 2, Coronis' offence, which even occurs a third time (in connection with element 4 , focalized by Apollo). It is tempting to consider this unique repetition as meaningful.

${ }^{23}$ Illig I932: 59 .

${ }^{24}$ That is to say, the only real stepping back in time happens between summary and elaboration (on analepsis see below). In that connection, it is worth mentioning that Slater 1979: $64-65$ seems to make rather too much of the fact that the beginning of Pindar's narratives can be 'followed by either a temporal clause ... or an equivalent aorist participle'. The relevant narratives nevertheless remain essentially chronological, even if one accepts Slater's questionable argument that these temporal clauses and participles are a step back in time. 
This, of course, is not to say that there are no instances of anachrony such as analepsis and prolepsis. Of these, analepsis is more frequent. ${ }^{25}$ Its most common function is to provide the logical or factual basis for an element in the story. For example, the narrative in Nemean 9 states that Adrastus, a native of Argos, ruled over Sicyon. An analepsis explains how he came to be the ruler of Sicyon.

For in time past [pote,${ }^{26}$ to escape bold-counseling Amphiaraus and terrible civil strife, he [sc. Adrastus] had fled from his ancestral home and Argos. No longer were Talaus' sons [sc. Adrastus and his family] rulers [sc. in Argos]; they had been overpowered by discord.

(Nemean 9.13-I4)

In accordance with Pindar's general reluctance to go over the same ground twice, his analepses tend to be completing, not repeating. And although parallels to the analepsis just quoted can be found (e.g. $O$. I0.3 $\left.{ }^{\mathrm{I}-} 34,5^{\mathrm{O}-} 5^{\mathrm{I}} ; P .9 .5^{-\mathrm{I}} 7\right)$, it is true that the device as such is not particularly frequent. There are at least three possible explanations for this relative lack of analepses in Pindar's narratives: the frequency of summary narratives, the regular concentration on a short episode, and Pindar's tendency to presuppose knowledge of the underlying myth.

Comparable to the general preponderance of subsequent narrative, there is a clear preference for singulative narrative in Pindar. However, some of the more summary passages not only compress the underlying myth, but also occasionally resort to iterative narrative. Perhaps the clearest example comes from Isthmian I, which praises various athletic victories by Castor and Iolaus:

and in athletic games they took part in the most contests, adorning their houses with tripods,

cauldrons, and bowls of gold, whenever they savored the crowns of victory; $[\ldots]$

They often crowned their hair with thick wreaths from these events.

(Isthmian I.18-22, 28-29)

The narrative does not specify the individual victories, but gives a summary and iterative account. The same ode contains another example of iterative narrative when Tiresias lists Heracles' future achievements (on the prior narration see below). While some are narrated in singulative

\footnotetext{
25 For a narratorial prolepsis see $O$. I.43-45.

26 Note that Pindar marks the anachrony of the analepsis.
} 
(though very summary) fashion, Tiresias also mentions 'what fortunes he [sc. Heracles] would encounter: all the lawless beasts he would slay on land, and all those in the sea' (I. I.6 I-63). ${ }^{27}$

The relative brevity of Pindar's narratives and his occasional tendency to focus on comparatively short episodes are not amenable to intricate narratives with multiple storylines or complex instances of simultaneous events. However, a straightforward example for simultaneous events can be found in Olympian 6, where Euadne secretly gives birth to her son Iamus, while her foster-father Aepytus consults the oracle in Delphi about her pregnancy (O. 6.37-49). However, the simultaneity of the two events remains implicit (a simple men ... de construction) and is not marked as such by the narrator.

Given that Pindar often does not attempt to give a full account of the underlying myth, it will be clear that his narratives abound in instances of ellipsis. In most cases these ellipses remain implicit. Now and then, however, the temporal ellipsis is marked as such. For example, the secret birth of the seer Iamus (including his mother Euadne's justification for naming him thus) is taken up by the clause 'And when he had plucked the fruit of delightful golden-crowned Hebe, ...' (O. 6.57-58), thereby indicating that his uneventful upbringing is passed over in silence. ${ }^{28}$

While Pindar has no secondary narrative that equals that of Bacchylides 5 in length or prominence, his odes provide a certain number of shorter examples. More particularly, there is a temporal feature that is worth singling out. While Pindar's primary narratives are mostly subsequent, he has a clear predilection for having his characters resort to prior narration, mostly in the form of prophecies, which can also be described as instances of (mostly external) prolepsis. Thus Apollo predicts that Troy will be sacked twice by Aeacus' descendants $\left(O .8 .4 \mathrm{I}^{-}\right.$ 46). Likewise, Tiresias informs the stunned parents Amphitryon and Alcmene of the great achievements that their newly born son Heracles will accomplish, ending with his marriage to Hebe, that is, his diviniza-

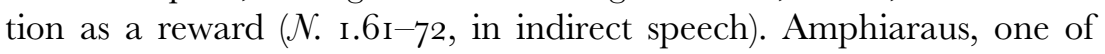
the Seven against Thebes, prophesies that the imminent second expedition against Thebes by the Epigoni will be successful, but Adrastus, another of the Seven, will lose his son $\left(P .8 .39^{-5}\right.$; ; the entire narrative

27 Cf. $P \cdot 3 \cdot 47^{-5} 53$ (on Asclepius treating various patients); 9.20-25 (on the activities of the huntress Cyrene).

28 Similarly, O. 1.67-68 (on Pelops reaching the age for marriage). 
covers little more than Amphiaraus' prophecy). Similarly, Heracles interprets Zeus' bird omen and predicts the birth of Telamon's son Ajax ( $I$. 6.50-56). A remarkable example is the case where Chiron 'predicts' to Apollo how the god will make love to the virgin huntress Cyrene $(P$. 9.38-66). Not only does Apollo know this himself (as Chiron says with a smile, $43^{-45}$ ), it is also an internal prolepsis. ${ }^{29}$ The narrator, however, recounts the same event in a very summary fashion (68-69). As in Olympian I3, a gnome ('Swift is the accomplishment once gods are in haste, and short are the ways', 67-68), so to speak, 'justifies' the brevity of the narrative. Pindar avoids going over the same ground twice in detail. A comparable case is Themis' recommendation that Thetis be married to a mortal instead of a god, because her son will be more powerful than his father $(I .8 .26 \mathrm{a}-46)$. Again, this is an internal prolepsis, with the 'repetition' by the narrator being very summary $(46-47)$.

The only secondary narrative of some length that is subsequent (and not prior) is the song that the Muses perform at the wedding of Peleus and Thetis. They relate how Hippolyta unsuccessfully tried to seduce Peleus, who was then rewarded by Zeus with Thetis' hand $\left(\mathcal{N} \cdot{ }_{5} \cdot{ }^{22-}-37\right)$.

\section{Pythian 4}

So far this chapter has largely ignored the ode that in some respects is unique. With its 299 lines Pythian 4 is more than twice as long as any other, and the contrast is even sharper when one considers the length of the narrative. ${ }^{30}$ It is little surprise, then, if the longer of the two narratives (I75 lines), which deals with Jason's quest for the Golden Fleece, has been described as 'epic-like'. ${ }^{31}$ Such a 'slow', that is, detailed narrative can of course be found elsewhere in Pindar, but the sheer length of his 'Argonautica' is unparalleled. The first part, in particular, is quite 'slow' and gives the impression that, for once, the story was indeed narrated for its own sake. In the second part one can see the narrative speed increase, together with a clear tendency to curtail the actual journey of the ship. The order of the entire narrative is essentially chronological, and there is one storyline only. ${ }^{32}$

\footnotetext{
29 To be exact, the second part of the prolepsis (59-65, about their child) is external.

30 For both see the comprehensive table in Hamilton i974: $3^{1-} 3^{2}$.

31 Race i997: I 258; similarly e.g. Braswell i988: I6r.

32 In the following table * means that the scene contains speech(es).
} 


\begin{tabular}{|c|c|c|}
\hline 246 & & ART THREE - GHAPTER FOURTEEN \\
\hline $7 \mathrm{I}-78$ & (7 lines) & $\begin{array}{l}\text { a Delphic oracle predicts that Pelias will die at the } \\
\text { hand of a son of Aeolus }\end{array}$ \\
\hline $78-120$ & $(43 *$ lines $)$ & $\begin{array}{l}\text { Jason arrives in Iolcus and meets Pelias, whom he does } \\
\text { not know }\end{array}$ \\
\hline $\mathrm{I} 2 \mathrm{O}-\mathrm{I} 3 \mathrm{I}$ & (I2 lines) & Jason's relatives gather and feast for five days \\
\hline $\mathrm{I} 32-\mathrm{I} 68$ & $\left(37^{*}\right.$ lines $)$ & second meeting of Jason and Pelias \\
\hline I69-I89 & (2 I lines) & gathering of a crew for the Argo \\
\hline I9O-2OI & (I2 lines) & omen and prayer before they set out \\
\hline $202-206$ & (5 lines) & journey to the Black Sea \\
\hline $207-2 \mathrm{I} 2$ & (6 lines) & Symplegades, journey to Colchis \\
\hline $212-223$ & (I2 lines) & Medea made to fall in love and help Jason \\
\hline $224-24 I$ & (I8* lines) & ploughing contest \\
\hline $24 I-246$ & (5 lines) & the Golden Fleece \\
\hline
\end{tabular}

At this point Pindar interrupts himself with one of his well-known Abbruchsformeln. He claims that there is not enough time (247-248) and then deals with the rest of the story (Jason kills the snake and flees together with Medea; the Argonauts on their way home reach Oceanus, the Red Sea and Lemnos) in a mere six lines (249-254). In other words, the most essential story element, the actual winning of the Fleece, is passed over in silence! ${ }^{33}$ This rush through the crucial remainder of the story is radical and rather un-epic - after all, the story of the Argonauts appears not to be narrated for its own sake, at least not all of it. But the shock of the extreme compression is to some extent mitigated by the fact that this part of the story is partially covered by the first narrative of Pythian 4, which exhibits a complex temporal structure. ${ }^{34}$

The subject matter of this narrative $\left(4^{-} 5^{8}\right)$ is the colonization of Cyrene (the victor's hometown) by Battus from the island Thera, which is predicted in two prophecies (prior narration). One is by the oracle in Delphi 'some time ago' (pote), which is said to confirm an earlier prophecy by Medea when the Argonauts reached Thera. ${ }^{35}$ Her speech covers the bulk of the narrative $\left({ }^{3} 3-56\right)$. She both predicts the colonization of Cyrene, including the descent of the founder Battus from the Argonaut Euphemus (I4-20, 50-57), and gives a twofold analepsis: how in Libya Euphemus received the clod from Poseidon's son Triton, which was then washed into the sea $(20-25,28-43)$, and how previously the

${ }^{33}$ Cf. Köhnken 1993 with a possible explanation for this striking fact.

${ }^{34}$ For both narratives see the analysis by de Jong I99rb; Hurst 1983 fails to differentiate between the narrative levels.

35 For the exact dating see above n. 4 . 
Argonauts had come to Libya from Oceanus (25-27). Prior narration in secondary narratives is quite common in Pindar, but the present case is exceptional for at least two reasons: the prophecies fall, as it were, into two stages and in reverse order (Delphic priestess - Medea). ${ }^{36}$ Secondly, Medea also gives a 'counterfactual' prophecy of what would have happened if Euphemus had returned home to Tainaros $(43-49)$ instead of going to Lemnos with the other Argonauts.

It is fair to say that, from a systematic point of view, the narratives in Pythian 4 contain little that cannot be found elsewhere in Pindar. It is, however, true that the main narrative is much longer and more detailed than any other, while the former displays an intricate temporal structure of twofold external prolepsis interwoven with an external analepsis in two stages.

\section{Bacchylides}

The fact that Bacchylides' oeuvre is not well preserved also affects our knowledge about the narrative sections within his victory odes. While five shorter poems (B. 2, 4, 6, Io and I4) can positively be shown to have contained no narrative, for five others (B. 7, 8, I2, ${ }_{14} \mathrm{~A}$ and ${ }_{14} \mathrm{~B}$ ) the question cannot be decided, because they are too fragmentary. The remaining sample of six victory odes that do contain a narrative section (B. I, 3, 5, 9, I I and I3) inevitably raises the question to what extent they can be considered typical or representative. ${ }^{37}$ This general caveat must be borne in mind in the following paragraphs that highlight similarities to and differences from Pindar, as developed in the first part of this chapter.

Like Pindar, Bacchylides locates his (generally subsequent) narratives in an unspecified past and regularly marks them off by means of the

\footnotetext{
${ }^{36}$ In a way, one could argue that Medea's speech is a tertiary narrative that is integrated into the secondary narrative of the Delphic oracle: 'the priestess ... prophesied ... that Battos would ... fulfill in the seventeenth generation that word spoken ... by Medea, which the high-spirited daughter of Aietes ... had once breathed forth from her immortal' $\left(P .4 \cdot 4^{-I I}\right)$. However, the primary narrator then seems to abandon this construction when he continues 'Such were her [sc. Medea's] words to the demigods who sailed with spear-bearing Jason: ...' (II-I2). One should probably treat both prophecies as secondary narratives, which are therefore given in reverse chronological order.

37 Of these, Bacchylides I is of very limited use, because only the end of the narrative section has been preserved.
} 
adverb 'once upon a time' (pote: $3.23 ; 5.56$; II.40). ${ }^{38}$ There is a similar contrast between the mythical past and the here and now of the celebration, as evidenced also by the relative distribution of verbs in the past tense (excluding, as before, gnomic aorists). Other similarities are the preponderance of singulative narration (for an example of iterative narration see I3.II4-I20, on the fear of the Trojans whenever Achilles attacked) and the frequency of temporal ellipsis, which usually remains implicit (explicit example: ir.92-95, Proteus roaming the forests 'for thirteen whole months').

Bacchylides also tends to focus on a shorter scene that is particularly amenable to dramatization (often including speeches) ${ }^{39}$ and regularly does not attempt to narrate the myth as a whole. This tendency results in a detailed, hence comparatively 'slow' narrative that covers a short time span. Thus the story of Croesus (3.23-62) highlights the crucial moment when he is about to commit suicide on the pyre and addresses Zeus and Apollo in a speech full of complaints. Similarly, Heracles' descent to the Underworld in order to fetch Cerberus $\left(5 \cdot 5^{6-}\right.$ I75) focuses on his conversation with Meleager (the Cerberus incident itself is not narrated at all), which, however, provides the frame for an extensive secondary narrative. ${ }^{40}$ Likewise, Ajax' spectacular defense against the attack of the Trojans (I3.IO5-I67) covers a comparatively short episode. ${ }^{41}$ While Pindar, too, often focuses on a

38 Cf. also dithyramb i9.I5 (with Maehler's conjecture).

39 Maehler 2004: 2I, 23.

40 Lefkowitz I969: passim stresses how much Bacchylides borrowed and adapted from epic poetry in his fifth ode. This model works well at a microstructural level and with a view to the secondary narrative (cf. esp. Il. 9.527-599). However, the very short time span of the framing (primary) narrative in Bacchylides is rather un-epic.

41 A similar predilection for shorter episodes can be found in Bacchylides' dithyrambs: I5 (Odysseus and Menelaus demand that the Trojans return Helen); i6 (after sacking Oechalia, Heracles sacrifices to the gods, while Deanira plans to send him the fatal garment); I7 (Theseus rescues the maidens from Minos' attacks by passing a test that involves diving into the sea); likewise, i8 also deals with a short episode, but is better not treated as narrative, because it is purely dialogic. Conversely, I9 (on Io) is Bacchylides' only dithyramb that attempts to treat an entire myth (B. Zimmermann I992: I02), albeit in summary fashion. Pindar's dithyrambs are too fragmentary to allow an extensive comparison of the narrative style. Even if his second dithyramb (frr. 7ob; 249; 8I) indeed covers a larger part of the myth (B. Zimmermann I992: II4 n. 4), the question must remain open whether this is representative for all his dithyrambs. To claim, with B. Zimmermann I992: iı6, a fundamental difference between the narrative styles of the two poets is not only based on comparatively little evidence from Bacchylides' dithyrambs and even less from Pindar's, but, more importantly, ignores the way in which Pindar structures his narratives in the victory odes. 
shorter episode, Bacchylides has a certain penchant for abruptly breaking off his narratives, so to speak, without prior notice (contrast Pindar's explicit Abbruchsformeln) and before they reach the crucial moment. This phenomenon, however, is more common in the dithyrambs (B. I5, I6 and $\mathrm{I}_{7}$ ) than in the victory odes $(5) \cdot{ }^{42}$

Conversely, not all Bacchylidean narratives single out a short episode. Thus the story about the madness of Proetus' daughters (II.40I I2) is fairly complete, but it, too, highlights salient moments, for example Proetus' desperate prayer to Artemis (95-I05), whereas other story elements are narrated more summarily. ${ }^{43}$

While the last example shows that narrative speed does not remain even throughout Bacchylides' narratives, it is true that he exhibits fewer and less abrupt changes of narrative speed than Pindar. Very short narrative sections and hence extremely summary passages, in particular, seem to be rare in Bacchylides, ${ }^{44}$ who mostly gives the overall impression of a more leisurely and balanced narrator than Pindar.

In terms of temporal structure, Bacchylides' narratives are essentially chronological and overall simpler than Pindar's (there is no equivalent to the chronologically complex Olympian 3). There are, nevertheless, instances of anachrony. Thus the story about the madness of Proetus' daughters (II.40-II2) contains two major analepses, both of which provide information that is crucial for a proper understanding: why did Hera punish them with madness? Answer: because of their hollow boast that their father's wealth exceeds Hera's (47-52). Why were Proetus and his family living in Tiryns and not in Argos? Answer: because of a quarrel between him and his brother Acrisius (64-72). ${ }^{45}$ Similarly, the final lines of the Croesus narrative (3.6I-62) analeptically explain that Apollo rescued him on account of his numerous offerings. ${ }^{46}$ And

42 Rengakos 2000, following Wilamowitz 1903: 103, speaks of the 'Abgerissenheit' of Bacchylides' narratives. The poet does give an indication of how the story ends, but in the form of hints and adumbrations, not in the form of explicit prolepses.

${ }^{43}$ On the exceptional dithyramb ig see n. 4r above.

44 Thus Hamilton i974: 8o, but cf. 9.10-20.

45 The two analepses are both introduced by the explanatory particle gar (van Groningen 1958: 196) and provide fundamental information. Maehler's description as 'Exkurse' (I982-I997: II 22I) or 'digressions' (2004: I45) is unfortunate. While the second analepsis goes further back in time than the first, the two should not be explained as the retrograde part of a ring composition, because in between (53-63) the narrator returns to the chronologically narrated main story.

${ }^{46}$ Cf. the explanatory analepsis at the end of dithyramb i6.34-35 (van Groningen I958: 190). Generally speaking, the narratives of the dithyrambs are even more linear 
I3.II4-I20 describe the Trojans' fear before Achilles stopped fighting for the Greeks (the anachrony being marked by prin 'before').

While narratorial prolepsis is rare in Pindar, it is difficult to say whether Bacchylides' only example is statistically relevant. Much more important, however, is the fact that it is a memorable instance of narratorial prolepsis. Similarly to Homer's well-known neppios-passages, Bacchylides exposes the Trojans' high hopes after Achilles' retreat as futile.

High-spirited in their great hopes and uttering arrogant shouts those Trojan horsemen [thought that they would lay waste] the dark-eyed ships [and return home again] and that their god-built city would hold feasts in [its streets?]. In truth they were destined first to crimson the eddying Scamander as they died at the hands of the tower-wrecking Aeacidae [i.e. Ajax and Achilles].

(I3.I57-I67; tr. Campbell I992)

The fact that the narrative ends with this gloomy anticipation of Trojan losses no doubt adds to its effect.

Bacchylides also provides examples for 'initial summary with subsequent elaboration'. Two of his narratives display a close thematic and temporal correspondence between the initial summary and the end of the elaboration. Thus the narrative about Proetus' daughters is framed by:

For her [sc. Artemis] the son of Abas [sc. Proetus] and his fair-robed daughters once [pote] established an altar at which many prayers would be made. [67 lines omitted] And they at once built a sanctuary and altar for her and drenched it with sheep's blood and established choruses for women.

(II.40-42, IIO-II2)

A similar frame can be found around the story about Croesus' rescue $\left(3.23^{-29}, 5^{8-6 I}\right)$. It is no surprise, then, if scholars again speak of 'ring composition', as, for example, Illig does, who, however, notes a crucial point ignored by some of his successors: there is only one ring. Bacchylides does not give the retrograde first part of a ring composition, but immediately launches the essentially chronological narrative. ${ }^{47}$ The argument whether 'ring composition' or 'initial summary with subsequent elaboration' better reflects the facts is, of course, of minor impor-

than that of the epinician odes (van Groningen 1958: 193), that is, contain fewer anachronies.

47 Illig 1932: 6o even 'rewrites' the beginning of the narrative in Bacchylides II, in order to demonstrate how Pindar, who according to Illig favors 'true' ring composition (as found in Pythian 3), would have structured the narrative. 
tance in view of the fundamental observation that chronological order prevails in Bacchylides' narratives.

Turning to secondary narratives, the observation can be made that Bacchylides does not share Pindar's general preference for prior narration (cf., however, I3.54-57: an unidentified goddess predicts the foundation of the Nemean games). Instead, he provides two rather spectacular examples of a feature that cannot be found in Pindar's extant odes: simultaneous (secondary) narration, that is, a character who describes what is happening. The same unidentified goddess gives a gripping account of Heracles' fight with the Nemean lion:

see the neck-breaking hand that Perseus' descendant [sc. Heracles] lays with all manner of skill on the flesh-eating lion; for the gleaming manmastering bronze refuses to pierce its unapproachable body: his sword was bent back.

$\left(13 \cdot 4^{6-54)}\right.$

Elsewhere Croesus gives an equally urgent report (underlined by the asyndetic construction $)^{48}$ of how the Persians are taking his city.

[The Persians are sacking my] city, the gold-swirling Pactolus is reddened with blood, the women are shamefully carried off from the well-built halls.

$(3 \cdot 43-46)$

The latter passage has been called a 'Reportage' ${ }^{49}$ Indeed, both instances of simultaneous narration turn the secondary narratees (and, by extension, the primary narratees) into immediate witnesses of the action.

The secondary narrative that sticks out for its sheer length is Meleager's 'autobiography' (5.97-154), addressed to Heracles. Its temporal features, however, are straightforward. The narration is subsequent, chronological, singulative and shows comparatively little variation in narrative speed.

Both Pindar and Bacchylides exhibit a considerable variety in the way they handle time in their narratives, as the preceding discussion has attempted to show. It is this very variety that makes it impossible to round off this chapter with a few concluding remarks without forcing oneself into a straitjacket which hardly does justice to the breadth of the evidence.

48 Maehler 1982-I997: II 49.

49 Maehler I982-I997: II 49, adducing the passage from Ode $\mathrm{I} 3$ as a parallel. 
Irene J.F. de Jong and René Nünlist - 978-90-47-42293-8 Downloaded from Brill.come4/26/2023 09:46:52AM via free access 
PART FOUR

DRAMA 
Irene J.F. de Jong and René Nünlist - 978-90-47-42293-8 Downloaded from Brill.come4/26/2023 09:46:52AM via free access 


\section{GHAPTER FIFTEEN}

\section{AESCHYLUS}

\section{J. BARRETT}

Tragedy, it has been said, is 'designed to resolve temporal tensions'. This is perhaps true nowhere as much as in the case of Greek tragedy, which enacts complex temporal schemes predicated in the first instance upon the demanding 'coincidence' of a (nearly always) 'ancient' myth and the 'now' of performance: distant 'thens' are made present as the (fifth-century) present is retrojected into the world of myth. ${ }^{2}$ Of a piece with this key premise are the rich temporal structures of the drama's narrative sections. This particular aspect of narrative practice, then, does work that is in some ways comparable to that of the plays more broadly. ${ }^{3}$ Although a consideration of these wider implications in any systematic sense is beyond the scope of this study, it is helpful to keep in mind that narrative manipulation of time offers one path to understanding any given narrative's function within the drama that contains it. ${ }^{4}$

Although narrative appears in all of Aeschylus' plays, its distribution is uneven. Seven Against Thebes, Suppliants, Choephori, and Eumenides contain comparatively small amounts, while there is something of an abundance in Persians, Agamemnon, and Prometheus Bound. ${ }^{5}$ The following discussion reflects this unevenness. This situation presents a dilemma with respect to Prometheus Bound: do we keep this play at arm's length because of its uncertain authorship, or do we grant it its due as an

${ }^{1}$ Burke i966: 137, cited by Rosenmeyer 1982: 330.

${ }^{2}$ Cf. Markantonatos 2002: 13-I4, and the comments of Käppel 1998 with respect to the chorus in this regard, esp. 66-67. This temporal complexity finds an analogue in tragedy's spatial practices: cf. Rehm 2002: 20-25. Cf. Duchemin i97o, esp. 85-86.

3 Cf. Goward 1999: 21-37, and 6o-62 on Aeschylus in particular.

${ }^{4}$ For examples of how this might work in Agamemnon see Duchemin 1974: 123, and I35, where she speaks of this play's 'caractère intemporel'; Anderson I997: II I-II3.

5 Seven Against Thebes is rich in description (of the attacking warriors and their shields), but for present purposes I bracket this apart from narrative. On the distinction between descriptive pause and description see Genette [1972] I980: 93-94 with n. I2. 
important witness to narrative practice in Athenian tragedy? Because, it may be said, narrative is at the center of this drama, I here 'err' on the side of paying 'too much' attention to this play. In the end, the danger in this approach is limited: only when generalizing about Aeschylean practice must we be careful when taking this play into account.

As a matter of convenience I group the narratives below into four broad groups: retrospective, prospective, mixed, and repeating. ${ }^{6}$ Within the first category I distinguish a subset of catalogue narratives, while the third category is comprised of narratives that, for various reasons, do not fit easily into any of the others.

\section{Retrospective narratives}

Retrospective narratives take the form of subsequent narration: they recount afterwards something that has happened earlier. A relatively straightforward example, without anachrony, is Atossa's account of her dream and the omen of the hawk and the eagle (Pers. I76-2II). ${ }^{7} \mathrm{Un}-$ problematic in terms of order, this narrative uses rhythm and frequency to help shape the unfolding and meaning of events in the drama. The Queen begins with the announcement that she has been 'incessantly visited at night by numerous dreams' (pollois men aiei nukterois oneirasi, I76). What seems initially to be an account of frequently repeated

${ }^{6}$ Since in $S A G \mathcal{N}$ the position is taken that drama is not narrative $(S A G \mathcal{N}$ г:6-7), the terms 'retrospective' and 'prospective' narratives are used instead of 'analepsis' and 'prolepsis'. It would be possible to identify a group of simultaneous narratives as well, yet this group is small. Here we would find, for example, the chorus' song about their own status and the state of affairs in Argos (A. 69-I03). Although Clytemnestra's account of events at Troy $(A .320-337)$ is imaginary (Spring 1917: 19I; Anderson 1997: II5), her narrative imagines these events as ongoing; and although the chorus' description of the assault on Thebes and the city's (imagined) fall (Th. 287-368) may well be understood as iterative (i.e., these are the kinds of things that happen when a city is attacked; see below), this narrative is also an account of the chorus' present fear. On simultaneous presentation see Goward 1999: 32-35.

7 This group also includes the messenger's report of the slaughter on Psyttaleia (Pers. 447-47I); the herald's account of the shipwrecks of those leaving Troy (A. 650670); Clytemnestra's account of Agamemnon's death (A. I379-1398); Aegisthus' 'family history' (A. I583-I602); Orestes' report of Apollo's command (Ch. 269-296); as well as the dialogic narrative at Choephori 522-539; and those discussed below as catalogues. Some in this category have minor anachrony, such as the analepsis at Persians $466-467$, where the messenger reports Xerxes' position 'atop a high hill near the sea' (464)from where he watched the battle - only after announcing that all in the Persian force at Salamis had died. 
experience becomes a report of 'last night's dream ... the most vivid I have yet beheld' (I79-I80). ${ }^{8}$ In other words, the narration is strictly speaking singulative, yet works as iterative: in recounting this particular (and particularly meaningful) dream, the Queen (also) puts on display the kind of dreams she has been having since Xerxes led the army to Greece. Her narrative thus renders this particular dream even more portentous than it might otherwise be, standing, so to speak, as the culmination of a lengthy history of such dreams. And the specific content of the dream - the symbolic yoking of the Hellespont and the Greek resistance - take on emphasis as the most 'vivid' (enarges, I79) expression of the (soon-to-be-realized) danger she fears.

This narrative's rhythm, too, emphasizes the looming disaster. Using language appropriate to the context of a dream, the Queen speaks of the 'appearance' of the two women (edoxatèn, I8I) and describes what she 'saw'. But the language of description gives way to a curious form of summary at i86-г87: 'One of them lived in her fatherland, Greece, which she had obtained by lot, the other in the land of the barbarians'. Without insisting on realism, one can easily see that this sentence contains a longer story: just what would the action of obtaining by lot look like in a dream? Up to the point in the dream when the conflict occurs (I88), then, no action is recounted except in summary form. Here, though, the narrative shows its interest in this conflict, and in the 'Greek' resistance, by giving substantial space to its telling: one of the two women 'struggled, tore the harness from the chariot with her hands, dragged it violently along ...' (I94-I95). Summary gives way to scene as the narrative turns from background to the portended danger.

The Queen's account, finally, opens a window on two important qualities of narrative in Aeschylean texts: first, that a narrative of even relatively simple temporal structure can prove to be quite complex, and, second, that this structure may articulate with the drama's broader engagement with time. The Queen's dream-like dreams already in Homer - is a portent: this relatively simple retrospective narrative, that is, proves to be more complex in that it also functions as a 'prospective' narrative, insofar as the dream figures the future. ${ }^{9}$ That the Queen herself recognizes this - at least as a danger - is evident from her

${ }^{8}$ For Persians I use the translation of Hall 1996.

9 The same may be said of her account of the hawk and the eagle, which follows that of her dream. 
anxiety. ${ }^{10}$ Furthermore, this 'coincidence' — or approximation - of past and future points to two key concerns of the play as a whole. First, the play's theological teaching insists that present action is comprehensible only with reference to the past - or put differently, the past is never entirely past in that it persists as (part of) the present; and second, the presentation of Persian anxiety and suffering takes place, in the words of Duchemin (1974: I37), in a 'temps-hors-du-temps', where past, present, and future are not always distinct. ${ }^{11}$ This retrospective, singulative narrative that also functions as a 'prospective' narrative and works as an 'iterative' narrative displays well both what complexity may lurk behind seemingly simple façades and how the temporal manipulations of narrative perform work that is analogous to - and part of - the (temporal) work of the play as a whole. ${ }^{12}$

Retrospective narratives more frequently do contain anachronies, as does Prometheus' account of the Titanomachy and its aftermath (Pr. I97-24I). The anachrony of this retrospective narrative displays some complexity: prolepsis within analepsis. The manipulation of rhythm and frequency here also deserves notice. Prometheus' narrative opens by marking what at first appears to be a sharp beginning of the fabula, referring to the onset of anger and conflict in the divine realm (epei takhista, I99-200). This apparent coincidence of story and fabula disappears, however, when Prometheus reports that his mother had foretold to him more than once that victory would come through trickery, not force. In the lines immediately prior to these, Prometheus says that when strife broke out he offered the best advice to the Titans without success: they dismissed his wily stratagems, thinking that they would be victorious through sheer violence alone (204-208). The source of his stratagems, however, is explained in an analepsis (209-2I3): they were formed on the basis of his mother's prophecies. Here we discover that the fabula begins earlier than the story at first makes clear. This analepsis, however, does more than recuperate a missing, earlier element of

10 The chorus as well acknowledge the danger at $215^{-2}$ I9. It must be said, however, that this scene produces dramatic irony that turns on this temporal ambiguity: the spectators as primary narratees would recognize that this retrospective narrative also functions as a prospective narrative since they would have been familiar, of course, with recent history. Cf. Aelion ig8r: I40-I4I.

11 On the play's theology see e.g. Paduano i978: 34-35 with nn. 7-8; WinningtonIngram i983: I-I5.

12 As Aelion I98I: I4I notes, this 'prospective' narrative proves to be retrospective in a different sense when the messenger enters: the disaster portended by the dream and omen has already occurred, and this 'future' event proves to be, in fact, past. 
the fabula: it also constitutes a prolepsis, for here we learn that the Titans will be defeated. Soon thereafter Prometheus' narrative moves from his alliance with Zeus to the present moment: it is due to his advice to Zeus that the Titans today are confined to Tartarus (219-22I). The prolepsis revealing that the Titans will be defeated, however, is of a special type, in that the victory prophesied by Gaia/Themis is never recounted. Rather, although Prometheus' narrative alludes to the victory, and even to how it was achieved, the battle itself - and the wily stratagem in particular - find themselves displaced by an ellipsis. And this ellipsis deserves notice.

It is, of course, a commonplace in Greek literature for traditional narratives to be presented via summary and ellipsis. In part, Prometheus' ellipsis conforms to this model: Hesiod's account was presumably familiar to many spectators and Aeschylus has relied upon this familiarity. But this explanation is only partially satisfactory, since Aeschylus here innovates: in identifying trickery as the decisive element in the Titanomachy, he departs from the (traditional) version in Hesiod. ${ }^{13}$ The ellipsis, then, refers to the familiar as it leaves unanswered the question: What was the trickery? The silence of this narrative about the Titanomachy as a whole has yet another consequence. Although the spectators as primary narratees may well be able to fill in much of what is passed over, the same cannot be said of the secondary narratee, the chorus. They, after all, have no idea about cosmic history, as is evidenced by their dialogue with Prometheus preceding this narrative. We must, then, recognize that although we may be left wondering what the trickery was, the chorus remain ignorant of the Titanomachy in toto, aside from its outcome, of course. (It must be said that Prometheus is most of all interested in establishing his role in the outcome of the battle, and an account of how it all happened is only peripheral to this task.) In any case, the text here contains something of a tension between the differing abilities of the narratees (primary and secondary) with respect to making sense of the ellipsis. ${ }^{14}$

13 Cf. Solmsen I949: 129 n. 22 with M. Griffith I983: ad 193-283, 216-218, and 219-22I. Just how many among the spectators may have been familiar with Hesiod's version is, of course, an unanswerable question. Given the status of Hesiod in this period, however, it seems likely that many would have been. In the end, my comments concerning innovation here will apply only to those spectators familiar with Hesiod.

${ }^{14}$ As both Solmsen 1949: I29 n. 22 and M. Griffith I983: ad 219-221 note, this version credits Prometheus with much, emphasizing the value of his intelligence. The 
With respect to this narrative, finally, I note the occurrence of iterative narration at 209, where Prometheus says that his mother gave her prophecy not one time alone (oukh hapax). Although it might be thought that the report of multiple acts of prophecy serves to condemn the Titans for the obstinacy that Prometheus mentions (207), he informs us that Gaia/Themis spoke the prophecy to him (emoi, 209). Prometheus' iterative presentation, then, serves principally to authorize, and to explain, his own intervention. His advice to Zeus proved to be valuable in fact, in that Zeus did defeat the Titans, but it proves now to be inspired by more than Prometheus' cleverness: his cleverness, he tells us, is supported by the prophetic powers of his mother.

Various forms of prolepsis occur in the messenger's account of the battle of Salamis (Pers. 353-432). At the outset, the narrative offers a brief suggestion of a snare in the form of an actorial 'prolepsis': a Greek tells Xerxes that the Greeks will attempt to flee once darkness falls (355-360). We, along with the Queen, are briefly invited to take this actorial 'prolepsis' as a guide to what will follow, just as Xerxes so fatefully does. This 'prolepsis', however, is immediately withdrawn, when the messenger explains that the Greek was lying (36I-362). (Indeed, both the Queen and the spectators, when listening to this narrative, know that - but not how - the Persians have suffered a disaster. $)^{15}$ Thereupon, however, follows a 'real' prolepsis, that of Xerxes' orders to his men concerning what they are to do at nightfall $(364-37 \mathrm{I})$. Having indicated what would happen at dark, the narrative proceeds to track the sailors' actions leading up to these prefigured events: preparations for the evening, and for the battle, were under way $\left(374^{-376)}\right.$. When darkness arrives and the sailors do as they were ordered, the messenger's narrative repeats, if in summary fashion, the substance of the prolepsis $(38 \mathrm{o}-38 \mathrm{II}) \cdot{ }^{16}$

The choral narrative of the events leading up to Iphigeneia's sacrifice at Aulis in the parodos of Agamemnon (IO4-257) contains a complex and subtle manipulation of temporal elements, including matters of order, rhythm, and frequency: we find both analepsis and prolepsis, as well as

\footnotetext{
ellipsis here allows that intelligence to remain somewhat enigmatic and, consequently, perhaps unlimited (in the eyes of the narratees).

15 Those in the audience who had been at the battle, needless to say, would be invulnerable to such a 'snare'.

16 Although I now find the arguments unpersuasive, some take the subject in line 374 to be the Greeks rather than the Persians. In this case, there would be no prolepsis. For Greeks see Hall ı996: ad 374-383; for Persians see Bakewell 1998.
} 
repetition, summary, and ellipsis. Altogether this magisterial display of narrative possibilities expresses in short order some of the play's most pressing concerns.

This narrative of events at Aulis begins with the omen of the eagles and the hare, which is followed by the seer Calchas' interpretation (I26-I45) and a prayer to Apollo (I46-I55), asking that he intervene to protect the Greeks from Artemis' wrath. The so-called 'Hymn to Zeus' then follows (160-I83), before the chorus resume the narrative proper and recount the debilitating delay in port, Agamemnon's quandary, and the preparations for the sacrifice itself $(184-257)$.

In reporting Calchas' interpretation of the omen, the choral narrative presents a revealing prolepsis. This actorial prolepsis announces the fall of Troy. When spoken at Aulis, of course, these prophetic remarks need not have been less believable than after Troy did in fact fall, but it is worth noting that for the chorus now, in Argos, recounting what happened some ten years earlier at Aulis, the fall of Troy is still-as far as they know - unrealised. This is, of course, relevant only because, in fact, Troy at this moment has fallen: what remains a 'future' event for the chorus - not only in terms of narrative order but also in terms of actual experience - is for the primary narratees, the spectators, an event of the past. This much, after all, the watchman announces at the play's outset. ${ }^{17}$

A second, internal prolepsis in Calchas' remarks comes via his prayer that Apollo somehow avert the delay in port with its debilitating consequences, one of which he identifies as 'another sacrifice' (I5O-I5I), clearly that of Iphigeneia. ${ }^{18}$ In calling this prolepsis 'internal' I include in the narrative of events at Aulis the death of Iphigeneia which itself is present only by way of highly marked and explicit ellipsis ('What fol-

${ }_{17}$ My comments above on the Queen's dream and the omen in Persians apply in large part, mutatis mutandis, to the omen of the eagles and hare at Agamemnon II I-I2O. Cf. Aelion I98I: I40-I42; cf. also Anderson 1997: III-II3, who speaks of the omen and its interpretation as 'a temporally looped chain of causality' (II3). An incisive analysis of riddles and metaphors in Agamemnon, with much to say about the passages I discuss here, is Ferrari 1997; cf. in particular her careful consideration of the omen and Calchas' interpretation of it at 26-35. Her elucidation shows well the temporal complexity of this passage. Cf. Stanford [1936] I972: I44-I49. Cf. also Peradotto I969: 246-247; M. Edwards 1977: 23-24; Goldhill 1984: 19-20.

18 But cf. Lebeck 1971: 34-35; M. Edwards I977: 24 with nn. 31 and 32; and Ferrari 1997: 26-28, who argue that there are multiple referents here, including the death of Agamemnon. Insofar as 'another sacrifice' refers to that of Agamemnon, this remains a prolepsis. 
lowed I neither saw nor tell', 247). The presence of her death, however, is so strongly felt and so important to the narrative that, I think, we have no choice but to acknowledge that even if the chorus choose not to tell it, it is the center of gravity around which the rest of the narrative turns. One indication, then, of how this narrative exploits the possibilities of its temporal code appears in this early proleptic announcement of the narrative's climactic moment: a moment which both marks the goal and conclusion of the narrative, on the one hand, and, on the other, finds itself displaced by the chorus' refusal to tell it. ${ }^{19}$

Following the 'Hymn to Zeus' (I6o-I83), the chorus continue their narrative of events at Aulis with the temporally ambiguous phrase 'and then' (kai tote, i84). As Fraenkel points out, ${ }^{20}$ the temporal adverb here signals continuity between the earlier narrative section concerning the omen and what the chorus now undertake to tell, but only vaguely. Indeed, as the syntax of this long opening sentence (I84-204) suggests, the temporal code of this narrative is complex and somewhat difficult to grasp..$^{21}$ Part of this difficulty is produced by an anacoluthon which arises when the initial subject (Agamemnon) never acquires a main verb and finds itself displaced by a different construction beginning with another temporal adverb ('when') at 188: And then the senior commander of the Achaean fleet, blaming no prophet, giving in to the blows of fortune, when delays in port ...' (184-188). What begins as an account of Agamemnon's response to the delay in the harbour and its attendant ills - including a new prophecy by Calchas, briefly alluded to in 'blaming no prophet' - turns within a few lines to these events which, in fact, precede the 'then' of line 184 . Only in 20I-204 do we hear more about the new prophecy. But if we are to understand just what Calchas says, we must reconstruct it from Agamemnon's response to it, which follows at 205-217. These dizzying anachronies are accompanied by two other temporal devices that deserve notice: repetition and extreme summary that verges on ellipsis.

Some of the proleptic elements of Calchas' prayer to Apollo (I46I55) - the delay in harbour and the sacrifice of Iphigeneia- are repeated in the chorus' narrative. The sacrifice reappears, in much

${ }^{19}$ Cf. Goldhill I984: 31 and Goward I999: 48 on this refusal.

${ }^{20}$ Fraenkel 1950: ad 205.

${ }^{21}$ Fraenkel I950: I I20 n. I, however, expresses puzzlement that the 'clear evidence' has not been perceived by all. On the difficulties here see Goldhill I984: 28-29; Goward 1999: $4^{8}$. 
greater detail, at 207-247. After appearing initially at I49 without elaboration, the delay is identified at 188 as causing hunger, while its consequences become more varied at $192-198$. This third and most elaborated reference to the delay provides an example of how summary may be so extreme that it verges on ellipsis. The winds that cause the delay in port are described by three adjectives meaning 'wearing out with idleness, causing famine, and making for bad moorings' (I94). It is these adjectives that summarize the events leading up to Calchas' prophecy and to Agamemnon's decision, but the summary is so condensed that the narrative here contains a series of virtual ellipses. This allusive quality continues in the following lines, which may, or may not, compensate for the 'ellipses' here. The 'wanderings of men' (195), after all, may allude to the necessity of wandering in search of food, a necessity that famine would likely impose. ${ }^{22}$ Even so, such 'compensation' is barely more informative than the summary it augments.

The repetition and maze-like structure of this narrative's temporal code reproduce an important thread of meaning in the choral narrative. The opening words of line 184 ('and then') mark the coincidence of temporal ambiguity at the narrative level and at the experiential level of the Greeks at Aulis. And this coincidence continues in several ways. As Bollack notes, ${ }^{23}$ the term the chorus use to describe the temporal effect of the delay (palimmēke, I96) indicates 'un retour en arrière, un retour sur soi en sens inverse'. Just as the narrative itself returns to familiar ground, that is, so do the Greeks experience 'un retour en arrière'. Evidence of such 'turning back' appears even at the textual level: hegemonn ho presbus (184-185) reappears as anax d' ho presbus (205); antipnoous ... aploias (I47-I48) is echoed in sumpneon ... aploiai (I87-I88); Kalkhas ... apeklagxen ( 156$)$ returns as mantis eklagxen (20I). Manipulation of the temporal code, then, is but one aspect of the narrative's attention to temporal displacement and uncertainty: meaning and narrative structure coincide in this regard. ${ }^{24}$

${ }^{22}$ Cf. Fraenkel i95o: ad i94.

23 Bollack I981: 27I.

${ }^{24}$ Bollack I981: 272 comments: 'Le temps n'est alors plus orienté ... les guerriers sont dépossédés de la possibilité de se fixer un but'. 


\section{Retrospective narratives: catalogues}

Unlike the plays of Sophocles and Euripides, those of Aeschylus contain a noteworthy subset of (typically) retrospective narratives that may be called 'catalogues'. ${ }^{25}$ This group is something of a special case in that these narratives generally recount only minimal action, while offering a virtual inventory of names (of people, places, etc.). ${ }^{26}$ This paucity of action makes order comparatively unimportant, though occasionally suggestive. In fact, the more such narratives approximate (mere) lists, the less chronology plays a role. Prometheus' account of his many benefactions to humans (Pr. 436-506) and Clytemnestra's 'beacon speech' (A. 28I-3II) are two instructive examples. The relative simplicity of these narratives is indicated in part by a paratactic style. Like Aeschylean catalogues generally, these two show little or no anachrony. ${ }^{27}$

Clytemnestra's 'beacon speech' $(A$. 28I-3II) recounts the ordered advance of fire signals from Troy to Argos. At once a story of action and a catalogue of beacon sites, this narrative is characterized by parataxis: an accumulation of narrative elements joined by various terms without temporal significance $(d e, t e, k a i)$. Here, however, the various elements are clearly ordered in a temporal sequence, and this narrative order corresponds to the sequence of events in the fabula. Indeed, Clytemnestra speaks of 'laws' (nomoi, 312) that govern the transmission of the signal from one beacon to the next: her narrative of this reg-

25 Not all such narratives in Aeschylus are retrospective, however. Prometheus' accounts of Io's future wanderings $(\mathrm{Pr}$. 707-735, 790-815) comprise geographical lists. Cf. Rosenmeyer 1982: I 12-II4 on geographical inventories in Aeschylus. Korzeniewski I967: 33 finds in these lists a 'Stilprinzip der frühgriechischen Dichtung' and speaks of a 'systematischer Aufbau' (35). Cf. Korzeniewski I966: 557-558. Paduano 1978: 4I calls the catalogue in the parodos of Persae a 'mezzo di amplificazione' producing a 'messagio dell'elefantiasi'. Cf. Saïd I988: 332.

${ }^{26}$ Aeschylean catalogues appear outside of narrative as well (cf. Rosenmeyer 1982: Io9-II7). I take up only those that are also narratives.

27 Other catalogues include: the chorus' account of those gone to Greece (Pers. I-64); the messenger's list of those who have died (Pers. 302-330); the messenger's list of places traversed by the Persian army in flight (Pers. 480-497); Darius' ghost's brief 'history' of Persian kings (Pers. 759-786); the chorus' list of territories ruled by Darius (Pers. 867-896); the Pythia's account of Delphic 'history' (Eu. I-I9). On this last passage see Rosenmeyer I982: III-II2, in particular his keen observation that by means of this list 'the liberating dimension of history enters and promises to unclog the old inflamed congestions' (II2). I understand the temporal patterns of the parodos of Agamemnon (discussed above) and of Cassandra's narratives (discussed below) as key parts of these 'congestions'. Here again, then, the temporal structure of this narrative carries out important work of the play — and of the trilogy — as a whole. 
ulated sequence reproduces the order which her narrative implicitly attributes to the events themselves. ${ }^{28}$ Coincidence of temporal orders here serves to demonstrate and, to some extent, to put on display the effectiveness of the 'laws' of the beacons. The narrative thus 'explains' how the beacons function, as it demonstrates the skillful forethought and conspicuous talents of Agamemnon's capable wife. Here, then, the organization characteristic of catalogues helps sustain the order of both fabula and story. ${ }^{29}$

Prometheus' account of his many benefactions (Pr. 436-506) displays a similar paratactic style, signaled again by use of kai, te, and $d e$. But if this narrative consists largely of a catalogue, the catalogue itself consists of actions. Prometheus here uses at least twelve different verbs to describe his 'gifts': 'I gave', 'I showed', 'I discovered', 'I yoked', 'I devised', 'I systematized', 'I made visible', etc. This catalogue, it seems, is really a series of highly summarized stories. What is lacking, however, is a temporal dimension connecting this collection of condensed stories. The many gifts of Prometheus, that is, appear to have been given all at once - or at least we are unable to say which may have been earlier, and which later. The particulars of the catalogue narrative, then, matter not as temporally distinct elements of a series of events, but rather as their sum total. The summary that is characteristic of the narrative, therefore, is significant in a double, even contradictory, fashion: on the one hand, this summary invites the narratee to imagine the content behind, for example, Prometheus' allusive report that he 'systematized' the mantic art (484), while, on the other hand, the rapid sequence of highly condensed reports of this type serves in the end to emphasize the absence of any account of what lies behind such summaries. Although the narratee may be unable to learn anything about how Prometheus accomplished these feats, the catalogue narrative makes clear that the actions of Prometheus himself are at issue here, not merely the 'gifts' that humans received. And it is the summary, in large part, that accomplishes this.

${ }^{28}$ Anderson 1997: 128 puts it this way: 'her speech guides the beacons to their finishline in Argos'.

${ }^{29}$ With Fraenkel 1950: ad 313 I understand Clytemnestra to be the source of the nomoi that govern the beacons. Not only does she display a masterful understanding of these nomoi, but she says with confidence 'Such are the rules of the torch-bearers' (312). On the strength of the pronoun moi in this line, Collard 2002 translates with 'my arrangements'. This matters because the coincidence of temporal orders proves to highlight her control, and organizational skills, in both domains. 


\section{Prospective narratives}

Few narratives prove to be prospective in their entirety. The most significant among these are Prometheus' accounts of Io's future wanderings and what they will lead to $\left(\operatorname{Pr} .707-735,790-815,844^{-876) .}{ }^{30}\right.$ These narratives are principally prophetic, although the prophetic statements are often interlaced with admonitions. Prometheus accordingly employs many imperatives alongside the future indicatives. That these imperatives indicate not only what Prometheus advises, but also what Io will do, is evident from the fact that the events related in the clearly prophetic account of Epaphus and his descendants (846-873) - an account marked by the prophetic present at 848 (tithēsin) and by future indicatives elsewhere - will occur only as a consequence of Io's obedience to Prometheus' commands. In introducing his prospective narrative, furthermore, Prometheus speaks of what Io must do (703-706), and in so doing he makes it clear that what he is about to describe is part of a single journey that concludes in Egypt.

The vocabulary of the journey, in fact, points to the most prominent temporal element of Prometheus' narratives. With two exceptions, these narratives show no anachrony. Rather, they track Io's journey closely: their progress coincides with hers. Indeed, Prometheus speaks of the track of his narrative (ikhnos, 845), a term that calls to mind the journey or path that Io will follow (hodos, 706) as it suggests the coincidence of the fabula's temporal order with that of his story. ${ }^{31}$ This coincidence reappears in the most substantial ellipsis of his narrative. Once his account of Io's wanderings brings her to Egypt and names her child by Zeus, it turns immediately $\left(8_{52}\right)$ to a much later time, that of the fifth generation, the Danaids. What happens in the meantime is, apparently, of no more concern to Io than it is to Prometheus: as the track of his narrative follows the path of her wanderings, it comes to a 'conclusion' of sorts when her journey ends. And it is here that his story jumps forward, abandoning its earlier strict adherence to the fabula.

This earlier strictness, however, is not absolute. Twice Prometheus' account includes an external prolepsis. At $724-727$ he speaks of the

\footnotetext{
${ }^{30}$ Substantial prospective narrative sections occur in Eumenides (68I-9I5), where Athena tells, piecemeal and in part through dialogue, the future of the Areopagus and of the Eumenides themselves. Amid these prophetic remarks, Orestes announces an oath (762-774) that in retrospect must be acknowledged to be prophetic at least in part.

31 Cf. Kaimio 1970: 84. On path as metaphor see Becker 1937; Nünlist 1998a: 228283 .
} 
future of the Amazons, and at $73^{2-734}$ he informs Io that her crossing of the Bosporus will engender a 'great story' including the naming of the spot after her. That this narrative does (a bit) more than track Io's journey is evident as well from the digression at 709-7II; here Prometheus reports on the (odd) practices of the Scythians.

\section{Mixed narratives}

A number of Aeschylean narratives fit comfortably into neither of the categories above because they contain various combinations of retrospective, present, and prospective elements. The most substantial and complex examples of this type are the last of the three narratives spoken by Darius' ghost (Pers. 800-820) and Cassandra's accounts of past, present, and future ills in Argos (A. I072-II72, II78-II97, I2I5-I245). Both of these narrators, of course, rely upon prophetic knowledge, a factor which partly explains the temporal richness of their narratives. Cassandra is inspired by Apollo, while Darius' ghost recalls oracles (739) given at some earlier point. This privileged knowledge applies in both cases to past as well as future events, and serves to explain to some degree the mixture of temporal frames in their narratives: past, present, and future are less distinct - or at least inseparable - when viewed from this privileged vantage point.

The ghost of Darius' account of the Persian army's suffering contains some anachrony that expresses in short order this narrative's temporal reach. A brief passage at the outset of his account encompasses all three temporal domains, moving from present to future to past. He begins by saying that Xerxes and his army are presently camped near the Asopus (805), before turning in the next line to the future misery that awaits them. This misery is explained as a consequence of what the army did in Greece, the subject of the lines that complete this passage (809-812). The reach of his narrative-from the (past) sacrilege in Athens to the (future) slaughter at Plataia - is made possible by Darius' knowledge of the divine decrees which he identifies in the lines introducing his account (800-802). There is, to be sure, no temporal confusion. Rather, the past events necessarily imply those to come, as the divine guarantees make clear: the temporal manipulations of this narrative announce that any account of Xerxes' present encampment near the Asopus is only part of a much larger story that reaches (at least) from the earlier sacrilege to the disaster that awaits. As often 
noted, the ghost's intervention in the events of the drama serves in large part to explain and justify on theological grounds the Persian suffering, and the temporal code of this narrative certainly furthers that purpose. ${ }^{32}$

Cassandra's dialogue with the chorus (A. I072-II72) contains in piecemeal form a narrative that reaches from the distant past to an imminent future. ${ }^{33}$ But this temporal expanse is not measured; there is no clear distinction between past and future. ${ }^{34}$ Both, for Cassandra at any rate, are thoroughly present. The gruesome deaths and eating of Thyestes' children are vividly at hand (I095-I097; note in particular the deictic toisde), as is the coming death of Agamemnon ('she reaches out her hand', in Io). Although we can distinguish between past and future, there is more than Cassandra's use of the 'prophetic present' tense to conjoin the multiple killings in the house. At I090-I092 her ambiguous language describing the house refers with equal force to murders both past and future. She speaks of a house 'that knows many sad tales of kindred murder $\ldots$ a slaughter-place for men' ${ }^{35}$

Much the same can be said of her narrative at 1215-I245. Indeed, this repeating narrative resumes not only the slaughter of Thyestes' children and that of Agamemnon, but also something of the temporal structure of the earlier, dialogical account. Both versions of these events begin with a vividly present past and then turn to an imminent future (tod' estai, iा Iо; teuxetai, I230), before representing the looming death of Agamemnon as a present reality. In this case, Cassandra speaks of the (now long-dead) children sitting near the house, hands full of their own flesh (I217-I222); speaks then of the plans afoot and the coming death of Agamemnon (I223-I23I); and finally announces that 'the female is the killer of the male' (I23I-I232). There is little suggestion that Cassandra

32 Cf. Broadhead I96o: xxix; Hall i996: I56-I57, with references. Saïd i981: 38, however, speaks of a 'rupture brutale avec le passé' in this play.

33 This is a peculiar form of dialogue, with Cassandra showing sporadic awareness of the chorus' presence and the chorus speaking of her in the third person (I083, Io93I094). Cf. Fraenkel I950: ad I095. This somewhat disjointed quality helps to convey Cassandra's mantic status, which is further evidenced by her narrative's temporal code.

34 Goward I999: 75 speaks of an 'unnatural timelessness' in Cassandra's narrative. Aelion 198I: I42 finds that this narrative 'détruit la notion même du temps'. Goethe speaks of the spectator as a 'seer' as a result of this narrative's remarkable temporal code (Rehm 2002: 8o; cf. P.G. Mason I959: 86).

35 The text here is problematic. I give the translation of Lloyd-Jones I979. Cf. Fraenkel i950: ad Iogiff. 
herself cannot distinguish between past and future, but her language makes it clear that this distinction is of little significance.

In the case of Cassandra, it is important to note that the familiarity of the traditional myth makes it possible for us to identify Thyestes' children as well as Agamemnon, as it enables us to distinguish the 'real' temporal location of the various events she reports. Her narratives are marked not only by this mixing of temporal frames, but also by an allusive style and much ellipsis. Our own ability to make sense of this (otherwise confusing) narrative terrain is made clear by contrast with the chorus' explicit commentary on their own failure to do the same (e.g. III2-III3, II30-II33). For them, after all, the events of which Cassandra speaks are not part of a familiar traditional myth. In this sense, then, the peculiarities of her narratives serve not only to depict the temporal fluidity of human experience seen from a prophetic point of view, but also to distinguish between primary and secondary narratees.

In the category of mixed narratives I include iterative narration (even if some examples may be identified as retrospective or prospective - or even simultaneous), because such narratives generally recount typical events, representative examples of the kind of thing that did or does happen. Io's account of her transformation and wandering in Prometheus Bound (645-682), for example, is retrospective without anachrony, but it is also an example of iterative narration. This narrative opens with an emphatic assertion that the dreams that set her suffering in motion were even more than frequent: 'Nighttime visions would always (aiei) enter my bedroom and speak soft words' $\left(645^{-647)}\right.$, she says by way of introducing what these visions actually said to her. She says further that she was possessed by such dreams every night until she worked up the courage to tell her father $\left(655^{-657}\right)$. The specificity of the dreams' quoted speech - more than seven lines long - might seem to conform imperfectly with the repeated appearances of the nighttime visions, and this might then appear to be an example of what Genette ([1972] I980: I2 I) calls 'pseudo-iterative' narration: 'scenes presented, particularly by their wording in the imperfect, as iterative, whereas their richness and precision of detail ensure that no reader can seriously believe they occur and reoccur [sic] in that manner, several times, without any variation'. Io does employ the imperfect here both introducing (646) and concluding (656) the reported speech. We may, then, follow Genette and understand the quoted speech here to represent the kind of speech produced by these recurring visions, rather than a single, 
identical speech that Io heard on many occasions. On the other hand, we are clearly in the realm of divine agency and realistic concerns may well be out of place. ${ }^{36}$

Although the chorus' account of Thebes' (imagined) fall in Seven Against Thebes (287-368) may be treated as an instance of simultaneous narration, it is best understood as an iterative account of a (typical) event. ${ }^{37}$ This passage contains lament and expression of fear, as well as prayer. In sum, however, the chorus present a vivid picture of (what is to be considered typical of) what happens when a (mythic) city is sacked. Although this narrative is not explicitly marked as iterative (by use of the imperfect, for example), one can hardly avoid reading it as such, in part because the chorus speak now in the present tense, now in the future, as their fear of what will happen proves to be inseparable from the account of what does happen. Some statements in the present tense confirm the status of the narrative as iterative, inasmuch as they constitute general claims: 'One man takes and kills another, sets a fire. Smoke pollutes the entire city, and raging, conquering Ares breathes on it, blotting out piety' $\left.\left(34^{0}-344\right)\right)^{38}$ The typicality invoked by the iterative character of this narrative finds corroboration and extension in the 'conspicuous use of Homeric phrasing'. ${ }^{39}$ In short, the fall of Thebes is presented as a vivid example of a (familiar) event, a variant of the paradigmatic case, the fall of Troy. ${ }^{40}$ This typicality need not render the narrative less powerful or haunting. In fact, it more likely augments these qualities in providing a template of sorts for understanding the

\footnotetext{
36 Another retrospective iterative narrative is Clytemnestra's account of her suffering during Agamemnon's absence (A. 855-894).

37 This type of iterative narrative might also be termed 'omnitemporal' inasmuch as the reference may be to the future as well as to the (present and) past. Other examples include the following choral narratives: the account of the impious type exemplified by Paris (A. 366-399); the description of the sorrows of war (A. 427-455); the narrative of the many terrifying things (deina, 586) on earth $\left(C h .5^{8} 5^{-636)}\right.$; and narrative sections of the 'binding song' ( $E u$. 299-396), in which the chorus recount their privileges, powers, and characteristic acts (cf. 550-565).

${ }^{38}$ Hutchinson I985: ad 342 identifies smoke 'like the other things described in $34^{\circ}-$ $342 \ldots$ as a basic element in the sack of a city'. Cf. A. 818.

${ }^{39}$ Hutchinson 1985 : ad 287-368. This will be true, of course, only for those spectators as primary narratees familiar with such Homeric language. But it is hardly adventurous to assume that many would recognize the allusion in line 322 (Aidai proïapsai) to the opening of the Iliad (Aïdi proïapsen, I.3). Hutchinson I985: ad 287-368 comments: 'no allusion could be more ostentatious'.

${ }^{40}$ Hutchinson I985: ad 328-329 identifies lines $326-329$ as offering another typical element: women being dragged by the hair - as at Troy and by a centaur on the Olympia pediment.
} 
horrors the chorus imagine: 'Think of Troy', we may understand them to say, 'and you will be thinking of Thebes'. ${ }^{41}$

\section{Repeating narration}

There are several examples of repeating narration which deserve notice: ${ }^{42}$ the Persian disaster in Greece is reported several times in Persians ${ }^{43}$ the Danaids' coming to Argos is recounted more than once in Suppliants, as is the story of Io; ${ }^{44}$ the death of Agamemnon is recounted or described in all three plays of the Oresteia; ${ }^{45}$ and the fall of Troy is rehearsed repeatedly in Agamemnon. This last case displays something of what such repetition can accomplish through variation in narrative modality, focalization, and temporal framework. At the play's outset the watchman announces that he sees the beacon indicating that Troy has (just) fallen. This highly condensed summary tells little, other than that much remains to be told $\left(3^{6-39)}\right.$ : it presents the fall as unelaborated event. The chorus then present the fall (104-I59) as a story dimly visible (to a seer) in the otherwise meaningless devouring of the hare by two eagles. No longer only a literal event, the fall is now encoded in the obscure language of the gods. Clytemnestra's account (320-347)

${ }^{41}$ The chorus cannot, of course, be aware of Troy's fall - which follows in mythic time. Rather, they say more than they can know. Cf. Hutchinson ig85: ad 287-368: 'The situation is mythical itself, but tragedy uses the resonance of famous myths to heighten the impact of the myth which is being presented to us'.

42 Spring 1917: I88-I9I notes that Aeschylus' use of the 'distributive method of exposition', together with the repetition it entails, resembles that of Sophocles $(\rightarrow)$. Although not limited to narrative sections, her careful and very useful study of gradual exposition in Aeschylus (and Sophocles) illuminates the work these repetitions do in demarcating various focalizations.

${ }^{43}$ In the Queen's dream and the omen (I76-2II); the messenger's narratives (249514); and the dialogic narrative between the Queen and Darius' ghost (709-738).

${ }^{44}$ Danaids: in the parodos at $\mathrm{I}-39$ and in the dialogic narrative between the chorus and Pelasgus (274-347); Io: 29I-3I5 (part of the dialogic narrative) and in the choral stasimon at $53^{\mathrm{I}-589}$. On repeated references to Io in this play see R.D. Murray $195^{8}$.

45 In Agamemnon: at IIO7-II28 Cassandra foretells his death; at I223-I238 she describes it as happening; at I343-1345 Agamemnon is heard to say he is being struck; at I372-I398 Clytemnestra recounts the deed in some detail. In Choephori: at 429-445 Agamemnon is said to have been mutilated and unlamented; at $49^{\mathrm{I}}-49^{6}$ Orestes and Electra 'remind' Agamemnon's ghost of the deadly bath and 'net' in which he was killed; at 980-1005 Orestes describes - and puts on display - the robe. In Eumenides: at $455^{-46 \text { I }}$ Orestes again describes the 'hunting nets'; at 625-639 Apollo describes Agamemnon's death in the bath. 
further expands the repertoire of narrative modalities in offering an imagined fall as real. ${ }^{46}$ These three tellings are followed by two eyewitness accounts, that of the Herald (503-582) and that of Agamemnon (810-828). Troy's fall, then, appears as unelaborated event signaled by a beacon; as the meaning of an omen; as imaginary event; and as an event seen through the eyes of two participants. This variety displays not only the varying focalizations of the different narrators, but also a range of possibilities for viewing the fall and its significance.

Just as important are the temporal schemes. In the choral narrative the fall is portended by an omen; for the watchman, the fall itself portends a murky future (34-39). Thus do these narratives underscore the 'temporally looped chain of causality' in the play: ${ }^{47}$ as the trilogy makes clear, the fall of Troy is a key link in an unbroken chain of events that includes the sacrifice of Iphigeneia at Aulis (where the omen is read by Calchas), and the death of Agamemnon, which is part of the vague future hinted at by the Watchman. Clytemnestra's account completes this sequence by conjuring a virtually timeless picture. Her narrative also opens the theme of Greek impiety at Troy (338-347), a theme picked up by the Herald $\left(524^{-} 537\right)$. As Spring points out ${ }^{48}$ the Herald's boast of the Greek destruction of Trojan altars (527) produces dramatic irony in 'repeating' Clytemnestra's warning at $34 \mathrm{I}^{\mathrm{I}}-34^{2}$ : this repetition serves to emphasize the destruction of the altars as both danger and success, although the irony here suggests that the success is illusory. Agamemnon also picks up the theological strand of earlier accounts and characterizes the fall as divinely sanctioned (810-828). In sum, then, this scheme of repetition in the play offers the fall as a prism through which we may view the characters via their differing focalizations, as it presents a range of modalities for thinking about the fall and its significance. It also illustrates economically the play's attention to theological matters and their relevance to the unfolding chain of events that surround Troy's fall. The fall, in short, is a kind of touchstone in the play, and the repeating narratives elaborate the richness of the fall in this capacity. ${ }^{49}$

46 The chorus' skepticism (272-280; cf. 35 $1-354)$ engages this pretense, of course.

47 Anderson 1997: II3.

48 Spring 1917: I90-I9I.

49 Anderson 1997: i22 sees the fall as 'a source of thematic and emotional reversal' in the play. The first stasimon $\left(355^{-487}\right)$ contains some elements that contribute to the play's distributive exposition of Troy's fall. Athena briefly mentions the fall of Troy at Eumenides 397-402; cf. Anderson 1997: I30-I32. 


\section{Conclusion}

Aeschylean tragic narratives display both a broad range of temporal schemes and a perhaps surprisingly sophisticated use of them. These narratives are sometimes simple in their temporal aspect, sometimes complex. And in some cases, apparently simple structures can prove to contain various layers of temporal reference. Even adjectives can contribute to a narrative's engagement with time, as the chorus' account of events at Aulis in Agamemnon shows. The uses of these temporal schemes, furthermore, demonstrate the kinds of work these formal elements can do. For example, these narratives can mimic in their temporal aspect something of the experience of the characters they describe, thereby assimilating the narratee to these characters in some ways - as we see in the parodos of Agamemnon. In addition, a narrative's temporal code may serve to differentiate between primary and secondary narratees, as we find in Agamemnon and in Prometheus Bound. Perhaps the most powerful use of temporal structure lies in the overlapping of form and meaning. A good example of this appears in Persians, where the narrative of the Queen (I76-2II) at once puts on display the possibilities inherent in such overlapping and shows what a complex temporal structure can look like. This account is retrospective and singulative but functions as 'prospective' and 'iterative', all while this temporal complexity dovetails elegantly with the play's theological concerns. It is this latter aspect - these narratives' abilities to harness what might appear to be mere formal elements and to exploit them in the service of larger concerns - that especially deserves notice. From Persians to Prometheus Bound, tragic narratives show a tendency to employ rich temporal structures that participate in the broader work of the plays that contain them. Indeed, the complexity of these temporal structures, and the uses they are put to, extend our understanding of the degree to which the genre as a whole is predicated on a densely textured engagement with time: if tragic performances occurred in a time (and place) marked off from ordinary experience, and if these performances relied upon a coincidence of distant pasts and the present moment, their narratives prove to have been an important avenue for exploring the significance of this key premise. 
Irene J.F. de Jong and René Nünlist - 978-90-47-42293-8 Downloaded from Brill.come4/26/2023 09:46:52AM via free access 


\title{
CHAPTER SIXTEEN
}

\section{SOPHOGLES}

\author{
I.J.F. DE JONG
}

\section{Introduction. Time awareness}

Time is of prime importance in tragedy: 'its subject matter is always one great event, which overthrows all that existed before: it means death, destruction, reversal of fortune; its strength rests on a contrast between before and after; and the deeper the contrast, the more tragic the event. That is why so many people, in tragedy, comment about time and its action. " ${ }^{\prime}$ Yet, speaking narratologically, time awareness is small: "Dramatists do not deal in "clock time" but in "dramatic time". In the hands of a good dramatist "clock time" can be compressed or expanded as required ... To facilitate their fluid treatment of time the Greek tragedians make sparing references to the time of day and its passing. There may be references to dawn or evening, "just now" or "soon" or "today"; but never in such a way as to invite the audience to consider precisely how long has elapsed between one part of the play and another.'2

Almost without exception the plot of Greek tragedies deals with one day in the lives of their main characters, a circumstance which Sophocles often thematizes: 'This day (hèe' hèmera) shall be your parent and

1 De Romilly i968: 5-6.

2 Taplin 1977: 290-294, quotation from 291-292. Other general studies on time in Sophocles include Morwood 1993 on the double time scheme in Antigone: short time (one day) versus long time (Creon is very much portrayed as someone who has already ruled for some time); Goward 1999 (prospective and retrospective narrative, time and the chorus); Hutchinson 1999 (the contrast between single, decisive, final events versus continuous states or repeated attempts); Heuner 200I (the relation between the 'objective' time structure and the 'subjective' time experience by the characters, and the linearity of the offstage time versus the discontinuity of the scenic time); Markantonatos 2002: 7-I2 (time games within drama and the narratives of drama); Rehm 2003: II9-139. 
your destroyer', says Tiresias to Oedipus $\left(O T\right.$ 438). ${ }^{3}$ But whereas the plot concentrates on one day, the totality of events represented ${ }^{4}$ is much larger, and to include the past and future retrospective and prospective narratives are necessary. Since in the Studies of Ancient Greek Narrative the position is taken that a play is not a narrative, ${ }^{5}$ the terms 'retrospective' and 'prospective narrative' have been introduced to replace 'analepsis' and 'prolepsis'; the terms 'analepsis' and 'prolepsis' are, of course, regularly used in connection with anachronies within embedded narratives. Narratives also function within the plot itself, anticipating later scenes or recounting what happened offstage. The first aspect of time which merits our attention therefore is order.

\section{Order I: retrospective narratives}

The majority of dramatic narratives concern the past before the start of the play and therefore are external retrospective narratives. In all situations and at all places in the play characters may turn to the remote past; for example, 'O ride of Pelops long ago, bringer of many sorrows, how dire was your effect upon this land! For since Myrtilus fell asleep, plunged into the sea, hurled headlong from the golden chariot with cruel torment, never yet has the torment of many troubles departed from this house' $\left(E l .5^{0} 4^{-5} 5^{15}\right){ }^{6}$

${ }^{3}$ Cf. $A j .778-779 ;$ Tr. г66-I68; El. 674, 783-784; and cf. Schwindt I994.

${ }^{4}$ In drama-theory: the story. Drama-theory, notably Pfister [1977] I988: I97-I98, distinguishes between story (totality of events in chronological order) and plot (events in the form and order as they appear in the play), while the narratological model adopted in $S A G \mathcal{N}$ (and applied to the narratives embedded in drama) works with fabula and story ( $\rightarrow$ Introduction), both distinctions basing themselves on the Russian formalist distinction between fabula and sjuzet. For an application of story-plot on Oedipus Tyrannus see M. Kraus 1994 (with apt criticism in Heuner 200I: 66). Pfister [1977] I988: 275-294 has a general discussion of aspects of time in drama.

${ }^{5}$ Cf. $S A G \mathcal{N}$ ז:6-7 and Genette [1983] 1988: 'This restriction [of narratology to the analysis of narrative mode] seems to me on the whole legitimate, since the sole specificity of narrative lies in its mode and not its content, which can equally well accommodate itself to a 'representation' that is dramatic, graphic, or other. There are chains of actions or events amenable to any mode of representation - the story of Oedipus ...-and we call them 'narrative' only because we encounter them in a narrative presentation. This metonymic slippage is understandable but very ill advised. I would therefore readily argue ... for a strict use (that is, one referring to mode) not only of the (technical) term narratology, but also of the word narrative ...'?

${ }_{6}^{6}$ Other examples: Aj. I293-1294, I295-1297; El. 837-847; Ant. 823-833, 944-987; Ph. 676-679. 
When we turn to the more recent past, the events which lead up to the plot of the play, it is characteristic of Sophocles not to present this prehistory in one block (as $\rightarrow$ Euripides does). ${ }^{7} \mathrm{He}$ may disclose elements of it at the opening of the play, as in the Antigone, where we hear (from Antigone) about $(\mathrm{C})$ Creon's edict forbidding the burial of Polynices issued the night before $(2 \mathrm{I}-36)$, (from Ismene) about (A) the fate of Oedipus and his sons in the past (49-57), and (from the chorus) about (B) the attack of the Seven against Thebes and the death of Eteocles and Polynices on the day before (I00-I47). But not seldom is crucial information about the past disclosed only at a very late stage, as when a messenger reports Calchas' revelation of Athena's wrath against Ajax (Aj. 748-783), which, finally, explains her vindictive behaviour towards him, about which we have heard and seen so much in the first part of the play. ${ }^{8}$ As Goward remarks, it is the task of the spectators to put together 'information given at different times during the course of the play and to create a sequential narrative' (of what happened in the past preceding the play). ${ }^{9}$

Sometimes it is not so much the spectators as the characters who have to piece together the past, and the prime example here is of course the Oedipus Tyrannus, which has been aptly called an 'Enthüllungsdrama' and detective story. ${ }^{10}$ Put in chronological order the prehistory of the Oedipus Tyrannus is as follows: (A) Laius receives an oracle that he will be killed by his son-(B) he exposes Oedipus, who is, however, handed over by a Theban servant to a Corinthian herdsman, who brings the child to the Corinthian royal couple-(C) Oedipus receives an oracle that he will kill his father and marry his mother-(D) he kills Laius - (E) defeats the Sphinx - and (F) marries Jocasta.

In the actual play, however, this narrative is fragmented into bits and pieces, smaller and larger retrospective narratives, which are recounted by different characters and in anachronical order. It starts with a

${ }^{7}$ Cf. Arist. Rh. I415ar8-20; Reinhardt [1933] I943: 47; Hulton r969: 53; H.W. Schmidt I97ı: 27; Gellie I972: I93; Roberts I989: г6ı.

${ }^{8}$ Cf. Winnington-Ingram I980: $39-43$, who also draws attention to the crucial depiction of Ajax in the past (before the contest and his madness) which Calchas' going back in time provides. Other examples: $T r$. 555-58I (how Deanira got the poison from Nessus), II59-II7I (a prophecy and oracle about Heracles' death). Oedipus' curse of his sons $\left(O C{ }_{1} 3^{8} 5^{-1} 3^{88}\right)$ is taken by most scholars to refer to his words in $4{ }^{12-} 427$ and is therefore no external retrospective narrative.

${ }^{9}$ Goward I999: 21.

10 Cf. Schadewaldt i97o: 466-476; Flashar i976; and Heuner 2001: 65-102. 
reference to (E) the Sphinx, thus marking the height of Oedipus' glory (35-39). An oracle brought back by Creon then introduces the central event of the play, (D) the murder of king Laius (IO3-I3I, repeated by the chorus in 290-292). The seer Tiresias is the first to reveal that (D') Oedipus is the murderer of Laius $(353,362)$; indeed, prodded on by a disbelieving and hostile Oedipus, he even refers, in riddling terms, to the facts that he (D") killed his father and (F) married his mother (449454). Dismayed, Oedipus himself once more clings to (E') his glorious defeat of the Sphinx (39I-398). Wanting to comfort Oedipus Jocasta tells him about (A) the oracle to Laius and (B) the exposure of their child (707-725), and argues that the oracle is disproved by (D"') Laius' death by robbers instead of his son $\left(726-75^{6}\right)$. However, stirred by one word in her brief report on Laius' death, Oedipus now recounts to her $(\mathrm{C})$ the oracle he once received and ( $\mathrm{D}^{\text {"', })}$ his murder of a man in circumstances similar to those of Laius as reported by Jocasta (77 I832). Oedipus now very much fears that indeed he killed Laius, but neither he nor Jocasta makes a connection with the two oracles (A and C) yet. Indeed, these seem disproved by the arrival of a messenger from Corinth, who reports the death of the king, Oedipus' 'father'. Wanting to reassure Oedipus, he informs him how $(B)$ he once received him as a baby from a Theban servant (I008-I053). Jocasta now understands the truth of what happened and after vainly trying to stop Oedipus from investigating his past any further she leaves the stage. At this point the eyewitness of Laius' murder enters, who, recognized by the Corinthian messenger, reluctantly confirms (B') how he once handed over the child he had been ordered to expose (II2I-II8I). Now Oedipus' moment of complete insight has come (II84-II85).

Scholars have remarked that this whole process of Oedipus finding out the truth about himself is not realistic, in that it is unlikely that husband and wife did not discuss the past before. In dramatic and narratological terms, however, this is a highly effective structure: the direction of the retrospective narratives is regressive, moving from a more recent past to the remote past: Oedipus begins his search with the question of his murder of Laius but ends with his birth and the even more vital point of his identity. In employing this technique of the 'piecemeal presentation' of a narrative Sophocles is clearly indebted to Homer $(\rightarrow)$, who exploited it to great effect, for example when making different characters in the Odyssey talk about Odysseus' return.

Apart from presenting the prehistory of the plot in a series of fragmented retrospective narratives, Sophocles may also reveal one and the 
same element of the plot's prehistory gradually, in the form of repeating narratives told by different characters. An example is Ajax' mad nocturnal onslaught on the herds. ${ }^{11}$ The first to tell us about it is Odysseus ( $A j$. I8-33), who is still trying to find out what has happened. The only thing he knows (from his own observation) is that animals have been slaughtered and (from a scout) that Ajax has been seen running through the fields in the night. Next, Odysseus is informed by Athena (36-65) that it was indeed Ajax who killed the beasts and that he is presently torturing other animals in his tent. She also tells him why Ajax has started on his expedition in the first place (he is angry because he had not been awarded Achilles' armour) and that, struck with madness by herself, he thinks that he is revenging himself on the Greek generals. This is then confirmed in a dialogue between the goddess and Ajax himself, with Odysseus as witness (9I-II7). Then the chorus enters, which, having only heard rumours, speculates about which god made Ajax do this and is still hopeful that it will all turn out not to be true (I4I-I47, I72-I85). Their fears are confirmed, however, by Tecmessa (2I4-220, 233-244, 284-327), who tells how Ajax left their tent in the middle of the night, sword in hand, came back to torture animals inside the tent, until, finally, he came to his senses and realised what he had done. By this time the spectators are fully informed about all the different stages of Ajax' action, the divine machinery behind it, and the perspectives on it of the main persons involved. ${ }^{12}$

Sophocles is particularly wont to use the device of the 'piecemeal presentation' in connection with oracles and prophecies. Their content is never quoted verbatim (as it usually is in, for example, Herodotus) but revealed only gradually, via the potentially distorting focalization of mortal characters. An example is the oracle concerning Philoctetes in the Philoctetes, which seems to change every time it is mentioned. However, when we allow for each character to have his own reasons for relating it, a reasonably consistent and dramatically effective picture emerges. ${ }^{13}$ In the prologue Odysseus tells Neoptolemus that with-

\footnotetext{
11 Cf. Segal i989-i9go and de Jong 2005.

12 Other examples of piecemeal distribution: the murder of Laius $\left(O T_{\text {IO3-I3I, } 290-}\right.$ 293, 359, 558-569, 707-862); Heracles' sack of Oechalia (Tr. I80-I99, 229-290, 335374, 395-489; cf. $S A G \mathcal{N}$ 1:259); and the quarrel between Eteocles and Polynices $(O C$ $324-420,42 \mathrm{I}-454, \mathrm{I} 29 \mathrm{I}-\mathrm{I} 325)$.

13 Cf. (too strongly) T. Wilamowitz i9ı7: 20 ('Die dramatische Wirkung der einzelnen Szene steht ihm ... höher als die einheitliche Anlage der Fabel, und er rechnet damit,
} 
out Philoctetes' bow he will not be able to capture Troy (68-69). He does not mention any oracle, and Neoptolemus' asking how he is to proceed (why not by force or persuasion, but by deceit?, 86-III) and his surprise, indeed disappointment, at hearing that something else apart from himself is necessary for the fall of Troy (I I4) imply that the youth is ignorant of its exact form, perhaps even of its very existence. This ignorance allows Odysseus to lay stress on the bow rather than the man (Philoctetes), thus somewhat sweetening the bitter pill for the young hero that he is not the sole captor of Troy. In his lying tale to Philoctetes, in which he pretends to return to Greece and which is aimed at luring Philoctetes into coming with him (343-390), Neoptolemus does not refer to any divine order that Philoctetes should go to Troy.

It is only in the lying tale of the 'Merchant', which is aimed at making Philoctetes even more eager to join Neoptolemus by telling him that Odysseus and Diomedes are after him (570-62I), that the oracle is introduced for the first time: it derives from the Trojan Helenus and prescribes that Philoctetes (and his bow) is to be brought to Troy by persuasion (610-613). At this stage, the recounting of the oracle seems not so much aimed at Philoctetes, who is only infuriated by the idea of being persuaded by his enemies (622-638), as at Neoptolemus, who ought to become even more convinced that the cause he is fighting for is a just one. When at the end of the play Neoptolemus, though having confessed his deceit and having given back the bow, is making a last effort - by persuasion - to make Philoctetes come with him to Troy, he himself once more recounts the oracle (1329-1342). This report is now fully aimed at Philoctetes and hence for the first time mentions that when coming to Troy he will be cured. However, even in its full and attractive form the oracle does not persuade Philoctetes. It is only the authority of Heracles which finally makes him decide to go to Troy: Heracles confirms the oracle in a prospective narrative which reveals that Philoctetes will be cured, kill Paris, and destroy Troy together with Neoptolemus and with the help of his bow. Only once in the course of this protracted revelation of the terms of the oracle is Sophocles using a sleight-of-hand or is perhaps even making a minor slip: when he makes Neoptolemus, who at the beginning of the play did not seem to know

dass, da das jedesmal vor Augen des Zuschauers wirklich Geschehende so zur stärksten Wirkung kommt, die ... Inkongruenz nicht bemerkt wird'); more appreciatively Hinds I967 and Easterling 1978. 
about the oracle at all (or only vaguely), recite it to Philoctetes very knowledgeably ('There is a man with us ..., Helenus, who tells us...'). ${ }^{14}$

The large number and deft handling of retrospective narratives dealing with the prehistory of plays has by now become clear. How about internal retrospective narratives? A large group is taken up by narratives recording events which have just taken place offstage, mainly messenger-speeches (e.g. the death of Jocasta, OT I237-I285), but also other types of narratives (e.g. the miracle with the tuft of wool, which makes Deanira realize her fatal mistake in sending Heracles the robe anointed with the unguent she got from the centaur Nessus, Tr. 672722). ${ }^{15}$ The close connection with the time of the onstage action is made clear by means of adverbs of time ('just now', 'recently') and the frequent opening of these narratives with the temporal conjunction epei, which indicates that they pick up from an earlier point in the play (thus, when the messenger in Oedipus Tyrannus starts his narrative with 'When frantic she [Jocasta] had passed within the vestibule, she rushed straight towards her nuptial couch...', he picks up from the moment when in I072 Jocasta left the stage, an act described by the chorus as: 'Why did the woman, Oedipus, leave hurried by a wild grief ?'). ${ }^{16}$

The fact that so much of the action of Greek tragedy is relegated to the offstage area and hence has to be reported to the spectators in the form of narrative can be explained by the central role of the chorus, which - almost without exception - remains onstage during the entire play and thereby precludes changes of place. But the interplay of onstage action and offstage narrative also has a dynamic and significance of its own: by the time they reach the stage the events reported have already taken place and therefore cannot be changed or influenced any more by those onstage. This is well illustrated by the two

14 Other examples: the oracle concerning Heracles in Trachiniae, for which see Gellie I972: 69; Heiden ı989: 34-36; C. Kraus ı991: 82-83; and Segal 20oo; Apollo's prophecy to Orestes in Electra, for which see L. Macleod 2001: 28-38; the oracle to Laius in Oedipus Tyrannus, for which see Heuner 2001: 74-76; the oracles concerning Oedipus in Oedipus Coloneus.

15 For the corpus of messenger-speeches see $S A G \mathcal{N}$ I:26r n. 20. Other offstage reports: $E l$. 4I7-427 (the dream of Clytemnestra), 882-9i9 (Chrysothemis finding Orestes' hairlock); Ant. 998-ro32 (the omens which Tiresias saw). It should be noted, however, that not all offstage reports are strictly speaking internal; the false stories about Orestes' death (El. 680-763) and Odysseus' mission to get Philoctetes (Ph. 6o362I) refer to events which largely precede the starting point of the plot.

16 See for this interpretation of epei at the opening of messenger-speeches Rijksbaron I976. 
burials of Polynices in the Antigone (249-277 and 407-440): the first messenger-speech confronts Creon with the fact that his edict has been violated on the very first day it was issued, the second with the even worse fact that it has been violated (again) by, as has become clear now, a woman. ${ }^{17}$

Another, smaller group of internal retrospective narratives derives from characters who look back on their own or other people's deeds performed in the play. An example is Creon's remorseful confession that his decisions have been totally mistaken and disastrous (Ant. I26 II275), which contains the tragic keywords hamartemmata 'tragic errors' and mathōn deilaios 'learning at one's cost'. ${ }^{18}$

\section{Order 2: prospective narratives}

Just as dramatic characters are often recalling or reflecting on the past, much of their energy is taken by - anxious or confidentialanticipation of the future. Not all of these anticipations are narrative (they may be short announcements or orders or the like), but occasionally we do have real prospective narratives. ${ }^{19}$ Often they concern the impending ruin of the main characters, as when Tiresias announces to Oedipus 'that he shall be revealed to be a native Theban, that he shall travel over strange land blind instead of seeing, and that he shall be revealed both a brother and a father to his children, both a son and a husband to his wife, and both a sharer in his wife and a killer to his father' (OT 452-46o; cf. earlier 417-425); the outcome will follow in I287ff. and after the play. ${ }^{20}$

Prospective narratives will naturally tend to employ prior narration, as in the example just given ('Oedipus shall be revealed'), but they may also take the form of subsequent narration, as in the case of Chrysothemis' report to Electra of Clytemnestra's dream: 'They say

\footnotetext{
${ }^{17}$ Heuner 200I, for the Antigone esp. IO-I2 and 24-25. For other interpretations of the doubling of burial and report see Scodel 1984 (where older interpretations).

${ }^{18}$ Other examples: $A j$. I383-1388 (Teucer looks back on Odysseus' consistently noble behaviour versus Ajax); Ph. I228 (Neoptolemus looks back on his deceit of Philoctetes); Tr. III4-II42 (Hyllus looks back on Deanira's fatal error with the poisoned cloak; note hēmarten, hamartèmenos 'having committed a tragic error').

${ }^{19}$ Cf. Goward I999: 25-26.

${ }^{20}$ Other examples: Tr. 705-722 (deaths of Deanira and Heracles); Ant. Io64-1086 (ruin of Creon); a positive prospective narrative: Ph. I325-I335 (Neoptolemus tells Philoctetes what will happen to him if he comes to Troy).
} 
that she was once more in company with your father and mine, who had come to the world of light; and then he took the staff which he used to carry, and which Aegisthus carries now, and planted it beside the hearth; and from it grew up a fruitful bough, which overshadowed all the land of the Mycenaeans' (El. 4I7-423). The dream is told in the form of subsequent narration, but has the function of a prospective narrative, announcing the return and revenge of Orestes. This prospective function becomes explicit in Electra's interpretation of the dream: 'Abandon these [Clytemnestra's libations], and cut locks from your hair ... Kneel and pray him to come in kindness from below the earth to help us against our enemies, and pray that his son Orestes may get the upper hand and may trample, alive and well, upon his enemies... I believe, yes, I believe that it is he who was concerned to send these ugly dreams to her.'21 Sophocles' frequent use of dreams, prophecies, and omens ${ }^{22}$ as prospective narratives for the spectators but ambivalent signs for the characters involved resembles Homer $(\rightarrow)$ and Herodotus $(\rightarrow)$.

A special case of prospective narrative is Oedipus Coloneus ro44-I055, where the chorus imagines the coming battle between Thebans and Athenians; this prospective choral narrative thereby replaces a retrospective messenger-speech. But it is not a matter of mere replacement: since the chorus is only imagining the battle, their narrative displays an effective mixture of the hypothetical ('I think', I054, I059; 'either ... or', I058I059, I074), the self-confident ('Creon shall be taken', I065; 'I predict a victory in the battle', Io6o), and the subjective ('Zeus grant to the guardians of the land's people to seize the prey with victorious might', I085-I089). ${ }^{23}$

Prospective narratives are also used in the context of guile and deceit, as in Electra 39-66, when Orestes sketches to the old pedagogue (and Pylades) how they must proceed to carry out Apollo's oracle and take revenge on behalf of his father: 'Do you go into this palace... and find out everything that they are doing, so that you can report to

\footnotetext{
${ }^{21}$ For Clytemnestra's dream see Bowman 1997. Another example is Tiresias' report to Creon on the negative omen he received (Ant. 998-Ior3), followed by his interpretation (Io64-I086), which in the form of a prospective narrative announces Creon's doom: 'Then know well that you shall not accomplish many racing courses of the sun ...'?

${ }^{22}$ Cf. the omens in Trachiniae, Oedipus Tyrannus, Oedipus Coloneus; the prophecies in Philoctetes, Antigone.

${ }^{23}$ Cf. Gellie I972: I79; Burton I980: 280-284; Goward 1999: 23; and Markantonatos 2002: 100-108.
} 
us with certain knowledge. They will never know you, grizzled as you are with age and the passage of time, and they will not suspect you. Tell this story, that you are a foreigner who has come from Phanoteus the Phocian ... and tell them, speaking on oath, that Orestes is dead by an accident, having fallen from his moving chariot in the Pythian games; let that be your tale. And we will first honour my father's tomb ... then we will return once more, carrying in our hands the bronze urn ... so that we can deceive them with our words and bring them happy news, that my body has already been burnt to ashes. ${ }^{24}$ The effectuation of the scheme follows onstage (from 66o onwards), including the false narrative here synoptically announced (68o-763). This structure, plotting followed by effectuation, will become a staple ingredient of the Euripidean $(\rightarrow)$ mechanema-plays, though there the effectuation usually takes place offstage and is reported by a messenger.

Just as Sophocles is the master of the false retrospective tale, he is also fond of inserting hypothetical, eventually not effected, or even downright false prospective narratives. ${ }^{25}$ An example of a hypothetical prospective narrative is Teucer imagining how his father will welcome him, now that he has not been able to save his brother Ajax: 'Smiling and kindly, I imagine, will be my welcome from Telamon, your father and also mine, when I come home there without you. Of course, seeing that even when fortune is good it is not his way to smile more graciously. What will he keep back? What evil will he not speak of me, the bastard born of the prize he won in battle, the betrayer, in my cowardice and weakness, of you, dearest Ajax, or in my cunning. So that with you dead I might control your lordship and your house? Such words will be uttered by a man who is irascible, fierce in old age, and quick to quarrel angrily over nothing. In the end I shall be rejected and cast out from the land, denounced as a slave, no longer a free man' ( $A j$. I008-IO2I). As so often in Sophocles, words have a double meaning: this hypothetical prospective narrative is in the first place expressive of Teucer's own present feelings of remorse and failure, but the spectators know that, according to tradition, Teucer indeed was to be banished by Telamon (and to found Salamis on Cyprus). ${ }^{26}$

\footnotetext{
${ }^{24}$ Another example is Philoctetes 54-69, when Odysseus tells Neoptolemus how to approach Philoctetes, tell him a false tale about himself and thus lure him into coming with him.

${ }^{25}$ Cf. SAGN I:266-267. Goward I999: 87-i 8 discusses both retrospective and prospective false narratives.

26 Other examples: Aj. 460-47o (Ajax' future after his disgraceful attack on the
} 
An example of a prospective narrative which in the end is not fulfilled is Antigone 773-780: Creon announces that he will bury Antigone alive and let her slowly die of starvation, but in II92-1243 a messenger reports that she committed suicide. The effect of inserting this prospective narrative is to underscore Creon's - ever increasing - loss of control in this play.

The obvious - though far from uncontroversial - example of a false prospective narrative is Ajax' announcement that he will bury his sword and give up his wrath against the Greek generals (Aj. 654-692). What complicates the matter here is that this narrative has a double function: for Ajax' intradramatic narratees, Tecmessa and the chorus, it is meant to be true, whereas Sophocles suggests the extradramatic narratees, the spectators and later readers, enough hints to see that this prospective narrative, though showing us an Ajax toying with the idea of reconciliation and sincerely pitying Tecmessa, is false (e.g. his going to the washing-places, loutra, suggests the washing of a corpse before burial; his going to the meadows near the shore means a return to the scene of his 'crime'; his reference to hiding his sword and Hades keeping the sword below suggest his own burial together with his sword; and his 'going where he must journey' conjures up the last journey, to death). ${ }^{27}$

The prospective narratives discussed so far are largely internal and only very occasionally refer to a future outside the plays. In the same way it is characteristic of Sophocles not to end his plays with prolonged external prospective narratives, as Euripides $(\rightarrow)$ does, revealing what the future has in store for his dramatic heroes. ${ }^{28}$ However, scholars have pointed out brief passages or remarks which seem to allude to the future outside the play and to other texts. ${ }^{29}$ An example is the prediction which Tiresias makes to Creon in Antigone 1080-1084: 'all the cities [which participated in the expedition of the Seven against Thebes] are stirred up by enmity, from which the mangled bodies have

herds), 496-505 (Tecmessa's fate after Ajax' death); and El. 973-985 (Electra's prospective narrative of the fame she and Chrysothemis are going to win when they kill Aegisthus).

${ }^{27}$ For a discussion of the many interpretations proposed see Garvie 1998: I84-I86, to which should now be added Goward I999: 88-91 and Lardinois 2005.

28 The topic of the closure of Sophoclean drama concerns the handling of time in general (not of the narrative parts) and therefore lies outside the scope of this chapter. For discussions see Kremer 1971; Roberts 1988; Segal 1996; and Goward 1999: 49-52.

${ }^{29}$ Other examples: Tr. I270-1271; OT I455-1457; El. I497-I498; Ph. I440-1441; OC I769-1772. Cf. esp. Roberts I988, with more scholarship. 
been consecrated by dogs or beasts, or some winged bird, carrying the unholy scent to the city with its hearts'. Hearing this, the spectators may have been reminded of the Athenian expedition led by Theseus to recover the bodies for burial and perhaps the later expedition of the victorious Epigoni, themes dealt with in other plays.

\section{Order 3: chronological versus anachronical}

From the temporal relationship between dramatic narratives and the plot of the plays in which they are embedded, this section turns to the order within narratives. The normal order is chronological, as is best illustrated by the group of long, continuous narratives in Sophocles: the messenger-speeches. Thus, Hyllus, reporting the poisoning of Heracles (Tr. 749-8I2), proceeds as follows: he met his father when he was sacrificing on Mt Ceneaum - then Lichas arrived, who gave Heracles the (poisoned) cloak of Deanira - the poison started to work-Heracles interviewed Lichas and then killed him-Heracles, suffering more and more, asked Hyllus to take him home-he will arrive soon.

Since they recount the events as they experienced them at the time, Sophoclean messengers only sparingly use analepses or prolepses, just like Euripidean $(\rightarrow)$ messengers. Only occasionally-but effectivelydo they insert an actorial analepsis, for example when the messenger in the Ajax quotes (in indirect speech) Calchas' account of Ajax' two instances of hubristic behaviour and words in the past (762-770a, 77ob775), which brought him Athena's anger, ${ }^{30}$ or a narratorial prolepsis, when the messenger in Electra says, halfway his (false) narrative of Orestes' death at the Pythian games, 'So far, things stood thus; but when one of the gods does mischief, not even a mighty man can escape' $(696-697){ }^{31}$

In the dialogical narratives, however, the order is often anachronical, being determined by the interplay of question and answer. An example is the dialogue between Oedipus and the chorus in Oedipus Coloneus 5 ${ }^{\mathrm{IO}-}$ 548 , in which his past is reviewed, first $(\mathrm{C})$ his marriage to his mother and $(\mathrm{D})$ the birth of two daughters, then (B) his defeat of the Sphinx, and finally (A) the killing of his father.

\footnotetext{
${ }^{30}$ Cf. OT I246-I250 (messenger reports Jocasta's reminiscences).

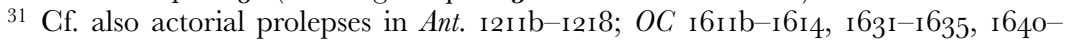
I644.
} 
Occasionally we find, both in continuous and dialogical narratives, the device of the 'epic regression' ( $\rightarrow$ Homer, $\rightarrow$ Pindar), which means that a narrator goes back in time step by step and then having reached the most remote event proceeds forward again. An example is Lichas' (partly false) report to Deanira on Heracles' prolonged absence (Tr. 248-290):32 (C) Heracles was sold by Eurytus as a slave to the Lydian queen Omphale and (D) upon his release sacked Oechalia by way of revenge (248-26oa) - (A) Eurytus had insulted Heracles (26ob-269a)(B) who in turn killed Eurytus' son Iphitus (269b-273) - (C') on account of this Zeus has him sold to the Lydians $\left(274^{-280}\right.$ - - (D') the city of Oechalia is sacked by Heracles $(28 \mathrm{I}-285)$. This order is both natural in that Lichas starts by correcting Deanira's idea that sacking Oechalia took Heracles so long ('No, he was first detained for a year in Lydia ...') and then proceeds to tell her the story from the start, and at the same time highly effective, since all stress is put on Heracles' revenge on Eurytus as the motive for sacking Oechalia, while his real motive, infatuation for Iole, is suppressed.

\section{Rhythm}

Tragic narratives are rather short by epic, historiographical, or novelistic standards (at most some hundred lines), but they nevertheless make effective use of differences in speed. The main distinction is the one between summary and scene. Mythological tales or events of the remote past are usually recounted in the form of summaries, while messenger-speeches and related continuous reports of personal experiences tend to include scenic passages.

Summary and scene can also be combined, as is usually the case in messenger-scenes, where in the dialogue preceding his report the messenger first reveals very briefly his main news and then, being asked for more information, turns to a more detailed report. An example is Oedipus Coloneus 1579-1585: '[messenger] Men of the city, the briefest way to tell my news would be to say that Oedipus is dead! But to tell in few words what happened neither the words nor the actions that took

${ }^{32}$ I base myself on Halleran 1986, who also refers to the way in which this narrative itself, with its untraditional emphasis on Zeus punishing Heracles for his stealthy murder of Iphitus, anticipates Deanira's stealthy murder of Heracles. Other examples of epic regression: Aj. 21-33; El. 404-427; and Tr. 555-581. 
place there permit. [chorus] Is the poor man dead indeed? [messenger] Be assured that that man has left our ordinary life! [chorus] How did it happen? Did the poor man die in a god-sent and painless fashion?' The same structure of brief announcement followed by a request for more information is found in the messenger-scenes of Euripides $(\rightarrow)$; one is also reminded of the device of the 'header' (found from $\rightarrow$ Homer onwards) or 'initial summary with subsequent elaboration' found in Pindar $(\rightarrow)$ and Bacchylides $(\rightarrow)$.

In the course of the messenger's narrative the rhythm also modulates, for example in the case of Electra 680-763. The pedagogue starts his (false) tale of Orestes' death in summary style (in the days preceding his fatal accident Orestes won all contests of the Pythian games in which he participated, 68I-697), to which he himself draws attention: 'And to speak briefly, when there is much to tell' (688). Then he turns to a very scenic report of the fatal race-course which ends with Orestes' death (698-756): he includes the names of all the participants, the colour of their horses, and the exact details of Orestes' grooming of his horses (at first he gives his right-hand horse room every time he makes his turn around the post and only grazes it, but the last time he relaxes his left-hand rein and thereby strikes the post and breaks his axle). After the youth's fatal accident, he wraps up his story very quickly, dismissing Orestes' burial in half a verse (757a).

This particular pattern is not difficult to account for: evoking the initial series of Orestes' successes increases the impact of his later death; turning to a very detailed eyewitness report in the middle adds to the authority of what in fact is a purely invented tale; and having reached the goal of his story (Orestes is dead), he hurries on to the present, the imminent arrival of some Phocians with Orestes' ashes. Though being highly scenic, this messenger-speech does not contain any direct speech. Indeed, unlike Euripidean $(\rightarrow)$ messengerspeeches, which invariably contain direct speeches (as well as indirect ones), Sophoclean messenger-speeches may contain speeches (notably Aj. 284-327 and 748-782; Ant. II92-I243; Tr. 734-812, 899-946; OC I586-I666), but quite a number do without and confine themselves to indirect representation of speech (El. 680-763; OT 1237-1285; Ant. 249-277, 404-440; Tr. 248-29o).

There is one more aspect of rhythm which is relevant to Sophocles: ellipsis (when an event is not recounted at all). In the first place, this plays a role - as everywhere in Greek literature - in the narration of events from the mythic past. Since - the main outline of - a story is 
well-known, it can be told allusively and elliptically. An example is the chorus' narrative of the attack of the Seven on Thebes: 'Beam of the sun, ..., you who made the man with the white shield who came from Argos in his panoply, go away in headlong flight with whistling bridle. Through the quarrelsome disputes of Polynices he was led forth against our land ...' (Ant. IO0-III). ${ }^{33}$ We do not hear that 'the man with the white shield who came from Argos' is Adrastus, that Polynices had come to him as a fugitive after his quarrel with his brother Eteocles, that he helped him because he is his son-in-law, and that the two brothers killed each other because of a curse from their father Oedipus. Strictly speaking, we should distinguish in cases like these between the elliptic narration by the intradramatic narrators, the chorus, for whom the events actually belong to the recent past, of which they themselves are a part, and who perhaps can therefore dispense with all kind of details, and the elliptic presentation by Sophocles, who can count on his spectators to fill in the details on the basis of their foreknowledge. Of course, intradramatic narrators can also leave out certain events deliberately, as does Clytemnestra in Electra 534-546: when discussing the sacrifice of Iphigeneia, she leaves out the reason why Agamemnon sacrificed his daughter (to appease Artemis after angering her by killing a stag and boasting about it), and offers other, less persuasive motives instead (for the sake of the army or his brother Menelaus). In her reaction Electra fills in emphatically the gap left by her mother: 'Ask the huntress Artemis what sin she was punishing when she held in check those many winds at Aulis; or I will tell you, since we may not lawfully learn from her' $(563-565)$.

The ellipses in mythological narratives are never marked. This is different in the other type of ellipsis, when characters, mainly messengers, avow explicitly that they have not been able to watch a certain event and hence have to leave a blank in their story. Thus Tecmessa, reporting Ajax' mad behaviour, says halfway her story: 'he sped off. What happened there (outside the tent, on the plain) I cannot tell you, but he came into the tent (again) bringing with him ...' (Aj. 294-296); or the messenger reporting Oedipus' death ends his story with a blank: 'But by what death that man perished, none among mortals could tell but Theseus. For no fiery thunderbolt of the god made away with him, nor any whirlwind rising from the sea at that time, but either some escort

\footnotetext{
33 Cf. also $S A G \mathcal{N}$ i:26o.
} 
from the gods or the unlighted foundation of the earth that belongs

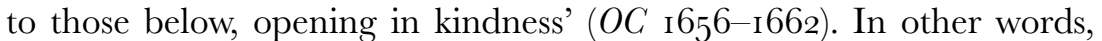
what we see is that Sophocles effectively exploits the restricted knowledge or understanding which internal narrators, generally speaking, have. We do not find similar explicit gaps in Aeschylean or Euripidean messenger-speeches, and it seems characteristic of Sophocles' interest in - the limits of - human perception and understanding to make his messengers, whose main function is to give an eyewitness report, defective. $^{34}$

\section{Frequency (repeating narration)}

Just as most of Sophocles' continuous narratives are told chronologically, they are also singulative: each event is recounted once. Occasionally, he may effectively employ iterative narration, when characters recount their way of life during a long period, as does Philoctetes: 'So one period of time after another went by for me, and I had to provide for myself under this poor roof. My stomach's needs this bow found for me ... And if I had to get some drink also or perhaps to cut some wood ..., I would struggle along and manage it', etc. (Ph. 285-316). Since Philoctetes clearly abhorred this way of life, the iterative narration in itself underscores the recurrent hardship of his life. ${ }^{35}$

Sophocles is particularly fond of repeating narration: the same events are told more than once, examples of which we have already come across in the discussion of retrospective narrative. The most obvious use of this form of narration is to present and contrast the focalization by different characters. The fight over Deanira by Achelous and Heracles is first presented briefly by the bride herself (Tr. 6-26), who speaks of Heracles in glorious terms, ascribes the victory of the son of Zeus to Zeus, but otherwise gives no details, because she was too terrified to watch. These details are later provided by the chorus (503-530), who explicitly motivate their ability to do so, and now ascribe Heracles' vic-

34 Other examples: OT I25 I-I254; Ant. 249-252; (outside messenger-speech) Tr. 2I23. For a full analysis of the gaps in the messenger-speech of Oedipus Tyrannus see Barrett 2002: $190-222$.

35 Other examples: El. 86-IO2 (Electra's repeated lamenting); OC 345-352 (Antigone's life as exile with her father). Iterative narration may also create a summary, as in Electra 688-697 ('of the contests that the judges proclaimed, he won all the prizes, and was cheered for his victories'). 
tory to - the arbitration of - Aphrodite. Both the details of the struggle and the role of Aphrodite make their narrative applicable to Iole, too, who has just before entered the stage and whose fate- she was won by Heracles after a fight and as the result of his desire- has just been revealed. Thus, Sophocles' sure touch has reserved the full story for this point in his drama, where the confrontation between the two women, Deanira and Iole, is about to reach its tragic climax. ${ }^{36}$

Another use of repeating narration is the combination of the anticipation of an event in the form of a prospective narrative and the report of its execution or fulfillment in the form of a retrospective narrative. Thus, the poisoning of Heracles is first fearfully and remorsefully anticipated by Deanira (712-718), then reported as effected by an angry and vindictive Hyllus, who acts as a messenger (749-8I2), and finally reflected on once more by the chorus in $82 \mathrm{I}-840{ }^{37}$

\section{Conclusion}

Narratives are frequent and highly important in Sophocles' plays. His retrospective narratives are both internal and external, whereas his prospective narratives are-largely-internal, which means that the future outside the plays is not narrated but only briefly alluded to. External retrospective narratives fill in the prehistory of the plot, often in several, not necessarily chronologically ordered instalments, while internal retrospective narratives report offstage events. Internal prospective narratives anticipate developments of the plot, either correctly (when seers speak) or misleadingly (when a deceiving plot is being hatched) or ambiguously (dreams).

Whereas the larger continuous narratives, mainly messengerspeeches, display a chronological order, other narratives and especially dialogical ones often turn to anachronical orders, such as epic regres-

${ }^{36}$ Cf. Gellie 1972: 634; Heiden I989: 21-30 and 78; and C. Kraus i991: 79-82 and 86-88. Other examples are Ajax $719^{-} 734^{+} 74^{8-783}$ and $795^{-802}$, where the messenger first tells his news about Teucer to the chorus, then, briefly, to Tecmessa; Tr. II4-I42, where Hyllus repeats the story of Deanira's death, told in $863-946$ by the nurse, to Heracles; Ph. 4-II and 264-275 (the Greeks leaving behind Philoctetes); $O C$ 365-384 and $\mathrm{I} 29 \mathrm{I}^{-} \mathrm{I} 307$, where the quarrel between Polynices and Eteocles is first reported by Ismene, who condemns (and pities) the two, then presented once more by Polynices himself, who feels he has a legitimate case.

37 Another example is Antigone ro64-1086 (Tiresias announces Haemon's death) and II92-I243 (a messenger reports it). 
sion. Longer narratives vary in rhythm, modulating between summary (to speed up or paint a general picture) and scene (for climactic events). Narratives concerning the mythic past may completely leave out certain events, whereby the spectators are supposed to fill in the gaps on the basis of their prior knowledge. While these instances of ellipsis remain implicit, Sophoclean messengers explicitly call attention to gaps in their narratives.

All in all, Sophocles' use of time in his narratives is designed to serve his general interest in the theme of mortals coming to terms with the vicissitudes of their lives and the ways in which the past encroaches on the present. 


\title{
CHAPTER SEVENTEEN
}

\section{EURIPIDES}

\author{
M.A. LLOYD
}

\section{Introduction}

The single most important factor in Euripides' treatment of time is that all his surviving tragedies observe the Aristotelian unity of time, and take place within a single day (Poetics r 449 bi3). This is also true of the surviving plays of Aeschylus $(\rightarrow)$ and Sophocles $(\rightarrow)$, with the sole exception of Aeschylus' Eumenides. A story of broad time span is treated in the course of a plot which occupies no more than one day, and this means that Euripides needs to employ a great number of external retrospective and prospective narratives. ${ }^{1}$ The relationship between story and plot corresponds to the relationship between offstage and onstage space, with the plays incorporating a much wider range of locations than can actually be represented on the stage. ${ }^{2}$ Euripides often makes a point of setting the action on a particularly significant day, on which a crucial series of events takes place in a short space of time (Alc. 20-21, 27; Hipp. 21-22, 369, 726, 889-89o; Hec. 43-44; Or. 48). This can itself contribute to the characteristically tragic sense of the sudden reversals to which human life is subject. ${ }^{3}$

${ }^{1}$ In the Studies in Ancient Greek Narrative the position is taken that tragedies are no narratives (cf. $S A G \mathcal{N}$ ı:6-7); for a more liberal view see Goward 1999: I0-15; Lowe 2000: I63-I64; Gould [199I] 200I: 319-322. The terms 'analepsis' and 'prolepsis' are therefore only applied to aspects of time within embedded narratives, while for the temporal function of the embedded narratives themselves the terms 'retrospective' and 'prospective narrative' are used.

2 The editorial policy of the present volume is to use Pfister's ([1977] I988: 197-198) distinction between story and plot with reference to a whole play, corresponding to the distinction between fabula and story with reference to narratives within a play (both systems deriving from the fabula/sjuzet distinction). It is unfortunate that 'story' is used in opposite ways in the two systems.

3 Cf. Lowe 2000: 165. 
Euripides, like the other tragedians, keeps precise indications of time to a minimum. Several of his plays (Hecuba, Electra, Ion, Iphigenia Aulidensis, as well as the fragmentary Phaethon) begin just before sunrise. ${ }^{4}$ This indicates daily routines in Electra and Ion, and is associated with nocturnal anxiety in Hecuba and Iphigenia in Aulis. It also reinforces the sense of a beginning, especially when tragedies so often deal with the events of a specific day (cf. $B a$. 677-679 at the beginning of a messenger-speech). There is, however, never any systematic indication in Euripides of the subsequent progression of the day towards nightfall.

This vagueness allows for a flexible treatment of the relationship between onstage and offstage time, which is especially notable in the context of messenger-speeches. 'Seldom if ever is there enough time, literally speaking, in between the departure of the main characters to a catastrophic event and the arrival of the messenger to report it for the things which he reports to have happened. ${ }^{5}$ The most extreme example of this in Euripides is in Andromache, where Orestes departs for Delphi (sixty miles away) at line Ioo8 and executes a plot which takes at least three days (I085-I087) before the messenger returns with the news at line I070. Some scholars have wrongly tried to make his movements more intelligible in literal terms. ${ }^{6}$ Choral odes regularly intervene at this point, doing something to cover the lapse of time. There is however no choral ode in Andromache before the corpse of Neoptolemus arrives, immediately after the messenger has finished his speech. Similarly in Electra, a choral ode (El. 699-746) may cover the time for the events described in the messenger-speech, but the messenger then arrives remarkably quickly after Aegisthus' death-cries are heard at line 747 .

There is a notable asymmetry between onstage and offstage time in Heraclidae. Eurystheus and his army are at the Megarian border at lines 278-279, but already overlooking the plain of Marathon at 389397; by then Demophon has made his own military preparations. The messenger arrives at line 784 with news of a pitched battle and the pursuit of Eurystheus to the Scironian rocks (860), and Eurystheus himself then arrives at line 928. The compression in Hercules Furens is even bolder, with the elaborate sequence of events described in the messenger-speech ( $H F$ 922-IOI5) corresponding to a simultaneous presentation which occupies a mere 24 lines (867-909). The beginning

\footnotetext{
4 Cf. Diggle i97o: ad 63.

5 Taplin I977: 293.

6 Cf. Lloyd [i994] 2005: I62-I63.
} 
of Heracles' madness, with his unexpected silence and distorted eyes, is treated both in simultaneous $(867-870)$ and retrospective (928-934) narration.

\section{Beginnings}

Euripides typically begins his plays with a prologue speech, in contrast to Sophocles, who begins with dialogue in six out of his seven extant plays. The effect is to present the prehistory of the play in a single block, rather than in the more fragmented manner favoured by Sophocles $(\rightarrow)$.

This practice leads to problems in identifying the point in the story at which the plot begins. A prologue speech is not usually an event in the plot, but is rather a narrative device by the playwright. The entrance of the prologue speaker is therefore not normally the beginning of the plot, with everything prior to that to be regarded as external retrospective narrative. In $M e d e a$, for example, the Nurse's account of Medea's grief is essentially simultaneous with her audible outbursts later in the play (96-97, II2-II4, etc.): 'Poor Medea, finding herself thus cast aside, calls loudly on his oaths, invokes the mighty assurance of his sworn right hand, and calls the gods to witness the unjust return she is getting from Jason' (20-23). ${ }^{7}$ It would also be unnatural to take Medea's grief as the beginning of the plot, and to take Jason's betrayal of her (I7I9) as retrospective narrative. The first event is usually what prompts the prologue speech. The plot of Medea thus begins with Jason's betrayal of Medea and marriage to the daughter of Creon (I6-ig; note 'now', I6). The Nurse's speech is prompted by her distress at this turn of events and Medea's reaction to it (56-58; cf. Hec. 68-76; IT 42-43). The plot of Ion begins with Creusa and Xuthus coming to Delphi (65-68), of Phoenissae with the truce organized by Jocasta $(8 \mathrm{I}-83)$, and of Orestes with the Argive assembly and the arrival of Menelaus (46-56). These events can only be taken as pieces of external retrospective narrative information if the prologue speech is treated as an event within the plot, as opposed to a narrative device by the playwright.

Gods differ from other prologue speakers in that their very arrival can be a crucial event, especially when it signifies the establishment of

\footnotetext{
7 Passages from Euripides are cited, sometimes with slight adaptations, from the Loeb translation by David Kovacs.
} 
their cult and the punishment of their enemies (Bacchae, Hippolytus). In Alcestis and Troades, by contrast, the plot begins with the departure of a protecting god (Alc. 23; Tr. 25). In suppliant plays, the plot begins with the crisis which prompted the supplication. The prologue speech explains the opening tableau (Hcld. 31-38; Andr. 39-44; HF 35-50; Hel. 6o-67). Electra is unusual in that there is nothing in particular that prompts the prologue speech, and the first event is the arrival of Orestes and Pylades at line 82.

\section{Retrospective narratives}

Euripides typically frames the plot with external retrospective narration at the beginning and external prospective narration at the end. The effect is to suggest that the play focusses on a single day from an extended story. The Nurse in Medea thus tells of the voyage of Argo through the Symplegades to Colchis to get the Golden Fleece for Pelias ( $\mathrm{I}-6)$, followed by Medea falling in love with Jason and sailing to Iolcus (6-8), persuading the daughters of Pelias to kill their father $\left(9^{-}-\mathrm{O}\right)$, and going into exile in Corinth, where she lived happily with Jason as man and wife (IO-I5). It is at this point that the Nurse describes the beginning of the actual plot: Jason's remarriage (I6-I9), and Medea's response to it $(20-45)$. This simultaneous narrative at the end of the prologue speech moves seamlessly into a dramatized presentation of the events.

There are completing external retrospective narrations later in the play. They include the details of the acquisition of the Fleece and Medea's role in it (476-482), Jason's oaths (I60-I63, I68-I70, 208-209, 4IO-445, 492-495, 698), and the murder of Apsyrtus (I67, 257, I334). There are also repeating external retrospective narratives: Medea's voyage to Iolcus (I66, 255-256, 43 I-435, 483-487, 534-544, I329-I335), the death of Pelias $(486-487,504-508,734)$, and Jason's remarriage (I40, 309-3 Io, 435-436, 488-489, 547-568, 69o-703).

Another example of Euripides' extensive employment of external retrospective narration is Andromache, where the whole story of the Trojan War is incorporated in a series of narratives: the marriage of Peleus and Thetis (I7-I9, I2I8-I2I9, I23I-I237, I253); the marriage of Andromache and Hector (I-4, 222-227); the judgement of Paris (274292); Cassandra's prophecy about Paris (293-300); Paris eloping with Helen (IO3-IO4, 592-604); Menelaus gathering an army $\left(324-325,605^{-}\right.$ 
6o9); Menelaus promising Hermione to Orestes (966-969); the sacrifice of Iphigenia (624-626); Menelaus promising Hermione to Neoptolemus (969-970); the Trojan War (304-308, 6Iо-6ı8, Іог8-Iо2 I, Iо37I046), including the deaths of Hector (8-9, го7-Io8, 399, 456-457) and Achilles $\left(247^{-248}, 654^{-656}\right.$, I235-1237); the capture and sack of Troy (I05-Iо6, 301-302, 362-363, 400, 455, Iог3-гог7, I022-I027), including the death of Astyanax (9-II) and Menelaus' sparing of Helen (627-63I, 685-686); Andromache going to Greece as Neoptolemus' concubine (I2-I5, 24-25, I09-II4, I4I-I42, 40I-403); Neoptolemus becoming king of Phthia (2I-23); Neoptolemus' first visit to Delphi (5I-53, I I94-I I96); Andromache giving birth to Molossus (24-25, 395-396); the marriage of Neoptolemus and Hermione (29-3I, I47-I53, 6I9-624, II86-II93); the death of Agamemnon (I028); Orestes killing Clytemnestra (972981, I029-I036); and finally Menelaus rebuffing Orestes' pleas to marry Hermione (97I-98I).

This kind of procedure could be illustrated many times over in Euripides' plays, with the plot set against a much larger background which is systematically reconstructed by retrospective narratives. He sometimes uses the chorus for this purpose (e.g. Tr. $5^{\mathrm{II}-567} ; \mathrm{Ph} .6^{6}{ }^{-}$ 675). ${ }^{8}$ In the case of Andromache, as in others of Euripides' plays (e.g. Iphigenia in Tauris, Orestes) the characters replicate familiar behaviour from earlier in the myth. ${ }^{9}$

Internal retrospective narrations are also common in Euripides, especially completing retrospective narrations describing events which have taken place offstage. The messenger-speech is the most notable example of this, ${ }^{10}$ but there are many other examples (e.g. Alc. $747-772$; Andr. 802-8I9; El. 509-523, 6i9-633).

\section{Prospective narratives}

Drama may create a more immediate sense of the present moment than narrative, but each moment also implies a future. The events only happen as they do because they are part of a larger pattern which is to a greater or lesser extent unrealized. This aspect of drama has been

\footnotetext{
8 Cf. Gould [I99I] 200I: 325 .

9 Lloyd [I994] 2005: 6-7.

10 Cf. de Jong ig9ra.
} 
well described by Suzanne Langer: 'In actual life we usually recognize a distinct situation only when it has reached, or nearly reached, a crisis; but in the theater we see the whole setup of human relationships and conflicting interests long before any abnormal event has occurred that would, in actual life, have brought it into focus'. ${ }^{11}$ In Medea, for example, the whole description of Medea's rage and grief in the prologue $\left(20^{-} 35\right)$ by itself implies that she is going to do something violent, and the Nurse's fears for the children creates the expectation that something is going to happen to them $\left(36,90^{-} 95\right.$, IOO-II 8$)$. This is, however, overlaid by the more frequent and explicit references to an attack on Jason's new family (37-45, I06-I Iо, I63-I65, 259-266, 282-29I, 364-409, 453$457,625-626,764-790)$. It thus comes as shock when Medea announces her intention to kill the children (792-793), regardless of whether there was a pre-existing version in which she kills them. Medea's concerns about which city will give her shelter (386-39I, 502-508) create an expectation that the issue will be dealt with later in the play.

Many of Euripides' plays contain an elaborate plan or intrigue $(m \bar{e}-$ chanema), which foreshadows the events described in the messengerspeech (e.g. IT I0I7-I055; Hel. I032-i Io6; Or. II05-I245). These plans are sometimes remarkably detailed and accurate. Medea thus describes her plan to the chorus: 'I shall send one of my servants and ask Jason to come to see me. When he arrives, I shall speak soothing words to him, saying that I hold the same opinion as he, that the royal marriage he has made by abandoning me is well made, that these are beneficial and good decisions. I shall ask that the children be allowed to stay, not with the thought that I might leave them behind on hostile soil for my enemies to insult, but so that I may kill the princess by guile. I shall send them bearing gifts, a finely woven gown and a diadem of beaten gold. If she takes this finery and puts it on, she will die a painful death, and likewise anyone who touches her: with such poisons will I smear these gifts' (Med. 772-789). She proceeds to give an equally accurate account of her murder of her children and flight from Corinth (790796). Contrast Creusa's plan to kill Ion, where she says 'If it [the poison] passes down his throat, he will never come to glorious Athens but will die and remain here' (Ion I037-I038), but Ion does not in the event drink the poison. The intrigue in Electra is worked out in dialogue (596663), and includes accurate predictions not only of what the plotters

\footnotetext{
11 Langer 1953: 311.
} 
themselves will do but also of the reactions of their enemies Aegisthus (637) and Clytemnestra (656). Murderous plans are foreshadowed more obliquely and allusively at Hippolytus 725-73I and Andromache $993^{-1008 .}$

In comparison to Sophocles, Euripides makes very little use of prophecies and dreams to foreshadow what is to happen: 'such proleptic items within the body of the a play are a marginal feature of Euripides' strategy'. ${ }^{12}$ There are dreams at Hecuba 68-97, Iphigenia Taurica 42-66, and Rhesus 780-788, but in Electra he eliminates the dream which is prominent in Aeschylus (Ch. 22-4I, 5I4-539) and Sophocles (El. 417-425). He makes much more use of predictions in prologue speeches, which have special authority when they are made by a god (Alcestis, Hippolytus, Troades, Ion, and Bacchae). Even in these cases, however, Euripides can manipulate the audience's expectations, and this is especially notable in Ion, where Apollo turns out to be unable to predict and control events. Hermes describes Apollo's intentions as follows: 'he means to give his own son to Xuthus when he enters this shrine and say that Xuthus is the father. In this way the boy will enter the house of Creusa his mother and be recognized by her: thus not only will Loxias' liaison be kept a secret but also the boy will receive what belongs to him' (Ion 69-73). As things turn out, Apollo's plan encounters a series of near-disastrous obstacles, and Creusa eventually recognizes Ion not in Athens but in Delphi. ${ }^{13}$

Euripides sometimes has prospective narration by the chorus. ${ }^{14}$ There are two examples of the chorus anticipating the outcome of a plot. At Medea 976-Ioor, the chorus correctly predicts the outcome of Medea's plot, while at Bacchae 982-991 they go so far as to quote what Agave will actually say (incorrectly in detail, but correctly in general sense; cf. I Io6-irog). The chorus of Hippolytus correctly predicts Phaedra's suicide $(767-775)$. Examples of external prospective narratives are Hecuba 444-483, where the chorus of Trojan slaves speculates about the future which awaits them in Greece, and Iphigenia Aulidensis $75 \mathrm{I}^{-802}$, where the chorus evokes the imminent war at Troy.

Euripides ends nine of his seventeen surviving tragedies with a speech by a deus ex machina, who explains aspects of the action which the humans may have misunderstood, gives them instructions, and predicts what will happen to them in the future. The god tells the characters

12 Goward I999: I22.

13 Cf. Hamilton I978: 279-283; Lloyd i986.

14 Cf. Gould [I99I] 200I: 325. 
their place in the myth, and relates the action to a continuing custom or cult. In several other plays (e.g. Medea, Hecuba), a human character is granted temporary predictive powers and fulfils a similar role. These prospective narratives balance the retrospective narratives in the prologue speech: Euripides' plays focus on one segment of a myth, and these speeches at the beginning and end of a play give the rest of the story in condensed form.

\section{Order within narratives}

Euripides' embedded narratives generally proceed in a lucidly chronological order. Medea typifies Euripides' treatment of events in narrative when she says 'I shall begin my story at the beginning' (Med. 475). In prologue speeches, there are only quite minor deviations from chronological order. In the prologue of Alcestis, for example, Apollo mentions his servitude to Admetus ( $\mathrm{I}-2)$ before the reason for it $\left(3^{-} 7\right)$, and his protection of Admetus' house (9) before the reason for that (IO-II). Messengers give their news in brief at the outset (e.g. Andr. I073-I075), but their speeches normally recount the events as they experienced them, in strict chronological order. They sometimes employ narrating focalization, especially in revealing ex eventu knowledge of a plot (e.g. Andr. I088, Iгол), in order to set out the events in a clearer chronological order. ${ }^{15}$ De Jong observes that the regular use of experiencing focalization means that there are few analepses or prolepses in messengerspeeches, and she finds very few cases even of implicit prolepses. ${ }^{16}$ Narratives in dialogue similarly proceed in chronological order, for example Creusa's narrative at Ion 265-307, in which there is a minor anachrony explaining her marriage to Xuthus (293-298).

Euripides' lyric narratives usually adhere to chronological order, for example the accounts of the earlier history of Thebes in the odes of Phoenissae (e.g. 638-675; cf. Arthur 1977), the description of the capture of Troy in Troades (5 $5^{\mathrm{I}-567}$, with some ex eventu knowledge at 534-535), the account of the foundation of the Delphic oracle at Iphigenia Taurica I234-I283, and the narrative of the Labours of Heracles at Hercules Furens 359-429. There is some anachrony in the 'shield of Achilles' ode (El. 432-486), which begins with the voyage of the Greek ships to Troy,

15 Cf. de Jong i99ia: 30-56.

16 De Jong i99ia: 45-49. 
and then moves back to Achilles receiving his armour (with its images of earlier episodes from myth), before moving forward to the murder of Agamemnon, and finally predicting the murder of Clytemnestra.

\section{Rhythm}

Lowe observes that in drama 'time runs at a fixedly literal rate', and that 'summary, stretch (retardation), and pause are virtually impossible'. ${ }^{17}$ It could be argued against this that there are examples of pause in Euripides, where the action comes to a standstill. This happens in speeches with passages of quasi-soliloquy like Orestes' reflections on nobility (El. 367-400) and Hippolytus' tirade against women (Hipp. 6i6-668). A subset of these speeches is the entrance soliloquy, where sometimes, as Bain says, 'the action freezes'. ${ }^{18}$ He discusses the pause at Hercules Furens 525-529, during which Heracles takes in the scene, and Megara's instructions to the children (520-522) are ignored (cf. Tr. I $285^{-}$- 332 ).

There is more scope for differences of speed in embedded narratives. Euripides' messenger-speeches are highly scenic, with more use of direct speech than Sophocles' $(\rightarrow)$. Occasionally, however, he speeds up the narrative with short passages of summary. A good example is the description of Aegisthus' slaves preparing a sacrifice (El. 798-802): 'the slaves ... put forth their hands to their work: some brought a bowl to catch the blood, others brought baskets, still others proceeded to light the fire and set cauldrons upright about the altar. The whole house resounded with activity' (cf. $M e d$. II4I-II42; Ba. I054-I057, II3II 136). Compare the response to the effect of Medea's poison on Creon's daughter (Med. II77-II80): 'And at once one servant went to her father's chambers, another to her new husband to tell of the bride's misfortune: the whole house rang with the sound of drumming footsteps'. The iterative optative is sometimes used in such contexts, as at Iphigenia Taurica 324-326: 'But when some of us fled, others ran up to the men and pelted them. When the men drove them off, those who had just run away came back and pounded the men with stones' (cf. Med. г2 I6; Hipp. I226I23I). A rather different use of iterative narration, with reference to an

\footnotetext{
17 Lowe 2000: I64.
}

18 Bain I98I: 24-29. 
imagined viewer, can be found in the following passage: 'You could have seen one of the women tearing asunder a bellowing fatted calf with her hands, while others tore heifers to pieces. You could have seen their flanks and cloven hooves hurled this way and that ...' $(B a$. 73774I; cf. Andr. II35-II36). The passing of time can also be evoked by comparisons: 'And in less time than a runner could have finished both legs of a hippodrome he flayed off the hide and loosened the flanks' (El. 824-826; cf. Med. I 18I-II84). The messenger-speech in Andromache begins with an unusually extended summary, describing Orestes' plotting (Andr. I085-I099), including an iterative direct speech.

\section{Frequency}

The frequency of the events represented in a play, as opposed to those described in embedded narrative, might be thought to be necessarily singulative. It could, however, be maintained that the opening sequences of several of Euripides' plays are in a significant sense iterative in that they represent either habitual behaviour or at least behaviour which has been going on for some time. This is the opposite of Genette's concept of 'pseudo-iteration' in Proust, referring to scenes which are ostensibly iterative 'whereas their richness and precision of detail ensure that no reader can seriously believe that they occur and reoccur in that manner, several times, without any variation'. ${ }^{19}$ These passages in Euripides are ostensibly singulative, but in reality have a significant iterative element.

Medea's offstage laments (96-2I3) are essentially an illustration of the behaviour described iteratively by the Nurse in the prologue $\left(20^{-} 3^{6}\right)$, and thus have an iterative quality of their own. In Troades, Hecuba's opening monody $\left(9^{8}-\mathrm{I}^{2}\right)$ similarly picks up on Poseidon's reference to her in his prologue speech $(37-38)$. Hermione's accusations in the agon of Andromache (I55-I58) illustrate the iterative behaviour described by Andromache in the prologue $\left(3^{2-} 35\right)$. This is even clearer in the case of Electra, where the domestic tasks which Electra performs in the prologue are evidently representative of her life in general (54-8I), and her lamentation is explicitly represented as typical (e.g. 'always' at line I45; the repetitive quality of Electra's laments is even clearer in

19 Genette [I972] I980: I2 I. 
Sophocles, e.g. El. 86-I20). Andromache's elegy has a similar quality (e.g. 'always', Andr. 9I), although she mentions her immediate situation at the end.

The beginning of Hippolytus is more elaborate. Hippolytus' first appearance (Hipp. 58-120) clearly illustrates (in both lyric and iambic modes) the characteristic pattern of behaviour which Aphrodite has described in her prologue speech (Hipp. IO-I9), namely devotion to Artemis, hostility to Aphrodite, enthusiasm for hunting, and rejection of sexual activity. The initial presentation of Phaedra (Hipp. I76-36r) is likewise an iterative illustration of Aphrodite's account of her plight (Hipp. 38-40). In Ion, Ion's opening monody (Ion 82-183) represents his mode of life in general as much as anything which he does on a particular day (note 'always', Ion I03). For a similar effect in a messengerspeech see Bacchae 680-7i3.

Euripides also employs repetition. The sequence of events in his plays is ostensibly chronological, but to a greater extent than in Aeschylus or Sophocles is organized as a repeating presentation of the same events in a variety of modes. One example of this is his exploitation of the tragic convention whereby 'a situation is realized first in its lyric, then in its iambic aspect - that is to say, first emotionally, then in its reasoned form' ${ }^{20}$ The most extreme example of this is in Alcestis, where Alcestis dies first in a lyric scene (238-279), and again at the end of an iambic scene in which both she and Admetus make lengthy speeches and engage in stichomythia (280-392). The same motifs are repeated at the end of each section: darkness coming over the eyes $(269,385)$, 'I am no more' (270-27I, 387), farewell to her children $(272,389)$. John Gould has used this scene as a paradigm case of the way in which Euripides' use of different modes of presentation means that 'both the action and the stage figures should be seen and felt by us, the audience, as fragmented and discontinuous'. ${ }^{21}$ This example is extreme because Alcestis dies at 272, the climax of a remarkable passage of simultaneous lyric narrative, and there is no attempt to relate the lyric and iambic sections in any naturalistic way. In other examples, the transition from lyric to iambic is subtly smoothed, for example by being presented as an attempt at more coherent utterance (Tr. 348-350, 366-367; Hel. 252253 ; cf. A. A. II78-II85). Scholars have pointed to the way in which

\footnotetext{
20 Dale [I954] i978: ad Alc. 280ff.
}

21 Gould i978: 50 = 200г: 9i. 
Euripides pushes this convention to an extreme as part of his presentation of Alcestis in an ambiguous condition between life and death. ${ }^{22}$

The anapaests which precede the parodos in Medea (96-i30), the parodos itself (I $3^{-2}$ I3 $)$, and Medea's opening speech (2I4-266) essentially recapitulate the Nurse's account of her behaviour in the prologue speech $(20-45)$. The same topics recur in various modes: Jason's oaths (2I-23, I60-I63, I68-I70, 208-209, 4I0-430); Medea's wish for death (24-26, 96-97, I4-I-I42, I5 $\left.{ }^{\mathrm{I}-\mathrm{I}} 54,226-227\right)$; her harshness and rejection of consolation (27-29, 98-IIO, I42-I43, I73-189); her regrets about leaving Colchis $\left(3^{0}-35, \mathrm{I} 66-\mathrm{I} 67,255^{-258}, 44^{\mathrm{I}-443}, 645^{-662)}\right.$ ); her hostility to her children $(36,92-93$, IO0-I05, II -II3, II6-II8). These themes are treated further in her speech in the agon $\left(465^{-} 5^{19}\right)$.

\section{Conclusion}

Euripides differs from Sophocles $(\rightarrow)$ in presenting the prehistory of the play in a block in the prologue speech, and he often also inserts external retrospective narratives later in the play. The prologue speech is balanced by external prospective narration at the end, often by a deus ex machina. The effect is to present the plot of the play as a brief if crucial segment of an extended story. The messenger-speech is the most notable example of internal retrospective narration in Euripides. More distinctive is his use of detailed and usually accurate internal prospective narration in his plotting scenes. His embedded narratives, both iambic and lyric, tend to proceed chronologically, and this is indeed an aspect of his characteristic clarity of structure. His boldest effects in the treatment of time are not in his embedded narratives but in his repeating presentation of the same events in a variety of modes.

${ }^{22}$ E.g. Gregory I991: 32; cf. Buxton I987: 19-23 = 2003: $173^{-179}$. 
CHAPTER EIGHTEEN

ARISTOPHANES

A.M. BowIE

Order

Because so many of the embedded narratives in Aristophanes are used to set the scene for the audience, most notably in prologues, it is inevitable that most of them will be external retrospective narratives. They may describe a situation that continues to exist at the start of the play, but the events themselves are almost always in the past. Because of the need for clarity, the order of events is simply chronological; the same is true of Euripides $(\rightarrow)$, who regularly begins his tragedies with prologue speeches. For the same reasons, the principal mode is 'summary': the speakers do not linger over the details, but move quickly through them to maintain the comic momentum. Similarly, these passages tend to be quite densely packed, as the speaker crams in as many amusing examples of the character of a Paphlagon or a Philocleon as he can. This is especially true of the prologues of the early plays, Acharnians, Knights, Wasps and Peace, but can also be found elsewhere.

A straightforward example of an external retrospective narrative is to be found in Peace, after the goddess has been pulled from the ground and the cities have begun to fraternise with each other (605-705). This is in fact one of the longest retrospective passages in Aristophanes. In it, Hermes relays to Trygaeus and so to the audience the reasons for Peace's absence from the world in recent years. ${ }^{1}$ The passage is in fact a condensed, often imagistic and indeed fanciful history of the Archidamian War. It begins with the accusations against Pheidias of embezzling moneys intended for Athena's chryselephantine statue, and Pericles' fears that he would be implicated, which are said to have led to

\footnotetext{
${ }^{1}$ On this speech see the analysis of Cassio ig85: 87-95.
} 
the Megarian Decrees, and then moves through the allies' supposed dealings with the Spartans and internal dissentions in Athens to Spar$\tan$ attempts to make peace after Pylos. The chronology is roughly that of the actual events before and during the war, though the amount of detail is slight, given the period covered, and the history tendentious at times. It is nonetheless an effective passage: peace has been made and this review of the war, laying blame on both sides, though more so on Athens, allows the audience to contrast the disagreeable picture of the past conduct of the war with the cheerful unity that is about to be achieved.

Though we do not find great complexity in Aristophanic narratives, no dense play of levels of narration or of secondary, tertiary, etc. narrators, no striking games with frequency of narration for instance, ${ }^{2}$ there are however subtle variations in the manner of the narration of these retrospective narratives. To take a simple example, in the scene between Blepyrus and the Man near the start of Ecclesiazusae, the situation is described by the parallel narratives of the two men's inability to find their clothes which have been stolen by the women (3II-37I). The strangeness of the story is added to by the double narration, whereby we see that Blepyrus' experience is shared with another, and not a matter of mere chance.

The Ambassador who comes to the Assembly at the start of Acharnians gives a straightforward account of their embassy to the Persian King $(65-92)$. However, the scandalous nature of their behaviour is neatly conveyed by the considerable gap between the lengthy time covered by the actual events and the small amount of text required to narrate them. The ambassadors set out 'in the archonship of Euthymenes' (67), that is in 437/436; they crossed the Caÿstrian plains in a leisurely manner and reached the King's palace in the fourth year, but he was absent for eight months, before he returned to entertain them. The time taken is twelve years, ${ }^{3}$ but the narrative of these years occupies merely nineteen and a half lines (in 65-92; the other lines are Dicaeopolis' bomolochic interventions); the ambassadors filled these twelve years with idleness, so there is nothing to relate. The contrast between the threadbare narrative of idle self-indulgence and the great swathe of time consumed justly draws Dicaeopolis' scorn.

\footnotetext{
${ }^{2}$ Iterative narration is not of course absent; cf. e.g. Eq. I337-I355; V. 85-130.

${ }^{3}$ Delays on such embassies were not unusual, but the extent of the delay here is remarkable; cf. M.C. Miller i997: II4-II7.
} 
In a number of retrospective narratives, Aristophanes experiments with the blending of subsequent and simultaneous narration of the current situation, sometimes adding bits of stage-action to complement and complete the narrative. The sense that the retrospective narrative is just a necessary setting of the scene is thus mitigated, as past and present are intertwined. For instance, at the start of Clouds, Strepsiades' narration of his past troubles with his son and his debts is intercut with 'present' embodiments of those problems, in Pheidippides' cries as he dreams of horse-racing, and in the account-book that is brought to Strepsiades and reveals the nature of the trouble he is in with his debts. ${ }^{4}$ Subsequent narration mutates from time to time into simultaneous narration: Pheidippides cries out 'Pheidon, you're cheating! Keep to your own lane!', which prompts Strepsiades' reply 'That's the problem that's destroying me: even when he's asleep he dreams of horse-racing!' $\left(25^{-26)}\right.$.

In Peace, we have a slightly more complex version of this, whereby one of the two Slaves ${ }^{5}$ begins to recount the past actions of his master in his response to the incessant war $\left(5^{0}-59\right)$. He tells how Trygaeus began by raving at Zeus for causing the war (56-6o), and immediately Trygaeus, offstage, echoes his words. He then tells of Trygaeus' failed attempt to climb a ladder to heaven and how he subsequently bought a huge beetle to fly there. Again, he quotes Trygaeus' words to the beetle, before he looks inside the house and sees Trygaeus rising up on his beetle, which he then describes simultaneously with its happening: 'Oh god! Neighbours! Come here: my master is rising up on high into the air on his beetle as if it were a horse!' (79-8I). After this, the pair are actually made manifest onstage to the audience, with Trygaeus warning his 'horse' to be careful. Here then we oscillate between subsequent and simultaneous narration with the addition at the end of a technique whereby narrative becomes stage-action. The Slave's description moves from the past, to the present behind the stage, before giving way to the actual representation of things before the audience's eyes. As we shall see elsewhere, narration of the past is thus so constructed that it leads naturally back to the present of the play, and the action ensues.

${ }^{4}$ Dover 1968: 91 notes how in this prologue 'the transition from emotional reaction to pure narrative is effected subtly', but the narrative is more varied than he allows.

${ }^{5}$ On the question of the exact attribution of the lines between the Slaves in this prologue, cf. Olson i998: 67. 
In many prologues, we are dealing with what one might call 'imaginary recollection', that is the 'recollection' of fictitious events, where the relationship between story and fabula is hypothetical and unrecoverable, because the speaker is not concerned with the chronological relationship between the elements in the narrative, but with creating a climax or other effects. This type of achronical narrative contrasts with the generally straightforwardly chronological narrative of most prologues discussed at the start of this chapter. An example of this is Dicaeopolis' prologue in Acharnians, in which he catalogues the pleasures and pains he has suffered. Here we have temporal markers, such as 'then', 'now' (9, I5, i9), and several of the examples are introduced by 'when', but there is no suggestion of a chronological order: rather there is an alternation in the form of pleasure-painpleasure - pain - greatest pain, building to the climax of the scandal of the current situation. Matters are of course complicated by the fact that these events may have been real ones, albeit on various stages, and some in the audience may have been able to put them in order, but from a narratological point of view this is unimportant. Chronology is not at stake here, so much as rhetorical ordering for effect. ${ }^{6}$

There is something similar in the prologue of Wasps. Xanthias' account of the manifestations of Philocleon's jury-mania has no chronological structure (87-I35): he talks - in the form of iterative narrationabout what Paphlagon does at night, about what he does when he sees 'Demos is beautiful' on a wall, what he does in the evening, the state of his nails and his possession of a beach for pebbles. However, when he gets to Bdelycleon's attempts to cure his father, temporal markers are much in use: 'first of all' he used persuasion (II5); 'then' he tried purification (II8); 'after this' he tried the Corybantes (II9); 'when however' that didn't work (I2I), he took him to Aegina; 'then' he put him in Asclepius' shrine (122), which also failed; 'from that time' they have not let him out (125). The chronology is clearly set out, but the order of events is less important than the sense of increasingly despairing and extreme expedients that Bdelycleon tries: we move from persuasion to simple acts of purification to resort to orgiastic cults, and finally to trips over the sea to a famous shrine. The end of this list leads back to the

\footnotetext{
${ }^{6}$ One could include here as parallels passages such as the speeches in Thesmophoriazusae, where two women narrate the effect of Euripides on household and economy, and Mnesilochus gives his fictitious account of his extra-marital escapades (443-519).
} 
present and Philocleon's recent attempts to escape allow Xanthias to explain why the stage is set up as it is, with blocked chimneys and nets strewn around the courtyard.

We find this technique of mixing passages of clear chronology with others where the chronology is unclear or irrelevant elsewhere. We looked earlier at the first part of Strepsiades' account of his problems. There follows an account of his marriage to his luxurious wife, the birth of their son and its aftermath in their discussions of a suitable name for him $\left(\mathcal{N} u\right.$. 4 $\left.\mathrm{I}^{-}-74\right)$. The earlier part of the account was chronologically imprecise and even random, but, after an exchange with Pheidippides, Strepsiades suddenly turns in line 42 to curse the match-maker who brokered the marriage to his wife. This introduces the story of that marriage. Here, in an expository passage, the sequence is carefully marked: he describes his earlier life; 'then' he married; 'when' he did, they were a pair with very different odours. A brief exchange with the slave about the wick interrupts, before Strepsiades continues the story about their dispute over a name for their son with 'after this'. 'At first', they disagreed; 'then' they compromised. The same pattern that we can see elsewhere appears here: one part of the narrative is told without a chronological structure, in Strepsiades' comically random description of his present troubles, which is in part embodied onstage; then the second part, where the audience needs to catch important basic information, is told with attention to clear temporal marking.

There is a variation on this in Knights, where there is a chronological framework, but its chronological aspect is again not the most important. In the prologue, the slave 'Demosthenes' recounts the experience of the members of Demos' household since the arrival of the Paphlagonian (40-79). It begins with the purchase of the Paphlagonian, which is given a precise date (itself unusual in Aristophanes generally), 'the previous new moon' (43). The various antics of the new slave do not have any necessary chronological relationship with each other, in that they are simply examples of his intolerable behaviour: they could be in any order and they could be repeated acts. None the less, Aristophanes does give them a temporal framework, but for a purpose other than the purely chronological. The slave is bought at the new moon, flatters the master and steals the gifts the other slaves intended for him (43-54). The narrative is of the past, but it is given in a mixture of past and present tenses, indicating that it also describes the present situation: Aristophanes does not repeat descriptions of actions, but often allows a single description to stand for repeated performance of that action. 
Demosthenes then gives the example of Paphlagon's theft of his own Pylian cake, which is dated to proeen (54), either 'recently' or even 'the day before yesterday'. Further examples follow, and the list ends with his threat that 'if you don't obey me, you die today' (68). 'Today' in its context of Paphlagon's threat is a general remark, but it also brings us back to the present of the play's action, which is emphasised by Demosthenes' concluding 'so now'. Here then, as in Peace above, the temporal markers do not so much order the events according to their actual chronology, but are imposed on the narrative in order to bring us back to the action, by the suggestion of an order: 'new moon - recentlytoday - now', and the action ensues. ${ }^{7}$

The need for clarity of exposition is often the cause of clearly articulated narratives. For instance, Dicaeopolis' speech to the Assembly (Ach. 497-556) is tackling the difficult task of justifying the actions of the Spartans to the Athenians, in war-time. Thus, clarity of exposition is needed, not just to save Dicaeopolis' skin, but in order that the audience may enjoy the humour of the tight-rope walking. The context, a formal speech before the Assembly, also demands rhetorical clarity. Dicaeopolis takes his audiences through the stages of the events in a clearly marked manner. The first two elements - the Megarian Decrees and the theft of Simaetha from Megara - are linked merely by the dismissal of the former as 'a little local difficulty' $(523) \cdot{ }^{8}$ The third - the Megarians' reciprocal theft - is introduced by 'and then' (526) and, as matters get more complex and exaggerated, the temporal relations are very carefully indicated: 'next' introduces each of the next four stagesthe start of the war, Pericles' reaction, the Megarian request to Sparta and Athenian refusal, and the 'rattling of shields'. In contrast to this careful chronology, the description in the last part of the speech of the belligerent preparations the Athenians would have made had a Spartan declared a Seriphian puppy contraband, abandons chronology completely in favour of the piling up of 32 genitives, the apparently random and turbulent expressions mirroring the mad-cap and chaotic nature of

${ }^{7}$ For this linking of a retrospective narrative and the present of the play's action see Euripides' $(\rightarrow$ ) prologues.

${ }^{8}$ On the problems of the actual timing of the events mentioned here and the difficulty of relating together in a historical pattern the features Dicaeopolis mentions, cf. Olson 2002: 205; these uncertainties do not affect the above analysis however. 
the Athenians' reaction. ${ }^{9}$ Chronology thus complements clarity and lays the ground-work of the argument, but is abandoned when a more boisterous form of expression is required to drive home the point Dicaeopolis is making and to prevent the speech from becoming too solemn an imitation of contemporary rhetoric. The extraordinarily increased density of events in this last part makes a potent conclusion, and is not matched for density by anything else in this author.

It is only at the end of Aristophanes' career that we find him using a straightforwardly chronological style of narration, with the temporal relations clearly expressed; nothing quite like this is found earlier. In the lengthy internally retrospective narrative of Plutus' visit to Asclepius' shrine $(P l$. 649-747), the narrative, lightly interrupted by bomolochic remarks by the Woman, proceeds in an entirely chronological fashion, just as Carion promises at the very start: 'I shall recount everything to you from toe to head' (ek tōn podōn es tên kephatēn, 650). The mode is essentially summary, but there are vignettes where it comes close to scene, such as in the description of the priest's stealing of the offerings (676-68I), or of Carion's treatment of the Old Woman, whose soup he had his eyes on (685-695). The narrative is clearly articulated by temporal markers: 'as soon as'... 'first'... 'then'... 'when'... 'then'... 'then'... 'when'... 'then'... 'after this'... 'after that'... 'then', and so on. Here there is no attempt to introduce variety or especially notable rhetorical climaxes of the kind that we have seen in the earlier plays. The contrast with these can be seen in Knights 624-682, where the Sausage-Seller's account of the debate in the Boule largely eschews such rigorous temporal marking. It is not absent, in that he uses expressions such as 'when I realised' $(632,658)$, 'then' $(640,647,665,675$, $678)$, but in general the connections between the sentences are made for instance through particles: the conjunctions become more common only towards the end. The sober (though not humourless) account of the visit to the god's shrine in Wealth thus relies on a clear temporal structure, whereas this more excitable and triumphalist account runs more smoothly from episode to episode.

A final case which we need to consider is the narration of a story, not in one place by one or more characters, but in the course of a play; the technique of the 'piecemeal distribution' such as found in Homer $(\rightarrow)$

9 Olson 2002: 2I5 notes how 'the pace of the description gradually accelerates, from two items per line (546-548), to three $\left(549^{-550}\right)$, to four (55I)'. 
and Sophocles $(\rightarrow)$. The most notable example of this is in Lysistrata. Running through that play is the history of events subsequent to the murder of Hipparchus, the brother of the tyrant Hippias..$^{10}$ The main aspects of the story are there, but they are not related in chronological order nor indeed are the episodes juxtaposed for the most part. This story, which resulted in the establishment of a democratic system in Athens under Cleisthenes, becomes the filter through which the Old Men in the play try to construct an identity for themselves and a justification for their opposition to the women's attempts to make peace. The women are thus characterised as tyrannical figures opposed to the democracy (though they have other filters, largely religious, which tell a different story). There are five episodes scattered through the play, which have the following chronological order: (A) the murder of Hippias' brother (630-634); (B) the defeat of the Alcmaeonids at Leipsydrium $(664-670)$; $(\mathrm{C})$ the bringing of Spartan aid to the Alcmaeonids (619-625); (D) the siege of the Peisistratids by Cleomenes (II5O-II53); (E) the besieging of Cleomenes in the Acropolis and his expulsion (273280). These appear in the play in the order $\mathrm{E}-\mathrm{C}-\mathrm{A}-\mathrm{B}-\mathrm{D}$. The Old Men announce this theme in their part of the parodos, when they say that the women will not make fun of men who besieged Cleomenes in the Acropolis, when he came to offer support to Cleisthenes' oligarchic rival, Isagoras (E). Their siege of the Acropolis is thus placed under the sign of the final triumph of the democratic politicians in 508, when Cleomenes, the Spartan king, was driven out in short time. They return to it at the start of the first part of the agon, which is another scene where the two semi-choruses confront each other and their values. They 'smell' the tyranny of Hippias in the women's actions and recall, in parodic form, help given to the Alcmaeonids by the Spartans after they had been defeated at Leipsydrium (C). This is then combined with their determination to imitate the tyrannicides, Harmodius and Aristogeiton, murderers of Hipparchus (A). The story of Leipsydrium starts the second part of the agon $(\mathrm{B})$. Finally, this sequence of events is given a more positive moral aspect, when Lysistrata takes it up from the men in her attempts to persuade the Athenians to accept the peace. She recalls the help that the Spartans gave in the besieging and expulsion of the tyrants from the Acropolis, which enabled Cleisthenes to introduce democratic rule (D). The events which the

10 Cf. further A.M. Bowie I993: 195-199. 
men had arrogated to themselves in a distorted way to explain their actions thus finally become one of the arguments that bring about peace.

In this example, the narrative is fragmented, both chronologically, spatially and in terms of its narrators, which are first the men and then the heroine. Elements of it are introduced at places in the action of the play where they have particular significance. The actual order in the fabula is not necessary to the understanding of the function of this story, which works by the repeated evocation of a democratic myth at important moments when the narrators wish to claim a certain meaning for their acts. ${ }^{11}$

We have so far looked at retrospective narratives: prospective ones are very much less common. There are of course a number of mentions of oracles, especially in the competition between Sausage-Seller and Paphlagon in Knights, but there the point of the scene is not really to tell of the future as to persuade Demos to choose one of them as his defendant. The external prospective narratives at the end of the play concerning the future nature of Athens, now that Demos has been rejuvenated by boiling and the Sausage-Seller has gained an identity, are employed to bring the play to its splendid conclusion. This technique is a common feature of Euripidean $(\rightarrow)$ exodoi: nine of his tragedies end with a deus ex machina who recounts the future events that await the characters. Aristophanic comedies regularly look forward to a brave new world, though they do not always go into very much detail about it and the prospective elements tend not to be formally set out as with a deus, but to be woven into the action. In Acharnians, Lysistrata and Peace, for instance, there are various hints at the future, but they come in the course of the action and in choral songs, rather than in a formal statement at the end of the play. As variants on this, we have those places where suggestions about the future suggest less unalloyed pleasure. The beatings which Pheidippides will administer to his father and mother $(\mathcal{N} u$. I 443) contrast with celebratory burning of the Phrontisterion. More vividly, there are many indications of the

11 Reference to the battles of the Persian Wars works in a similar, though rather more reduced fashion: Marathon (285) and Salamis (675) are mentioned by the men as emblems of their opposition to the women (Hippias in fact came with Darius' generals on the campaign that ended at Marathon); and then Artemisium and Thermopylae are evoked by the Spartans when they and the Athenians celebrate the peace at the end of the play (1247-1270). 
thoroughly disagreeable nature of the new world created by the women in Ecclesiazusae: again, the contrast complicates our response to the achievements of the play's action.

The oath sworn by the women in Lysistrata not to yield to their husbands does look forward to the successful sex-strike, but their promises, to sit around seductively teasing their husbands but never performing what are presumed to be their usual sexual acts, are not in fact truly prospective, since they go into the Acropolis and refuse to go home. It is however a seed for one of the more hilarious scenes in the second part, when Myrrhine titillates but ultimately abandons her frustrated husband Cinesias.

There is nonetheless a good example of an internal prospective narrative in Frogs. When he visits Heracles, Dionysus asks him for advice on and recommendations for the journey to Hades. After jokes about how to get there by self-destruction, Dionysus asks him to describe the route he took himself, which he does: 'You will immediately come to a great lake without bottom ... an old man in a boat this size will take you across for two obols ... you will see snakes and all manner of terrible beasts ... the sound of auloi will reach you, and you will see a most beautiful light, as we have here on earth, and groves of myrtle and blessed bands of men and women ... the initiates ...' (137-r64). Prospection and retrospection are here interestingly combined: the passage gives a retrospective account of his own earlier journey, but it is done in a prospective manner as an account of what Dionysus will encounter. This is an unusual passage for Aristophanes, not just in its prospective quality, but also for the way that, in contrast to the Lysistrata passage just discussed, it describes things some of which will be actually be seen onstage later in the play.

\section{Rhythm}

In these embedded narratives, to maintain the comic momentum, Aristophanes varies the length of time spent on each episode. We have already seen something of this technique in the account of the visit to the shrine of Asclepius in Wealth 649-747. In some cases, there is symmetry. In Dicaeopolis' opening speech, for instance, the first pleasure and pain each get four lines, the next pair only two, before he launches into his complaint about the behaviour in political life in Athens. Similarly, in Clouds, Strepsiades' two sections on the history of 
his marriage, in terms of their different backgrounds on their weddingday and their discussions of a name for their son, are of equal length (fifteen lines). In the prologue of Knights, there is greater variety. There is a lengthy description of the purchase of the slave and his immediate take-over of Demos $\left(43^{-57)}\right.$ : this establishes the character of the man immediately. There are then short passages of three and a half and two and a half lines, on his keeping other slaves away and his use of oracles, before another longish section (seven and a half lines) about his tyrannical behaviour towards his fellow slaves rounds the speech off. Although this speech is essentially a retrospective narrative, it has also something of a prospective nature, as it prepares us for Paphlagon's behaving in just the manner described; and, in its generalising nature, it is to some extent iterative: Paphlagon did not do all of this just once. The main charges against him are given the main emphasis, with two other apparently less important charges there for variety and change of pace. The reference to Paphlagon's use of oracles is however a seed; it may appear unimportant here, but he will ultimately be undone by the competition in presenting oracles to Demos.

\section{Simultaneous narration}

We have seen above cases where simultaneous narration comes into a retrospective prologue or other past-seeking narration. Such narration is also found in a small number of cases on its own. One could start here with the parodies of Euripides' Telephus, Helen, Andromache in Thesmophoriazusae. At the same time as the plays are acted out, the characters provide a commentary on what is happening: 'he has grabbed my child from my breast', cries the mother of the wine-skin child, and 'struck by this knife its bloody vein will stain the altar', replies Mnesilochus (Th. 690-695). This is not an unusual technique, indeed it is a common one for giving instructions to the actors and information on staging to readers, but it becomes more relevant to our subject when, having told the child that he holds its mother responsible for its death, Mnesilochus cries: 'What's this? The little girl has become a skin full of wine - with Persian slippers on!' (733-734). The humour arises from the contrast between on the one hand the farcical comic action and its simultaneous narration, and on the other the tragic narrative that structures it. Here the simultaneous narration is, as is usual in Aristophanes, of events onstage. There is a single example of extended narrative of 
offstage events in the prologue of Peace discussed above, where the narrative is given first by a slave who comes onstage to inform his fellow slave and then by a slave who looks offstage and describes what he sees.

Audiences can also be involved in simultaneous narration in comedy. In Wasps, the slaves describe (or rather make up) the reactions of the audience to the invitation to guess what mania Philocleon is suffering from: 'Amynias son of Pronapes here says he is keen on dicing ...' and so on (74-75). There is however one case where this technique is used to notable rhetorical effect. As the farmers begin to try to drag Peace from her prison, Trygaeus and Hermes make sense of what is going on for the audience. Actions are attributed to individuals and peoples, so that the no doubt rather chaotic scene onstage takes on meaning. It enables Aristophanes to make fun of these people for their unwillingness or inability to contribute to the freeing of Peace. Lamachus is accused of getting in the way of the operation; the Argives are standing around laughing at others' misfortunes; the Spartans - at least those imprisoned after Sphacteria - are pulling hard; the Megarians are too weak from hunger to achieve anything, and so on $\left(47^{-}{ }^{-5}\right.$ I9). The jokes are quite harsh, but in the new atmosphere of peace they belong in the past: in fact, ultimately everyone does their bit. After Peace has been freed from the ground, Hermes delightedly describes the scene onstage in which the various previously warring cities have begun to fraternise, despite their black-eyes $\left(53^{8}-54^{2}\right)$. In a world where a peace-treaty was about to come into force, this must have been an affecting moment for the audience. Trygaeus then moves the narration onto the reactions of the audience, and he and the god divine the trades of the members of the audience by their reactions to what is happening onstage: 'Can't you see that crest-maker tearing his hear out?'-'And that pitchforkmaker has farted in the face of the sword-smith!' (545-547). Simultaneous narration therefore allows the playwright to draw the audience into the action, which is especially appropriate in Peace, a play which is precisely about the unification of everyone in the newly peaceful world.

\section{Conclusion}

In conclusion, if Aristophanes does not make extensive use of radical disjunctions of time, he nonetheless makes very subtle use of such play with time as he does employ. Most narratives are external retrospective 
ones, but he varies considerably the manner in which time is employed, in order to maintain comic momentum, provide a dramatic climax, or involve the audience. The rhythm is again varied for comic purposes, and simultaneous narration provides a number of comic scenes. The delicacy and economy on display throughout is notable. 
Irene J.F. de Jong and René Nünlist - 978-90-47-42293-8 Downloaded from Brill.come4/26/2023 09:46:52AM via free access 
PART FIVE

ORATORY 
Irene J.F. de Jong and René Nünlist - 978-90-47-42293-8 Downloaded from Brill.come4/26/2023 09:46:52AM via free access 


\section{CHAPTER NINETEEN}

\section{ANTIPHON}

\section{M.J. EdWARds}

The importance of time in the rhetorical sphere was recognised by Aristotle, who in the Rhetoric (I.3.4) classified speeches according to whether they dealt with future, past or present events: deliberative rhetoric concerns the future, forensic the past, and epideictic generally concerns the present. We shall concentrate here on the narrative sections of forensic speeches and so on the past, considering examples of forensic narrative in Antiphon, Lysias and Demosthenes. As in $S A G \mathcal{N}$ I, 'narrative' will be taken to mean the discrete element or elements of a speech where the speaker, acting as narrator, gives his version of the events that caused the dispute.

In forensic narratives, which are embedded in a non-narrative hosting text, the story of the crime that is narrated comprises most of the details of the overall fabula, although other elements of the fabula may occur in other parts of the speech. In Antiphon 5, for example, the speaker, Euxitheus, complains about the way he has been treated by the relatives of Herodes in the time between his arrest and the trial $(5.8-19)$. This treatment (the use of what he claims is a highly unusual legal process to bring him to trial) is part of what is for the narratees the overall fabula of the events concerning the alleged murder of Herodes, and may have formed part of his opponents' story. But Euxitheus uses it as part of his argumentation, restricting his narrative to the events leading up to and immediately following the alleged murder itself (5.20-24). The bulk of the story, however, will be told in the narrative, most noticeably when, as in the following example, that narrative forms a single, self-contained section of the speech.

Let us, then, take as our Antiphontean example the narrative from the first speech, Against the Stepmother. ${ }^{1}$ Although rather shorter than the

${ }^{1}$ For commentaries and discussions see Blass I887-1898: I I87-194; Jebb I893: I 6467; Wijnberg 1938; Kennedy 1963: I32; Due 1980: 16-28; Gagarin 1997; Usher 1999: 28-30; Gagarin 2002: I46-I52; M.J. Edwards 2004. 
extended narratives of, for example, Lysias, this is the longest sustained narrative in Antiphon's three surviving courtroom speeches. It may be significant in this regard (despite the paucity of preserved Antiphontean speeches) that the Stepmother narrative was delivered in the only prosecution speech among them. ${ }^{2}$ Here the unnamed speaker is prosecuting his stepmother for poisoning his father, and unusually in a forensic context is an external narrator, since he was only a boy when his father died a number of years earlier $(\S 30){ }^{3}$ His status as external narrator becomes clear when at times he indicates that he is inferring certain facts; for example, 'she asked if she was prepared to follow her instructions and, I imagine, received a ready assent'. ${ }^{4}$ Indeed, the fact that he had not witnessed the events himself clearly gave his imagination free rein to devise a persuasive story, though, as is common, he confidently announces that he will 'tell a truthful story' (§ I3).

\section{Frequency and rhythm}

Forensic narratives are primarily singulative, while events which are important to a case usually are repeated during the proofs section of the speech. Our speaker narrates his story in three stages (\$§ I4-I6, I6-I8, I8-20). The style of the narrative is simple, with short clauses giving the narrative a staccato feel, in contrast to a more complex style adopted elsewhere in the speech, most notably in the proem.

The first stage introduces the four characters. Opening in 'epic' fashion ('There was an upper room in our house ...'), the narrator introduces his father and his father's friend, Philoneus, who when he visited Athens used to stay in that room. They are immediately juxtaposed to the female characters: Philoneus' slave mistress (pallake ), whom he intended to put in a brothel, and the stepmother, who befriends the mistress and sympathises with her plight, which she claims to share, but without giving any details (implicit ellipsis). The stepmother suggests a

2 Aristotle (Rh. 3.I6.6) states that narratives in defence speeches need not be as long as those in prosecutions. This is reasonable (especially since prosecutors spoke first and therefore had the opportunity, as well as the need, to paint a damning picture of their opponent's actions) and may reflect actual practice, though, for example, Lysias I, On the Killing of Eratosthenes, is a notable exception to Aristotle's rule. Further on Antiphon's practice see $S A G N$ i:318.

${ }^{3}$ Cf. $S A G \mathcal{N}$ г:319.

${ }^{4}$ Cf. also 'she imagined perhaps that if she gave him more' (§ I 9 ). 
solution to restore their men's love, which at this stage is not specified (implicit ellipsis), and indeed, few details of the couples' circumstances are provided.

The rhythm in this first section modulates between summary, where the men are concerned, and something near to a scene, including indirect speech, where the women are concerned $\left(\S \S \mathrm{I} 5^{-1} 6\right)$, the difference in narrative speed helping to put stress on the negative actions of the women.

With a vague temporal marker, 'after this' $(\S \mathrm{I} 6)$, the story moves on to a second stage and to another setting, as the two men both plan to leave Athens for Piraeus, Philoneus to perform a sacrifice to Zeus Ctesius and the father to set sail for Naxos. Philoneus thinks it an excellent idea that they go together and stay at his house, and they are accompanied by the mistress. On arrival, the sacrifice is performed. As before, there is less detail here than there appears to be at first sight. The reason why Philoneus is sacrificing to Zeus in his household guise is not revealed, nor why the father is going to Naxos. Again, details of the journey from Athens to Piraeus are omitted, as are the details of the sacrifice. This summary style is then briefly abandoned in order to narrate in detail the mistress' thoughts as to how to administer the drug, whether before or after supper, and her decision to follow the advice of her instigator, who is now maliciously nicknamed Clytemnestra ( $(\mathrm{I} 7)$. The slowing down of the narrative speed again serves to paint in detail the incriminating actions of the two women. The narrator's deft handling of rhythm becomes apparent when he explicitly says that he will not go into the details of the supper (ellipsis) but will pass on to the administration of the poison. His promise to tell 'as briefly as possible' is a commonplace feature of rhetorical narratives, as the narrator seeks to avoid boring his audience, but in fact heralds a detailed and scenic section, which in its detail will hopefully win the jurors over, despite his lack of any real evidence, by rousing pathos for the two men and anger against the stepmother.

The third stage of the story, again introduced by the rather vague time-marker, 'after they had dined', commences with the two men pouring libations and sprinkling frankincense. The narrator slows down to a scenic pace, paying lavish detail to the pious actions of the men and their reasons for doing so; they are trying to secure the gods' favour, Philoneus for his sacrifice to Zeus Ctesius and because he is entertaining a guest, the father because he is about to set sail and is being entertained by his friend. Their pious behaviour is contrasted with the irreli- 
gious actions of the mistress, as she pours the drug (note the vivid use of the historic present tense, enekhei). With ample pathos the narrator then states how the men 'grasping their own slayer, drained their last drink on earth' ( $\$ 20$, with another historic present, ekpinousin).

After this climactic slowing down, the narrator speeds up again, and recounts the deaths of the two men, the one instantaneously, the other after twenty days ${ }^{5}$ and the torturing and execution of the mistress in summary fashion. The narrator leaves mentioning his father's deathbed injunction to bring his murderers to justice, which he gives a more prominent, separate place in his proem ( $(\mathrm{I})$ and epilogue $(\S 30)$. Instead, he ends the narrative very effectively by turning - in the course of one and the same sentence - from subsequent narration to prior narration, expressing his wish for the stepmother to be punished. From time to time in the course of the rest of his speech he comes back to parts of his earlier narrative; for example, '[my brother] will ask you to refrain from punishing a crime which the guilty woman could not bring herself to refrain from committing' ( $(22)$; or 'he was the victim who involuntarily came to a violent end; for he was on the point of sailing from his country and was dining under a friend's roof, when she, who had sent the poison, with orders that a draught be given him, murdered our father' (\$ 26).

\section{Order}

The role of the narrative in a forensic speech was, of course, to give the jurors the speaker's version of events, in a persuasive manner that formed part of the overall argumentation. The story tends to be told in a chronological fashion by the narrator, who is very often a participant in it, since litigants in Athenian courts were expected to deliver their own cases. ${ }^{6}$ In our speech the speaker is an external narrator, who uses his ex eventu knowledge to insert three ominous internal prolepses, the first two in the climactic scene of the administration of the poison: 'while they offered their prayers, prayers never to be (emelle) fulfilled,

${ }^{5}$ Again, note the vivid use of the historic present in apothneskei ('dies') and empiptei ('falls ill').

${ }_{6}^{6}$ They might, however, be represented by an advocate (sunēgoros). Cf. in general Rubinstein 2000. 
men of the jury' and 'grasping their own slayer'. ${ }^{7}$ These prolepses do not serve to heighten the suspense, but the pathos, and hence are of an incriminating nature. The jurors, explicitly addressed, are supposed to become filled with anger and pity. A somewhat different effect is achieved by the last prolepsis: (giving Philoneus the larger draught) the mistress 'did not yet know (oupō eidei) that she had been duped by the stepmother before the deed was done' (§ I 9 ). Very effectively, the narrator here prepares for his later point that though the mistress was guilty and deservedly executed, it is the stepmother who was the real culprit and hence deserves to be punished too $(\S 20)$.

In addition to these narratorial prolepses we find actorial ones, which take the form of the intentions of the bad women: the stepmother thinks she knows 'how to restore Philoneus' love for her and our father's for herself' ( $\mathrm{I}_{5}$ ), and the mistress gave Philoneus the larger draught, 'thinking perhaps that if she gave him more, he would love her more' (§ I 9 ).

The one internal narratorial analepsis is completing: when the mistress deliberates when to administer the poison, before or after supper, she decides for the latter course, 'thereby carrying out the suggestion of this Clytemnestra here' ( $\left.\S_{17}\right)$ : this suggestion had not been recorded before, in the course of the initial planning between stepmother and mistress $\left(\S \S I^{-1} 6\right)$. The narrator effectively presents this incriminating piece of information at the point it is put into action, thereby adding to the charge against the stepmother.

\section{Conclusion}

If one wished to point to a parallel for the kind of relatively straightforward, singulative, and chronological narrative we find in Antiphon I, the messenger-speeches of Euripides $(\rightarrow)$ present themselves. ${ }^{8}$ Though here we are dealing with an internal, rather than an external narrator, we find the same kind of clear and straightforward narrative. The messenger-speeches of Andromache 1085-1165, Helena 1526-1618,

${ }^{7}$ On which see M.J. Edwards 2004: 59-62.

8 The similarity between the narrative of Antiphon I, in particular the scene of the giving of the poison, and the tragic messenger-speech was noted by Gernet 1923: 42 n. I. Cf. in more detail Due I980: 20. 
and Iphigenia Taurica I327-I4I9 display a comparable use of ex eventu prolepses: ${ }^{9}$ for example, 'we knew nothing of this yet (viz. that guards had been posted in the temple, where Neoptolemus is about to enter, and who will later kill him)', which resembles Antiphon's 'the mistress did not yet know that she had been duped by the stepmother before the deed was done' (§ I 9 ).

As noted above, the narrative of Antiphon I differs from those of speeches 5 and 6 in being a single entity. Antiphon 5 , On the Murder of Herodes, may be analysed as having two narratives, at $\$ \S 20^{-2} 24$ and $29-$ 30, and Antiphon 6, On the Chorus-Boy, has three, at $\S \S \mathrm{II}-\mathrm{I} 3,2 \mathrm{I}-24$ and $34^{-} 4^{0 .}{ }^{10}$ The general pattern of singulative, chronological narrative is discernible in speech 5 , as the speaker, this time an internal narrator, tells the story of the voyage from Mytilene to Aenus that was interrupted by a storm $(\$ \S 20-2 \mathrm{I})$, during which the voyagers began drinking and Herodes disappeared ( $(23)$; an unfruitful search was conducted, after which the speaker continued on his voyage $(\$ 24)$, and in his absence Herodes' relatives conducted a second search, which resulted in the torture of two men ( $\S 29-30)$. The details are even sparser than those given in the Stepmother narrative, but as there they are picked up in later sections of the speech and used as the basis of various arguments, most notably an extensive examination of the torture evidence $\left(\S \S 3^{\mathrm{I}-52) .}\right.$ Similarly, in speech 6 the speaker gives a few details of his arrangements for the training of the boys' chorus ( $\left.\$ \mathrm{II}^{\mathrm{I}} \mathrm{-I} 3\right)$, but more facts are revealed as the speech progresses and the speaker's political rivalries become more and more apparent. The second stage of the narrative describes events on the day of the dead chorus-boy's funeral, when the speaker's opponents laid their charge (\$\$2I-24), while the third stage, although taking the story on, also contains an analepsis concerning the events before the funeral that led to the laying of the charge $\left(\$ \S 35^{-36)}\right.$. Antiphon thereby demonstrates that he is capable of changing the order of events in his narratives according to the demands of effective persuasion. The weighing up, indeed, of the most effective means of persuasion will have determined the logographer's choice in any given case between these two basic narrative structures, of a discrete, extended narrative and of separate, briefer narratives. Lysias $(\rightarrow)$, with his brilliant skills of narration, tends towards the former model;

\footnotetext{
${ }^{9}$ Cf. de Jong i99ra: $45^{-49}$ and $52^{2-56 .}$

10 For an analysis of the narrative of speech 6 see $S A G \mathcal{N}$ I:319-322.
} 
the versatile Demosthenes $(\rightarrow)$ tends towards the latter and provides a good example of how to make the best of a weak case by breaking up the narrative. 
Irene J.F. de Jong and René Nünlist - 978-90-47-42293-8 Downloaded from Brill.come4/26/2023 09:46:52AM via free access 


\section{CHAPTER TWENTY}

\section{LYSIAS}

\section{M.J. EDWARDS}

The central importance of the narrative in Lysias' speeches is well established. ${ }^{1}$ He had a talent for writing vivid, fluent, self-consistent and plausible narratives, primarily in a simple, flowing style. Narrative is therefore the key element in Lysias' persuasive technique. It is then interesting to observe that his narrative method, in terms of temporal structure, is entirely unspectacular. Two characteristics also found in Antiphon $(\rightarrow)$ recur in Lysias, viz. the telling of the story in its temporal sequence and the inclusion of additional details in other, non-narrative sections of the speech.

Thirty-one speeches are preserved in the medieval manuscripts of Lysias, with three more extended fragments in Dionysius and one speech, the Eroticus, in Plato's Phaedrus (230e-234c). The authenticity of many of these is disputed, in the sense both of whether they were actually written by Lysias and of whether they were delivered on the occasion on which they purport to have been delivered. Of the forensic speeches that have the best claims to be genuine in both senses ${ }^{2}$ several are fragmentary or are secondary speeches delivered in support of a main speech. ${ }^{3}$ Among the remainder, the employment of a discrete, extended narrative section is clearly Lysias' preferred method: in speech

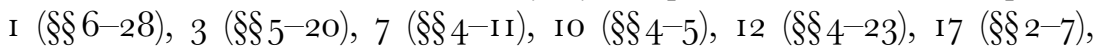

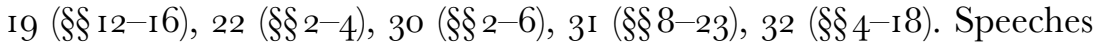
I6 and 25 have no clear narrative section, which is partly dictated by the nature of these speeches; ${ }^{4}$ and it is perhaps only in speech 13 , Against Agoratus, that we have significant mixing of narrative and proof

\footnotetext{
1 Cf. e.g. $S A G \mathcal{N}$ i:333.

2 Numbers I, 3, 4, 5, 7, I0, I2, I3, I4, I5, I6, I7, I8, I9, 21, 22, 25, 26, 27, 28, 29, 30, 31, 32; following the discussion of Usher i999: 54-I 6 .

${ }^{3}$ Numbers 4, 5, I4, I5, I8, 21, 26, 27, 28, 29 .

4 Cf. the comments of Usher in Edwards \& Usher 1985: 252-253, 269-27o. Speech 25 has the air of a political pamphlet.
} 
elements, though even here one might argue that there is a discrete narrative section, punctuated by proofs $(\S \S 5-42)$. Again, this is not to say that narrative and proofs are separated in a regimented sense: elements of one regularly occur in the other, as in the example below. But the basic fourfold structure in Lysias of proem, narrative, proofs and epilogue is clear.

A representative example of Lysias' skill in narrative is found in speech 32, Against Diogeiton, ${ }^{5}$ where an unnamed speaker acts as an advocate (sunegoros) on behalf of the elder son of the deceased Diodotus. ${ }^{6}$ The son, on reaching maturity, is prosecuting Diodotus' brother Diogeiton, who has been the guardian of Diodotus' three children (two sons and a daughter), and the case is delivered for him by the husband of his sister. ${ }^{7}$ The narrator therefore is internal, playing a role himself in the events.

\section{Frequency}

As usual in oratory, the narrative is mainly - though not completely (see below)-singulative. It is recounted in two main stages. In the first $\left(\S \S 4^{-8}\right)$, the narrator gives the earlier background to the case in three parts: the relationship between the two brothers Diodotus and Diogeiton, Diodotus' shipping business, and his marriage to Diogeiton's daughter (\$4); Diodotus' preparations for military service - his will and details of the estate - and his departure $\left(\$ \S 5^{-7}\right)$; and after Diodotus' death, Diogeiton's deception of his widow (concealing her husband's death), and the arrangements he made for the widow and her children $(\S \S 7-8)$.

In the second and longer stage of the narrative $\left(\S \S 9^{-18}\right)$, the narrator recounts Diogeiton's abandonment of the boys when the elder one reached maturity and how they turned for help to the speaker $(\S \S 9-\mathrm{IO})$, their mother's intervention and in response to her pleas the speaker's calling of a family conference (\$§II-I2), at which she attacked Diogeiton (her own father), demonstrating his embezzlement of her chil-

\footnotetext{
${ }^{5}$ For a commentary on this speech see Carey I989. Cf. further Blass 1887-I898: I 6o8-6I5; Jebb i893: 293-296; Usher i999: 80-82.

${ }^{6}$ The narrative occupies fifteen sections $\left(\S \S 4^{-1} 8\right)$ of the 29 sections of the speech preserved by Dionysius of Halicarnassus in his essay on Lysias.

7 The case is presumably a dike epitropess, a private prosecution of a guardian for corruption. Cf. e.g. Osborne I985: 57.
} 
dren's estate ( $\left.\$ \mathrm{I}^{2}-\mathrm{I} 7\right)$, and finally how the members of the family were so devastated by her words that they could only weep and depart in silence ( $(\mathrm{I} 8)$. The mother's accusatory story is voiced largely by herself as a secondary narrator in direct speech, a remarkable feature of Lysias' oration. Her embedded narrative serves to characterise herself - as a modest, Athenian woman, who nevertheless has to speak out to protect her family - and add to the characterisation of Diogeiton as avaricious and dishonest. It also, shrewdly, helps Lysias to get round the legal difficulty that women were not permitted to testify in court. Indeed, she even includes a kind of testimony, thus acting as a witness: 'I offer to swear to the truth of this ...' (§ $\mathrm{I} 3)$.

Her report on what has happened partly repeats events which had already been recounted by the primary narrator (we are dealing with a repeating analepsis), thus adding emphasis and - even more-pathos: 'when you are their father's brother, and my father, and their uncle and grandfather' (§ I2); cf. '[Diodotus] summoned his wife ... and her father, who was also his father-in-law, and his brother, and grandfather and uncle of the little ones' $\left(\S_{5}\right) ;{ }^{8}$ 'you received from him, when he went on the expedition, five talents in deposit' ( $\left.\mathrm{I}_{3}\right)$ - cf. 'he then gave him a will and five talents of silver in deposit' $\left(\S_{5}\right)$; 'And you thought fit to turn these ... out of their own house, in worn-out clothes, without shoes or attendant or bedding or cloaks; without the furniture which their father bequeathed to them, and without the money which he had deposited with you' ( $\S_{16}$ ), a detailed and visual version of the earlier 'the poor wretches, turned out of doors, wept aloud and besought me not to allow them to be deprived of their patrimony and reduced to beggary' ( $($ Io). At times, on the other hand, her version supplies details not mentioned in the version of the primary narrator: for example, 'she [the widow of Diodotus] convicted him [Diogeiton] further of having recovered seven talents and four drachmae of bottomry loans ... for she showed that in the course of his removal from Collytus to the house of Phaedrus the children had happened upon the register, which had been mislaid, and had brought it to her' (\$ I4). This whole event and the specification of the places are lacking in the primary narrator's version and we are dealing with a completing analepsis.

${ }^{8}$ Since Diodotus married his brother's daughter, his wife was also his niece, his brother was also his father-in-law, and his children were his brother's grandchildren and nephews. 
As is customary, the proof section repeats parts of the narrative: for example, the long list of expenses the uncle allegedly made on behalf of his orphaned nephews $(\$ \S 20-24)$ works out his earlier words, as quoted by the narrator in the narrative section: 'Now I have spent a great deal of my own money on your support' (§9). Since the primary narrator is now giving a list of expenditure, the details are not told in chronological order.

\section{Speed}

Like Antiphon $(\rightarrow)$, Lysias tends to adopt a simpler style in his narratives than in the remainder of his speech, and his main manipulation consists in accelerating or slowing down the narrative speed. The narrative opens 'at the beginning' (\$3), the birth of the two main characters $(\S 4)$. As so often in ancient narrative, no date is given. The narrator spells out that they were brothers with the same father and mother (homopatrioi kai homomettrioi) - a piece of information that is intended to put the later behaviour of the brother Diogeiton in an even darker light - and that they had divided up the invisible property (i.e. money and other valuables) and shared the visible property (i.e. land and buildings), which will have been a regular occurrence when two or more brothers inherited an estate. The next event is recounted again without an exact time-marker: 'when Diodotus had made a large fortune in the shipping business', Diogeiton persuaded him to marry his daughter (another regular occurrence), by whom he had three children $\left(\S_{5}\right)$. An equally vague time-marker adds the next event ('some time later'), which takes us forward to the time when Diodotus was preparing for his military service.

Now the narrator slows down, giving a detailed account of how Diodotus summoned his wife and brother to a meeting, set out to his brother his financial affairs and his will, and left duplicate deeds in his house. The next set of events is again told quickly: Diodotus went off to serve with Thrasyllus and died at Ephesus. The members of the jury will have recognized that he dies in the year $409 \mathrm{BC}$. Diogeiton 'for a while' (vague time-marker) concealed his death from his wife and took possession of the deeds. When he eventually informed the family of Diodotus' death, the sons performed the customary rites, lived for a year in Piraeus and then, when their provisions ran out, were sent up to the city, while their mother was married with a dowry considerably 
less (one-sixth) than Diodotus had provided for her $(\$ \S 7-8)$. We see how the narrator deals with these relatively unimportant events in summary fashion. He even leaves out an event (implicit ellipsis): the men who died at Ephesus were buried at Notium (cf. X. Hell. I.2.II), and so the burial rites referred to here will have involved the dedication of a cenotaph (a tomb is mentioned at $\S 2 \mathrm{I}) .^{9}$

We now enter the second stage of the narrative, which begins 'seven years later', the intervening period being left out (implicit ellipsis). The vital point of the elder boy reaching adulthood and Diogeiton abandoning his care for the children is, of course, told in great - and incriminating - detail and scenically, including the indirect and direct quotation of speeches. Diogeiton summoned the boys and told them what their father had left them (indirect speech). The indirect speech mode is then abandoned in favour of the direct one, which allows the narratees to check Diogeiton's words for themselves (which will later be revealed to have been incomplete and incorrect): he has spent a large amount of money in supporting them, but is now himself in difficulties and so the elder boy must henceforth provide for them himself $(\S 9)$. The boys left Diogeiton in tears and went to their mother, then brought her to see their uncle (the narrator), who takes ample time to describe the impression the boys made on him at that moment ( $\S \mathrm{IO}) .{ }^{10}$ His clichéd promise not to dwell too long on one subject ('of the mourning that filled my house at that time it would take long to tell': explicit ellipsis) in fact adds to the pathos of his story, suggesting as it does that there would be much to tell. The events leading up to the final meeting are told in quick strokes, whereby there are hints of iterative narration, which are suggestive of the (negative) reluctance of Diogeiton and the (positive) insistence of the narrator: 'I called upon this man to allow his handling of the money to be investigated. Diogeiton at first refused, but finally he was compelled by his friends' ( $(\mathrm{I} 2)$.

For the final meeting the narrator slows down again, making the scene dominated by the attack of the mother on her own father Diogeiton. After a brief introductory section in indirect speech ('when we held our meeting, the mother asked him what heart he could have, that he thought fit to take such measures with the children'), he 'gives the floor to' her, and the narratees can hear her demolish Diogeiton's case

\footnotetext{
${ }^{9}$ Cf. Carey ig89: ad loc.

${ }^{10}$ They are described as weeping by two different participles in quick succession (dakruontes and klaontes).
} 
herself. She begins by recalling her and her sons' relationship to him, how he received five talents on deposit from Diodotus (which he had not mentioned to the boys, §9), and how she would swear to the truth of this on her children's lives (\$§ I2-I3). Such an oath would normally have been the only way that a woman's testimony could be heard in court, and the direct speech comes to an end here so that its effect is not reduced. For a brief while the narrator changes to representing the woman's words in indirect speech, which allows him to speed up a little: we hear about Diogeiton's other financial misappropriations, with the persuasive detail that the boys had by chance found the register of them. It may also be the case that such a full description of monetary matters would have seemed less effective if put directly in the mouth of a woman who had professed her modesty in $\S$ II.

As the narrator returns to direct quotation again, it is the money that directly concerned the mother, her dowry, that she focuses onthe very same sum that Diogeiton had told the boys their father had left to them (§§I5-I6). She does not spell out the implicit wrong done to her (as the primary narrator had already informed the narratees, the money Diogeiton provided for her had been much less than her husband had given her, §8), but immediately turns to an emotional description of the destitute state her sons were left in by the guardian's actions, in contrast to the affluence in which Diogeiton's children by his second marriage were living $(\S \S \mathrm{I} 6-\mathrm{I} 7) .{ }^{11}$ The theme of Diogeiton's avarice brings the mother's speech to an appropriate climax, as the powerful tricolon of fearing the gods, feeling shame before her, and remembering his brother counts for less in Diogeiton's eyes than money (khremmatōn) - the very last word of her speech ( $\mathrm{I} 7 \mathrm{7})$.

The mother's speech naturally had a profound effect on her audience, whose reaction and thoughts are presented in the form of embedded focalization by the primary narrator: how they recalled the children's treatment and remembered the dead man, how unworthy was the guardian he left in charge of the estate and how difficult it was to find somebody trustworthy to look after one's affairs. The reaction of Diogeiton is suppressed by the narrator, who effectively ends his narrative by recounting how the relatives wept 'as sadly as the sufferers' and went away in silence $(\S \mathrm{r} 8)$.

\footnotetext{
11 She naturally says 'the children you have had by my stepmother', playing on that commonplace prejudice against stepmothers highlighted in Antiphon I.
} 


\section{Order}

The narrative of the Against Diogeiton speech is relatively straightforward and chronological, with no noticeable examples of anachrony.

One possible example of an actorial prolepsis is contained in the embedded focalization of Diodotus in the opening stage of the narrative: 'thinking that because of these bonds nobody would be more bound to treat his children justly' $\left(\S_{5}\right)$. It is this expectation which the ensuing narrative and entire speech will show to have been false, thanks to the depravity of the brother. The expectation has been carefully prepared for by the narrator in the preceding section of the narrative, with its stress on Diodotus and Diogeiton being brothers born of the same father and mother, dividing their property and sharing their estate, intermarrying, and the one brother, when he was enrolled for military service, giving his will to the other. All of this would naturally lead to the well-founded expectation that Diogeiton 'treat his brother's children justly'. The emphasis placed on the brothers having the same parents $\left(\S_{4}\right)$ also carries the double implication that Diogeiton was the natural choice of guardian for Diodotus' children and therefore his alleged behaviour was all the worse because of that. ${ }^{12}$ Diodotus being cheated in his expectation is later noted several times: the boys beg their uncle/the narrator not to allow them to be 'abused by those who ought least to have done so' ( $(\mathrm{I}$ ) $)$; the mother opens her accusation against her father by 'you are their father's brother, my father, their uncle and grandfather' (§I2); and finally the members of the family at the end of the story all recall 'the dead man, how unworthy was the guardian he had left in charge of his estate' and what is more 'reflected on how hard it is to find somebody who can be trusted with one's affairs' (§ I8).

\section{Conclusion}

Lysias' narratives are mainly told chronologically and singulatively. Repeating narration is confined to the argument sections, which repeat in larger or smaller detail parts of the narrative. The main temporal device employed to great effect by Lysias is speed: the careful alternation of scene, for important parts, and summary, for unimportant parts

\footnotetext{
${ }^{12}$ Cf. Carey I989: ad loc.
} 
or characterizing sections. Ellipsis can both be employed for the skipping of uneventful or unimportant episodes or, in the case of explicit ellipsis, to suggest a multitude of facts, which perhaps in reality could never have been substantiated. 
CHAPTER TWENTY-ONE

\section{DEMOSTHENES}

\section{M.J. EdWARds}

By no means all narratives in forensic speeches are recounted in one single unit. The complex inheritance cases that form the corpus of extant speeches by Isaeus, for example, tend to have two, three or more narrative sections, which help (at least on the face of it) to make the details more intelligible to the jurors. ${ }^{1}$ Another good example of a narrative being split into several parts (in this case three) is provided by Demosthenes in his speech 55, Against Callicles. ${ }^{2}$ Here, the unnamed son of Teisias defends himself against a prosecution for damages brought against him by Callicles. The two men own adjacent farms in a hilly farm district, divided by a public road, and Callicles sues the speaker for water damage to his farm caused by a wall along the road, built by the speaker's father, that had dammed a watercourse.

\section{Order}

The first narrative part $(\$ \S 3-4)$ recounts the main event of this speech, the building of the wall by the speaker's father. The main point the narrator wants to make is that this event took place long ago (more than fifteen years, 'almost before I was born', while both their fathers were still alive) and that neither at the moment of building was a protest raised nor during this long period of time was any complaint made, 'and yet of course it rained then, just as it does now'. The detail that at the time of the building Callicles was already an adult and living in Athens carries the double implication that he is unfairly using his greater experience against the speaker, part of the picture the speaker

\footnotetext{
${ }^{1}$ Cf. M.J. Edwards 2006: 76-78.

${ }^{2}$ For discussions of this speech see Blass i887-I898: III.r 253-257; Usher 1999: I86I89.
} 
paints of him as a sycophant, and again that, being in Athens, unlike his father, Callicles did not know exactly what was going on on the farm. Earlier the narrator had already remarked, much in the same vein, that the father 'of course knew the facts more accurately than these men [Callicles and his brother Callicrates, who is also present in court]'. The narrative ends here and is followed by a section of proofs, in which the speaker elaborates on the central point of the preceding narrative, asking his opponent why no complaint had been made earlier and suggesting that the reason for his present conduct is malicious prosecution ('sycophancy'), a charge made right at the start of the speech and reiterated on numerous occasions (\$§ I, 2, 6, 9, 21, 22, $23,26,28,29,33,35){ }^{3}$

The second narrative part follows in $\S \S 9-$ II. As announced in the argumentation just preceding, the narrator now wants to explain, through his narrative, that his father 'committed no wrong in walling in the land'. In order to do so, he starts by saying that the land around which the wall was built was private property, a fact admitted by the opponents. He then briefly turns to the recent past, just prior to the trial (no exact time-marker), and recounts his failed attempt at arbitration by local people who know the situation. This then naturally leads into a description, in the present tense, of the properties of the two parties and the road that divides them. The narrator explains that the two sides' properties were separated by a road, and since their farms were surrounded by hills, rainwater would flow partly down the road and partly onto the farms. The relevance of this description becomes immediately clear in the sequel, when the narrator goes back into the past for a second time, now to a time before that recounted in the first narrative part, viz. when the piece of land 'was inundated after a heavy downpour' (no time-marker), an event which induced his father to build the wall. But before he tells this, he first goes back in time even more, to the time (no time-marker) when the property belonged to another, unnamed man, who neglected it. During his ownership the water overflowed on two or three occasions, damaging the land and starting to make a channel for itself. The narrator then returns to the time of the father, who sees the damage caused by the latest inundation, as well as

3 This was, of course, a commonplace accusation made by defendants against their prosecutors, but the speaker here is unusually persistent in his claim, perhaps because he had lost earlier cases. 
encroachments of his neighbours, and builds the wall (§ I2). Temporally, therefore, we are now back to the moment when the first narrative part opens in $\S 3$.

We see that the building of the wall, recounted in the first narrative part as a fact from the past, is now looked at again from a legal point of view: the speaker's father had the right to build the wall, since it was his property, it was no watercourse, and he was suffering from real damage through inundation. The narrator is careful to indicate how he knows about his father's motives (after all he was still very young when the building took place), by adding his source: 'so I am informed by those acquainted by the circumstances'. This remark must also compensate for the circumstance that the case is tried not by locals, as he had wanted, but by a court in Athens. For this same reason the narrator engages his audience, the jurors: 'if you could have seen the place, you would know at once that I am the victim of sycophancy'. ${ }^{4}$

As in the case of the first narrative part, the second narrative part carefully lays the foundation for the argumentation that follows, where the speaker mainly addresses the point that the piece of land is not a watercourse but private land. The argument repeats parts of the narrative (the land is private property) and occasionally adds new details (the land has trees and tombs on it, and hence cannot be a watercourse).

After this set of proofs, the narrator comes to his third narrative part $\left(\S \S 23^{-24}\right)$, the purpose of which, as again is announced in the argumentation preceding it, is to demonstrate that the damage Callicles' property had suffered was very minor, thereby indicating once more that he was acting maliciously in asking for a fine of a thousand drachmae. The narrator now goes back to a point of time (no specific timemarker) after the alleged damage to Callicles' land, but prior to the suit (significantly referred to as 'this malicious action against me').

The speaker's mother, as he explains in an introductory section, was a long-standing friend of the mother of the opponents, just as their husbands had been (a new detail; in $\S 3$ we had only heard that the men were neighbours). When she visited Callicles' mother, the latter told her in tears what had happened. The narrator is careful to add it was through his mother, herself an eyewitness (twice stressed, §24), that

\footnotetext{
${ }^{4}$ Note the striking verb sukophantoumai $(\S 9)$.
} 
he himself got to know about what had happened, a source likely to be taken as reliable by the jury, and a fact which the speaker buttresses with a prayer for blessings if he is telling the truth and the opposite if he is lying. This prayer is presumably added by the narrator because, as we noted with the mother in Lysias' $(\rightarrow$ ) Against Diogeiton, he could not bring his mother into court as a witness. Unlike Lysias, Demosthenes does not attempt to give the woman direct speech, but this was perhaps unnecessary: even in indirect speech her report suffices to make clear that the actual damage was minor. The point of her report is made explicit by the narrator at the start of the argumentation which follows on his last narrative: 'So trivial, men of the jury, was the loss that befell them, yet for this I am made defendant in a suit with damages fixed at a thousand drachmae!' This then leads to another instance of the speaker's repeated charge that Callicles is acting like a sycophant, and the remaining proofs seek to drive this message home to the jurors, with occasional repetition of parts of the earlier narrative (e.g. 'But since in the beginning my father was within his rights in enclosing the land and these people never made any complaints during the lapse of so long a time ..., $\S_{26}$ ).

On the basis of the three narrative parts we can reconstruct the fabula of Demosthenes' Against Callicles as follows: (A) neglect by an earlier owner, (B) leads to inundations, (C) which induces the new owner to build a wall. (D) After more than fifteen years this wall during a heavy rainfall allegedly damages the property of the plaintiff. (E) The narrator's mother visits the neighbour's farm and hears about the damage, (F) which she reports to her son. $(\mathrm{G}) \mathrm{He}$ attempts to settle the matter by local arbitration, but this attempt fails and a lawsuit follows. We see that this fabula is turned into a story with a different order of events: (first narrative part) $\mathrm{C}$ - (second narrative part) $\mathrm{G}-\mathrm{B}-\mathrm{A}-\mathrm{C}-$ (third narrative part) $\mathrm{E}-\mathrm{F}$. As this overview shows, the alleged fact of the damaging of the plaintiff's property $(\mathrm{D})$ is never recounted by the speaker (who presumably was not present at the farm) and only the results are reported to him by his mother.

\section{Speed and frequency}

The first part of the narrative is told singulatively and in summary style. This speed is suggestive of the main point the speaker is making: that fifteen years passed without any incident (indeed, as the third part will 
make clear, with the two neighbours and their wives living happily next to each other). The central point itself, that no complaints were lodged, is made at length, with a succession of clauses (out' ... oute ... oud' ... all' oud' ... oude ...) and five different verbs expressing forms of protestation.

The second part of the narrative again starts in summary style, when the speaker refers to his call for private arbitrators. Then follows a narrative pause, in which the narrator gives a detailed description of the road between the two properties and how these are surrounded by a mountain from which water runs down, partly into the road, partly onto the farms. The water that pours into the road flows down the road when there is no obstruction, but necessarily overflows onto the farms when there is one. The balanced detail is striking, and continues. The actual inundation which led his father to build the wall is told very briefly, but when recounting the handling of the land by its previous owner the narrator turns to iterative narration, to stress that there had been 'two or more' earlier inundations. Likewise, the second reason for the father to build the wall is told in iterative narration: 'neighbours started to encroach upon the property and walk across it'.

The third stage of the narrative starts off with an introduction of the two mothers in iterative and summary style: 'they were intimate friends' and 'they used to visit each other', to which a summary detail about the fathers is added ('their husbands had been friends while they lived'). The pace slows down, appropriately, when the narrator comes to the vital point of his mother being told about and later seeing with her own eyes and finally reporting to her son the damage. Her report is given in indirect speech, with the details of the damage to the barley, wheat and jar of olive oil being carefully recorded, culminating in the jar not being damaged at all. The repeated and emphatic negation (ou ... ouden) forms a fitting climactic - or better bathetic - end to the third part of the narrative.

\section{Other examples}

Demosthenes, of course, was more than capable of composing extended blocks of narrative in the manner of Lysias $(\rightarrow)$. A fine example of his technique in this regard is the narrative of speech 54, Against Conon. The main story is told in four stages, separated by witness statements, and as is regular practice in the orators, some more details appear later in 
the speech, inserted into the argumentation. ${ }^{5}$ But one of the marks of Demosthenes' supreme talent was the ability to adapt his speeches to the rhetorical requirements of the situation. The Against Callicles is an example of this. On a far larger scale, in his masterpiece On the Crown, Demosthenes narrates the history of his career in three chronological stages, the crucial third stage (the alliance with Thebes prior to the defeat at Chaeronea) being subdivided into two parts: his career down to $346 \mathrm{BC}(\S \S 17-52)$, his career from $34^{6-340 \mathrm{BC}}\left(\S \S 53^{-109}\right)$, the Theban alliance ( $\$ \mathrm{I}^{\mathrm{I}} 6 \mathrm{O}-\mathrm{I} 79$ and $\left.2 \mathrm{II}-226\right)$. In the middle of the second and third stages he sandwiches his defence against the technical charges for which Aeschines was prosecuting Citesiphon, perhaps because his arguments on these points are his weakest. ${ }^{6}$ In between the two parts of the Theban narrative he inserts a comparison between himself and Aeschines ( $\left.\S \mathrm{I}_{\mathrm{I}} 8 \mathrm{O}-\mathrm{I} \mathrm{I} \mathrm{I}\right)$, and a justification of his policy $(\$ \S \mathrm{I} 92-2 \mathrm{IO})$ : the former is prepared for by an attack on Aeschines' parentage and career in $\S \S$ I22-I59; the latter, with the claim 'do not put the blame on me if Philip happened to prevail in the battle: its outcome was in the hands of the gods, not mine' (§ I93), which prepares for the uncomfortable telling of the securing of the doomed alliance with Thebes.

\section{Conclusion}

The speech by Demosthenes analysed in this chapter shows that though there is a tendency in the Attic orators to narrate the story in chronological order, whether in one or several parts, an anachronical order is found too. Dividing the narrative into three parts, the narrator moves through time both forward and backward, choosing an order which is most effective. Like Antiphon $(\rightarrow)$ and Lysias $(\rightarrow)$ Demosthenes effectively varies the speed of his narration to accentuate or downplay parts of his story.

\footnotetext{
${ }^{5}$ For an analysis see $S A G \mathcal{N}$ 1:344-346.

6 The so-called ordo Homericus. Cf. Usher 1993: I7-I9.
} 
PART SIX

\section{PHILOSOPHY}


Irene J.F. de Jong and René Nünlist - 978-90-47-42293-8 Downloaded from Brill.come4/26/2023 09:46:52AM via free access 


\section{PLATO}

\section{K.A. Morgan}

Plato's dialogues present a definitional challenge for narratologists. While some dialogues open with what one may call 'framing elements', where a narrator declares or shows that he will narrate a past philosophical conversation, others present such conversation as a dramatic dialogue (without a frame). As I have argued in $S A G \mathcal{N}$ I, however, it is preferable to proceed on the hypothesis that even those dramatic dialogues may be treated as narratives, told by an invisible and suppressed narrator. This is made clear in the opening of the Theaetetus, where a framing conversation between two Socratic disciples makes it explicit that the omission of framing elements is a matter of stylistic effect (though not without philosophical resonance). ${ }^{1}$

As might be expected in an author of Plato's subtlety, narratological features have philosophic implications. This is the certainly the case with time. Both as an element of the sensible world and as an aspect of dialogue, time is frequently thematized. Philosophic discourse is characterized by leisure and by measured progression through the topic at hand. Unlike the orator, the philosopher need not speak under the constraints of the water clock. His only responsibility is to the integrity of the argument. As a human being, the philosopher must inhabit the world of time, but his true allegiance is to the realm of the intellect, timeless and unchanging. He must exercise his memory accurately and remember the arguments that have passed and the intellectual commitments and admissions he has made (philosophical analepsis). He must be able to forecast the implications of such commitments and admissions, as well as foresee objections and what he will do to meet these objections (philosophical prolepsis). While keeping an eye on the 'big picture' he must also assess what is relevant to the topic at

${ }^{1}$ For the distinction between framed and dramatic dialogues see $S A G \mathcal{N}$ i:357-358. For the function of these framing elements see further $36 \mathrm{I}-368$. 
hand, controlling the pace and digressiveness of the discussion. These considerations apply also to the narrators in the framed dialogues.

\section{Temporal settings}

All Platonic dialogues present themselves as reports or representations of philosophical conversations held in the past, and are thus instances of subsequent narration. The central action of the dialogues (as opposed to that of the frames) takes place mostly in the Athens of the last third of the fifth century and the very beginning of the fourth century BCE. ${ }^{2}$ The Laws (which floats in time and is localized in Crete) is an obvious exception, while the main action of the Parmenides, although it takes place in Athens, is set when Socrates was a young man. Plato does not consistently provide a precise temporal framework for the conversations he composes. While the central action of, for example, the Symposium is fixed in $4 \mathrm{I} 6$, and that of the Apology, Crito, and Phaedo in 399, many of Socrates' conversations are not given a precise chronological specification. Moreover, Plato does not seem to have been concerned to avoid anachronism. ${ }^{3}$ Socrates' conversation with Phaedrus in the Phaedrus is set at a time when both Phaedrus and Lysias (also portrayed as present in Athens) were not in the city. ${ }^{4}$ In three dialogues where the main action is narrated by a disciple of Socrates after the master's death (Phaedo, Parmenides, Theaetetus), the framing element transports the reader into a world of reception where stories of Socrates are told repeatedly in the first forty or so years after his death.

Precision in temporal setting is not, then, in itself of paramount importance to Plato. Precise indications create particular effects. Thus

${ }^{2}$ For the temporal settings of the dialogues see D.S. Clay 2000: I7-I9; Blondell 2002: $65^{-66 .}$

3 The date of composition of the Menexenus is fixed post-386 by an anachronism, and the same goes for the Symposium (dated post-385 because of a reference to Spartan activities in Arcadia at 193a): Rutherford 1995: 4.

${ }^{4}$ Rutherford 1995: 4; for a spirited attempt to read philosophical significance into this anachronism see Nussbaum I986: 212-213, 228-233. Blondell 2002: 32-34 plausibly develops a notion of 'historical irony' in the dialogues, where the events of the late fifth and early fourth century form an important background against which we are meant to read the dialogues. By 'basing his characters primarily' on historical persons, Plato can intimate 'the results and outcomes of their attitudes and lives' (33). Good examples of this kind of irony are, of course, the character of Alcibiades in the Symposium and Nicias in the Laches. 
the specification that the action of the Symposium took place when Agathon won his first tragic victory (4I6) serves to explain the reason for the party, but also to set the action in the run up to the disastrous Sicilian expedition that left Athens in 4I5. The expedition was the particular project of the same Alcibiades whose boisterous intervention changes the course of the conversation in the dialogue. The conversations of the Euthyphro and Theaetetus gain particular resonance given that they take place immediately before Socrates' trial.

Dialogues can also be grouped thematically and methodologically by cross-references. Thus the opening of the Sophist, a 'dramatic' dialogue, presents the same cast of characters as that of the Theaetetus (itself a framed dialogue), albeit with the addition of an important new figure, the Eleatic Stranger. The first words in the dialogue refer to an appointment made the day before to meet again (2I6a), and correspond to the close of the Theaetetus, where the appointment is made (2 Iod, with no return to the frame). The beginning of the Statesman is staged as an immediate continuation of the conversation of the Sophist $(257 \mathrm{a}-\mathrm{c})$. The conversations are set, therefore, on two consecutive days. The Timaeus (I7a-Igb) and Critias likewise look back to a Republic-like discussion on the previous day. Such cross-references help to group these dialogues, but neither the grouping nor the setting (the time of Socrates trial and the Panathenaic festival) serve the interests of historical verisimilitude. Rather, the Theaetetus-group elaborates a picture of philosophical life and methodology that gains poignancy from the imminence of Socrates' death. The setting of the Timaeus and Critias in the context of the Panathenaic festival helps to foreground issues of Athenian history and then to place them in the wider context of cosmic development. ${ }^{5}$ It is noteworthy also that indications of relative chronology between individual dialogues at the dramatic level need not correspond with any reconstructed order of composition. Thus the Parmenides presents Socrates as a young man, but the dialogue is usually considered 'late', and it also contains an incisive critique of the very theory of Forms for which Socrates will argue in dialogues where his character is older. ${ }^{6}$

\footnotetext{
${ }^{5}$ On the setting of the Theaetetus group see now Blondell 2002: 387-389 (who argues against the widely accepted notion that the trial of Socrates is an important background for the Sophist and Statesman). For the Panathenaic context of the Timaeus and Critias see K. Morgan 1998.

${ }^{6}$ For a suggestive consideration of the implications here see Griswold 2002: I38I39.
} 


\section{The iterative/repetitive world of Socratic dialectic}

Plato's Socrates is an exemplar of the philosophical life and his depiction is carefully calculated to underline the most important aspects of this lifestyle. Each dialogue is, as C. Gill points out, an encounter with 'its own integrity and significance'. ${ }^{7}$ Specific interlocutors make claims and mistakes that arise from their personality and intellect. Yet Socrates is a constant. Reading the dialogues makes one aware that Socrates asks the same kind of questions in the same kind of way, over and over again. Individual dialogues are samplings of his constant activity. The practice of Socratic dialectic in the dialogues is thus exemplary and, broadly speaking, iterative, in that each dialogue (and indeed all the dialogues as a group) presents once a practice that was continual. What is more, this aspect of Socrates is explicitly thematized. In the Apology, Socrates tells the story of how his efforts to understand the oracle that nobody was wiser than he led him to spend his life questioning others $(2 \mathrm{I} b-23 \mathrm{~b})$. Even when threatened with death he cannot promise to refrain $(29 \mathrm{c}-\mathrm{d}) .{ }^{8}$ Moreover, followers of his adopt the same practice, which creates great irritation among the Athenians (23c). Socrates is always making fun of orators (Mx. 234-235); Hippias accuses Socrates of always splitting hairs and not grappling with the whole topic (Hp.Mi. $36 \mathrm{gb}-\mathrm{c}) .^{9}$ His single-minded lifestyle also makes Socrates the object of repeated conversations by others. The young Charmides remarks that his companions speak frequently about Socrates (Chrm. I56a), and in the Laches, Lysimachus asks his sons whether this is the Socrates of whom they have often spoken (I8Ia).

The counterpart to this iterative presentation is repetition. Iterativity and repetition might seem to exclude each other, in that the former represents one action as a sample of many, and the latter tells an action more than once. The two features complement each other, however, since each emphasizes the essential consistency of the Socratic life and philosophical interaction. It is, moreover, difficult to distinguish conceptually what might be called rhetorical uses of repetition (where

\footnotetext{
7 Gill 2002: I53.

${ }^{8}$ Moreover, he continues his usual discursive practice in the days before his execution in the days before his execution (Phd. 59d).

${ }^{9}$ At $L a$. 187e-188b Nicias comments that any one who converses with Socrates is drawn into a defense of his whole life and warns that the present conversation is an example. For further examples of Socrates' activity presented as repetitive by himself or others see Hp.Mi. 372b; Men. 8ge; R. 487b.
} 
the interlocutors talk about repeating material external to the present conversation) from narratological ones (where the interlocutors actually repeat what has previously been said in the narrative text). This is no accident. The reader is encouraged to extrapolate from the text at hand to create a mental construction of the philosophical life; iterative presentation and references to repetition (as well as actual repetition) ensure that the boundaries between text and fabula (broadly conceived) seem permeable.

Repetition and assessment of prior material is an important aspect of philosophic progress. Interlocutors must keep in mind what they have said previously, so that their argument may be consistent and productive. ${ }^{10}$ This applies both to prior agreements in the present conversation and to those in prior conversations. When Crito tries to persuade Socrates to escape from prison, Socrates demurs. He cannot now abandon the principles by which he has lived:

This is not a new development. I have always been the sort of person who is not persuaded by any of my friends more than by the argument that appears the best to me as I reason it out. I cannot, indeed, throw out the arguments that I spoke before, now that this fortune has come upon me, but they appear to me to be pretty much the same ... Was it said well on each occasion, or not, that we should pay attention to some opinions and not others? Or was it well spoken before I had to die, but now after all it has become perfectly obvious that it was spoken to no purpose, just for the sake of argument, and it was really a nonsensical and childish game?

(Cri. $46 \mathrm{~b}-\mathrm{d})$

Socrates' task in the Crito is to convince his friend that the conclusions they reached in the past still apply in the present.

Socrates, then, prizes consistency, both in word and action: we must discover the best arguments and then live by them. In the Gorgias Socrates extracts from the sophist a definition of rhetoric as public persuasion, and then comments that he has done this so that Gorgias will not be surprised if he asks the same kind of question later, a kind of proleptic repetition $(454 \mathrm{~b}-\mathrm{c})$. Yet Socratic consistency can irritate. Callicles complains that Socrates 'keeps talking nonsense' (Grg. 49oe) when he diverts discussion of political power to talk about food and drink and doctors, and that 'on each occasion you twist the arguments up and down' (5IIa) - a comment that applies equally to the present conversation and many past ones. Socrates, however, is unabashed:

\footnotetext{
${ }^{10}$ Cf. Grg. $457 \mathrm{~d}-\mathrm{e}$.
} 
his own view (that doing wrong is more shameful than suffering it) 'has been spoken many times already' but can be repeated once again (508d). His arguments are secure and he insists 'I always say the same thing' (509a). Thus he ironically praises Callicles for saying the same things to him as he does to his friends $(487 \mathrm{c}-\mathrm{d})$, but also does not hesitate to charge him with inconsistency: 'you declare that I always say the same things and blame me for this, but I say the opposite of you, that you never say the same things about the same topics' (49Ib; cf. $5^{\mathrm{I} 8 \mathrm{a}-\mathrm{b}) .{ }^{11}}$

Iterative narration and repetition show Socrates and his interlocutors living in a world where both intellectuals and ordinary citizens are concerned with a recurring set of problems about how to live their lives. The Laches opens with Lysimachus' iterative narrative of how he and Melesias educate their children ( $\left.179^{c}-\mathrm{d}\right)$. They often talk to their sons about the noble deeds of their forefathers, but are ashamed that they have no deeds of their own to point to. They blame their own fathers for spoiling them. They urge noble actions on their sons, their sons promise to comply, and the fathers thus try to discover what activities will be beneficial to them. Laches responds that this question is applicable not only to them but to those who are occupied with public affairs, who take their private affairs lightly and manage them carelessly (I8ob). This exchange occurs before the entry of Socrates into the conversation. It therefore sets up dialogue with Socrates as a response to a recurrent problem, and as Nicias will shortly remark, all conversation with Socrates follows the same pattern. ${ }^{12}$ The beginning of the Menexenus addresses a similar and recurrent '(pseudo-)' problem that faces the composer of the state funeral oration: what shall a speaker say on short notice when he must improvise? Socrates asserts that most speakers have speeches prepared long before. Nor is it difficult to improvise, given that the content is so predictable. In the body of the dialogue Socrates gives an oration which he has purportedly heard from Aspasia, but which she herself has partly improvised and partly sourced from an oration she wrote for Pericles (236b). Socrates' speech, then, has a strong iterative feel: he presents once a speech which we are to think is delivered in similar terms on many occasions.

11 The refusal of the sophists in the Euthydemus to argue consistently causes the conversation to break down $(287 \mathrm{a}-\mathrm{b})$.

12 Above, n. 9. 
Similarly, various philosophical theories are presented in the dialogue as recurrent within Socrates' intellectual milieu, and interlocutors often use or reject them. For example, Euthydemus and Dionysodorus give a demonstration of the familiar argument that it is impossible to tell a lie. Socrates says that he has heard the argument from many, 'and however often I hear it, I am always amazed; indeed, Protagoras' circle made much use of it, as did those who came before them. To me it always seems amazing, since it overturns both others and itself' (Euthd. 286c). Iteration and repetition again blur: the argument is rehearsed in the present situation, but is a sample of a pattern that has often been used before, and Socrates points out that the sophists are repeating, in effect, a piece of common intellectual property. Likewise in the Philebus, Socrates remarks that paradoxes concerning the one and the many are commonplace, and casts his comment in an iterative fashion: 'almost everyone has now agreed that we should not engage in such things, that they are childish and too easy and great impediments for those who take up arguments' (I4d). It is also clear, moreover, that certain arguments are familiar within the Socratic circle. At Phaedo roob, Socrates tries to explain his theory of causation: 'This is what I mean. There is nothing new about it; in no way have I stopped saying what I always said on other occasions in my past argument ... I am going to return to those much-discussed entities and begin from them [i.e. the Forms]'. ${ }^{13}$ The difference between Socratic arguments and sophistic ones seems to be that sophistic ones are used to score what Socrates regards as cheap points, whereas Socrates' theories are open to analysis and contribute towards an intellectual 'big picture'. ${ }^{14}$

Repetition of arguments may thus be positive or negative. Past agreements can pave the way for future progress while repeated reconsideration is necessary to ensure that they still hold good (since argumentative results are always provisional). ${ }^{15}$ Repetition of argument can also, how-

${ }^{13}$ Cf. Cebes' earlier reference to the theory of recollection 'which you have frequently been accustomed to speak of' (72e).

14 Thus the 'impossibility of contradiction' argument is self-refuting, equivocation between the one and the many is an impediment to argument, but the Forms are a workable starting point for further discussion.

${ }^{15}$ Need for continued analysis: Phd. ro7b ('even if our first assumptions are persuasive to you, nevertheless they must be examined more clearly. I think that if you analyze them sufficiently, you will follow the argument, to the extent that it is possible for a human to follow it'); $G r g .513 \mathrm{C}$. 
ever, mark argumentative or rhetorical breakdown. Lysias' reported oration in the Phaedrus is criticized for pointless repetition of the same things twice (Phdr.235a). With a recalcitrant opponent, Socrates must repeat his questions several times over (Hp.Mi. $\left.3_{64} \mathrm{c}\right) .{ }^{16}$ At its worst, this sort of repetition leads to vicious circularity. At Lysis 213b-c, Socrates remarks that 'It's necessarily going to happen that we come to the same agreement we did in our former discussion', that a man is an enemy to his friend, while the discussion at Philebus I3c stalls because the interlocutors are drifting back to old positions (necessitating a new start). ${ }^{17}$ Repetition is not only a narrative liability, but an intellectual danger. When argument after argument seems false, the experience can lead to 'misology', the belief that 'there is nothing sound or stable either in facts or in arguments'. The victim ends up loathing argument and missing the chance of knowing the truth (Phd.gob-d). The aspiring philosopher must, therefore, exercise persistence and methodological self-awareness to ensure that repetition is productive rather than vicious.

Considerable patience is required, therefore, fully to embrace the philosophical life. The topics considered are complex and demand thorough analysis. So it is that the motif of starting the analysis again is not infrequent in the Platonic corpus. ${ }^{18} \mathrm{~A}$ few examples will suffice. Repeated efforts to define self-control within the Charmides are frustrated, and thus at Charmides I67a-b, Socrates tries again, with the remark 'Third time lucky: let us examine it again, as if from the beginning' (the result will prove unsuccessful, and further consideration is left for the future). This is not, strictly speaking, repetition in the narratological sense of the word; the same speech act is not presented more than once. Yet the same topic is covered repeatedly. The need to start again is (unsurprisingly) pronounced in aporetic dialogues, which can end with the assertion that the question needs to be considered from the beginning (Euthphr. I5c-d; Prt. 36ra-d; cf. 349a). In larger dialogues, the need to start afresh can be used to articulate the argument. At Republic 348b Socrates urges Thrasymachus to 'go back to the beginning and answer'. ${ }^{19}$ The need to discuss a fresh topic for the sake of

\footnotetext{
16 Socrates too can be accused of coming back uselessly to the same point (Chrm. I66b-c).

17 Other examples of vicious argumentative circularity occur at Euthphr. I5b; Grg. 517c; Prt. 36r; Men. 79b-e.

${ }_{18}$ Grenet 1956.

19 Similar references to fresh starts at Prm. I42b, I55e, 165e; Plt. 268d (another
} 
completeness may also be seen in terms of starting again. ${ }^{20}$ The articulation of a discussion in such terms is connected with the need for a leisurely intellectual pace. When examining the theory of flux in Theaetetus Socrates declares that they must look over the account again in a leisurely way (I54e-I55a). Socrates' digression on the philosophical life in the dialogue makes a similar point:

Free men always have what you are talking about: leisure, and they conduct their discussion in peace and at leisure. Just as we are now for the third time changing one argument for another, so do they, if a topic comes up that, as in our case, pleases them more than the one that lies before them. It is no concern to them whether they speak briefly or at length as long as they achieve the truth. The others [orators] always speak without leisure, for the flowing of the water clock urges them on.

$(\mathrm{I} 72 \mathrm{~d}-\mathrm{e})$

Philosophical conversation and its image, the philosophical dialogue, do not, then, operate according to the rules that govern more formal speech. As long as the interlocutors keep in mind the connection of their conversation with their larger goals, digression is encouraged, and closure is provisional.

Let us consider a more extended example of iterative presentation in the Symposium. Socrates' repetitive behaviour is stressed. Aristodemus speaks of his habitual fits of abstraction ( $\mathrm{I} 74 \mathrm{~d}-\mathrm{I} 75 \mathrm{~b}$ ), and Alcibiades declares that Socrates' bewitching words conquer always, not just once (2I3e). The centerpiece of the dialogue is Socrates' remarkable narrative of his conversations with Diotima, through which she initiated him into the mysteries of love. His narrative is motivated by Agathon's prior speech on love, whose contents he has demolished through elenchus (I99c-20Ic). Then, however, Socrates claims he had begun his talks with Diotima by repeating the sort of things Agathon had been saying about love and she used the arguments Socrates had used on Agathon to refute him (201e). Agathon's speech, then, and Socrates' response are cast as a repetition of a previous exchange where Socrates played the part of Agathon. As Socrates begins his narrative, the discussion between Diotima and Socrates (in the past) continues precisely from the point where that between Agathon and Socrates stopped, thus map-

starting point); Phlb. 34e, 5ra (matters still outstanding); Tht. 187b, d; Ti. 48a-b, 48d, 6ga.

20 At Republic 450a-b Socrates asserts that they must start a fresh debate on the status of women, and at $497 \mathrm{~d}$ Socrates starts his exposition on philosopher kings in the cause of completeness. 
ping past and present conversations onto each other. At 202e, Diotima moves into exposition. The argument from then until 207a is continuous, but at that point we learn that the conversation was conducted not on one occasion but in a series of conversations 'whenever she talked about erotics'. We learn in retrospect that the presentation has been iterative. From 207a to the end of Socrates' Diotima narrative at 212a, the argument is presented once again as a smooth progression. The break at 207a articulates the argument into two parts and throws the conclusion of the speech (which deals with the drive for immortality) into high relief. But what is the overall effect of iterative presentation? Since Socrates is convinced that what Diotima says is true, he repeats the argument at the dinner party, and feels no qualms about consolidating many conversations into one (present) argument. Why should he? For he shares Diotima's belief that we should move from the particular to the universal, from many arguments delivered on many occasions to one stable truth. Correspondingly, the Platonic dialogues are conversations repeated both within the world of the narrators and by subsequent readers of the text, fragments of a larger picture that the philosophical reader must integrate.

Living and speaking consistently and with an eye to this integration helps to bring us into contact with a timeless, changeless, and nonsensible world. ${ }^{21}$ The physical universe in Plato is sometimes characterized as subject to cycles of creation and destruction $(T$. 22c; Plt. 26gb-27oa), and human souls, themselves immortal, undergo a cycle of birth and death (Phd. 72a; Phdr. 248c-249c; R. 6r7d-62rb). What is important for present purposes is the relationship between language (and thus narrative) and these realms of existence. As Timaeus remarks at Timaeus $29 \mathrm{~b}-\mathrm{c}$, words relating to the intelligible world are lasting and irrefutable (to the extent that they can be), while words relating to the sensible world can at most be 'likely'. Time itself is once said to be a moving image of eternity ( $T$ i. $37 \mathrm{~d}-\mathrm{e})$, but to the extent that our speech can be stable, it approaches more closely eternal verity. The problem seems to be that the sensible world demands narrative (cf. Ti. Igb-c). Thus the narrative of the Platonic dialogue occupies an uneasy middle ground between the progression that humans demand in a successful narrative and the philosophical urge towards stability: the movement towards consistency and stability is itself the story, and is expressed by

${ }^{21}$ Cf. Phd. $78 \mathrm{~d}$ (on the Forms); Prm. I4I, I5Ie (on the One). 
cycles of repeated argumentation. This tension is present also in the eschatological narratives in the corpus (in Gorgias, Phaedo, Republic, and Phaedrus), which are iterative in that they describe once a sequence of events that is conceived as repeating itself almost infinitely. ${ }^{22}$ They tell the story of afterlife rewards and punishments and the narratives have the satisfactory closure of good rewarded and evil punished, but there is every indication that the cycle of birth and death will (in most cases) repeat. Yet they also provide an accessible image of the non-sensible world.

\section{Analepsis}

All Platonic dialogues are instances of subsequent narration. The presence of Socrates in every dialogue but one (the Laws) ensures that we receive the dialogue as a report about or representation of the past, albeit an idealized past that in Plato's case is a forum for thought experiment. The dialogues are set in a world where there is an intense interest about what Socrates did and said. In the case of framed dialogues a narrator recounts a dialogue from the past. This dialogue therefore is one huge analepsis. In the case of dramatic dialogues the invisibility of the primary narrator creates an effect of simultaneity. But here too narrating characters may embed analepses.

Dramatic dialogues sometimes start with reference to philosophical conversations that took place before the dialogue opened (external analepsis). In the Timaeus Socrates starts by summarizing the conclusions that were reached in a discussion on the previous day. In the Philebus, the narratee enters the conversation when the argument is already in progress and thus a recapitulation of prior argumentation is needed (IIa). In these instances, analepsis allows Plato to focus on a particular segment or aspect of a larger problem. In other dialogues, external analepsis may be used as a springboard for discussion. In the Charmides (I6Ib), Charmides tries to use someone else's definition of self-control when he has difficulty coming up with his own definition. At Theaetetus I52a (cf. 20Ic-d) Socrates reports Protagoras' man-measure doctrine in his exploration of the problem of knowledge. Such attempts to use other people's theories to solve problems or to quote them as illustra-

${ }^{22}$ Cf. also Nightingale's (2002) important discussion of the myth of the Phaedo in terms of a (quasi-)Bakhtinian chronotope, the 'eschatology of the present'. 
tions or authorities are rarely successful. ${ }^{23}$ Socrates' own references to what he has heard from others in the past are usually vague or confined to myth and myth-like material (Diotima's doctrine of love is an exception).

Internal analepsis is an essential aspect of philosophical discussion. It secures commitment to past argument and helps to articulate the discussion by summarizing results or pointing out where the interlocutors made a mistake. Past experience can help to guide future action, and here analepsis is a didactic tool. It can also be used as a weapon; an interlocutor may be accused of not remembering what he has said earlier, or a simple restatement of a prior position may disguise itself as progress. ${ }^{24}$ Examples of recapitulation of past argument for the sake of clarity are Phaedo 73a-74a (recapitulation of the proofs for recollection, which Socrates will subsequently expand), ${ }^{25}$ and Republic $543^{\mathrm{a}-}$ $544 \mathrm{~b}$, where Socrates summarizes the digression on the community of women, children, and possessions, and takes the conversation back to where they left off before the digression: 'Like a wrestler, then, give me the same hold again, and when I ask the same question, try to make the same reply as you were going to at that point'. ${ }^{26}$ Politicus $275 \mathrm{C}-\mathrm{d}$ provides an example of backtracking when the argument has proved unsatisfactory. The Eleatic Stranger states that they must go back to a prior division where they started to lose track of the statesman, and he repeats the mistaken definition: 'at that point we called [statesmanship] simply "the science of the rearing of herds". Do you remember?'27 Conversely, Theaetetus 205c-e uses a past agreement ('Do you remember then, my friend, that a little while ago in our previous discussion we accepted - and thought that it had been well said - that there was no

${ }^{23}$ Socrates encourages Meno not to cite what Gorgias said on the teachability of virtue but to answer for himself (Men. $7 \mathrm{IC}-\mathrm{d})$, and he makes a similar move at Protagoras $347 \mathrm{e}-348 \mathrm{a}$.

${ }^{24}$ For the latter see Euthphr. I4a-c, where Euthyphro simplistically summarizes his past position and Socrates caustically comments, 'Surely, Euthyphro, if you had wished you could have summed up what I asked for much more briefly. But the fact is that you are not eager to instruct me.'

${ }^{25}$ Cf. 9 Ic- - d, 95b-e.

${ }^{26}$ Other examples: Plt. $297 \mathrm{c}-\mathrm{d}$ (reminder of an earlier agreement that it was not possible for a large mass of people to achieve political wisdom); and Phlb. I9c-d (summary of the recent argument as a prelude to demanding that Socrates clear up the difficulties they have encountered).

${ }^{27}$ Cf. Chrm. I72d: 'I don't think, Critias, our agreement on what we were talking about just now - that self-control would be a great good if it were like this - was well made ...'? 
account of the first things of which the rest are composed ...') to show that their more recent analysis is unsatisfactory.

Internal analepsis often takes the form of evoking a past argument so that it may be reconsidered or refuted. At Protagoras $359 \mathrm{a}-\mathrm{c}$, Socrates prepares to attack Protagoras' conception of the parts of virtue:

On the basis of these assumptions, I said, ... let Protagoras here defend himself and show how the things that he said in the first instance are right — not what he said at the absolute beginning ... but what he said later ... At that point, immediately, I was very surprised at his answer, and still more so now that I have gone through these issues with you. So, I asked him whether he asserted the courageous were confident, and he said, 'Yes, and eager'. Do you remember, Protagoras, making these answers?

He agreed he had.

Come then, I said, tell us ...

And of course, Socrates goes on to show that Protagoras' position is incoherent. A similar use of analepsis to close the jaws of a dialectic trap can be seen in the Gorgias:

Socrates: In the first part of our discussion, Gorgias, it was stated that rhetoric is concerned with the words that are about ... what is just and unjust. Yes?

Gorgias: Yes.

Socrates: Now, when you said those things at that point, I supposed that rhetoric could never be an unjust thing, since it always crafts discourses about justice. But when you were saying a little later that the orator could even use rhetoric unjustly, I spoke those words I did because I was so surprised and considered that what was being said was inconsistent. I said that if, like me, you thought it worthwhile to be refuted, it was worth having a discussion, but if not, we should let it go. And later, now that we have made the examination, you yourself see that it has been agreed that it is impossible for the orator to use rhetoric unjustly. (46ое-46ra)

In these instances, analeptic review shows that Socrates' interlocutor has mistaken intellectual commitments and that his arguments have been inconsistent. ${ }^{28}$ Memory of and commitment to a line of argument is, therefore, risky, although essential. No progress can be made unless

${ }^{28}$ Cf. Grg. 49rb-c and 518a-b (Callicles accused of inconsistency); Hp.Mi. 369a (Hippias is not using his art of memory and has forgotten what the consequences of his position are). 
one holds opinions and is prepared to argue for them and be refuted. ${ }^{29}$ Arguments are, however, repeatedly reviewed and must always be seen as provisional.

The deployment of memory is important even at the metaphysical level. Whatever one thinks of the seriousness with which Plato may have entertained 'recollection' (the activation of prenatal knowledge) as an explanation of the problem of knowledge, it is striking that the ability to 'recollect' parallels the need for philosophical interlocutors to remember and activate their arguments. At Phaedo 72e-73a external analepsis merges with metaphysical recollection:

'Besides, Socrates', Cebes replied, '[what you say] is also in agreement with that argument (if it is true), which you have frequently been accustomed to present to us, that learning really happens to be nothing other than recollection ...'

'But Cebes', said Simmias in response, 'what sort of proofs are these? Remind me - since at the present moment I don't precisely remember'.

'One very fine argument', said Cebes, 'is that ...'

$(72 \mathrm{e}-73 \mathrm{a})$

As so often in Plato, narrative form and philosophical content play off each other.

Narrative of the past can be didactic. In the Apology, Socrates engages in autobiography to try to convince the jury that he is innocent of the charges brought against him and shows himself learning the appropriate lessons from his experiences. After hearing the report of the Delphic oracle that he is the wisest of men, Socrates questions various Athenians and discovers that their pretensions to knowledge are false. His conclusion, which he regards as an imperative to philosophize, is that human wisdom is of little value. Similarly, Socrates' intellectual biography at Phaedo 96a-Iooa tells how he dabbled with natural science in his youth, attempted (unsuccessfully) to find satisfaction in the philosophy of Anaxagoras, and finally settled on a method of hypothesis. The motive for telling the story is the following: 'If you wish, I will narrate to you my experiences. Then, if any of the things I say appears useful to you, you will use it for persuasion on the matters about which you speak' (96a). Nor is it only Socratic autobiography that can prove didactic. Nicias in the Laches states that Socrates draws his interlocutors into giving an 'account about himself, how he lives now and how he has lived his past life ... I think it is no bad thing to be reminded that

${ }^{29}$ Commitment to past argument, Cri. $46-49 ;$ Plt. $292 \mathrm{~b}-\mathrm{d}, 304 \mathrm{e}$. 
we have acted or are acting not well. The one who does not escape these critiques must surely take greater thought for the rest of his life' ( $188 \mathrm{a}-\mathrm{b})$.

Finally, we must consider cases where analeptic comment causes us to look at prior action in a new light. At Charmides $\mathrm{I} 62 \mathrm{c}-\mathrm{d}$ Socrates narrates that during the course of the conversation he had just reported, Critias had been growing agitated, and that this convinced him of something he had suspected for a while, that Charmides had taken his definition of self-control from Critias. So too, at Republic $336 \mathrm{~b}-\mathrm{d}$, Socrates reports that Thrasymachus had long been trying to break into the discussion and that he himself had avoided looking at him, and subsequently $\left(35^{\mathrm{Oc}}-\mathrm{d}\right)$ that Thrasymachus made a series of damaging admissions not as Socrates had just narrated them, but with much baulking, sweating, and reluctance. These episodes show Socrates explicitly as a master narrator. ${ }^{30}$ We may compare also the passages cited above where Socrates tells an interlocutor that he was surprised at the time a statement was originally made, clearly foreseeing that this would lead to contradiction. Apart from Socratic mastery of the argument, these passages show, perhaps, that a philosophical narrator will concentrate on presenting the essentials of the argument rather than on peripheral issues of personal embarrassment or triumph. These 'human interest' issues are presented after the action has been narrated for the first time, and emphasize that the argument must be allowed to run its full course. ${ }^{31}$ They also invite us to speculate about what else may have been going on in the 'background'. In the most extreme case, Euthydemus 29oe-29ia, analeptic comment may even make the reader suspicious about the accuracy of the narrative. Here, Socrates reports a stretch of argument as belonging to Clinias. Crito demurs, 'That young boy said such things?' Socrates responds, 'Perhaps it was Ctesippus after all who said these things, and I don't remember? ... Perhaps some higher being was present and said them? For I know well that I did hear them'. Crito comments, 'Yes, Socrates. I also think that a higher being said them - very much so'. Socrates has revealed himself as an unreliable narrator-both Crito and the narratee are convinced it must have been Socrates who made the argument. The episode, however, is in line with the ironic mask of incompetence Socrates adopts in this dialogue.

\footnotetext{
30 For further discussion see $S A G \mathcal{N}$ I:36r-364.
}

31 Cf. Phd. 63d, 84c-d. 


\section{Prolepsis}

Just as the philosopher must have an effective memory of what he and others have said, so he must be able to foresee the likely course of the argument. We have already seen how Socrates reveals that he has an almost uncanny ability to predict when a line of argument will lead to trouble. These predictive abilities also lead to the portrayal of Socrates as a mantis, or seer. ${ }^{32}$ We must also examine a representative sampling of instances where Socrates engages in a narrative form of prophecy, prolepsis, in which he attempts to project what he or hypothetical interlocutors might say in response to questions. If Socrates attempts to run away from prison and the laws of the city accuse him of trying to destroy them, what will he respond? $(\mathrm{Cri}$. 50a-c) - a question that is followed by substantial quotation of this hypothetical conversation. At Protagoras 33oc-e Socrates imagines a series of questions put to him and Protagoras by a hypothetical questioner and at 330e-33ra, this questioner reviews the prior argument and finds an inconsistency. Later in the same dialogue, Socrates asks Protagoras to help him convince the many what is really going on when they speak of being overcome by pleasure:

Perhaps if we say 'You are not right, men, but wrong'... they would ask us 'If it is not being defeated by pleasure, Protagoras and Socrates, what in the world is it? What do you say it is? Tell us'... If they should ask us 'What do you say it is, what we were calling being defeated by pleasures?' I would speak to them this way, 'Listen. Protagoras and I will try to explain it to you'... They would agree. Then you and I would ask them again ... Now what if we asked them the opposite? ...

$\left(353^{a}-354 a\right)$

This hypothetical conversation goes on until $357 \mathrm{e}$ and ends by establishing that the pleasant is good and the painful bad, an essential point for the final refutation of Protagoras. Examples could be multiplied, but enough has been said to show that this kind of hypothetical narrative is an important feature of the dialogues. Not only does it serve to impress upon the reader the need to be able to forecast the implications of one's argument, but it helps to distance Socrates from the argument, to make it less a matter of personal eristic victory. ${ }^{33}$ In the Crito, Socrates at first

\footnotetext{
${ }^{32}$ For an analysis of Socrates as a seer see K. Morgan forthcoming.

33 An interesting comparandum here is the narratorial intervention of the Homeric narrator in certain 'if not' situations ('Odysseus would have perished, if Athena had
} 
aligns himself with Crito as the object of the laws' critique; in the Protagoras he aligns himself with the sophist, even though the end result will be the latter's refutation. In the Theaetetus he even makes himself the object of a stinging critique by a Protagoras brought back from the grave $\left(\mathrm{I}_{6} \mathrm{e}^{-}-\mathrm{I} 68 \mathrm{c}\right)$. The point must partly be that it does not matter who makes the argument, nor does it matter when (the futurity of these prolepses is dubious). What does matter is the logos.

\section{Rhythm}

Reports of philosophical conversation are eagerly received within the Platonic corpus, and requests for such reports may be accompanied by the plea that the narrator give a really detailed account. ${ }^{34}$ Socrates himself is a great lover of discourses. ${ }^{35}$ It is Socrates' disciples, however, who are particularly concerned with the accurate reproduction of Socratic conversation. The Phaedo opens with a conversation between Phaedo and Echecrates in which $(58 \mathrm{c}-\mathrm{d})$ Phaedo confesses that nothing gives him more pleasure than talking or hearing about Socrates, and Echecrates asks Phaedo to try to recall the last day of Socrates as carefully as he can (a request repeated at $88 \mathrm{~d}-\mathrm{e}$ ). ${ }^{36}$ Socrates is sometimes portrayed as having been a helpful source in the commission of these conversations to memory (Smp. I73b; Tht. I43a). As with entire conversations, so with individual arguments. At Lysis 21 $1 \mathrm{a}-\mathrm{b}$, Lysis is much taken with a stretch of argument that he wants Socrates to repeat to his friend Menexenus.

Lysis ... said to me quietly, without Menexenus noticing, 'Socrates, say to Menexenus what you have been saying to me'. And I said, 'you will say these things to him, Lysis, for you were certainly paying attention'. 'Absolutely', he said. 'Try then', I said, 'to recall them as best you can, so you can say them to him clearly, and if you forget any of them, ask me again the first time you meet me'.

(2 I Ia-b)

not given him forethought'). As was remarked in $S A G \mathcal{N}$ i:I6-17, this different kind of hypothetical narrative in Homer creates tension or pathos.

${ }^{34}$ The desire for an exact and full account seems to be a mark of a curious intellect, and characterizes also Solon's request to the Egyptian priests at Timaeus 23d.

35 Phdr. 227b (Socrates asks Phaedrus for an account of how he and Lysias have been spending their time); Euthd. $272 \mathrm{~d}$ (Socrates tells Crito that he remembers well the conversation he had with the sophists and will try to tell the whole story from the beginning).

${ }^{36}$ Cf. Prm. I26b-127a; Smp. 172a-173b. 
Here Plato presents a basic impulse behind the reproduction of Socratic conversation, although we must acknowledge that his own strategies need not coincide with such constructions. Note the stress on accuracy, Socrates' offer to coach the student on details, and, importantly, the pedagogical strategy that lies behind. The student must internalize the argument, so that it can become his own as he repeats it.

The narratee might, then, expect that story-time will match fabulatime, and as a general description of the pace of the conversations portrayed, this is accurate enough: the illusion is that the dialogue takes the same time to read as the conversation did to conduct. This scenic pace strengthens the effect of simultaneity, as we seem to overhear the conversations and thus become pupils ourselves. We have already seen, however, that things are not always so simple - witness Socrates' admission in Republic 350c-d that his refutation of Thrasymachus actually took place more slowly than his narration of it. I shall consider these variations of pace under the headings of slow-down and acceleration.

\section{Slow-down}

The narratological phenomenon of slow-down is relatively rare in the Platonic corpus, although we have seen that philosophical leisure is an important theme. Particularly in longer dialogues a speaker sometimes appeals for patience if he senses that the discussion is rushed. At Theaetetus I72C (cf. I83d, I54e-I55a), the digression upon the philosophical life is introduced by the observation that although theories are rushing upon them fast and furious, this is no cause for concern, since they have time to consider them. Both Socrates and the Eleatic Stranger stress that subjects must be dealt with in the proper order and unhurriedly (R. 528d; Plt. 264a-b, 277a-c; Phlb. I7a). A long stretch of the Statesman (283b-286c) is devoted to a 'prophylactic' argument on the topic of excess and deficiency in argument and introduction of the criterion of due measure. One must not, says the Stranger, get impatient with the length of a discussion - the criterion is how well the discussion helps the inquirer, not whether it is long or short. ${ }^{37}$ These methodological discussions are not, of course, examples of slow-down, but they do

\footnotetext{
37 Compare also Prodicus' comments on long and short discourses as reported at Phaedrus $267 \mathrm{~b}$.
} 
show how aware Plato was of the pace of his narrative and mean that interpreters should pay special attention to these issues.

Slow-down is most noticeable when a Platonic narrator describes an emotional state or sets a scene. In the first category we may place passages such as Phaedo 59a, where Phaedo the narrator describes how 'an absolutely strange emotion came over me, an unaccustomed mingling of pleasure mixed together with pain, as I realized that soon he was going to die', or 88c, where Phaedo describes the depression that seized the company at the objections of Simmias and Cebes. Sometimes the emotions are those of Socrates: his spellbound reaction to Protagoras' Great Speech (Prt. 328d), his terror in the face of Thrasymachus' violent objections to his line of argument $(R .336 \mathrm{~d})$, his overwhelming arousal at his glimpse of what lay underneath Charmides' cloak (Chrm. I55de). In all three instances, Socrates is the narrator of his own emotions, and indeed, our familiarity with his irony makes us unlikely to take his enchantment, his terror, or his helpless arousal at face value. In each case, he soon rallies to take up his argumentative task, and his exaggerated description of his emotions acts as narrative punctuation, marks the magnitude of the task he faces, and casts him as a philosophical hero whose devotion to argument conquers any emotional weakness.

The infrequent examples of scene setting are never casual. In the Protagoras Socrates paints a detailed picture of the collection of sophists he sees when he enters the house of Callias, lingering over the relationships between the sophists and their respective audiences and throwing in resonant allusions to the Odyssey for good measure $\left(3^{\mathrm{I}} 4 \mathrm{e}^{-}-3^{\mathrm{I}} 6 \mathrm{a}\right)$. The verb of entry in this passage is repeated three times. The first time is at $3 \mathrm{r} 4 \mathrm{~b}$, 'When we went in we came upon Protagoras ...', after which Socrates describes the scene for a page and a half. The second is at 3r6a3, 'And we had just gone in, and Alcibiades came in behind us', and finally we are given a summary sentence, 'When we entered, then, we spent a few moments examining the scene thoroughly' (316a6-7). The repeated entry creates suspense (when will they actually speak to Protagoras?), but the summary also draws attention to Socrates' act of narration (as do the Homeric allusions), marking the scenic descriptions a construct. It may thus be compared with the passages treated above in my discussion of analeptic comment on previous action, where we are made to reassess what has been put into, or left out of, the narrative. 


\section{Acceleration}

Just as the concept of slow-down exists at the levels both of content and of form, so too does acceleration, or passing more rapidly than normal through material. We have seen already that important philosophical topics deserve a leisurely treatment, but another aspect of the staging of philosophical conversation is the pressure of time, which makes it necessary to move quickly past inessentials. There is a tension between the limited time we may dedicate to philosophy and the nature of the world of eternal truth that is the object of the philosophical quest. Similarly, there is a tension between the vastness of any given subject and the narrative time/space that may be devoted to it. Such tensions are especially marked when the world of the philosopher comes into contact with the everyday. In his defence speech, Socrates is keenly aware that he has only a short time to dispel a long-standing prejudice against him (Ap. I8e-19a; cf. 37a), while in the Phaedo the pressure of time is caused by the imminence of Socrates' execution (6re, Io8d). ${ }^{38}$ Mythological vistas also seem to generate an inability to tell the tale in full. ${ }^{39}$

Present concerns pale when compared with the big cosmic picture that is the business of philosophy. The immortality of the soul makes this picture even more crucial. The Republic is particularly aware of such timeframes. ${ }^{40}$ When Socrates is dismayed at the swarm of arguments called by the discussion, Glaucon responds, 'for those who have sense, the measure for listening to such discussions is one's whole life' (45ob). Socrates will not stop his arguments until he has given Thrasymachus something useful

'for that life when they have been born again and come upon such arguments'. 'You speak with reference to a small period of time!' he said. 'Nothing at all', I said, 'in comparison to all of time'.

In the introduction to the myth of Er at the end of the dialogue, we learn that the magnitude of the rewards for justice must be measured

38 Note the deliberate ambiguity at Phaedo Io8d: Socrates says that his life is too short for a long explanation, and this could refer both to his death, and to the immensity of the subject (the nature of the true earth).

39 Phd. I08d; R. 6i5a; Plt. 277b.

$40 \mathrm{Cf}$. also $A p$. 4oe (the whole of time could be regarded as a single night if death is oblivion); Phd. IO7c ('If indeed the soul is immortal, it needs our care not only for that period of time which we call life, but for all time'). 
not within the compass of a single lifetime, but on the scale of eternity: " "What great thing", I [Socrates] said, "could there be in a short period of time? For that whole period of time from childhood to old age would, I suppose, be trivial in comparison with all of time"' (6o8c). Human life may seem long to us, but is dwarfed by eternity.

If the whole of life is but a moment, one cannot afford to lose any time in inappropriate or unproductive argumentation. When argument is inductive, generalizing from many examples, the participants may decide to cut short the citation of multiple instances (Phlb. 5od). Accepting a hypothesis can also prevent excessive repetition or the laborious task of addressing multiple objections (R. 437a; Phlb. 24d-25a). Sometimes a subject cannot be fully treated because of current constraints, such as mortal nature (Phdr. 245b, 246a; R. 435c-d, 5o6d-e, 5o9c; Ti. $48 \mathrm{c})$. Sometimes worthy subjects are rejected because of the need for focus. Thus Timaeus refuses to digress on self-existent forms (Ti. $5^{\mathrm{IC}-}$ d) or multiple worlds $\left(T i .55^{\mathrm{c}-\mathrm{d}}\right.$ ), while in the Theaetetus (I84a) Socrates will not be drawn into a discussion of the side issue of monism. Occasionally, however, such subjects are merely deferred, to be revisited later (whether this is within the confines of the dialogue or not). ${ }^{41}$ The Eleatic Stranger in the Statesman resists the temptation to digress on true subdivisions, but promises to come back to it some other time $\left(263^{a}-\mathrm{b}\right.$; cf. 284 d). He never returns to the topic within the dialogue, but in the Republic Socrates does return to deferred topics: to the question of the feasibility of the ideal city (47Ic-502c, deferred from $458 \mathrm{a}-\mathrm{b})$, and the education of the philosopher kings at $502 \mathrm{e}^{-} 5^{\mathrm{O}} 3 \mathrm{a}$. The narrative reinforces the notion that the dialogues are snatches of a much larger conversation, whose measure is not one, but many lives.

On the narratological level we may note several types of acceleration, manifested as ellipsis, where we pass over parts of the action deemed to have only marginal philosophical interest for present purposes. Plato often accelerates over transitions, particularly at the beginning of a dialogue. In the beginning of the Laches the original four interlocutors decide to take their problem to Socrates, who is addressed by Lysimachus at I8od. The reader must imagine that the interlocutors have walked over to Socrates to engage him in conversation, but no indication of this action appears in the text. At the beginning of the Gorgias the initial exchanges are between Callicles, Chaerephon, and

41 Cf. also Ti. 38d-e (discussion of the places of the stars is deferred to another occasion) and $38 \mathrm{~b}$ (discussion of the effects of time on language is also deferred). 
Socrates, and Chaerephon is encouraged to speak directly to Gorgias at $447 \mathrm{c}-\mathrm{d}$. We must imagine either that they have all been talking quietly on the fringes of the larger group, or that they have been standing to one side and now approach. Again none of this appears in the text. ${ }^{42}$ Protagoras 3I4C combines this speedy movement towards the main conversation with the ellipsis of a conversation not relevant to the present topic:

When we had agreed on this we walked on. When we were in the porch we stood and conversed on a topic that had occurred to us when we were on the road. So that it would not be incomplete, but so that we could enter once we had brought it to a conclusion, we stood in the doorway and conversed until we came to an agreement with each other.

$(3 \mathrm{I} 4 \mathrm{c})$

This little vignette also illustrates the principle I have discussed earlier, that philosophers should take a leisurely attitude to conversation and allow it to run its natural course.

Omission of 'unimportant' detail is frequent. In my discussion of analepsis, I referred to the passage in the Republic where Socrates confesses that his narration did not do justice to the hesitations of Thrasymachus. Socrates' analeptic comment makes it clear that his account of the conversation was, in fact, accelerated. We find similar acceleration over the baulking by an opponent at Protagoras 333d: 'At first Protagoras was coy - for he alleged that the argument [on Socrates' terms] was hard to manage - but then he agreed to answer' (cf. $338 \mathrm{e}$, $348 \mathrm{~b})$. Plato also passes relatively quickly over the response of listeners, as one example of many will show. In the Protagoras, Protagoras makes a spirited counterattack against Socrates, who comments, 'When he had made this speech he produced applause and praise from the audience. At first I was like someone who has been struck a blow by a good boxer: I went blind and became dizzy' (339d-e). ${ }^{43}$ Like the primary narrator, secondary narrators may omit details they feel to be irrelevant. When Socrates tells the myth of Thamus and Theuth in the Phaedrus, he passes over Thamus' comments on all the arts except writing, which is the issue at hand. Aristodemus in the Symposium leaves out

\footnotetext{
42 At Phaedrus 242b we are to envisage Socrates getting up, starting to cross the stream and then stopping. At Theaetetus I43b Euclides suggests that he and Terpsion go inside and have a slave read the text of a Socratic conversation to them. One line later, Euclides can state, 'This is the book'.

${ }^{43}$ Ap. 35e; Prt. 334c, 337c, 338b, 348c, $35^{8}$ passim; Euthd. 276c, 303b; Smp. 176e-177a, I98a; R. 338a, 344d, 368c.
} 
details of the dinner party before the serious conversation starts (I75aI76a). Even once the diners have made the decision to talk about love, not all speeches are reported, and not verbatim (178a, I80c). The pace quickens even further at the end of dialogue, when the drinking party degenerates into a drunken brawl $(223 \mathrm{~b})$, and even the final exchange between Socrates, Agathon and Aristophanes is merely sketched.

One last instance of acceleration is interesting because it shows that such ellipsis may be a mistake. At Euthydemus 29rb, in the frame conversation, Socrates reports to Crito the discussion he had with the sophists and Clinias. Crito asks whether their intellectual search was successful and Socrates wryly admits that it was not. 'Why should I tell you the long version?' he asks. They ended up back where they had started. Socrates' account here is accelerated, but Crito is not satisfied. 'How did this happen to you?' he asks. Socrates and Crito now reconstruct in detail in the frame conversation the same material that Socrates passed over (29IC-293a). Crito is not a quick enough thinker to be able to supply the argument for himself. The narrative is compressed, but then must be expanded in the frame.

\section{Conclusion}

The issue of time in Platonic narrative is linked to the issue of the operation of time in mortal life. The immortal human soul is encased in a time-bound shell and subject to the laws of the physical world, yet its best destiny is to free itself from these constraints. How to represent the eternal, and the attempt to find it, in narrative? As the Socratic narrator sometimes points out, it is impossible to represent the (timeless) eternal realm in a narrative, which is defined by the progression of time. The sensible world, however, demands some kind of narrative. It is fitting, therefore, to conclude by noting that Plato occasionally plays on this tension. Even in the case of narration about the sensible realm, a true narrative seems impossible. I am speaking, of course, of the disorderly narrative motion in the Timaeus, where we are told that narrative order does not correspond to the order of creation and that the narrative is 'random' because human beings are under the dominion of chance (34b-c; cf. 44c, 6Ic-d). It has long been recognized that in certain Platonic narratives fictive genesis may replace conceptual analysis, and present as separated in time things that, in reality, co-exist. Examples of such myths are the cosmogony of 
the Timaeus just mentioned and the origin of the state in Republic 2 and Laws $3 .{ }^{44}$ Moreover, the comparison of different constitutions in Republic 8 is presented as a narrative of decline, a diachronic treatment of a synchronic reality. As the Timaeus tells us, there is an interrelationship between time and language (38b). In that dialogue Timaeus states that this subject is best discussed on another occasion. But perhaps all the dialogues meditate upon this.

${ }^{44}$ Frutiger 1930: 190-I9I. 


\section{GHAPTER TWENTY-THREE}

\section{XENOPHON}

\section{K.A. Morgan}

Xenophon's Socratic works (Memorabilia, Apology, Symposium, Oeconomicus) report instructive conversations between Socrates and various interlocutors on the authority of an unnamed narrator who was either present himself or heard the reports of others. Like the Platonic dialogues, therefore, they are not concerned with transmitting a complete narrative of Socrates' life, but with the presentation of paradigmatic episodes. In all of them except the Oeconomicus the presence of the narrator is overt, as is his apologetic purpose: to defend the memory of Socrates from any suspicion that he was a bad influence on Athenian society and to argue that, on the contrary, he was a public benefactor. In keeping with this goal, all narration is subsequent narration, looking back at or reconstructing the events of an exemplary life. ${ }^{1}$ This feature is, to be sure, one aspect of the entire genre of sōkratikoi logoi, which seems to have been generated as a response to the execution of Socrates in 399 BC. This generic focus also has one important implication for the present inquiry: the anecdotes that are narrated are all given deeper resonance by the one event that is never narrated in any of the works: the execution of Socrates. Every example of Socratic virtue is measured against and criticizes his unjust death. This is made an explicit structuring principle of the Memorabilia, which begins with the narrator stating that 'I have often wondered by what arguments Socrates' accusers persuaded the Athenians that he was worthy of death' (I.I.I) and ends with Socrates' equanimity in the face of death, a summary eulogy, and the assertion that Socrates' companions continue to miss him 'as being most useful for the practice of virtue' (4.8.II). The focalization of the narrative (and indeed the genre) through a Socratic disciple creates, then, a kind of implied prolepsis: a narrative of the past looks to a

${ }^{1}$ As Gray has pointed out, Xenophon's Memorabilia is marked by formal features connecting it with later rhetorical manuals that report the sayings of wise men (V.J. Gray 1998: I59-177). 
future event that, while still in the past from the point of view of the narrator, continues to have repercussions in the present.

As was the case with the narrative of the Hellenica $(\rightarrow)$ the material is presented (at least in the case of the Memorabilia and Oeconomicus) with some lack of temporal precision, explicable here (as it is not in the historical work) by the focus on exemplary conversation. The Memorabilia is the least temporally focused, given that it is a collection of anecdotes from the whole range of Socrates' activities, grouped by topic. An exception to this trend are the anecdotes connected with Socrates' interaction with Critias when the latter was a member of the ruling junta of the 'Thirty Tyrants' (404-403 BC), which gain their point from their historical setting. The Symposium, although it purports to record the events of a specific dinner party (with a dramatic date of 42 I BC.), aims to prove that it is worthwhile to tell not just serious actions of good men, but also their recreation, and therefore reconstructs an entire party. The Oeconomicus, although its narrative structure is more complex (including an embedded narrative) still represents a single conversation at an indeterminate time that distills the fruits of Socrates' experience in management. The Apology has an obvious dramatic date of 399, the year of Socrates' death, for its narrative. Unlike Plato's version of Socrates' defence, which masquerades as a court speech, Xenophon's is set in a narrative frame and has a particular purpose: to bring out an aspect of Socrates' defence that he considers to have been insufficiently appreciated in other treatments (that Socrates had decided that death was preferable to life, I.I). The temporal setting is specific, but rather than simply reporting Socrates' speech at his trial, the narrative starts by reporting Socrates' conversation with Hermogenes (who is the cited source for the defence speech) in the days immediately preceding the trial (2-IO). In this work, we must conclude, argument over how precisely to interpret Socrates' intentions with regard to his defence (how, that is, to focalize him) has led to an extension of the temporal range of the fabula, the inclusion of material prior and subsequent to the occasion of his defence speech. ${ }^{2}$ This enables the narrator to end effectively by referring briefly to Socrates' steadfastness as he met his end: 'after he decided that dying was better for him than living ... he did not soften with regard to death, but awaited it and died cheerfully' (I.33).

\footnotetext{
${ }^{2}$ Cf. V.J. Gray ig89b for a discussion of Xenophon's concerns with conforming to contemporary standards of rhetorical appropriateness.
} 


\section{Order}

The recollections of the Memorabilia have two temporal points of reference: a general one of the years of Socrates' maturity, and the specific time of his trial and death. The series of anecdotes is related with the general aim of proving that the accusations against him were unjust (explicitly at I.2.I, 9, 49-64). The narrator's own reflections at beginning, end, major subdivisions, and elsewhere (e.g. I.2.2 I-24, where he muses on the phenomenon that people forget words of instruction when they pay no attention to them and then applies these thoughts to Critias and Alcibiades), in addition to references to his selective activity, make the narratee aware of a constant shuttling back and forth between past and narrative present. The narrator, then, presents himself as being constantly concerned with application of the past to his own present. Prolepsis, by contrast, is not an important feature of the work, although related to prolepsis are instances where the narrator or Socrates explores the possible course of future arguments or actions. Thus the narrator speculates 'Perhaps someone might say in response to this, that Socrates should have taught his companions moderation before politics' (I.2.I7; cf. I.2.I9), before dealing with this objection. ${ }^{3}$ Or Socrates asks Chaerecrates to explain how he would behave if he wanted to win someone over (2.3.II-I3). If external analeptic narrative in the Memorabilia as a whole serves the purpose of illustrating larger moral points, it does so also at the actorial level in the Symposium. Thus at 4.23 Socrates defends himself against the charge of being indulgent to the passion of Critobulus for Cleinias by telling how Critobulus' father entrusted him to Socrates in order to have Socrates help him calm his passion, and how in fact the situation has already improved. Similarly at $4.29-32$ Charmides justifies his pride in his current poverty by narrating the state of tension in which he lived when he was rich.

The deployment of analepsis becomes more complex in the Oeconomicus, where concentration on a single subject entails closer attention to what is said at each point in the discussion. We find therefore a higher proportion of internal analepsis than in other Socratic works by Xenophon. There is also a substantial amount of external actorial analepsis as Socrates recounts a useful conversation he had previously had with Ischomachus, the prototype of the Athenian gentleman. The

\footnotetext{
${ }^{3}$ Cf. V.J. Gray 1998: 6o-73 for the voice of opposition as a structuring device in the Memorabilia.
} 
complexity of the analepses in this dialogue makes it the chief focus of my current analysis. ${ }^{4}$

First: external analepsis. Like Plato's Symposium, the Oeconomicus nests conversations within conversations. This nesting acts as a structural device (although there are also external analepses with no structuring function: e.g. $4.20 ; 3.7)$. The primary narrator reports the conversation between Socrates and Critobulus in a floating present. The conversation between the two takes up the first part of the dialogue (I.I-6.II). Within this first part secondary narratives by Socrates report stories about the Great King of the Persians and Cyrus the Younger $\left(4 \cdot 4^{-20}\right)$, but then Socrates proposes to narrate the conversation he had with Ischomachus. This he does from 7-21, and there is no return to the framing conversation at the end of the work. Within this conversation, Ischomachus narrates conversations he has previously had with his wife and how he and she put into practice the principles he enunciated in these conversations. He also (7.I4-I5) reports how he and his wife recalled the advice previously given to them by their parents concerning moderation. With Socrates' encouragement, Ischomachus also tells the principles he uses in his daily life and gives examples of how he has put them into practice. As we might expect, these tales of principle and practice are, broadly speaking, iterative, in that Ischomachus narrates once actions and speeches that he makes on an ongoing basis (cf. I3.IO: 'These, then, are the things I do when I want to make people more obedient, teaching those whom I want to make overseers'). Given the exemplary status of Ischomachus' narrated actions and conversations, it is also no surprise that the temporal specificity of these reports does not seem to be a particular concern. Ischomachus' first conversation with his wife is explicitly marked as such (7.43), but subsequent conversations are labelled by topic rather than being arranged by temporal succession (e.g. 8.I-23: the importance of taxis in the household, with an inset narrative of Ischomachus' visit to a Phoenician ship and his conversation there concerning nautical taxis; I0.2-9 on cosmetics).

As in Plato $(\rightarrow)$, internal analepsis keeps track of the progression of the discussion. The initial conversation between Socrates and Critobulus establishes that the latter has no idea how to manage his wealth. Critobulus wants advice on how to increase his property, unless Socrates thinks that they are already rich enough. Socrates responds that al-

\footnotetext{
4 On the complex structure of the Oeconomicus see further Pomeroy I994: I7-I8.
} 
though he (Socrates) is rich enough, Critobulus, although he is wealthier than Socrates, sometimes seems poor to him. Critobulus is incredulous, but Socrates argues that only he has sufficient property for his needs, whereas Critobulus lives beyond his means (2.I-8). This first part of their exchange is summarized and marked off by an internal analepsis where Socrates remarks 'And don't you think that this is an amazing situation you have constructed for yourself, Critobulus, that a little while ago when I said I was rich, you laughed at me as though I knew nothing ... but now you command me to help you and to take care that you don't at all become a truly poor man?' (2.9). Analeptic survey of the prior discussion continues at 2.II-I2, as Critobulus tries to persuade Socrates to give him financial advice, until at 2.I6 Socrates promises to refer him to those who are knowledgeable. A series of hypothetical questions (3.I-4, e.g. 3.I: 'What if I prove to you, first of all, that some people build expensive and useless houses while others build ones for much less that have everything they need, will I seem to you to demonstrate one of the activities of estate management?') encourage Critobulus to learn what he needs, and the next stage of the discussion can commence. Analepsis and anticipation of the argument by Socrates here perform a protreptic function in addition to articulating the discussion.

Elsewhere it is the 'pupil' who initiates analepsis so that he may keep track of the argument and promote progress. At 6.I, after an extensive Socratic digression on farming, Critobulus asks Socrates to 'go back to where you left off talking about estate management and try to go through the subjects connected with this'. In order to do so, Socrates proposes to 'recapitulate the agreements we have reached' (6.2) to provide a model for the remaining discussion (which he does at 6.4-10, preparatory to narrating his conversation with Ischomachus). Again, in the inset conversation with Ischomachus, Socrates reminds his teacher what he said about successful farm management, since he thinks this topic has not yet been covered in enough detail (15.6). Finally, analepsis may mark intellectual progress, as at I9.I4. Here Socrates, puzzling over the problem of how to plant an olive tree, remarks 'but I am again thinking why, when you asked me a while ago briefly if I knew how to plant, I said no. For I thought that I would not be able to say at all how one should plant, but when you made the effort to ask me point by point, I answer you, as you say, the things which you know as an expert farmer'. This makes Socrates realize the value of teaching by means of questions. 
The narrative of the Apology is set within a general framework of reminiscence (subsequent narration) studded with external actorial analepses as Socrates (and his accuser) argues over how to interpret his past actions and speech. Thus when Meletus complains that Socrates has taught the young to obey him rather than their parents, Socrates confesses that he has indeed done this when the issue is education, since he is an expert, but counters that listening to experts is sound Athenian democratic practice (20-2I). The most effective anachrony in the work, however, is the actorial prolepsis reserved for the conclusion. After the end of the trial Socrates is reported to have made some choice remarks concerning the ethics of Anytus, one of his accusers, who had been annoyed with Socrates over some remarks that the latter had made concerning his son's education (precisely the issue that Meletus had focused on). Socrates explicitly lays claim to the power of prophecy that attends Homeric heroes and makes a prediction:

'I predict that he will not continue in the slavish occupation that his father has prepared for him, and because he has no serious advisor, he will fall into some shameful desire and will advance far in villainy.' His speech was no lie, for the young man took pleasure in wine and never stopped drinking day or night and in the end became worthless both to his friends and to himself. So Anytus because of his son's evil education and his own ignorance has an evil reputation even though he is dead.

$\left(3^{-}-3 \mathrm{I}\right)$

We see here the convergence of actorial prolepsis and narratorial analepsis, as Socrates anticipates the disaster awaiting Anytus and his son and has his prophecy confirmed by the narrator, who looks back on the prophecy from his own temporal perspective. ${ }^{5}$ This use of prolepsis confirms Socrates' wisdom, yet it is only an extreme example of a more general phenomenon, the ethical expertise that ensures he continues to be beneficial to those who remember him. Because of his steadfastness in life and death Socrates' future reputation is assured - and constructed and perpetuated in the work before us.

\footnotetext{
${ }^{5}$ A more generalized prophecy is also found in Plato's Apology 39b-c. For the connection of this motif with ancient poetic vitae see Compton I99o.
} 


\section{Rhythm}

I noted above that only two of Xenophon's four Socratic works are tied to specific occasions. Yet the narrator of each makes it clear that the conversations have been selected for their exemplary qualities: that of the Symposium for its presentation of good men at play, that of the Oeconomicus because it distils management experience, that of the Apology because it crystallizes Socrates' heroic virtue in the face of death. The multiple conversations of the Memorabilia present examples of Socratic usefulness to his friends and controvert general misapprehensions about Socrates. Even within the Apology, there are explicit indications of selectivity, as we shall see, but it is the Memorabilia that goes the furthest in making selectivity of anecdotes a guiding narrative principle. In philosophical narrative, then, as well as in Xenophon's $(\rightarrow)$ historical narrative the textual space devoted to an event is determined by what is worth remembering rather than by actual duration. I shall begin here with the Symposium, since it comes closest to presenting a complete narrative unit, defined by the prelude to the occasion, the party itself, and its conclusion.

The narrative of the dinner party involves Socrates and other members of the Athenian elite (most of the characters are historically attested), and combines scenic narration, direct quotation of the conversation, and various summary statements. There is, perhaps, greater variety in temporal rhythm precisely because the narrator is attempting to present a complete occasion and chooses not to skip from highlight to highlight, as he does in the Memorabilia, but to include more scenic detail (consonant with his opening conviction that the deeds of gentlemen are 'worth remembering' (axiomnemmoneuta) even when they are amusing themselves). The opening supplies the real historical background (the victory of the boy Autolycus) and the important information of the host's love for him (I.I-2) against which the narrative (itself largely fictional) is set. ${ }^{6}$ Then comes the dinner invitation and preliminary reactions to it in some detail (I.3-6), followed by a swift summary of further reactions and the arrivals of the guests (I.7-8). The narrator then emphatically marks the beginning of scenic narration:

\footnotetext{
${ }^{6}$ For the historical significance of the background and characters in the dinner party see Huss 1999: 398-403.
} 
Now someone who took note of what happened would immediately have thought that beauty is something royal by nature ... the beauty of Autolycus drew everybody's gaze to him. None of those watching failed to experience something in his soul because of him. Some became rather silent, while others somehow took a pose. All people who are possessed by a god seem worth looking at ... Callias then because of his love was worth looking at ... so they were feasting in silence.

(I.8-IO)

Interestingly, this scenic narration is thematized and made paradigmatic in itself of psychic reactions (note 'worth looking at' and 'took a pose'), but if extended would have undermined the promised conversation, and thus the entrance of a buffoon is needed to start the conversation that takes up most of the rest of the work. Short summary passages accelerate the narrative over inessential episodes such as the removal of the dinner tables (2.I) or various performances of the entertainers or the buffoon (2.I, 8, II, 22-23; 3.I), as also over the reactions of the company $(2.17,27 ; 3 . \mathrm{I}$, IO, I4; 6.I; 8.42), whether those reactions are general laughter or surprise, or consist in many people asking similar questions or making similar remarks simultaneously. Especially characteristic is the iterative presentation functioning as a summary at 4.56: "Certainly", they replied, and when they had once said "Certainly", they all replied this for the remainder of his questions'. It is clear that Socrates' substantive comments and conversations are the focus of the narrative. Both acceleration and slow-down are employed to this end, so that, for example, the narrative can focus on the details of the exchange between Socrates, Callias, and Lycon on the scents and odours appropriate to men and women $\left(2 \cdot 3^{-5}\right)$. This exchange is introduced by a brief summary of a musical performance by the entertainers ('and when the flute-girl had played the flute for them and the boy played the cithara, and both of them seemed to cheer the company to everyone's great satisfaction, Socrates said ...', 2.2). The quoted dialogue that follows eventually turns from real to metaphorical scent (that of kalokagathia, the excellence of a gentleman), and scene becomes summary as the company considers where one might find a teacher for this ('Then many people spoke, and one of them said "Where will he find a teacher of this?" and someone else said that it was not teachable ...'). Socrates changes the subject since the topic is debatable: it must be put off for another time, and he directs attention towards the dancing girl (2.7). Socrates stops the progress of the discussion, then, when it draws too close to the usual subject matter of Socratic conversation. 
The Oeconomicus starts abruptly: 'I once (pote) heard him having a conversation about estate management also, along the following lines' (I.I). The use of pote marks the opening of a narrative, but the lack of specificity in providing referents for 'him' and 'also' is notable (see below under 'Frequency' for other examples of 'once' and 'also' in the Memorabilia). The narrator demands of the narratee that (s)he have a familiarity with the broad situation, constructing a rhetoric where Socrates needs no introduction. ${ }^{7}$ The conversation is with Critobulus (we are not told the identity of the narrator) and represents the kind of Socratic conversation with which we are familiar from Plato, where one topic is examined in depth. As will be the case with the Memorabilia, the didactic and exemplary function of the work dictates a certain selectivity in the narrative material. We hear a conversation between Socrates and Critobulus knowing that it is but one Socratic conversation of many, but also that it has been selected because it is thought to typify Socratic techniques and opinions on the subject. Within this constraint, Oeconomicus purports to represent the content of an entire conversation, although the failure to return to the framing Critobulus conversation from the inset Ischomachus conversation means that one is uncertain how either conversation ended, even though Socrates had promised (6.12) to narrate the entire conversation: 'What if I narrate to you from the beginning (ex arkhēs diēgessomai) how I once (pote) met a man who seemed to me really to be one of these [gentlemen]'. Selectivity is even more evident in the Ischomachus conversation and its tertiary narrative. Ischomachus chooses to narrate to Socrates particular examples of his conversations with his wife and of his own practices, although each conversational vignette moves at a leisurely pace. Socrates (II.I) has to prevent him from multiplying examples of the admirably 'masculine temperament' of his wife in order to make him concentrate on himself. Throughout the conversation Socrates is greedy for detail ('Narrate completely', II.6, II), whereas Ischomachus is keener to impart principles (II.7, I2), and indeed the methodological points made towards the end of the work (19.13-I6) are tied to the amount of detail that is necessary to make a point and teach one's pupil. Thus when Socrates asks

${ }^{7}$ For those familiar with the Memorabilia, it is as though the Oeconomicus were merely the beginning of a new chapter in that work. This presumption of generic familiarity is shared with Platonic dialogues ( $S A G \mathcal{N}$ I:366). Cf. $S A G \mathcal{N}$ i:379 for the introductory formulae of the Socratic works and the impression that they form a continuous sequence'. 
how to plant olives, Ischomachus replies 'Here again you're making trial of me, when you know very well'.

In the Apology, the scope of the work extends beyond the trial itself to include illustrative pre-trial and post-trial material. Moreover, at section 22, the narrator is explicit that more was said during the trial than he has reported; all he wants is to make it clear that Socrates' chief concern was to avoid the appearance or actuality of any improper behaviour towards gods or men. Socrates' consciousness of his innocence and his belief that the time had come for him to die explains his 'big talking' (megalègoria, I). Even though all of Socrates' behaviour at the time of his trial was exemplary, the narrator's particular focus on an overlooked explanation for his conduct makes the quality of the narrative more than usually uneven. Detailed reports of speech are followed by swift acceleration to the next exemplary moment. Thus the narrator lingers on the pre-trial exchange with Hermogenes that establishes Socrates' attitude to the court (I-9) and sums it up at Io with the remark 'He [Hermogenes] said that having assessed the situation in this way, when his opponents accused him of not believing in the gods the city believed in and introducing new divinities and corrupting the youth, Socrates came forward and said ...' There follows Socrates' self-justification, punctuated by the uproar of the jurors (reported in summary). Demolition of his accuser Meletus gives way to brief anecdotes of his attitude during the penalty phase of the trial and while he was in prison (23) and to a slightly more extended presentation of his remarks as he left the courtroom (24-30). The verdict is presumed, rather than reported (23). Finally, the narrative ends with the narrator's comments on the blessed nature of his hero's fate (32-34).

The Memorabilia can be considered a compendium of wisdom, grouped by topic. ${ }^{8}$ This organization dictates an episodic narrative, and the narrator makes his theory explicit at 4.6.I:

I shall try also to tell this: how he used to make his companions better at discussion. For Socrates used to think that those who know what each individual thing is can also explain it to others, but he said that it is not astonishing that those who do not know trip up both themselves and others. Because of this he never used to stop examining with his companions what each individual thing is. Now it would be a great task to go through how he defined everything, but I shall tell this much: what I think will demonstrate the method of his enquiry.

\footnotetext{
8 SAGN г:380.
} 
Similarly (though less theoretically), the narrator at I.3.I says that he will set down 'as much as I can recollect' of the actions and conversations by which Socrates benefited his companions. ${ }^{9}$ Since the first part of book I focuses on rebutting the accusations brought against Socrates at his trial, there is more argument than narrative, based on a summary of Socratic practice. Consequently, questions of slowdown and acceleration do not come to the forefront. The pace starts to slow with the more detailed treatment of Critias and Alcibiades, which begins with an overview of their relationship with him (I.24-28) and then proceeds to narrate individual conversations involving them, punctuated again by summary statements ('What sort of relationship existed between Critias and Socrates and how they behaved towards each other has been narrated, and I would say that nobody can get an education from someone he does not like', I.2.38-39). At I.3, the narrative takes on the quality it will retain for the rest of the work, as the narrator announces his intention of reporting beneficial conversations. Individual anecdotes are reported and carefully set within an evaluative framework. As one example of many, I cite the beginning of book 3, as the narrator declares, 'I shall now narrate this, that he benefited those who strove for noble achievements by making them attentive to the things for which they strove' (3.I.I). This is followed by scenic accounts of his conversations with a young man who wanted to be a general and his spoken reflections on generalship (3.I.I-2.4), and then a preliminary ring composition is completed as the narrator concludes, 'By examining in this way what the excellence of a good leader was, he dismissed all other considerations and left behind only the creation of happiness for those whom he led' (3.2.4).

\section{Frequency}

Whatever their relationship to subsequent chreiai literature, the Socratic works also exhibit a strong affiliation with their Platonic $(\rightarrow)$ counterparts in terms of their creation of the 'iterative world' of Socratic dialectic. Socrates is a model of virtue for Xenophon's narrator, who chooses his anecdotes with care for the lessons they teach. Yet we are continually made aware that these narratives are merely examples of a wider

\footnotetext{
${ }^{9}$ Cf. e.g. also r.6.I; 2.7.I; 3.3.I.
} 
practice. Even the narrator's opening statement in the Memorabilia, 'I have often wondered ...', sets the tone: reflection on Socrates' life is an ongoing process that can mirror the learning that went on in his presence. This learning takes place because Socrates presents a consistent set of values and argues for them consistently. Iterative presentation can thus be an accurate portrayal of Socrates' because all of Socrates' actions are typical.

Xenophon created a specifically 'iterative' narrative in the Memorabilia, a characteristic that is closely connected with the selectivity examined above, whereby the narrator chooses exemplary Socratic conversations for presentation to a wider public as a didactic and apologetic tool. These effects are created by a combination of markers. The narrator uses the imperfect to express the repeated aspect of Socrates' actions, he characterizes his words or deeds with forms of the demonstratives toioutos and toiosde (which lend a generalizing tone), and he may say that Socrates does something 'often'. Thus in response to charges of atheism, the narrator responds 'he often used to sacrifice openly at home and often at the common altars of the city' (I.I.2). Or following a discussion of the imprisonment of madmen and the treatment of parents, we hear 'because of such things as this, he often used to think about how ignorance differs from madness' (1.2.50). The opening narration of his encounter with Hippias the sophist is significant. This episode follows examples of his obedience to and respect for the laws:

He often used to speak like this to others, and I know that he once [pote] had a conversation with Hippias of Elis also concerning justice along the following lines [toiade]. When Hippias arrived in Athens after a long absence he was present when Socrates was saying to some people that it was amazing: if one wished to have someone taught to be a cobbler, one would not be at a loss where to send him to get this ... but if one should wish to learn justice oneself or to have it taught to one's son or servant, one does not know where to go to obtain this. When Hippias heard this he said, as if mocking him, 'Are you still saying those same things, Socrates, which I once heard from you a long time ago?' And Socrates said, 'And what is more strange than this, Hippias, I not only always say the same things, but on the same subjects.'

This passage employs all the markers specified above: the use of the imperfect, of 'often', and of the demonstrative toiade. It also uses pote to introduce an exemplary narrative, a technique with which we are familiar from Pindar $(\rightarrow)$ and others. Even more important, it addresses in its content the issue at hand: Socrates says the same things on the same subject. This continues even over a period of years, and the 
imminence of his own death changes nothing. This congruence of formal features and content is familiar from Plato $(\rightarrow)$ although less developed.

It is beyond the scope of this study to review all the means by which Xenophon articulates his Socratic anecdotes. Besides the formula mentioned earlier ('he often used to ...'), we may note the repeated use, either alone or in combination, of past general conditions (3.9.12, I3: 'if someone said X, he said Y'; cf. 3.I4.I), genitive absolutes (3.I3.I-6; 4.2.3), and formulae such as 'and once' (kailde pote, 2.3.I, 5.I; 3.3.2), 'again once' (palin pote, I.6.II, I5), evoking impressions of both regularity and a certain temporal indeterminacy. Even phrases introducing speech like 'like this, more or less' (hōde pōs, 2.I.2I; 4.6.2, I4; cf. 2.I.34) that speak for honesty of a narrator who does not claim to be able to reproduce Socrates' words precisely, also indicate perhaps that precise words are not important. It is the method and effect that matter. Paradoxically then, the episodic nature of the Memorabilia is no barrier to benefiting from it and acquiring a detailed acquaintance with Socrates' wisdom because of Socrates' consistency. He always says the same kind of thing in the same kind of way ('more or less like this'). Indeed, we are told that the very recollection of him when absent was a benefit (4.I.I), and this is of course a gloss on the object of the work as a whole.

\section{Conclusion}

Analysis of Xenophon's narrative art has become increasingly sophisticated in the last decades. We now have a much greater appreciation for the way he constructs didactic narrative. Many of Stadter's acute observations on the Cyropaedia might also be applied to Xenophon's Socratic works: the use of narrative for moral instruction, the creation of a narrative of virtue that teaches the narratee how to relate to others, the creation of a chronotope of 'biographical time', the generalization of time and space that features timeless repetition of action, and finally the complex interrelationship that is implied between the narratee's (and in the case of the Socratic works, the narrator's) awareness of his or her own present and the world of Socrates. ${ }^{10}$ The exemplary conversations

10 For the Cyropaedia as didactic narrative see Stadter I991: 464-468; on the construction of time see $472-477,49$ I. 
investigated in this chapter are not, of course, as unified a narrative as the Cyropaedia, but they do suggest Xenophon's broad interest in constructing experimental narratives that combine features of several genres: sōkratikoi logoi, instructional literature, the biographical or anecdotal 'pamphlet', and history. 
PART SEVEN

BIOGRAPHY 
Irene J.F. de Jong and René Nünlist - 978-90-47-42293-8 Downloaded from Brill.come4/26/2023 09:46:52AM via free access 


\section{GHAPTER TWENTY-FOUR}

\section{XENOPHON}

\section{BEGK}

The Cyropaedia is a novelistic treatment of Cyrus the Great's life with the express didactic purpose of imparting to its readers an appreciation of the elements of effective leadership. ${ }^{1}$ A comprehension of Xenophon's purpose is essential to understanding his use of time, since many of the most didactic parts of the book are relatively long sections of dialogue interspersed with brief narrative passages. ${ }^{2}$ The question that the Cyropaedia poses is a simple one: what in Cyrus' birth (genea), natural ability (phusis), and education (paideia) enabled him to found and maintain such a large empire, uniting such a wide variety of peoples, over such an immense geographic extent? The fictionalized biographical form adopted by Xenophon presents the growth and maturation of Cyrus' leadership skills as the natural outcome of a longterm educational, interactive, and interpersonal developmental process. Xenophon's portrayal of Cyrus' development into a charismatic individual can only unfold over time and in contact with others.

There are four discernable 'phases of temporal movement' in the Cyropaedia, which present the story of Cyrus' life from birth (I.2.I) to death (8.7). ${ }^{3}$ The first period, which narrates the education and development of Cyrus, is coextensive with book I. The other three phases, which occupy books 2-8, expose the narratee to a mature Cyrus who effectively copes with all manner of situations as they arise. They correspond to Cyrus' conquest of Assyria (Babylon; 2.I.I-7.5.36), the

\footnotetext{
${ }^{1}$ I have consulted the OCT edited by E.G. Marchant (I9Io) and W. Gemoll's Teubner edition (I9I2). I cite the Greek text according to Walter Miller's, whose Loeb edition (I9I4) and translations I have also used. Philip Stadter's article (I99I) brilliantly addresses many of the issues dealt with in this chapter and was of inestimable value to me. The reader is urged to consult it for further enlightenment on many subjects I could only briefly refer to here.

${ }^{2}$ Cf. Gera 1993 on the use of dialogue in the Cyropaedia.

${ }^{3}$ On this and the following see Stadter 1991: $474-477$. For a sweeping inclusive definition of biography see Momigliano I993: II.
} 
first year of his reign as king of Babylon (7.5.37-8.6.19), and his death in old age (8.7). Our analysis of the narrator's use of time will proceed along these outlined phases.

\section{Phase I: Cyrus' education and development}

This temporal phase warrants a detailed analysis since it represents the most sophisticated part of the work vis-à-vis time. The prologue (I.I.I6) sets forth the topics of leadership and obedience oscillating from the human world in which men seek, for the most part unsuccessfully, to establish and maintain dominance over other men, to the analogous realm of mankind's successful domestication of animals, before returning to the human sphere with the success story of Cyrus. Temporally the narrator begins at an indefinite period in his own lifetime when he first reflected on the historical vicissitudes of various forms of government (democracy, monarchy, oligarchy) in response to popular upheavals. The sustained durative nature of the narrator's reflections and observations is underlined by the use of the imperfect tense (edokoumen, enenooumen, enethumoumetha, egignōskometha, etc.), while the omnitemporal or iterative character of recurring or habitual behaviors in the animal and human realms is presented generally with the present tense and the iterative subjunctive with the particle an. The realization (enenoesamen) that Cyrus proved capable of mastering this seemingly impossible task disrupts the narrator's pessimistic reverie and compels a change of opinion on his part. His knowledge (ismen) appears to approach certitude as he summarizes the widespread and unquestioned obedience Cyrus' rule occasioned among numerous subjugated peoples, in contrast with that of other kings who strive only to maintain power over their respective subjects. We are thus given a proleptic glimpse of Cyrus' eventual greatness in adulthood before the narrative begins with his childhood and youth. ${ }^{4} \mathrm{~A}$ man capable of such effective leadership over such far-flung territories warrants study, we are informed, and this narrative promises to present the results of the narrator's investigation into the natural endowments and educational background of Cyrus.

\footnotetext{
${ }^{4}$ This type of rhetorical magnification of the subject (auxesis, amplificatio) is typical in the prologues of ancient historical works. Cf. Marincola i997: 34-43.
} 
The narrative proper commences with the usual biographical topos of genos: Cyrus' parents are Cambyses and Mandane (I.2.I). The narrator elects not to present childhood anecdotes, including the prophecy, attempted exposure, discovery, and assumption of the throne, as reported by Herodotus (I.IO7-I30), which, though apocryphal, would conduce to his expressed aim of presenting Cyrus' phusis. Instead he describes Cyrus' advantages in typical Xenophontic style with a string of superlatives (eidos men kallistos, psukhēn de philanthrōpotatos kai philomathestatos kai philotimotatos) representing characteristics that render him personally appealing, intellectually superior, and capable of enduring toil and danger. The alleged sources of this information are stories and songs related even today, a reference to the narrator's own time. This cursory description of Cyrus' physical and intellectual endowments is abruptly followed by an omnitemporal discussion of Persian education (I.2.2-I6), reminiscent of Herodotus' (I.I3 $\left.{ }^{-}{ }^{-I} 40\right)$ and Plato's (Alc. I I20e-123e), which in turn sets up many of the themes developed in Cyrus' interaction with his grandfather Astyages. As we are informed later (I.3.I), this was 'the education that Cyrus received until he was twelve or a little older'. We are thus encouraged to read this omnitemporal account in retrospect as a narrative of Cyrus' own education. One section of this narrative (I.2.I5) briefly supplements information about the Persian constitution regarding access to education and offices that he refrained from mentioning earlier (internal completing analepsis). The final section of this omnitemporal narrative is then located in the narrator's own time as he discusses some of the residual signs (marturia) of this training evidenced in contemporary Persian customs regulating the public display of certain bodily functions (I.2.I6). ${ }^{5}$ The

5 The Cyropaedia contains frequent references to the narrator's own time that usually provide contemporary supporting evidence for time-honored customs. Cf. e.g. I.3.2 (Persian dress and frugal lifestyle); I.3.9 (procedures associated with the royal office of wine pourer); 4.2.8 (Hyrcanians even to this day hold positions of trust and authority); 4.3.2 (custom of conveying wives and concubines to the battlefield); 6.I.27 (Cyrus abolished the method of managing a chariot still employed today among the Cyrenaeans); 7.I.45 (descendants of Egyptians continue to dwell in the interior of Asia Minor to this day); 7.I.47 (the scythe-bearing chariots still in use today by successive Persian kings); 7.3.15 (the monument of the eunuchs who committed suicide over the bodies of Abradatas and Penthea is still standing); 7.5.70 (same type of guard instituted by Cyrus maintained over Babylon even today); 8.I.6 (as instituted under Cyrus, nobility still are in constant attendance at court); 8.I.7 and 24 (institutions inaugurated by Cyrus still maintained today); 8.3.9 (Persians stand where king will pass just as they do today); 8.3.13 (tradition of wearing a filet around the tiara retained even now); 8.3.34 (the procession of the king, as instituted by Cyrus, continues to be conducted in the present); 8.4.5 
narrative's return to Cyrus' deeds beginning with those of childhood (praxeis, arxamenoi apo paidos) is then signaled (I.2.16).

In the following section (I.3.I-4.3) the narrator elects to recount Cyrus' childhood from approximately his twelfth year and to reprise only some of the specifics of his training up to this age with completing internal analeptic references presented in part by Cyrus (actorial analepsis) discussing his own past educational experiences in Persia (I.3.I5-I7) and later by the primary narrator (I.4.3). An ellipsis of this magnitude in true ancient biography is quite common, owing often to the lack of information on the early childhood experiences of wellknown individuals. ${ }^{6}$ The presence of this ellipsis here in a largely fictional account indicates authorial intent, however. ${ }^{7}$ It is evident that this section will serve to highlight his natural charm and aptitude as well as the benefits he has derived from his Persian education and the Median training he now receives.

His encounter with his grandfather, the Median king Astyages, is presented in long scenic passages of direct speech that are interspersed with brief narrative ones. The purpose of this detailed encounter is to stress the difference between the Medes and Persians in regard to frugality and temperance of lifestyle (sōphrosune $\vec{e}$, a contrast that is explicitly made (I.3.2), including a reference (nun eti) to the narrator's own time period. We see through Cyrus' eyes the external trappings of Median royalty adorning his grandfather's person. The poverty of the Persians vis-à-vis the Medes is brought out indirectly inter alia by a reference to Cyrus' delight at having the chance to learn to ride horses, something that he cannot do among the Persians, where the horse is a rare animal because of the mountainous terrain (1.3.3). In a long exchange between himself and his grandfather Cyrus critiques luxurious Median dining and drinking practices (I.3.4-I I).

\footnotetext{
(custom of seating in accordance with honor introduced in time of Cyrus continues to present day); 8.5.28 (the wonderful beauty of Cyrus' wife, the daughter of Cyaxares, is still a topic today); 8.6.5 (the satrapies Cyrus established continue in the possession of the descendants of those who received them even to this day); 8.6.9 (Cyrus' organization of garrisons upon the citadels persists in present day); 8.6.16 (yearly visitation of the provinces still done); 8.8.I-27 (long postscript on the present degenerate state of the Persians). Cf. Stadter 1991: 472 n. i9 and $S A G \mathcal{N}$ г:392-394.

${ }^{6}$ Cf. Pelling I988 = 2002a: $283-300$ and I990a $=2002 \mathrm{a}: 30 \mathrm{I}-338$.

${ }^{7}$ Xenophon does not choose to exploit the story of Cyrus' childhood and his violent seizure of power as portrayed in Herodotus' Histories (I.IO7-I30) since in his fictional portrait Cyrus does no wrong to friends and family nor is he wronged by them.
} 
The interweaving or blending of the iterative and singulative modes is very interesting in these passages, rendering it difficult to gauge the amount of time elapsed. The primary narrator abruptly blends a series of iterative references in the encounter scene with Astyages with the singulative mode. After Cyrus kisses him in greeting, the primary narrator recounts his habitual treatment of Cyrus, employing imperfect tenses (I.3.3). This is continued to the next episode, which initially describes Astyages repeatedly entertaining his grandson with lavish dinners before proceeding to the account of one of their exchanges at a dinner (I.3.4). The dialogue allows the primary narrator the opportunity of giving a dramatic condensed version of Cyrus' impressions. Previous dining experiences, including his encounters with Sakas, are alluded to in actorial completing analepses (I.3.IO-II). There is one proleptic threat, wherein Cyrus promises to displace Sakas as his grandfather's cup bearer (I.3.9). This threat is later never realized, however, as Cyrus wins over Sakas too with his charm (I.4.5). That this vignette showcases in an exemplary way Cyrus' charming personality is attested in the summarizing iterative statement at the beginning of the section:

Such amusement he furnished them at dinner; and during the day, if he saw that his grandfather or his uncle needed anything, it was difficult for any one else to get ahead of him in supplying the need; for Cyrus was most happy to do them any service that he could.

(I.3.12)

As the time for Mandane's departure approaches, Astyages attempts to persuade Cyrus to stay with him by outlining future benefits and activities he would enjoy if he should stay with him (actorial prolepsis). The issue of the completeness of his training in justice (dikaiosune $\overrightarrow{\text { ) }}$, a concern voiced by his mother Mandane, is dealt with by Cyrus in an actorial completing internal analeptic anecdote recounting an episode in his Persian education (I.3.I6-I7). The beginning of the next chapter indicates that this dialogue with his mother was just part of their total exchange on the subject of Cyrus staying with his grandfather Astyages (I.4.I). ${ }^{8}$ Throughout Cyrus' encounters with his grandfather and mother the narratee is exposed to a 'sustained test of wills' as the young Cyrus repeatedly resists them and yet in the end obtains his desires, while retaining their love and affection. ${ }^{9}$

8 'In this way Cyrus often chattered on. At last, however, his mother went away, but Cyrus remained behind and grew up in Media.' Cyrus' talkativeness is alluded to later on in an actorial analepsis (I.4.12).

9 Tatum I989: 97. 
In a summarizing iterative section (I.4.I-6) many events are related encompassing Cyrus' personality transformation and gradual attainment of maturity in the context of his interpersonal relations with his peers, their fathers, and other older males, including the first tests of his abilities in horsemanship and hunting (I.4.4-5). The iterative mode is then given up for a singulative presentation of Cyrus' first real hunt in the wild (as opposed to the animals in the game park), in which he chases and brings down a deer, despite almost being thrown from his horse, and slay a boar (no definite temporal marker; I.4.7-8). This scene concludes with a brief dialogue between Cyaxares and Cyrus (I.4.9).

The narrative continues with several dialogue scenes between Cyrus, Astyages, and other boys, who encourage Cyrus to approach Astyages on their behalf, which he does (I.4.IO-I3). Cyrus, after an indefinite period of dejection, finally persuades Astyages to let him and the other boys hunt free roving game (I.4.I4-I5). The narrative of the hunt scene serves to reveal Cyrus' qualities in a competitive arena. This leads into an abrupt acceleration through several years of time ${ }^{10}$ and resumption of the narrative when Cyrus is fifteen or sixteen years old (I.4.I5-I6).

Cyrus' encounter with the son of the Assyrian king, his first military engagement, is the subject of this next section, narrated in the singulative mode (I.4.I6-24). In a dialogue between Astyages and Cyrus we glimpse the budding strategic ability of the future conqueror (I.4.I9). His tactical skills are as yet insufficiently developed: Cyrus is compared to a well-bred but untrained hound (kuōn gennaios apeiros) who rushes recklessly upon a boar (I.4.2I; cf. I.4.I5). Cyrus' intense passion for battle is clearly and grotesquely put on display as he rides around gloating over the slain (I.4.24). Cyrus then departs from Media and returns to Persia (I.4.25). A concluding scenic dialogue between Cyrus and an unknown Mede struck by his beauty serves to demonstrate his sōphrosune (I.4.26-27).

Cyrus, now back in Persia (no details of his journey are mentioned), ${ }^{11}$ resumes his education, beginning with one more year in the class of boys (I.5.I). This as well as his entry into the class of youths (ephēbes) is very briefly recounted in accelerated narrative tempo.

10 This is expressed in a brief iterative summarizing statement: 'Thus Cyrus passed most of his time, contriving some pleasure and good for all, but responsible for nothing unpleasant to any one'.

11 This represents a considerable ellipsis. 
The narrator then reports the ahistorical accession of Cyaxares to the throne upon Astyages' death, which leads into a discussion of the Assyrian king's intentions to obtain power over the Medes and Cyaxares' response to this threat (I.5.2-6). Cyaxares, who gets wind of this plot, enlists the support of the Persians and in particular the leadership skills of Cyrus, who has now (another considerable ellipsis), as we are informed, 'completed his ten years among the youths (ephēbes) also and was now in the class of mature men' (1.5.4). Cyrus accepts the invitation and appears before his army to address them in a speech to his troops in which he stresses inter alia the preparatory value of education (including knowledge of the gods) for the upcoming confrontation (I.5.7-I4). After a brief transition Cyrus enters into a long conversation with his father that presents the secrets of good generalship (I.6.I-46). Perhaps the most important didactic section of the work, this dialogue contains numerous internal actorial completing analeptic references to Cyrus' prior training in the form of reminiscences (I.6.3, $5^{-8}$, I2- ${ }^{-} 5,20$, $23,28-29$ ) and an external actorial analepsis referring to an obsolete form of training administered in the time of Cyrus' forefathers (I.6.3 ${ }^{\mathrm{I}}-$ 32). ${ }^{12}$ Both Cyrus and his father function as secondary narrators in this dialogue when recounting these past events. Some of the analeptic references reflect that the same statements were made on more than one occasion in the past, that is, the iterative mode is indicated (oida se legonta aei, r.6.6). Cyrus predictably puts into action much of his father's advice in the subsequent books.

\section{Phase II: Cyrus the conqueror}

In this long section of the work, representing the second temporal phase of Cyrus' life, the narrator artfully intermingles scenic passages with singulative and iterative narrative passages (2.I.I-7.5.36). A reading of the first few sections of book 2 nicely illustrates this technique. After a brief transitional paragraph describing Cyrus' crossing of the Persian frontier and his entry into Media, the narrator again resorts to scenic presentation of a dialogue to present the fundamentals of the military situation, with the interlocutors now being Cyrus and Cyaxares (2.I.I9). Another brief narrative transition introduces speeches Cyrus deliv-

${ }^{12}$ Cf. also I.6.45-46, which is a general external analepsis presenting the 'lessons of history'. 
ers successively to the Persian peers (hoi homotimoi) and to the soldiers with some audience response (2.I.II-I8). The following section of the work outlines the measures adopted by Cyrus to reorganize, equip, and train his army for battle prior to the arrival of the enemy, without the passage of time being clearly chronicled (2.I.20-3I). The iterative mode abounds as his continuous efforts are narrated in detail. The narrator again makes brief reference initially, in the iterative mode, to Cyrus' habitual practice of providing entertaining conversation at dinner (2.2.I), prior to presenting, in the singulative mode, an illustrative example of this practice (2.2.I-3I). Occasionally past events are referred to analeptically, as when, for example, Hystaspas, as a secondary narrator, recounts, in his conversation with Cyrus, what happened at dinner the day before yesterday (2.2.2-5; actorial completing analepsis). The summarizing iterative statement which concludes this dinner conversation reveals its incompleteness: 'Things of this sort, both grave (spoudaia) and gay (geloia), were said and done at the dinner party' (2.3.I).

Many of the somewhat longer narrative passages present details of military affairs (e.g. battle with Assyrians, 3.3.57-4.I.I). ${ }^{13}$ Unlike Xenophon's $(\rightarrow)$ Anabasis or Hellenica, which orient the narratee with frequent geographical and temporal references, the narrator in the Cyropaedia eschews precise temporal references and holds geographic references to a minimum. The sporadic and vague nature of the temporal references thus conveys the passage of time but does not permit an exact tally of days or years. ${ }^{14}$ The impression thus conveyed to the narratees is one of

13 Cf. also 6.2.4-I3 (preparations for battle with Croesus); 6.3.I-9 (final day's march prior to engaging with Croesus' forces); 7.I.I-6 (description of pre-battle activities and equipment); 7.I.23-28 and 30-4I (narrative of battle with Croesus' forces); 7.4.13-5.6 (Cyrus departs from Sardis and marches to Babylon, subduing territories on the way, and, upon his arrival, arrays his forces before Babylon); 7.5.IO-I9 (siege operations before Babylon); 7.5.26-36 (capture of Babylon).

14 For example, 2.3.I ('on the next day'); 3.3.I ('on the following day'); 3.3.5 ('that night $\ldots$ on the next day'); $3 \cdot 3.29$ ('on the following day'); 3.3 .34 ('early on the following day'); 4.2.28 ('when daylight came'); 4.2.29 ('as it was summer'); 4.4.I ('when it was just past midday'); 4.4 .9 ('when it was day'); 4.5.I4 ('at daybreak'); 5.2.I ('early the next morning'); 5.2 .2 ('toward evening of the second day'); 5.2 .22 ('when day dawned'); 5.3.I ('they arrived on the fourth day'); $5 \cdot 3.28$ (six or seven days predicted by Gadatas for march); 5.3 .52 ('at midnight the signal horn sounded'); 5.3 .57 ('they proceeded all night long'); 5.5 .5 ('on the following day'); 6.I.I ('after spending that day in the manner described'); 6.2.25 ('more than fifteen days' journey'); 6.3.I ('on the first day'); 6.4.I ('early on the following day'); 6.I.I4 ('for winter is coming, you know') 7.2.2 ('when daylight came'); 7.3.I ('on the following day'); 7.4.4 ('that night ... at daybreak'); 7.5.33 ('when day dawned'). Cf. Stadter I991: 475. 
a series of episodes with intervening indefinite segments of time being either completely suppressed (ellipsis) or vaguely hinted at (summary). This episodic style with frequent use of ellipsis allows the narrator to maintain his focus on Cyrus unimpeded by other extraneous and distracting circumstances. The use of dialogue adds considerable dramatic quality to the work, as frequent scenic passages present Cyrus and others interacting with various individuals and groups. ${ }^{15}$

In general a chronological progression from one scene to another is consistently maintained. There are some notable deviations from this pattern, however. Gobyras, as a secondary narrator, for example, directs the attention of the narratees to past events as he recounts analeptically ${ }^{16}$ the murder of his only son at the hands of the Assyrian prince who has now assumed the throne at his father's demise (4.6.27). ${ }^{17}$ Croesus' account (as secondary narrator) of his past misfortunes represents a similar analepsis (7.2.17-24). This encounter with Croesus concludes with a proleptic iterative statement: 'At hearing these words Cyrus wondered at his good spirits, and after that he always used to take Croesus with him wherever he went ...' (7.2.29). In general, however, the use of the iterative mode is held to a minimum (e.g. 6.I.2324; 7.I.I, I.IO-I4, 4.I5). In the wake of the battle with Croesus, the narrator presents a brief analeptic analysis of the battle, in which he evaluates the merits of the enemy forces and Cyrus' army (7.I.46-49). Occasionally two events are presented as occurring simultaneously. For example, the presentation of the long parting scene between Abradatas and his wife Panthea, framed between references to Cyrus performing sacrifices and finding the omens from his sacrifice favorable prior to his final battle, has the effect of adding an almost holy quality to what the narratees are led to suspect will be the couple's final parting (6.4.I-I2). ${ }^{18}$

15 Bal [1985] I997: 60: 'The more dialogue a narrative text contains, the more dramatic that text is'.

16 This is an internal actorial completing analepsis, since Gobryas' daughter is portrayed as still in mourning for her dead brother $(5 \cdot 2.7)$.

17 On secondary narrators in the Cyropaedia see $S A G \mathcal{N}$ i:399-400.

18 The narratee's expectations are not disappointed (cf. 7.I.29-32 and 7.3.2-I6). The simultaneity of these two events is indicated by the way the narrator introduces the parting scene between Abradatas and Panthea, that is, with a reference to Cyrus performing the sacrifices as the rest of the army arms and arrays itself (6.4.I). This is just what Abradatas is doing in this scene, as his wife helps him don his armor (6.4.2-II). This is immediately followed by the narration of Cyrus finding favorable omens and commencing an address to his assembled generals, one of whom must be Abradatas (6.4.12). 
In another type of example of simultaneous activity in the military sphere, the narrator relates that Adusius is sent to Caria with an army while Cyrus stays in Sardis to make siege engines (7.4.I..$^{19}$

\section{Phase III: Cyrus king of Babylon}

In the wake of the war Cyrus' attention gravitates from the administration of Babylon to the administration of his newly conquered empire (7.5.37-8.6.19). Securing his personal safety and leisure and setting an example for others to follow appear to be his paramount concerns. Xenophon relies heavily in this section on the iterative mode to convey Cyrus' habitual behavior in the conduct of his empire $(7 \cdot 5 \cdot 37-40$, 68; 8.I.I6-2I, 23, 34, 37-44; 8.2.I-4, 25-28; 8.3.50; 8.4.2-5, 31; 8.5.3I6; 8.6.I6-I8, 22-23). Summary passages, both singulative and iterative, preponderate over 'scenes' (including direct speech) ${ }^{20}$ for the most part, as the narrator presents Cyrus' reflections, rationale, and behavior which led to the formation and observation of the institutions and customs that he describes (e.g. 7.5.58-7I; 8.I.6-8.2.I3; 8.6.7-IO, I4-23). ${ }^{21}$ The narrator exploits the iterative mode, in particular, as an especially effective means of summarizing long-term patterns of behavior or habitual activities. Prolepsis and analepsis are rare. ${ }^{22}$ We are thus swept through one year of the king's life in a few pages. ${ }^{23}$

\section{Phase IV: The death of Cyrus}

The next temporal phase covers Cyrus' (ahistorical) death of old age in Persia (8.7.I-28). What would be an ellipsis of enormous magnitude is narrowly avoided by an intervening summarizing section of extremely

19 Cf. also 4.2.I (which describes the arrival of messengers of the Hyrcanians while Cyrus is engaged in managing affairs); 5.3.25 (many Assyrians surrender their horses and arms while Cyrus is occupied with arrangements about a fortress).

20 For example, the speeches delivered by Cyrus, Artabazus, and Chrysantas $\left(7 \cdot 5 \cdot 4^{2-}\right.$ $5^{6}$ ) and by Cyrus and Chrysantas (7.5.72-8.I.5), by Cyrus (8.4.32-36; 8.6.3-6, I I-I3), by Cambyses $(8.5 \cdot 22-26)$, dialogues $(8.3 .26-47,4 \cdot 7-27)$.

21 Cf. however Cyrus' (7.5.72-86) and Chrysantas' (8.I.I-5) speeches.

22 Cf. e.g. the internal prolepses at 8.5.2 (narratorial) and 8.6.15 (actorial).

23 The length of the elapsed time period is indicated at 8.6.19 ('when the year had gone around'). Explicit indications of the passage of time are rare (e.g. 8.4.28: 'on the following day'). 
accelerated narrative which presents a brief epitome of the remarkable achievements of Cyrus' military activity immediately prior to this final phase (8.6.20-2I). Most of the general administrative activities involving the king that took place in the intervening years have been alluded to in the previous section, as the institutions and ceremonies that he inaugurates withstand the test of time. This includes such habitual behaviors as his seasonal change of residence (8.6.2 I-22). The positive response of his subjects to his rule over time is also mentioned in a brief iterative section (8.6.23). No specific incidents however are related. Cyrus' imminent death is proleptically indicated to him in a vision: 'Make ready, Cyrus; for thou shalt soon depart to the gods' (8.7.2). His loss of appetite on three successive days signals to him that he must summon his friends and family $\left(8.7 \cdot 4^{-5}\right)$. The rest of the section contains his words of advice to them, in which, as might be expected, he recounts briefly salient events of his life and the disposition of his empire (8.7.6-28). At the close of this final speech he shakes hands with those present and dies.

The final hotly disputed section of the book contains a long and detailed analysis by the narrator of why the enduring legacy that Cyrus strove to fashion was rather quickly derailed by declining moral standards, greed, decline in physical fitness, abandonment of traditional behaviors and discipline, increasing effeminacy, and ineffective military practices $(8.8 . \mathrm{I}-27)$. If this concluding section is authentic, then Xenophon does not seem to want to detract from Cyrus' achievements; in fact he concedes that without the personality of a ruler like Cyrus such achievements are not possible (8.8.I).

\section{Conclusion}

In conclusion, the Cyropaedia relies on a predominantly dramatic presentation of Cyrus. Dialogues and speeches abound. The character and personality of Cyrus is conveyed to us in his interactions with the other main characters in the drama of his life. These same dialogues or conversations often serve analeptically to fill in past events that have been suppressed through ellipsis (e.g. Cyrus' conversation with his mother Mandane regarding his prior training in Persia) or even serve the dual purpose of analeptically reprising past training and proleptically foreshadowing future behavior (e.g. Cyrus' long dialogue with his father Cambyses on military tactics, etc.). 
Several major ellipses occur in the representation of Cyrus' youth (phase I) and are only partially filled in by later analepses. Long scenic passages interrupted by briefer narrative passages are the rule. The longest narrative passages in phase II are generally descriptions of training, troop dispositions and battles. An exact reconstruction of the chronology is rendered impossible because of vague or infrequent temporal references. Ellipses are usually not indicated as the narratee is transported rapidly from one scene to another in an 'unrelenting accumulation of long dialogues'. ${ }^{24}$

In phase III of the work the narrator details Cyrus' year in Babylon spent primarily consolidating his conquests with the establishment of administrative institutions. The use of speeches is more evenly balanced with more frequent use of the iterative narrative mode to convey habitual activities undertaken by Cyrus and his subjects. The narrative pace of this section is generally accelerated vis-à-vis the prior sections as the narrator condenses in one book the events of one year. The intervening time period from the end of his first year in Babylon to his old age (when his parents are long ago deceased) is sketched very briefly. The final retrospective assessment of Cyrus' life, achievements, and thought is fittingly delivered by Cyrus himself on his deathbed in the work's fourth and final temporal phase.

${ }^{24}$ Stadter I99I: 46 I. 
GHAPTER TWENTY-FIVE

\title{
PLUTARCH
}

\author{
M. BEGK
}

\section{The biographer at work}

In the writing of history a selection process is necessarily operative which stresses events deemed 'important', while giving only cursory attention to what is considered insignificant detail. ${ }^{1,2}$ This mindset allows the historian to 'dwell for ten pages on one day and pass over ten years in two lines'. ${ }^{3}$ Among the ancients Plutarch was more aware than most of this selection process and its consequences for the representation of the past. His awareness includes the perception that his is a different form of historical writing - one that comprises and explores preferentially the lived experience of the individual. In the prologue to the Alexander and Caesar he articulates this quintessential distinction between historiography and its genus proximum political biography: ${ }^{4}$

I am not writing history but biography, and the most outstanding exploits do not always have the property of revealing the goodness or badness of the agent; often, in fact, a casual action, the odd phrase, or a jest reveals character better than battles involving the loss of thousands upon thousands of lives, huge troop movements, and whole cites besieged. ${ }^{5}$

(Alex. I.2)

Even though he is chronicling the lives of individuals who distinguished themselves primarily in the politico-military sphere, the supreme province of ancient historiography, his primary concern as a biographer

\footnotetext{
${ }^{1}$ Plutarch's Parallel Lives are cited according to the Teubner edition of Ziegler. All translations unless otherwise indicated follow the Loeb edition of Perrin I9I4-1926.

${ }^{2}$ On the major characteristics of the genre of ancient historiography see Marincola 1997.

${ }^{3}$ Veyne [I97I] I984: I7-I8.

${ }^{4}$ Cf. Geiger I985: 22; Burridge i992; and Burridge 1997.

5 Translation by Waterfield I998.
} 
is the delineation of character that arises from a judicious selection and presentation of material conducive to this aim. ${ }^{6}$ This aspect of Plutarch's methodological approach is of extreme importance for understanding his representation of time in his biographical narratives. The time span for biography comprises an individual's lifetime experiences beginning sequentially at birth and ending with the inevitability of death. ${ }^{7}$ The temporal framework of biography is therefore more circumscribed than that of Herodotus' Histories, for example. Plutarch follows primarily chronological sequence, as is generally the case in ancient historiography. ${ }^{8}$ Chronologically disparate events, however, representative of central themes or characteristics are frequently grouped together in the narrative not unlike Suetonius' per species method of categorization, a technique that exerts a significant influence on the rhythm and temporal structure of the Lives. ${ }^{9}$

Finally it seems apparent that Plutarch composed some of his Lives simultaneously. ${ }^{10}$ The six Lives for which this compositional strategy is evident are those of Pompey, Crassus, Caesar, Cato Minor, Brutus, and Antony. The Cicero and Lucullus appear to belong to an earlier phase of compositional activity. Simultaneous composition, especially since the Lives are regarded as a single collective project by Plutarch, ${ }^{11}$ results in the abbreviation of some overlapping accounts in several Lives. The Conspiracy of Catiline, for example, is narrated at length with great attention to detail in the Cicero (IO-22), while extremely abbreviated accounts are presented in the Crassus (13.3-5), the Cato Minor (22-24.3), and the Caesar (7.5-8).

\footnotetext{
${ }^{6}$ Cf. also Cat.Mi. 7.3; Pomp. 8.6-7; Dem. I1.7; Cim. 2.2; and Nic. I.5 for the emphasis on character portrayal.

7 Momigliano i993: Ir: 'An account of the life of a man from birth to death is what I call biography'. Cf. Geiger 1985: I4-29 and Pelling 2002a: 365-386.

${ }_{8}$ Plutarch regularly displays concern for chronologic accuracy (e.g. Them. 2.5), but chronology is not the most important organizational principle of the Lives; cf. next n.

${ }^{9}$ Moles I988: 9 and Stadter i989: lii: 'Considerations of chronology are secondary to those of character and subject'.

${ }^{10}$ On this see Pelling 2002a: $\mathrm{I}-44$.

11 Cf. Beck 2002: I67.
} 


\section{Narrative slowing down I: the grand scenes}

The significance of Plutarch's compositional methodology is readily apparent in the Alexander and Caesar, a key pair. The main themes include ambition (philotimia) and the control over one's self and others. In a psychologically revealing anecdote that prefigures many of Alexander's most notable traits, Plutarch recounts the breaking of Bucephalas. ${ }^{12}$ This type of narrative slowing down in the service of greater representative significance gives rise to what Françoise Frazier has termed 'grand scenes' (grandes scènes). ${ }^{13}$ In these scenes Plutarch tends to interweave the representational modes of speech and narrative. This particular scene showcases Alexander's resoluteness, acute powers of observation, daring, and courage. Alexander is able to get a far more powerful animal to submit to his control, just as he will subjugate a far greater (and presumably more powerful) empire to make it his own. The implied proleptic significance of the anecdote is alluded to by the final statement placed in the mouth of Philip: 'My boy, seek a kingdom to match you. Macedonia is not large enough to hold you' (Alex. 6.8). ${ }^{14}$ Similarly a well-known anecdote depicting Caesar's involuntary captivity by pirates subtly apprises us of the hidden attributes Sulla previously divined in the Life (Caes. I.8-2.7). Plutarch employs this anecdote to render a psychologically much more complex portrait of Caesar. $\mathrm{He}$ is a deceptive man, capable of disarming humor that cloaks his true feelings and intentions. Alexander's domination of Bucephalas is analogous to Caesar's psychological domination of the pirates. Both of these key anecdotes exemplify Plutarch's use of narrative retardation to showcase traits associated with brilliant leadership ability. ${ }^{15}$

12 Cf. Stadter I996 and Whitmarsh 2002.

13 Frazier i992. Briefer, less dramatic versions of these grand scenes are termed by her 'micro-scenes'. Cf. e.g. the story of Timocleia (Alex. I2).

14 Cf. Stadter i996: 292-294.

15 Other notable grand scenes include, for example, Alex. 30 (Darius and the eunuch); 50-5I (murder of Cleitus); 6o (Alexander and Porus); Caes. 32 (Caesar at the Rubicon); 6I (Caesar at the Lupercalia); 66 (assassination of Caesar); Sol. 27 (meeting with Croesus); Cor. 33 (Valeria and Volumnia); Ant. 77 (the death of Antony and Cleopatra) and 83 (Octavian and Cleopatra); Agis I7 (Chilonis); Brut. 23 (Brutus and Porcia); Aem. 36 (Aemilius on Fortuna); Dem. 29 (death of Demosthenes); Pomp. 78-79 (murder of Pompey); Crass. 3I (death of Crassus); Them. II (council of war prior to Salamis); Cat.Mi. 68-70 (suicide at Utica); Fab. I3 (recognition of Fabius' prudence by Minucius); Pyrrh. 2-3.5 (childhood episode). 


\section{Narrative slowing down II: extensive narration of significant historical events}

In addition to these grand scenes, which rarely exceed two chapters in length, another type of extended narrative slowing down is very prevalent in the Lives. ${ }^{16}$ Usually Plutarch's heroes were at one time or another involved in significant historical events of a political or military nature. Plutarch usually adapts narratives of these events from historical sources such as Herodotus, Thucydides, Theopompus, Ephorus, Timaeus, Polybius, Dionysius of Halicarnassus, Sallust, and Livy by including or emphasizing only those events which are tangential to the actions and character of his protagonist, very often supplementing them with additional information and material he has gleaned from his research (cf. Nic. I.5).

These events which may take up a very large part of the biography may reflect anywhere from only a few months to several years of the subject's life. In the Nicias, for example, this major event is the Sicilian expedition. Of the thirty chapters of the Life this event is treated in chapters $12-30$, or in other words it takes up 63 percent of the biography (story-time, as usual measured in amount of text), but the event itself occupies only approximately two years of Nicias' 57 year lifetime $^{17}$ (fabula-time). The paired Crassus has a correspondingly long narrative of the equally disastrous and brief Parthian expedition (I633). Other examples of this type of narrative slowing down include the account of Themistocles' role in the second Persian War against Xerxes (Them. 7-18) $)^{18}$ and Aristides' involvement in the war against Xerxes' forces (Salamis and Plataea, Arist. 8-2I). ${ }^{19}$ Many more examples of this type could be adduced. ${ }^{20}$ It is important to note that Plutarch varies

16 Occasionally grand scenes are embedded in the extended narrative of historical events. Cf. e.g. Brut. 23 (revealing the relationship between Porcia and Brutus).

17 ca. 470-413 BCE.

18 48o BCE. The story of Themistocles' ostracism and life in the Persian Empire might also be included in this category (Them. 23-3I).

19 His actions at Marathon receive only one chapter (Arist. 5).

${ }^{20}$ Cf. e.g. also Luc. 7-36 (war against Mithridates); Fab. 2-27 (Second Punic War against Hannibal); Cim. 6-I4 (leadership role in allied activities); Cam. I5-30 (repulsion of Gauls under Brennus); Cat.Ma. I2-I4 (war against Antiochus); Lys. 3-2 I (final phase of Peloponnesian War and postwar activities); Sull. I I-24 (Mithridatic War); Cic. Io22 (conspiracy of Catiline); Ages. 6-ig (campaigns in Asia Minor and Greece), 27-35 (Agesilaus versus Epaminondas, including Leuctra and Mantinea), 36-40 (service in Egypt); Pomp. 24-29 (bellum piraticum), 30-42 (war against Mithridates), 59-79 (Civil War, 
the pace and mode of the narrative continuously within these sections as he develops some scenes and employs both singulative and iterative narrative modes. In the Agesilaus, for example, the pace of the narration of his campaign in Greece and Asia Minor (Ages. 6-ig) is slowed down considerably in several long scenes describing encounters between the Spartan king, Lysander, Pharnabazus, and Megabates (Ages. 7-8, I II3), while the habitual problems confronting him in his dealings with Lysander are narrated in the iterative mode. Very often these episodes of narrative slowing down approach the grand scenes in terms of their density and dramatic portraiture.

\section{Narrative acceleration}

Just as Plutarch selects some themes or topics for narrative elaboration (slowing down), he also consciously restricts his narration of some events which he judges to be inconsequential to his main purpose of depicting character and moral attributes. This renders the rhythm of his narrative much faster-paced in some places, especially when compared to more historically oriented sources. His narratives of some of the great battles in his biography of Alexander provide excellent examples of this. For example, the account of the actual battle of Issus is very brief, only one sentence (Alex. 20.8). ${ }^{21}$ Instead he focuses on relatively minor incidents that display inter alia the trust Alexander placed in Philip (Alex. 19.4-9), Alexander's cool response to the amenities of Darius' captured camp (Alex. 20.II-I3), and his treatment of the captured Persian women, a demonstration of his great restraint (Alex. 2 I.I-II). It is not surprising that he transports into this narrative sequence, in the form of an internal prolepsis, the story of Barsine, the widow of Memnon, whom Alexander takes as his mistress and who is 'the only woman he was intimate with prior to his marriage' (Alex. 21.7-9). ${ }^{22}$

Sometimes this narrative acceleration takes the form of ellipsis. ${ }^{23}$ Due to lack of information Plutarch tends to have very abbreviated accounts

including flight and death of Pompey); Per. 25-28.3 (war against the Samians); Ant. 3352 (Parthian expedition); and Brut. 8-53 (the assassination of Caesar and Philippi).

${ }^{21}$ Observed by Stadter 1996: 296-297.

22 The battle of Issus took place in November of 333 BCE, the capture of Damascus, at which time Barsine fell into Parmenio's hands, occurred in December of that year.

${ }^{23}$ Genette [1972] I980: 43: ' $\ldots$ ellipsis or leap forward without any return is, obviously, not an anachrony but a simple acceleration of the narrative ....' 
of his subjects' childhood and youth. In some cases he provides no real information at all. In the Crassus, for example, we first hear a report about his father Publius Licinius Crassus, who was accused of corrupting a Vestal virgin out of avarice (Crass. I). The theme of avarice is then continued proleptically in the account of Crassus' acquisitiveness in adulthood and the questionable ways in which he accumulated his enormous fortune (Crass. 2). This section, which contains some rough temporal indicators, is followed by a chronologically indefinite passage in the iterative mode that relates his habitual behaviors and pursuits of adulthood (Crass. 3). When Plutarch then returns to a chronologically dateable event, the seizure of power by Cinna and Marius in $87 \mathrm{BCE}$, we encounter a Crassus who is now nearly twenty years old (Crass. 4.I). In other words, Plutarch has ushered us through nearly two decades of his subject's lifetime in three chapters without having told us really anything that Crassus said or did before the age of nineteen. Such cursory or lacunate treatments of childhood and youth in which the narrator accelerates through the first third or half of his subject's life abound in the Lives. ${ }^{24}$

Later on in the Life, when narrating the events of Crassus' and Pompey's joint consulship, Plutarch is compelled to admit that 'their contentiousness rendered their consulship barren politically and without achievement', thereby absolving himself of the need to narrate at length the events of the year 7o BCE (Crass. I2.3). From Crassus' consulship Plutarch immediately turns to the censorship (an implicit ellipsis of four years), which he 'discards' with an explicit ellipsis: it 'passed without any results or achievements whatever' (Crass. I3.I). Another implicit ellipsis of one year brings us to the eventful narrative of the Conspiracy of Catiline (63-62 BCE: Crass. I3.3). The next event mentioned, Caesar's return to Rome to canvass for the consulship, occurs in 6o BCE (Crass. I4.I). This technique of hastening through uneventful periods of his subjects' lives by mentioning only notable offices or a few major acts, while silently skipping over years at a time, is a very common one in the biographies and lends them their episodic quality. ${ }^{25}$

${ }^{24}$ Cf. e.g. the Lives of Solon, Publicola, Lycurgus, Numa, Camillus, Aristides, Cato the Elder, Cimon, Lucullus, Fabius Maximus, Nicias, Coriolanus, Lysander, Sulla, Agesilaus, Pompey, Pelopidas, Marcellus, Dion, Timoleon, Aemilius Paulus, Sertorius, Eumenes, Phocion, Demetrius, Antony, Marius, Agis, Cleomenes, Tiberius and Gaius Gracchus, Philopoemen, and Flamininus.

25 Cf. e.g. Moles i988: 33 on this technique in the Cicero. 
Plutarch also avoids including any long speeches that are so much of part of ancient historiography. This results in a much faster paced narrative style. In a groundbreaking study of Plutarch's literary technique in the Coriolanus Donald Russell ${ }^{26}$ was clearly able to show the modifications the biographer made to his primary source's account, Dionysius of Halicarnassus' Roman Antiquities. Whereas Dionysius revels in the presentation of long and detailed speeches, Plutarch's corresponding narrative proceeds at a much faster pace primarily by omitting the speeches altogether. ${ }^{27}$ As we would expect, Plutarch's characterization of Coriolanus is deepened vis-à-vis Dionysius' portrait (8.6I-62), especially in its emphasis of the dominating passions (pathe $\vec{e}$ of philotimia and $\operatorname{org} \bar{e} .^{28}$

Sometimes Plutarch conflates similar events in the narrative to avoid tedium or to focus more strongly on the main protagonist's actions. ${ }^{29}$ In the Caesar, for example, he does not distinguish between the three final senatorial debates on the fate of Catiline's co-conspirators (Caes. 7.7). In the Cicero and Crassus he indicates his awareness that there were in fact three separate debates on December 3 rd, $4^{\text {th }}$, and $5^{\text {th }}{ }^{30}$

\section{Foreshadowing}

Plutarch often inserts in the proems or early sections of the Lives instances of foreshadowing. The Alexander provides some excellent examples of this technique. ${ }^{31}$ Plutarch's narrative begins with an account of the strange story of Olympias' and Philip's courtship, an example of an external analepsis that contains several instances of foreshadowing which presage future greatness and precede and accompany his birth (Alex. 2.2-3.9). One story recounts the cohabitation of Olympias with a great snake, seen stretched out beside her body as she slept (Alex. 2.6). In response to Philip's query the Delphic oracle informed the king that he needed to honor Ammon with more sacrifices than any other god

\footnotetext{
26 Russell i963: 21-28 = i995: 357-372. Cf. also Duff i999: 205-240.

27 This type of narrative abridgement or compression as it occurs in the Crassus, Pompey, Caesar, Cato Minor, Brutus and Antony is discussed in great detail by Pelling 2002a: 9I-II5.

28 Russell [i963] i995: 369-370.

29 Cf. Pelling 2002a: 9I-92.

30 Cf. Cic. I9. I-4 and 20.4-21.5; and Crass. I3.3.

31 Cf. Stadter I996 and Whitmarsh 2002.
} 
and that he would lose the eye he had used to peer through the chink in the door to glimpse the god in the form of a snake sleeping with Olympias (Alex. 3.I-2). Philip later did in fact lose his eye at Methone in 354 BCE. ${ }^{2}$

The destruction of the temple of Artemis at Ephesus in a conflagration, as it coincides with the birth of Alexander, elicits another foreshadowing (Alex. 3.6-7). This time some magi who happen to be in Ephesus run about the city striking their faces and shrieking that a great ruin and disaster had been born unto Asia on that day. This chapter concludes with Philip's receipt of the news of his son's birth, which fortuitously coincides with three victories, the defeat of the Illyrians by Parmenio, the capture of Potidaea, and his victory at the Olympic Games in a horse race (Alex. 3.8-9). His delight was only increased when he heard the seers proclaim that his son, born under such circumstances, would be invincible (anikêton), as Alexander in fact later proves to be. ${ }^{33}$ Numerous other Lives exhibit this structural feature to some degree. ${ }^{34}$

Very often Plutarch incorporates early in the Life information drawn from a chronologically later period to explain or illuminate physical appearance, education, and other attributes that become fully manifest in adulthood. The Pericles incorporates citations of comic poets to describe humorously the physical anomaly of the mature Pericles' elongated head shape (Per. 3.3-7). ${ }^{35}$ The account of Pericles' education contains numerous such chronologic dislocations (Per. 4-6). Plutarch first discusses his early education with Damon in music (Per. 4.I-4). Thereafter we learn about Zeno the Eleatic and Anaxagoras, who fall into Pericles' young adulthood and maturity (Per. 4.5-6). The earliest of these teachers, Anaxagoras, arrived in Athens during the mid or late 470 s when Pericles (born ca. 495 BCE) was about twenty years of age, Zeno's arrival on the scene in Athens is dated to ca. 450, and Damon's

\footnotetext{
32 An event not recounted by Plutarch. Cf. Alex. 26.II-27.II, 50.II, for allusions to Alexander's divine paternity.

33 Alexander's future conquests are also portended in his encounter with the Persian envoys and his despondency at his father's achievements (Alex. 5.I-6), and in the Bucephalas anecdote (Alex. 6).

${ }^{34}$ Cf. e.g. Cat.Mi. ${ }^{-}$3; Caes. I.4; Alc. I-I6; Cic. 2; Per. I-2 (building program); Pomp. $2.5^{- \text {IO }}$.

35 The descriptions of Alcibiades (Alc. I.3-8), Alexander (Alex. 4.I-4) and Pompey (Pomp. 2.I-4) fall into this category.
} 
association with Pericles occurs in the 440 and $430{ }^{36}{ }^{36}$ The long anecdote (Per. 6) illustrating the benefits Pericles derived from Anaxagoras' instruction recounts events that took place sometime shortly before Thucydides son of Melesias' ostracism (ca. 443 or $436 / 437 \mathrm{BCE}$ ), that is, when Pericles was in his early 5 os (or around 6o if we accept Krentz's alternate date). ${ }^{37}$ The next chapter of the Life resumes with the narration of Pericles' youth, early military service, prior to his involvement in politics, and his political ascent that is causally related to the death of Aristides (ca. $467 \mathrm{BCE}$ ) and Cimon's removal from Athens due to his foreign campaigns (476-463 BCE, Per. 7.I-5).

The Crassus, as noted above, incorporates information deriving from later periods in the statesman's life and transfers it to the beginning sections in discussing Crassus' avaricious behavior (Crass. 2-3). ${ }^{38}$ Similarly the proem of the Cicero contains two anecdotes referring to the time of his entry into politics and his quaestorship on Sicily (Cic. I.5-6). The prologue of the Aristides begins with a striking statement which cites sources who claim that the statesman was of modest means, during his lifetime, and his daughters after his death (external prolepsis) could not marry for a very long time because of their indigence (Arist. I.I). In the ensuing discussion Plutarch examines the credibility of this assertion in light of the known details of Aristides' adult life. The proem of the Cato Maior launches into a description of the Censor's appearance and behavior that is clearly taken from his adulthood, since it contains references to his military service and oratorical ability. The proem of the Sulla contains an anecdote that refers to a time period after the war with Jugurtha and flashes forward from there to another anecdote concerning a freedman, and former fellow lodger, whom he had executed during the proscriptions, when he 'had at last become absolute in power' (Sull. I). Finally Pompey's restraint in his dealings with women and his modest diet are thematized early in the Life, before the narrative returns to his youth (Pomp. $2 \cdot 5^{-}$I2). ${ }^{39}$

Sometimes Plutarch openly acknowledges chronologic displacements. For example, he concludes his discussion of the Younger Cato's divorce

\footnotetext{
${ }^{36}$ Cf. Stadter I989: 68-69, ad loc.

37 On the probable date see Stadter I989: I3I-I32 and I83-I84 (citing Krentz I984).

38 The return to a more chronologically oriented narrative is signaled by alla tauta men husteron.

39 Plutarch signals at the end of this chapter that he will expand on these things later: tauta men oun husteron (Pomp. 2.12). The next chapter indicates the approximate chronology by identifying Pompey as 'still being a meirakion' (Pomp. 3.I).
} 
of Marcia, in a section devoted to Cato's relationship with women, with the remark: 'This incident occurred at a later time, it is true, but since I had taken up the topic of the women of Cato's household I decided to anticipate it' (Cat.Mi. 25.II-I3). ${ }^{40}$ Sometimes he simply flashes forward to complete a topic, as in the narration of Agesilaus' future aid to the exiled Megabates (Ages. 13.3-4). Both of these examples as well as the example of Barsine in the Alexander cited above display Plutarch's tendency to bring related information together thematically, even if this disrupts the chronological framework of the Life.

He also does not hesitate to employ external prolepses. At the end of some Lives, for example, Plutarch traces the fate of the subject's descendants (e.g. Cat.Mi. 73; Cat.Ma. 27.7; Ant. 87). The Aristides contains an external prolepsis that recounts how Alexander the Great, many years later when he was King of Asia, rewarded the valor and munificence of the Plataeans (who had voluntarily ceded a portion of their territory to the Athenians so that they might defend Greece on their own soil) by building the walls of Plataea (Arist. Ir.9). In the Cato Maior Plutarch rebukes the Censor's anti-Hellenic remark that 'Rome would lose her empire when she became infected with Greek letters' with the terse observation that 'time has certainly shown the emptiness of this illboding speech of his, for while the city was at the zenith of its empire, she made every form of Greek learning and culture her own' (Cat.Ma. 23.2-3). In the Lycurgus he follows the stability of Lycurgus' laws for five hundred years after the statesman's death until their eventual abrogation during the reign of Agis (Lyc. 29.6-30.2).

\section{Omnitemporal narration of habitual or characterizing behaviors}

When describing the general characteristics of an individual's behavior Plutarch abandons a strictly chronological presentation in favor of iteratively recounting habitual behaviors occurring in various stages of life (childhood, adolescence, adulthood, senescence). The Themistocles, for example, contains long sections of iterative narrative usually composed with the imperfect tense. The section recounting Themistocles' childhood contains several instances of foreshadowing presented iteratively in the context of his early education that serve to adumbrate the

40 Cf. also Cat.Mi. 30.9-3 I.I. 
statesman's future rhetorical ability and pragmatic intelligence (Them. 2.I-7). ${ }^{41}$ The personal qualities of Tiberius and Gaius Gracchus are compared at length in the beginning of their double Life (TG and CG 23). Agesilaus' habitual behavior as king, especially the way he dealt with the Ephors, is discussed at length by Plutarch (Ages. 4.2-5.4). Plutarch, in his account of Pericles' early political successes, frequently discusses in a timeless iterative way his powerful oratorical ability, unflappable nature, and other tactics he employs to consolidate his power (Per. 5.I, $7 \cdot 5^{-8.6}, 9.2-5$, I I.2-I2.3) ${ }^{42}$

\section{Achronic narration}

Plutarch employs another technique in which he strings together various anecdotes without supplying clear temporal indicators. The Alcibiades is one such case in which presumably the relative opaqueness of the chronology in the first half of the Life directly follows from the biographer's desire to accentuate his portrayal of Alcibiades' complex character $(A l c . \mathrm{I}-\mathrm{I} 6) \cdot .^{43}$ In this section of the Life Plutarch oscillates back and forth between anecdotes from Alcibiades' childhood, youth (eti meirakion $\bar{o} n$ ), and adulthood without maintaining the chronological sequence of the events he narrates. The Cato Maior also posed some challenges for Plutarch, which he resolves by selectively grouping his discussion of the statesman's career and private life. In particular it is the Censor's famous sayings which attract his attention due to their characterization potential. These he presents randomly without, in the majority of cases, any temporal reference points, and some, it should be noted, he presents as habitual statements (iterative mode), introducing them with the imperfect elege (Cat.Ma. 8-9). ${ }^{44}$

\footnotetext{
${ }^{41}$ Frost 1980: 65, ad loc. sees Themistocles' later qualities of sunesis and philotimia as being projected back to his youth in this section.

${ }^{42}$ Habitual activities ushered in by powerful statesmen such as Romulus, Lycurgus (Spartan agogge) and Numa also fall under this timeless iterative category.

${ }^{43}$ Cf. Russell [1966] 1995 and Duff 2003.

${ }^{44}$ The exceptions being the reference to King Eumenes' visit to Rome and Scipio's solicitation of aid for exiles from Achaia at the instance of Polybius.
} 


\section{Analepsis}

Several Lives begin with an analeptic account of events leading up to the birth of the protagonist. These events usually add a supernatural quality to the individual's Life and mark him out from among his peers as one destined for greatness. The Alexander, as we have seen, exemplifies this technique. ${ }^{45}$ Several other Lives employ this narrative strategy.

The Theseus begins its account of the protagonist's life with the analeptic story of Pittheus, Aegeus, Aethra, and the oracle (Thes. 3). The Lycurgus traces initially the illustrious doings of the statesman's forebears. The proem of the Aemilius Paulus briefly presents the vicissitudes of the Aemilii, including Lucius Paulus' misfortune at Cannae (Aem. 2). The Cicero traces the origins of the family back to Tullus Attius, 'an illustrious king of the Volscians who waged war upon the Romans with great ability' (Cic. I.2). In the Agis the king's lineage is traced back six generations to Agesilaus, 'who crossed into Asia and became the most powerful Greek of his time' (Agis 3).

The episode of Pompey's dealings with Metellus on Crete, which reflects negatively on Pompey and tarnishes somewhat his triumph over the pirates, analeptically concludes the narrative of the bellum piraticum (Pomp. 29). This is a typical example of the use of an internal completing analepsis to set off for thematic purposes an event from a prior sequence. A notable example of an external heterodiegetic analepsis which serves the same purpose is contained in the Cato Maior. In this Life Plutarch is particularly concerned with Cato's ostensible rejection of Hellenic paideia. In a section of the Life critical of Cato's habit of selling off old and infirm slaves rather than supporting them in their old age after years of service, Plutarch cites several fifth-century Athenian examples of the generous treatment of various animals that were maintained beyond their years of usefulness (Cat.Ma. 5). ${ }^{46}$

Most examples of analepsis are less intrusive than this however. Usually analepses serve to introduce past events that have been suppressed (paralipsis) into a context later in the narrative which enhances their significance. We are encouraged to assess in a different light Agesilaus'

45 Cf. Stadter i996 and Whitmarsh 2002.

46 On this section of the Cato Maior see Beck 2000: 20-25. Plutarch explicitly assails Cato's anti-Hellenic stance later in the Life (Cat.Ma. 23.2-3). 
desire to gratify his son's wishes in the Sphodrias affair when we learn that he was exceedingly fond of children and used to join in his childrens' play when they were very young and was seen riding 'about on a stick at home pretending that it was a horse' (Ages. 25. I I). Sometimes the analepsis is an external one as in the case of Lycurgus' prudent warning in one of his three laws not to undertake frequent campaigns against the same enemy to prevent them from developing their military capability (Ages. 26.5). This analepsis supports Antalcidas' reproach of Agesilaus' frequent campaigning against the Thebans. ${ }^{47}$

\section{The analeptic sunkrisis}

The comparative structure of the Parallel Lives is underscored in the analytical postscript or sunkrisis appended to all but four ${ }^{48}$ of the 22 pairs of Lives. In these brief analeptic essays Plutarch weighs the positive and negative sides to the two protagonists' conduct and reiterates the deeds (repeating internal analepses) that are significant in this evaluative process, occasionally in a more critical way. ${ }^{49}$ The emphasis is placed sharply on moral instruction in the sunkriseis.

Occasionally Plutarch inserts in the sunkrisis important information that he has omitted in the Life proper (completing internal analepses). He acknowledges, for example, his neglect to mention that Crassus struck Lucius Annalius in the face with his fist and 'drove him bleeding from the forum' (Crass. 35 (2).3). His reference to Crassus' maltreatment of women in the sunkrisis (Crass. 34 (I).2) is also not supported in the Life, even though the story of his father's corruption of the Vestal virgin Licinia in the proem (Crass. I.4-5) appears to foreshadow this theme (along with avarice).

47 Agesilaus' obsession with Thebes and its negative consequences is alluded to in the sunkrisis (Pomp. $8_{3}$ (3).2).

48 Phocion/Cato Minor, Alexander/Caesar, Themistocles/Camillus, Pyrrhus/Marius. On the sunkrisis in general see Duff i999: 243-286.

49 Cf. Duff i999: 259. 
Not infrequently Plutarch makes reference to his own time in the Lives. This occurs, for example, in those situations when he refers to what he has seen with his own eyes (autopsy). Plutarch has witnessed the whipping to death of the Spartan youths at the altar of Artemis Orthia (Lyc. I8.2). He has seen Agesilaus' spear still on display in his own day in Sparta (Ages. I9.II) and the statue of Lysander on display at Delphi (Lys. I). Plutarch apparently visited the sanctuary of the Nymphs at Mieza, 'where even now people point out the stone seats and shady walks Aristotle used to frequent' ${ }^{50}$ (Alex. 7.4) and, in Chaeronea, he has seen 'Alexander's Oak', located near the communal grave of the Macedonian dead, which Alexander pitched his tent against (Alex. 9.2). When tracing the descendants of Antony, Plutarch has harsh things to say about Nero, who came to the throne in his time (Ant. 87.9).

Sometimes the reference to the narrator's own time reflects the impact of a past action on present circumstances. This includes for instance aetiological explanations of customs, laws, names, etc., that are still in use in Plutarch's day, such as the origin of the military term 'maniple' (Rom. 8.7-8) and the wedding salutation Talasio (Rom. I5.I4), for example. These references all mark the interpenetration of the historical past in the narrator's present.

\section{Conclusion}

From our examination of Plutarch's literary technique in the Parallel Lives it is evident that they are symmetrical compositions with unifying themes that serve to modulate the narrative representation and referencing of time. Plutarch generally signals his major concerns quite early in the proem or early chapters of the first Life in the form of anecdotes, for example, which prognosticate future greatness, abilities, traits, persistent behavioral patterns, problems, etc. These themes are most vividly emergent in the 'grand scenes' of the Lives, sections in which the narrative is greatly slowed down. Longer episodes of narrative slowing down often showcase the main protagonist's specific involvement in major historical events. Plutarch tends to accelerate the narrative

\footnotetext{
50 Translation by Waterfield 1998.
} 
through, or omit from it altogether, long presentations of battles. He rarely presents speeches of any length. Plutarch often clusters chronologically disparate events for thematic purposes or he presents such information omnitemporally, by employing the iterative mode of narration, to facilitate characterization. Another technique involves the retrojection or displacement of information derived from adulthood into the narrative of childhood and youth to supplement the lack of information on these phases of his biographical subject's life. External and internal prolepses and analepses are often used to highlight behavior by recontextualizing it or clustering similar instances thematically. Plutarch concludes most of the pairs analeptically with a brief retrospective essay (sunkrisis) in which the major accomplishments and characteristics of the two heroes are recalled and evaluated instructively in an impartial way. 
Irene J.F. de Jong and René Nünlist - 978-90-47-42293-8 Downloaded from Brill.come4/26/2023 09:46:52AM via free access 


\section{GHAPTER TWENTY-SIX}

\section{PHILOSTRATUS}

\section{T.J.G. WhitMARSH}

The Philostratean corpus ${ }^{1}$ is large and varied, but only one work stands out for its narratologically rich handling of time. In honour of Apollonius of Tyana is, at one level, a biography of the eponymous holy man (hence its most common mistitling as The Life of Apollonius of Tyana). Its narrative spans the life of its protagonist, progressing (mostly) chronologically, and its focus is almost exclusively upon him and his actions. Even so, it is crucially not a conventional biography - for Apollonius is not a conventional biographical subject, but a holy man, a theios anerr, operating in the grey area between mortal, hero and god. Just as Apollonius conflates different categories (mortal, divine, heroic), ${ }^{2}$ so Philostratus' work exceeds the received boundaries of genre, sloping from biography into encomium, even hymn. The representation and manipulation of time is a crucial vehicle for Philostratus' strategy. As we shall see, the ability to slip between multiple time-frames - shared by narrator and subject alike - is emblematic of the potent otherness of this extraordinary text.

\section{Time awareness}

The central role of time in the narrative presentation of In honour of Apollonius of Tyana (henceforth Apollonius) is visible from the very start, where the narrator promises programmatically to 'give an accurate account (exakribossai) of the man and the times (tois khronois) when he said or did this or that' (1.2). Like the claim to 'accuracy' (akribeia), the emphasis upon strict chronology looks to Thucydides $(\rightarrow)$, an important

${ }^{1}$ On questions of authorship and attribution see de Lannoy 1997.

2 On problems of categorisation of Apollonius see esp. Jones 2004. 
narratorial (and indeed stylistic) model for this text. ${ }^{3}$ Chronological progression is, indeed, the guiding narrative principle throughout.

The narrative is also presented subsequently. The narrator gives considerable emphasis to his chronological posterity to events. Thus, when introducing Apollonius for the first time, he comments that the former 'lived in times (khronous) neither ancient nor recent' (I.2). The narrator also displays prominently his status as a 'rewriter' (cf. metagrapsai, I.3) of the transmitted sources on the life of Apollonius, particularly Damis. ${ }^{4}$ The attention paid to the narrator's activity qua narrator, handling his sources, recalls Herodotus $(\rightarrow)$ and Herodian $(\rightarrow)$, and presents a special version of the 'reference to the narrator's own time' motif.

On several occasions, the narrator intervenes to corroborate the transmitted account based on his own experience: here, present tenses such as 'I know' (oida) or 'I think' (hēgoumai) transport us out of the past-tense narrative. ${ }^{5}$ In the most explicit acknowledgement of this, the narrator claims at one point that there was more love of gladiatorial games in Athens at the time of Apollonius 'than now (nun) in Corinth' (4.22), an example of the 'reference to the narrator's own time' motif that goes back via Herodotus $(\rightarrow)$ to Homer $(\rightarrow)$.

Time also has an abstract, ineffable, mystic quality about it, eluding the comprehension of mere mortals. Apollonius - who, we are told, himself had a prodigious memory - sang a hymn to memory, in which he said that everything withers through time (khronos), but thanks to memory time (khronos) itself is ageless and undying (I.I4). When arraigned before Domitian, he was asked by the emperor who was his advocate: 'Time (khronos)', he replied, 'the spirit of the gods, and the love of wisdom' (3.34). This evokes the traditional ${ }^{6}$ Greek language of time as the great arbiter of justice (and hints self-referentially at the sage's final vindication through the narrative we are reading); but it also demonstrates Apollonius' otherworldly attention to the longue durée rather than the immediate surroundings. Apollonius perceives time from a more detached perspective than the humans around him.

This is also expressed in the different chronological frameworks employed within the narrative. Apollonius himself, like his teachers, the

\footnotetext{
${ }^{3}$ For Thucydides' emphasis upon chronology see Th. 2.I; for the importance of Thucydidean akribeia to Philostratus in Apollonius see $S A G \mathcal{N}$ I:425-426.

4 SAGN I:424-430.

5 2.2, 7, I8; 3.8, 4I; 4.13; 5.2; 6.27; 7.I; 8.31.

${ }_{6}$ Particularly in tragedy: $\mathrm{cf}$. in general de Romilly 1968.
} 
Brahmans (3.30; and also the Ethiopian sages, 6.4), is said to have been preternaturally long-lived (8.29; cf. I.I4). During this long period, we encounter numerous Roman emperors. Apollonius interacted directly with Nero, Vespasian, Titus, Domitian and Nerva, but he is in fact already active under Tiberius (I.I5): if we count Claudius, Galba, Otho and Vitellius too (each of whom Apollonius knew well enough to criticise them, 5.32), then the fabula spans ten reigns. In other literature too, of course, time can be quantified imperially: this is how Suetonius (in his Lives of the Caesars) and Plutarch proceed, and also later historians such as Philostratus' contemporary Cassius Dio (and the slightly later $\rightarrow$ Herodian). In Apollonius, however, emperors are said to have come and gone with seeming rapidity (and sometimes without direct impact on the main narrative), as though they were bit-players in the macronarrative of Apollonius' ministry.

Even so, imperial chronology of one kind plays an important subterranean role. The Apollonian fabula spans the period from Tiberius to Nerva, ${ }^{7}$ a significant phase in the history of the Roman empire. Now it might of course be argued that the fabula was determined by historical reality. It is not, however, clear that our narrator - who ponders the question whether Apollonius died aged 90 or Ioo, or indeed died at all (8.29) - knows any exact historical dates for him. The traditions surrounding Apollonius' birth and death were no doubt overlain with contradictory mythicism as quickly as those about Jesus. ${ }^{8}$ The choice of the Tiberius-to-Nerva fabula is better explained as a strategic one: this means that the backdrop for Apollonius' actions is always Roman political turbulence. Behind the apparent disregard for politics ('no polity concerns me', said the sage, 'for I live under the gods' command', 5.35), Apollonius reflects a conventional narrative (found in, for example, Tacitus, Suetonius and Dio Chrysostom) of first-century politics: Tiberius was the author of decline (explicitly stated by Apollonius at 5.32), and Trajan (implicitly) was the restorer of the 'new age' of liberty.

Roman politics also affect the presentation of time in another way. Datable events almost always concern Rome, ${ }^{9}$ and more particularly the emperor. Thus we read of the opening of Nero's gymnasium (4.42), the imprisonment of Musonius Rufus (4.46; M. Rufus in gaol). Nero's

7 Nerva's death coincides, at least approximately, with Apollonius' (8.27).

${ }^{8}$ E.g. Lane Fox 1992.

9 The exceptions are natural disasters, such as the famine at Ephesus and the earthquakes in the eastern Mediterranean (4.4). 
tour of Greece and ban on philosophers (4.47), Vindex' revolt (5.Io), the year of the four emperors (5.II; 69 CE), Titus' capture of Jerusalem (6.29), Domitian's vine edict (6.42), the purifying of the Vestal cult (7.6), the murder of Sabinus (7.7), the relegation of Orphinus and Rufus (7.8), Domitian's murder $(8.25) \cdot{ }^{10}$

Time in Greece, on the other hand, operates in a different way. ${ }^{11}$ Here, the only time-markers are annually recurrent, namely festivals (the Epidaurian, 4.I7-I8; the Athenian Dionysia, in the month of Anthesterion, 4.2I) and the traditional league meeting of the Amphictyonic Council (4.23). Whereas Rome is the site of development and change, Greece is dominated by cyclical repetition. Indeed, much of Apollonius' labour is devoted to restoring Hellenic temples, customs and manners to the way they were. ${ }^{12}$ Time at Rome expresses change; time in Greece preserves things as they were. The two temporal systems, Roman and Greek, collide when Nero shifts the Olympic games to coincide with his visit to Greece in CE 67. Apollonius, predictably, disapproves: 'I predict he will win in Olympia, for who is foolhardy enough to stand against him? But he will not win the Olympia [viz. the Olympic games], since they are not holding them at the right time' (5.7). ${ }^{13}$

Apollonius, however, is not a straightforward ambassador of traditional Hellenism. His own temporal routine is derived from mystical oriental ritual, and is built around the natural cycles of the day. In India, a number of prescriptions surround time: strangers are only allowed in Taxila for three days at a time (2.23); the king is not allowed

${ }^{10}$ Domitian's particular attempts to control time will be discussed below, in the section on books 7 and 8.

${ }^{11}$ For different constructions of time within the same cultural unit see Csapo \& Miller 1998: in classical Athens, aristocratic time is 'experienced simultaneously as unity, continuity, and eternal repetition' (97; cf. 97-Ioo passim); democratic-imperial time, on the other hand, is a linear construct privileging change and the potentiality for development (IOO-IO4).

12 I.2; 4.5 (Lucullus); 4.I6 (statue of Palamedes); 4.2I (emphasis on the glorious Athenian past); 4.22 (gladiatorial games decried); 4.23 (tomb of Leonidas); 4.27 (Spartans exhorted to the ancient ways); 4.32 (another Spartan); 5.20 (an Athenian is rebuked by comparison with ancestors). Nero is also implicitly praised for allowing the cities to be rejuvenated (5.2I). Both Apollonius (e.g. 3.3I; 6.2I) and the narrator (e.g. I.I; 7.I 2 2I) use positive examples drawn from the Greek past. Cf. e.g. Swain I996: 387-388. Interestingly, not all archaism is good: arkhaia is used as insult to the backward Baeticans (5.9).

${ }^{13}$ We do, however, find Domitian celebrating the festival of Adonis (7.32): cf. below, section on books 7 and 8. 
to spend time with the Brahmans for more than one day (3.34); and, in particular, the Brahmans perform their religious rituals at significant times, namely midnight, midday, daybreak (3.33). The Ethiopian gymnosophists also worship at midday (6.14); and it is thus no surprise to find Apollonius reverencing the sun at this time (7.I0). We also find him undertaking significant activity at daybreak $(5 \cdot 3 \mathrm{I} ; 6.6)$.

Overall, then, the representation of time plays a crucial role in the articulation of religious and cultural meaning in this text. There are at least three different temporal systems at work in Apollonius: the Roman, the Greek, and the mystic-oriental. These different temporalities operate in different contexts and registers: the Roman is primarily political, the Greek primarily civic-religious, and the mystic-oriental follows the natural patterns of the sun.

\section{Structure and segmentation}

The Apollonius is a variety of biography. In chronological terms, the narrative as a whole is structured around the life of one individual. Yet it is not simply one of birth-to-death. Birth is not mentioned until I.5; we open, rather, with a discussion of Pythagoras, who is compared less favourably to Apollonius (Socrates is also mentioned). Apollonius is thus inserted into a larger sequence, the history of Greek holy men. This sense that our subject is part of a larger, self-renewing tradition of Greek philosophy is underlined elsewhere: at 7.I-3, he is also inserted into a series of philosophers who opposed tyrannical rule.

If birth is not exactly the beginning, then neither is death exactly the end. For a start, the narrator equivocates between the traditions as to his age at death (9o or Ioo?, 8.29). ${ }^{14}$ More pertinently, a radical uncertainty surrounds Apollonius' end: 'as for the way he died, if he did die at all, there are many stories, but none is given by Damis [the narrator's principal source]' (8.29). If he did die, he certainly continued to practise and communicate philosophy afterwards (8.3I). The normal temporal limits of biography, then, do not apply in this case: Apollonius' story begins before he was born and continues after his death.

\footnotetext{
14 Although near the start he is said to have been Ioo at death (I.I4).
} 
The internal architecture of the work - what Don Fowler calls its 'segmentation', its division into coherent sense-making units ${ }^{15}$ - is determined by a number of features, not all of them temporal. The most conspicuous segmental device is of course the book structure, which is evidently built around geography. Thus book I focuses upon Apollonius' childhood, early development and voyage to Parthia; books 2 and 3 with the eastern limits of the world, that is, India and the Brahmans; book 4 with Greece, Ionia and Neronian Rome; book 5 with the western limits of the world (Gadeira), and the interview at Alexandria with Vespasian; book 6 with the southern limits, Ethiopia and the gymnosophists; books 7 and 8 with Domitian and Rome. There is, of course, a temporal dimension corresponding to the geographical and thematic unity of the books, but it is not especially stressed. Only the beginnings of books 2 and 8 use temporal markers: the former opens (in the $\rightarrow$ Thucydidean fashion) with a reference to the following summer (2.I), while the latter refers to the dawning of the day of Apollonius' trial (8.I).

There are, however, further strategies of segmentation at work in the text, marking different sequences off from each other. Occasionally, temporal change indicates such transitions. A strong example comes at 4.I7, where arrival at Athens coincides with autumn (metopōron). By far the most prominent device for moving to a different phase is (as indeed we also find in the previous example) geographical relocation. Thus, for example, at 4.II: 'Having cleansed the disease from the Ephesians, and having had enough of matters in Ionia, he set off for Greece'. In such transitional phases, time operates straightforwardly (and almost imperceptibly) to mark linear sequence.

Yet different phases of the narrative do have distinctive temporal qualities. I identify three types of narrative temporality. Firstly, we have sequences of what I shall call 'regular' narrative, where events follow one another in a logically and temporally consecutive chain. Secondly, we have long stretches of 'paradigmatic' narrative (in contrast to the syntagmatic, chronological linking of regular narrative): here selected anecdotes are relayed in order to exemplify aspects of Apollonius' wisdom. Such episodes are still part of the narrative, but chronology is looser, sometimes explicitly so. A good example comes at 4.32: 'around this time' (peri ton khronon touton), ${ }^{16}$ a descendant of Callicratidas was

\footnotetext{
15 Fowler I997.

16 The same phrase is used at $4 \cdot 46$.
} 
charged with affront to traditional Spartan ways by Apollonius and corrected. The action is neither motivated by anything beforehand nor does it affect anything afterwards: it simply contributes to the aggregate body of evidence for his devotion to Greek tradition. Elsewhere, anecdotes illustrating similar points may be introduced with the phrase 'and this too' $(4.33,45 ; 6.40)$ : the episodes are linked by philosophical rather than temporal considerations.

Finally, we have chunks of 'narratorial digression', where the narrator offers his own generalised excurses on history, botany, ethnography and so forth. These tend to be concentrated at the beginnings of books: for example, book 3 begins 'About the Hyphasis, its size as it crosses India and its remarkable features, one should know the following ...' (see also the openings of I.I-3; 3.I.I-2.I; 5.I-4; 6.I; 7.I.I-3.2). ${ }^{17}$ These thus function as pauses, waymarking the narrative; they also underline the narrator's intellectual authority. ${ }^{18}$ There is, however, an occasional ambiguity about such passages, in cases where the narrator's own ruminations are interwoven with reports of Damis' observations. For example, 'They [Damis and Apollonius] claim to have seen there trees of a kind that exist nowhere else on earth, and are called Geryon's. They are two in number, and grow from the grave that holds Geryon ...' (5.5.I). Is the second sentence here, and the long discussion that follows it, to be credited to the primary narrator or the reported narrator, his 'source' Damis? Is it, consequently, a narratorial digression or part of the regular narrative of Damis' and Apollonius' experience in Cadiz?

I want to focus for the remainder of this section, however, upon the relationship between regular and paradigmatic narrative (narratorial digression is less widespread, and serves primarily to segment the narrative). These two forms interact in interesting, dynamic ways. Regular narrative is dominated by decisive events, often temporally pinpointed, narrated in chronological order. Paradigmatic narrative, however, is fundamentally achronical: it is dominated by Apollonius' discourses and sayings, and it has its own distinctive feel. The narrator presents

${ }^{17}$ Unsurprisingly, the Indian books 2 and 3 also contain a significant amount of narratorial digression of a geographic or ethnographic nature: this is clustered at the beginning of the two books, but interleaved with regular narrative. Cf. 2.3 (Prometheus); 2.9 (Dionysus); 2.13 (on elephants); 2.18 (the Indus); 2.2I (Porus); 3.4 (cinnamon and pepper trees); 3.5 (Ganges plain); 3.6-8 (dragons). There is also a 'digression from the narrative' (ektrope tou logou) at 7.39, in the form of a disquisition on wizardry. Rommel I923: I-59 shows that the material for these digressions is all traditional.

${ }_{18}$ A technique that may look to Herodotus: cf. $S A G \mathcal{N}$ i:I05-Io6. 
himself as distilling the most 'memorable', ${ }^{19}$ 'worthy of telling', ${ }^{20}$ or 'important'21 sayings or episodes from a larger stock (sometimes identified with Damis' book). Such passages are characterised by markers of iterative presentation, suggesting that the anecdote exemplifies, metonymically, Apollonius' consistent and unchanging nature, rather than taking its precise place in a narrative chain of events. For example, 'he said many such things (polla toiauta) to the king' (I.39); 'of this kind (toiauta) were the events on the boat' (4.I7); 'delivering discourses of this kind (toiauta)' $(6.3) .^{22}$

It might be initially tempting to take regular narrative as the substance of the narrative, and downplay the significance of paradigmatic narrative, as mere filler: this, indeed, is implicitly what I did above when I characterised the thematics of individual books or pairs. ${ }^{23}$ Indeed, there are good reasons to believe that the narrator privileges regular narrative. The most concentrated and memorable phase comes in books 7 and 8, where the narrator employs a variety of techniques to assimilate Apollonius' confrontation with Domitian to an exciting, suspense-filled narrative. Here considerable attention is given to the passing of time, to different modes of measuring it, and to the importance of achieving tasks within given timeframes. The narrative as a whole thus builds to a climax in this thrilling account of the confrontation between emperor and philosopher.

If we do take regular narrative as most important, then we can identify two ancillary roles played by paradigmatic narrative. Firstly, a segmental function: it marks transitional periods between important episodes. $^{24}$ Thus, for example, after his miraculous reappearance to Demetrius and Damis after the trial, Apollonius is said to have sailed to Olympia and discoursed there on a variety of topics (8.I5-I8), a classic case of paradigmatic narrative. There is little identification of time internal to this phase, ${ }^{25}$ and no sense at all that the order of events is

\footnotetext{
19 axion epimnēsthènai and related: $5.9 ; 6.35,39,40$.

20 axion eipein and related: $1.19 ; 2.4, \mathrm{I} 6 ; 5.7 ; 6.23$.

21 spoudaios and related: $4.22 ; 6.35 ; 7.28$.

22 For further examples see I.II, I2, I4, I6, 40; 2.I6; 3.40, 50;4.22; 5.7, 20, 24; 6.35, 43 .

23 An excellent example of succumbing to this temptation is Jones I970, a strategically abridged translation.

24 Regular narrative transitions can occur without 'buffering', though: cf. 6.28, where we pass quickly and unfussily from the Ethiopian episode to Apollonius' relations with Titus.

25 Only a single reference to a promise to act 'tomorrow' (8.17).
} 
significant, or indeed chronologically accurate. The phase as a whole, however, is carefully marked out: they sailed to Olympia in autumn (8.I5), and the stay lasted forty days (8.19). The paradigmatic sequence works at two levels: (I) the events internal to it contribute achronologically to the stock of wonderful stories about Apollonius; (2) from the perspective of the larger narrative in which it is embedded, this unit of time provides a buffer between the trial and the final sequence of the narrative, the deaths of Domitian and Apollonius himself. This segmental role is also indicated by demonstrative pronouns: a phrase like 'of this kind (toiauta) were the events on the boat' (4.I7) also serves to conclude a phase of paradigmatic narrative, allowing a fresh phase to begin.

The second ancillary role played by paradigmatic narrative is to signify the passing of longer periods of time within regular narrative. The Indian episode is particularly interesting in this respect, because it slips gradually from regular into paradigmatic narrative. When Apollonius and Damis first arrive in India, the temporal rhythm is relatively compact, as introductions are made, and visitors come and go. After a while, however, we reach a series of markers of transition to a more general description, tied to a slacker chronology: 'filling themselves with these things (toutōn) they were amazed at the men [the Brahmans], and day after day (hoshemerai) they asked all kinds of (pampollous) questions about their wisdom on all topics (es panta), and they themselves were asked many questions in return' (3.40). After narrating a series of discussions of diverse topics, the narrator caps the section: 'such (toiaide) were the conversations Apollonius held with the sages over the four months there ...' (3.50). The Indian sojourn is now over: Apollonius and Damis return westwards. The paradigmatic phase has served to loosen up the rhythm, so that the narrative can convey four months' activity without having to describe every day's events.

Paradigmatic narrative, then, is an important way of internally articulating the narrative: it also allows for variations in narrative rhythm, which serve to draw more attention to the major events in the regular narrative. I want to conclude this section, though, by adverting to a rather different hypothesis as to the relationship between these two phases. We have been presuming that the regular narrative is most important, and paradigmatic narrative ancillary. If Apollonius teaches us one thing, however, it is that change and flux at the worldly level is nothing as to the magnificent eternal truths of the cosmos. After his journey to India, at any rate, Apollonius is serenely impervious to mun- 
dane influences. Modern scholarship has tended to privilege narrative action over philosophical discourse (even likening the text to a novel). ${ }^{26}$ It is hard, however, to avoid the conclusion that for Apollonius himself this would appear to be misplaced emphasis on the worldly at the expense of philosophical discourse. ${ }^{27}$ If this is accepted, then we can take the narrator's manipulation of rhythm as a form of challenge to the narratee to read as Apollonius himself would: we should prefer to focus upon the timeless, edifying material rather than the pacy narrative around it.

\section{Rhythm}

In 'regular' narrative the story-time tends to coincide with the fabulatime. This is particularly evident in books 7 and 8, which are dominated by the clash between Apollonius and Domitian. Indeed, whereas most books open with narratorial digression, book 8 begins with a flamboyant convergence between the two time systems. 'Let us now go', the narrator exhorts the narratee, 'to the court-room to hear the man's defence against the charge: for it is already sunrise, and the entrance is open to the select audience' (8.I). We are invited to submit to the chronology of the narrative: it is, so the conceit suggests, sunrise for us as well as for Apollonius.

This desire to mimic fabula-time leads to a certain self-consciousness over the handling of narrative rhythm. The narrator's biggest concern is with acceleration and slow-down. In the work's first paragraph, he cuts short a discussion of Pythagoras, so as to 'hurry' (speudonta) on to the task he has set himself. This pattern is repeated throughout. ${ }^{28}$ In particular, the narrator agonises over questions of ellipsis - or paralipsis, as he refers to it. The following is a striking example:

For the sake of accuracy [akribologias] and avoiding ellipsis [mēden paraleleiphthai moi] of any of the things Damis wrote of, I would have liked to have spoken of the important events [ta spoudasthenta] that took place while they journeyed through barbarian lands, but my narrative [logos] drives me on [xunelaunei] to greater and more wondrous topics.

26 E.L. Bowie i978; E.L. Bowie i994.

27 Cf. e.g. $S A G \mathcal{N}$ r:433-435, on Apollonius' immunity to thauma ('awe') before opulence and exotic sights.

28 Apollonius too is capable of impatience: cf. esp. I.39 ('we have stayed here for a longer time (khronou) than we should have done'). 
The narrative urgency identified at the outset manifests itself once again: the logos drives the narrator along his path, faster than the travellers themselves journeyed in fabula-time. There are indeed other examples in the text of this desire to focus upon the 'important' (spoudaios) material, so as to avoid narrative 'length' (mēkos, 4.34; 6.35). On other occasions, however, the narrator acknowledges his inability to practice paralipsis owing to the importance of the topic (I.9; 2.21, 28; 3.45), or apologises for extending (mêkunein) his narrative (logos) (4.25; 7.2). In sum, the narrator wants to be seen as exercising a careful and judicious control over the rhythm of his narrative. He might well be offering an implicit endorsement of Apollonius' claim that the abilities to speak at length (makrologein) and to speak concisely (brakhulogein) are complementary virtues (8.2)..$^{29}$

\section{Narratorial anachrony}

Because regular narrative follows fabula-time so closely, anachrony is relatively rare, and strictly tactical. On two occasions, complexities in the transmission of the narrative enforce a certain disorder. At I.26, we read of Apollonius' interview with the magi. Since Damis (the narrator's source for this episode) was not party to these discussions, the narrator cannot reveal the contents. We are told, however, that he 'once' (pote) asked Apollonius about them, and was told that 'they are wise, but not completely'. We immediately return from this prolepsis to the chronology of the narrative again, with the phrase 'this will come later' (tauti men husteron, I.27). ${ }^{30} \mathrm{~A}$ less conspicuous example comes at 4.16, where Apollonius' interview with Achilles is reported in direct speech after the event, since Damis was not present at the original.

Narratorial prolepsis is much more common in the account of Apollonius' childhood than elsewhere. This sequence is predominantly paradigmatic narrative, inserted loosely into the overall chronological framework of Apollonius' aging (Apollonius was fourteen, I.7; Apollonius was sixteen, I.7; his father died, his brother was twenty-three, I.23). In this phase, prolepsis demonstrates Apollonius' embodiment,

${ }^{29}$ Alluding to Pl. Grg. 449c, where Gorgias claims equal competence in brakhulogein as in makrologein.

${ }^{30}$ It is not clear to me to which later point the narrator is referring. We may be dealing with an unintentional slip or a conscious unfulfilled prolepsis. 
even at this early stage, of the qualities he would show as an adult. ${ }^{31}$ Thus despite Proteus' comments in a dream to his mother, he was more of a prophet than Proteus, 'as my forthcoming narrative will show' (I.4); a comment about Apollonius later became apophthegmatic (I.8); Apollonius stared at the ground 'as he was accustomed to do when he had grown older' (I.Io); his amazing memory would stay with him till he was Ioo (I.I4). At one point, this strategy is deliberately marked. Noting that not even Euphrates in later life accused him of sexual impropriety, the narrator reins himself in: 'but I must defer these matters to their proper time (khronous)' (I.I3). These prolepses all serve to emphasise the point that even as a child Apollonius already shows himself a philosopher: in a telling simile, the narrator compares him to an eaglet that flies with its parents at first, but outsoars them when he fully fledged (I.7).

Occasionally, the narrator will deviate from strict chronology to pursue proleptically Apollonius' relationship with an individual. Thus at 5.39, we are told that the interview with Vespasian was the cause of the quarrel with Euphrates: several accusations later made by the latter are cited, as is an anecdote about him nearly hitting Apollonius with a stick. ${ }^{32}$ After the same scene, the remainder of Apollonius' relations with Vespasian are narrated together proleptically (5.4I). The reasons for both anachronies no doubt lie in the particular narrative circumstances: the narrator is tying up loose threads before the end of book 5 , and the transition from the Egyptian to the Ethiopian episode. For similar tying up see Hesiod $(\rightarrow)$. The final type of prolepsis comes in the form of portents, which cluster at the beginning and the end, predicting Apollonius' birth and death (I.4; cf. I.5; 8.23). These evidently serve to underline the cosmic significance of the protagonist.

Narratorial analepsis is also relatively uncommon, and again has a particular tactical role to play. Sometimes (e.g. 5.I9) the narrator will remind us of an earlier prophecy of Apollonius' at the point at which it is fulfilled. On two occasions, figures are introduced whose prior acquaintance with Apollonius is now narrated for the first time (Demetrius, 4.42; Aelian, 6.I6). Because the narrative focuses so relentlessly upon Apollonius, there is little opportunity to develop parallel

${ }^{31}$ A device also found in Plutarch $(\rightarrow)$.

32 The phrase 'I must leave the man alone' (emoi de aphektea tou andros) looks like a promise to abstain from further treatment of Euphrates, but in fact he resurfaces periodically $(6.7,28 ; 7.9,36)$. 
storylines concerning other figures: these analepses are in this respect directly analogous to the prolepses adverted to in the previous paragraph, in that in both cases indispensable narrative dealing with (nonApollonian) individuals is condensed anachronically and presented at the point where the individuals in question encounter Apollonius.

There are two occasions, however, on which parallel storylines are indeed cultivated. The first comes at 6.7 , where Euphrates is said to have mandated a certain Thrasybulus to preempt Apollonius' visit to Ethiopia, and to slander him. The second is more dramatic. After the description of the trial, the narrator switches from Rome to Dicaearchia, where Demetrius and Damis were waiting for news of Apollonius. The segue between the two parallel storylines is effected by means of a brief analepsis: 'on the previous day' (i.e. previous to the day of the trial, which has just been narrated) Damis arrived and discussed events with Demetrius (8.II). This analepsis is only tolerated for a brief moment. Chronology 'catches up' in the following sentence: 'and again on the following day Demetrius asked him about the same subject ...'. The analepsis here thus marks the shift of focus away from Apollonius, which is pretty much unparallelled in the rest of the narrative. It is, moreover, almost instantaneously revoked, thanks to the epiphany in the following chapter (8.12). This exceptional deviation from regular practice is mitigated by the condensed brevity of the scene: as Demetrius explicitly observed, Apollonius reappears after a miraculously short period of time (8.12). The use of parallel storylines here focuses attention upon the anxieties and fears of acolytes.

The narrator's approach to anachrony is, thus, ambiguous. On the one hand, the tendency to focus exclusively upon Apollonius, 'to give an accurate account (exakribōsai) of the man and the times (tois khronois) when he said or did this or that' (I.2), militates against deviation from the temporal order of the fabula. On the other hand, the narrator takes pleasure in demonstrating his full control over the narrative, and makes creative use of prolepsis, analepsis and parallel storylines at tactical moments. We should make two further observations. Firstly, reference to the postponement of material in narratorial digressions ${ }^{33}$ is, strictly speaking, no prolepsis (since digressions float above the chronology of narrated time); but it does play the same role, of buttressing the sense of the narrator's control over his material. Secondly, there are the

${ }^{33}$ Cf. esp. 2.I7, where the account of snakes is explicitly deferred until the dragon narrative $(3.6-8)$. 
references to the writings of Apollonius and Damis, for example: 'That he [Apollonius] really did visit Cissa he himself acknowledges in a letter which he wrote to the sophist of Clazomenae; for he was so kind and loyal that when he saw the Eretrians, he remembered the sophist and wrote to him an account of what he had seen' (I.34). ${ }^{34}$ When exactly in the fabula Damis and Apollonius write down such memoirs is not indicated, but the references are inserted at the appropriate place in the story, that is, at the moment the event which the memoir will cover took place. Again, it would be far-fetched to call such references prolepsis, but they certainly are a form of anachrony.

\section{Actorial anachrony}

Prolepsis of one kind plays an absolutely fundamental role in the Apollonius. If Apollonius' wisdom is embodied in one skill, it is prophecy. This was a quality enhanced by his time with the Indian Brahmans (3.Io, I6, 40; cf. 6.I3), and he discusses it at length with them (3.42); but even beforehand he was to be found predicting the length of his stay with the Persian king Vardanes (I.22), and extolling the teetotal life as conducive to prophecy (2.37). It is the master discipline, from which others flow (notably medicine, 3.44). Apollonius wrote a book on the subject (3.4I). It is upon his prophetic powers that the Roman suspicion of wizardry was based (4.44; 7.II, 20; 8.5, 7 (ix)); the narrator provides a vigorous defence in a narratorial digression (5.12). Apollonius visited oracular sites (4.I4; 8.I9), his arrival in Ionia was predicted by Didyma and Colophon (4.I); he is even compared directly to an oracle (5.33). Even Damis was capable of prophecy of a sort, which he comically compares to the powers of an old beggar woman (3.43). Given this, it is unsurprising to find a huge number of predictions that turn out to be true. These thus are actorial prolepses which primarily function to illustrate character. ${ }^{35}$

\footnotetext{
${ }^{34}$ For example, Damis: I.I9, 24, 34; 3.17, 45; 4.25; 5.26; 6.4, 7, 22, 32; 7.42; Apollonius: I.24; 3.2, I5; 4.19; 6.33 (letter); both: I.26, 32; 2.4, 8, I9, 20; 3.3, 9, I2, 54-56; $5 \cdot 5^{-6 .}$

35 I.22; 3.33; 4.4, 6, I8 (proven true at 5.I9), 24, 34; 5.7, IO, II, I3, I8, 24, 30; 6.32, 39; 7.IO, 4I; 8.I4, 23, 27. We might also take the Homeric quotation uttered to Domitian'you shall not kill me, for I am not mortal'-as a prediction (8.5, = Hom. Il. 22.13; cf. 8.8, I2).
} 
Actorial analepses are varied in their use. Aside from banal cases where previous events are recalled simply to make an ethical point, ${ }^{36}$ we do find 'flashback' direct speech used to fill out new characters, such as the Indian king (2.30-32) and Nilus the Egyptian acolyte (6.I6). Here, actorial analepsis allows the primary narrator to introduce new figures into the narrative without having to divert attention from Apollonius and Apollonian chronology. Occasionally also we find the device of a character 'remembering' an earlier occurrence: at 3.18, for example, Apollonius remembered Phraotes saying that the Brahmans begin their training by understanding themselves, which allows him to understand why Iarchas dismisses the Greek emphasis upon self-knowledge. Cases like this serve to germinate a narrative 'seed' planted earlier in the text.

One form of actorial analepsis is highly distinctive to this narrative: the mystical ability to recall events to which one has not been consciously party. Apollonius repeatedly solved riddles by bringing to bear his preternatural insight into the past (I.Io; 6.5, 43). An extreme example is the ability to recall previous existences. This is a particular skill of the Brahmans (3.19-22), and Apollonius presently follows suit (3.23-24). The Brahman Iarchas was also wise enough to be able to know Apollonius' past in this life, which he duly recapped (3.I6). This form of actorial analepsis is directly parallel to the cases of prophecy we discussed above as a form of actorial prolepsis: it contributes nothing substantial to the plot (as conventionally understood), except to characterise the amazing sages in question. ${ }^{37}$ That said, one part of Iarchas' recollection of his previous life did indeed prove significant, namely the account of the Ethiopians' expulsion from India (3.20): Apollonius' awareness of this overshadowed his visit to the gymnosophists in book 6 .

The ability of sages intellectually to range freely over time, both forward and backwards, is thus a highly significant aspect of this narrative, and generates a number of intriguing effects. Take, for example, the case of a character who recalled a prophecy now validated by the present event (1.29; 7.18; 8.12). Clearly at one level this is actorial analepsis; but it is also an analepsis of a prophecy that predicted

\footnotetext{
36 E.g. 2.5, I4.

37 This is not to say that the contents of such analepses are insignificant. That Iarchas was in a previous life the great Indian king Ganges and Apollonius a humble Egyptian sailor constructs a clear hierarchy between the two. A different form of actorial analepsis comes at 6.I4, where we find Apollonius summarising his life story (in this incarnation) to Nilus and Thespesion: the point of this is to show the latters' conversion to Apollonius' point of view, and to his admiration for the Indians.
} 
the 'present' moment. Time is viewed as a complex, but magnificently coherent system, at least to the sages whose cosmic understanding is emblematised by their mastery of it.

In several respects, then, Apollonius' intellectual command of time and space makes him into a kind of 'omniscient' narrator. $\mathrm{He}$ is, indeed, implicitly assimilated to the narrator of Apollonius, ${ }^{38}$ whose predominant focus upon Apollonius and the chronological progression of time is occasionally subverted as he ranges more freely. A particularly striking illustration of the similarities between narrator and hero as regards their ability to anticipate the future comes right at the beginning, in a dream experienced by Apollonius' mother (I.4). The dream visitor is Proteus, who prophesies that she will give birth to (a) Proteus. 'We must recall Proteus', the narrator comments, 'particularly when my story as it unfurls will show the man to be more of a prophet than Proteus ...'. There are three levels of prognosis alluded to here: Proteus' prophecy about Apollonius' birth, Apollonius' superlative skill in prognostication, and the narrator's proleptic reference to that skill.

That said, there is one case of false actorial prolepsis on Apollonius' part, and it is significant. Usually it was Apollonius who confounded the expectations of others, ${ }^{39}$ but the Brahmans replied 'contrary to his anticipation' to his question on the subject of self-knowledge (3.18). This reinforces the sense of hierarchy between Indian and Apollonian wisdom. Comparably, Apollonius is normally the object, not the subject of 'wonder' (thauma), but he does wonder at the Brahmans. ${ }^{40}$

There is, however, one further, intriguing case of limitations in Apollonius' knowledge. When Apollonius visited the Ethiopian gymnosophists, Euphrates sent Thrasybulus ahead to slander him. The narrator reveals this (6.7), but - fascinatingly - it seems to have occurred unbeknownst to Apollonius. It was left to Damis to work out the truth when he heard Timasion's analeptic account of his meeting with Thrasybulus (6.9). Apollonius, however, found himself 'momentarily astonished' (ekplageis ... pros brakhu) by Thespesion's accusations against him (based upon the slanders), 'because he had not yet heard the truth about Thrasybulus and Euphrates' (6.13). On this occasion, it seems, his pow-

\footnotetext{
${ }^{38}$ For stylistic assimilation of the two see $S A G \mathcal{N}$ I:424.

39 Thus at 7.32 Domitian mistakenly looked forward to hearing Apollonius' confession of conspiracy with Nerva; at 8.8, the expectation of the court-room audience that Domitian will hunt after Apollonius was frustrated (Demetrius expressed a similar expectation at 8.13).

40 SAGN I:433-435.
} 
ers of omniscience deserted him, even though 'he guessed what had happened, as he usually did' (6.13). In this instance, the demands of the plot (for a narrative of secret connivance) seem to outweigh the demands for consistent characterisation of Apollonius as omniscient.

This exception, however, only points up the general rule, that Apollonius is characterised as omniscient, and thus as possessing an awesome ability with prolepsis and analepsis.

\section{Suspense}

I want to conclude with a brief discussion of the narrative technique of suspense, used most vividly in books 7 and 8 , and the trial of Apollonius before Domitian. This is framed, at the beginning of book 7 (I-2), with an account (in the narratorial digression mode) of a series of famous philosophers who confronted tyrants. This sets the framework of expectations for what will follow: a contest between two forms of power, intellectual-spiritual and political. The narrator tells us explicitly (7.I, 2) that Apollonius outdid each of these, and so the narratee is led to expect success. But there is no explicit statement at this point of the form that this success will take: victory in law, or noble martyrdom? Will Apollonius survive the confrontation with the most impressive figure in Rome's gallery of brutal and despotic tyrants?

The tension between foreknowledge and ignorance is manipulated throughout this episode. Apollonius foresaw his arrest, but keeps his intentions secret even from Damis (7.10). What is he planning to do? Demetrius and Damis are said to have tried to dissuade him from going to Rome by offering plausible excuses, and this cues a certain level of anxiety on the narratee's part; Apollonius predictably resists (7.III4). The anxious anticipation of Damis and Demetrius is a recurrent theme, and serves as a kind of false actorial prolepsis (7.38; 8.II, I3). They represent a certain kind of reading of the future, built around the axiomatic assumption of regular human society: the emperor always wins. Apollonius teaches us otherwise, but without ever thinking to allay their (or indeed our) fears.

When Apollonius was arrested, the emperor gained total control over his time. He and Damis were told to wait until he was ready (7.22); they were forewarned that they would see him on the following day (7.28); they are summoned to the court 'at the time of the filling of the market-place' (peri plèthousan agoran, 7.29; also 7.31); Apollonius 
eventually achieved his private hearing only when the emperor was at leisure $(s k h o l \vec{e})$, in the midst of the ritual time of a festival of Adonis (7.32). Subsequently, Apollonius was held for five days (7.40). When he entered court, attention is given to the length of time for which he is to speak, and to the priming of the clock (8.2).

So, the scene is set for a confrontation between two masters of time, one with the power to tell the future and the past, the other with the power to hold others in temporal rhythms of his own choosing. Before we reach the court, however, the narrator punctures the suspense: in a moment of narratorial digression discussing the sources for the court scene, he lets slip that 'he won his case and quit the court-room' (7-35). This narratorial prolepsis is marked by a characteristic statement of restraint and return to narrated time: 'but we are not yet in the courtroom ...'. It is too late, however, and the tension is gone. This is not, however, a moment of narrative failure, but a carefully controlled affront to our received sense of genre. It reminds us that we are not reading a conventionally exciting narrative. Of course we know-as if we ever doubted it - that Apollonius would win in the end. The Apollonius throughout hooks the reader's expectation of conventional, linear story-telling, but ultimately offers us a new form of narrative in which future and past (as well as parallel events) are all instantaneously knowable, at least to the avatars of cosmic wisdom. 
PART EIGHT

THE NOVEL 
Irene J.F. de Jong and René Nünlist - 978-90-47-42293-8 Downloaded from Brill.come4/26/2023 09:46:52AM via free access 


\section{GHAPTER TWENTY-SEVEN}

\section{GHARITON}

\section{J.R. MORgan}

The Greek novels vary considerably among themselves in their handling of time. The earliest of them, Chariton's Callirhoe, is already a highly competent work of fictional narrative, but in this respect, as in many others, it opts for a relatively simple approach.

The dramatic date of the fictional narrative is conveyed by the inclusion of historical characters, such as the Syracusan statesman Hermocrates and the Persian king Artaxerxes, but, although one might term this work an attempt at an 'historical novel', it does not completely avoid inconsistencies or anachronisms. ${ }^{1}$ There is nothing in the narrative itself to correlate it with real chronology, either in terms of historical events or through an internal calendar: the closest it comes to chronological specificity is at 3.5. I, where the Syracusans hesitate to send out their fleet in winter and would prefer to wait for spring, but are overruled by the hero's impatience to search for his beloved. The narration is subsequent, as in all the novels, but since the narrator is fictitiously constructed as a contemporary of the events he narrates, modelled in this as in other respects on the historian Xenophon, it is impossible to tell by how much the act of narration is conceived as subsequent. In a few places the narrator uses the present tense of circumstances and institutions still prevailing in his own time. ${ }^{2}$

The length of time covered by the story is not precisely quantified, but seems to be in the order of two or three years. That covered by the fabula is rather longer: an important and recurrent external analepsis looks back to the defeat of the Athenians by the Syracusans under the leadership of the heroine's father, Hermocrates, possibly some twenty years or so before the story begins; and an external prolepsis looks forward to the return to Syracuse of the heroine's son, an infant when

${ }^{1}$ For the concept of 'historical novel' and its applicability to Chariton, including his historical anachronisms, see Hägg 1987 .

${ }^{2}$ 5.I.3, 2.2, 4.5, 9.I; 6.8.6-7. 
the story ends, and so perhaps twenty years or so later. The spaces between these limits to the fabula and the beginning and end of the story are left unfilled. Within the time span framed by the beginning and end of the story, no time is left altogether un-narrated, though we are not always told what each of the protagonists was doing in a given period. The narrator frequently gives indications of the beginning and ending of days and nights, but longer, more rapidly narrated, periods are generally left vague. We are told at 3.7.7 that Callirhoe gives birth to Chaereas' son seven months after her marriage to Dionysius; we shall see shortly how the passage of this time is handled; and at 5.4 .4 an adjournment of thirty days before the case brought by Dionysius against Mithridates comes before the Great King passes in a single sentence. But more often the time taken, for example, in journeys is not specified, so that the sum total of the narrative's chronology remains impossible to calculate.

In terms of order too, Callirhoe is narrated in a relatively straightforward fashion. The primary narrator presents events, for the most part, in their chronological order: the story more or less reproduces the corresponding section of the fabula. The primary exception to a strictly chronological presentation derives from the technical problem of narrating events happening simultaneously in different plot-strands; we shall see that this occasionally requires some temporal back-tracking. Although the work contains numerous prolepses and analepses, both narratorial and actorial, they are, with only a few exceptions, internal ones. The analepses, in particular, generally summarise material already familiar to the primary narratee and rarely introduce significant new information. This is not to say that they are without function for characterisation or dramatic effect.

The one aspect of time which is not simple in this novel is rhythm. We shall see that the narrative is characteristically constructed as a series of scenes strung like pearls on a thread of summary. These scenes broadly correspond to the sections of the narrative designated by the passage of single days and night, and account for nearly ninety percent of the total text. $^{3}$

Within the broad outlines presented in these opening observations, let us now turn to a more detailed examination of time in Callirhoe.

\footnotetext{
${ }^{3}$ Hägg I97ı: 82.
} 


\section{Order}

This is a story that begins at the beginning and ends at the end, and delivers information chronologically to its primary narratee, who thus generally knows more than the characters. This disables surprise and suspense, but generates irony. A good example is the sequence towards the end of the novel where Chaereas and Callirhoe are finally reunited: Chaereas does not know the identity of his beautiful captive, but the events leading up to Callirhoe's capture and presence in Chaereas' camp have been fully narrated in their 'correct' place. It is easy enough to see how an anachronic presentation, with the 'truth' about Callirhoe being presented to the primary narratee only in retrospect as it became known to Chaereas, would have worked and what effects it might have produced.

There is, I think, only one major paralipsis that forms an exception to this characteristic mode. Near the beginning of the novel, Chaereas is tricked into believing his wife unfaithful and in a fit of violent jealousy kicks her in the stomach, leaving her apparently dead (I.4.I2). The primary narratee at this point is kept fully informed that she is in fact only unconscious. It is only later, however, that the narrator reveals that she was pregnant by Chaereas at the time of the attack (2.8.5). This surprising piece of information is disclosed only at the point where Callirhoe herself realises her condition, and it provides crucial motivation for her decision to marry another man in order to provide her child with a father.

On just a few other occasions, noted in the following section, information is presented for the first time in minor analepses, either narratorial or actorial, again as it becomes known to the characters rather than as it occurs, and thus serves as part of the apparatus of motivation.

\section{Analepses}

I noted above that virtually all of Chariton's analepses are internal ones, but let us begin by noting the one important event from before the beginning of the story that is constantly referred to. This is the defeat of the Athenian expedition by Syracuse under the leadership of Hermocrates. This event is mentioned by the primary narrator in the very first sentence of his narrative, as the defining mark of Hermocrates and hence his daughter Callirhoe. 
The Syracusan general Hermocrates, the man who defeated the Athenians, had a daughter called Callirhoe. ${ }^{4}$

Her father's eminence is so much part of the heroine's being that she uses it repeatedly at moments of difficulty as a way to assert her identity or point up the reversal of her position: for example, as the tombrobbers carry her over the sea to Miletus she exclaims:

'Father, in this very sea you defeated three hundred Athenian warships; a tiny boat has carried off your daughter, and you do nothing to help me.'

(I.II.2)

Memory of the defeat of Athens is also operative in other characters, as when the Persian King affects to want to take special care of Callirhoe out of gratitude to her father $(5.8 .8) .{ }^{5}$ Other events prior to the timeframe of the story are mostly disregarded. We are, for example, told nothing of the earlier experiences of the protagonists. Leonas tells the pirate Theron that Dionysius has recently lost the wife he loved (I.I2.7), but their life together and circumstances of her death are never mentioned.

A small number of internal analepses contain information hitherto unknown to the primary narratee. At 7.I.3-4, after Dionysius has left with the King to fight against the Egyptian rebels, Chaereas goes to his house. At that point, the narrator reveals that, before he left, Dionysius had instructed a servant to deceive Chaereas into believing that the King had adjudged Callirhoe to Dionysius as the price of his loyalty. This motivates Chaereas' desperate decision to join the war on the Egyptian side. On an earlier occasion (6.8.I-2), the chronologically displaced information that the Egyptians have murdered their satrap, elected a native king, and have already reached Syria and Phoenicia is presented in indirect speech as the contents of a message brought to the King at Babylon. The narrator narrates the reporting of events rather than the events themselves. Similarly the defeat and death of the Egyptian king is made known to the primary narratee only at the point where the news is delivered to Chaereas in direct speech (8.2.3). In none of these cases does the new information occupy more than a line or two of the text, and in the last two at least it concerns events that took place in a theatre at some geographical distance from that of the

\footnotetext{
4 Throughout the translation used is that of Reardon, in Reardon I989.

5 Cf. also 3. Io.6; 7.2.3, 5.8.
} 
main plot, which it would have been awkward and unnatural to include in its 'proper' place.

The remaining internal analepses fall into three main groups: a) major narratorial analepses; b) actorial analepses of a more or less neutral sort; c) lamentations, when characters review their experiences in a highly emotive manner. All three of these groups repeat what has already been narrated.

a) At the beginning of book 5 , that is at the exact half-way point of the text, the primary narrator inserts a detailed recapitulation (summary) of the story so far:

How Callirhoe, the most beautiful of women, married Chaereas, the handsomest of men, by Aphrodite's management; how in a fit of lover's jealousy Chaereas struck her, and to all appearances she died; how she had a costly funeral and then, just as she came out of her coma in the funeral vault, tomb robbers carried her away from Sicily by night, sailed to Ionia, and sold her to Dionysius; Dionysius' love for her, her fidelity to Chaereas, the need to marry caused by her pregnancy; Theron's confession, Chaereas' journey across the sea in search of his wife; how he was captured, sold, and taken to Caria with his friend Polycharmus; how Mithridates discovered his identity as he was on the point of death and tried to restore the lovers to each other; how Dionysius found this out through a letter and complained to Pharnaces, who reported it to the King, and the King summoned both of them to judgement - this has all been set out in the story so far. Now I shall describe what happened next.

(5.I.I-2)

There is a similar narratorial recapitulation at the start of the last book of the novel:

How Chaereas, suspecting that Callirhoe had been handed over to Dionysius, determined to avenge himself on the King and so went over to the Egyptian side; how he was appointed admiral and gained control of the sea; how after his victory he seized Aradus, where the King had placed his own wife for security, and along with her all his train and Callirhoe too - all of that has been described in the previous book.

Neither of these analepses serves any organic function in the story; they are communications directly between the primary narrator and the primary narratee. The first of them covers events from the beginning of the story to the end of book 4. Although there is clearly some selection and compression of incident taking place, the recapitulation covers the entire narrative so far in a more or less uniform way, with no major omissions, and no additions. The events are listed in exactly the same 
order as when they were first narrated, even to the extent of reproducing the slight anachrony caused by the narration of simultaneous events in two theatres. ${ }^{6}$ There is no re-interpretation or re-evaluation of the episodes mentioned, and they are viewed from the same external perspective. The second recapitulation is more limited in its scope, and covers only the events of book 7 . Here again, however, the order and perspective of the original narrative is reproduced. The major difference between the two passages is that the second combines its analepsis with the text's most detailed and significant prolepsis (to be discussed below), whereas the first moves only to a short and non-specific prolepsis.

These narratorial summaries are without parallel in our corpus of extant novels. Their phraseology ${ }^{7}$ imitates that of the summaries found at the beginning of most books of Xenophon's Anabasis (which may not be genuine but were already included in the text in antiquity), and thus they may be part of the intertextual construction of this narrator as a fictional Xenophon. On the other hand, it is clear that they also function as structural markers, each drawing a major section of the story to a conclusion and moving it forward to the next stage. Other functions, however, are not excluded. It has been suggested, for example, that these recapitulations indicate that Callirhoe was first published in serial form, or that they are signs of orality (or aurality). ${ }^{8}$ Such speculation aside, it is clear that they serve to remind the narratee of the crucial points of the story in order to avoid any incomplete understanding of its climactic moments, the trial at Babylon and the recognition and reunion of the two protagonists.

b) Of the actorial analepses, some are presented in direct speech, and a rather smaller number in indirect speech. An example of the latter is when Phocas is telling Dionysius about the destruction of Chaereas' ship:

Phocas told him about the sailor who had given him the informationwhere the ship was from, the purpose of their journey, who was on board; he told him also about his own tactics of involving the Persians

6 The experiences of Callirhoe are followed up to the point where she decides to marry Dionysius; at 3.2.17 the narrative jumps back in time to tell what happened to Chaereas during the same period.

${ }^{7}$ Especially the formula en tōi prosthen logōi dedèlotai ('has been shown in the previous account') at 8.I.I, X. An. 2.I.I; 3.I.I; 5.I.I; 7.I.I.

${ }_{8}$ Most recently in Hägg I994; S. West 2003. 
and about that night - how the ship was attacked and burned, and the crew killed or captured.

This repeats events narrated in 3.7.I ff. Again the order of the elements of the recapitulation corresponds to that of the primary narrative, and so does quite a lot of the wording. But in this case the events are focalised by a secondary internal narrator, who is ignorant of the fact that Chaereas and Polycharmus were taken alive and not killed. This omission produces a situation where Dionysius wrongly believes that his rival is dead, which is an important causative factor in the development of the subsequent intrigue. ${ }^{9}$

More frequently these actorial analepses are presented in direct speech, as part of one of the novel's scenes. One of the first occurs at 2.5.IO, when Callirhoe first tells Dionysius about herself:

'I am the daughter of Hermocrates, the Syracusan general. I had a sudden fall, and lost consciousness; and my parents gave me a costly funeral. Tomb robbers opened my tomb; they found me conscious again and brought me to this place, and Theron gave me to Leonas here in a deserted spot.' She told them everything else but said nothing about Chaereas.

$(2.5 \cdot 10)$

Again the order of the elements is the same as in the primary narrative, and no new information or even colouring is added. However, she does omit the central fact of her marriage to Chaereas, as explicitly noted by the primary narrator. The function of this passage, and others like it, ${ }^{10}$ is to clarify how much of the story a character (in this case Dionysius) knows, and to highlight any gaps or errors in that knowledge.

c) Special mention must be made of the soliloquies, prayers and conversations in which protagonists lament their fates. A recurrent element of these speeches is a tendentious and partial review of the character's experiences. No new factual material is added, but events which have already been narrated are subjected to new and subjective interpretations. Since the plot-function is not to inform anyone but to express emotion and character, it is natural for a rather freer approach to

9 Similar actorial analepses in reported speech at 2.4.3; 6.7.I; 8.1.4, 5.7.

10 2.I.3-4, 8-9; 3.4.6, I3-I4; 3.9.I-3, I0.2; 4.3.I-5, 5.8; 5.9.4-5, I0.7; 7.2.3-4; 8.I.I6I7, 7.3 ff., 7.9-8.II. The last case is the most extensive, as the protagonists re-narrate pretty well the entire novel to the Syracusan assembly. The plot-function of this is to motivate the festivities with which the story concludes, but in this case the length of the analepsis suggests that the recapitulation is also partly for the benefit of the primary narratee, who now at last can see the unity of the plot. 
chronology and even accuracy to be taken. Here is the lamentation of Callirhoe, after she has been sold to Dionysius' steward. It is obvious that the interpretation of her experiences implicit in this enumeration of them differs from that of the primary narrator and expresses her character in a particularly distressing situation:

'First you [sc. Fortune] made my lover my murderer - Chaereas, who had never even struck a slave, kicked me and killed me, me who loved him; then you gave me into the hands of tomb robbers and brought me out from the tomb on to the sea, and set over me the pirates, who were more frightening than the waves. My celebrated beauty I was given to this end that the brigand Theron should get a high price for me. I have been sold in a deserted spot and not even taken to a city like any other bought slave-Fortune, you were afraid people might see me and think me nobly born! That is why I have been handed over like a mere chattel to I know not whom, Greeks or barbarians or brigands once more ... Truly I am lost to you, Chaereas, separated from you by so vast an ocean! You are mourning for me and repenting and sitting by an empty tomb, proclaiming my chastity now that I am dead; and I, Hermocrates' daughter, your wife, have been sold this day to a master!'11 (I.I4.7-IO)

\section{Prolepses}

The vast majority of prolepses in Callirhoe are internal. But just as there is persistent looking back to Hermocrates' defeat of the Athenians, there is one event beyond the end of the story which is referred to several times: the return of Callirhoe's son to Syracuse and the greatness he will achieve there. ${ }^{12}$ The historical identity of this child is never specified, but Chariton may be trading on his audience's knowledge of the importance of people named Dionysius in the history of fourth-century Syracuse. In other words, the prominent external analepses and prolepses both serve to anchor the fictional plot more firmly in perceived historical reality.

In addition the novel ends with an external actorial prolepsis, as Callirhoe prays to Aphrodite for a happy life together with Chaereas. ${ }^{13}$ Formally, of course, the text offers no sign whether this wish comes

11 Comparable lamentations at I.8.3-4; 3.8.9, I0.4-8; 4.I.II-I2, 3.I0; 5.I.4-7, 5.2-3, Io.6-9; 6.2.5-8, 6.2-5; 7.5.2-5.

12 2.9.Iff.; 3.8.8; 8.4.5, 5.15, 7.12.

13 8.8.r6: 'I do not blame you, lady, for what I have suffered; it was my fate. Do not separate me from Chaereas again, I beg of you; grant us a happy life together and let us die together!' 
true or not; but the implication of its placing, in conjunction with the generic happy ending, is that the protagonists will share a happy lifetime together after the end of the story, and that the story ends when it does because nothing narratable happens to them again. ${ }^{14}$

The internal prolepses of this novel fall into six broad categories: a) explicit narratorial prolepses, on various scales; b) narratorial references to the decisions of gods, etc., which carry the implication of certain fulfilment; c) various foreshadowing devices, such as dreams and omens (there are no oracles in this novel); d) actorial prolepses, when characters think, as they often do in this text, about the future; much of what they say is wishful thinking, which nevertheless delineates the paths that the story might take, and is sometimes actually predictive; e) seeds, that is to say, details that will be important in the development of the plot but whose significance is not necessarily immediately apparent; f) intertextual analogues whose parallel to the story provides implicit predictions.

a) A clear example of a simple narratorial prolepsis occurs at I.6.5 in connection with Callirhoe's funeral:

And what was done with the intention of paying honour to the dead girl started a train of greater events.

The 'train of greater events' begins immediately, as Theron sees the wealth being entombed with the apparently dead heroine and conceives his scheme of robbery, which in its turn leads directly to the separation and adventures of the protagonists. Thus the prolepsis encompasses the whole of the story, but its lack of specific detail gives away nothing beyond the fact that a story is about to happen; the primary narratee must continue reading to form any idea at all of the great events that will come to pass. The positioning of this prolepsis is clearly strategic: the novel appears to have lost its heroine, against all the rules of the genre, within the first few pages; but the prolepsis provides a formal reassurance that this is not the end of the story.

This passage is, however, not typical of Chariton's technique. Later narratorial prolepses tend to be of a rather shorter range and function to move the story forward into its next episode; we seem to be dealing with the 'header' technique, also found in Homer $(\rightarrow)$ or Pindar $(\rightarrow)$.

\footnotetext{
${ }^{14}$ In a sense, then, all these novels end generically with an external prolepsis: 'and they lived happily ever after'.
} 
For instance, when Mithridates is perishing of love for Callirhoe, the narrator says:

He would have perished altogether if he had not found consolation in the following way ...

And then moves directly into the events that brought him the consolation - the discovery of Chaereas among his slaves. On other occasions, the narrator looks forward not to events but to the future of his own act of narration; we are dealing with a cross-reference rather than a prolepsis. This is another technique for moving the story forwards, without disclosing any significant details. We have already seen how the major analepsis at the very centre of the text (5.I.I) turns at its close to such a cross-reference ('Now I shall describe what happened next'). There is a similar effect at the point when the narrator makes the first major switch between the two story-lines of the central part of the story (3.2.17):

But once more, even on that day, the evil spirit vented his spite. How he did so I shall tell you shortly; ${ }^{15}$ first I want to relate what happened in Syracuse during the same time.

b) In this last example the narrator's cross-reference is combined with a statement about divine activity. There is a similar combination in the novel's lengthiest and most interesting proleptic passage, which occurs at the beginning of the last book, again in combination with a major and explicit analepsis:

But Fortune was minded to do something as cruel as it was paradoxical: Chaereas was to have Callirhoe in his possession and fail to recognise her; while taking others' wives on board of his ships to carry them off, he was to leave his own behind, not like Ariadne asleep, and not for Dionysus to be her bridegroom, but as spoils of war for his own enemies. But Aphrodite thought this too harsh; she was growing less angry with him. At first she had been incensed by his misplaced jealousy: she had given him the fairest of gifts, fairer even than the gift she had accorded to Alexander Paris, and he had repaid her kindness with arrogance. But now that Chaereas had made honourable amends to Love, in that he had wandered the world from west to east and gone through untold suffering, Aphrodite took pity on him; having harassed by land and sea

15 This promise is not exactly fulfilled: in the first place the section of the story occupied with events in Syracuse (the Chaereas strand) is not short; and when the Callirhoe strand is eventually resumed the activities of the 'evil spirit' are not mentioned. Nonetheless the prolepsis is not felt or intended as a false one, and its effect is still to move the narrative into a new section. 
the handsome couple she had originally brought together, she decided now to reunite them. And I think that this last chapter will prove very agreeable to its readers: it cleanses away the grim events of the earlier ones. There will be no more pirates or slavery or lawsuits or fighting or suicide or wars or conquests; now there will be lawful love and sanctioned marriage. So I shall tell you how the goddess brought the truth to light and revealed the unrecognised pair to each other.

(8.1.2-5)

Here, uniquely in this novel, the narrator gives a detailed and explicit prolepsis of events to come, looking forward over the whole of the eighth book. The narratee is left in no doubt that the story is going to end happily, although the precise mechanism by which it will reach the required conclusion remains the object of some suspense. But we may note that here, in the latter part of the extract quoted, the prolepsis is combined with a cross-reference: we hear not so much of the events themselves as of the telling of them by the narrator. And the first part of the extract concerns the thoughts and intentions of two deities, Tyche and Aphrodite. Although these concern the future and their proleptic truth is implicitly guaranteed, nonetheless the thoughts themselves arguably come in approximately the appropriate chronological place. In this way Chariton contrives to have his cake and eat it: he can exploit the literary effects of prolepsis while formally respecting the strictly chronological order his narratorial persona demands.

It is, then, characteristic that the greatest number of Chariton's prolepses is associated in some form with divine activity. This technique is employed as early as the first chapter of the narrative, when, after the introduction of the heroine, we are told:

But Eros intended to make a match of his own devising ... Eros likes to win and enjoys succeeding against the odds. He looked for his opportunity and found it as follows.

(I.I.3-4)

This looks forward to the first encounter and instant inamoration of the protagonists. Later in the story, this kind of prolepsis is used to introduce a plot-twist or move the story on to its next phase. So, for example, when Callirhoe prays at the temple of Aphrodite near Miletus that she should be attractive to no one but Chaereas,

Aphrodite refused her prayer. After all, she is the mother of Eros, and she was now planning another marriage - which she did not intend to preserve either.

This refers to Callirhoe's relationship with Dionysius, whom she will reluctantly marry to provide a father for Chaereas' child. But the last 
clause looks much further forward, to Dionysius' loss of Callirhoe. It seems clear enough that the divine prolepsis, here as elsewhere, inscribes the narratee's sense of generic propriety: it is unusual enough for a romantic heroine to commit bigamy, but it would be quite unthinkable for her not to be reunited eventually with her true love; without being specific about details and dissipating the narratee's curiosity, the intrusion of Aphrodite provides a reassuring guarantee that the fiction will ultimately comply with the romantic norms. On the other hand, personified Fortune intervenes to thwart those same generic expectations, as in this passage leading to Callirhoe's discovery of her pregnancy:

Fortune outwitted her, though; Fortune, against whom alone human calculation has no power. For Fortune relishes victory, and anything may be expected of her. So now she brought about an unexpected, indeed incredible state of things. How she did it is worth hearing. Fortune laid her plot against Callirhoe's loyalty to her husband.

$(2.8 .3-4)$

This passage is in delicate balance with the previous quotation. Neither reveals anything very specific about the way the story will go; but the medium-term threat to Callirhoe's loyalty to Chaereas has to be read against the longer-term assurance that her second marriage will not survive. These carefully staged and limited glimpses of the future guide the narratee's expectations and responses. ${ }^{16}$

c) Unlike other novels, Callirhoe contains no formal oracles. There is one case of favourable omens from a sacrifice (8.2.9), when Chaereas makes an offering to Aphrodite at Paphos, which both foreshadow and prompt the return of the protagonists and their companions to Sicily. Nor does the novel make use of elaborately predictive dreams. Though its dreams are implicitly god-sent and authoritative, they are often used to motivate action in the short-term rather than provide previews of long-term plotting. Two partial exceptions are provided by complexes where the dream is interpreted within the narrative frame. In the first, Dionysius dreams of his first wife:

'she was taller and more beautiful - I saw her there beside me as clearly as if I were awake. In my dream it was the first day of our married life;

\footnotetext{
${ }^{16}$ Further proleptic uses of divinities at I.I.I 6 ; 3.2.I7, 3.8, 3.I2, 4.I0; 4.5.3; 8.3.6. The powers in question (Aphrodite/Eros, Fortune, Providence) are easily read as metanarrative embodiments of important elements of the romantic genre.
} 
I was bringing her home after our wedding, from my estate by the sea, and you were singing the wedding song.'

This foretells in fact Dionysius' second marriage to Callirhoe, who also comes to his house from his seaside estate, and surpasses all women in beauty. This interpretation is immediately advanced by Dionysius' major-domo, Leonas, who has just purchased Callirhoe with the intention that his master should fall in love with her. Similar is $5.5 \cdot 5$, where, just before the court at Babylon goes into session:

she saw herself in Syracuse entering Aphrodite's shrine, still a maiden; then returning from there and seeing Chaereas and her wedding day. She saw Syracuse all decked out with garlands and herself being escorted by her father and mother to the bridegroom's house. She was on the point of embracing Chaereas when she suddenly started up from her dream.

$(5 \cdot 5 \cdot 5)$

When she tells her servant Plangon of this dream she is told that it is good and will 'happen in reality'. The prolepsis is double: it both foreshadows the unexpected reappearance of Chaereas in the courtroom, ${ }^{17}$ and looks forward to the return of the couple of protagonists to Syracuse at the very end of the novel, when their first wedding will be as it were re-enacted. ${ }^{18}$

d) It is difficult to generalise about actorial prolepses in this novel, as many characters think at various moments of their hopes and wishes for the future. The extent to which these cases accurately foreshadow the future varies enormously, as does their authority. So, for example, when Dionysius, after a first rebuff from Callirhoe,

did not give up hope of winning Callirhoe over; Love is naturally optimistic, and he was confident that by attention to her he could achieve his desires,

we can easily see that his hopes are unlikely to come to fruition, because we know of Callirhoe's unshakeable devotion to Chaereas. So although Dionysius, at the level of character, intends this to be a true prolepsis, at the level of the primary narrator and narratee this is a false prolepsis, more significant as an index of character than as a narratological device. On the other hand, a character's thoughts

17 Unexpected to Callirhoe, that is. The primary narratee knows that Chaereas has come to Babylon with Mithridates, and so is better placed to interpret the dream than the characters themselves.

${ }_{18}$ Other dreams, at I.I2.5; 2.3.5, 9.6; 4.I.I; 8.2 .9 are harder to classify as proleptic. 
about the future can sometimes be used to signal a possible course that the story might take, and so dramatise the issues involved. A good example of this occurs in 2.9.I ff., where Plangon and Callirhoe develop diametrically opposed strategies for the future based on the fact of Callirhoe's pregnancy: Plangon foreseeing that it is exactly the tool needed to persuade Callirhoe to marry Dionysius, while Callirhoe first considers abortion, and then at length imagines a son like his father who will regain his rightful place in the world and sail back to Syracuse to rediscover his true family. Neither exactly foreshadows the future, though both correctly foresee some elements of it: the point rather is that the conclusion of the second book uses these partial prolepses to delineate a problem which the next book will resolve.

On other occasions, however, the actorial prolepsis serves to predict the future pretty accurately, although one might argue that the primary narratee is not in a position to judge their accuracy, except in retrospect. To take just two examples, both connected with Dionysius. Soon after falling in love with Callirhoe, he is reluctant to take her back to the city,

because when people saw her, they would all talk about her, her beauty would enslave the whole of Ionia, and report of her would reach the Great King himself.

And later, when she has agreed to marry him, he again ponders whether to celebrate a hasty marriage in the country, or do it in style in the city:

'Even now Rumour is rushing to carry to Sicily the strange news that Callirhoe is alive - tomb robbers opened her tomb and carried her off, and she has been sold in Miletus! Syracusan warships will soon be descending on us with Hermocrates in command, demanding his daughter's restoration. What am I to say? "Theron has sold her to me." "Theron? Where is he?" Even if they believe me, am I to tell them the truth - that I receive stolen goods from a pirate? Practice your defence, Dionysius; you may have to plead it before the Great King.'

Elements of this passage prefigure the development of the story with uncanny accuracy, before there is ever any suspicion of the Great King becoming involved in the intrigue. But, even once their accuracy is recognised retrospectively, the primary effect is ironic: Dionysius is arguing that a formal wedding in town is less likely to spawn disastrous rumours, but in the end his decision to marry Callirhoe in Miletus produces exactly the results he here attributes to the alternative course of action. 
d) Chariton's novel is not rich in seeds. Here we shall briefly note just one: the temple of Aphrodite near Miletus. The seed is first planted in I.I4, when Leonas is awestruck by Callirhoe's appearance, because it is local belief that Aphrodite manifests herself in the area. Later, Plangon advises Callirhoe to go to Aphrodite's shrine to pray, and it is on her second visit there that Dionysius first sees her, and falls instantly in love, and later it is his chosen site for the first attempt to woo her. Because the place holds such special meaning for him, he dedicates there a golden image of Callirhoe, which is duly encountered by Chaereas when he lands by chance in the same locality, and becomes the means through which he learns that Callirhoe has married for a second time.

e) In a broad sense all the Greek novels are built on the foundations of the Odyssey and the plots of Athenian New Comedy. These guarantee generically the way that plots will achieve closure. But within the genre of romance, Chariton is particularly adept at exploiting intertextual parallels as a way of controlling the realisation of his text. The insertion of whole lines more or less verbatim from the Homeric poems confirms parallels between Callirhoe and the two Homeric heroines, Helen and Penelope. ${ }^{19}$ Like Helen, Callirhoe has two husbands, the second in Asia and the first in Greece, who comes to reclaim her. As soon as the pattern is recognised, it provides an implicit prolepsis of the ending of her story: as Helen returned to Menelaus, so eventually Callirhoe is certain to return to Chaereas. ${ }^{20}$ And like Penelope she remains ambiguously faithful to her husband, despite the existence of other claimants to her hand; here the implicit prolepsis is of return and reunion.

However, Homeric intertexts also provide more explicit and shorterterm prolepses. For example, at 6.2.4, when Artaxerxes is thinking about how he can take Callirhoe for himself, the narrator quotes a line from the passage of the Iliad where Agamemnon is confronted with the question of returning Chryseis to her father. The parallels between the two situations - a great king who desires a woman who is in some sense forbidden to him - already hints that Artaxerxes' passion for Callirhoe

19 The Homeric quotations and their functions are discussed in J.R. Morgan 2007, with references to G.W. Müller i976; Laplace I980; Fusillo I990; Manuwald 2000; Hirschberger 200I.

${ }^{20}$ The parallel is double-edged, however. At 5.2.8 Dionysius ponders on the story of Helen, casting himself in the role of Menelaus. The analogue leads him to fear that there will be some Paris among the Persians, who will steal his wife from him. 
will end in much the same way as Agamemnon's for Chryseis, in other words that he will eventually relinquish her. ${ }^{21}$

Homer is not the only source of such proleptic parallels. One simple example occurs at I.6.2, when the apparently dead Callirhoe is compared to the sleeping Ariadne. The comparison speaks to the narratee, who knows that she is merely unconscious, prefiguring her awakening. And in a sense that no first-time reader would perceive, the fact that Ariadne, after being treated badly by her first husband, becomes the bride of Dionysus, foreshadows Callirhoe's second marriage, to a man named Dionysius. ${ }^{22}$

\section{Simultaneity and parallel storylines}

Hägg has calculated that Chaereas and Callirhoe are separated for about eighty percent of the narrative. ${ }^{23}$ After Callirhoe is stolen from the tomb by Theron and his gang, the narrative stays with her until the point where she decides to marry Dionysius, when the narrator wrenches the story back to Chaereas in Syracuse (3.2.17, quoted above). $\mathrm{He}$ then narrates what Chaereas has been doing during this time. The same time period (around two months) is thus narrated twice over, but with no repetition of material. This technique, however, is exceptional. The narrative stays with Chaereas until the end of 3.6, and it is in the following chapter that Callirhoe gives birth to her son, seven months after marrying Dionysius. The impression given is that the events centring on Chaereas have taken up those seven months, during which time Callirhoe's position has been more or less stable. At 4.2.I there is another transition from Callirhoe back to Chaereas, which indicates that Chaereas' position has not materially altered since the last time he was the centre of attention.

So Callirhoe was burying Chaereas in Miletus while Chaereas was working in Caria in chains. He was soon physically worn out ... ${ }^{24} \quad$ (4.2.I)

${ }^{21}$ On this see Biraud I986.

22 Allusions linking Callirhoe to Ariadne occur also at 3.3.5; 4.I.8; 8.I.2. The last of these examples (quoted above) finally negates the parallel, and makes the play on the names of Dionysus and Dionysius most obvious.

${ }^{23}$ Hägg 1971: I40.

${ }^{24}$ Note that the Greek text here has a simple men ... de antithesis, without the explicit temporal correlation of the English 'while'. 
The imperfect eirgazeto ('was working') covers a continuous and unchanging state of affairs stretching to when Chaereas was last seen. Now the narrative continues, from the moment the attention leaves Callirhoe, and things start to happen again with Chaereas. Hägg ${ }^{25}$ likens the procedure, which is found from Homer $(\rightarrow)$ onwards, to a relay race: 'first one person, then the other is responsible for the action narrated, but the same stretch of time is not traversed more than once'.

\section{Rhythm}

Forty-four percent of Chariton's text is taken up with direct speech, which finds its characteristic home in 'scenes', where the pace of the narrative slows right down, and events are presented almost dramatically, as if playing out in real time. These slower narrative sections, which occupy (on Hägg's calculation) some ninety percent of the text, are generally meticulously marked by the passage of days and nights. The 'scenes' are connected by rapidly narrated stretches of longer time. The alternation of summaries and scenes is what one finds in most narratives, of course, but it is particularly conspicuous in Chariton, as his summaries are very summary and his scenes very extended. This feature of Chariton's narrative has been subjected to detailed analysis by Hägg, ${ }^{26}$ and the present treatment can do no more than restate and exemplify his conclusions.

To take just one example, from the point where the narrative switches back to Callirhoe in 3.7.I. The incident where Chaereas' ship is ambushed and destroyed by the Persian garrison acting on a tip-off from Dionysius' steward Phocas, although of great importance in the story, is disposed of in fewer than twenty lines of text. A dream of Chaereas appears to Callirhoe, and although some words are spoken, the narration is still brief. As a result of the dream Dionysius is much perturbed, consoles his wife and watches over her 'for many days' (3.7.7). Callirhoe's child is born, and she quickly recovers from the birth (3.8.3). At a public ceremony to celebrate, the pace slows. The text presents Dionysius' prayer to Aphrodite, followed by Callirhoe's, a dialogue between Callirhoe and the priestess of the temple about the two strangers who had recently visited the temple. The pace picks up

\footnotetext{
25 Hägg I97ı: I5I.

26 Cf. also Reardon ig89: i , for a summary of Hägg's findings.
} 
again momentarily, as Dionysius becomes jealous, and then slows down for another scene, when he interviews Phocas, learns about the ship, reacts emotionally, interrogates Phocas in detail, and, after corroborating Phocas' story, tells Callirhoe what he has learned. She laments at length, and the day that began with the ceremony only finishes at the beginning of book 4 . This patterning of alternating rapid and slow narration persists throughout the novel, and is clearly designed to throw the story's emotional climaxes into relief. The scene par excellence of this text is the trial at Babylon, which is presented in great detail, with full presentation of rhetorical speeches on both sides.

Scenes without direct speech are less common. Hägg singles out the narrative of the royal hunt (6.4.I-6), where vivid descriptive details, of the kind lacking from most of the narrative, abound. ${ }^{27}$ Chariton, however, never completely pauses his narrative for a descriptive excursus.

\section{Frequency}

Frequency is not really much of an issue for Chariton's simply narrated novel: the singulative mode predominates massively. Repetition is confined to the analeptic summaries discussed above. There are one or two cases where Chariton appears to be engaging in iterative presentation, though he does not mark it specifically as such. The clearest example is at I.II.I-4, which covers the voyage in Theron's ship from Syracuse to Athens. The voyage itself passes in a line or two, though it takes several days. But in the course of it, Callirhoe laments her fate, in direct speech. The narrative resumes:

While she was lamenting her lot in this fashion, the brigands were sailing past small islands and towns.

(I.II.4)

We are hardly intended to assume that her lament lasted the whole of the voyage, or that she only voiced her sorrows once. It is easier to assume that the short speech contained in the text is intended as a representative instance of repeated behaviour, and that a single example is narrated to stand for many. ${ }^{28}$

27 Hägg i97ı: 93 .

28 Another possible example of iterative presentation is the account of the thoughts of Mithridates before he departs for Babylon (4.7.2). 


\section{Conclusion}

Chariton's handling of time is thus relatively simple, but the apparent simplicity masks an assured competence and sense of effect. His novel offers an informative comparison, in one direction to the more unsophisticated Xenophon of Ephesus, and in the other to the self-conscious non-linearity and complexity of the later novelists. 
Irene J.F. de Jong and René Nünlist - 978-90-47-42293-8 Downloaded from Brill.come4/26/2023 09:46:52AM via free access 


\title{
XENOPHON OF EPHESUS
}

\author{
J.R. MORgan
}

In many important respects Xenophon's handling of time is like Chariton's $(\rightarrow)$. For the most part this is a straightforward narrative in chronological order, but the author's ambition to cram as much sensational incident into as short a compass as possible has led to some difficulties and oddities. It must remain an open question to what extent if any this is due to the status of the text that we have. Arguments that our version of the Ephesiaca is an epitome have been vigorously rebutted, but the sense remains for many readers that something fuller and more satisfactory lurks behind the extant text. ${ }^{1}$

The narration is subsequent, but further precision is impossible. Whereas Chariton $(\rightarrow)$ locates his story at a fairly precise date in the past and links it to historical figures, Xenophon's is in temporal free-fall. There is no attempt to set a dramatic date: some institutions appear to belong to the imperial period, but probably represent no more than a default-setting reflecting the world familiar to author and his readers. ${ }^{2}$ Rome is conspicuous by her absence, even when the action briefly moves to Italy. There is no reference to any historical figure or event. The narrator never speaks of his own time as distinct from that of the story.

The total time span covered by the story is similarly vague. Hägg has counted sixty days identifiable by temporal markers. ${ }^{3}$ In a few cases the days are clearly marked as consecutive, ${ }^{4}$ but most of the action takes place on single-day units separated by unspecified periods of time. In

1 The fullest statement of the epitome theory is Bürger I892; for rebuttal see Hägg [ig66] 2004.

2 The presence of an eirenarch, police officer (2.13.3; 3.9.5), is conventionally used as evidence for the date of composition, but cf. O'Sullivan i995: 4-9. Xenophon's Egypt is governed by an archon who seems a bit like a Roman prefect, but who has a relative with a Greek name.

${ }^{3}$ Hägg 1971: 58-59. I am greatly indebted to the whole of his discussion.

${ }^{4}$ So e.g. tề deuterai ('on the next day', I.I2.3). 
only a few cases is a precise length of time mentioned, such as the ten days it takes Habrocomes and Hippothous to travel to Mazacus (3.I.2), or the thirty days for which Perilaus promises to keep his hands off Anthia and whose expiry is marked at 3.3.7. Generally Xenophon will cover these intervening periods with a formula such as 'for many days' (pollais hèmerais, e.g. 2.7.I) or 'for a long time' (epi polu, e.g. I.5.2) or 'as time went on' (khronou dielthontos, e.g. 5.7.I). In this way, the whole time span of the story is covered, but, as the action is for most of the novel divided into two separate narrative strands, there are frequent temporal gaps in each of them, during which action must occasionally be presumed to have taken place. ${ }^{5}$

The story mostly follows the order of the corresponding part of the fabula, although, as we shall see, Xenophon's technique for handling simultaneous or parallel narrative produces some vagueness at transitions. We are told nothing of the lives of the protagonists before the story begins. ${ }^{6}$ Two (heterodiegetic) analeptic narratives delivered by secondary characters must relate to a time prior to the beginning of the story, with which neither has any organic connection. The first is Hippothous' account of his youthful love for Hyperanthes (3.2.I). The period separating these events and the narration of them is altogether unclear: there is no indication of Hippothous' current age. The second is the story of the fisherman Aegialeus, in which he recounts his elopement with the woman whose embalmed corpse he keeps in his bedroom (5.I.4-II). These events took place while he was an ephebe and are narrated when he is an old man, and so his narrative extends the fabula back a generation before the beginning of the story. The endpoint of both story and fabula of the novel is provided by the following closure:

They [Anthia and Habrocomes] themselves hereafter were living [diègon], leading their life together as a festival. Leucon and Rhode shared everything with their companions; and Hippothous too decided to spend the rest of his life in Ephesus. He now erected a great tomb for Hyperanthes in Lesbos, and adopting Cleisthenes as his son, he was living [diegenen] in Ephesus with Habrocomes and Anthia. ${ }^{7}$

${ }^{5}$ So at 3.9.2 Habrocomes' journey from Mazacus to Tarsus has been made unnarrated during the preceding section focussed on Anthia.

${ }^{6}$ Anthia's narrative of a traumatic experience in a graveyard is a fiction to account for the epilepsy she feigns to avoid service in a brothel (5.7.4-9).

7 The translation used is that of G. Anderson in Reardon I989. 
Even here there is indeterminacy: the two imperfects diēgon and diegen terminate the fabula at an unspecified point shortly after the end of the story, while their life together is still continuing, but stop short of including the whole of their lives.

\section{Order}

For the most part the narrative is chronological. The single significant anachrony is worth discussion. At 2.13.8 Anthia extracts an oath from Perilaus to wait thirty days before the marriage to which she has been forced to agree. After a passage centred on Habrocomes, the text returns to Anthia with the comment that 'the thirty days had passed and Perilaus was making preparations for the wedding'. ${ }^{8}$ At this point the narrator introduces a new character:

While Anthia, taken from the robbers' lair [lacuna], an old doctor from Ephesus called Eudoxus arrived in Tarsus. He had been shipwrecked on a voyage to Egypt. This Eudoxus went round all the local aristocracy of Tarsus, begging for clothes or money and describing his misfortune; among them he approached Perilaus in turn and told him that he was an Ephesian and a doctor by profession. Perilaus took him and brought him to Anthia, thinking she would be glad to see someone from Ephesus. She was sympathetic to Eudoxus and tried to find out whether he could tell her anything about her own family. But he told her that he knew nothing, since he had been away from Ephesus for a long time. But Anthia was still pleased to see him, since he reminded her of the people back home. And so he had become a familiar visitor to the household and came to see Anthia each time, enjoying every comfort and always asking her to send him back to Ephesus, for he had a wife and child there.

$(3 \cdot 4 \cdot \mathrm{I}-4)$

It is clear that Eudoxus arrived at Tarsus and became familiar with Anthia during the thirty-day period which was formally concluded in the previous chapter, and that this is therefore a narratorial completing analepsis. The next chapter begins with more analeptic pluperfects:

8 3.3.7. The pluperfect parelēluthesan ('had passed') and imperfect pareskeuazeto ('was preparing'), re-establishing Anthia's situation by looking back into the period when her strand of the story has been out of camera shot (and in the case of the imperfect introducing a new piece of information), are characteristic of Xenophon's technique for handling transition between the two story-lines. 
Now when Perilaus had made all the preparations for the wedding, and the day had arrived, a sumptuous dinner was ready for them, and Anthia had been dressed in a bridal dress. But she did not stop weeping night or day, but always had Habrocomes before her eyes

It seems that the day which has now arrived is not the expiry of the thirty-day delay but the end of a further period of preparation, during which Anthia has been weeping continually. The pluperfects look back into a time span which has been occluded by the analepsis about Eudoxus. The anachronicity of this section is unparalleled in Xenophon, and seems to serve no particular purpose. As it could easily have been avoided by narrating the arrival of Eudoxus in its 'proper' place, we may be looking at a careless piece of work by an epitomator who was slow to realise the importance of Eudoxus and had to insert an explanation of his identity and presence.

\section{Analepses}

This novel lacks the extended narratorial repeating analepses so prominent in Chariton $(\rightarrow)$. The most important function of narratorial analepsis is to effect transitions between and co-ordinate the separate narrative threads. The characteristic procedure (already glimpsed in the passage about Eudoxus) is to end a section of narrative with a brief repeating analepsis, summarising the position in which the one protagonist is about to be left, and to begin the next with another brief repeating analepsis, with the verb in either the pluperfect or the imperfect tense, summarising the position in which the other protagonist was left at the end of the last section but one. This technique is treated in more detail in the section on simultaneity below.

Actorial analepses are much more frequent, in both direct and indirect speech. ${ }^{9}$ They often have a clear argument function, when action is motivated by the communication of information from one character to another. So, for example, when, in search of Anthia, Habrocomes comes to

the estate where Anthia had been living with Lampon the goatherd, who had been given her as a wife by Manto, he took him along the shore and asked Lampon to tell him if he knew anything about a girl from Tyre. The goatherd said that her name was Anthia; he told him about the

9 These are fully discussed by Hägg I97ı: $267-277$. 
marriage and how he had respected her; he told him about Moeris' love, the order to execute her, and the journey to Cilicia. And he said that the girl kept talking about someone called Habrocomes. Habrocomes did not say who he was but got up at dawn and rode for Cilicia, hoping to find Anthia there.

$(2.12 .2-3)$

This repeats material from the immediately preceding chapters, of which the primary narratee hardly needs reminding, but it motivates Habrocomes' trip to Cilicia. ${ }^{10}$

There are cases, on the other hand, where these actorial repeating analepses serve no particular argument function. For instance, at the beginning of the third book Habrocomes and Hippothous exchange narratives. Hippothous tells about his youthful love-affair in a long external analepsis. Habrocomes' reply is succinctly conveyed in indirect speech:

Habrocomes told him that he was an Ephesian and that he had fallen in love with a girl and married her; he mentioned the prophecies, the voyage, the pirates, Apsyrtus, Manto, his imprisonment, his flight, the goatherd, and the journey to Cilicia.

The sense of shared misfortune cements the friendship between the two characters, but most of what Habrocomes says is a simple list, in chronological order, of the main points of his part of the action: it is not important for the plot that Hippothous should know these particular details. ${ }^{11}$ Hippothous does now tell his new friend about the beautiful girl he had captured not long before, in whom Habrocomes immediately recognises Anthia, but there was nothing in Habrocomes' analepsis to prompt this revelation. It may be that these actorial analepses are intended to help the primary narratee keep track of the rapidly alternating plot strands. Hippothous' account of his encounter with Anthia is worth dwelling on. It repeats events recounted by the primary narrator in the second book, but with significant differences of focalization: most importantly he is ignorant of Anthia's identity. But Hippothous is the one character who features in both story-lines, and

${ }^{10}$ On the other hand, the brief narratorial repeating analepsis identifying Lampon ('who had been given her as a wife by Manto'; verb in the pluperfect tense) looks slightly further back, across a short episode centred on Habrocomes to Anthia's forced marriage at 2.9.4. This clearly is a prompt for the primary narratee: possibly a feature of oral style; or a hint that there was once a version where the intervening episode was longer.

${ }^{11}$ In fact the same details tend to return stereotypically in these actorial analepses. 
his role as a bridge between them is exemplified in the way that he conveys information here.

Another actorial analepsis that clarifies things for the primary narratee concerns the secondary characters Leucon and Rhode, servants of Habrocomes and Anthia, with whom Habrocomes is eventually reunited in Rhodes. Their account of their experiences is briefly expressed in indirect speech, but brings together widely separated episodes:

... and told their own story - their journey to Syria from Tyre, Manto's anger, the disposal, the sale to Lycia, their master's death, their wealth, their arrival in Rhodes.

This is not quite in chronological order, since Manto's anger was the cause of their being sent to Syria and then disposed of for sale; this anger is already known to Habrocomes, and there is no reason for them to tell him about it.

The fullest analepsis occurs at the climax of the novel. The protagonists have been reunited and in bed Anthia tells Habrocomes of her experiences:

'I have found you again, after all my wanderings over land and sea, escaping robbers' threats and pirates' plots and pimps' insults, chains, trenches, fetters, poisons, and tombs. But I have reached you, Habrocomes, lord of my heart, the same as when I first left you in Tyre for Syria. No one persuaded me to go astray: not Moeris in Syria, Perilaus in Cilicia, Psammis or Polyidus in Egypt, not Anchialus in Ethiopia, not my master in Tarentum. I remain chaste, after practising every device of virtue.'

$(5 \cdot \mathrm{I} 4 \cdot \mathrm{I}-2)$

Untypically, this review conspicuously does not observe chronological order. Its function is not to inform Habrocomes about her adventures; this has already taken place without much emphasis. ${ }^{12}$ Nor at this stage does the primary narratee need a recapitulation of the story. The point is rather to establish Anthia's chastity and underwrite fidelity as the novel's primary value. The analepsis is rhetorically arranged (with rhetorical plurals) to build from the general to the specific, and hence to the most precisely imagined threat. Similar compromises with the principles of chronology can also be found in analeptic lamentations, as at $5 \cdot 5 \cdot 5$ :

\footnotetext{
12 5.I3.5: 'there were many different stories from all of them: each of them told all that had happened to them and all that they had done'.
} 
'Were the tombs, murders, bonds and pirates' lairs not enough?'13

\section{Prolepses}

The prolepses can be divided into a number of categories: a) narratorial prolepses; b) prolepses implied by the intentions of the divine; c) prophetic dreams and oracles; d) actorial prolepses; e) seeds. Unlike Chariton $(\rightarrow)$, Xenophon does not use intertextual analogies proleptically, beyond the obvious generic assumption that plots of this sort will have a happy ending.

a) Xenophon's narrator is given very few prolepses. They are all internal and of relatively restricted extent. So when Perilaus defeats Hippothous' robber gang,

he took Anthia and felt sorry for her when he found out the dreadful fate that had been about to overtake her. But his pity for her was the beginning of another terrible calamity.

$(2.13 .5)$

This looks no further forward than to the next sentence, when he falls in love with her and presses her to consent to marriage; we seem to be dealing with the 'header' technique. Another narratorial prolepsis simply confirms that a prophetic dream is in fact prophetic. ${ }^{14}$

b) Statements by the narrator about the intentions of the gods are similarly less frequent in this novel than in Chariton's $(\rightarrow)$. The action is prompted by the anger of Eros, and for the first four chapters his agency in the protagonists' inamoration is repeatedly stressed. After Habrocomes throws himself on the god's mercy, we are told:

even after this prayer Eros was still angry and intended to take a terrible revenge on him for his arrogance.

The implication is that something bad will happen, but at this point Xenophon loses interest in the vengeance of Eros, and it is not clear whether Eros' revenge comprises all the ensuing adventures or only the

13 Xenophon's laments are fewer and shorter than Chariton's; cf. 3.5.3, 8.6-7; 5.I.I3, 7.2, 8.7.

14 I.I2.4: 'as soon as he dreamt this, he was in a panic and expected his dream to portend some dreadful outcome, and the terrible thing happened', looking forward to the attack by pirates in the next sentence. 
love-sickness that immediately follows. This confusion is compounded: the protagonists' parents seek the advice of the oracle of Apollo at Colophon, as a result of which the marriage takes place. But after the wedding night we are told that

they had forgotten even the oracle. But fate [to heimarmenon] had not forgotten, nor did the god who decided these things neglect them.

The god is not named, but Xenophon means us to understand Apollo, not Eros. The prolepsis here, then, guarantees that the words of the oracle will be fulfilled, but the agency of Eros is now conclusively superseded by that of Apollo. Here again the narrator loses interest in divine planning, and Apollo's agency is not mentioned again in the narratorial voice. When the protagonists attract the lust of a pair of pirates, Habrocomes himself exclaims:

'The oracles are beginning to be fulfilled; the god is taking his revenge on me for my arrogance.'

He must mean Eros, but this is hardly the moment of revenge that Eros was said to be scheming; nor is there anything in the oracle that could easily be identified with this turn of events. These 'divine' prolepses then deliver an immediate effect of foreboding, but do not give an accurate or coherent view of the way that the plot will actually develop. ${ }^{15}$

c) Whereas Chariton eschews the literary device of oracles and predictive dreams, Xenophon makes prominent but puzzling use of it. I have already mentioned the consultation of the oracle at Colophon by the protagonists' parents, which kick-starts the adventure plot. The response they receive is this:

'Why do you long to learn the end of a malady and its beginning?

One disease has both in its grasp, and from that the remedy must be accomplished.

But for them I see terrible sufferings and toils that are endless;

Both will flee over the sea pursued by madness;

They will suffer chains at the hands of men who mingle with the waters;

And a bedchamber shall be the tomb for both, and fire the destroyer;

And beside the waters of the river Nile, to Holy Isis

\footnotetext{
${ }^{15}$ It is worth noting in passing that similar prolepses involving divine agency occur in embedded narratives by secondary narrators: 3.2 .4 ; 5.I.6.
} 
The saviour you will afterwards offer rich gifts;

But still after their sufferings a better fate is in store.'

The text of these lines is corrupt, but even so there are serious difficulties. ${ }^{16}$ The 'terrible sufferings and endless toils' are sufficiently imprecise to cover most of the protagonists' subsequent experiences. The 'men who mingle with the waters' are presumably the pirates who will shortly capture them. Habrocomes is thrown into chains by the pirate chief Apsyrtus at 2.6.4; but Anthia is enchained only by the land-bound robber Anchialus (4.5.3) and the jealous woman Rhenaea (5.5.4). The reference to pursuit by madness is difficult to interpret, and has been subjected to textual emendation; as it stands it might refer either to the madness of love, or else to the dream of Habrocomes at I.I2.3, which is introduced by the statement that the prophecies 'began to take effect', and which features a woman who might be Lyssa, the personification of Madness (though the text does not say so; see below). The bedchamber as tomb presumably relates to Anthia's apparent suicide just before her marriage to Perilaus (3.6), and the destroying fire to the episode where Habrocomes is about to be burned at the stake (4.2.8-9). In that case we must write off the oracle's prediction of these fates for both of them as poetic licence. The reference to the Nile is clearly a corruption, since in the next chapter the parents ask which river the oracle meant. Anthia prays to Isis in Memphis at $4 \cdot 3 \cdot 3$, and takes refuge in the temple of Isis at 5.6.6, where she receives another oracle. The final reunion takes place at the temple of Isis in Rhodes, but the concluding celebrations do not take place beside the Nile, as the oracle suggests they will. There is clearly something amiss here, whether we ascribe the oddities to scribal corruption, epitomisation, later redaction, or authorial incompetence. We can say, however, that the oracle is designed to give a sense of unpleasant experiences leading to a happy ending, but in such an enigmatic fashion that the primary narratee has no real sense of the plot in advance.

The other oracle signals the imminent reunion of the protagonists. If the first oracle was hyper-enigmatic, this one leaves no room whatsoever for doubt. Having prayed to Apis for a true oracle about Habrocomes, Anthia comes out of the temple to hear the children playing in front of the precinct shout in hexametric chorus:

'Anthia will soon recover her own husband, Habrocomes.'

${ }^{16}$ Cf. F. Zimmermann 1949-1950; Hägg ı97ı: 228-23ı. 
This message cheers her up, but she is not sufficiently in control of her own destiny to act on it. The prolepsis looks forward past her experiences in a South Italian brothel to the scene of reunion in Rhodes (5.I3.4). The word 'soon' (takhu) covers an indeterminate length of time, which includes a voyage from Alexandria to Tarentum, a few days being rested after the brothel-keeper buys her, her spell in the brothel (possibly a single day), followed by a period of convalescence from her 'epilepsy', her purchase by Hippothous, a sufficiently long period of daily contact with Hippothous for him to fall in love with her, and a sea-voyage of a few days from Italy to Rhodes. This looks like an action-packed month or so, at least. So 'soon' is perhaps not so much a measure of time within the narrative as of the length of the narrative itself before the happy resolution is reached.

There are several predictive dreams in the novel, but they are enigmatic. ${ }^{17}$ Just before the first attack by pirates, Habrocomes

dreamt that a woman stood over him, fearful in appearance and superhuman in size, and dressed in a blood-red robe; and the vision seemed to set the ship alight; the rest perished, but he swam to safety with Anthia. As soon as he dreamt this, he was in a panic and expected his dream to portend some dreadful outcome, as indeed it did.

This dream immediately precedes and predicts the first pirate attack; the red robe of the woman (phoiniken) punningly predicts the Phoenician nationality of the pirates, though otherwise her identity is never made clear.

An even more puzzling dream is that at 2.8.2:

He [Habrocomes in Apsyrtus' gaol] dreamt that he saw his father, Lycomedes, dressed in black, wandering over every land and sea, stopping at the prison, freeing him, and letting him leave his cell; and that he himself took the form of a horse, went through many lands in pursuit of a second one - a mare - and finally found her and became a man again. When he dreamt this, he leapt up and was a little more hopeful.

The second half of the dream allegorically predicts Habrocomes' search for and reunion with Anthia, after his release by Apsyrtus; perhaps the horses in the dream hint at the importance of Hippothous in the story. ${ }^{18}$ The first part of the dream is also not literal: the wandering of

17 For discussion of the dreams in the light of oneirocritical theory see PlastiraValkanou 200I.

${ }^{18}$ Habrocomes will travel on horseback in search of Anthia (2.12.3, I3.4), but the dream seems to predict more than this. 
Lycomedes may signify his death, but it is difficult to understand how the father is involved in Habrocomes' release, even allegorically. The dream is never referred to again, and its function appears to be less to provide genuine prolepsis in the long term than to manage emotions in the short term. The final dream comes as the resolution of the novel is approaching, and again its prolepsis is coded. In Tarentum Anthia

dreamt she was with Habrocomes, and both were beautiful, and it was the time when they were first in love. Some other beautiful woman appeared and was dragging Habrocomes away from her; and at last, when he cried out and called to her by name, she started up and the dream came to an end.

Given the generic presumption that dreams are in some sense predictive, it is easy to read the first part of this as a prolepsis of reunion. But the beautiful rival corresponds to nothing either in Habrocomes' past or in the remaining sections of the plot. This is more plausibly intended as a reflection of Anthia's waking concerns. The most interesting thing about this third dream is that Anthia engages in an act of interpretation, and reaches and acts on a pessimistic conclusion that the primary narratee knows to be an incorrect one.

d) As in Chariton $(\rightarrow)$, Xenophon's characters often think and speak about the future, and in much the same ways. The proleptic status afforded these thoughts by the primary narratee is often determined by generic conventions. So when a character looks forward to a happy ending, as when Hippothous says to Habrocomes,

'Now you, Habrocomes, will set eyes on your beloved and recover her in time',

the primary narratee will see the words as a straightforward prolepsis, but more pessimistic thoughts will be read as ironic. Most of these actorial prolepses work over very short ranges. A common form is for a decision to be taken and then acted on: the most complex and farreaching such instance is when the pirates 'decided to attack and kill those who resisted, but to sell the rest in Phoenicia with the booty' (I.13.2). Another frequent device is to give characters vague forebodings, which are then immediately fulfilled. For example, just before the lustful pirates Corymbus and Euxinus make their first approaches to the protagonists, Habrocomes and Anthia are 'full of apprehension', and 'suspected no good would come of it' (I.I6.I-2). 
e) seeds: there is one good example of a 'seed' in this novel. Before their adventures really begin, the protagonists make a splendid dedication at the Temple of Helius in Rhodes. The prominence afforded to this hints that it will be of importance later, and this is confirmed in the final book, when Habrocomes revisits the temple, and discovers that his faithful servants Leucon and Rhode have set up a supplementary dedication next to it. This precipitates the first stage in the climactic reunion.

\section{Simultaneity and parallel storylines}

The protagonists are separated for nearly two-thirds of the total text, often by wide geographical distances. The action switches between them more than thirty times. The temporal relationship between the narrative strands has been comprehensively analysed by Hägg, whose findings I paraphrase..$^{19}$ In the majority of cases, the transition is effected by means of a men ... de antithesis, which leaves the temporal relationships imprecise. ${ }^{20}$ In a few cases the transition is accompanied by a phrase that apparently connotes simultaneity. ${ }^{21}$ But on closer inspection it becomes clear that the simultaneity is only between the last sentence or so of the first section and the opening of the new one. In other words, the pattern seems to be the same as the 'relayrace' in Chariton $(\rightarrow)$ (and $\rightarrow$ Homer), with the episodes conceived as successive and in chronological order, rather than simultaneous with temporal backtracking at transitions. Each narrative thread in isolation then consists of sections of frantic action, alternating with static nondevelopment while the focus is elsewhere. This impression is confirmed, for example, by the role of Hippothous, who appears in both narrative strands, sometimes in consecutive episodes, making clear that they are not simultaneous. Similarly there are at least two occasions when an episode ends with the beginning of a journey, which has been completed or nearly completed by the time the narrative focus returns to that particular thread. The journey is thus conceived as taking up the

\footnotetext{
19 Hägg i97ı: I54-I77.

20 Translators often tend to import the word 'meanwhile' into such contexts, which implies a precision the Greek text does not possess.

21 2.I2.I (en de toutois); 4.4.I (en toutōi de).
} 
time covered by the intervening episode from the other strand, maintaining the chronological succession of the episodes. ${ }^{22}$

Hägg identifies only one clearly anomalous passage. ${ }^{23}$ At the end of 2.II the goatherd to whom Anthia has been married disobeys Manto's orders to kill her and sells her to some Cilician merchants who set sail at nightfall (nuktos epelthousēs). They are shipwrecked and captured that night (tēn nukta ekeinēn) by Hippothous and his bandits. Attention then shifts to Habrocomes in Tyre. Meanwhile (en de toutois) a letter arrives from Manto with the lying news that she has ordered Anthia to be sold in Syria. Habrocomes sets off in search of her, comes to the goatherd and learns the truth; at dawn (heothen) he sets off for Cilicia. At 2.I3.I we are back with Anthia on the same night (ekeiness tês nuktos), and in the second half of the sentence a new day begins (tēei de hexés). The extraordinary density of time-markers here signifies some special attention to time and synchronicity. Xenophon intends that Habrocomes' interview with the goatherd should be imagined as taking place directly after the sale of Anthia to the Cilician merchants, and at the very moment when she is being captured by Hippothous. The morning when Habrocomes sets off for Cilicia is the same as when Anthia is being prepared for sacrifice. Hägg is wrong, I think, to argue that the events of 2.12 'must cover several days'. However implausible we might find it in terms of real time, Xenophon has constructed a single day in the course of which Manto orders the goatherd to kill Anthia and then writes a untruthful letter; the goatherd is sufficiently moved to spare Anthia's life and sell her instead; Manto's letter is delivered and Habrocomes sets off in search of her; Anthia's ship is wrecked; Habrocomes talks with the goatherd and Anthia is captured by Hippothous.

\section{Rhythm}

In Xenophon we find the same alternation of summary and scenes as in Chariton $(\rightarrow)$. The effect is rather different, however, as Xenophon's narrative is very rapid and his scenes are seldom allowed to develop as they do in Chariton. Even Xenophon's most extended scenes, such as the protagonists' wedding-night (I.8-9), are small-scale by compar-

\footnotetext{
22 2.I3.I/2.I4.I; 3.3.7/3.9.2.
}

23 Hägg i97ı: I77. 
ison. It is thus not easy to demarcate between scene and summary. Xenophon makes far less use of direct speech than does Chariton, almost as if he is deliberately avoiding a scene that plays in 'real-time'. A few scenes contain detailed description, and come close to making an actual pause in the narrative. The most prominent among these is the description of the tapestry in the protagonists' bridal chamber:

The chamber had been prepared: a golden couch had been spread with purple sheets, and above it hung an awning with an embroidered Babylonian tapestry. Cupids were playing, some attending Aphrodite, who was also represented, some riding on Nabataean ostriches, some weaving garlands, others bringing flowers. These were on one half of the canopy; on the other was Ares, not in armour, but dressed in a cloak and wearing a garland, adorned for his lover Aphrodite. Eros was leading the way, with a lighted torch. Under this canopy they brought Anthia to Habrocomes and put her to bed, then shut the doors.

Within this framework, however, there is nevertheless a marked difference between different parts of the novel. Book 4 is much shorter than the rest and each day/night unit occupies less textual space.

\section{Frequency}

As in Chariton $(\rightarrow)$, the narration mainly is singulative. Unlike Chariton, however, Xenophon does clearly mark out a few items as iterative. This applies especially to lamentations. At 3.8.7, for example, we have at first sight a single lamentation (with a verb of speaking in the aorist tense: ephese) from Anthia on board of a ship on her way to Alexandria. But at the end of the direct speech, the narrator says that 'she lamented in this fashion time after time'. ${ }^{24}$

\section{Conclusion}

Xenophon's handling of time is, like Chariton's, rather simple, and for the most part time is not thematised or emphasised. In some aspects, such as prolepsis, there may also be issues of incompetence or epitomisation.

24 tauta hekastote edakrue; the tense has changed to an iterative imperfect. Similar iterative laments at 4.5 .3 and 5.8.3, both designated with the word pollakis ('often'). 


\title{
GHAPTER TWENTY-NINE
}

\section{LONGUS}

\author{
J.R. Morgan
}

The handling of time in Daphnis and Chloe is radically different from that of the two 'pre-sophistic' novels by Chariton and Xenophon of Ephesus. The relation of story to fabula is more complex, and the presentation of the story admits the effective use of anachronies. Furthermore, the passage of time, precisely notated, is important in the structure of the novel, and indeed coheres with important themes of the text.

The text is introduced by an account of how the narrator discovered a painting in a grove in Lesbos, sought an explanation of it from a local exegete, and produced his narrative as a verbal counterpart to the visual image. The narration is thus subsequent but reasonably close to the discovery of the painting, but there are no clues as to the dramatic date of the frame narrative. The - strictly speaking, secondary - narrative ${ }^{1}$ it introduces is located in an indeterminate and distant past. Again there are no specific indications of dramatic date, but the action implies a Lesbos of independent city-states, and there are hints that the relations between the two most important of them, Mytilene and Methymna, are intended to reflect Thucydides' narrative of the Mytilenaean revolt of 428 BCE. ${ }^{2}$

The prologue includes not only the narrator's narrative of his encounter with the painting and the composition of the very text we are reading, but also an announcement that his text will be

a possession to delight all mankind, which will heal the sick and comfort the distressed, stir the memory of those who have been in love, and give preparatory instruction to those who have not.

(proem 3)

If we take the text as a whole, then, the end-point of the fabula is each and every act of reading, reaching forward into eternity. ${ }^{3}$ Within this

\footnotetext{
1 Cf. $S A G \mathcal{N}$ i:507.

2 J.R. Morgan 2004: 186; and, with reservations, Cueva 2004: 44-6r.

3 The proem stresses not only the universality of the book's lessons, but their permanent relevance, 'so long as beauty exists and eyes can see' (proem 4).
} 
'primary' fabula, there is a large expanse of unnarrated time, possibly several centuries, covering the period between the end of the story of Daphnis and Chloe and the narrator's encounter with the image of their experiences, and an even longer one, currently running at nearly two millennia and daily increasing, between the composition of the text and the effects on future narratees.

If we only consider the (secondary) narrative introduced by this prologue, we observe that the order of the story displays changes in comparison to its fabula (which we might call the 'secondary' fabula). The story begins with the discovery and adoption of the baby Daphnis by the goatherd Lamon, followed at an interval of two years, by a symmetrical account of the discovery and adoption of the infant Chloe by the shepherd Dryas. The exposure of the two children by their natural families is presented only through two external completing actorial analepses after their recognition in the final book of the novel. Daphnis' father, Dionysophanes, narrates the circumstances of his son's exposure in 4.24.I-2, and Chloe's father Megacles has a symmetrical counterpart at $4 \cdot 35 \cdot 3-4$. The story thus withholds the truth of the children's origins and identities and makes them the object of the primary narratee's curiosity and speculation, until the earlier part of the fabula is dramatically revealed at the resolution of the plot.

The starting point of the fabula, however, predates the birth and exposure of its protagonists. The important secondary character, the cowherd Philetas, in an internal completing actorial analepsis, tells Daphnis and Chloe of the epiphany of the god Eros in his garden. In the course of this account, he reports the god's own external completing actorial analepsis:

'I know in your first youth you used to graze your wide herd of cattle on that hill-side; I was with you there as you played your pipes beside those oak-trees when you were in love with Amaryllis, but you could not see me, even though I was standing right next to the girl. I made her yours, and now you have fine sons, herdsmen and farmers.'

$(2.5 \cdot 3)$

A few sentences later, Philetas himself tells Daphnis and Chloe of the same events, from a different perspective:

'I was once young myself, and in love with Amaryllis. I lost my appetite, never drank a drop or slept a wink. My soul ached, my heart throbbed, my body was a-cold. I would cry out as though I was being beaten, fall silent as though I was a dead man, dive into rivers as though I was on fire. I would call on Pan to aid me, for he had been in love himself with 
Pitys. I would bless Echo for repeating Amaryllis' name after me. I would smash my pipes, because they charmed my cows but did not bring me Amaryllis.' ${ }^{4}$

$(2.7 \cdot 4-6)$

These analepses establish an analogy between the experiences of Daphnis and Chloe and those of an earlier generation, which allows them to identify their own 'illness' as love. They also underwrite the novel's gospel of the never-ending cycles of nature and human life.

Similarly, although the story ends with the wedding-night of Daphnis and Chloe, the narrator inserts an external prolepsis into the penultimate chapter, which extends the fabula to include the rest of Daphnis and Chloe's lives and the birth of their own children:

Not only that day but for as long as they lived, they led a pastoral life for most of the time. The gods they worshipped were the Nymphs, Pan and Love; they owned very many flocks of sheep and goats, and thought that fruit and milk were the sweetest food. Moreover, they put a baby boy to a nanny-goat, and set their second-born, a little daughter, to suck at the dugs of a ewe. The former they named Philopoemen, the latter Agele, and in this way of life these children grew old with them. ${ }^{5} \quad(4 \cdot 39 \cdot \mathrm{I}-2)$

The 'secondary' fabula thus stretches from the youth of Philetas to the old age of Philopoemen and Agele, comprising three turns of the cycle of life in demonstration of the point that the experience of love recurs in each successive generation. The 'primary' fabula extends this truth into an infinite future.

The period between the youth of Philetas and the birth of Daphnis and Chloe is not narrated. The entire lifetime of the two protagonists, however, is. After their discovery by their foster-fathers, thirteen years are covered in a single sentence (I.7.I). The prolepsis at the end, as we have seen, covers the rest of their lives after marriage. Between these two comes the main story, carefully arranged into a series of seven seasons, and thus covering a period of a little less than two years. The seasons articulate the progression of the protagonists' love. ${ }^{6}$ In the first spring (I.9-1.22) Daphnis and Chloe fall in love; their passion becomes more heated in the summer (1.23-27). Autumn is a particularly important season: each of the two autumns in the sequence commands an entire book. The first (1.28-3.2) includes the meeting with Phile-

${ }^{4}$ Note the iterative presentation of most of this passage.

${ }^{5}$ The last clause of the passage quoted is excised by some editors, but its implication that Daphnis and Chloe lived to an extreme old age is important.

${ }^{6}$ J.R. Morgan I994: 66-69. 
tas, who gives Daphnis and Chloe their first instruction about Eros. The succeeding winter $\left(3 \cdot 3^{-} \mathrm{II}\right)$ is a period of suspension and separation; but in the second spring (3.12-23) amorous feelings are reactivated and heightened and Daphnis is initiated into sex by his neighbour Lycaenion. The second summer sees the first mention of marriage. The second autumn comprises the whole of the fourth book, and brings about the recognition of the protagonists and culminates in their marriage. It is clear that the seasonal cycle counterpoints the erotic development of Daphnis and Chloe. There is a double ideological point to this deployment of temporal markers. Firstly, it demonstrates the close connection between humanity and nature; and secondly the cycle of the natural year mirrors the cycle of human generations, whose thematic importance we have already seen emphasised by the forward and backward extension of the fabula beyond the limits of the story.

Longus' awareness and exploitation of time is also to be seen within each of the seasons. Typically each of the seasons begins with a description of the countryside and its activities. The general state of the protagonists is conveyed through iterative narration, detailing their typical actions over the whole season. Within the season a few days are singled out for extensive singulative treatment, and on those days the narrator seems to take particular care to plant markers of the passage of time. The best way to illustrate this rather individual narrative pattern will be to analyse one or two of the seasons in some detail.

The first spring begins with a temporal pause ${ }^{7}$ as the narrator describes the vernal flora and fauna. This glides into an iterative account of the young couple's response:

Everything was so full of the joy of spring that they, being young and innocent, copied what they heard and saw. Hearing the birds singing, they sang; seeing the lambs skipping, they leaped lightly, and copying the bees they gathered the flowers; some they tucked inside their clothes, some they wove into daisy chains and brought to the Nymphs. As they grazed their flocks side by side they did everything together. Many a time [pollakis] did Daphnis round up sheep that strayed off, and many a time [pollakis] did Chloe drive down over-bold goats away from the cliffs.

${ }^{7}$ Unlike Chariton $(\rightarrow$ ) and Xenophon of Ephesus $(\rightarrow)$, Longus does have a number of passages where time is paused or which stand outside narrative time entirely, as for instance the excursus on the swimming of cows at I.30.6, or the description of the Lesbian coastline, in the present tense, at 2.12.2. The best example of a pause is the lengthy ekphrasis of Dionysophanes' park at $4 \cdot{ }^{2-}-3$. 
There were even times when one looked after both flocks while the other was engrossed in a game. Their games were pastoral and childish. She would find some asphodel stalks somewhere, start weaving a cricket-trap, and forget all about her sheep as she toiled away at it. He would cut some slender reeds, bore through the partitions at the joints, stick them together with soft wax, and practise playing the pipes till night fell.

(I.9.2-I0.2)

Explicit markers, such as the word pollakis, and the use of the imperfect tense indicate that these are repeated actions without precise temporal location. The narrative becomes singulative and specific for the first signs of love; the tense of the narrative switches to the aorist. The day in question starts at I.I2.I, when two of Daphnis' goats get into a fight and he falls into a pit while chasing them. He is extracted by Chloe, assisted by a cowherd from a nearby farm, and goes to wash in the spring by the shrine of the Nymphs. It is the sight of his naked body that causes Chloe to feel sexual attraction for the first time. The day ends at I.I3.3, when they drive their flocks home. The next day (I.I3.4) Chloe watches Daphnis closely, as her feelings grow more intense. She persuades him to take another bath. At this point the narrative briefly drops back into iterative mode, describing her symptoms of love over the ensuing days, in the imperfect tense (I.13.5-6). A singular occasion is marked by the word pote ('one day') and the reappearance of aorist verbs: this day functions as a scene, with a lengthy soliloquy by Chloe.

The next chapter (I.I5) begins with a narratorial analepsis, containing the information that Dorcon, the cowherd who had helped to pull Daphnis out of the hole, had fancied Chloe from that day forth. He starts bringing gifts, at first to both, but then exclusively to Chloe; all this is iterative, and it is not clear exactly how it relates temporally to the foregoing narrative. It makes most sense to suppose that the giving of gifts began before the day of Chloe's soliloquy and continues after it. Within the days of gift-giving, one is briefly singled out (pote and the aorist) as particularly significant: this is when Dorcon presents Chloe with a kissubion, an ivy-cup, the programmatic artefact of pastoral poetry; here the shift in frequency marks the symbolic importance of the moment. Another specific occasion $(p o t e)^{8}$ begins at I.I5.4. Daph-

8 There is no indication, explicit or implicit, of the period separating this occasion from the previous specific day. The logic of the narrative requires the passage of several but not many days. 
nis and Dorcon have an argument about who is the more handsome. The rhythm slows to a full-blown scene as their speeches are given in full. The kiss which Daphnis wins as the prize is the beginning of his erotic awakening. Just as Chloe's first feelings led to an iterative passage in which the symptoms of love were repeatedly enacted, so Daphnis now is reduced to a symmetrically iterative aporia (I.I7.2-4). He too has a soliloquy, but his differs from Chloe's in that it is presented as iterative:

If ever he was alone and apart from her, he would break into this sort of absurd soliloquy. ${ }^{9}$

The next section is more summary, but clearly concerns a single occasion. Dorcon approaches Chloe's foster-father Dryas, and asks for her hand in marriage, only to be rebuffed (I.I9.I-3). Dorcon devises a rustic trick to get his hands on Chloe, and its execution takes place in the next scene (1.20.2-22.4). ${ }^{10}$ The time of day is established by the fact that Chloe is bringing the flocks to the spring to drink: this element of the pastoral routine has been carefully located by the narrator as taking place after the midday siesta (I.8.2). Dorcon lies in wait and jumps on her, only to find himself beset by her dogs. After he is rescued and helped on his way by the innocent protagonists, they spend the rest of the day collecting the animals that had scattered in terror. Thus ends the day, but the next day (I.22.4) their unnamed feelings are as strong as ever.

Within the overall scheme of this season, it is clear enough that certain days are marked out by their singularity as of particular importance: the two days when Chloe and Daphnis respectively experience their first twinges of desire, the day of the kissubion (ivy-cup), the day of Dorcon's attempted rape. These are either cardinal points of the plot or of iconic significance. This use of rhythm and frequency to articulate and emphasise key points of the story is a recurrent feature of the text. For example, in the ensuing summer, which covers a much shorter span of text than the spring, the single incident treated in this way is the famous episode of the swallow and cicada, which encodes, in a symbolic way, some of Longus' primary themes and truths. ${ }^{11}$

\footnotetext{
9 Imperfect tense, apelèrei.

10 Again the intervening period is not specified.

11 J.R. Morgan 2004: I70-I7ı. And again in the novel's only winter, the season's only action is encompassed in two consecutive days.
} 
The first autumn displays a similar pattern. The day of Daphnis and Chloe's encounter with Philetas, who tells them about Eros, is emphasised by its expansive treatment (2.3.I-8.I). The longest section of narrative in this season, however, concerns the disruption of the countryside by a party of young city people from Methymna. This begins with an iterative narration of their journey along the coast, in which typical holiday activities are presented as repeated actions (2.12.I-5). We slip into a single day, and the aorist tense, at 2.I3.I, when a rustic steals their mooring-rope. The next morning (heothen, 2.13.2), the Methymnaeans discover the loss and then sail on to Daphnis and Chloe's area. By a freakish accident, their ship is set adrift when one of Daphnis' goats gnaws through its temporary mooring. They first resort to violence and then a quasi-judicial hearing, which ends in them being chased away. They apparently get back to Methymna by land on the same day, and convene an assembly which votes for war with Mytilene. A military expedition is launched on the following day (tês epiousēs, 2.20.I), during which Chloe is abducted, and Daphnis has a vision of the Nymphs, promising her return. By the time he completes his devotions, it is nearly sunset (2.24.3). The ensuing night is narrated twice (repeating narration): once briefly from Daphnis' standpoint (2.24.4), and then again at greater length from the perspective of the Methymnaeans $(2.25 \cdot \mathrm{I}-4)$. It is filled with supernatural horrors. The next day begins at 2.26.I: the terrors continue, until at midday the Methymnaean commander experiences a vision of the god Pan. Chloe is released and is reunited with Daphnis 'around the time of the second pasture' (2.30.I), that is to say, late in the afternoon, after the flocks have rested through the hottest part of the day. There are sacrifices and rustic celebrations, until this eventful day comes to an end with nightfall at 2.31.2. The next day celebrations continue, with exchanges of stories and dancing, and Daphnis and Chloe make their way home when it is already dark (2.38.I). The following day is another of those iconic ones, completing the second book with Daphnis and Chloe taking competitive oaths by different deities, an important moment in the story's agenda of gender differentiation.

This stretch of narrative is thus spread over six consecutive days: (I) 2.I3.I; (2) 2.I3.2-I9.3; (3) 2.20.I-25.4; (4) 2.26.I-3I.2; (5) 2.3I.2-38.2; (6) 2.38.2-6. It is obvious that the four central days are allocated more story-time (and hence text) than the first and the last in the sequence, reflecting the density of incident and its thematic importance. It is also striking that the narrator has been generous with temporal markers 
within this sequence, even if some of them have a rustic flavour. The passage of time, and the length of time represented by the successive incidents of the plot is clearly significant to him. A similar precision can be found, for example, in the elaborate intrigues and resolutions of the final book.

One particular temporal indicator acquires symbolic importance in this novel: noon. In Daphnis and Chloe this is a numinous time, when the action of the divine is at its most felt. It is at the very height of midday (mesembrias akmazousess) that Lamon discovers the infant Daphnis (I.2.2). Later midday prompts scenes of heightened eroticism between the two, as yet innocent, protagonists: first when the sight of one another's bodies bewitches them (I.24.I), and later as the setting for the episode of the swallow and cicada (I.25.I). It is at noon that Eros appears to Philetas in his garden (2.4.I) and Pan appears to the Methymnaean general in a supernaturally induced sleep (2.26.5).

\section{Analepses}

This novel completely lacks narratorial repeating analepses of the sort that occur in Chariton $(\rightarrow)$. Narratorial completing analepses are fairly few and minor in extent, if not always in importance. On three occasions they are internal, as we have seen in the case of Dorcon's infatuation with Chloe. ${ }^{12}$ The second example concerns Daphnis and Chloe's piety to the Nymphs:

Even before that time they had never passed by without a thought: every day at the beginning of grazing they would stop at the shrine, and on their way home from grazing they would kneel in worship, and they never failed to make some offering, a flower or a fruit or fresh foliage or a libation of milk. ${ }^{13}$

$(2.2 .5)$

The third is the introduction of the important secondary character Lycaenion, and here the analepsis is both internal and external, containing information both about her earlier life and her recent interest in Daphnis:

This man had a little lady he had brought from the city, young, pretty and by country standards rather glamorous. Her name was Lycaenion.

12 I.I5.I: 'Dorcon ... had been amorously inclined towards Chloe since that day, and with every day that passed the flames in his heart burned fiercer'.

13 Note the iterative narration. 
Every day she watched Daphnis drive his goats out to pasture in the morning and home from pasture in the evening, and she had set her heart on making him her lover, using presents as a bait to catch him; on one occasion she had even waylaid him when he was by himself and given him a set of pipes as a gift and honey in the comb, and a deerskin bag. ${ }^{14}$

$(3 \cdot \mathrm{I} 5 \cdot \mathrm{I}-3)$

The other external narratorial analepsis is also connected with the introduction of a new secondary character. When Daphnis' natural brother Astylus first appears, we are told that he was 'not unacquainted with the pain of love' (4.I7.I).

Of the actorial analepses, we have already noted the external completing ones in which the two natural fathers, Dionysophanes and Megacles, reveal the circumstances of their children's exposure as babies. There are one or two cases of internal completing actorial analepsis, the most extensive and important of which is Philetas' account of his encounter with the god Eros, which (as noted above) contains within it external analepses about Philetas' youth. Two other actorial analepses are interestingly placed in the mouth of the divine Nymphs, thus supplementing the usual proleptic function of divine utterance with an authoritative revelation of the past. In the first of these analepses the Nymphs reveal to Daphnis that they have been protecting Chloe from her birth (2.23.I); in the second they reveal what happened to the Methymnaean ship after it was set adrift by Daphnis' goat (3.27.2). This analepsis is coupled with a divine prolepsis, in that they are able to guide Daphnis to the purse of money that was lost with the vessel and that will enable him to become a viable suitor of Chloe, and to look beyond that, in coded terms, to his recognition as a member of the urban aristocracy. ${ }^{15}$

The majority of actorial analepses are repeating ones, and have the simple argument function of transferring necessary information from one character to another. ${ }^{16}$ The most extensive of them occurs when Chloe is reunited with Daphnis after her Methymnaean adventure:

${ }^{14}$ Here too the analepsis for a large part takes the form of iterative narration.

15 'In time to come you really will be rich' (3.27.5).

16 This forms an illuminating contrast with the summary analepses of which Xenophon of Ephesus $(\rightarrow)$ is so fond: in that case argument function is less important than reminding the primary narratee of the complexities of the plot. Longus' text, with a higher level of literary ambition, assumes a primary narratee who can concentrate on and retain the story. 
She told the whole story: the goats' ivy, the sheeps' howling, the pine budding on her head, the fire on the land and the noise on the sea, the two kinds of piping, one martial, one peaceful, the night of terror, and how when she did not know the way the music had shown her the way home.

$(2.30 .3)$

The unusual degree of detail here allows Daphnis to recognise the supernatural nature of her deliverance and thus to identify the agency of Pan, which had been foretold in his vision of the Nymphs.

Other extended analepses cluster around the recognitions of Daphnis and Chloe. The symmetrical completing external analepses of the two natural fathers are prompted by symmetrical repeating internal analepses from the two foster-fathers, in which they disclose their discovery of the exposed infants (4.19.4-5, 30.3-4). These are good examples of the care the narrative takes to motivate its incidents. Lamon, for example, is worried by the threat that Daphnis will be taken away to the city to become the plaything of the homosexual parasite Gnathon; he tries to avert this by producing the tokens that prove to his master Dionysophanes that Daphnis is of a wealthy family, only for the master to recognise the tokens as the ones exposed with his own child.

Most of the other actorial analepses are simple, but an interesting variant is the partial analepsis where a character deliberately and significantly suppresses one element of the narrative. In the first book, Daphnis is briefly abducted by pirates, who also beat up Dorcon and steal his cows. He is rescued when, in return for a kiss, the dying Dorcon gives Chloe a set of pipes to which the cows have been trained to respond, resulting in the capsizing of the pirate ship. Here is what happens when Daphnis and Chloe are reunited:

She told him the whole story: how she had run to Dorcon, how he had trained the cows, how she had been told to play the pipes, and that Dorcon was dead. The kiss was the only thing she did not mention, out of modesty.

Daphnis never does learn about that kiss, but symmetrically he conceals from Chloe his erotic tuition in the wood by Lycaenion.

\section{Prolepses}

The prolepses in Longus fall into the following categories: a) narratorial prolepses; b) divine prolepsis, principally by the means of dreams; c) actorial prolepses; d) seeds; e) intertextual prolepsis; f) a series of myths 
told by characters, which apart from their 'argument' function act as coded prolepses for the primary narratee ('key' function).

a) We have already mentioned the narratorial prolepsis at the end of the novel, which extends the fabula to include the birth of the protagonists' children. Other narratorial prolepses are few in number and limited in extent. When Daphnis and Chloe make pious offerings to the Nymphs, the narrator comments:

Later they were repaid for this by the gods. ${ }^{17}$

This is not typical of this narrator, however. Elsewhere his proleptic interventions are restricted to anticipation of the immediately ensuing event: so when Daphnis is looking for the putrefying dolphin which conceals the Methymnaeans purse, the narrator says 'he was not to have much difficulty finding it'. ${ }^{18}$

This is the most convenient place to discuss the complex temporal function of the painting described by the primary narrator in the prologue. At the very end of the text, we discover that the image was dedicated by Daphnis and Chloe themselves, and that it functions thus, for them, as a pictorial narrative of their experiences. ${ }^{19}$ For the primary narratee, on the other hand, the images of the picture functions in the same way as, for example, the proems of the Homeric $(\rightarrow)$ epics: they announce events of the story he is about to read: ${ }^{20}$

It showed women giving birth and others dressing the babies in swaddling clothes, babes abandoned and beasts of the flock feeding them, shepherds taking them up and young people making pledges, a pirate raid and an enemy invasion, and much else, all of it amorous. (proem 2)

In listing these images, the narrator re-enacts his own earlier failure to understand them until explained by an exegete. The painting is conceived as containing several panels in which the same characters recur, rather like a comic strip, but the narrator at this stage affects not to see the connections between them. He also presents them in an order which does not exactly reflect that of the story, in which the pirate

\footnotetext{
17 This concludes the iterative analepsis about their previous piety. The interplay of past and future is made explicit in the Greek: ton proteron khronon ... husteron.

18 3.28.2; compare I.II.4, where the single word hōde ('in the following manner') guides the narratee into the next chapter.

${ }^{19}$ For the identification of the images dedicated by Daphnis and Chloe with the painting seen by the narrator see Wouters 1989-1990.

${ }^{20}$ It is better not to speak of prolepsis in this case, since the story has not started yet.
} 
raid precedes the protagonists' exchange of oaths. ${ }^{21}$ All this is of course deeply duplicitous: at the moment of narration the narrator is already in possession of all relevant information. The result is that the primary narratee is also unable to reconstruct the story from this scant data: he is provided with a few individual episodes from the plot, but no sense of the narrative grammar that binds them together. The pictorial 'proem' whets rather than blunts his curiosity.

b) Longus' narrator does not have privileged access to knowledge of the gods' intentions. The gods do, however, issue instructions to characters through dreams. At 1.7.2 Lamon and Dryas have simultaneous dreams of Eros, whom they do not recognise, commanding them to send their foster-children out to the pastures. This is balanced by dreams at the end of the story, when Eros appears to the two natural fathers. For Dionysophanes he unstrings his bow (so indicating the accomplishment of his mission) and gives the command to produce Chloe's tokens at a feast. When he does so, the tokens are recognised by Megacles, who announces that he has had a dream that he is about to become a father. ${ }^{22}$ The Nymphs appear twice to Daphnis. In the first they reveal their lifelong care for Chloe, and then foretell her safe return from the clutches of the Methymnaeans through the agency of Pan (2.23.3-5). The second vision is when they guide him to the lost purse, and look forward to a time when he will be really wealthy $\left(3 \cdot 27 \cdot 4^{-}-5\right)$. Pan appears to Bryaxis, the Methymnaean commander, and commands him to return Chloe; he also drops the remark that she is a girl 'from whom love intends to make a story', an intensely metanarrative moment looking forward to the production of the novel itself (2.27.2). ${ }^{23}$

The gods thus employ non-enigmatic dreams to give the characters orders that will bring about their will. For the primary narratee, however, the dreams indicate the benevolent control that the gods, particularly Eros - whose agents Pan and the Nymphs are-, exert over the whole of the protagonists' lives. Their proleptic function thus extends beyond the specific injunction to guarantee that the ending of the whole story will be a happy and meaningful one.

${ }^{21}$ For fuller discussion see J.R. Morgan 2004: I45-I48, and the bibliography given there.

${ }^{22}$ Megacles thus gives an analeptic account of a proleptic dream; but the prolepsis is merely of the revelation of something that has already occurred. The same device is found in Homer $(\rightarrow)$ and Heliodorus $(\rightarrow)$.

${ }^{23}$ Discussed more fully by J.R. Morgan 2004: 193 . 
c) As in other novels, the characters of Daphnis and Chloe speculate about and plan for the future. It seems to be a feature of this text, however, that such actorial prolepses are often erroneous, and thus creative of irony. A simple example comes when Chloe has been abducted by the Methymnaeans, and Daphnis looks forward pessimistically to her future life (2.22.2). The primary narratee's sense of generic propriety will surely suggest that the story will not short-circuit at this point and in this way. I want to single out two particular examples of actorial analepsis, which seem to be of particular thematic significance.

The first concerns the suggestion that the protagonists' foster-families have material ambitions dependent on their foundlings eventually being reunited with their biological families, whose wealth is guaranteed by the recognition tokens. So, early on, Dryas refuses Dorcon's suit for Chloe,

reflecting that the girl was worthy of a better match than this, and fearing that he would get into serious trouble if he were ever found out. (I.19.3)

This motif resurfaces at the end of the third book, when at first Dryas is tempted by the gifts offered by Chloe's suitors, but then reflects

that the maiden was of too high a class for agricultural suitors and that if she ever found her real parents she would make him and his wife very wealthy.

Symmetrically Lamon is hostile to the suggestion of marriage between Chloe and Daphnis,

who in his recognition tokens gave signs of high estate, and who would make them free and masters of a larger farm.

These ambitions generate the interplay of characters between the two foster-fathers, each of whom plays his cards close to his chest and cunningly exploit the situation to maximum financial and social advantage.

The second comes when Lycaenion has initiated Daphnis into sexual intercourse, and looks forward to the time when he will try out his new found skills on Chloe:

'When Chloe does this sort of wrestling with you, she will scream and cry and lie in a pool of blood. Don't be scared of the blood, but when you persuade her to give herself to you, bring her to this spot, so that no one can hear her if she shouts, and if she bleeds she can wash in the stream. ${ }^{24}$

$(3 \cdot 19 \cdot 2-3)$

${ }^{24}$ Fuller discussion in J.R. Morgan 2004: 208-210. 
Every aspect of her vision of the future is significantly wrong. Chloe eventually loses her virginity, joyfully and apparently without pain or mess, on her wedding night. More to the point, Lycaenion is wrong to assume that Daphnis will immediately have sex with Chloe. His new knowledge has brought with itself the existential freedom not to use it immediately or unreflectively, as well as an awareness of the responsibilities that belong with love. Lycaenion's false prolepsis marks the difference between her facile and physical view of sexual relations and the romantic ethos that surrounds the protagonists and which the novel ultimately underwrites.

d) The seed par excellence is the recognition token. When the two babies are discovered at the very beginning of the novel, each is accompanied by valuable objects. The mere existence of these objects creates the presumption that the children will be recognised and that the tokens will have a part to play in the process. As we have seen, attention is drawn to them - and to their function-on several occasions during the course of the novel. The recognition scenes of which they are the seeds duly take place and constitute the resolution of the plot.

e) The seed-function of the recognition tokens is partly intertextual. Stories of children exposed at birth and eventually recognised by and reunited with their natural families were widespread in ancient literature, but are particularly characteristic of the plots of New Comedy. The intertextual relation to New Comedy is accentuated in the last book, where stereotypical characters from the comic stage, such as the feckless young man and the parasite, signal the shift of the plot from countryside to city. Recognition of the intertextual switch from Theocritean pastoral to Menandrian comedy brings with it the realisation that the plot will resolve in a comic manner, as in fact it does, with recognition paving the way to a wedding celebration typical of comic endings.

There is, however, one intertextual prolepsis which is characteristic of Longus' procedures, and quite distinct from this sort of general awareness of generic proprieties. At the end of the third book comes an episode where Daphnis exerts his newly acquired manhood by climbing a tree, against Chloe's wishes, to fetch her a beautiful apple which had been left on the topmost branch by the fruit-pickers. Verbal echoes confirm that this is modelled on a famous poem by Sappho, one of Longus' principal intertexts, and especially appropriate for a story set 
on Lesbos. The image of the apple left on the topmost bough is from a wedding song or epithalamium, also imitated by Catullus. An ancient commentator explains that the apple represents the bride, whose virginity remains unpicked for her husband..$^{25}$ The primary narratee was thus cued to understand the apple episode as a prolepsis of the projected wedding; deterred by Lycaenion's warnings from taking Chloe's virginity literally, Daphnis does so figuratively.

f) Finally, a brief word about the three inset myths in each of the first three books: the myth of the wood-dove as told by Daphnis to Chloe, and containing a reference to the story of Pan and Pitys (I.27); the myth of Pan and Syrinx as told by Lamon after the recovery of Chloe from the Methymnaeans (2.34); and the myth of Pan and Echo, again told to Chloe by Daphnis, in explanation of an actual echo (3.23). It is widely recognised that these myths stand in some sort of counterpoint to the novel's central plot. Details from each of them can be read as proleptic in a narrow sense. Thus the theft of cows in the first myth immediately precedes the pirate-raid in which Dorcon's cows are stolen, and the dismemberment of Echo in the third myth is aligned with the painful and bloody defloration which Lycaenion has envisaged for Chloe. As a series, the myths present an escalation both of male violence towards a female victim and of overt sexuality. The later clearly reflects the growing sexual awareness of Daphnis and Chloe, while the latter points towards Daphnis' eventual taking of Chloe's virginity. In each of the myths, the female victim undergoes a metamorphosis that results in the creation of new beauty and harmony. This, in one sense, points towards the metamorphosis of Chloe from girl to woman, from virgin to bride, and beyond that to her transformation into text. The relation between these myths and the main story is not a straightforwardly proleptic one, however. Daphnis is not to be equated with Pan, and his romantic love avoids the infliction of suffering which is a recurrent feature of the three myths. Rather, the myths rehearse narrative possibilities that the main stories avoids. ${ }^{26}$

${ }^{25}$ Sappho fr. I05 LP, also used in Cat. 62. The explanation of the symbol is by Himerius (Or. 9.I6). Discussion, and further bibliography, in J.R. Morgan 2004: 22I222.

${ }^{26}$ For fuller discussion of these myths see J.R. Morgan 2004: I7I-I72, I95-198, 213216; also MacQueen 1985; Philippides I980-I98I; Pandiri 1985; Wouters I991. 


\section{Conclusion}

Longus' handling of time is one aspect of a new level of sophistication, both technical and ethical, that demarcates Daphnis and Chloe from Chariton and Xenophon of Ephesus. His novel is compact and Alexandrian in its aesthetics. 
GHAPTER THIRTY

\title{
HELIODORUS
}

\author{
J.R. Morgan
}

The length, complexity and technical innovation of Heliodorus' novel make a complete analysis of his treatment of time impossible within the compass of a chapter of this length. ${ }^{1}$ What follows is unavoidably partial and selective.

The narration is subsequent. The narrator occasionally writes in the present tense, for instance when giving details of the construction of the armour worn by Persian cataphracts or of the geography of Ethiopia, ${ }^{2}$ but there is no further precision about the supposed date of narration. The dramatic date of the action is established by the inclusion of historical circumstances, but these are not without contradictions. Part of the action depends on the presence of a Persian satrap and his wife in Egypt, which provides a dramatic date between the Persian conquest of Egypt in ${ }_{225}$ BCE and the Egyptian campaign of Alexander the Great. This is confirmed by the striking absence of the city of Alexandria from the opening sequences near the mouth of the River Nile. However, the important character Calasiris exiles himself from Memphis after an encounter with the Greek courtesan Rhodopis, who is mentioned by Herodotus in connection with the brother of Sappho, which suggest a date rather earlier in the sixth century BCE. ${ }^{3}$ Conversely there is a reference to a monument of the Epicureans in Athens, which is several centuries before its time (I.I6.5). No recognisable historical events are integrated into the plot, and the action thus cannot be assigned to any particular historical year.

Although Heliodorus does not thematise the passing of the seasons in quite the same way as Longus $(\rightarrow)$, parts of the plot are nevertheless

\footnotetext{
${ }^{1}$ A detailed narratological treatment of Heliodorus is offered by Futre Pinheiro 1987; Futre Pinheriro 1998 restates some of her conclusions with special emphasis on time.

2 9.I5.I-6; I0.5.I-2.

3 Rhodopis is mentioned at 2.25.I; cf. Hdt. 2.134-I35.
} 
dependent on points of the calendar, such as the time of year when navigation is safe; and the events of the military episode in book 9 are carefully synchronised with the annual inundation of the Nile, which is a necessary component of the plot-mechanism.

\section{Order I: analepsis}

The novel is famous for beginning in medias res, which results in the most radical separation of fabula and story to be found in any of the Greek novels. Not only are large and important parts of the fabula already in the past when the story begins, to be revealed later through lengthy external completing analepses, mostly actorial but occasionally narratorial; but events within the story itself are often presented anachronically. Again this takes the form of important completing analepses to fill in parts of the plot which have happened, as it were, off-screen, but it is also characteristic of this novel that prolepses of varying range and extension are deployed to guide the narratee's expectations, often in a duplicitous way.

The fabula begins with the conception of the heroine Charicleia in the royal palace of Ethiopia, some eighteen years before the beginning of the story. ${ }^{4}$ Its end-point is provided by one of the novel's prolepses, which looks forward to her passing her life (sumbiōsetai) at her beloved's side 'in glorious and royal estate' (6.15.4). The story begins shortly after the protagonists have been shipwrecked near the mouth of the Nile after eloping from Delphi, and concludes just before the celebration of their marriage in the Ethiopian capital Meroe, which is referred to in a future participle in the very last word of the narrative. ${ }^{5}$

Of the parts of the fabula preceding the beginning of the story, Charicleia's conception, birth and exposure are narrated in an embroidered message from her mother Persinna, read by Calasiris and reported by him to Cnemon as an analepsis within an analepsis (4.8.3-6). Her rescue is narrated (in an analepsis within an analepsis within an analepsis) by the Ethiopian ambassador (later identified as the gymnosophist Sisimithres) who hands her over to Charicles in Egypt when she is seven years old; his narrative is reported by Charicles to Calasiris, who reports Charicles' narrative to Cnemon; the whole of this seven years

\footnotetext{
4 4.8.4. The heroine is seventeen years old at the end of the novel.

5 telesthēsomenōn (I0.4I.3).
} 
is narrated, though the period between her rescue and the encounter between the ambassador and Charicles is covered in a single sentence. ${ }^{6}$ The ten-year period from this point until the moment when Charicles tells his story to Calasiris and seeks his help in overcoming his fosterdaughter's resistance to marriage is included in Charicles' narrative to Calasiris. Again most of the fabula-time is narrated very quickly. ${ }^{7}$ Finally the much shorter period between Calasiris' first meeting with Charicles and the scene of shipwreck with which the novel begins forms the substance of Calasiris' long and detailed analeptic narrative first to Cnemon alone, and then, in a second instalment, to the company assembled in Nausicles' house. ${ }^{8}$

The previous experiences of the protagonists, however, are not the only parts of the fabula supplied by external completing analepses. It is a feature of Heliodorus' plotting that a number of at first sight unconnected stories turn out to be intimately interwoven and germane to the fabula of the novel. Thus Calasiris tells Cnemon of his own encounter with the Greek courtesan Rhodopis, and his self-imposed exile to avoid sexual temptation, and the prophecy he had received that his two sons would fight one another (2.25.I-6). He initially occludes the first period of his exile, but later reveals to Charicleia that he had visited Ethiopia, met Persinna, and been commissioned to look for her long-lost daughter; in a short doubly inset analepsis Calasiris reports that Persinna told him that she had been searching unsuccessfully for her lost child since its exposure (4.I2.I-I3.I). ${ }^{9}$

Events in Memphis after Calasiris' disappearance are disclosed gradually. In the first book of the novel, the robber-captain Thyamis reminds his men that he was born the son of the high priest at Memphis, but that the office had been usurped by his younger brother (an actorial completing external analepsis, I.I9.4). When Thyamis' stronghold is attacked by another gang of brigands, there is a narratorial completing analepsis, partly internal, but partly external, explaining that the

\footnotetext{
6 'So for several years (ta men oun prōta) she passed unnoticed, but, as time went by (tou khronou proiontos), and she grew into the full blossom of youth, it became clear that her beauty was out of the ordinary' (2.31.3). All translations are from Reardon Ig89.

7 'She rapidly acquired Greek; like a vigorous young plant, the bud of her childhood burst rapidly into the flower of youth' (2.33.4).

8 2.24.5-5.I.2; 5.I7.I-33.3.

9 There are difficulties of interpretation with this part of Calasiris' narrative, which cannot be squared with what he says elsewhere. He may be lying. Cf. $S A G \mathcal{N}$ i:534 on this.
} 
attackers have been commissioned by Thyamis' brother, now named for the first time as Petosiris (I.33.2). When Calasiris begins to tell Cnemon his story, he mentions that his elder son is called Thyamis, the first confirmation of the connection between the back-stories of Calasiris and Thyamis (2.25.6). The full story is reserved until the introduction of the Persian princess Arsace, when a long and detailed narratorial external analepsis explains her part in the intrigue: after Calasiris' disappearance she had conceived a passion for Thyamis, which, although unreciprocated, had provided Petosiris with the material to denounce his brother to Arsace's husband, the satrap Oroondates (7.2.I-5). This part of the fabula is thus disclosed more or less in reverse chronological order, the full version being enigmatically withheld until such time as it is necessary for full comprehension of the story.

Charicles tells his own story to Calasiris to explain his presence in Egypt: the death of his daughter in a fire on her wedding-night, and the subsequent death of the mother, drove Charicles to seek solace for his grief in travelling (2.29.2-5). A peculiar further detail is added in his speech to the Delphians after the 'abduction' of Charicleia, which he interprets as a punishment for an incident when he entered the shrine before the proper time and 'beheld that which it is a sin to behold': Apollo had on that occasion foretold that he would lose the sight of that which he loved the most (4.19.3).

Another important element of the earlier part of the fabula is the territorial dispute between Persia and Ethiopia over the frontier and particularly over the possession of the emerald mines. It is this that accounts for the presence of the young Sisimithres in Egypt with the seven-year old Charicleia. The theme re-emerges later in the novel when the emerald mines are the reason for the war that brings Charicleia's father Hydaspes into Egypt. ${ }^{10}$

Finally, Cnemon's story, begun in the first book of the novel and completed in the second, accounts for his presence and that of the slave girl Thisbe in Egypt. ${ }^{11}$ This external actorial analepsis contains subordinate analepses. Cnemon is able to tell from his own experience the story of his stepmother Demaenete's passion for him and the

10 2.32.2; 8.I.I-3. This analepsis refers to a long standing dispute, predating the novel's story but not really part of it (heterodiegetic external analepsis).

11 I.9.I-I8.I; 2.8.4-9.5. Not all of Cnemon's story relates germanely to the main plot. On the connections see J.R. Morgan [I989] I999. 
intrigue concocted by Thisbe and Demaenete leading to his conviction for attempted parricide. Subsequent events are conveyed to him first by a friend Charias, who tells him of Thisbe's continuing scheming culminating in the suicide of Demaenete. After Thisbe's dead body is found in Thyamis' secret cave and at first mistaken for Charicleia, Cnemon narrates what took place after the death of Demaenete, culminating in Thisbe's departure from Athens with her lover, an Egyptian merchant named Nausicles. ${ }^{12}$ Cnemon narrates all this information directly but at the end supplies its provenance in an account given to him by another acquaintance, Anticles, with whom he has come to Egypt. At this point Cnemon alludes to subsequent adventures, clearly including an account of how he became the captive of Thyamis and his robbers; he promises to return to these at a later time, and duly does so much later when he tells his story to Nausicles, adding the information that

he had faced many dangers and experienced many adventures, finally being captured by buccaneers; but he had managed to escape, only to be captured for a second time as soon as he had set foot in Egypt by the bandits called Herdsmen. ${ }^{13}$

The primary narratee still does not have the whole story about Thisbe, however. A letter discovered on her corpse adds the information that for ten days she has been a prisoner of an unnamed robber who is infatuated with her (2.I0.I-4). Shortly afterwards the primary narrator fills in more gaps, identifying her robber-lover as Thermouthis, who has already made an appearance in the story, and explaining how 'a few days previously"14 he had ambushed Nausicles and stolen her. An additional twist comes with Calasiris' revelation that Nausicles' intention was to sell her into Ethiopia as confidante of the queen in the Greek-speaking court there (2.24.3). Thisbe seems never to have been aware of his treachery.

The chronology of these last passages is straightforward, but as we delve back into the early stages of the fabula the temporal relationships of the various strands are impossible to determine with any precision. Some obvious synchronisations are provided where the strands

12 The name is carefully planted here to confirm that Cnemon knows the name of Nausicles and is thus able to identify him when he appears in the story as the owner of the house in which Calasiris tells Cnemon his story.

13 The 'many adventures' are never narrated.

14 oligōn prosthen hèmerōn (2.12.2); obviously identical with the ten days mentioned in Thisbe's letter. 
intersect, for example with the transfer of the seven-year-old Charicleia from Sisimithres to Charicles. On the other hand, we are given no indication of the duration of Calasiris' exile. If we accept his account of his visit to Ethiopia as genuine, the implication is that he then made his way directly to Delphi, but he gives no clue as to how long the journey took, nor of how long he was in exile before finding his way to Ethiopia. The logic of the action simply requires a reasonably lengthy absence to accommodate the intrigues over the priesthood at Memphis, Thyamis' flight to the world of outlawry and his rise to become bandit-chief through winning the respect of his men. There is no specific clue as to how deep in the past Cnemon's experiences in Athens lie. Thisbe was stolen from Nausicles ten days before the opening of the text, but we are not told how long she had been in Egypt before then; the logic of the plot suggests that Cnemon had been a member of Thyamis' band for some period before Thisbe was captured, and that, as he came to Egypt in search of her, that she had been in that country for rather longer than he. As for Charicles' strand, we can reason that his natural daughter was of marriageable age before Charicleia was seven years old, and must therefore have been at least ten years her senior. It seems logical to conclude that the birth of Charicles' daughter is the earliest chronological point in the novel, and hence should be regarded as the start of the fabula..$^{15}$ Whether it is legitimate to apply such deductive processes to a fictional text whose author seems not to have been much concerned with the question is a different issue. What we can say, however, is that the way in which the separate strands eventually connect with each other, with their relevance becoming apparent in retrospect, underwrites the role of Providence in Heliodorus' world. The birth and early death of Charicles' natural daughter form part of a providential plan for the life of Charicleia, predating even her birth.

The discussion so far has focused on the parts of the fabula preceding the beginning of the story. It is clear that the fabula emerges from the story in a radically anachronic way, quite different from the practice of any of the other novels. However, the presentation of these earlier parts of the fabula through external actorial completing analepses conforms, by and large, to a chronological ordering of the story. That is to say that narrative acts by characters in the story are reported by the primary narrator at the moment in the story when those acts are performed.

\footnotetext{
15 Unless the mysterious incident in the temple predates even the birth of Charicles' daughter.
} 
Critics have drawn attention to the 'dramatic' mode of presentation thus achieved: the complete story is not told by the narrator, but allowed to emerge through the natural interaction of the characters in the story ${ }^{16}$

The part of the fabula later than the beginning of the story is also presented anachronically. This is partly effected through actorial internal analepses, but the primary narrator himself also offers completing internal analepses. As an example, let us examine the episode in the bandits' cave. A chronological presentation would run something like this: a rival gang of bandits, who had been driven off by Thyamis and his men from the richly laden ship at the beginning of the novel, and who have been briefed by Thyamis' brother Petosiris to capture him if possible, attack Thyamis' stronghold in the hope of recovering the spoils which they had lost. Thyamis tells Cnemon to hide his beloved Charicleia in a secret cave to keep her safe, and orders his right-hand man Thermouthis to bring a sacrificial animal. Cnemon takes Charicleia to the cave, and hides her in its depths. While Cnemon is on his way back to Thyamis, Thermouthis also goes to the cave in order to hide his beloved Thisbe; he leaves her near the cave-mouth. As the battle begins to go against him, Thyamis has second thoughts and decides to kill Charicleia to prevent her falling into the clutches of his enemies. He runs to the cave, encounters Thisbe near the entrance, mistakes her for Charicleia and kills her, dropping his sword near the body. He throws himself into the battle and is captured alive. Thermouthis is wounded in the battle, swims ashore and hides until nightfall. At nightfall, Theagenes and Cnemon go the cave to release Charicleia, but discover Thisbe's body and at first mistake it for Charicleia. They realise their mistake, and there is a reunion. Thermouthis returns to the cave and discovers Thisbe's body.

The chronological sequence is changed in the story. The identity of the attacking bandits and their motivation are revealed only in an internal narratorial analepsis at the point when they take Thyamis alive; this analepsis is the one that also contains information about the back-story of Thyamis and Petosiris, and is thus partly internal and partly external, reversing chronological order:

[internal] They were in fact from the same band of brigands who had fled from Thyamis and his men by the Heracleotic mouth of the Nile. Angered at being robbed of other people's property and resenting the

16 The fullest treatment remains that of Hefti i95o. 
loss of the plunder as much as if it actually belonged to them, they had mustered their comrades who had been left at home and called upon the aid of the surrounding villages, offering a fair and equal division of the spoils they expected to take. Thus they were the leaders of the assault, but their reason for taking Thyamis alive was this. [external] $\mathrm{He}$ had a younger brother, Petosiris, at Memphis, who had treacherously and in defiance of ancestral usage usurped the office of high priest from Thyamis. Petosiris' inquiries had revealed to him that his elder brother was the leader of a band of outlaws, and he was afraid that Thyamis might one day seize an opportunity to take action against him; besides, he could see that he was generally suspected of having murdered the missing Thyamis. And so he had sent word round the bandit villages, offering cattle and large sums of money as a reward for anyone who brought his brother to him alive.

$(\mathrm{I} \cdot 33 \cdot \mathrm{I}-2)$

Thermouthis simply disappears when commanded to fetch a sacrificial animal; only at the point where he returns to the cave to find Thisbe does the narrator analeptically explain how he had shut her in the cave. This analepsis is also the one that contains the information about Thermouthis' capture of Thisbe from Nausicles: it too is partly external and partly internal, this time in chronological sequence:

[external] A few days previously, while she had been travelling in the company of Nausicles the merchant, Thermouthis had waylaid them on a narrow road through the foothills and carried her off. [internal repeating] In the confusion of the battle that followed the enemy's assault, he had been sent by Thyamis to fetch the victim for sacrifice and [internal completing] had taken the chance to put Thisbe where no weapon could touch her, hoping to keep her alive for himself. No one had seen him as he shut her in the cave, but in his frantic haste he had left her close by the entrance.

$(2.12 .2-3)$

By this point of course, Theagenes and Thyamis have already found her body and identified it. One effect of postponing the narration of Thermouthis' activities is that the primary narratee, like the characters in the story, is led to believe that it is was Charicleia that Thyamis killed. ${ }^{17}$ Her identity is revealed to him only at the moment when it is revealed to the characters. It is the amazement of Theagenes and Charicleia at this turn of events that prompts Cnemon to tell

17 The narrator carefully tells us that Thyamis' victim spoke to him in Greek before she died, which facilitates the false identification for both Thyamis and the primary narratee. On the other hand, the fact that she is at the mouth of the cave, not in its inner depths where Cnemon left Charicleia is a clue to the primary narratee that the dead woman is not Charicleia; Thyamis does not know whereabouts in the cave Charicleia was left. 
the second instalment of his own experiences (an actorial external analepsis, discussed above), in order to explain her presence in Egypt. The narrator's analepsis fills in only the details of which Cnemon himself could not have been aware. Even at this point, the characters do not know who killed Thisbe or why; the primary narratee can easily deduce that Thisbe was the woman killed by Thyamis when he intended to kill Charicleia, but this is not confirmed in the story until Cnemon draws attention to Thyamis' sword (2.14.4).

Similar anachronies, with parts of the fabula supplied by completing internal actorial analepses, occur later in the story also. For example, Theagenes and Charicleia are separated, she being taken away by Nausicles as a replacement, Thisbe and he by the Persian phrourarch Mitranes to be sent to the Great King; Nausicles brings Charicleia back to his house, where she is recognised and reunited with Calasiris. They then set off to try to find Theagenes, but are forestalled by a chance meeting with a friend of Nausicles who tells them:

'Mitranes is not there at the moment. This very night he went off to fight the Herdsmen who live in the village of Bessa; he had sent some young Greek he had captured to Oroondates in Memphis - to be taken on from there, I suppose, as a gift to the Great King - but the men of Bessa and their newly chosen leader Thyamis mounted a surprise attack and seized the young man, who is now in their possession.'

$(6.3 \cdot 4)$

This fills in not only the information about what happened to Theagenes after his separation from Charicleia, but also about the progress of Thyamis, who was last heard of being captured alive by Petosiris' bandits. The 'dramatic' mode of presentation that we noted earlier is obvious again here. The primary narrator does not provide all the information, but it emerges plausibly within the story. We might equally phrase this in terms of focalisation: the events at this point are focalized by Charicleia and Calasiris, and the text presents only what they see and hear. More striking, perhaps, is the casual inclusion of the new information about Thyamis. An important section of his story is simply occluded here. It is not clear whether the men of Bessa are the same group of bandits who captured him; nor, if they are, why they have decided not to shop him to Petosiris; nor, if they are not, how he escaped; nor how he has risen so quickly to become the chieftain of his new associates. More details about the theft of Theagenes are revealed later, when Achaemenes, the son of Arsace's servant Cybele, enters the story. The first item of information about him is when a doorkeeper in the palace mentions that he has gone to buy some eye-ointment (7.I4.3). 
He enters the story in person a page or so later, and peers through the keyhole of the room where Theagenes and Charicleia are being kept. He immediately falls in love with her but fancies that he recognises Theagenes; as he reflects he realises that he is

'the man that Mitranes, the commander of guards, gave me the other day to take to Oroondates so as to be sent on to the Great King. Thyamis and the men of Bessa took him from me, and I came within an inch of losing my life - in fact I was the only one of the escort party to get away.'

After their encounter with Nausicles' friend, Charicleia and Calasiris decide to make their way to Bessa to reclaim Theagenes from Thyamis. Just outside the village they come upon a lot of dead bodies, mostly Persian. An old woman tells them what has happened, namely that Mitranes had sent a detachment of troops to Bessa to exact reprisals for the theft of Theagenes, but that they were ambushed by the locals, and that Mitranes and most of his men died. She goes on to say that Thyamis has now decided to mount a surprise attack on Memphis itself before the satrap can prepare a campaign of extermination against Bessa. At this point her analepsis turns to prolepsis, in a play of timeframes that is characteristic of Heliodorus. She brings into play the possibility of Thyamis' restoration to the priesthood, and mentions a rumour that the satrap is fighting a war against the Ethiopians (6.I3.I5). These two pieces of information look forward to events at Memphis, described in book 7 , and to the military narrative of book 9 .

Although this 'dramatic' use of actorial completing analepses, both internal and external, is a central feature of the novel's narrative strategy, we should not ignore its use of narratorial analepsis. We have already encountered a few cases of external narratorial analepsis in discussing the parts of the fabula before the story. There are also internal narratorial analepses. The most extended of these comes at the point when Charicleia has been brought back to Nausicles' house, but Cnemon still believes the woman he has heard lamenting is Thisbe. The narrator begins with a prolepsis of the reversal that is about to take place; we shall return to this. He then backtracks to the moment where Theagenes and Charicleia were left alone on the robbers' island after the departure of Cnemon and Thermouthis, and devotes several pages to narrating their kisses and conversations, then the arrival of armed men, who turn out to be Mitranes and his soldiers, accompanied by Nausicles, and then the trick by which Nausicles claims Charicleia as Thisbe, while Theagenes is retained by Mitranes (5.4.3-9.2). 
The analepsis ends with the text of the letter which Mitranes writes to Oroondates. At that point the narrator returns to Calasiris and Cnemon in Nausicles' house the next morning.

At a basic formal level this is Heliodorus' version of simultaneity and the handling of parallel storylines. From the point when Cnemon and Thermouthis leave the cave, the narrative focus remains on them: Cnemon loses Thermouthis, then meets Calasiris and becomes the narratee of his story. Our narratorial analepsis covers the same day and night. This may explain the apparently untypical use of the primary narrator to make an extended completing analepsis, when the novel usually allows information to emerge within the frame of the action. ${ }^{18}$ There are two narrations of the same day and night, both by the primary narrator; the difference is that the first contains substantial embedded narratives, whereas the second is more straightforward. This leads to an extreme disparity of length between the two narratives of the same amount of fabula-time,,$^{19}$ giving rise to the sense of a substantial backtracking. This is reinforced by the presence of two cross-references within the analepsis. The first part is marked explicitly as a recapitulation of what has already been read:

After Thyamis had fallen into his enemies' hands and become their prisoner, and the island had been set alight and evacuated by the Herdsmen whose home it had been, Cnemon and Thermouthis, Thyamis' henchman, sailed across the lake at dawn on a mission of reconnaissance to discover what the enemy had done with their captain; their adventures have already been narrated. ${ }^{20}$

(5.4.3; referring to $\left.2.19^{-20}\right)$

The second cross-reference is on the introduction of Mitranes:

So Theagenes and Charicleia were brought before the commander, who was none other than Mitranes, the commander of guards in the service of Oroondates, the Great King's satrap in Egypt, who, as we have seen [hōs dedèlotai], had been paid a great deal of money by Nausicles to come to the island in search of Thisbe.

(5.8.2; referring to 2.24)

In this case the reference is not to something said by the primary narrator himself, but to information given by Calasiris to Cnemon. ${ }^{21}$

\footnotetext{
18 Cf. $S A G \mathcal{N}$ i:529-530.

${ }^{19}$ In Reardon I989, 57 pages compared to four.

${ }^{20}$ hōs ... eiretai (5.4.3; the reference is to 2.19-20.)

${ }^{21}$ There is perhaps a recognition in this that the exposition of the fabula, the plot as a whole, is shared between the primary narrator and his characters, on a more or less equal footing. Similarly, when the issue of the emerald mines is revived, we find a
} 
A final example of narratorial completing analepsis occurs when Charicleia is put on trial for the murder of Cybele, and is worth analysing as an example of the complexity and subtlety with which the novel juggles with its time-frames. First Charicleia does everything she can to get herself condemned to death. The primary narrator explains, in a completing analepsis, that

this was because the previous night in her prison cell, after telling Theagenes all that had happened and hearing in turn of his ordeals, she had made a compact with him to accept voluntarily any death that might be inflicted on them, and so be rid forever of a life without hope, an exile without end, and a fate without pity.

Her abuse of Arsace duly leads to her conviction, and she is led away to be burned at the stake, only to find that the flames do her no harm. When she is taken back to gaol and discusses this turn of events with Theagenes, she suddenly remembers a dream that she had had in the night, in which Calasiris told her that the jewel pantarbe would provide protection from flames (8.II.2). In other words, we are now given an actorial analepsis of different events within the same night which has already been the subject of a narratorial analepsis. What is more, the actorial analepsis concerns a proleptic dream about events which are by now in the past. What had been proleptic in the night (but then forgotten) functions, for both primary narratee and character, as an analeptic explanation of the events it foretold. ${ }^{22}$ Theagenes in his turn suddenly recalls his dream of the self-same night, which like Charicleia's consisted of a vision of Calasiris. In this case, however, the proleptic dream is still proleptic, for both character and primary narratee, looking forward to their release from Arsace's prison and arrival in Ethiopia.

Before we turn to prolepsis, a brief word about repeating analepses. Heliodorus' novel in general presumes a high level of concentration on the part of its narratee, and almost perfect recall. Despite the complexity of the story and its presentation, there is little help given in the form of straightforward recapitulations. We have already noted one example above. Another comes in the ninth book, when Oroondates

\footnotetext{
cross-reference, 'as has already been narrated' (hōs eirêtai, 8.I.3), which relates to words of Sisimithres spoken to Charicles, and relayed by him to Calasiris, and by Calasiris to Cnemon.

${ }^{22}$ We are dealing with the 'recalled prophecy' device; cf. Homer $(\rightarrow)$ and Longus $(\rightarrow)$.
} 
has implemented a ruse to escape from the besieged city of Syene and join up with the rest of his army:

For [gar] Oroondates had issued instructions for the rest of his army to assemble at Elephantine, but when he observed the Ethiopians bearing down on him unexpectedly, he had been obliged to make a dash for Syene with a few troops; there he had been walled in by the earthworks and compelled to beg for his life; Hydaspes had promised to spare him, but then Oroondates had proved the most treacherous of men: he had arranged for two Persians to cross the water with the Ethiopians and dispatched them ostensibly to canvass opinion at Elephantine as to the conditions on which they would be prepared to make terms with Hydaspes, though in reality their mission was to discover whether they would rather make ready for battle at whatever time he himself might be able to make good his escape.

(9.I3.2-3)

This recapitulates a section of the narrative which had been told largely from the point of view of Hydaspes, with Oroondates' deceptions emerging either by implication or as the Ethiopian king becomes aware of them. The analepsis restates events with a narratorial omniscience in keeping with the historiographical tone of this military episode, and may thus be viewed as a deliberate stylistic mannerism to position this part of the text generically.

An extensive repeating analepsis which may serve a similar purpose occurs when Cnemon tells his story to Nausicles (6.2.3-4). This is presented in indirect speech, and condenses the whole of his narrative into a few sentences, even maintaining the documentary provenance of parts of it with references to Cnemon's informants, Charias and Anticles. As noted above, a small amount of new information is added at the end. This recapitulation has a limited argument function: the primary narrator goes out of his way to tell us that Nausicles was left in two minds as to whether to come clean about his relationship to Thisbe, but that he decided to say nothing for the time being. His knowledge of Cnemon's past and social standing will motivate the offer of marriage to his daughter that follows a few chapters later, but the details given in the summary lead nowhere. I have argued elsewhere ${ }^{23}$ that Cnemon's story stands in thematic antithesis to the main plot, and I suggest that the main reason why the primary narratee should be reminded of it in detail at this moment is to retriangulate Cnemon ethically and bring out the full ethical significance of his withdrawal from the pilgrimage to Ethiopia in favour of marriage to Nausicles' daughter.

${ }^{23}$ J.R. Morgan [1989] I999. 
Finally, the narrator can make rhetorical use of repeating analepsis. A good example occurs when Calasiris finally returns to Memphis just in time to prevent his sons fighting a duel to the death. A selective account of his experiences heightens the sense of an amazing peripeteia:

The father who had beheld his sons engaged in single combat, their swords drawn against one another, who had come within an ace of the misery of having his children die within the sight of the eyes that gave them birth, himself became the agent of peace. He had proved unable to escape destiny's ordinance, but his arrival in the nick of time to witness what had been preordained had brought him happiness. The two sons now had their father restored to them after his ten years of homeless wandering. He had been the cause of a quarrel over the priesthood for which they had been prepared to shed one another's blood, but the very next moment with their own hands they garlanded his head and crowned him with the insignia of his holy office.

$(7.8 . I-2)$

\section{Order 2: prolepsis}

I will focus on three types of prolepsis: a) narratorial prolepsis; b) significant actorial prolepsis; c) the proleptic apparatus of oracles, prophecies and dreams. A recurrent theme will be the interplay of past and future.

a) The primary narrator makes sparing but effective use of prolepsis. These are all fairly short-term anticipations designed to arouse expectations about the episode that follows. So as Theagenes and Cnemon make their way to the bandit island to release Charicleia from the cave, the narrator says:

Little did he know what sorrows awaited him there.

The primary narratee knows that Thyamis has returned to kill Charicleia and has run his sword through a Greek-speaking woman. The reference to Theagenes' approaching sorrows activates anxieties that this might have been the heroine, and prepares for a scene of high emotions. The sorrows foretold, however, are mistaken ones: for a few moments Theagenes will believe that the body he finds is that of his beloved, but he will quickly discover the truth.

We have already mentioned the extended narratorial analepsis which fills in the adventures of Theagenes and Charicleia from the point of their separation from Cnemon to the time when Charicleia is brought 
to Nausicles house in the guise of Thisbe. The analepsis is preceded by a prolepsis, which it purports to explain:

In a short while Cnemon was going to experience joy, which heaven therefore was now combining with sorrow ... For the woman he had heard lamenting was not Thisbe, but Charicleia! This is what had happened to her...

In this case, the prolepsis supplies the knowledge that whatever perils are about to be narrated analeptically, Charicleia has survived them. At the same time it raises an enigma that propels the primary narratee forward into the next section of the story. How has it come about that Charicleia, whom we left in the cave with Theagenes, is alone and masquerading as Thisbe?

As Theagenes and Charicleia enter Arsace's palace, the narrator's prolepsis prepares the way for their ordeals in the ensuing episode. The primary narratee already knows that Arsace has designs on Theagenes, but for the characters her hospitality looks like a change of fortune for the better. The prolepsis makes sure that we grasp the irony, but shrouds the exact nature of the threat and its outcome in ominous imprecision:

But had they had any inkling of the fatal pride that dwelt in the palace and of the harm it would cause them, they surely would never have entered it. Now the fate that presided over the tournament of their destiny had ceased its persecutions for a few hours and smiled on them, but their happiness was to be short-lived, its brief day succeeded by new sorrows that destiny was already preparing. Fate was delivering them like willing captives into the hands of their foe, imprisoning, by a semblance of kindness and hospitality, two young people, strangers in a foreign land and unsuspecting of what lay in store for them.

$(7.12 . I-2)$

The final example of narratorial prolepsis occurs when Theagenes and Charicleia are captured by the Ethiopians, mounted on horses and taken off to the Ethiopian king. The tableau that concludes book 8 is interpreted by the narrator, with the benefit of his knowledge of the end of the story, as a prolepsis of their imminent change of status.

The scene was like the preliminary appearance and introduction of the actors in the theatre before the play begins; strangers in a foreign land, prisoners in chains who a moment ago had been haunted by a vision of their own violent death, were now being not so much led as escorted in captive state, guarded by those who were soon to be their subjects. 
Again the comment combines analepsis and prolepsis, emphasising the moment as a hinge of transition between past and future; in this case the prolepsis looks forward, rather vaguely, to a state of affairs that will prevail after the end of the story, when the protagonists are married and ensconced as part of the Ethiopian royal family. Its form is deeply metanarrative, comparing the scene in the story to a proleptic convention in the theatre. ${ }^{24}$

b) As in the other novels, Heliodorus' characters talk a great deal about the future. In many cases, they combine analepsis and prolepsis, marking the moment as a cusp. For example, when Achaemenes tells Oroondates what has been going on in the palace at Memphis, he follows his account of Theagenes' arrival and Arsace's infatuation with a forecast of what might happen next (8.I.4-8). When explaining his strategy to Charicleia, Theagenes combines analepsis (about how he has frustrated Achaemenes) with prolepsis (about how Achaemenes might react) (7.26.8-Io). In lamenting her misfortunes in Arsace's palace, Charicleia modulates form a catalogue of past woes to one of anticipated horrors (7.I4.5-8).

The case of actorial prolepsis on which I wish to dwell is, however, of a rather different kind, and demonstrates Heliodorus' metanarrative tendencies. In the ninth book, when Theagenes and Charicleia are being taken to see Hydaspes, the issue arises of whether she should immediately reveal her true identity to her father. Of course, to do so would bring the story to a premature ending, so Charicleia has to be provided with reasons for a strategy of remaining incognito. In considering her strategy she in effect maps out the course of action of the last book of the novel; but the reasons that she gives for postponement read in some ways as a self-justification of the novel's length and complexity:

Great ends can only be achieved by means of equal greatness. A story whose beginnings heaven has made convoluted cannot be quickly resolved. In particular it may be dangerous to reveal abruptly things that the passing years have made obscure, especially when the central figure of our entire story, the key to the whole tangled web of complexity and

24 Telò 1999 argues plausibly that the word proanaphonēsis, translated above as 'preliminary appearance', is a technical term of ancient literary criticism. In the Homeric scholia it seems to mean something very like 'prolepsis'. This would give the metaliterary screw another twist, with Heliodorus effectively designating his prolepsis as prolepsis. 
recognition, is missing. I refer of course to my mother, Persinna ... if we let ourselves be carried away by our joy and reveal the truth about ourselves before the time is right, when those who could recognise and corroborate the truth of our story are not present to do so, then we run the risk of unwittingly annoying our hearer ... the one incontrovertible token of recognition is maternal instinct ... let us not deprive ourselves of the one thing that would make all the other tokens convincing. ${ }^{25} \quad$ (9.24)

This 'mapping scene' creates expectations of a recognition scene in which Persinna's instinctive affinity to her daughter will be of paramount importance, and this is indeed the way it transpires.

c) More than in any of the other novels, Heliodorus' Ethiopian Story is articulated by an apparatus of predictive devices, which demonstrate both divine management of the world and the author's control of his plot. They also manipulate the primary narratee's attempts to secondguess the way that the story will proceed. ${ }^{26}$

Due to the story's particular temporal structure, the interplay of prolepsis and analepsis takes another form in this respect. We have already examined the scene in Arsace's dungeon where the protagonists each speak analeptically of a proleptic dream, which refers to events which are already past for both character and primary narratee. Since so much of the fabula is presented through extended actorial analepsis, it is a recurrent trope that proleptic devices are narrated after the events which they predict have already occurred. As a simple example, we may cite the dream of the Phoenician wrestler at 4.I6, predicting his victory in the Pythian Games. The Phoenicians tell Calasiris of this dream in a doubly inset analepsis after the victory has been won; it thus serves as analeptic explanation for their presence in Delphi.

In other cases, slightly more complex, we find an actorial analeptic account of a proleptic dream referring to events already in the past for the narrating character but which have not yet appeared in the story. For example, Calasiris narrates to Cnemon a dream he had in Delphi in which Apollo and Artemis entrusted Theagenes and Charicleia to him and commanded him to take them to the land of his birth (3.II). He is already in Egypt by the time he makes his narration, but neither the primary narratee nor the secondary narratee has yet been told of his departure from Delphi.

${ }^{25}$ The scene is discussed in more detail in J.R. Morgan I989: 308-310.

${ }^{26}$ Detailed treatment of this in J.R. Morgan ig89. 
In yet other cases, an analeptically narrated prolepsis may contain references to some events which have occurred in the time between the original prediction and the moment of narration, but also to events which are still in the future for both narrating character and the primary narratee. An example of this sort is Calasiris' foreknowledge that the courtesan Rhodopis would be the start of his misfortunes, which led him to exile himself from Memphis to avoid sexual temptation. He tells Cnemon of this when he has already returned to Egypt. But the information about Rhodopis is joined with a prediction that his two sons would take up swords against one another, which is not fully fulfilled until Arsace stages their duel in book 7.

Finally there are proleptic visions which refer straightforwardly to events which are in the future for characters and primary narratee alike. A simple example of this is the pronouncement by the gymnosophists that the ceremony of sacrifice to welcome Hydaspes back to Ethiopia after his successful campaign in Egypt will be disrupted by some commotion, the outcome of which will be joyful (IO4.2).

The 'argument' function of some of these proleptic narratives is interesting. Near the beginning of the novel, Thyamis has a dream:

He was in Memphis, his home-town, and found himself at the temple of Isis, which he dreamed was all ablaze with torchlight; the altars and sacred hearths were drenched with the blood of all kinds of animals; the gates and colonnades were teeming with people, who filled the whole place with a confused babble of chatter. When he went inside the shrine itself, he dreamed the goddess came to him, gave Charicleia into his hands, and said, 'Thyamis, this maiden I deliver to you; you shall have her and not have her; you shall do wrong and slay her, but she shall not be slain'.

The story foregrounds the issues of interpretation raised by this dream. At first, Thyamis reads it to conform with his own desires, as a prophecy that he would have Charicleia as wife, and inflict the wounds of defloration on her. However, as the battle against the other bandits turns against him, he reinterprets his dream to mean that he would have her but lose her, and would really slay her. Acting on this palpable misinterpretation he goes to kill her, but in fact his victim turns out to be Thisbe instead. Thyamis' two wrong interpretations of the dream lead him to act in a way that brings about its true fulfilment, in a way unforeseen by him. ${ }^{27}$

\footnotetext{
27 Discussed at more length by Bartsch I989: 93-98.
} 
The major prolepsis in the novel is the oracle that Calasiris receives in Delphi, and of which he tells Cnemon near the end of book 2. This oracle provides a predictive armature from which the whole plot is suspended, but it too raises important difficulties of interpretation. It is worth quoting and unpacking this oracle in full:

\footnotetext{
'One who starts in grace and ends in glory, another goddess-born:

Of these I bid you have regard, O Delphi!

Leaving my temple here and cleaving Ocean's swelling tides,

To the black land of the sun will they travel,

Where they will reap the reward of those whose lives are passed in virtue:

A crown of white on blackening brows.'
}

The Delphic crowd is at a loss to understand any of this, but both Calasiris and the primary narratee quickly see the punning allusions to the names of the protagonists in the opening lines: Charicleia's name is compounded of kharis ('grace') and kleos ('glory'), while Theagenes' name consists of thea ('goddess') and the suffix -genes, meaning 'born from'. The third line refers to their elopement from Delphi under Calasiris' supervision: an event in the past for Calasiris as he narrates, and already known to the primary narratee, as he first encounters the protagonists in the novel's opening tableau at the mouth of the Nile. The reference to 'the black land of the sun' is eventually disambiguated as indicating Ethiopia, which Calasiris discovers to be the land of Charicleia's birth. For him as he narrates this discovery is already in the past; but neither the primary nor the secondary narratee can understand it until Calasiris releases the information that Charicleia's parents are black-skinned and the Sun is the principal deity of Meroe. The last two lines of the oracle are still unresolved at the time of Calasiris' narration; and indeed he dies before their meaning becomes clear. The crown of white refers to the insignia of Ethiopian priesthood with which Charicleia and Theagenes are invested on the very last page of the text, and the 'blackening brows' are not to be taken literally but indicate their assimilation into a new Ethiopian identity. However, the story encourages the primary narratee to interpret this oracle in ways that turn out to be incorrect, much as Thyamis was induced to misinterpret his dream. The oracle at first seems to promise a happy ending as a reward for the protagonists' chastity and piety. But when they get to Ethiopia, they find that it is the custom there to sacrifice virgins in celebration of victory, and the proof of their virtue given by the magic Ethiopian gridiron in fact condemns them to death. The 
white crown for a moment seems to be the fillet tied round the head of a sacrificial victim, and the blackening brows a reference to the spilling of blood. The long-term prolepsis of the oracle, then, so far from defusing the tension of the plot maintains its unpredictability by allowing for a series of false references before the true one is finally reached. ${ }^{28}$

Anachrony, in all its aspects, is the hallmark of Heliodorus' novel. The flexibility and sophistication of his technique marks an important advance in the history of Greek narrative, and anticipates that of the modern novel.

\section{Rhythm}

The novel falls into two distinct halves, with marked differences in the way they handle duration and rhythm. From the daybreak at the beginning of the novel to the end of book 5, we have five carefully marked day/night units. ${ }^{29}$ The rhythm of this part of the novel is very expansive. With the exception of the relatively short day that runs from 2.I9.3 to 2.20.4, the primary narrative consists in very large part of scenes which play out in, as it were, real time. This is of course a byproduct of the anachronic structure discussed above: lengthy embedded narratives in direct speech inevitably extend the narrative time devoted to the days in which they occur. This is particularly striking in the case of the fourth day/night in the novel, which, on Futre Pinheiro's calculation takes up 73 pages of the Greek text, mostly occupied with Calasiris' narrative. The passage of time in this longest single day in any Greek novel is articulated by a series of textual markers: it is midday when Cnemon meets Calasiris (2.21.6); a meal is served when they return to Nausicles' house (2.22.2). By 3.4.9 the sun has set, and in a brief return to the primary narrative lamps are lit. Calasiris continues telling his story through the night: at 4.4 .2 'no little part of the night has passed', and Calasiris comments on Cnemon's stamina as narratee. At the beginning of book 5, Calasiris again comments on the passage of time, and proposes a break for sleep; Cnemon only agrees because he has heard the sound of voices, indicating the return of Nausicles. After

\footnotetext{
${ }^{28}$ For detailed discussion of this idea see J.R. Morgan 1989.

${ }^{29}$ For details of the time-scheme of the novel see Futre Pinheiro 1998. Successive dawns are registered at I.I, I9; 2.I8, 20; and 5.IO.
} 
a miserable few hours for him, in which he is convinced that Thisbe has come back to life and blunders around the house in the dark, the cocks crow at 5.3.2 and (after the narratorial analepsis covering the experiences of Theagenes and Charicleia during the same day) dawn finally breaks at 5.IO.I.

In the second half of the novel time begins to pass much more quickly. The amount of text devoted to each day decreases, and although the primary narrative continues to comprise successive days up to 7.19.5 (eleven days from the opening of the novel), thereafter time becomes more subject to ellipsis: for example, at 7.20.I five or six days pass. From the beginning of book 8 in particular it becomes increasingly hard to plot the action in precise chronological terms, and temporal indicators become less frequent. This pattern is reversed only in the final day of the novel, during which most of the action of book Io occurs.

\section{Pauses and ellipses}

This novel includes rather more descriptive pauses where fabula-time ceases to move than the other novels. In the last book alone, a whole chapter is devoted to a survey of the geography of Meroe (I0.5) and to a riddling description of a giraffe (I0.27). The ninth book contains a chapter on the festival of the Neiloa and its theological significance, and another of detailed description of the armour of the Persian cataphract cavalry.

Most of the time span of the novel is narrated, some of it in vague phrases denoting the passage of a considerable time. Within this overall structure, the passage of time in certain narrative threads may be occluded. For example, at the end of book 6 Calasiris and Charicleia have an encounter with a necromantic old woman outside Bessa. The action switches to Memphis at the start of the next book, and at 7.6 Calasiris and Charicleia arrive just in time to witness the duel of Thyamis and Petosiris. The latter part of their journey to Memphis has clearly taken place out of shot. There is nothing particularly remarkable about this, but attention must be drawn to a particularly interesting and sophisticated ellipsis. In I0.2 Hydaspes is in Syene and writes a pair of letters to be taken on ahead to Meroe by quick riders, one to the gymnosophists and one to his wife. The text of the letters is followed immediately by their reception and reading. The effect is rather like 
a fade in a film, where the writer's voice-over continues as the shot changes to one of the recipient reading the letter. This is an economical device, with the effect of simply eliding the passage of time taken up by the journey from Syene to Meroe, specified by other writers as a matter of a month or more. ${ }^{30}$

\section{Conclusion}

This chapter has concentrated on specific aspects of time in Heliodorus, particularly issues of order, and the effects of anachronies. Within the space available, it has not been possible to catalogue the phenomenon completely, but I hope that enough has been said to indicate that there is a sea-change in complexity and sophistication compared to the other novels. This is clearly a sign of the text's literary ambitions and aspirations. Just as Homer succeeded in telling the story of the whole Trojan War within the formal constraints of a single episode from its tenth year, or in compressing the entire story of Odysseus' return to Ithaca into a short period in the twentieth year of his absence, so Heliodorus tells the whole story of his heroine's seventeen years of life in a narrative which ends a month or so after its opening scene.

${ }^{30}$ Hdt. 2.29, 31: certainly known to Heliodorus, who makes intertextual reference to Herodotus on several occasions. Aristides $(36.55 \mathrm{~K})$ estimates the journey as taking between four and six months. 
EPILOGUE

TIME IN ANCIENT GREEK LITERATURE

\author{
I.J.F DE Jong \& R. NÜNLIST
}

\title{
Chronology
}

Surveying the various analyses of time in Greek literature, a first observation immediately offers itself: most narrative texts display an order that is chronological. This phenomenon is hardly surprising, since the very definition of a narrative is to some extent built on the notion that time progresses. Most narrators will proceed in an order that is essentially chronological, with the result that their texts are recognizable as a narrative. Even the narratives of Pindar, which have generally been treated as anachronical because they seemed to be structured according to the principle of ring-composition, upon closer examination appear to be mostly chronological too. What seemed to be temporal ringcomposition often turns out either to be thematic ring-composition, or the narrator makes use of the device of 'initial summary with subsequent elaboration': he first gives the gist of the story in summary form and then narrates it in more detail in essentially chronological order.

A text that is not strictly chronological is Hesiod's Theogony: while the general sequence of the genealogies is chronological, within the single genealogy the narrator regularly pushes ahead and narrates the birth and experiences of characters who belong to later generations of the same family branch. The demands of genealogy here prevail over strict chronology. For genuinely anachronical narratives we must turn to those of secondary narrators (in epic or drama). Thus, while some of the narratives embedded in drama are chronological (especially prologue narratives and messenger-speeches, but also, for example, Atossa's report of her dream in Aeschylus' Persians), choral narratives and narratives recounted in dialogue form often display very different orders. A notorious example of temporal complexity is the parodos of Aeschylus' Agamemnon. A recurrent type of anachronical order is first to move backwards in time and then forward again (so-called 'epic 
regression'). Even in oratory, where narratives tend to be chronological for the sake of clarity, Demosthenes may opt not only to fragment his narrative (this phenomenon is found in other orators too) but to present events in an anachronical order that best suits his strategy of persuasion.

Occasionally, we find only a semblance of chronology, as is the case in many Aristophanic narratives. They begin chronologically, but soon, under the influence of emotions, end in temporal chaos and the piling up of events in a random order.

Another variation on the chronological order is found in the genres of biography and historiography. Here a narrator may wish, for reasons of thematic unity, to group together events that in fact belong to different times. We find this feature in Herodian, Plutarch and Philostratus. Philostratus even alternates chronological narration with achronical, paradigmatic narration: the linear account of Apollonius' life is interspersed with anecdotes which are hard to pinpoint temporally but illustrate behaviour that is characteristic of him.

\section{Time awareness}

An important aspect of the handling of time and one that lies at the basis of many others, such as rhythm and frequency, is the question of explicit time awareness: do we regularly find time-markers that help us identify at which point of the story we are and how much time each event takes up? Interesting and manifold variations are discernible here, which show that there is no generic uniformity in this respect. Thus in epic and elegiac poetry there is a marked difference between on the one hand Homer and Apollonius of Rhodes, who regularly provide precise time-markers, indicating the days and nights and often the individual parts of a day (and the seasons in the case of Apollonius), and, on the other, Hesiod, the Homeric hymns, Callimachus and Theocritus, who are vague where the marking of time is concerned. Interestingly enough, there is one Homeric hymn, the one to Hermes, which does abound in time-markers. Their frequency and specificity turn this hymn, which recounts Hermes' theft of Apollo's cattle, into a kind of 'police report'. In Callimachus the occasional time-marker is inserted not so much for the sake of establishing a precise chronology but in order to convey a programmatic or meta-poetic message. By beginning his Aetia with the story of the Charites at Paros, which takes place when 
Minos extended his rule over the Cyclades, Callimachus signals that the Aetia begins where Hesiod's Theogony ends and is therefore supposed to be read as a form of sequel.

Turning to the genre of historiography, we may observe that Herodotus and Xenophon by and large employ unspecific and relative timemarkers (type 'after that'), whereas Thucydides provides a model of precise marking (by year and by seasons) that is followed occasionally by Xenophon and more systematically by Polybius. A highly detailed day-to-day chronology is adopted by Arrian, who in this way invites the narratees, as it were, to 'join' the hero Alexander on his expedition. Arrian also indicates the years (dating them by means of Greek archonships), sometimes, in Thucydidean fashion, the seasons and, in the case of important battles, even the months. Herodian proceeds by reigns of emperors rather than years. The historical works of Josephus, at last, stand out for their unique specificity: events are dated by reference to the reigns of Roman emperors, Hasmonaean rulers, or Roman procurators of Judaea. In his account of the Jewish war he also includes references to the months of the Macedonian calendar. When dealing with climactic moments in his narrative, Josephus even inserts more than one time-marker. In spite of the differences among the individual historiographers, the genre as a whole is characterized by a comparatively high density and specificity of time-markers. This, no doubt, is related to its subject matter. The same point also applies to the temporal framework at large. Homer or Apollonius of Rhodes may precisely indicate the temporal structure of their narratives, but the story as such is located in an unspecific, probably remote past, whereas historiographers such as Herodotus not only 'date' their main stories but even the 'mythical' past that precedes it.

As is readily understood, the narratives of drama, which usually cover relatively short periods of time, have little need for explicit timemarkers. From a modern perspective it comes as a surprise, however, that the same situation prevails in the narratives that are embedded in the orators. In spite of the courtroom setting, they proceed in a surprisingly vague way ('then', 'after some time') and only occasionally resort to equally vague but highly suggestive phrases such as 'when $\mathrm{X}$ had made a large fortune' or the like. This remarkable nonchalance regarding the marking of time may perhaps be related to the general tendency in the orators to give the impression of speaking spontaneously and without premeditation. More generally, the observation can be made that many of the texts treated in this volume appear to prefer markers 
of relative chronology. This observation even applies to historiography, which, as seen, displays a comparatively high density of specific markers.

Turning to philosophy, a similar lack of specific dating can be seen, excepting the dialogues related to the death of Socrates. This seems to be related to the iterative nature of this type of text: though strictly speaking recording one particular dialogue, the suggestion clearly is that this dialogue represents many similar ones (see below on frequency).

The biographers Xenophon and Plutarch reproduce the model found in Herodotus or Xenophon's historical works rather than in Thucydides, and thus are vague in their temporal marking. The striking exception is Philostratus, who, in the regular narrative parts (as opposed to the digressions and paradigmatic parts), employs three time systems: one Roman, one Greek and one mystic-oriental, depending on the current location of his hero, the sage Apollonius.

The novels, finally, again show different patterns. Chariton and Xenophon of Ephesus are closer to Herodotus or Xenophon in their vagueness. Conversely, Longus makes a highly intricate use of the seasons in order to mark the progression of the young heroes on their path towards maturity. In the case of Heliodorus the number of timemarkers varies in the course of the novel. From daybreak at the beginning of the novel to the end of book 5 , we have five carefully marked day-night units, but in the second half of the novel temporal markers become less frequent. Only on the final day, recounted in book Io, does precise chronology return.

\section{Analepsis}

The use of anachronies, analepsis and prolepsis, depends to a considerable degree on the length of the narrative in question: a short narrative tends to contain fewer instances, a long narrative more. Another factor is the relationship of story and fabula: if story and fabula coincide, there are, by definition, no external analepses (and prolepses). This is a relatively rare phenomenon in general, the Greek examples being Hesiod's Theogony and Josephus' Antiquities, which aim at giving a history of the world from the beginning until the present. Most Greek narrative texts, however, do make use of analepses in considerable numbers and to a great variety of purposes. 
A first use of the external, usually heterodiegetic, analepsis, found in virtually all the texts, aims to provide background information on characters, places or objects. Sometimes a particular twist is given to this general use, for example when the analepses have an aetiological function (Apollonius of Rhodes and Callimachus) or when they contain intertextual reverberations (Apollonius of Rhodes, Callimachus, Thucydides and Xenophon's Hellenica). Polybius even uses this type of analepsis in order to engage in polemical discussions with predecessors. Such analepses are mostly narratorial, but the novels also have characters introduce other characters by means of actorial analepsis.

A second recurrent use of narratorial analepsis is the 'obituary': the narrator throws a summary look back at the entire career of a character who has just died, often with patent evaluation on his part. In Homer such obituaries take the form of external analepses: the moment a hero dies, the narrator fills in his background, often to pathetic effect. Conversely, these analepses are internal in historiographical texts (mainly Arrian, Herodian, Josephus) and thus form a conclusion to part of the narrative (cf. below on closural prolepsis). A variant is the analeptic sunkrisis found at the end of almost all the Lives of Plutarch, in which he weighs the pros and cons of the characters of the two protagonists.

A third general and widespread use of analepsis is the internal actorial type, that is, when characters inform other characters about something that has happened. These analepses are often repeating, in that they repeat what the primary narrator has recounted before. Thus they allow the narratees to gauge how the characters assess the event in question, a focalization that regularly differs from that of the primary narrator. Such analepses thus may have a characterizing function. The reverse situation applies when the narrator explains the outcome of predictions or prophecies by characters (see below on prolepsis). A very special variant of actorial analepsis is the one found in Philostratus, where the sage Apollonius repeatedly solves riddles by bringing to bear his preternatural insight into the past, that is, his recollection of events to which he was not consciously a party.

The actual beginnings of narratives regularly pose problems to both the narrator and modern scholars alike. Historiographers, in particular, often grapple with the question as to where their histories should begin. A good example is Herodotus, who first rejects several beginnings before he then chooses his own. Many historiographers begin their works with one or more books of 'prehistory' (Thucydides, Polybius, Herodian). Similarly, a biographer such as Plutarch usually begins 
with an analeptic account of events that lead up to the birth of the protagonist. Scholars are confronted with the question as to whether to have the main story begin with these prehistories or rather take them as external analepses. If the narrative speed is different (summary), it seems preferable to see them as different from the main story, that is, as instances of external analepsis. In connection with this, it is interesting to note that Apollonius of Rhodes, who resembles a historiographer in more than one respect, likewise raises the implicit question as to where his narrative begins. While it is clear that the main story opens with the departure of the Argonauts, it is more difficult to determine the beginning of the fabula: is it the oracle to Pelias or Hera's anger at Pelias, which triggered the oracle, or the adventures of Helle and Phrixus, which caused the Golden Fleece to reach Colchis? Different characters and the narrator himself give different answers. Indeed, most aetiological external analepses in the Argonautica go back to the beginnings of time and often culminate in the present of the narrator's own time. The narrator seems to suggest that his real 'fabula' is a history of the Greek world at large.

External analepses, both narratorial and actorial, are often used to insert famous exploits from the past that serve as a standard against which the present behaviour of the characters can be measured. These comparisons may be negative or positive, moralizing or exhortative. This paradigmatic use of the embedded narrative is widespread and occurs in many of the texts treated in this volume.

Analepses also play a role in connection with the device of narrative delay or paralipsis: when the narration of an event is suppressed at its proper place in the temporal sequence of events in order to be recounted later, at a more effective place. This device is found in rudimentary form in Homer and Hesiod and is used to great effect by Thucydides and Plutarch. If in these cases the retrieval of deliberately suppressed information is conscious and effective, an analepsis may also be used simply to fill in the narratees about something they need to know in order to understand what follows.

A fairly widespread use of the analepsis, attested from Homer onwards, is the serialization of analepses through the whole work, which, when pieced together, form a complete story. Examples are the returns of Odysseus, Agamemnon and Menelaus in the Odyssey, the story of the Golden Fleece in Apollonius of Rhodes, the history of Athens and Sparta in Herodotus or the history of the Temple of Jerusalem in Josephus' Jewish War. In the case of Heliodorus, with his spectacular 
in medias res opening, a whole series of analepses and, often, analepses within analepses is necessary to provide the narratees with large chunks of essential information. This allows them to assemble the pieces one by one and reconstruct the entire action that precedes the massacre at the beginning of the novel.

In drama, a function similar to that of analepsis is fulfilled by retrospective narratives. The whole genre abounds in such retrospective narratives, which, when external, set out the prehistory of the play either in one piece (the prologue narratives of Euripides and Aristophanes) or in a series of narrative sections (Aeschylus, e.g. the fall of Troy in Agamemnon; Sophocles, e.g. Oedipus' story in Oedipus Tyrannus). Although Euripides and, to a lesser degree, Aristophanes like to start with stretches of uninterrupted narrative, it should be noted that these too are sometimes later completed by means of retrospective narratives. Thus a series of retrospective narratives recount the fall of Troy in Euripides' Andromache, or Athenian history subsequent to the murder of Hipparchus in Aristophanes' Lysistrata. A special device, found primarily in Sophocles, is the repeating retrospective narrative, that is, when different (secondary) narrators recount the same story but with different focalizations, as is the case in Ajax with the several versions of how Ajax in a rage of madness killed the herds. Internal retrospective narration mainly occurs in the form of messenger-speeches, which inform characters and spectators about events that just before took place offstage.

A special variety of retrospective narrative is the one found in Aristophanes, where a narrative about a past event is interspersed with simultaneous narration of the current situation. An example is, in the opening scene of Clouds, Strepsiades' narration of the past troubles with his son, which is intercut by the cries of that son dreaming of his horseracing.

On occasion, the main purpose of a (repeating) analepsis is to provide the narratees with a recapitulation in order to refresh their memories (cf. the structuring function of prolepsis as 'header' below). This use of the analepsis is found in Homer, Apollonius of Rhodes, the historiographers, forensic oratory and some of the novels. Such recapitulations are especially appropriate in lengthy and complex narratives, where the narratee will be particularly grateful for such an aidemémoire (Polybius and, though not nearly as frequently as one might expect, Heliodorus). In less extensive texts this seems even more a question of the individual narrator's preference and, perhaps, his trust in 
the narratees' competence: Chariton, for example, has recapitulations, whereas Longus does not. Thucydides and Xenophon (historical works) use them at transitional points: these narrators end a section with a brief repeating analepsis, summarizing the position in which the one protagonist is about to be left, and then begin the next section with another brief repeating analepsis, which summarizes the position in which the other protagonist had been left before. A variant of the recapitulating analepsis is found in the dialogues of Plato and, to a lesser degree, Xenophon, where speakers recapitulate for their own benefit (and that of the primary narratees) the upshot of the argument so far.

A last, particular use of analepsis is the combination with prolepsis, which can take two forms: the analepsis is followed by (or incorporates) a prolepsis or has itself proleptic force. Instances of the first type are ubiquitous, for example when Herodotus talks about the past and future of the Alcmeonids. A particularly forceful example is found in Cassandra's narrative in Aeschylus' Agamemnon, which moves from past to present to future, and often does not even distinguish between them. For the second type we may think of characters recounting omens or dreams (Penelope's dream which adumbrates Odysseus' revenge in the Odyssey, Tiresias' report on the omen of the birds which bodes ill for Creon in Sophocles' Antigone) or the analepsis on Jason's robe, which, recalling his affair with Hypsipyle and that of Theseus with Ariadne, heralds no good for his present affair with Medea.

\section{Prolepsis and foreshadowing}

External narratorial prolepsis indicates what happened after the end of the main story. Narrators vary in their wishes to look beyond their own stories. In Homer, Hesiod, the Homeric hymns and Theocritus the narrators hardly look into the future. The Homeric narrator only once, but very effectively, looks at the destruction of the wall around the Greek camp after the fall of Troy and in his stress on nature taking over again conveys an air of tragic futility and at the same time poetic selfconsciousness. Theocritus even suppresses prolepses where they might be expected, for example when recounting the marriage of Helen and Menelaus but omitting any hint at what is in store for them. Both Apollonius of Rhodes and Callimachus, however, insert many external prolepses, which often culminate in references to the narrator's own time and thus suggest a continuity of the past with the present. 
Of the historiographers, Herodotus regularly anticipates the future conflict between the victors of the Persian wars, Athens and Sparta, while his successors hardly go beyond the end of their stories, Thucydides' references to his own exile being a moot point. A special case in this context are Arrian's many references to Alexander's plans that came to naught owing to his premature death. The historiographers do, however, anticipate the fate of individuals, in the form of so-called proleptic closure.

Among the dramatists, Aeschylus and Sophocles have little to no external narratives (only occasional references), whereas Euripides abounds in them: the uninterrupted anticipations that dei ex machina often make at the end correspond to equally uninterrupted external retrospective narratives at the beginning. Aristophanes' approach is similar to Euripides': his plays regularly look ahead to a brave new world, though his anticipations are less detailed than Euripides' and not formally set off but rather interwoven with the action.

The orators and philosophers hardly provide examples of external narratorial prolepsis. Of the biographers, it is Plutarch who at the end of the biographies often traces the fate of the subject's descendants. In the case of the novel, finally, it is Chariton who more than once refers to the return of his heroine's son to Syracuse and the greatness that he will receive there, examples of external prolepses that serve to anchor the fictional plot in 'historical' reality.

Internal narratorial prolepsis and the more implicit device of foreshadowing are found almost anywhere (exceptions are Plato, Xenophon in his philosophical works and the Cyropaedia) and may be put to different uses: to create suspense, pathos or irony. In particular, the repeated prolepsis of one and the same event, for example the death of Patroclus in the Iliad or the destruction of the Temple in the Fewish War, will not fail to make a strong impression on the narratees. In the case of Polybius' account of the Second Punic War, which is replete with Roman defeats, the repeated prolepses to later Roman successes give his work a decidedly teleological outlook.

Narratorial prolepsis can also have a structuring function when it informs the narratees of what the narrative has in store for them: we are dealing either with the ubiquitous short 'header' device (type 'Alexander now decided to make an expedition to Egypt') or with the more intricate 'initial summary with subsequent elaboration' device that is prominent, for example, in Pindar. Related to this device is the proem, prologue or preface. Strictly speaking, these are not prolepses, 
since the story has not begun yet, but they serve to inform the narratees about the story that is about to unfold before their eyes. The present volume discusses the proems of several authors (Homer, Apollonius of Rhodes, Herodotus, Arrian, Herodian, Euripides, Xenophon's Cyropaedia, Plutarch). One such opening deserves particular attention: the painting in Longus' Daphnis and Chloe, a pictorial 'proem' that whets the narratees' appetite, since the narrator, suppressing his ex eventu knowledge, describes exactly what he saw (and did not quite understand) at the time - later it will turn out to be a pictorial representation of the story we are about to read. Comparable is the tendency of biographers such as Plutarch and Philostratus to insert paradigmatic anecdotes about the main characters at an early stage of their biographies, while still recounting their childhood. Another form of narratorial prolepsis that owes its existence primarily to structuring purposes is the clustering of thematically similar events that are in fact temporally distinct (Philostratus).

A very particular technique of foreshadowing, which is primarily found in Hellenistic poetry, is the so-called prequel technique, whereby stories are narrated that precede their better-known sequels, for example the affair between Medea and Jason in the Argonautica, which forms the prequel to Euripides' Medea. While the narrator never explicitly refers to these later events, he nevertheless counts on his narratees' knowledge of the sequel, which allows him to create various effects, ominous, humoristic, etc. An example is Theocritus' Polyphemus, who hopes that a future visitor (Odysseus) will teach him how to swim. Closely related are the more incidental types of prolepsis, triggered by intertextuality, for example in Chariton (where quotations from Homer mark Callirhoe as a Helen and Penelope) and Longus (Daphnis climbing a tree to fetch an apple for Chloe is reminiscent of a wedding song by Sappho, and the primary narratee is cued to take the episode as foreshadowing their wedding). These intertextual prolepses are comparable to their analeptic counterparts (discussed above).

Actorial internal prolepsis regularly takes the form of either apprehensive or optimistic emotions. A special type are the prophecies, dreams and omens, which can be found in several texts (Homer, Apollonius of Rhodes, Herodotus, Arrian, Josephus, Aeschylus, Sophocles, Philostratus, several novels). Here, different effects may be created depending on whether the prophecy is misunderstood or not heeded by a character (this is a widespread motif), or the prophecy is not reliable (a variant found, for example, in Arrian and Longus). In all these 
cases it is of crucial importance to compare the outcome, as related by the primary narrator, with the original omen. An intermediate position between mere emotions and actual prophecies is taken by characters who announce or hatch plans or speculate about their fulfilment. Here, the narratees' interest lies in examining whether and how these plans are executed, noting that certain characters are unaware of the plans and are deceived. However, on occasion it is the narratees themselves who are misdirected, when (repeated) prolepses do not actually lead to the expected outcome (e.g. Euripides' Medea contains several references to her intention to kill Jason, but in the end she kills the children).

A less dramatic but more argumentative use of the actorial prolepsis is found in Platonic dialogue: philosophers should not only be able to recapitulate earlier parts of a dialogue (internal analepis, see above) but also foresee the future course of the argument or their interlocutors' prospective arguments (internal prolepsis). Sometimes this anticipation is given the form of whole stretches of hypothetical dialogue: 'if you were to say X, I would say Y ...'. A similar form of hypothetical prospective narration is found in drama (e.g. Teucer imagining how his father will receive him after Ajax' death in Sophocles' Ajax, or characters who 'rehearse' a scene, usually to be played out offstage, for example the pedagogue's report about Orestes' alleged death in Sophocles' Electra).

Actorial external prolepsis can be a powerful tool to extend the fabula beyond the limits of the story. The Homeric narrator, for example, hardly anticipates the fall of Troy himself. Instead he has his characters do so on a regular basis. Similarly, characters in Polybius, Pindar, Euripides, Plato (Apology), Chariton and Longus make external prolepses at the end of the story.

\section{Parallel storylines and simultaneity}

Longer narrative texts tend to deal with more than one storyline and feature characters who are at different locations. Several devices are available to the narrator to connect these storylines. Most frequent is the well-known and hence unobtrusive combination of the Greek particles men and $d e$ ('on the one hand ... on the other'). This construction merely indicates that there are two storylines, but does not address the question of their temporal relationship (it is, in fact, used for many purposes other than signaling multiple storylines). Another elegant and, as 
it were, camouflaged link between two storylines is the narrator following in the footsteps of a character who moves from A to B or accompanying news that spreads from A to B (Herodotus, Thucydides, Herodian). More conspicuous is the use of temporal correlatives such as ophra ... tophra... ('while ..., in the meantime ...'). Finally, there are other forms of explicit synchronisation: 'at the same time' or even expressions of the type 'on the same day that X did A Y did B'. This type is found in Herodotus, Thucydides, Xenophon and Josephus (though, the latter two include instances that are in fact historically inaccurate). Interestingly enough, the first part of Polybius' work makes only sparing use of explicit synchronisation, because, as he himself explains, there was no real connection between the different parts. The turning point comes with the I4oth Olympiad, after which he regularly switches between the different locations and hence storylines. The fact that Polybius explicitly addresses the question is characteristic of this self-conscious narrator in general.

In the case of the men ... de-construction, which leaves the actual temporal relationship between the two storylines open, two general types can be discerned. One has been described as 'relay-race' or the 'continuity of time principle': the narrator switches from storyline A to storyline $\mathrm{B}$; while he is dealing with $\mathrm{B}$, the action of $\mathrm{A}$ remains stationary; when he returns to A, time there has moved on. This method is found in Homer, Apollonius of Rhodes, Herodian, Chariton and Xenophon of Ephesus. A second method has it that the narrator, when switching back from B to A, retraces his steps and goes back in time. Apollonius of Rhodes and Josephus use this method. The historians Thucydides and Xenophon often insert brief recapitulations at points of transition. A mild form of such going back in time is found in Homer, when, for example, characters focalize events which have already been recounted by the narrator. Another method of handling simultaneous material is by recapturing it in the form of completing analepses that are inserted at the point where the information actually becomes relevant. This is the method used by Thucydides and Heliodorus, and, in the form of retrospective narratives by messengers, by the dramatists. 


\section{Rhythm}

The rhythm (or speed, duration) of a narrative text as a whole is to some degree determined by the time span that is covered by this text. Thus narratives that focus on a comparatively short time span (e.g. Homer, Homeric hymns, Callimachus' Hymns, Heliodorus) are bound to display a narrative speed that is relatively slow, while narratives that cover years, decades or even centuries (e.g. Hesiod, historiographers, biographers) are generally narrated at a faster pace. It will be obvious, however, that no text maintains a steady narrative speed throughout. Rather, all the narrative texts covered in this volume display a more or less intricate combination of segments that are narrated now more slowly ('scenes'), now faster ('summaries'), now more slowly again, etc., the differences in speed being relative and not absolute. Such an alternation of slowing down and accelerating is extremely common, though the individual implementations of the principle, needless to say, vary considerably, even within a single text. To paint a complete picture exceeds the boundaries of this epilogue, but some trends are discernible. At one end of the spectrum we find, for example, the Homeric epics, which, by comparison, present a comparatively balanced picture, whereas Pindar or Callimachus' Aetia regularly show changes between 'fast' and 'slow' that are both more abrupt and extreme. This, of course, is not to say that the narrator of a more balanced text such as the Homeric epics cannot put the device of varying the narrative speed to use in a very efficient way.

It is hardly surprising that narrators tend to devote more textual space (i.e. slow down) to events that they consider particularly important, while less important events can be rushed through at a higher pace ('summary') or omitted altogether ('ellipsis'), with the boundaries between extreme summary and explicit ellipsis being fluid. Slowly narrated 'scenes' are often a clear indication of the narrator's emphasis and have at the same time a tendency to make their way into our memories. In addition to this and (especially in the case of fictional texts) somewhat paradoxically, such passages with their high amount of detail also tend to appear more authentic (which Roland Barthes calls 'l'effet de réel'). A recurrent large-scale pattern is that the thematic centrepiece in slower narrative speed is either preceded (Herodotus, Thucydides) or framed (Homer) by sections that are noticeably faster.

However, slowing down need not always mean that this particular event is of primary importance. The same device can also be applied to 
a more tangential event in order to postpone the narrating of another, more important event ('retardation'). The narrator as it were abuses the fact that slowing down is often taken as a sign of importance. The overall effect is the creation of suspense and expectation in the narratees.

If slowing down does not always indicate importance, summary passages do not automatically imply a lack thereof either. Thucydides, for example, occasionally uses summaries to bring out the swiftness that he considers characteristic of the Athenians.

Generally speaking, ellipsis can be found in all the texts treated in this volume. However, the device is particularly prominent in two types of texts: (I) those which, instead of narrating stories at length and in some detail, show a high degree of selectivity in that they rather allude to or largely presuppose prior knowledge about them (Pindar, Aeschylus, Sophocles, Callimachus, Theocritus); (2) texts which cover a large time span (e.g. Hesiod, historiographers, biographers) and are therefore bound to skip certain periods. In line with its generally allusive, that is, suggestive rather than explicit narrative style, the former group normally makes use of implicit ellipsis, while the latter group uses both the explicit and implicit form of ellipsis.

Summaries can also have a structuring function, in that they open a new narrative section by giving its gist in advance, which is then elaborated in more detail (header technique, see above). Similarly, a summary can also be a closural device, when the end of an episode repeats its essence in a summary fashion.

Given that direct speech leads to an approximate equation of the narrative speed with 'reality', the insertion of speeches results in scenes and hence in a slower narrative pace. Consequently, a high proportion of direct speech (e.g. Homer, Homeric hymns, Apollonius of Rhodes (especially book 3), Callimachus' Hymns, Chariton, Heliodorus) leads to an overall narrative speed that is slow. A similar effect can, of course, be achieved by the accumulation of much narrative detail. Direct speeches and a high amount of detail both give the impression of authenticity and immediacy. The occasional insertion of a speech equally results in a temporary slowing down of the narrative speed, even within a narrative that in itself is short (e.g. Pindar, messenger-speeches in tragedy, Callimachus' Aetia). Conversely, post-Homeric literature shows a noticeable increase in the use of indirect speech, which, among other things, accelerates the narrative speed. A similar acceleration is achieved by the post-Homeric tendency to suppress 'doublings' such as the one, for 
example, of command and execution of command, which are normally narrated with equal detail in Homer.

The description of characters, objects, locations, etc. is a common feature of narrative literature. However, instances of a genuine 'pause' (i.e. the narrative 'clock' comes to a temporary halt and the characters are, as it were, 'frozen' in motion) are not as ubiquitous as might, perhaps, be expected. The Homeric epics, for example, contain only a few instances of real pauses, Chariton and Xenophon of Ephesus none. Other authors use the device more frequently, especially when they insert digressive material (Apollonius of Rhodes, historiographers, Philostratus, Heliodorus). Such digressions can take a generalizing or even omnitemporal form.

\section{Frequency}

The bulk of the narratives analysed in this volume are singulative: each event is narrated once. Given that singulative narration is, so to speak, the default mode (in Xenophon's Anabasis with particularly striking effect), one might be tempted to leave it there and focus on the other types of frequency that depart from it. However, at least one of its features is worth singling out. There are passages that are written in what is formally recognizable as singulative narration, but where contextual or generic considerations suggest that what appears to be a single event is in fact not. This feature mainly occurs in two variants. In the first variant, the relevant text is either a biography (Xenophon's Cyropaedia, Plutarch, Philostratus) or contains biographical material (especially historiography) and presents an event (or several) that is clearly meant to be not merely incidental but paradigmatic for the character in question. In other words, the narrated event is in fact understood to have happened not once but several times. A similar combination of singulative form and iterative implication can be found in philosophical dialogue (Xenophon, Plato): the same or a very similar conversation could have and, in fact, will have taken place more than once. Some of Thucydides' speeches have a similar implication, as do certain passages in drama and in Theocritus.

Iterative narration normally goes hand in hand with summary, in that several equal and recurrent events are narrated once, which can save time or space, as Polybius knew well. Iterative narration can thus be used in an efficient way to draw up a general, characteristic back- 
ground against which the 'scene(s)' and their particulars can be played (in singulative narration). Although virtually all the texts analysed here do make use of iterative narration, it remains the exception, singulative narration being the rule. (Extensive stretches of iterative narration will have to wait for texts such as Proust's $A$ la recherche du temps perdu.)

While the passages in iterative narration are for the most part subsequent, some texts contain a noticeably high proportion of simultaneous iterative narration because they deal either with the, by definition eternal, privileges and spheres of activities of divinities (especially Homeric hymns, Callimachus' Hymns) or with recurrent ('omnitemporal') features of humankind or nature as described in similes (Homer, Apollonius of Rhodes) and certain generalizing digressions.

The conceptual counterpart to iterative narration is repeating narration: the same event is narrated more than once. On a small scale, repeating narration can occur when an initial header or a closural summary (on both see above) repeats the gist of the episode in question. On a larger scale, repeating narration can be used in order to remind the narratees of the story so far (cf. above on analepsis). Such recapitulations are normally placed with particular care at important way stations of the narrative. Overall, however, most narrators treated in this volume show a general reluctance to go over the same ground more than once.

Repeating narration generally invites the narratees to compare the two (or more) versions with each other. Particularly interesting are the cases where the two (or more) versions are not focalized by the same narrative agent, which often leads to illuminating insights into their respective outlooks and, more generally, contributes to their characterization. The tensions and differences between the various versions can also be exploited for other purposes such as dramatic irony (when it is clear whose version is 'accurate') or suspense (when it is not). While full-fledged experimentation with repeating narration (e.g. Faulkner's Absalom, Absalom!, mentioned in the Introduction, or the famous film Rashomon by the Japanese director Kurosawa) remains a prerogative of modern (literary) art, ancient Greek authors are far from ignoring the high potential that lies in this device. 


\section{Subsequent, prior and simultaneous narration}

As is the case with narrative literature in general, in ancient Greek literature too the default form of narration is subsequent (witness Thomas Mann's famous description of the novelist as 'raunender Beschwörer des Imperfekts'). The fact that the act of narrating postdates the events is on occasion made expliclit or even stressed (e.g. by Homer, who sets off the 'mortals today' from the semi-divine heroes of the past, or in Philostratus' Life of Apollonius). Some narrators feel the desire to tell the naratees a great deal about their own time (the 'reference to the narrator's own time' motif). The same feature can take the specific form that, at the time when the events took place, things were not yet there. Conversely, things may not be there any more at the time of the narrating, or, more often, things are said to be still there even now (Herodotus, Callimachus, Apollonius of Rhodes, Plutarch).

Extended prior narration by primary narrators is a rare phenomenon in general and apparently not extant in Greek literature at all (excepting a puzzling passage in Hesiod's Works and Days). The only Greek examples of the device are found in secondary narratives, where it is the characters who make prophecies.

Simultaneous narration, finally, is most frequently found in the form of simultaneous-iterative narration (see above on frequency). It has already been stated above that Aristophanes is fond of interspersing analepsis with snippets of simultaneous narration. Extended simultaneous narration is rare but, when used, can be highly effective: thus in Idyll $\mathrm{I} 6$ Theocritus uses it to suggest that Hiero's warfare, strictly speaking an event of the future, is already in full swing. The chorus' narration of the imagined fall of Thebes in Aeschylus' Seven against Thebes and Clytemnestra's account of the fall of Troy in Aeschylus' Agamemnon can also be taken as instances of simultaneous narration. A prominent characteristic of simultaneous narration is its immediacy and vividness. The narratee seems to be an immediate witness to the events that are unfolding right before his or her eyes (for example, when in Bacchylides I3 a secondary narrator gives a gripping account of Heracles' fight with the Nemean lion). Perhaps one could even argue that the insertion of verb forms in the so-called 'historic present' (e.g. in messengerspeeches or forensic oratory) is a form of pseudo-simultaneous narration: by inserting historic presents into a generally subsequent narrative, the narrator creates the impression that the narrative is simultaneous, which increases its vividness. 


\section{Envoi}

This second volume of Studies in Ancient Greek Narrative examines time as a narratological category and attempts to implement the kind of diachronic narratology that was envisioned by Fludernik (see Preface). It traces the forms and uses of various temporal devices within texts and within genres. As has been the case in $S A G N$ I, the overall conclusion is that most narratological categories are not bound by genre: the same devices occur in different genres, and genres are not homogeneous where the use of narrative devices is concerned.

Needless to say, there are other ways of looking at time in narrative texts. One is the philosophical-historical approach that is pursued, for example, in the multi-authored volume Constructions du temps dans le monde Grec ancien. ${ }^{1}$ This volume aims to analyse the 'temporalisations', that is, the manifold ways in which the Greeks mark rhythms, cut up time into individual units, create chains of events, etc. It discusses time as a psychological, philosophical and social product.

Another way of approaching time is through linguistics. The moods and tenses of the Greek verbal system have attracted the attention of readers and scholars from antiquity onwards. In recent years, fostered and influenced by the pragmatic 'school' of linguistics, there has been a noticeable increase in scholarly discussions. ${ }^{2}$

The narratological analyses of the present volume is a first attempt to offer a comprehensive discussion of this phenomenon in ancient Greek literature. In many cases, the individual analysis could do little more than scratch the surface of what is in fact a vast subject. It is the sincere hope of the editors that the insights collected in this volume will inspire new and more research that will enlarge, refine or modify the picture presented here.

\footnotetext{
${ }^{1}$ Darbo-Peschanski 2000.

${ }^{2}$ For an interesting set of examples and bibliography, see Allan \& Buijs 2007.
} 


\section{BIBLIOGRAPHY}

Aelion, R., 'Songes et prophéties d'Eschyle: une forme de mise en abyme', Lalies 3 (I98I) I33-I46.

Alden, M., Homer Beside Himself. Para-Narratives in the Iliad (Oxford 2000).

Allan, R., Buijs, M. (eds.), The Language of Literature. Linguistic Approaches to Classical Texts (Leiden 2007).

Anderson, M., The Fall of Troy in Early Greek Poetry and Art (Oxford 1997).

Arthur, M.B., 'The Curse of Civilization: The Choral Odes of Phoenissae', $H S P h$ 8I (1977) I63-185.

Auerbach, E., Mimesis: The Representation of Reality in Western Literature, tr. by W.R. Trask ([1946] Princeton I953).

Bain, D., Masters, Servants and Orders in Greek Tragedy (Manchester I98I).

Bakewell, G., 'Persae 374-83: Persians, Greeks, and peitharkōi phreni', CP 93 (I998) 232-236.

Bakhtin, M.M., The Dialogic Imagination: Four Essay, tr. by G. Emerson, M. Holquist (Austin I98I).

Bal, M., Narratology. Introduction to the Theory of Narrative (Toronto [1985] I997).

Barrett, J., Staged Narrative: Poetics and the Messenger in Greek Tragedy (Berkeley 2002).

Bartsch, S., Decoding the Ancient Novel (Princeton I989).

Bassett, S., 'The Proems of the Iliad and the Odyssey', AfP 44 (1923) 339348.

Beck, M., 'Anecdote and the Representation of Plutarch's Ethos', in L. van der Stockt (ed.), Rhetorical Theory and Praxis in Plutarch (Louvain 2000) I5-32.

_ , 'Plutarch to Trajan: The Dedicatory Letter and the Apophthegmata Collection', in P.A. Stadter, L. van der Stockt (eds.), Sage and Emperor: Plutarch, Greek Intellectuals, and Roman Power in the Time of Trajan (98-II7A.D.) (Leuven 2002) I63-I73.

Becker, O., Das Bild des Weges und verwandte Vorstellungen im frühgriechischen Denken (Berlin I937).

Bernsdorff, H., 'Polyphem und Daphnis. Zu Theokrits sechstem Idyll', Philologus I38 (I994) 38-5I.

Bilde, P., Flavius Josephus between Jerusalem and Rome: His Life, his Works and their Importance (Sheffield i988).

Biraud, M., 'L'hypotexte homérique et les rôles amoureux de Callirhoé dans le roman de Chariton', in Sémiologie de l'amour dans les civilisations mediterranéennes (Paris I986) I-27.

Blass, F., Die attische Beredsamkeit, I-III.2 (Leipzig I887-I898).

Blondell, R., The Play of Character in Plato's Dialogues (Cambridge 2002).

Boedeker, D., 'Protesilaos and the End of Herodotus' Histories', ClAnt 7 (I988) $30-48$.

Bollack, J., L’Agamemnon d'Eschyle: le texte et ses interprétations, II (Lille I98I). 
Bosworth, A.B., From Arrian to Alexander. Studies in Historical Interpretation (Oxford I988).

- 'The Historical Context of Thucydides' Funeral Oration', $7 H S$ i2o (2000) I-I6.

Bouvier, D., 'Temps chronique et temps météorologique chez les premiers historiens grecs', in C. Darbo-Peschanski (ed.), Constructions du temps dans le monde grec ancien (Paris 2000) II 5-I4I.

Bowen, A.J., Plutarch: The Malice of Herodotus (Warminster i992).

Bowie, A.M., Aristophanes. Myth, Ritual and Comedy (Oxford I993).

Bowie, E.L., 'Apollonius of Tyana: Tradition and Reality', ANRW II.I6.2 Ber$\operatorname{lin}(\mathrm{I} 978)$ I652-I699.

— , 'Philostratus: Writer of Fiction', in J. Morgan, R. Stoneman (eds.), Greek Fiction: The Greek Novel in Context (London I994) I8I-I99.

Bowman, L., 'Klytaimnestra's Dream: Prophecy in Sophokles' Elektra', Phoenix 5I (I997) I3 I-I5I.

Braswell, B.K., A Commentary on the Fourth Pythian Ode of Pindar (Berlin I988).

Broadhead, H.D., The Persae of Aeschylus (Cambridge i96o).

Brunt, P.A., Arrian, I-II (Cambridge MA i976-1983).

Bürger, K., 'Zu Xenophon von Ephesus', Hermes 27 (I892) 36-67.

Burke, K., Language as Symbolic Action (Berkeley I966).

Burridge, R.A., What are the Gospels? A Comparison with Graeco-Roman Biography (Cambridge I992).

- 'Biography', in S.E. Porter (ed.), Handbook of Classical Rhetoric in the Hellenistic Period: 330 B.C.-A.D. 400 (Leiden I997) 37I-39I.

Burton, R.W.B., The Chorus in Sophocles' Tragedies (Oxford I980).

Buxton, R.G.A., 'Euripides' Alkestis: Five Aspects of an Interpretation', in L. Rodley (ed.), Papers given at a Colloquium on Greek Drama in honour of R.P. Winnington-Ingram (London I987) I7-3I [repr. in J.M. Mossman (ed.), Oxford Readings in Euripides (Oxford 2003) I70-I86].

Cairns, F., Tibullus (Cambridge 1979).

Carey, C., Lysias: Selected Speeches (I, 3, 7, I4, 3I, 32) (Cambridge I989).

Cassio, A.C., Commedia e partecipazione. La Pace di Aristofane (Naples I985).

Cawkwell, G., 'Introduction', in R. Warner, Xenophon: A History of my Times (Harmondsworth I979) 7-48.

Clare, R., The Path of the Argo: Language, Imagery and Narrative in the Argonautica of Apollonius Rhodius (Cambridge 2002).

Clark, M., 'The Concept of Plot and the Plot of the Iliad', Phoenix 55 (200I) I-8.

Clarke, K.J., Between Geography and History: Hellenistic Constructions of the Roman World (Oxford I999).

Clauss, J.J., 'Cosmos without Imperium. The Argonautic Journey through Time', in M.A. Harder, R.F. Regtuit, G.C. Wakker (eds.), Apollonius Rhodius (Leuven 2000) II-32.

Clay, D.S., Platonic Questions. Dialogues with the Silent Philosopher (University Park PA 2000).

Clay, J.S., The Politics of Olympus. Form and Meaning in the Major Homeric Hymns (Princeton I989). 
- Hesiod's Cosmos (Cambridge 2003).

Cobet, J., 'The Organization of Time in the Histories', in E.J. Bakker, I.J.F. de Jong, H. van Wees (eds.), Brill's Companion to Herodotus (Leiden 2002) 3874 I 2 .

Cohen, S.J.D., fosephus in Galilee and Rome (Leiden I979).

Collard, C., Aeschylus: Oresteia (Oxford 2002).

Compton, T., 'The Trial of the Satirist: Poetic vitae (Aesop, Archilochus, Homer) as Background for Plato's Apology', A7P i I I (1990) 330-347.

Coventry, L.J., 'Philosophy and Rhetoric in the Menexenus', $7 H S$ Iog (I989) II5.

Csapo, E., Miller, M., 'Democracy, Empire, and Art: Towards a Politics of Time and Narrative', in D. Boedeker, K. Raaflaub (eds.), Democracy, Empire and the Arts in Fifth-Century Athens (Cambridge MA I998) 87-I25.

Cueva, E.P., The Myths of Fiction (Ann Arbor 2004).

Culler, J., Structuralist Poetics: Structuralism, Linguistics and the Study of Literature (London 1975).

Dale, A.M., Euripides: Alcestis (Oxford [1954] I978).

Darbo-Peschanski, C. (ed.), Constructions du temps dans le monde grec ancien (Paris 2000).

Dewald, C., 'Wanton Kings, Pickled Heroes, and Gnomic Founding Fathers: Strategies of Meaning at the End of Herodotus' Histories', in D.H. Roberts, F.M. Dunn, D. Fowler (eds.), Classical Closure: Reading the End in Greek and Latin Literature (Princeton I997) 62-82.

—_, 'Explanatory Notes', in R. Waterfield, Herodotus: The Histories (Oxford I998) 594-735.

— ' 'Form and Content: The Question of Tyranny in Herodotus', in K.A. Morgan (ed.), Popular Tyranny: Sovereignty and its Discontents in Ancient Greece (Austin 2003) 25-58.

- Thucydides'War Narrative: A Structural Study (Berkeley 2005).

Diggle, J., Euripides: Phaethon (Cambridge I970).

Dover, K.J., Aristophanes: Clouds (Oxford ig68).

- Theocritus: Select Poems (Oxford 197I).

Duchemin, J., 'L'espace et le temps dans le théâtre d'Eschyle', Revue de Synthèse (I970) 80-95.

$\longrightarrow$, 'Du lyrisme à la tragédie: réflexions sur l'Agamemnon et les Perses d'Eschyle', in J. Heller, J. Newman (eds.), Serta Turyniana: Studies in Greek Literature and Palaeography in honor of Alexander Turyn (Urbana IL I974) I22-I42.

Duckworth, G.E., Foreshadowing and Suspense in the Epics of Homer, Apollonius and Vergil ([diss. Princeton I933] New York I966).

Due, B., Antiphon: A Study in Argumentation (Copenhagen i980).

Duff, T., Plutarch's Lives: Exploring Virtue and Vice (Oxford I999).

— ' 'Plutarch on the Childhood of Alkibiades (Alk. 2-3)', PCPhS 49 (2003) 89-II7.

Easterling, P.E., 'Philoctetes and Modern Criticism', ICS 3 (I978) 27-39.

Edwards, M., 'Agamemnon's Decision: Freedom and Folly in Aeschylus', California Studies in Classical Antiquity io (1977) I7-38.

Edwards, M.J., 'Narrative Levels in Antiphon I, Against the Stepmother', in A. Ló- 
pez Eire, A. Ramos Guerreira (eds.), Registros lingüisticos en las lenguas clásicas (Salamanca 2004) 5 ${ }^{\mathrm{I}-63}$.

-, 'Isaeus the Rhetorician: A Forgotten Classic', in L. Calboli Montefusco (ed.), Papers on Rhetoric, VII (Rome 2006) 67-80.

Edwards, M.J., Usher, S., Greek Orators, I: Antiphon and Lysias (Warminster I985).

van Erp Taalman Kip, A.M., 'Intertextuality and Theocritus I3', in I.J.F. de Jong, J.P. Sullivan (eds.), Modern Critical Theory and Classical Literature (Leiden I994) I53-I69.

Fantuzzi, M., Hunter, R., Tradition and Innovation in Hellenistic Poetry (Cambridge 2004).

Ferrari, G., 'Figures in the Text: Metaphors and Riddles in the Agamemnon', CP 92 (I997) I-45.

Flashar, H., 'Die Handlungsstruktur des König Ödipus', Poetica 8 (I976) 355359.

Flower, M.A., Marincola, J.M., Herodotus: Histories, Book IX (Cambridge 2002)

Fludernik, M., 'The Diachronization of Narratology', Narrative I I (2003) 33'-348.

Forster, E.M., Aspects of the Novel ([London i927] Harmondsworth i979).

Fowler, D., 'Second Thoughts on Closure', in D.H. Roberts, F.M. Dunn, D. Fowler (eds.), Classical Closure: Reading the End in Greek and Latin Literature (Princeton 1997) 3-22.

Fraenkel, E., Aeschylus: Agamemnon, I-III (Oxford [1950] I962).

Fränkel, H., Wege und Formen frühgriechischen Denkens, ed. by F. Tietze (Munich I960) I-22.

$\longrightarrow$, Noten zu den Argonautika des Apollonios (München i968).

Frazer, R.M., 'Hesiod's Titanomachy as an Illustration of Zielinski's Law', GRBS 22 (I98I) 5-9.

Frazier, F., 'Contribution à l'étude de la composition des 'Vies' de Plutarque:

l'élaboration des grandes scènes', $A \mathcal{N} R W$ II.33.6 Berlin (I992) 4487-4535.

Frost, F.J., Plutarch's Themistocles: A Historical Commentary (Princeton I980).

Frutiger, P., Les mythes de Platon (Paris i930).

Fusillo, M., Il tempo delle Argonautiche: un'analisi del racconto in Apollonio Rodio (Rome I985).

— ' 'Il testo nel testo: la citazione nel romanzo greco', MD 25 (I990) 27-48.

Futre Pinheiro, M., Estruturas técnico-narrativas nas Etiópicas de Heliodoro (diss. Lisbon 1987).

_ ' 'Time and Narrative Technique in Heliodorus' "Aethiopica"', $A N R W$ II.34.4 Berlin (I998) 3148-3173.

Gagarin, M., Antiphon: The Speeches (Cambridge 1997).

- Antiphon the Athenian: Oratory, Law, and Justice in the Age of the Sophists (Austin 2002).

Garvie, A.G., Sophocles: Ajax (Warminster 1998).

Geiger, J., Cornelius Nepos and Ancient Political Biography (Stuttgart I985).

Gellie, G.H., Sophocles. A Reading (Melbourne I972).

Genette, G., Narrative Discourse: An Essay in Method, tr. by J.E. Lewin ([Paris 1972] Ithaca NY I980). 
, Narrative Discourse Revisited, tr. by J.E. Lewin ([Paris I983] Ithaca NY I988).

Gera, D.L., Xenophon's Cyropaedia: Style, Genre, and Literary Technique (Oxford I993).

Gernet, L., Antiphon: Discours (Paris I923).

Gill, C., 'Dialectic and the Dialogue Form', in J. Annas, C. Rowe (eds.), New Perspectives on Plato, Modern and Ancient (Cambridge MA 2002) I45-I7I.

Gnuse, R.K., Dreams and Dream Reports in the Writings of Josephus: A TraditionHistorical Analysis (Leiden I996).

Goldhill, S., Language, Sexuality, Narrative: The Oresteia (Cambridge I984).

- The Poet's Voice (Cambridge I99I).

Gomme, A.W., Andrewes, A., Dover, K.J., A Historical Commentary on Thucydides, I-V (Oxford I945-I98I).

González, J.M., 'Musai Hypophetores: Apollonius of Rhodes on Inspiration and Interpretation,' HSPh IOо (2000) 270-292.

Gould, J., 'Dramatic Character and "Human Intelligibility" in Greek Tragedy', PCPS 24 (1978) 43-67 [repr. in J. Gould, Myth, Ritual, Memory, and Exchange (Oxford 200I) 78-III].

- , Herodotus (London I989).

_ , "“... And Tell Sad Stories of the Deaths of Kings": Greek Tragic Drama as Narrative, 'Corbett Lecture' (Cambridge I99I) [repr. in J. Gould, Myth, Ritual, Memory, and Exchange (Oxford 200I) 319-334].

Gow, A.S.F., Theocritus, I-II (Oxford [1950] I952).

Goward, B., Telling Tragedy. Narrative Technique in Aeschylus, Sophocles and Euripides (London I999).

Gray, R., Prophetic Figures in Late Second-Temple Fewish Palestine: The Evidence from Josephus (New York I993).

Gray, V.J., The Character of Xenophon's Hellenica (London I989a).

— ' 'Xenophon's Defence of Socrates: The Rhetorical Background to the Socratic Problem', CQ 39 (I989b) I36-I40.

— 'The Moral Interpretation of the 'Second Preface' to Arrian's Anabasis', $7 H S$ i 10 (1990) I80-186.

, The Framing of Socrates. The Literary Interpretation of Xenophon's Memorabilia (Stuttgart I998).

Green, P., 'Text and Context in the Matter of Xenophon's Exile', in I. Worthington (ed.), Ventures into Greek History (Oxford I994) 215-227.

Gregory, J., Euripides and the Instruction of the Athenians (Ann Arbor I99I).

Grenet, P., 'Note sur la structure du Lachès', in Mélanges de philosophie grecque, offerts à Mgr. Diès par ses élèves, ses collègues, ses amis (Paris I956) I 2 I-I28.

Gribble, D.W., Alcibiades and Athens: A Study in Literary Presentation (Oxford 1999).

Griffin, J., Homer on Life and Death (Oxford I980).

Griffith, M., Aeschylus: Prometheus Bound (Cambridge 1983).

Griffith, R.D., 'In the Dark Backward: Time in Pindaric Narrative', Poetics Today I4 (I993) 6o7-623.

Griffiths, A., 'Euenius the Negligent Nightwatchman (Herodotus 9.92-96)', in R. Buxton (ed.), From Myth to Reason (Oxford I999) I69-182.

Griffiths, F.T., Theocritus at Court (Leiden I979). 
Griswold, C.L., 'Comments on Kahn', in J. Annas, C. Rowe (eds.), New Perspectives on Plato, Modern and Ancient (Cambridge MA 2002) I29-I44.

van Groningen, B.A., The Proems of the Iliad and the Odyssey (Amsterdam I946).

$\longrightarrow$, La composition littéraire archä̈que grecque (Amsterdam I958).

Grote, G., History of Greece, IX (London I852).

Groten, F.J., 'Herodotus' Use of Variant Versions', Phoenix I7 (I963) 79-87.

Hägg, T., 'Die Ephesiaka des Xenophon Ephesius - Original oder Epitome?', Classica et Medievalia 27 (I966) in8-i6r [repr. as 'The Ephesiaca of Xenophon Ephesius - Original or Epitome?', in T. Hägg, Parthenope: Selected Studies in Ancient Greek Fiction (Copenhagen 2004) I59-I98].

- Narrative Technique in Ancient Greek Romances (Stockholm I97I).

-, 'Callirhoe and Parthenope: The Beginnings of the Historical Novel', ClAnt 6 (I987) I84-204.

, 'Orality, Literacy and the "Readership" of the Early Greek Novel', in R. Eriksen (ed.), Contexts of Pre-Novel Narrative. The European Tradition (Berlin I994) 47-8I.

Hall, E., Aeschylus: Persians (Warminster I996).

Halleran, M.R., 'Lichas' Lies and Sophoclean Innovation', GRBS 27 (I986) 239-247.

Hamilton, R., Epinikion: General Form in the Odes of Pindar (The Hague 1974).

— , 'Prologue, Prophecy, and Plot in Four Plays of Euripides', AfP 99 (1978) 277-302.

Hannah, R., Greek and Roman Calendars: Constructions of Time in the Classical World (London 2005).

Harder, M.A., 'Intertextuality in Callimachus' Aetia', in Callimaque. Sept exposés suivis de discussions (Genève 2002) I89-233.

—, 'Allowed to Speak ... The Function of Direct Speech in Callimachus' Hymns and Aetia', Hermathena I73-I74 (2002-2003) 45-56.

- 'The Invention of Past, Present and Future in Callimachus' Aetia', Hermes I3I (2003) 290-306.

Hardie, P.R., Vergil's Aeneid: Cosmos and Imperium (Oxford I986).

Hartog, F., The Mirror of Herodotus, tr. by J. Lloyd ([Paris I980] Berkeley I988).

Hefti, V., Zur Erzählungstechnik in Heliodors Aethiopika (Vienna I950).

Heiden, B., Tragic Rhetoric. An Interpretation of Sophocles' Trachiniae (New York I989).

Hellwig, B., Raum und Zeit im homerischen Epos (Hildesheim I964).

Henry, W.P., Greek Historical Writing: A Historiographical Essay Based on Xenophon's Hellenica (Chicago I966).

van Henten, J.W., 'Commonplaces in Herod's Commander Speech in Josephus' A.F. I5.I27-I46', in G. Lembi, J. Sievers (eds.), Josephus and Jewish History in Flavian Rome and Beyond (Leiden 2005) I83-206.

Herington, J., 'The Closure of Herodotus' Histories', ICS I6 (I991) I49-i6o.

Heubeck, A., 'Zur inneren Form der Ilias', Gymnasium 65 (I958) 37-47.

Heuner, U., Tragisches Handeln in Raum und Zeit. Raum-zeitliche Tragik und Ästhetik in der sophokleischen Tragödie und im griechischen Theater (Stuttgart 200I).

Hidber, Th., Herodians Darstellung der Kaisergeschichte nach Marc Aurel (Basel 2006). 
Higgins, W.E., Xenophon the Athenian: The Problem of the Individual and the Society of the Polis (Albany NY I977).

Hinds, S., 'The Prophecy of Helenus in Sophocles' Philoctetes', CQ I7 (I967) I69-I80.

Hirschberger, M., 'Epos und Tragödie in Charitons Kallirhoe. Ein Beitrag zur Intertextualität des griechischen Romans', WJA 25 (200I) I57-I86.

Hölscher, G., 'Josephus', in RE 9 (I9ı6), ı934-2000.

Hölscher, U., Die Odyssee. Epos zwischen Märchen und Roman (München I989).

Hopkinson, N., Callimachus: Hymn to Demeter (Cambridge I984).

Hornblower, J., Hieronymus of Cardia (Oxford I98I).

Hornblower, S., A Commentary on Thucydides, I-II (Oxford I99I-I996).

— , 'Panionios of Chios and Hermotimos of Pedasa (Hdt. 8.104-106)', in R.C.T. Parker, P. Derow (eds.), Herodotus and his World. Essays from a Conference in Memory of George Forrest (Oxford 2003) 37-57.

Hulton, A.O., 'The Prologues of Sophocles', GER I6 (I969) 49-59.

Hunter, R., Apollonius Rhodius, The Argonautica: Literary Studies (Cambridge I993).

- Theocritus and the Archeology of Greek Poetry (Cambridge 1996).

- Theocritus: A Selection (Cambridge i999).

- The Encomium of Ptolemy Philadephus (Berkeley 2003).

Hurst, A., 'Temps du récit chez Pindare (Pyth. 4) et Bacchylide (I I)', MH 40 (I983) I54-I68.

$\longrightarrow$, 'Aspects du temps chez Pindare', EFH 31 (I985) I55-I97.

Huss, B., 'The Dancing Sokrates and the Laughing Xenophon, or the Other "Symposium", AfP I20 (I999) 38I-409.

Hutchinson, G.O., Aeschylus: Septem contra Thebas (Oxford I985).

— Hellenistic Poetry (Oxford I988).

—_, 'Sophocles and Time', in J. Griffin (ed.), Sophocles Revisited. Essays presented to Sir Hugh Lloyd-Fones (Oxford I999) 47-72.

Ibendorff, E., Untersuchungen zur darstellerischen Persönlichkeit des Polybios (Rostock I930).

Illig, L., Zur Form der pindarischen Erzählung: Interpretationen und Untersuchungen (Berlin I932).

Immerwahr, H.R., Form and Thought in Herodotus (Cleveland ig66).

Iser, W., The Act of Reading: A Theory of Aesthetic Response ([Munich 1976] Baltimore 1978 ).

Jackson, S., 'Callimachus: Coma Berenices: Origins', Mnemosyne 54 (200I) I-9.

Janko, R., Homer, Hesiod and the Hymns (Cambridge I982).

Jebb, R.C., The Attic Orators from Antiphon to Isaeus, I-II (London I893).

Jones, C.P., Philostratus: Life of Apollonius (Harmondsworth I970).

—-, 'Apollonius of Tyana: Hero and Holy Man', in E.B. Aitken, J.K. Berenson Maclean (eds.), Philostratus's Heroikos: Religion and Cultural Identity in the Third Century C.E. (Atlanta 2004) 75-84.

de Jong, I.J.F., 'Iliad I.366-392: A Mirror-Story', in D. Cairns (ed.), Oxford Readings in Homer's Iliad (Oxford [1985] 2002) 478-495.

- 'The Biter Bit: A Narratological Analysis of H.Aphr. 45-29I', WS 102 (I989) I $3-26$. 
Narrative in Drama: The Art of the Euripidean Messenger-Speech (Leiden I991a).

—, 'Tijdsaspecten in Pindarus' Pythische vier', Lampas 24 (I99Ib) I992 IO.

-, 'Auerbach and Homer', in: J.N. Kazazis, A. Rengakos (eds.), Euphrosyne. Studies in Ancient Epic and its Legacy in honor of D.N. Maronitis (Stuttgart I999) I54-I64.

— A Narratological Commentary on the Odyssey (Cambridge 200ra).

_ ' 'The Anachronical Structure of Herodotus' Histories', in S.J. Harrison (ed.), Texts, Ideas, and the Classics: Scholarship, Theory, and Classical Literature (Oxford 200ib) 93-II6.

— ' 'Narrative Unity and Units', in E.J. Bakker, I.J.F. de Jong, H. van Wees (eds.), Brill's Companion to Herodotus (Leiden 2002) 245-266.

- Narrators and Focalizers. The Presentation of the Story in the Iliad ([Amsterdam I987] London 2004).

— 'Where Narratology Meets Stylistics: The Seven Versions of Ajax' Madness', in I.J.F. de Jong, A. Rijksbaron (eds.), Sophocles and the Greek Language. Aspects of Diction, Syntax, and Pragmatics (Leiden 2005) 73-93.

Kaimio, M., The Chorus of Greek Drama within the Light of the Person and Number Used (Helsinki i970).

Käppel, L., 'Die Rolle des Chores in der Orestie des Aischylos: Vom epischen Erzähler über das lyrische Ich zur dramatis persona', in P. Riemer, B. Zimmermann (eds.), Der Chor im antiken und modernen Drama (Stuttgart I998) 6I-88.

Kennedy, G.A., The Art of Persuasion in Greece (Princeton I963).

Klooster, J.J.H., 'Gods, Humans and the Building of the Argo in Apollonius' (forthcoming).

Köhnken, A., 'Mythical Chronology and Thematic Coherence in Pindar's Third Olympian Ode', HSPh 87 (I983) 49-63.

- 'Narrative Peculiarities in Pindar's Fourth Pythian Ode', SCI I2 (I993) 26-35.

—_, 'Perspektivisches Erzählen im homerischen Epos. Die Wiedererkennung Odysseus-Argos', Hermes I3I (2003) 385-396.

Konstan, D., 'A Note on Theocritus Idyll ı', CP 74 (I979) 233-234.

Korzeniewski, D., 'Studien zu den Persern des Aischylos, I', Helikon 6 (Ig66) $548-596$.

- 'Studien zu den Persern des Aischylos, 2', Helikon 7 (I967) 27-62.

Kraus, C., 'Logos men est' archaios: Stories and Story-telling in Sophocles' Trachiniae', TAPA г2 I (I99I) 75-98.

Kraus, M., 'Erzählzeit und erzählte Zeit im König Ödipus des Sophokles', in A. Bierl, P. von Möllendorff (eds.), Orchestra. Drama, Mythos, Bühne (Stuttgart I994) 289-299.

Kremer, G., 'Die Struktur des Tragödienschlusses', in W. Jens (ed.), Die Bauformen der griechischen Tragödie (München I97I) II7-I4I.

Kuhn-Chen, B., Geschichtskonzeptionen griechischer Historiker im 2. und 3. Fahrhundert n.Chr. Untersuchungen zu den Werken von Appian, Cassius Dio und Herodian (Frankfurt a.M. 200I).

Kullmann, W., 'Vergangenheit und Zukunft in der Ilias', Poetica 2 (I968) I5-37.

Lämmert, E., Bauformen des Erzählens (Stuttgart 1955). 
Lane Fox, R., The Unauthorized Version: Truth and Fiction in the Bible (Harmondsworth I992).

Lang, M.L., Herodotean Narrative and Discourse (Cambridge MA I984).

Langer, S., Feeling and Form (London i953).

de Lannoy, L., 'Le problème de Philostrate (état de la question)', ANRW II.34.3 (I997) 2362-2449.

Laplace, M., 'Les légendes troyennes dans le "roman" de Chariton, Chairéas et Callirhoé', REG 93 (I980) 83-I25.

Lardinois, A.P.M.H., 'The Polysemy of Gnomic Expressions and Ajax' Deception Speech', in I.J.F. de Jong, A. Rijksbaron (eds.), Sophocles and the Greek Language. Aspects of Diction, Syntax, and Pragmatics (Leiden 2005) 213-223.

Latacz, J., Homer. His Art and his World (Ann Arbor I996).

Lateiner, D., 'No Laughing Matter: A Literary Tactic in Herodotus', TAPA Io7 (I977) I73-I82.

- The Historical Method of Herodotus (Toronto I989).

Lattimore, R., 'The Wise Adviser in Herodotus', CP 34 (I939) 24-35.

— ' 'The Composition of the History of Herodotus', CP 53 (I958) 9-2 I.

Lattimore, S., Thucydides: The Peloponnesian War (Indianapolis I998).

Lawall, G., Theocritus' Coan Pastorals: A Poetry Book (Cambridge MA I967).

Lebeck, A., The Oresteia: A Study in Language and Structure (Washington DC I97I).

Lefkowitz, M.R., 'Bacchylides' Ode 5: Imitation and Originality', HSPh 73 (ı69) 45-96.

Lehmann, G.A., 'The "Ancient”" Greek History in Polybios' Historiae: Tendencies and Political Objectives', SCI Io (I989-I990) 66-77.

Lendle, O., Kommentar zu Xenophons Anabasis (Bücher I-7) (Darmstadt I995).

Létoublon, F., 'Le messager fidèle', in J.M. Bremer et al. (eds.), Homer: Beyond Oral Poetry (Amsterdam i987) I23-I44.

Lloyd, M.A., 'Divine and Human Action in Euripides' Ion', A\&A 32 (I986) $33^{-45}$.

- Euripides: Andromache (Warminster [I994] 2005).

Lloyd-Jones, H., Aeschylus: The Oresteia (Berkeley I979).

Lowe, N.J., The Classical Plot and the Invention of Western Narrative (Cambridge 2000).

Luraghi, N., 'Local Knowledge in Herodotus' Histories', in N. Luraghi (ed.), The Historian's Craft in the Age of Herodotus (Oxford 2001) I38-i6o.

Luschnat, O., Thukydides der Historiker, in RE Suppl. I2 (I97I) I086-I354.

Macleod, C., Collected Essays (Oxford I983).

MacLeod, L., Dolos and dike in Sophokles' Elektra (Leiden 200I).

MacQueen, B.D., 'Longus and the Myth of Chloe', ICS io (1985) Ir9-I34.

Maehler, H., Die Lieder des Bakchylides, I-II (Leiden I982-I997).

- Bacchylides: A Selection (Cambridge 2004).

Malten, L., Kyrene: Sagengeschichtliche und historische Untersuchungen (Berlin I9I I).

Manuwald, G., 'Zitate als Mittel des Erzählens - zur Darstellungstechnik Charitons in seinem Roman Kallirhoe', WJA 24 (2000) 97-I22.

Marasco, G., 'Erodiano e la crisi dell'impero', ANRW II.34.4 (Berlin I998) $2837-2927$. 
Margolies DeForest, M., Apollonius' Argonautica: A Callimachean Epic (Leiden I994).

Marincola, J., Authority and Tradition in Ancient Historiography (Cambridge 1997).

Markantonatos, A., Tragic Narrative: A Narratological Study of Sophocles' Oedipus at Colonus (Berlin 2002).

Martin, W., Recent Theories of Narrative (Ithaca NY ig86).

Mason, P.G., 'Kassandra', fHS 79 (1959) 80-93.

Mason, S., 'Figured Speech and Irony in T. Flavius Josephus', in J. Edmondson, S. Mason, J. Rives (eds.), Flavius Josephus and Flavian Rome (Oxford 2005) 243-288.

Mehmel, F., Virgil und Apollonius Rhodius. Untersuchungen über die Zeitvorstellung in der antiken epischen Erzählung (Hamburg I940).

Meiggs, R., Lewis, D.M., A Selection of Greek Historical Inscriptions to the End of the Fifth Century BC, (Oxford [ig69] i988).

Meister, K., 'Die synchronistische Darstellung des Polybios im Gegensatz zur Disposition des Ephorus und Theopomp', Hermes 99 (I97I) 506-508.

Mendilow, A.A., Time and the Novel (London I952).

Meyer, A., De compositione Theogoniae Hesiodeae (diss. Berlin I887).

Millar, F., 'Polybius between Greece and Rome', in J.T.A. Koumoulides (ed.), Greek Connections: Essays on Culture and Diplomacy (Notre Dame IN I987) II8.

Miller, M.C., Athens and Persia in the Fifth Century BC. A Study in Cultural Receptivity (Cambridge 1997).

Miller, N. (ed.), Romananfänge. Versuch zu einer Poetik des Romans (Berlin i965).

Moles, J.L., 'The Interpretation of the "Second Preface" in Arrian's Anabasis', $7 H S$ I05 (1985) I62-i68.

$\longrightarrow$, Plutarch: The Life of Cicero (Warminster ig88).

, Review of V.J. Gray, The Character of Xenophon's Hellenica (London I989), CQ 42 (I992) 28I-284.

— 'Truth and Untruth in Herodotus and Thucydides', in C. Gill, T.P. Wiseman (eds.), Lies and Fiction in the Ancient World (Exeter I993) 88-121.

- 'Herodotus Warns the Athenians', PLLS 9 (I996) 259-284.

Momigliano, A., Essays in Ancient and Modern Historiography (Oxford 1977).

- The Development of Greek Biography (Cambridge MA I993).

Morgan, J.R., 'A Sense of the Ending: The Conclusion of Heliodoros' Aithiopika', TAPA i ig (I989) 299-320.

—, 'The Story of Knemon in Heliodoros' Aithiopika', fHS Io9 (r989) 99II3 [repr. in S. Swain (ed.), Oxford Readings in the Greek Novel (Oxford I999) 259-285].

—_ 'Daphnis and Chloe: Love's Own Sweet Story', in J.R. Morgan, R. Stoneman (eds.), Greek Fiction: The Greek Novel in Context (London I994) 64-79.

- Longus: Daphnis and Chloe (Oxford 2004).

—, 'Intertextuality in the Greek Novels', in T. Whitmarsh (ed.), Cambridge Companion to the Ancient Novel (Cambridge 2007) forthc.

Morgan, K., 'Designer History: Plato's Atlantis Story and Fourth-Century Ideology', $7 H S$ i 8 (I998) Iо I-I I8.

— 
Morhange, J.L., 'Incipit narratifs. L'éntrée du lecteur dans l'univers de la fiction', Poétique Io4 (1995) 387-410.

Morrison, J.V., Homeric Misdirection: False Predictions in the Iliad (Ann Arbor 1992).

Morwood, J., 'The Double Time Scheme in Antigone', CQ 43 (I993) 320-32I.

Most, G.W., 'Hesiod's Myth of the Five (or Three or Four) Races', PCPhS 43 (I997) I04-I27.

Muellner, L., The Anger of Achilles: Mēnis in Greek Epic (Ithaca NY I996).

Müller, C.W., 'Chariton von Aphrodisias und die Theorie des Romans in der Antike', $A \mathcal{E}^{2} A 22$ (1976) II5-I36.

Müller, G., Die Bedeutung der Zeit in der Erzählkunst (Bonn I947).

Murray, J., 'The Constructions of the Argo in the Argonautica of Apollonius', in M.A. Harder, M.P. Cuypers (eds.), Beginning from Apollo. Studies in Apollonius Rhodius and the Argonautic Tradition (Leuven 2005) 88-ro6.

Murray, R.D., The Motif of Io in Aeschylus' Suppliants (Princeton I958).

Myres, J., Herodotus, the Father of History (Oxford I953).

Neitzel, H., 'Hesiod und die lügenden Musen', Hermes Io8 (1980) 387-40I.

Nightingale, A., 'Toward an Ecological Eschatology: Plato and Bakhtin on Other Worlds and Times', in R.B. Branham (ed.), Bakhtin and the Classics (Evanston IL 2002) 22I-249.

Nünlist, R., Poetologische Bildersprache in der frühgriechischen Dichtung (Stuttgart I998a).

—, 'Der Homerische Erzähler und das sogenannte Sukzessionsgesetz', $M H$ 55 (I998b) 2-8.

Nussbaum, M., The Fragility of Goodness. Luck and Ethics in Greek Tragedy and Philosophy (Cambridge, I986).

Nuttall, A.D., Openings: Narrative Beginnings from the Epic to the Novel (Oxford I992).

O'Sullivan, J.N., Xenophon of Ephesus. His Compositional Technique and the Birth of the Novel (Berlin I995).

Olson, S.D., Aristophanes. Peace (Oxford i998). , Aristophanes. Acharnians (Oxford 2002).

Opelt, I., 'Furcht und Schrecken bei Herodian', ANRW II.34.4 Berlin (I998) 2928-2952.

Osborne, R., 'Law in Action in Classical Athens', $\mathcal{J} H S$ I05 (I985) 40-58.

Ott, U., Die Kunst des Gegensatzes in Theokrits Hirtengedichten (Hildesheim I969).

van Otterlo, W.A.A., Untersuchungen über Begriff, Anwendung und Entstehung der griechischen Ringkomposition (Amsterdam I944).

Otto, W., 'Herodes', in RE Suppl. 2 (I9I3), I-205.

Paduano, G., Sui Persiani di Eschilo. Problemi di focalizzazione drammatica (Rome I978).

Pandiri, T.A., 'Daphnis and Chloe: The Art of Pastoral Play', Ramus I4 (1985) II6-I4I.

Patzer, H., 'Gleichzeitige Ereignisse im homerischen Epos', in H. Eisenberger (ed.), Hermeneumata (Heidelberg I990) I53-I72.

Payen, P., 'Comment résister à la conquête? Temps, espace et récit chez Hérodote', REG Io8 (1995) 308-338.

Pelling, G.B.R., 'Aspects of Plutarch's Characterization', ICS I3 (I988) 257-274. 
, 'Childhood and Personality in Greek Biography', in C.B.R. Pelling (ed.), Characterization and Individuality in Greek Literature (Oxford I990a) 213244 .

- 'Conclusion', in C.B.R. Pelling (ed.), Characterization and Individuality in Greek Literature (Oxford I99ob) 245-262.

- 'Thucydides' Archidamus and Herodotus' Artabanus', in M. Flower, M. Toher (eds.), Georgica: Greek Studies in Honour of George Cawkwell (London I99I) I20-I42.

— Herodotus', Histos I (1997) [www.dur.ac.uk/Classics/histos/ı997/

pelling.html].

, Plutarch and History (London 2002a).

— ' 'Speech and Action: Herodotus' Debate on the Constitutions', PCPS 48 (2002b) I23-I58.

Peradotto, J., 'The Omen of the Eagles and the ทेंos of Agamemnon', Phoenix 23 (I969) 237-263.

Perrin, B., Plutarch's Lives, I-XI (London I9I4-1926).

Pfister, M., The Theory and Analysis of Drama, tr. by J. Halliday ([München I977] Cambridge I988).

Philippides, M., 'The Digressive aitia in Longus', CW 74 (I980-I98I) I93-I99.

Philips, F.C., 'Narrative Compression and the Myths of Prometheus in Hesiod', Cf 68 (1972-I973) 289-305.

Plastira-Valkanou, M., 'Dreams in Xenophon Ephesius', SO 76 (200I) I37-I49.

Pohlenz, M., Herodot: der erste Geschichtsschreiber des Abendlandes (Leipzig 1937).

Pomeroy, S.B., Xenophon: Oeconomicus: A Social and Historical Commentary (Oxford I994).

Powell, J.E., A Lexicon to Herodotus (Cambridge I938).

Puelma, M., 'Die Dichterbegegnung in Theokrits Thalysien', MH i7 (I960) I $44-\mathrm{I} 64$.

Race, W.H., Pindar, I-II (Cambridge MA i997).

Rahn, P.J., 'The Date of Xenophon's Exile', in G.S. Shrimpton, D.J. McCargor (eds.), Classical Contributions: Studies in Honour of Malcolm Francis McGregor (Locust Valley NY i98i) I03-i i9.

Reardon, B.P. (ed.), Collected Ancient Greek Novels (Berkeley I989).

Redfield, J.M., 'The Proem of the Iliad. Homer's Art', CP 74 (I979) 95-I Io.

Rehm, R., The Play of Space: Spatial Transformation in Greek Tragedy (Princeton 2002).

- Radical Theatre. Greek Tragedy and the Modern World (London 2003).

Reichel, M., 'Retardationstechniken in der Ilias', in W. Kullmann, M. Reichel (eds.), Der Übergang von der Mündlichkeit zur Literatur bei den Griechen (Tübingen I990) I25-I5I.

- Fernbeziehungen in der Ilias (Tübingen I994).

Reinhardt, K., Sophokles (Frankfurt a.M. [1933] I943).

— Die Ilias und ihr Dichter (Göttingen I96I).

Rengakos, A., 'Zeit und Gleichzeitigkeit in den homerischen Epen', $A \mathcal{E}^{2} A$ 4I (I995) I-33.

- 'Spannungsstrategien in den homerischen Epen', in J.N. Kazazis, A. 
Rengakos (eds.), Euphrosyne. Studies in Ancient Epic and its Legacy in Honor of D.N. Maronitis (Stuttgart I999) 308-338.

—_, 'Zu Bakchylides' Erzähltechnik', in A. Bagordo, B. Zimmermann (eds.), Bakchylides Ioo Fahre nach seiner Wiederentdeckung (München 2000) IOI-II2.

Richardson, N.J., The Homeric Hymn to Demeter (Oxford I974).

Richardson, S., The Homeric Narrator (Nashville I990).

—, 'Truth in the Tales of the Odyssey', Mnemosyne 49 (I996) 393-402.

Ricoeur, P., Time and Narrative, I-II tr. by K. McLaughin, D. Pellauer ([I983] Chicago I984-I985).

Rijksbaron, A., 'How Does a Messenger Begin his Speech? Some Observations on the Opening Lines of Euripidean Messenger-Speeches', in J.M. Bremer, S. Radt, C.J. Ruijgh (eds.), Miscellanea tragica in honorem 7.C. Kamerbeek (Amsterdam I976) 293-308.

Rivier, A., 'Mythe et poésie: leurs rapports et leur fonction dans trois épinicies de Pindare', Lettres d'humanité 9 (I950) 6o-96 [repr. in A. Rivier, Etudes de littérature grecque (Genève I975) 259-288].

Robert, C., 'Zu Hesiods Theogonie', in Mélanges Nicole (Geneva I905) 46I-487 [repr. in E. Heitsch, Hesiod (Darmstadt I966) I53-174].

Roberts, D.H., 'Sophoclean Endings: Another Story', Arethusa 21 (I988) I77Ig6.

- 'Different Stories: Sophoclean Narrative(s) in the Philoctetes', TAPA Ir9 (I989) I6I-I76.

de Romilly, J., Time in Greek Tragedy (Ithaca NY i968).

Rommel, H., Die naturwissenschaftlich-paradoxographischen Exkurse bei Philostratos, Heliodoros und Achilleus Tatios (Stuttgart I923).

Rood, T.G.B., Thucydides: Narrative and Explanation (Oxford I998).

Rosenmeyer, T., The Green Cabinet (Berkeley I969).

- The Art of Aeschylus (Berkeley 1982).

Rubinstein, L., Litigation and Cooperation: Supporting Speakers in the Courts of Classical Athens (Stuttgart 2000).

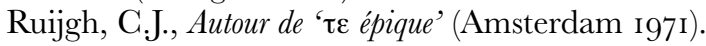

Russell, D.A., 'Plutarch's Life of Coriolanus', $7 R S$ (1963) 2 I-28 [repr. in B. Scardigli (ed.), Essays on Plutarch's 'Lives' (Oxford r995) 357-372].

— , 'Plutarch, Alcibiades, I-I6', PCPS I2 (I966) 37-47 [repr. in B. Scardigli (ed.), Essays on Plutarch's 'Lives' (Oxford I995) I9I-207].

Rutherford, R., The Art of Plato (London i995).

Sacks, K., Polybius on the Writing of History (Berkeley i98i).

$S A G \mathcal{N}$ I = de Jong, I.J.F., Nünlist, R., Bowie, A. (eds.), Narrators, Narratees, and Narratives in Ancient Greek Literature.: Studies in Ancient Greek Narrative I (Leiden 2004).

Saïd, S., 'Darius et Xerxès dans les Perses d'Eschyle', Ktema 6 (I98I) I7-38.

— 'Tragédie et renversement: l'exemple des Perses', Métis 3 (I988) 32 I-34I.

Schadewaldt, W., Iliasstudien (Berlin [1938] I966).

- Hellas und Hesperien. Gesammelte Schriften zur Antike und zur neueren Literatur I (Zürich [1960] I970).

Schmakeit-Bean, I., Apollonios Rhodios und die attische Tragödie: Gattungsüberschreitende Intertextualität in der alexandrinischen Epik (Groningen 2003). 
Schmidt, E.A., Bukolische Leidenschaft oder über antike Hirtenpoesie (Frankfurt a.M. I987).

Schmidt, H.W., 'Die Struktur des Eingangs', in W. Jens (ed.), Die Bauformen der griechischen Tragödie (München I97I) I-46.

Schmitz, T.A., 'Ist die Odyssee 'spannend'? Anmerkungen zur Erzähltechnik des homerischen Epos', Philologus I38 (I994) 3-23.

_ , "I hate all common things": The Reader's Role in Callimachus' Aetia Prologue', HSPh 99 (i999) I5 I-I78.

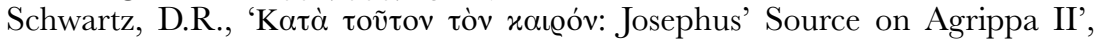
Jewish Quarterly Review 72 (I982) 24I-268.

- Studies in the Jewish Background of Christianity (Tübingen I992).

Schwindt, J.P., Das Motiv der Tagesspanne. Ein Beitrag zur Asthetik der Zeitgestaltung im griechisch-römischen Drama (Paderborn I994).

Scodel, R., 'The Achaean Wall and the Myth of Destruction', HSPh 86 (I982) 33-53.

— 'Epic Doublets and Polyneices' Two Burials', TAPA I I4 (I984) 49-58.

Seaton, R., Apollonius Rhodius: Argonautica (Cambridge MA igi2).

Segal, C., Poetry and Myth in Ancient Pastoral. Essays on Theocritus and Virgil (Princeton I98I).

— , 'Drama, Narrative and Perspective in Sophocles' Ajax', SEJG 31 (I989I990) 395-404.

— 'Catharsis, Audience, and Closure in Greek Tragedy', in M.S. Silk (ed.), Tragedy and the Tragic in Greek Theatre and Beyond (Oxford I996) I49-172.

_ ' 'The Oracles of Sophocles' Trachiniae: Convergence or Conclusion?', HSPh IO0 (2000) I5I-I72.

Sidebottom, H., 'Herodian's Historical Methods and Understanding of History', ANRW II.34.4 (I998) 2775-2836.

Slater, W.J., 'Pindar's Myths: Two Pragmatic Explanations', in G.W. Bowersock, W. Burkert, M.C.J. Putnam (eds.), Arktouros (Berlin I979) 63-7o.

- 'Lyric Narrative: Structure and Principle', ClAnt 2 (I983) I I7-I32.

Smart, J.D., 'Athens and Egesta', $7 H S 92$ (I972) I28-I46.

Smith, P.M., Nursling of Mortality: A Study of the Homeric Hymn to Aphrodite (Frankfurt a.M. I98I).

Solmsen, F., Hesiod and Aeschylus (Ithaca NY i949).

Spring, E., 'A Study of Exposition in Greek Tragedy', HSPh 28 (I9I7) I35-224.

Stadter, P.A., Arrian of Nicomedia (Chapel Hill I980).

—

—_, 'Fictional Narrative in the Cyropaideia', AfPP I I2 (I99I) 46I-49I.

_ 'Anecdotes and the Thematic Structure of Plutarchean Biography', in J.A. Fernández Delgado, F. Pordomingo Pardo (eds.), Estudios sobre Plutarco, IV: Aspectos formales (Madrid I996) 29I-303.

Stanford, W.B., Greek Metaphor: Studies in Theory and Practice (New York [1936] I972).

Stanzel, K.H., Liebende Hirten. Theokrits Bukolik und die alexandrinische Poesie (Stuttgart I995).

Sternberg, M., The Poetics of Biblical Narrative. Ideological Literature and the Drama of Reading (Bloomington I985). 
Stoddard, K., The Narrative Voice in the Theogony of Hesiod (Leiden 2004).

Strasburger, H., 'Herodots Zeitrechnung', in W. Marg (ed.), Herodot (Munich I965) $688-736$.

Strootman, R., The Hellenistic Royal Court. Court Culture, Ceremonial and Ideology in Greece, Egypt and the Near East (diss. Utrecht 2007).

Swain, S., Hellenism and Empire. Language, Classicism and Power in the Greek World $A D$ 50-25o (Oxford 1996).

Taplin, O., The Stagecraft of Aeschylus (Oxford I977).

- Homeric Soundings: The Shaping of the Iliad (Oxford I992).

Tatum, J., Xenophon's Imperial Fiction (Princeton I989).

Telò, M., 'Eliodoro e la critica omerica antica', SIFC I7 (I999) 7I-87.

Theunissen, M., Pindar: Menschenlos und Wende der Zeit (München 200o).

Thomas, R., Oral Tradition and Written Record in Classical Athens (Cambridge I989).

— ' 'Herodotus' Histories and the Floating Gap', in N. Luraghi (ed.), The Historian's Craft in the Age of Herodotus (Oxford 200I) I98-2 Io.

Tomashevsky, B., 'Thematics', in L.T. Lemon, M.J. Reis (eds.), Russian Formalist Criticism. Four Essays ([1925] Lincoln NE I965) 6I-95.

Tuplin, G.J., 'Xenophon's Exile Again', in M. Whitby, P.R. Hardie, M. Whitby (eds.), Homo viator: Classical Essays for Fohn Bramble (Bristol I987) 59-68.

- The Failings of Empire: A Reading of Xenophon Hellenica 2.3.II-7.5.27 (Stuttgart I993).

Usher, S., Greek Orators, V: Demosthenes: On the Crown (Warminster i993).

$\longrightarrow$, Greek Oratory: Tradition and Originality (Oxford I999).

Veyne, P., Writing History: Essay on Epistemology, tr. by M. Moore-Rinvolucri ([Paris I97I] Middleton CT i984).

Walbank, F.W., A Historical Commentary on Polybius, I-III (Oxford I957-1979).

- , Polybius (Berkeley I972).

- Polybius, Rome and the Hellenistic World (Cambridge 2002).

Waterfield, R., Plutarch: Greek Lives (Oxford i998).

West, M.L., Hesiod: Theogony (Oxford I966). , Hesiod: Works and Days (Oxford I978).

—, 'An Unrecognized Injunctive Usage in Greek', Glotta 67 (I989) I35I 38 .

- Homeric Hymns, Homeric Apocrypha, Lives of Homer (Cambridge MA 2003).

West, S., 'Kerkidos paramythia? For Whom Did Chariton Write?', ZPE I43 (2003) $63-69$.

Wheeler, G., "Sing Muse ...". The Introit from Homer to Apollonius of Rhodes', CQ 52 (2002) 33-49.

Whitman, C.H., Homer and the Heroic Tradition (Cambridge MA I958).

Whitmarsh, T., 'Alexander's Hellenism and Plutarch's Textualism', CQ 52 (2002) I74-I92.

Whittaker, C.R., Herodian, I-II (London I969-I970).

Widmer, W., Kaisertum, Rom und Welt in Herodians META MARKON BASILELAS HISTORLA (diss. Zürich I967).

Wijnberg, S., Antiphons Eerste Rede (Amsterdam I938).

Wilamowitz-Moellendorff, U. von, Timotheos: Die Perser (Berlin I903). 
- Hellenistische Dichtung (Berlin I9o6).

Wilamowitz-Moellendorff, T. von, Die dramatische Technik des Sophokles (Berlin I917).

Williams, F., 'A Theophany in Theocritus', CQ 2I (I97I) I37-I45.

Williamson, G.A., Josephus: The Jewish War, rev. by E.M. Smallwood ([Harmondsworth I959] London I98I).

Williamson, H.G.M., 'The Historical Value of Josephus' Jewish Antiquities, XI, 297-30I', JTS 28 (I977) 50-55.

Winnington-Ingram, R.P., Sophocles. An Interpretation (Cambridge I980).

$\longrightarrow$, Studies in Aeschylus (Cambridge I983).

Wouters, A., 'The عixóves in Longus' Daphnis and Chloe IV 39,2: 'Beglaubigungsapparat'?', SEJG 3I (I989-I990) 465-479.

—_, 'Longus' Daphnis en Chloé. Het prooemium en de ingelaste verhalen', Handelingen van de Koninklijke Zuidnederlandse maatschappij voor Taal-en Letterkunde en Geschiedenis 45 (I99I) 213-242.

Zielinski, T., 'Die Behandlung gleichzeitiger Ereignisse im antiken Epos', Philologus Suppl. 8 (I899-I90i) 405-449.

Zimmermann, B., Dithyrambos: Geschichte einer Gattung (Göttingen I992).

Zimmermann, F., 'Die Ephesiaka des sog. Xenophon von Ephesos. Untersuchungen zur Technik und Komposition', WJA 4 (I949-1950) 252-286.

Zimmermann, M., Kaiser und Ereignis. Studien zum Geschichtswerk Herodians (München I999). 


\section{THEMATIC INDEX}

acceleration, II 52, 58, 96, IO7-IO9, I37, I93, 228, 238, 31 Ing, 332, 362, 364-367, 376, 378, 379, 390, 395, 396, 4OI, 40In23, 402, 4IO, 422

analepsis, 3-5, 5ni5, 6-9, I3, 20, 2OnII, 2I, 22, 22nI 8, 23, 24, 24n $26,26-29,33,36,37,4 \mathrm{In} 6$, $42,42 \mathrm{nI} 2,43,43 \mathrm{nI} 3,45,4^{8}$, 48n $32,49-52,57,60,62,66-$ 68, 70, 7on 28,7 on 30, 71, 72, 72n33, 78-80, 89-9I, 96, 99, I02, I05, I07, III, II5, II6, II9, I23-I26, I28-I33, I33n4, I33n6, I39-I44, I48, I49, I54-I6o, I6onI5, I6I, I62, I72, I73, I75, I77-I79, I8onı8, I8I, I84, I88I9I, IgInI7, I99-202, 2I6, 22I, 222, 222n $24,222 \mathrm{n} 25,223,225 \mathrm{n} 29$, 226, 229, 230, 242n24, 243, 243n26, 246, 247, 249, 249n45, $249 \mathrm{n} 46,256 \mathrm{n} 6,256 \mathrm{n} 7,258,26 \mathrm{o}$, 276, 286, 293ni, 300, 325, 326, 33I, 345, 355-359, 363, 366, 371-374, 387-389, 389n8, 391, 39InI2, 392, 393, 393ni6, 394396, 403, 408, 409, 4II, 424, 425, 427, 427n37, 428, 429, 433-439, 439n9, 439nio, 440, 442, 450, 454-457, 457nio, 457nI , 458, 468, 469, 47I, 474, 475, 475nI4, 475nı6, 476, 477nı 7, 478n22, 479, 484-486, 486nio, 488-500, 503, 508-512

analepsis and prolepsis combined, 28, I28, 259, 512

beginning, 8, I9, 65, 83, 9I-93, II5, II 6, I40, I52, I73, I98, 233, 234, $295,4 \mathrm{I} 8,4 \mathrm{I} 9,468,484,509-$ 5 IO ellipsis, I2, 33, 37, 45, 48, 59, 77, 78, 78n5 I, 94-96, го6, I08, г20, I34, I48, I5 In6, I56, I94, 210, 227, 229, 230, 244, 248, 259, 26oni 4 , 26I-263, 266, 269, 288, 289, $292,322,323,333,336,365^{-}$ 367, 388, 390nI I, 39I, 393-396, 40I, 40In23, 402, 422, 503, 517518

ending, I9, 9I-93, I04, II6, II7, I40, I73, 240nI 2 epic regression, 27, 35, 24InI6, 287, 287n32, 29I, 505-506 eternal prolepsis, 50, 55nir, 6r, 62

fabula, $2-5,9,9$ n2o, Io, I3, I820, 32, 33, 55 $\mathrm{nI}, 65,67,9 \mathrm{I}^{-} 94$, I07, I36, I79, I83, I84, I93, 209, 210, 240-242, 258, 259, 264266, 276n $4,293 \mathrm{n} 2,308,3 \mathrm{I} 3$, 321, 340, 349, 362, 370, 400, $4 \mathrm{I} 5,422,423,425,426,433$, $434,454,455,467-470,477,484^{-}$ 489, 49I-493, 493n2I, 499, 503, 508

foreshadowing, 8, 74, 74n40, 8o, IO2-I04, I04n20, I44, I44ni6, I56, I6o, 205, 298, 299, 395, 403, 404, 406, 409, 44I, 444-446, 448, $5^{\mathrm{I}-}-5^{\mathrm{I}} 5$

frequency, 3, I3, 34, 45, 78, I09, II8, II9, I30, I33, I33n4, I48-I50, I66, 208, 256, 258, 260, 290, 302, 306, 322, 330, 340, 377, 379, 450, 466, $47 \mathrm{I}, 472,519-520$

'header' device, 35, 49, 73, I19, I24, I42, I5O, 203, 236, 288, 44I, 459, $5 \mathrm{I} 3$ 
initial summary with subsequent elaboration, 44ni8, 49, 52, II9, I67n $4,235,236,236 \mathrm{n} 8,242,25 \mathrm{O}$, 288, 505

iterative narration, I3, I4, 34, 34n $5 \mathrm{I}$, $4^{6}, 4^{8}, 5^{\mathrm{O}}, 5^{\mathrm{I}}, 54,54^{\mathrm{n} 6}, 54^{\mathrm{n} 8}$, 55nir, 96, IOonir, IIo, iII, II8I2I, I28, I32-I38, I49, I50, I6I, I66, 208, 243, 248, 256n6, 257, 258, 26o, 269, 27o, 27on 36 , 270n37, 273, 290, 290n35, 30I303, 306n2, 308, 315, 333, 338, 34I, 348-35I, 353-355, 372, 376, 379, 380, 386, 389, 390, 390nio, 39I-396, 401, 402, 406, 407, 407n42, 409, 4II 42O, 450, 45on28, 466, 466n24, 469n4, $47 \mathrm{O}-473,474 \mathrm{nI} 3,475^{\mathrm{nI}} 4,477 \mathrm{nI}$, $5^{19-520}$

iterative/repetitive, $34^{8}, 35^{\mathrm{O}}, 35^{\mathrm{I}}$

omnitemporal narration, I4, I7, 34, 44, 46, 47, 47n31, 48n35, 52, $55,64,65 \mathrm{n} 8,76-80$, I36, г66, 233n2, 27on37, 386, 387, 4o6, 4 I I

order, $2-4,8$, Io, I8, 20, 35n 55,36 , 39, 39ni, 4I, 42, 47, 47n3o, 48$52,56,57,62,67,8$ I, $84-86$, го6, I22, I30-I33, I33n4, I39, I42, I48, I49, I53, I66, I67, I70, I72, I74, I75, I87, I99, 210, 2I5, 216, 225, 226, 236n8, 240-242, 245, 247 , 247n36, 249, 25I, 256, 26o, 26I, 264-266, 276, 276n $4,277,282$, 286, 287, 29I, 300, 305, 308-313, $324,326,332,335,337,340,342$, 362, 367, 37I, 4I9, 420, 425, 434, 435, 438, 439, 443, 453-455, 457, $45^{8}, 464,468,477,484,486,489$, $496,504,505^{-508}$

paradigmatic narration, I30, I35, I44, I59, 205, 270, 369, 376, 4I8421,423

paralipsis, 6, 6nı6, 2I, I23, I42, I44, 408, 422, 423, 435 parallel storylines, 9, 30, 69, 80, I43, 216, 225, 225n29, 226, 230, 424, $425,44^{8}, 454,4^{6} 4,493,5^{1} 5^{-5} 5^{16}$ pause, I2, 32, 33, 77, 94, I08, го9, Iogn28, III, I24-I26, I37, I53, I69, I93, I94, 210, 255n5, 30I, 34I, 4I9, 450, 466, 470, 470n7, 503,519

piecemeal distribution, 36,70 , 266n3o, 268, 278, 279, 279ni2, 3I I

prequel, 76, 5I4

prior narration, 2, 2n6, 46n23, 5052,82 , IOO, IO2, III, 233n2, 243 $247,25 \mathrm{I}, 282,324,52 \mathrm{I}$

proem, 19, 24, 27, 28, 63, 66, 73n 35 , 75, 78, 197, I97ni, I98, I99, 203, 208, 322, 324, 330, 386, 403, 405, 408-4Io, 467n $3,477,478,5^{1} 3^{-}$ 5I4

prolepsis, 2n6, 3-5, 5nI5, 6-8, 20, $24^{-27}, 27 n 34,28,29,37,40$, 4on4, 42, 43, 43ni3, 49, 52, 6o, 62, 66, 67, 70, 7on28, 7I, 73, 73n 34, 73n35, 74-76, 79, 80, 84, 86, 87, 87nı2, 88, 89, 96, го2I04, III, II7, I23ni6, I25-I28, I33n4, I34, I40, I42, I44, I45, I45ni7, I45ni8, I46, I46nig, I46n20, I54-I56, I56nI2, I58, I60, I6I, I75-I77, I79-181, I84, I90-I92, I99, 203-206, 206ni9, 207, 216-2I9, 2Igni8, 220, 22I, 223, 230, 243, 243n25, 244, 245, 245n29, 247, 249n42, 25o, 256n6, 258-26o, 26oni6, 26i, 26ini8, 262, 266, 276, 286, 286n3 , 293ni, 299, 300, 324-326, 335, 345, 349, 36o, 36r, 369, 371, 374, 386, 389, 393, 394, 394n22, 395, 399, 40I, 402, 405, 406, 4II, 423, 423n3o, 424-43o, 433, 434, 438, 440, 44I, 44InI4, 442, 442nI5, 443, 444, 444ni6, 445, 445ni8, 446-448, 459, 46o, 46onI5, 462, $463,466,469,475-477,477 \mathrm{n} 20$, 478,478 n22, 479-48I, 484, 492, 
$494,49^{6-498}, 49^{8 \mathrm{n}} 24,499^{-502}$, $5^{\mathrm{I} 2}-5^{\mathrm{I}} 5$

proleptic closure, I27, I42, I54, I76, 204, 513

prologue, see proem

prospective narrative, I45, 256, 256n6, 257, 258, 258nio, 258ni2, 266, 266n 3o, 267, 269, 273, 275n2, 276, 280, 282, 282n2o, 283, 283n21, 284, 284n25, 285, 285n26, 29I, 293, 293nI, 296, 297, 299, 300, 304, 313-3I5, 5I3

'reference to the narrator's own time' motif, 3, I7, 46, 50, 6o, 6on25, 67, 68, 72n33, 75, 8I, 87, 92, I54, I92, 205, 387, 387n5, 388, 4IO, 4I 4

repeating narration, $13,34,36,49$, 79, II9, I33, I66, I67, 208, 256, 262, 268, 27I , 272, 279, 290, 29I, 296, 303, 304, 335, 35I, 473, 509, 520

retardation, 32, 44, 77n48, 301, 399 retrospective and prospective narrative combined, 257, 267, 512 retrospective narrative, I59, I89, 202, 222n $27,256,25^{6 n} 6,257,25^{8}$, 258nio, 258ni2, 264, 264n25, 267, 269, 27on $36,273,275 \mathrm{n} 2,276,277$, 277n8, 278, 279, 28I-284, 284n25, 290, 29I, 293, 293nI, 295-297, 300, 304-307, 3IOn7, 3II, 3I33I $6,396,4^{\text {II }}, 435,5^{\text {II }}$

rhythm, 3, IO, IOn2I, Ion22, II, I2, 3I, 33, 37, 43, 44, 44nI7, 52, 58, 59, 62, 76, 93-96, го7, го8, IOgn29, III, I20-I22, I30, I33, I33n4, I34, I37, I38, I48, I50, I5I, I53, I66, I67, I70, I7I, I7InIo, I72, I77, I93, I94, 208, 209, 227, 228, 236-238, 245, 249, 25I, 256258, 260, 287, 288, 292, 301, 3I4, 317, 322-324, 332, 334, 335, 340, $342,36 \mathrm{I}, 375,398,4 \mathrm{OI}, 42 \mathrm{I}-423$, 430, 434, 449, 465, 472, 502, $5^{\mathrm{I} 7}$ $5^{19}$ ring composition, I9, 35, 236n8, 240, 24I, 24InI7, 24In2I, 242, 249n45, 25o, 25on47, 379, 505

scene, II, 3I, 32, 34, 37, 57, 76, 77, 93, 95, I07-I09, I38, I48, I5I, I57, I93, I94, 209, 210, 227, 228, 228n37, 23o, 237, 257, 275n2, 287, 288, 292, 30I, 3II, 323, 333, 335, 362, 363, 375, 376, 379, 388, 390, 39I, 393, 394, 396, 434, 449, 450, $465,466,47 \mathrm{I}, 472,502,5 \mathrm{I} 7$

seed, 8, 24, 3I4, 3I5, 427, 44I, 447, $459,464,476,480$

simultaneity, 30, 3I, 3In46, 69, Io6, I24, I25, I28, I42, I43, I53, I73, I74, 244, 355, 362, 393ni8, 448, $45^{6}, 4^{6} 4,493,5^{\mathrm{I}} 5^{-} 5^{\mathrm{I}} 6$ simultaneous iterative narration, 34, $45,4^{6}, 46 \mathrm{n} 23,47,5 \mathrm{I}, 53,53 \mathrm{n} 2$, 54n5, 54nio, 55, 62, 78, гоo, IOonio, IOI, I08, IIon3o, III simultaneous narration, 2, 46, 50, 54n8, 55, 82, I00-IO2, III, 2I8, 25I, 256n6, 269, 27o, 294-296, $303,307,315-317,376,520,52 \mathrm{I}$ singulative narration, I3, 34, 36, 46, 48, 49, 5I, 53, 53ni, 53n3, 54, 55, 62, 78, IOonII, I09, II8-I20, I33, I34, I36, I37, I49, I50, I66, 208, 243, 248, 25I, 257, 258, 273, 290, $302,322,325,326,330,335,340$, 389-392, 394, 40I, 45o, 466, 470, $47 \mathrm{I}, 5 \mathrm{I} 9$

slow-down, II, IIn23, I2, 32, 33, 44, 58, І08, І09, І2 1, I34, I38, I48, I53, I7I, I93, 2I4, 227, 228, 323, $324,332,333,341$, 362-364, 376, 379, 399-4OI, 4IO, 422, 450, 5I7 speed, see rhythm

story, 2, 4, 5, 5ni3, 7, I8, 20, 23, 26, $34,36,55,56,65,67,68,70,75$, 90, 99, II7, I39, I67, I70, I72, I74, I84, I84n5, I88, I93, I98-200, 206, 207, 221 , 227, 249n45, 258, 266, 340, 34I, 433, 469, 48I, 488, 508 
subsequent narration, 2, 46, 48-5I, $53,53 \mathrm{nI}, 53 \mathrm{n} 3,54,54 \mathrm{n} 8,55,62$, 8I, I00, I66, I79, 218, 233, 243$245,247,25 \mathrm{I}, 256,282,283,307$, 324, 346, 355, 369, 374, 4I4, 433, $453,467,483,520,5^{2 I}$

summary, II, 3i-34, 34n 5I, 35n53,

$37,40,43-45,49,55,56,58,64$, 71, 76, 78, 79, 82, 90, 93-95, I07, I08, II8, II9, I2I, I38, I47, I5I, I66-I68, I68n5, I69, I70, I72, I73, I77, I78, I84, I9I, I93, I94, I99, 200, 210, 2I 7, 227-230, 235, 235n7, 236-239, 243-245, 248n4I, $249,257,259-263,265,27 \mathrm{I}, 287$, 288, 290n35, 292, 301, 302, 305, 3II, 323, 324, 333, 335, 340, 34I, $355,356,35^{6 \mathrm{n}} 24,35^{6 \mathrm{n} 26,} 363$,
$369,373,375,376,378,379$, 386, 389, 390, 39onio, 392-394, 427n37, 434, 437, 438, 449, 450, 456, 465, 466, 472, 475n 6,495 , $5^{\mathrm{I} 7}$

suspense, 4, 22, 25, 28, 28n4o, 44, 73, 77n48, 86, Io9, Iogn28, I23ni $6,325,363,420,429,430$, 435,443

time awareness, I, I7, I8, 63, 64, 82, 97, 98, 98n6, I22, I37, I50, I85, 2І $3,275,294,4 \mathrm{I} 3,470,506-508$ time span, 4, 5, 5nI3, 45, 5I, 55, $55^{\mathrm{nI}}, 56,57,59,62,65,83,88-$ 90, 95, 99, I84, I98, 221, 227, 237ng, 242, 248, 248n40, 293, $39^{8}, 434,453,45^{6}, 5^{\circ} 3$ 